\author{
UNIVERSIDADE DE SÃO PAULO \\ FACULDADE DE FILOSOFIA, LETRAS E CIÊNCIAS HUMANAS \\ DEPARTAMENTO DE LETRAS MODERNAS \\ PROGRAMA DE PÓS-GRADUAÇÃO EM ESTUDOS \\ LINGUÍSTICOS E LITERÁRIOS EM INGLÊS
}

CLÁUDIA SANTANA MARTINS

A "Epopeia do Comércio":

Os lusíadas na tradução de William Julius Mickle

(Versão Corrigida)

São Paulo

2015 


\section{UNIVERSIDADE DE SÃO PAULO \\ FACULDADE DE FILOSOFIA, LETRAS E CIÊNCIAS HUMANAS DEPARTAMENTO DE LETRAS MODERNAS \\ PROGRAMA DE PÓS-GRADUAÇÃO EM ESTUDOS LINGUÍSTICOS E LITERÁRIOS EM INGLÊS}

\section{A "Epopeia do Comércio": Os lusíadas na tradução de William Julius Mickle}

Cláudia Santana Martins

Tese apresentada ao Programa de Pós-Graduação em Estudos Linguísticos e Literários em Inglês do Departamento de Letras Modernas da Faculdade de Filosofia, Letras e Ciências Humanas da Universidade de São Paulo, para a obtenção do título de Doutora em Letras.

(Versão Corrigida)

De acordo.

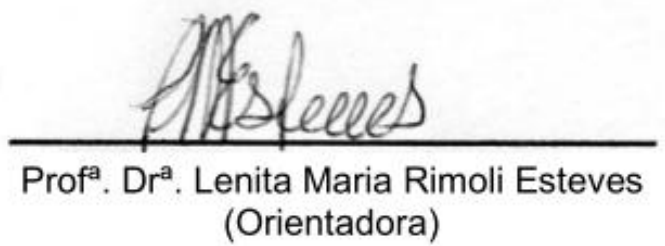

São Paulo

2015 
Autorizo a reprodução e divulgação total ou parcial deste trabalho, por qualquer meio convencional ou eletrônico, para fins de estudo e pesquisa, desde que citada a fonte. 


\section{CLÁUDIA SANTANA MARTINS}

A "Epopeia do Comércio": Os lusíadas na tradução de William Julius Mickle

Tese apresentada à Faculdade de Filosofia, Letras e Ciências Humanas da Universidade de São Paulo para obtenção do título de Doutora em Letras

Aprovada em:

\section{BANCA EXAMINADORA}

$\operatorname{Prof}(a) . \operatorname{Dr}(a)$ Instituição:

Julgamento: Assinatura:

$\operatorname{Prof}(a) . \operatorname{Dr}(a)$ Instituição:

Julgamento: Assinatura:

Prof(a). Dr(a). Instituição: Julgamento: Assinatura:

Prof(a). Dr(a). Instituição:

Julgamento: Assinatura:

Prof(a). Dr(a). Instituição: Julgamento: Assinatura: 
A Maria da Graça e Luiz Carlos, sem os quais esta tese não teria sido possível. 


\section{AGRADECIMENTOS}

À Prof ${ }^{a}$. Dr ${ }^{\mathrm{a}}$. Lenita Maria Rimoli Esteves, pela orientação competente, apoio, incentivo e amizade.

À Prof ${ }^{\mathrm{a}}$. Dr ${ }^{\mathrm{a}}$. Marcia Maria de Arruda Franco, pelos comentários e sugestões fornecidos por ocasião do Exame de Qualificação.

À Prof ${ }^{\mathrm{a}}$. Dr ${ }^{\mathrm{a}}$. Maria Viviane do Amaral Veras, pelo apoio e estímulo, pelos comentários e sugestões fornecidos por ocasião do Exame de Qualificação e como membro da Banca de Defesa.

Ao Prof. Dr. John Milton, pelo apoio e incentivo durante todo o percurso, assim como pela participação na Banca de Defesa.

À Prof ${ }^{\mathrm{a}}$. Dr ${ }^{\mathrm{a}}$ Ana Elvira Luciano Gebara e ao Prof. Dr. José Garcez Ghirardi, pela participação em minha Banca de Defesa e pelos interessantes comentários e sugestões apresentados.

A meus pais, pela revisão da tese e comentários.

À minha irmã Angela Tesheiner, pela ajuda em várias questões de tradução e redação.

À amiga Theresa Ann Wymer, pela ajuda na tradução das poesias escritas em inglês setecentista.

Ao amigo Prof. Henrique D'Arce, da Kingston University London, que me enviou pelo correio a cópia, obtida na British Library, da biografia de Mickle escrita pelo Rev. John Sim.

À amiga Andreia Schweitzer, pelo auxílio na tradução do poema de Torquato Tasso em homenagem a Vasco da Gama.

A todos os meus amigos e, em especial, aos colegas de mestrado e doutorado, por tornarem minha vida mais interessante e divertida.

Aos amigos do grupo Valami Lesz, fonte constante de informação e inspiração.

À Coordenação de Aperfeiçoamento de Pessoal de Nível Superior (CAPES) pelo apoio financeiro. 
"Um grande império certifica outro. Talvez isso seja propaganda. Entretanto, comunidades imaginadas dependem de histórias e lendas que as mantêm agregadas. Tais histórias são a nação, como muitos teóricos dizem agora e os poetas sempre disseram. E muitas vezes o modo como um poeta lê os velhos mitos que lhe são mais importantes lança uma luz sobre as crenças, se não as mentiras, pelas quais ele e sua nação vivem."

(Lawrence Lipking) 


\section{RESUMO}

MARTINS, Cláudia Santana. A "Epopeia do Comércio": Os lusíadas na tradução de William Julius Mickle. 2015. 361 f. Tese (Doutorado em Letras) Faculdade de Filosofia, Letras e Ciências Humanas, Universidade de São Paulo, São Paulo, 2015.)

O objeto de estudo deste trabalho é a tradução de Os lusíadas, de Luís Vaz de Camões, feita pelo poeta escocês William Julius Mickle e publicada na Inglaterra em 1776. Essa tradução foi um sucesso na época de sua publicação e no século seguinte, tornando-se, ao longo dos anos, a mais lida e citada de todas as traduções da obra para o inglês. Pretende-se mostrar que a tradução de Mickle reflete a intrincada rede de convenções, normas e interesses vigentes no Reino da Grã-Bretanha no final do século XVIII, e que as grandes liberdades tomadas por Mickle com o poema original se articulam a fatores históricos, sociais e econômicos, assim como às normas culturais da época, uma fase de transição entre o Neoclassicismo augustano e o Romantismo. A tese a ser demonstrada é que, em sua tradução e nos elementos paratextuais que a acompanham, Mickle reencena e atualiza o conceito medieval da translatio imperii et studii - a ideia de que haveria uma transmissão do leste para o oeste não só do controle imperial, mas também da cultura e do conhecimento. Mickle adaptou o épico camoniano para o público britânico do final do século XVIII, rotulou-o como "A Epopeia do Comércio" e acrescentou paratextos de cunho ideológico. Manipulando o poema original tanto no aspecto poético quanto ideológico, Mickle transformou Os lusíadas em uma narrativa a serviço do Império Britânico e contribuiu - como outros poetas de sua época que celebraram o crescimento da riqueza e do poder britânicos - para forjar uma identidade poética e cultural para o Império Britânico.

Palavras-chave: Luís Vaz de Camões. William Julius Mickle. Estudos da Tradução. Ideologia. Manipulação. 


\begin{abstract}
MARTINS, Cláudia Santana. The "Epic Poem of Commerce": Os lusíadas translated by William Julius Mickle. 2015. $361 \mathrm{f}$. Thesis (Doctor of Letters) Faculdade de Filosofia, Letras e Ciências Humanas, Universidade de São Paulo, São Paulo, 2015.)

The object of study of this work is the translation of Luís Vaz de Camões's Os lusíadas by the Scottish poet William Julius Mickle, published in England in 1776. This translation was a success in its time and in the ensuing century, having become over the years the most widely read and quoted among all the translations of Os lusíadas into English. It will be shown that Mickle's translation reflects the intricate network of conventions, norms and interests prevailing in Britain in the late 18th century, and also that the great liberties he took with the original poem are connected to historical, social and economic factors, as well as the cultural norms of the time, a transitional period between the Augustan Neoclassicism and Romanticism. The thesis to be demonstrated is that, in his translation and paratextual elements that accompany it, Mickle reenacts and updates the medieval concept of translatio imperii et studii - the idea that not only imperial power, but also knowledge and culture, were transferred from East to West. Mickle adapted Camões's epic for the late eighteenth-century British audience, labelled it as 'The Epic Poem of Commerce' and added ideologically charged paratexts to his translation. By manipulating the original poem both poetically and ideologically, Mickle transformed Os lusíadas into a narrative at the service of the British Empire and contributed - like other poets of his time who celebrated the growth of Britain's wealth and power - to forge a poetic and cultural identity for the British Empire.
\end{abstract}

Keywords: Luís Vaz de Camões. William Julius Mickle. Translation Studies. Ideology. Manipulation. 


\section{LISTA DE FIGURAS}

FIGURA 1 - Mapa antropomórfico Europa Regina, de Johannes Putsch.............. 44

FIGURA 2 - Detalhe do mapa Europa Regina, de Putsch........................................ 44

FIGURA 3 - Reprodução da folha de rosto de The Lusiad ..................................... 143

FIGURA 4 - Gravura de John Mortimer................................................................ 146 


\section{SUMÁRIO}

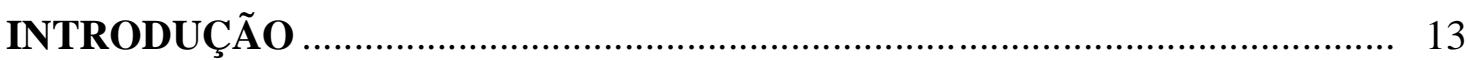

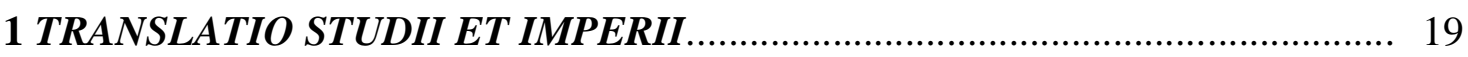

1.1 O “CLÁSSICO” E A ORIGEM DO CONCEITO DE TRANSLATIO........ 21

1.2 A TRANSLATIO NO INÍCIO DA IDADE MODERNA.......................... 25

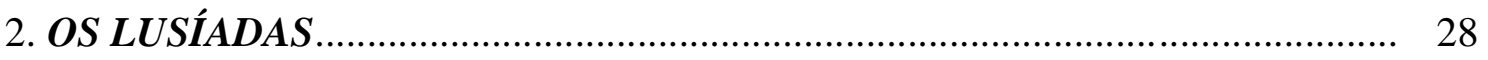

2.1 CONTEXTO SÓCIO-HISTÓRICO-POLÍTICO-ECONÔMICO: A

EXPANSÃO MARÍTIMA PORTUGUESA …....................................... 28

2.2 CONTEXTO CULTURAL-LITERÁRIO: RENASCIMENTO/

MANEIRISMO ........................................................................... 31

2.3 LUÍS VAZ DE CAMÕES................................................................. 34

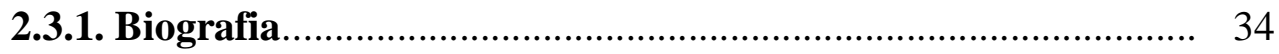

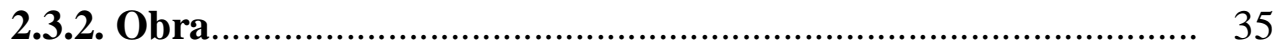

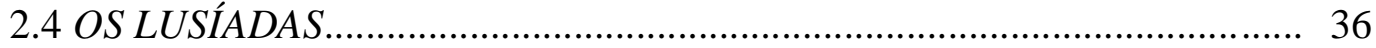

2.5 A TRANSLATIO N'OS LUSÍADAS...................................................... 40

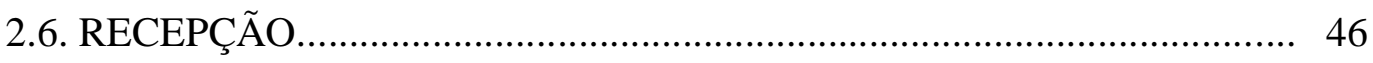

2.6.1 Recepção da obra em Portugal entre os séculos XVI e XVIII... 46

2.6.2 Recepção da obra em outros países europeus entre os séculos

XVI e XVIII....................................................................... 52

2.6.2.1 Espanha...................................................................... 52

2.6.2.2 Latim....................................................................... 54

2.6.2.3 Inglaterra................................................................ 54

2.6.2.4 Itália.............................................................................. 56

2.6.2.5 França..................................................................... 57

2.6.2.6 Holanda, Polônia, Rússia................................................... 61

2.6.2.7 Século XIX...................................................................... 61

3 A GRÃ-BRETANHA SETECENTISTA .................................................... 63

3.1 CONTEXTO SÓCIO-HISTÓRICO-POLÍTICO-ECONÔMICO................. 64

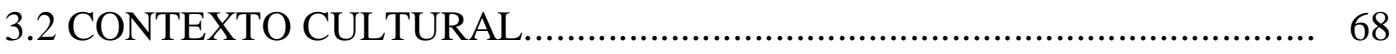

3.2.1 A era da "harmonia universal", do comércio e dos autores..... 68

3.2.2 Identidade nacional e visão de mundo.................................... 73

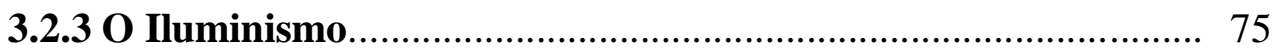


3.2.4 Neoclassicismo 77

3.2.5 Graveyard School e Pré-Romantismo.......................................... 80

3.3 RETÓRICA, POESIA ÉPICA E TRADUÇÃO....................................... 82

3.3.1 Retórica na Grã-Bretanha do século XVIII............................ 82

3.3.1.1 Hugh Blair: retórica e concepção de poesia épica............... 83

3.4 A TRADUÇÃO NA GRÃ-BRETANHA DO SÉCULO XVIII.................... 90

3.4.1 A tradução na França: as belles infidèles.................................. 92

3.4.2 A tradução na Grã-Bretanha................................................ 94

3.4.2.1 Teorizações sobre tradução.............................................. 94

3.4.2.2 Alexander Fraser Tytler (1747-1813)............................. 104

3.4.2.3 Tradução de outra epopeia moderna................................. 106

3.5 A TRANSLATIO NA GRÃ-BRETANHA DOS SÉCULOS XVII E XVIII... 107

3.6 CONSIDERAÇÕES FINAIS................................................................ 114

4 WILLIAM JULIUS MICKLE E THE LUSIAD; OR THE DISCOVERY OF

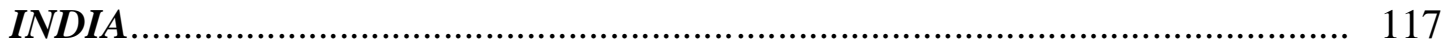

4.1 BIOGRAFIA DE MICKLE ............................................................ 117

4.2 OUTRAS TRADUÇÕES DE MICKLE.................................................... 122

4.3 ELEMENTOS PRÉ-ROMÂNTICOS NA OBRA POÉTICA DE MICKLE....... 123

4.4 MODO DE INSERÇÃO DE MICKLE NO SISTEMA LITERÁRIO........... 130

4.4.1 Um escocês em Londres e Oxford............................................ 130

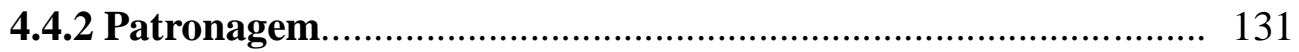

4.5 MODO DE CIRCULAÇÃO DA OBRA................................................... 136

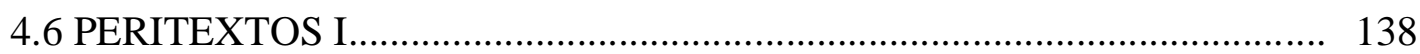

4.6.1 Formato, papel, número de cópias, encadernação, capa........... 139

4.6.2 Folha de rosto..................................................................... 141

4.6.3 Dedicatória, lista de assinantes, página de errata..................... 143

4.6.4 Ilustração do frontispício da segunda edição............................ 145

4.7 PERITEXTOS II: OS ENSAIOS DA INTRODUÇÃO À TRADUÇÃO DE

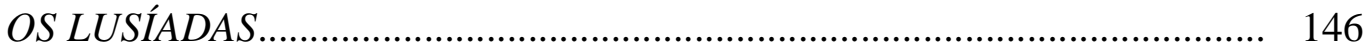

4.7.1 Introdução........................................................................ 147

4.7.2 A história do descobrimento da Índia........................................ 157

4.7.3 A história da ascensão e queda do Império Português no

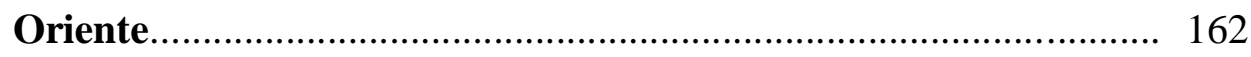


4.7.4 A vida do autor

4.7.5 Dissertação sobre Os lusíadas e observações sobre a poesia épica.

4.7.6 Comentários de Mickle sobre a sua concepção de tradução...... 187

4.7.7 Agradecimentos de Mickle aos assinantes............................... 190

4.7.8 Dissertação sobre a Jerusalém libertada e a Henriade............... 191

4.7.9 Apêndice à segunda edição …................................................. 192

4.7.10 Dissertação sobre o episódio da Ilha dos Amores ................... 192

4.7.11 Dissertação sobre os brâmanes ................................................. 194

4.8 PERITEXTOS III: NOTAS DE RODAPÉ.............................................. 199

4.8.1 Explicitar o significado de termos.......................................... 199

4.8.2 Acrescentar informações históricas, geográficas ou culturais... 200

4.8.3 Elogiar ou defender Camões.................................................... 201

4.8.4 Apontar as influências clássicas de Camões................................ 201

4.8.5 Criticar os tradutores anteriores d'Os lusíadas........................ 202

4.8.6 Defender ou exaltar a Inglaterra (ou Grã-Bretanha)............... 203

4.8.7 Defender um ponto de vista moral.......................................... 204

4.8.8 Defender um ponto de vista ideológico...................................... 204

4.9 RECEPÇÃO DO LUSIAD DE MICKLE................................................. 205

4.9.1 Recepção na época da publicação.............................................. 206

4.9.2 Recepção em Portugal no século XVIII.................................... 217

4.9.3 Análises do Lusiad publicadas logo após a morte de Mickle..... 219

4.9.4 Repercussão entre os românticos........................................... 221

4.9.5 Recepção no período vitoriano................................................ 226

4.9.6 Recepção no século XX e nos tempos atuais.............................. 228

5 ANÁLISE COMPARATIVA ENTRE ORIGINAL E TRADUÇÃO............... 232

5.1 OBSERVAÇÕES GERAIS................................................................. 232

5.2. FATORES IDEOLÓGICOS: A EPOPEIA DO COMÉRCIO.................... 234

5.2.1 A glorificação do comércio ........................................................ 234

5.2.1.1 O comércio n' Os lusíadas................................................ 234

5.2.1.2 O comércio no Lusiad de Mickle..................................... 235

5.2.2 A “bélica excelência"........................................................... 244

5.2.3 A apropriação dos heróis portugueses.................................... 245 
5.2.4 Os povos nativos: visões etnocêntricas...................................... 249

5.2.5 A translatio da translatio studii et imperii................................... 255

5.3 FATORES POÉTICOS: PRÉ-ROMANTISMO_..................................... 259

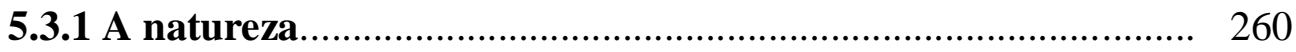

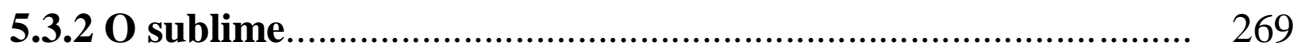

5.3.2.1 O conceito de "sublime".................................................. 269

5.3.2.2 O sublime no Lusiad..................................................... 272

5.3.3 Outros elementos românticos.................................................. 283

5.3.4 Adequação ao gênero épico...................................................... 290

5.4 FATORES IDEOLÓGICO-POÉTICOS............................................... 293

5.4.1 Cristianização da mitologia camoniana..................................... 293

5.4.1.1 A cristianização da Vênus e da Ilha dos Amores................ 293

5.4.1.2 Omissão de Referências Mitológicas................................. 302

5.4.2 Vasco da Gama, o herói............................................................ 303

5.4.3 Atenuação ou supressão da voz crítica do original.................... 311

5.4.3.1 O Velho do Restelo............................................................. 311

5.4.3.2 O final do discurso de Paulo da Gama.............................. 315

5.4.3.3 Os epifonemas.............................................................. 317

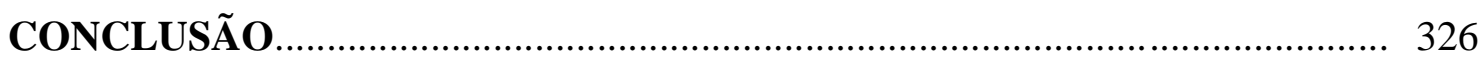

REFERÊNCIAS BIBLIOGRÁFICAS ......................................................... 329

APÊNDICE A: Análise do poema “Almada Hill”, de Mickle............................. 349

APÊNDICE B: Lista das traduções completas de Os lusíadas para o inglês....... 359 


\section{INTRODUÇÃO}

Os lusíadas de Luís Vaz de Camões ultrapassam, em termos de importância cultural, social e histórica, os limites de seu tempo e local de criação. A grande epopeia nacional portuguesa apresenta, em vários aspectos, um alcance universal. Para os brasileiros, Os lusíadas são, além de uma obra-prima e uma das matrizes fundadoras da língua portuguesa, uma narrativa da história das navegações portuguesas - que levaram, entre outras conquistas, ao "descobrimento" do Brasil por Portugal. Ainda que essa narrativa não seja documental, e sim poética e retórica, ela nos fornece um acervo imenso de informações sobre aquele momento histórico.

O poeta escocês William Julius Mickle não foi o primeiro a traduzir Os lusíadas para o inglês; essa primazia coube a Sir Richard Fanshawe ${ }^{1}$, em 1655. A tradução de Fanshawe, contudo, circulou apenas entre um grupo restrito de intelectuais, caindo, em seguida, no esquecimento. $^{2}$ A tradução de Mickle, a segunda para a língua inglesa, alcançou uma repercussão muito maior, tornando-se, ao longo dos anos, a mais lida e citada de todas as traduções da obra para o inglês. ${ }^{3}$ (FERREIRA, 1992a, pp. 64-65; 1992b, p. 70).

As transformações de fundo (acréscimos, omissões, adaptações etc.) operadas n'Os lusíadas de Camões pela tradução de Mickle estão relacionadas às condições históricas, sociais e econômicas de sua produção, assim como aos papéis atribuídos à atividade tradutória no setecentismo britânico. Mickle integrou a epopeia camoniana não apenas à conjuntura sócio-histórico-político-econômica da Grã-Bretanha do século XVIII - herdeira, ironicamente, da riqueza propiciada pela expansão marítima portuguesa do século XVI -, como também às normas culturais da época, uma fase de transição entre o Neoclassicismo augustano e o Romantismo, quando, embora a influência clássica ainda estivesse presente, diversos elementos chamados por alguns estudiosos de "pré-românticos" começavam a se evidenciar.

Com muita habilidade, Mickle montou um verdadeiro "pacote" para vender o seu produto, rotulando o poema de Camões como a "Epopeia do Comércio" e acrescentando à tradução diversos elementos paratextuais: uma introdução em que refuta a tese do "bom

\footnotetext{
${ }^{1} \mathrm{O}$ nome Fanshawe às vezes é grafado como "Fanshaw". Adotamos a grafia "Fanshawe" por ser a mais usada atualmente, mas em citações mantivemos a grafia usada pelo autor citado.

${ }^{2} \mathrm{O}$ interesse pela tradução de Fanshawe ressurgiu no século XX, com a publicação de duas novas edições, uma de Geoffrey Bullough (1963) e outra de Peter Davidson (1998).

${ }^{3}$ Ramos e Lousada (1992, pp. 9-11) listam 18 traduções de Os lusíadas para o inglês, das quais dez completas, até 1980. Deve-se acrescentar à lista de traduções completas a de Landeg White, publicada pela Oxford University Press em 1997. (Ver a lista de traduções completas para o inglês no Apêndice B.)
} 
selvagem" e defende a expansão ultramarina; uma história do descobrimento da Índia; uma história da ascensão e queda do Império Português no Oriente; uma biografia encomiástica de Camões; uma dissertação sobre Os lusíadas e a poesia épica; uma dissertação sobre a "máquina"4 da Jerusalém libertada de Tasso e da Henriade de Voltaire; uma dissertação sobre a ficção da Ilha dos Amores; e cerca de setecentas notas explicativas, algumas bem longas. ${ }^{5} \mathrm{O}$ tradutor foi muito feliz nessa operação, conseguindo transformar o seu produto em um sucesso de vendas: os mil exemplares da primeira edição foram rapidamente vendidos e uma segunda edição foi publicada dois anos depois. Ao todo, essas duas edições lhe renderam cerca de mil libras, uma quantia razoável na época ${ }^{6}$. A popularidade dessa tradução nos séculos XVIII e XIX pode ser comprovada por suas sucessivas reedições na Grã-Bretanha: nove edições foram publicadas em pouco mais de um século desde a primeira publicação. Ainda hoje a tradução de Mickle, mesmo sendo distribuída gratuitamente na Internet, é vendida nas grandes livrarias de língua inglesa, tanto em versões impressas como eletrônicas. (FERREIRA, 1992a, p. 65; 1992b, p. 70; ESTORNINHO, 1960, p. 153).

Nosso trabalho pretende mostrar que a tradução de Mickle de Os lusíadas, na forma do "pacote" acima descrito, espelha a complexa rede de convenções, normas e interesses (conflitantes, paralelos ou convergentes) em vigor no Reino da Grã-Bretanha naquele momento. Essa rede se evidencia pelos discursos representados na obra (quando falamos em "obra" não nos referimos apenas à tradução em si, mas também aos vários paratextos que a acompanham). A tese a ser demonstrada é a de que a tradução de Mickle reencena o ideal da translatio imperii et studii, o conceito medieval segundo o qual haveria uma transmissão do leste para o oeste não só do controle imperial, mas também da cultura e do conhecimento.

As questões formuladas por Paul St. Pierre (1993) ao esboçar os pressupostos de uma "arqueologia da tradução", baseada em conceitos do filósofo Michel Foucault desenvolvidos em A arqueologia do saber (1986), A ordem do discurso (1971) e, mais especificamente, no texto "Politics and the Study of Discourse" (1991), foram de grande auxílio para a organização inicial de nosso trabalho. O pressuposto teórico fundamental do estudo aqui empreendido é o de que a tradução é um discurso, no sentido de um conjunto de enunciados ou atos de linguagem que articulam elementos linguísticos e extralinguísticos - nas palavras

\footnotetext{
${ }^{4} \mathrm{O}$ uso da mitologia pagã.

${ }^{5} \mathrm{Na}$ segunda edição, Mickle ampliou ainda mais a introdução e transformou em dissertação uma nota de rodapé sobre os princípios religiosos e a filosofia dos brâmanes.

${ }^{6}$ Soma que equivaleria atualmente a cerca de 120 mil libras. Todos os cálculos de equivalência monetária foram feitos no sítio Measuring Worth (<http://www.measuringworth.com/ukcompare/>) empregando o Purchasing Power Calculator.
} 
de Foucault (1986, p. 55), "práticas que formam sistematicamente os objetos de que falam”. O "sentido" não está apenas nas palavras, nem sequer no texto - é construído social e culturalmente, como tudo o que se refere ao uso da língua. Assim, para St. Pierre (1993, p. 61), um texto original e sua tradução estão conectados dinamicamente entre si por meio de critérios que regulam as suas relações. A tradução torna visível a existência desses critérios, contribuindo para uma conscientização dos elementos subjacentes à cultura e dos papéis que os textos desempenham em sua própria cultura e nas culturas estrangeiras.

Como já observaram Bassnett e Lefevere (1992, p. vii), toda tradução reflete uma ideologia e uma poética, sendo, como tal, manipulação exercida a serviço do poder. Entretanto, é fundamental ressaltar que não concebemos uma tradução (ou, de maneira mais geral, uma obra) como mero veículo de expressão de ideologias. Uma tradução faz parte do mundo que procura representar. Texto e contexto não são elementos dissociados; o contexto atua na formação do texto, mas o texto também forma o seu contexto. E o tradutor não é apenas um receptor passivo de influências ideológicas; é também um agente transformador.

Nessa perspectiva, um de nossos objetivos é descrever de modo amplo os vários aspectos da tradução de Os lusíadas efetuada por William Julius Mickle relacionando-os às suas condições de enunciação. Para isso, abordagens prescritivistas, por mais sólidas ou instigantes que possam ser, não seriam adequadas. O enfoque de André Lefevere nos pareceu o mais apropriado para o estudo aqui empreendido, por permitir uma ampla análise das relações dessa tradução com o contexto sócio-histórico-político-econômico e cultural de sua produção. A conceituação de Lefevere (2007, p. 12) possibilita o estudo tanto dos aspectos positivos quanto negativos das reescrituras:

Reescritura é manipulação, realizada a serviço do poder, e em seu aspecto
positivo pode ajudar no desenvolvimento de uma literatura e de uma
sociedade. Reescrituras podem introduzir novos conceitos, novos gêneros,
novos artifícios, e a história da tradução é igualmente a história da inovação
literária, do poder formador de uma cultura sobre outra. Mas a reescritura
pode reprimir a inovação, distorcer e conter, e, em uma era de crescente
manipulação de todos os tipos, o estudo dos processos de manipulação da
literatura, exemplificado pela tradução, poderá nos ajudar a nos tornarmos
mais atentos ao mundo em que vivemos.

Os fatores que Lefevere indica como fundamentais para a análise de uma reescritura são aqueles que exercem algum tipo de coerção sobre o tradutor. Em alguns textos Lefevere menciona apenas a ideologia e a poética; em outros, inclui o "universo de discurso" e a língua. Em nosso estudo, daremos maior destaque aos dois primeiros elementos, mas, 
ocasionalmente, nos referiremos aos outros dois. Entendemos "ideologia", em sentido bastante amplo, como um conjunto de ideias, doutrinas e visões de mundo que orientam nossas ações. ${ }^{7} \mathrm{~A}$ "poética" se refere às normas e convenções estéticas que dominam o sistema literário em determinada época. (LEFEVERE, 1992, p. 26). Por "universo de discurso" Lefevere (1992, p. 41) entende o conjunto de objetos, conceitos, conhecimentos, crenças e costumes compartilhados por uma cultura em certo período. E, finalmente, o fator "língua", englobando os níveis locutório e ilocutório, é aquele em que se discutem as diferenças entre a língua de partida e a de chegada.

Utilizamos a palavra "sistema" neste trabalho com um sentido próximo ao dado por Lefevere (1992, p. 12): é um termo neutro, descritivo, indicando um conjunto de elementos inter-relacionados que compartilham certas características que o tornam distinto de outros sistemas. Citando os formalistas russos, Lefevere (1992, p. 14) diz que a literatura é um dos sistemas que constituem o complexo "sistema dos sistemas" conhecido como "cultura"; esta, por sua vez, é o ambiente em que se forma um sistema literário. O sistema literário e os outros sistemas que pertencem ao sistema social interagem, influenciando-se mutuamente.

Talvez valha a pena frisar que nossa concepção de sistema não é a de blocos rigidamente delimitados e que se pretendem representações de uma realidade externa absoluta, imutável e universal. Ao contrário: trata-se apenas de uma ferramenta de análise, que pode variar conforme o tema, o objetivo e a amplitude da análise empreendida. Assim como Vilém Flusser - que foi nosso objeto de estudo na dissertação de mestrado, Vilém Flusser: a tradução na sociedade pós-histórica -, vemos linhas teóricas como modelos, não como "essências". Não são “a verdade": são ferramentas de recorte da realidade.

Nessa mesma linha, gostaríamos de observar que, ao utilizarmos termos de classificação periodológica como "Maneirismo", "Neoclassicismo" e "Romantismo" não estamos associando a esses termos nenhuma interpretação positivista ou evolucionista, nem atribuindo a eles um valor absoluto. São apenas descrições aproximativas de tendências tradicionalmente consideradas predominantes em cada período e que consideramos didaticamente úteis. Obviamente nem todos os estilos, correntes ou movimentos ocorreram de forma igual em todos os lugares, por isso procuramos levar em conta as especificidades locais, assim como a

\footnotetext{
${ }^{7}$ Ao definir ideologia, Lefevere (1992, p. 16) diz estar adotando a definição de Jameson: "Ideology would seem to be that grillwork of form, convention, and belief which orders our actions" ["Ideologia seria o entrelaçamento de formas, convenções e crenças que ordenam nossas ações"]. No entanto, essa definição publicada no livro de Jameson, The Prison-House of Language: A Critical Account of Structuralism and Russian Formalism (Princeton: Princeton University Press, 1972, p. 107), parece se referir ao pensamento de Althusser, e não do próprio Jameson.
} 
eventual ocorrência simultânea de mais de um estilo, corrente ou movimento em um determinado local. Afinal, como observou Lefevere (1981, p. 55), "uma literatura nunca é, em nenhum momento de sua história, o conjunto monolítico como os compêndios escolares tendem a apresentá-la, mas sim, em cada fase de sua evolução, um arranjo de tendências diferentes, muitas vezes antagônicas, dominadas pelo conjunto de obras literárias que determinada época aceita como "canônicas","

Outra característica de nosso trabalho que gostaríamos de destacar é a preocupação didática que, acreditamos, deve acompanhar todo trabalho acadêmico. Foi essa preocupação que nos levou a acrescentar ao trabalho informações que, com certeza, alguns leitores conhecem e outros poderiam, sem grande dificuldade, pesquisar em enciclopédias ou na Internet. Levou-nos também a traduzir para o português todas as citações, até mesmo os poemas. Ainda mais: atendendo à recomendação de nossa Banca de Qualificação, retraduzimos para o português todas as citações da tradução de Mickle de Os lusíadas. É preciso esclarecer que as traduções de poemas cumprem, neste trabalho, apenas a função didática - são literais, privilegiando o conteúdo. Assim, preferimos acrescentar as traduções literais dos poemas escritos originalmente em língua inglesa como notas de rodapé, mantendo os poemas em inglês no corpo do texto. Todas as citações feitas a partir de edições em língua estrangeira foram traduzidas pela autora deste trabalho, a não ser quando outra fonte for indicada nas referências. A tradução e a retradução dos poemas escritos em inglês setecentista foi trabalhosa; embora tenhamos contado com as sugestões de uma amiga norte-americana, Theresa Ann Wymer, além da revisão de nossa orientadora, Lenita Esteves, e o auxílio de dicionários da época (principalmente o Dictionary do Dr. Johnson), obviamente há certo nível de subjetividade envolvido na escolha de determinadas soluções. Nas retraduções, quando o termo empregado pelo tradutor pareceu-nos próximo àquele utilizado em português, procuramos manter o termo usado por Camões.

A organização do trabalho em capítulos reflete os passos que consideramos necessários para demonstrar que o Lusiad de Mickle reencena uma translatio studii et imperii, adaptando Os lusíadas em termos poéticos e ideológicos à Grã-Bretanha do século XVIII. Assim:

O Capítulo 1 discute o conceito de translatio studii et imperii e seu percurso na Europa desde a era medieval até o início da era moderna, demonstrando a sua permanência ao longo dos anos.

\footnotetext{
8 " [...] a literature is never, at any moment in its history, the monolithic whole which textbooks tend to present it as, but rather, in each phase of its evolution, a collocation of different, often antagonistic, trends dominated by the set of literary works a given era accepts as "canonized."
} 
O Capítulo 2 descreve o ponto de partida da translatio que será reencenada por Mickle: o Império Português dos séculos XV e XVI (o contexto social, histórico, político, econômico e cultural em que Os lusíadas foram escritos); apresenta sucintamente o autor, Luís Vaz de Camões, e o poema Os lusíadas; aponta Os lusíadas como uma encenação do conceito de translatio e encerra-se com uma exposição da recepção ao épico camoniano desde sua publicação até o final do século XVIII.

O Capítulo 3, por seu turno, examina o ponto de chegada da translatio: o momento histórico, social, político, econômico e cultural em que foi efetuada a tradução de Mickle de Os lusíadas para o inglês.

O Capítulo 4 focaliza o agente da translatio, o tradutor William Julius Mickle, seu modo de inserção no sistema literário, e os modos de circulação, suportes materiais e elementos paratextuais de sua tradução de Os lusíadas, assim como a recepção dessa tradução tanto na época de sua publicação quanto em épocas posteriores.

O Capítulo 5 apresenta uma análise comparativa entre o original e a tradução, orientada pelos conceitos de Lefevere, a fim de ressaltar as modificações efetuadas por Mickle no sentido de adaptar Os lusíadas, nos aspectos ideológico e poético, à Grã-Bretanha de sua época.

A Conclusão oferece uma síntese do trabalho, relacionando o que foi exposto nos demais capítulos com a tese defendida. 


\section{TRANSLATIO STUDII ET IMPERII}

Este capítulo discute o conceito de translatio studii et imperii e seu percurso na Europa desde os tempos medievais até o início da era moderna. A translatio studii et imperii é um conceito de origem medieval, segundo o qual, em analogia com o movimento do sol, haveria uma transmissão do leste para o oeste não só do controle imperial, mas também da cultura e do conhecimento. A civilização, surgida no Oriente Próximo, teria sido gradualmente transmitida para a Grécia e depois para Roma. Curtius (1996, p. 62) comenta que a ideia da sucessão de um império por outro encontrava sustentação na Bíblia - no Eclesiástico 10:8 (“O poder passa de uma nação para outra por causa da injustiça, da violência e das riquezas") ${ }^{1}$ e em Daniel 2:21 ("Ele muda os tempos e as estações; ele remove os reis e estabelece os reis; é ele quem dá a sabedoria aos sábios e o entendimento aos entendidos" ${ }^{2}$. Essas passagens eram usadas na Europa medieval para fundamentar a translatio imperii, ou seja, a ascensão e queda dos impérios e as mudanças de domínio político. A legitimidade do Império de Carlos Magno foi justificada exatamente com base na ideia de translatio: o Império Romano estaria sendo transferido para o Império Carolíngio.

Na história contada no livro de Daniel (2:29-49), o rei Nabucodonosor, da Babilônia, sonhou com uma grande estátua, de cabeça de ouro, peito e braços de prata, ventre e coxas de bronze, pernas de ferro e pés parcialmente de ferro e parcialmente de barro. Enquanto Daniel admirava a escultura, uma enorme pedra caiu do alto, acertando os pés da estátua e destruindo-a. A pedra cresceu até se transformar em uma montanha e cobrir toda a Terra. $\mathrm{Na}$ interpretação de Daniel, o rei seria a cabeça de ouro, e as outras partes da estátua seriam diferentes impérios que se sucederiam no controle e domínio do mundo. Posteriormente, pensadores cristãos como Santo Agostinho, São Tomás de Aquino e Lutero, deram uma interpretação mais historicista ao sonho: a cabeça de ouro seria o Império Babilônico; o peito e os braços de prata, o Império Medo-Persa; o ventre e as coxas de bronze, a Grécia Helenística; as pernas de ferro seriam o Império Romano, e os pés de ferro e barro denotariam o Império Romano dividido. (Há várias outras interpretações, com maiores ou menores discrepâncias em relação a essa, que é a mais frequente no final da Idade Média.)

\footnotetext{
${ }^{1}$ Tradução extraída do sítio Bíblia Católica Online. Disponível em:

< http://www.bibliacatolica.com.br/24/28/10.php\#.URpm4h1mVa4>. Acesso em 12 fev. 2013.

${ }^{2}$ Tradução extraída do sítio Bíblia Online. Disponível em: <http://www.bibliaonline.com.br/aa+acf/dn/2〉. Acesso em 12 fev. 2013.
} 
O historiador medievalista Jacques Le Goff (1990, pp. 305-306) observa que esse relato de Daniel introduz uma contagem mítica do tempo histórico que alcança grande repercussão, possibilitando uma 'tentativa de periodização 'política' da história e, ao mesmo tempo, um esboço de descrição e interpretação da evolução histórica, do ponto de vista político e cultural". A concepção de que a história desloca os centros de poder para o oeste será uma das fontes da ideologia ocidental e acentuará “o isolamento da civilização cristã pela rejeição às civilizações contemporâneas, a bizantina, a muçulmana, as asiáticas"3 (LE GOFF, 2008, p. 145). Outro aspecto dessa teoria - mencionado por Haywood (2009) - é que ela é a imagem de uma transmissão unidirecional, em que o poder e a cultura são transferidos sem alterações. Por meio dela, a historiografia cristã assume a forma de uma história dos vencedores, aqueles que foram escolhidos por Deus.

A língua era um importante aspecto da translatio studii que acompanhava a translatio imperii. O humanista italiano Francesco Petrarca - o formulador, segundo Erwin Panofsky (1960, p. 30), da ideia de renovação sob a inspiração dos clássicos, que viria a ser muito influente na Renascença - sempre demonstrou grande preocupação com o aspecto linguístico da translatio imperii. Petrarca teria esperado que a nova era trouxesse não apenas uma regeneração política, mas, acima de tudo, a purificação da gramática e dicção latinas, a revivificação do grego e o regresso aos antigos textos clássicos.

A tradução, obviamente, desempenhou um papel primordial na translatio studii. $\mathrm{O}$ próprio termo translatio, em latim, significava ao mesmo tempo "tradução" e "transferência". ${ }^{4}$ Foi por meio de traduções que os romanos se apropriaram da riqueza cultural da Grécia. Na Idade Média, esse processo de apropriação teve continuidade - a cultura pagã dos gregos e romanos precisou ser adequada aos padrões cristãos medievais. O latim escrito se transformou em língua franca na Europa medieval - a língua em que se escreviam os textos científicos, jurídicos e religiosos. O latim vulgar, por sua vez, deu origem às línguas vernáculas europeias. Por volta do século IX, as diferenças entre o latim clássico e o vulgar já eram tão acentuadas que a própria Igreja e a realeza passaram a autorizar as traduções para o vernáculo. Essas vieram a ter um importante papel na maturação e padronização das línguas vernáculas. Ao descrever o percurso da translatio studii et imperii na Europa desde a era

\footnotetext{
3 "l'isolement de la civilisation chrétienne en rejetant les civilisations contemporaines, la byzantine, la musulmane, les asiatiques".

4 A palavra traductio não existia em latim, tendo surgido apenas quando as línguas vernáculas já estavam se estabelecendo. O primeiro a usá-la foi Leonardo Bruni, baseando-se, segundo Berman (1988, p. 30), no particípio passado traductum empregado pelo autor latino Aulo Gélio. Para Gélio, porém, traductum não significava "traduzido", e sim "transportado".
} 
medieval até o início da Idade Moderna, procuraremos acompanhar também, no contexto dessa teoria, o percurso da tradução.

\subsection{O “CLÁSSICO” E A ORIGEM DO CONCEITO DE TRANSLATIO}

No interessante livro The classic: literary images of permanence and change, Frank Kermode (1983) discute a permanência do clássico e suas relações com o imperialismo. A doutrina do clássico como modelo pressupõe que o antigo seja mais ou menos acessível e, em certo sentido, contemporâneo, ou que sua natureza seja tal que ele possa, por estratégias de adaptação [accomodation], ser transformado em acessível e contemporâneo. A questão é: como as obras do passado podem conservar a identidade na mudança? (KERMODE, 1983, pp. 15-16).

Kermode (1983, pp. 16-20) cita o Étude sur Virgile, de Sainte-Beuve, que defende a tese de que o poeta Virgílio deu uma nova forma não apenas à poesia, mas à civilidade [civility, termo que abrange as paixões, o gosto e a sensibilidade], tornando-se o clássico do império e o modelo [type] de todos os clássicos e da cultura latina universal. T. S. Eliot, no ensaio "What's a Classic?", endossa a tese de Sainte-Beuve e a doutrina que a acompanha, de que "a história é, sob toda aparência de mudança, uma unidade; que o moderno não é completamente novo, mas uma renovação de um clássico que a ação do tempo obscureceu, e que agora reaparece em uma nova relação com o moderno"6.

Uma das razões pelas quais Virgílio é considerado o elo entre a Roma pagã e a cristã, entre o velho e o novo mundo, é a Quarta Écloga, que foi interpretada pelos cristãos medievais como uma profecia do nascimento do Cristo:

Eis que chega a fase final da profecia de Cumas.

Eis que recomeça a grande ordem dos séculos.

Já volta outra vez a Virgem, volta o reino de Saturno.

Uma nova geração já desce do alto céu.

Essa criança, cujo nascimento porá fim à Idade do Ferro

E trará de volta a Idade do Ouro em todo o mundo,

Proteja-a, casta Lucina: já reina o teu querido Apolo. ${ }^{7}$

\footnotetext{
${ }^{5}$ ELIOT, T. S. O que é um clássico? In: Ensaios escolhidos. Lisboa: Cotovia, 1992.

6 “ $[$.... history is, under all appearance of change, a unity; that the modern is not absolutely new, but a renovation of a classic which the action of time has obscured, and which now reappears in a new relationship with the modern."

7 "Ultima Cumaei venit iam carminis aetas; magnus ab integro saeclorum nascitur ordo. Iam redit et Virgo, redeunt Saturnia regna; iam nova progenies caelo demittitur alto.
} 
Mesmo que atualmente os estudiosos refutem a vinculação estabelecida pelos cristãos medievais e interpretem essa écloga no contexto da missão recebida por Virgílio de exaltar o Império (a écloga seria um epitalâmio ao nascimento do filho de Marco Antônio e Otávia), o importante é que ela abriu, para Virgílio, as portas para o mundo cristão.

Na Eneida Virgílio (1983, p. 25) retoma seu papel de profeta do Império (um “império sem fim"): "A estes nem ponho limites às conquistas nem tempo: dei-lhes um império sem fim".

No Livro VI, Eneias, em sua jornada pelo Inferno na companhia da sibila de Cumas, escuta dos lábios de Anquises a profecia da volta da Idade do Ouro sob Augusto:

Volta, agora, teus olhares para aqui: olha esta nação; são os teus romanos. Este aqui é César e toda a descendência de Iulo, destinada a vir sob a grande abóbada do céu. Este é César Augusto, filho dum deus, que tantas vezes ouviste ser-te prometido; de novo há de trazer do Lácio séculos de ouro, por entre as campinas outrora governadas por Saturno; estenderá seu império mais longe que o país dos garamantes e dos indianos [...] (VIRGÍlLIO, 1983, p. 136).

[...] tu, romano, lembra-te de governar os povos sob teu império. Estas serão tuas artes, impor condições de paz, poupar os vencidos e dominar os soberbos. (pp. 137-138)

Na Vita Constantini, do historiador romano Eusébio, pode-se ler um discurso de Constantino em que este recita a Quarta Écloga em uma tradução grega que enfatizava o seu caráter de profecia do nascimento de Cristo. Em 324 d.C., Constantino transformou Bizâncio em Constantinopla, concebendo-a como a nova Roma, e lá estabeleceu a sede de seu poder imperial. Ao transferir a sede do império para o Oriente, Constantino teria, na visão de Kermode (1938, p. 29), criado a divisão entre a cristandade europeia e a oriental, produzindo uma situação histórica que centralizava o poder nas mãos do Papa e que levou à falsificação de um documento, a Donatio Constantini [Doação de Constantino], possivelmente no século VIII ou IX, pelo qual Constantino legava ao Papa Silvestre - e, por extensão, a todos os seus sucessores - a autoridade suprema sobre todos os outros bispos no Ocidente e sobre os patriarcas de Antioquia, Alexandria, Constantinopla e Jerusalém. O imperador também cedia

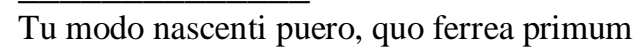
desinet ac toto surget gens aurea mundo, casta fave Lucina: tuus iam regnat Apollo." Disponível em: <http://rainybluedawn.com/translations/latin/eclogue4.htm>. Acesso em: 18 fev. 2013. Traduzimos para o português cotejando o original e a tradução para o inglês que consta nesse sítio. 
ao Papa a cidade de Roma, toda a península itálica e todas as províncias e estados do Império do Ocidente.

Segundo Kermode (1983, pp. 29-30), quando Leão III coroou Carlos Magno em 800, ele o fez com base na autoridade da Doação. A coroa pertencia a ele e ele a transmitia a Carlos Magno como um "favor apostólico", transferindo o império do Oriente para o Ocidente e transformando um franco em imperador de todos os romanos, do Ocidente e do Oriente. Carlos Magno não aceitou esse papel, preferindo restringir sua influência aos cristãos europeus. O conceito de império do Papa era mais amplo em extensão, mas incluía também a doutrina da subordinação do imperador ao Papa - o que veio a gerar muitos conflitos mais tarde. Ao adotar o lema Renovatio Romani Imperii [Renovação do Império Romano], Carlos Magno enfatizava o caráter ocidental de seu reinado. E como a translatio imperii devia ser acompanhada da translatio studii ${ }^{8}$, a renascença carolíngia foi uma renovação das letras clássicas, que, introduzindo mudanças nos modelos clássicos, os tornaram mais acessíveis aos novos tempos.

Kermode (1983, p. 30) ressalta que, apesar da interpretação independente dada por Carlos Magno a seus poderes e deveres, a doutrina imperial tinha origem papal. Ao transferir o império de um franco para um germânico na coroação de Otto I, o Papa João XII, no ano de 962, estava novamente exercendo o direito de efetuar a translatio imperii. Seguiu-se, como sempre, a translatio studii, o que era essencial para manter a mística do império.

Durante a dinastia dos Hohenstaufen no Sacro Império Romano-Germânico, Otto von Freising, tio de Frederico I, o Barba Ruiva, estabeleceu, em sua Chronica sive historia de duabus civitatibus [Crônica ou história das duas cidades], escrita entre 1143 e 1146, uma correlação entre translatio imperii e translatio sapientiae, afirmando que tanto o poder quanto o saber se transferiam do leste para o oeste. Seguindo Santo Agostinho, Freising fala na sucessão de quatro impérios mundiais, a Babilônia, o Império dos Medos e Persas, a Grécia e Roma. A expressão translatio sapientiae se modifica ao longo do tempo, primeiro para translatio studii sapientiae, e depois, enfim, para translatio studii. (STIERLE, 1996, pp. 56$57)$.

Afirmando que a alegoria é um dos principais instrumentos pelos quais os textos antigos são adaptados às culturas modernas, Kermode (1983, p. 39) menciona, entre outros exemplos, a alegorização de Homero pelos estoicos; as exegeses bíblicas dos helenísticos; e a

\footnotetext{
${ }^{8}$ Embora essa expressão não houvesse ainda surgido, como comentaremos a seguir.
} 
preocupação da Escola de Chartres, no "Renascimento" do século XII, em estabelecer a autoridade de autores pré-cristãos, especialmente Platão, por meios alegóricos.

Para Kermode (1983, p. 40) há duas formas de se preservar um clássico. A primeira depende da filologia e da historiografia, e implica um esforço hermenêutico, uma pesquisa sobre o que o clássico significou para o seu autor e seus melhores leitores, e o que pode ainda significar para aqueles que possuam os conhecimentos e talentos necessários. A segunda seria o método da adaptação [accommodation], ou seja, "qualquer método pelo qual o velho documento pode ser induzido a significar o que não se pode dizer que tenha afirmado expressamente" . O principal instrumento para isso é a alegoria (tomada em um sentido amplo, que inclua, por exemplo, a profecia). ${ }^{10}$

Outro instrumento privilegiado para a translatio dos clássicos é a tradução. Na Idade Média, a tradição exegética operava em quatro níveis interpretativos (literal, moral, alegórico e anagógico) para reconstituir os textos pagãos da Antiguidade greco-latina como textos cristãos (ROBINSON, 1997, p. 53). À medida que as línguas vernáculas começaram a se firmar, a tradução foi chamada a contribuir nessa tarefa.

Ao final da Idade Média, a tradução se envolveu em novos tipos de translatio. O poeta e trovador francês Chrétien de Troyes, autor de novelas arturianas e considerado o primeiro grande novelista de língua francesa, expõe no prefácio da novela Cligès (1176) uma teoria segundo a qual a Grécia seria a origem da cavalaria; esta teria sido depois transmitida para Roma, e daí para a França (a França ideal de Chrétien era, na verdade, a Inglaterra): “[...] na Inglaterra, que naquela época era chamada de Bretanha" ${ }^{11}$. Tendo chegado ao extremo oeste da Europa, o movimento de translatio lá se encerraria. O ideal de amor cortês de Chrétien é inconcebível sem um novo ideal de língua. O próprio narrador se apresenta como tradutor do latim morto para o francês vivo. O francês se torna o veículo privilegiado da translatio studii. Na novela, a tese do prefácio é encenada: o jovem Alexandre, filho do imperador grego de mesmo nome, decide ir para o oeste a fim de se tornar um cavaleiro na corte arturiana. (STIERLE, 1996, pp. 58-59).

\footnotetext{
9 "any method by which the old document may be induced to signify what it cannot be said to have expressly stated".

${ }_{10}^{10}$ Ao enfrentar o paradoxo evocado pelo clássico - o de que há uma identidade, mas esta muda -, Kermode (1983, p. 44) conclui que "the books we call classics possess intrinsic qualities that endure, but possess also an openness to accomodation which keeps them alive under endlessly varying dispositions" ["os livros que chamamos de clássicos possuem qualidades intrínsecas que persistem, mas possuem também uma abertura para a adaptação que os mantêm vivos sob disposições incessantemente variáveis"]. Ao admitir "qualidades intrínsecas" para os clássicos, Kermode aceita um critério que poderíamos considerar "essencialista". Em nossa visão, qualquer que seja a forma de se ter acesso ao clássico, ela dependerá sempre de uma interpretação.

11 "[...] en Engleterre, qui lors estoit Bretaigne dite". A antiga Bretanha, palco de tantas lendas e mitos, ocuparia parte do território francês e quase todo o Reino Unido atual.
} 


\subsection{A TRANSLATIO NO INÍCIO DA IDADE MODERNA}

No século XVI, quando a lealdade religiosa a Roma estava chegando ao fim e soberanos precisavam assegurar a continuidade e sacralidade de sua autoridade, a adaptação de temas imperialistas para exaltar a nação se tornou mais sistemática e elaborada. Carlos I da Espanha converteu-se em um soberano quase universal, sendo eleito imperador do Sacro Império Romano, com o título de Carlos V; rei de Nápoles e Sicília, como Carlos IV; e colecionando títulos como o de Conde da Holanda, da Zelândia e vários outros, além de dominar um território que se estendia não apenas do Mar do Norte até o Mediterrâneo, mas também até o Atlântico e para além do Novo Mundo. (KERRIGAN; BRADEN, 1989, p. 7). Católico, Carlos V restaurou o imaginário e os rituais do antigo Império Romano. Nas palavras de Kermode (1983, p. 57): "ele era Augusto, trazendo a Idade do Ouro virgiliana, e assim como Virgílio estava para Augusto, os grandes artistas da época estavam para Carlos"12. O humanista e filólogo Antonio de Nebrija (1444-1522) redigiu a primeira Gramática de la lengua castellana postulando uma translatio studii que culminava na Espanha. Língua e império eram vistos como elementos de um conjunto inseparável: o momento de esplendor da língua escrita coincidiria com o advento do império. E até o escritor italiano Ludovico Ariosto (1474-1533), no poema épico Orlando furioso, anunciou Carlos V como aquele que, ao estabelecer a monarquia universal, restauraria o domínio de Astraea, a personificação da justiça, da inocência e da pureza, que aparece na Quarta Écloga de Virgílio como a Virgem para simbolizar a vinda de uma Idade de Ouro e que havia sido, para Dante, o símbolo do império sagrado.

$\mathrm{Na}$ França, o escritor renascentista Jean Lemaire de Belges reavivou a lenda das origens troianas da Gália, surgida no século VII, ao publicar Les Illustrations de Gaule et Singularités de Troie por volta do ano de 1500. Na história contada por Lemaire de Belges, o príncipe troiano Astíanax, filho de Heitor, sobrevivente da Guerra de Troia, muda seu nome para Francion (ou Francus), torna-se o rei da Gália céltica e funda a dinastia que dará origem a Pepino e Carlos Magno. A lenda de Francus servirá de base para a epopeia inacabada de Pierre de Ronsard, La Franciade, escrita sob encomenda de Henrique II (os quatro primeiros cantos foram publicados em 1572, o mesmo ano da publicação de Os lusíadas).

Na Inglaterra, a dinastia Tudor também elaborou um mito de criação, segundo o qual os britânicos eram uma raça única, descendente de um fugitivo de Troia, Brutus (uma invenção

\footnotetext{
12 "he was Augustus, bringing in the Virgilian Golden Age, and as Virgil was to Augustus so were the great artists of the time to Charles".
} 
de Geoffrey de Monmouth, no século XII). O rei Artur, também criação de Monmouth, foi acrescentado ao mito, dando aos ingleses uma ascendência troiano-céltica. Segundo Kermode (1983, p. 58), “A renovatio da Igreja e do Império ingleses encontrou o seu Eusébio ${ }^{13}$ em Foxe $^{14}$, o seu Virgílio em Spenser" ${ }^{\prime 15}$. Os artistas apologistas da rainha Elisabete, beneficiários da translatio studii que acompanhava a renovação, se desdobravam para glorificar o imperium, valendo-se das técnicas da retórica clássica. Astraea foi identificada a Elisabete. Ariosto transformara Carlos $\mathrm{V}$ no arauto de Astraea, mas a Inglaterra era governada pela própria deusa. Spenser, muito influenciado por Ariosto, construiu The Faerie Queene em torno da figura de Elisabete e escreveu uma Quarta Écloga, nos moldes de Virgílio, em homenagem à rainha. (HAMILTON, 1990, p. 187; KERMODE, 1983, p. 59). Vemos, assim, os clássicos retornando sob novas roupagens para dar sustentação ao império.

$\mathrm{Na}$ época elisabetana, a tradução desempenhava um papel fundamental na formação da identidade nacional, pois essa identidade estava ligada à consolidação da língua nacional. Nas palavras de Francis Otto Matthiessen (1931, p. 3):

Um estudo das traduções elisabetanas é um estudo dos meios pelos quais a Renascença chegou à Inglaterra. A nação se tornara consciente de sua inferioridade cultural em relação ao Continente, e de repente foi tomada pelo desejo de superar seus rivais nas letras, assim como em navios e ouro. $\mathrm{O}$ trabalho do tradutor era um ato de patriotismo. Ele também, assim como o viajante e o comerciante, podia fazer algo em prol do país: ele acreditava que os livros estrangeiros eram tão importantes para o destino da Inglaterra quanto as descobertas dos navegadores, e trouxe-os para a sua língua natal com todo o entusiasmo de uma conquista. ${ }^{16}$

Como observa Eric Cheyfitz (1997, p. 101, p. 103), ao ligar o viajante ao tradutor, Matthiessen indica que a "conquista" dos livros estrangeiros, a sua tradução para o inglês, era o caminho para a conquista da identidade nacional, a sua transferência/tradução da barbárie

\footnotetext{
${ }^{13}$ Eusébio (265?-339), bispo da Cesareia, historiador do cristianismo, conhecido por sua História eclesiástica, uma vasta compilação de documentos sobre a história da Igreja.

${ }^{14}$ John Foxe (1516/17-1587), historiador inglês, puritano, autor de Actes and Monuments, popularmente conhecido como $O$ Livro dos Mártires, que contém relatos da perseguição e martírio de protestantes pelos pagãos e pela Inquisição.

${ }^{15}$ "The renovatio of English Church and Empire found its Eusebius in Foxe, its Virgil in Spenser".

16 "A study of Elizabethan translations is a study of the means by which the Renaissance came to England. The nation had grown conscious of its cultural inferiority to the Continent, and suddenly burned with the desire to excel its rivals in letters, as well as in ships and gold. The translator's work was an act of patriotism. He, too, as well as the voyager and merchant, could do some good for his country: he believed that foreign books were just as important for England's destiny as the discoveries of her seamen, and he brought them into his native speech with all the enthusiasm of a conquest."
} 
para a civilização. Havia, portanto, uma identificação entre tradução e translatio, e a tradução era uma espécie de passaporte para a civilização.

Vemos, assim, que o conceito de translatio studii et imperii chegou ao início da Idade Moderna com plena força, e que a tradução era um de seus principais veículos. No Capítulo 2, seção 2.5, estudaremos a influência desse conceito em Portugal no século XVI e n'Os lusíadas; no Capítulo 3, seção 3.5, veremos como ele foi utilizado na criação de uma retórica poética para exaltar o crescente poder do Império Britânico; no Capítulo 4, examinaremos como Mickle o aplicou nos paratextos à tradução de Os lusíadas, e no Capítulo 5, na própria tradução. 


\section{OS LUSÍADAS}

Este capítulo investiga o ponto de partida da translatio reencenada por William Julius Mickle: o poema épico Os lusíadas, de Luís Vaz de Camões, em seu contexto social, histórico, político, econômico e cultural, assim como a recepção a Os lusíadas em Portugal e na Europa desde sua publicação até o final do século XVIII (quando Mickle elaborou a sua tradução).

A primeira seção relata o momento histórico da criação da epopeia camoniana: a expansão marítima, nos séculos XV e XVI, que rendeu grande prosperidade a Portugal até a catástrofe que se abateu sobre o reino um pouco antes do final do século (logo após a publicação d'Os lusíadas, em 1572), com a morte de D. Sebastião, a derrota diante dos sarracenos, em 1578, e a subsequente passagem de Portugal para o domínio espanhol, em 1580. A segunda seção descreve, sucintamente, o Quinhentismo literário português - as características do Renascimento e do Maneirismo e a coexistência entre a cultura medieval e a clássica. A terceira seção focaliza o autor, Camões, em duas subseções: biografia e obra. A quarta seção descreve, em linhas gerais, o poema Os lusíadas. A quinta seção aponta a filiação da epopeia camoniana à teoria da translatio studii et imperii, da qual seria uma encenação. A sexta e última seção aborda a recepção a Os lusíadas tanto em Portugal (primeira subseção) quanto nos demais países europeus (segunda subseção), desde a época da publicação da obra até o final do século XVIII, quando foi lançada a tradução de Mickle. O estudo da recepção da obra foi incluído aqui não apenas porque Mickle teve acesso a muitas dessas fontes, direta ou indiretamente, como também porque, de qualquer forma, elas contribuíram para a imagem que o século XVIII britânico formou a respeito do épico camoniano.

\subsection{CONTEXTO SÓCIO-HISTÓRICO-POLÍTICO-ECONÔMICO: A EXPANSÃO MARÍTIMA PORTUGUESA}

A partir do século XI, a Europa Ocidental passou por uma série de transformações que levaram à transição do feudalismo para o capitalismo, assinalando o fim da Idade Média e início da Idade Moderna. Nesse período, que os historiadores costumam chamar de Renascimento Comercial, as atividades comerciais, até então secundárias, adquiriram uma importância econômica cada vez maior. Em consequência, acentuou-se a influência dos comerciantes (burguesia mercantil ou comercial), com o enfraquecimento paralelo da nobreza 
medieval. Os grupos econômicos interessados na livre circulação de mercadorias aliaram-se ao poder real na busca de uma maior centralização que possibilitasse o crescimento e dinamização de suas atividades. Surgiram, assim, os Estados Modernos, ou Monarquias Nacionais.

A ampliação dos mercados consumidores instigava os comerciantes a buscar as riquezas provenientes de regiões fora da Europa. Produtos como especiarias, drogas e metais preciosos eram muito valorizados no mercado europeu, mas o monopólio dos turcos, árabes e italianos freava o desenvolvimento de tal comércio. Com a formação do Estado Moderno, foi possível mobilizar recursos em escala nacional para a expansão marítima, dando início às Grandes Navegações.

Nesse novo cenário, Portugal exerceu um papel de vanguarda em relação às demais nações europeias, tendo sido um dos primeiros países europeus a fixar fronteiras relativamente estáveis e a centralizar o poder nas mãos do rei. A monarquia portuguesa se formou ao longo das guerras contra os invasores árabes da Península Ibérica, a chamada Reconquista, a partir do século VIII. Em 1139, Afonso Henriques, filho de Henrique de Borgonha, foi proclamado rei de Portugal, rompendo os laços com Leão e Castela. Em 1385, com a Revolução de Avis e a aclamação de D. João I como rei de Portugal, os portugueses completaram a formação do seu Estado Nacional.

Os monarcas da dinastia de Avis (1385-1580) incentivaram a expansão marítima. A crescente classe mercantil lusitana estabeleceu postos comerciais em vários pontos da Europa, mantendo relações econômicas com os povos nórdicos e outros comerciantes na Inglaterra, Península Itálica e na região de Flandres. Em 1415, a conquista de Ceuta, cidade islâmica no Norte da África, empreendida por uma expedição composta pela fina flor da aristocracia portuguesa do século XV - incluindo D. Duarte, D. Pedro e D. Henrique, filhos do rei D. João I - marcou o início da expansão marítima portuguesa.

Segundo Charles Boxer (1980, p. 34), um fator importante que favoreceu a expansão marítima portuguesa foi o fato de Portugal ter vivido um período de relativa paz ao longo do século XV (exceto pelo episódio de Alfarrobeira, em 1449), enquanto os outros países da Europa Ocidental estiveram envolvidos em guerras civis ou externas - Guerra dos Cem Anos, Guerra das Duas Rosas — ou se viram diante de ameaças de invasão, como aquelas promovidas pelo avanço turco nos Bálcãs e no Levante.

O fator religioso também contribuiu para impulsionar as navegações em Portugal. Mesmo depois da Reconquista, os portugueses continuaram se empenhando no combate aos muçulmanos, que consideravam inimigos de sua fé. A difusão da fé nos territórios 
conquistados sempre foi uma das principais metas da coroa portuguesa, e a busca do reino lendário do Preste João, um soberano cristão que poderia se tornar um aliado fundamental no combate aos muçulmanos, era uma preocupação constante dos reis portugueses no início das Grandes Navegações.

Um último fator que instigou muitos aventureiros a se lançarem em longas expedições na fase inicial das navegações foi a procura do ouro da Guiné.

Pouco a pouco, os portugueses foram avançando pela costa africana, abrindo várias feitorias e colonizando ilhas atlânticas, como os Açores, Madeira, São Tomé, Cabo Verde e Canárias. Em 1488, Bartolomeu Dias atingiu o Cabo da Boa Esperança, antes conhecido como Cabo das Tormentas, no sul da África.

Em 8 de julho de 1497, a frota de Vasco da Gama zarpou do Restelo, em Lisboa, rumo à Índia. Como a história dessa expedição constitui o tema central de Os lusíadas, veremos mais detalhes sobre ela ao longo deste trabalho. Por enquanto, diremos apenas que, apesar das perdas (da tripulação total de 170 homens, distribuídos em quatro embarcações, retornaram apenas 55 homens em duas embarcações), a expedição foi bem-sucedida em seus objetivos, com a chegada de Vasco da Gama a Calecute, nas Índias, em 1498.

O ciclo das grandes conquistas ultramarinas portuguesas não se encerrou com a chegada de Vasco da Gama a Calecute: em 1500, a esquadra de Pedro Álvares Cabral aportou no Brasil; dando sequência à conquista de postos comerciais na África e nas Índias, os portugueses construíram um forte em Cochim e fundaram postos comerciais em Sofala, Mombaça e Moçambique em 1503; em 1510 e 1511 tomaram, respectivamente, Goa e Malaca; finalmente, chegaram até Macau, onde, em 1557, estabeleceram uma base de comércio entre a China, o Japão e a Europa. (SILVEIRA; MONGELLI; CUNHA, 1993, p. 15; BETHENCOURT; CURTO, 2007, p. 1).

O período entre meados da década de 1490 e início da década de 1540 é considerado por muitos historiadores como a Idade do Ouro para Portugal. O comércio exterior expandiuse de modo impressionante, gerando prosperidade a vários grupos e indivíduos no reino. Logo em seguida, no entanto, Portugal enfrentou diversos problemas econômicos e políticos, que culminaram, ao final do século, com a morte de D. Sebastião, a derrota diante dos sarracenos, em 1578, e a subsequente passagem de Portugal para o domínio espanhol, em 1580. 


\subsection{CONTEXTO CULTURAL-LITERÁRIO: RENASCIMENTO / MANEIRISMO}

As descobertas científicas e marítimas realizadas nos séculos XV e XVI deram à humanidade uma nova visão da realidade e de suas possibilidades. O próprio conhecimento do planeta modificou-se depois dos descobrimentos advindos das Grandes Navegações. Boxer (1980, p. 15) observa:

O cronista espanhol Francisco López de Gómara, na dedicatória de sua História geral das Índias para o imperador Carlos V, escrita em 1572, descreveu os descobrimentos ibéricos das rotas oceânicas das Índias ocidentais e orientais como "o maior acontecimento desde a criação do mundo, depois da encarnação e da morte Daquele que o criou". Aproximadamente dois séculos mais tarde, o economista político escocês Adam Smith afirmava textualmente o mesmo ao escrever: "A descoberta da América e a da passagem para as Índias Orientais, através do cabo da Boa Esperança, são os dois maiores e mais importantes acontecimentos de que se tem registro na história da humanidade".

Boxer comenta que, antes dos descobrimentos de portugueses e espanhóis, os vários ramos da humanidade encontravam-se dispersos e isolados. Um dos aspectos do Renascimento foi exatamente o de buscar harmonizar o Neoplatonismo pagão com a religião cristã e assimilar as influências orientais, judaicas e árabes. Esse processo já havia se iniciado, na verdade, com a tomada de Constantinopla pelos turcos e a consequente fuga dos sábios para a Itália, em 1453. Os sábios bizantinos desempenharam um papel fundamental na disseminação dos estudos clássicos e na revalorização da tradição greco-romana em vários campos do conhecimento.

O Renascimento italiano se inicia, justamente, a partir do interesse em descobrir e recuperar os textos originais das obras de autores da Antiguidade greco-latina. A tradução e o comentário de textos teóricos greco-latinos, em especial a Poética de Aristóteles e a Arte poética de Horácio, levaram à formulação de preceitos estéticos. A doutrina renascentista preconizava o domínio da Razão, o conhecimento baseado na observação da Natureza e a imitação dos Antigos, até mesmo quanto a preceitos extraídos de Aristóteles ou Horácio, como o da verossimilhança (não cabe ao autor narrar o que realmente acontece, mas o que é possível, verossímil), o da necessidade (deve haver uma concatenação entre as partes e o todo de modo que cada parte seja considerada necessária à ação), o da conveniência (manter uma harmonia interna entre o tema e os meios de expressão, assim como uma harmonia externa entre a obra e o público a que se destina), as distinções rígidas entre os gêneros, a regra das três unidades para o teatro e da ação única para a epopeia. 
Em Portugal, as mudanças culturais também foram profundas. Desde a Revolução de Avis, de 1385, com o fortalecimento do nacionalismo, a língua portuguesa começou a se firmar, ganhando espaço em relação ao latim e ao castelhano. No século XVI foram publicados dois tratados normativos de gramática: o de Fernão de Oliveira, em 1536, e o de João de Barros, de 1540. Os lusíadas, publicados em 1572, tiveram grande importância na fixação de uma ortografia do português moderno. No reinado de D. João III, completou-se a reforma universitária em Coimbra, com a fundação do Colégio das Artes, em 1548. Foram criadas as disciplinas de grego, latim, hebraico, matemática e filosofia, e celebridades de toda a Europa foram convidadas a lecionar ali. Coimbra se transformou em um centro de cultura humanística - pelo menos até 1555, quando o Colégio das Artes passou à responsabilidade da Companhia de Jesus. (SILVEIRA; MONGELLI; CUNHA, 1993, pp. 21-22).

A atividade literária em Portugal no início do século XVI reflete a atmosfera de otimismo e ufanismo evocada pela prosperidade econômica e pelas conquistas marítimas. Ao final da Idade Média, o Humanismo já havia iniciado um movimento de redescoberta das conquistas culturais da Antiguidade greco-latina e estimulado uma concepção de vida centrada no conhecimento humano e não divino. O Renascimento ou Classicismo, desenvolvido a partir do Humanismo, enfatizou ainda mais a concepção antropocêntrica do mundo e a valorização do conhecimento científico.

A maioria dos historiadores literários considera como marco inicial do Renascimento em Portugal o ano de 1527, quando o poeta Sá de Miranda retornou a Portugal de uma temporada de cinco anos de estudo na Itália trazendo consigo várias inovações dos poetas do Renascimento italiano: o verso decassilábico, o terceto, o soneto, a epístola, a elegia, a canção, a ode, a oitava, a écloga, a comédia clássica. (MOISÉS, 1980, p. 63).

O Renascimento português seguiu o preceito fundamental do italiano: a imitação dos modelos greco-latinos. Imitação não no sentido de cópia, mas da obediência às regras estabelecidas com base na observação dos antigos. Desde que essas regras fossem seguidas, o autor podia se expressar de acordo com seu talento pessoal, manifestando as características que lhe fossem peculiares. Camões expressou muito bem essa ideia ao falar em "engenho e arte" n'Os lusíadas (I, 2, 8) - a "arte" se referia às técnicas aprendidas dos antigos; o "engenho" seria o talento pessoal.

A arte clássica era racionalista, buscando o equilíbrio entre a razão e a imaginação, e idealista, visando ao universal e ao impessoal, devendo "expressar verdades eternas e superiores”. (MOISÉS, 1980, p. 63). 
É importante, contudo, ressaltar a persistência de vários elementos da tradição medieval durante os séculos XV e XVI e mesmo até os dias atuais. Isso se verificou em toda a Europa, mas de modo especial em Portugal. Lá o Renascimento não foi uma ruptura completa com o espírito medieval, mas antes uma busca de conciliação entre a herança medieval e a clássica. Desse modo, as duas formas de poesia, a popular e a clássica, foram simultaneamente cultivadas. O próprio Sá de Miranda não renunciou à "medida velha"; assim como Camões, dedicou-se a ambas as formas. Essa tentativa de conciliação entre os dois modelos resultou também em diversas composições de características híbridas, simbióticas. (BUESCU, 1994, pp. 37-38).

Além disso, na época de Camões, em reação à Reforma Protestante, que ocasionara a cisão do Catolicismo, a Igreja Católica Romana lançou a Contrarreforma. Entre 1545 e 1553, desenvolveu-se o Concílio de Trento, que estabeleceu, entre outras medidas, a retomada do Tribunal do Santo Ofício, a chamada Inquisição (que, na verdade, já funcionava em Portugal desde 1536), a criação do Index Librorum Prohibitorum (relação de livros proibidos pela Igreja) e o incentivo à catequese dos povos do ultramar, com a fundação de novas ordens religiosas, como a Companhia de Jesus. Em meio a esse clima de agitação espiritual, política, social e cultural, produziu-se uma nova arte, ainda inspirada no Classicismo, porém marcada por uma atmosfera inquieta e pessimista, traduzida em formas distorcidas e ambivalentes: o Maneirismo. Para alguns estudiosos de sua obra, Camões seria um autor maneirista. Um dos defensores dessa ideia, o camonista Jorge de Sena (1980, p. 81), afirma que o Maneirismo teria predominado em Portugal entre 1550 e 1620 - o início corresponderia, aproximadamente, à época de instauração do Concílio de Trento (1545-1564), com suas angústias e incertezas. Vítor Manuel de Aguiar e Silva (2006, p. 478), outro importante estudioso que considera Camões maneirista, caracteriza o Maneirismo como "dilacerado por contradições insolúveis", "conturbado por um pathos e uma melancolia de raízes bem fundas". Na poesia maneirista, o tema da ilusão e da efemeridade da vida "adquire uma expressão pungente e agónica, reflexo de profunda turbação interior”. 


\subsection{LUÍS VAZ DE CAMÕES}

\subsubsection{Biografia}

As biografias de Luís Vaz de Camões se ressentem da pouca documentação histórica para comprovar os episódios narrados. Esta biografia se baseou em diversos textos, mas, principalmente, no Dicionário de Luís de Camões (2011, pp. 80-94).

Camões teria nascido em 1524 ou 1525, em uma família da pequena nobreza, originária da Galiza. Não há documentos registrando a sua passagem por escolas ou universidades, mas supõe-se que tenha frequentado o Colégio de Santa Cruz, em Coimbra. Durante a juventude, compôs poemas que evidenciam um convívio palaciano em Lisboa. Ainda nesse período, alistou-se como soldado raso em uma expedição militar a Ceuta. Perdeu um olho em uma batalha naval no Estreito de Gibraltar e regressou a Lisboa. Levava uma vida boêmia, frequentando tabernas. Em 1552, feriu, em uma briga, a Gonçalo Borges, criado do Paço. Condenado à prisão, Camões foi perdoado e libertado sob a condição de prestar serviços na Índia. Viajou na nau São Bento, da frota de Fernão Álvares Cabral, que partiu do Tejo em 24 de março de 1553, com cinco naus (sendo que uma se incendiou ainda no porto). Essa viagem seguiu o mesmo trajeto da célebre expedição de Vasco da Gama; enfrentou uma violenta tempestade no Cabo da Boa Esperança, em que três naus se perderam, e chegou a Goa em 1554 .

Camões permaneceu mais de 16 anos no Oriente. Participou de diversas expedições e batalhas. Em Macau, foi nomeado "provedor dos defuntos e ausentes". Nesse período, teria começado a escrever Os lusíadas. Na viagem de volta a Goa, naufragou - segundo a lenda, salvou-se a nado, levando consigo o manuscrito de Os lusíadas. Foi preso novamente em Goa - ao que se diz, por apropriação indébita dos bens dos defuntos. Libertado, seguiu para Moçambique, onde foi preso outra vez, supostamente por causa de dívidas. Após a libertação, levou uma vida miserável em Moçambique até, graças à ajuda de amigos, retornar a Portugal, entre 1569 e 1570.

Publicou, finalmente, Os lusíadas, em 1572. Passou a receber, pelos serviços prestados à Coroa, uma pensão anual de 15 mil réis. Apesar disso, Camões viveu seus últimos anos na pobreza, provavelmente amargurado pelo descaso com que os conterrâneos encaravam sua obra e pela derrota de Portugal em Alcácer-Quibir, onde morreu o jovem rei D. Sebastião, em 1578. Doente, talvez vítima da peste que assolava Lisboa, Camões faleceu em 10 de junho de 
1580, sendo enterrado em campa rasa. Poucos meses depois, Portugal perdeu a independência, passando para o domínio da Espanha.

\subsubsection{Obra}

A produção literária de Camões divide-se em três gêneros: lírico, teatral e épico. A obra lírica, dispersa em manuscritos, foi reunida e publicada postumamente em 1595 na coletânea que recebeu o título de Rimas, compreendendo redondilhas, odes, canções, sextinas, oitavas, sonetos, elegias, éclogas e outros poemas curtos. Duas tendências principais, em choque no século XVI, perpassam a lírica de Camões: o estilo medieval, ou "medida velha", expresso em redondilhas, e o estilo clássico, "medida nova" ou dolce stil nuovo, baseado em decassílabos. A maioria dos sonetos de Camões segue o estilo italiano, derivado de Petrarca; as canções adotam o modelo de Petrarca e de Pietro Bembo. Já as odes revelam a influência da poesia trovadoresca, modificada por um gosto mais clássico, enquanto as sextinas mostram inspiração provençal. Algumas éclogas imitam o estilo bucólico de Virgílio; outras, o estilo clássico italiano. (MOURÃO E VASCONCELOS, 1847, pp. 74-80; SILVEIRA; MONGELLI; CUNHA, 1993, pp. 34-35).

As obras teatrais de Camões se resumem a três comédias: El-Rei Seleuco, Filodemo e Anfitriões. A atribuição de El-Rei Seleuco a Camões é, no entanto, controversa. (ANASTÁCIO, 2005b). Trata-se de uma peça em um só ato, sobre a paixão de Antíoco, filho do rei Seleuco I Nicator, por sua madrasta, a rainha Estratonice. O tema - extraído de um fato histórico, contado por Plutarco e repetido por Petrarca e pelo cancioneiro popular espanhol - é desenvolvido ao estilo de Gil Vicente. Anfitriões, publicada em 1587, é uma adaptação do Amphitryon de Plauto e segue o estilo clássico. Composta em redondilha maior, a peça se utiliza do bilinguismo para indicar, com as falas em castelhano, a inferioridade social. $\mathrm{O}$ Filodemo, peça composta na Índia e dedicada ao governador Francisco Barreto, é uma comédia moral, em cinco atos, e trata dos amores de um criado, Filodemo, por Dionisa, a filha do fidalgo a quem serve. Contém elementos autobiográficos e revela aguda observação psicológica. (ALVES, 2001, pp. 114-115; MOISÉS, 1980, p. 67).

A poesia épica de Camões é representada pelo poema Os lusíadas, que, por se constituir no objeto de estudo deste capítulo, será tratado em destaque a seguir. 


\subsection{OS LUSÍADAS}

O poema Os lusíadas é considerado não apenas a grande epopeia nacional portuguesa, mas uma das principais epopeias da Idade Moderna, junto com a Jerusalém libertada, de Torquato Tasso, e $O$ Paraíso perdido, de John Milton. Pelo fato de expressarem a visão de mundo de sua época com tanta lucidez, abrangência e profundidade, Os lusíadas assumiram um lugar de destaque na cultura universal.

A ideia de se criar um épico nacional que expressasse a magnitude das realizações portuguesas existia desde o século XV, quando se iniciaram as navegações. O italiano Angelo Poliziano chegou a se oferecer, em carta de 1491 a D. João II, para compor em latim um poema exaltando as conquistas do povo português. (ANASTÁCIO, 2005a). No prólogo do Cancioneiro Geral, de 1516, Garcia de Resende preconizava a criação de uma epopeia que exaltasse os valores nacionais. Historiadores como Damião de Góis e João de Barros, assim como o novelista Jorge Ferreira de Vasconcelos e o poeta Antônio Ferreira, entre outros, clamavam pela celebração poética dos "altos reis" e os "altos feitos" (SILVEIRA; MONGELLI; CUNHA, 1993, p. 28). Coube a Camões, na confluência entre um momento histórico privilegiado e a exaltação Quinhentista às antigas epopeias (de Homero e Virgílio), materializar esse desejo, com a publicação de Os lusíadas em 1572.

O poema se divide em dez cantos, contendo ao todo 1.102 estrofes e 8.816 versos. Cada estrofe é formada por oito versos decassílabos, em sua maioria heroicos, em oitava rima (a rima é alternada nos primeiros seis versos e emparelhada nos dois últimos: $a b a b a b c c$ ).

O tema da obra é a história de Portugal - desde as origens míticas (a fundação da Lusitânia por Luso, filho ou companheiro do deus Baco, e as narrativas sobre o pastor Viriato) até as Grandes Navegações -, relatada a partir de vários acontecimentos que se desenvolvem durante a viagem de Vasco da Gama às Índias. Os lusíadas são uma obra de alcance enciclopédico, refletindo as concepções geográficas, históricas e sociais de seu tempo e da Antiguidade. É certo que Camões se valeu de uma grande variedade de fontes, mas não é fácil determinar exatamente quais são elas e como ele veio a conhecê-las. A Eneida, de Virgílio, e a Odisseia, de Homero, são os modelos principais; a Eneida é o modelo direto, enquanto a influência da Odisseia é, sobretudo, indireta, filtrada pela Eneida. Para elaborar as narrativas históricas, Camões recorreu às crônicas de João de Barros, Fernão Lopes de Castanheda, Rui de Pina e Duarte Galvão, além do roteiro da expedição de Gama, supostamente redigido por Álvaro Velho. (SILVEIRA; MONGELLI; CUNHA, 1993, p. 28). Entre os autores reconhecidos pela maioria dos comentadores como fontes de Os lusíadas estão historiadores e 
cientistas antigos, como Ptolomeu, ${ }^{1}$ Diógenes Laércio, Tito Lívio, Mela, Plínio (o Velho), Estrabão e Pompônio; autores da literatura clássica (não apenas Homero e Virgílio, mas também Ovídio, Horácio, Xenofonte, Lucano, Valério Flaco e inúmeros outros); autores da literatura italiana moderna, como Francesco Petrarca, Dante Alighieri ${ }^{2}$, Ludovico Ariosto, Giovanni Boccaccio, Bernardo Tasso e Jacopo Sannazaro; vários autores da literatura castelhana, como Juan de Mena, Juan Boscán e Garcilaso de la Vega; e outros autores portugueses, como André de Resende, Antônio Ferreira de Castro e Francisco de Morais. (ALBUQUERQUE, 2008; CIOFFARI, 1948, pp. 282-295; PIMPÃO, 2000, pp. vi-xi; RODRIGUES, 1979).

O poema se divide em três partes: 1) Introdução (as 18 primeiras estrofes), subdividida em Proposição (estrofes 1 a 3), em que o Poeta se propõe a cantar as façanhas dos heróis portugueses; Invocação (estrofes 4 e 5), em que o Poeta se dirige às musas do rio Tejo simbolizando a própria pátria portuguesa - , pedindo-lhes inspiração; e Dedicatória (estrofes 6 a 18), endereçada ao rei D. Sebastião; 2) Narração (desde a estrofe 19 do Canto I até a estrofe 144 do Canto X); e 3) Epílogo (da estrofe 145 do Canto X até o final). ${ }^{3}$

Quanto ao plano do enunciado, de acordo com Salvatore D’Onofrio (1981, pp. 129-130) há uma sobreposição de três planos históricos diferentes: a) Presente da enunciação, referente à época da publicação do poema (1572), correspondendo ao futuro do enunciado; b) Presente do enunciado, situado à época da expedição do Gama (1498) e correspondendo ao passado da enunciação; c) Passado do enunciado, abrangendo o período desde a fundação de Portugal até a viagem do Gama. Essa sobreposição segue os modelos da Odisseia e da Eneida. A inversão temporal, com o início da narração in medias res, confere mais dramaticidade ao relato.

Já no plano da enunciação, D’Onofrio (1981, pp. 121-129) identifica uma estrutura com três tipos diferentes de pontos de vista:

\footnotetext{
${ }^{1}$ Segundo Luciano Pereira da Silva (1915, pp. 2-3, p. 19), as noções de Camões sobre a estrutura ptolemaica do universo não viriam diretamente de Ptolomeu, e sim do Tratado da Sphera de Pedro Nunes, publicado em 1537, uma tradução do latim para o português de De Sphaera, de Sacrobosco, que, por sua vez, é um resumo do Almagesto de Ptolomeu e dos Elementa Astronomica (Elementos de Astronomia), de Alfragano.

2 Dante raramente é citado pelos camonistas como uma fonte de Camões, mas Cioffari (1948) menciona declarações de vários tradutores - entre os quais se destaca Mickle, que indicou com precisão a estrofe dedicada aos sapos em Os lusíadas (II, 27) como imitação da Divina Comédia (Inferno IX, $76-78$ e XXII, 25-27) - que apontam essa influência. O ensaio de Cioffari apresenta exemplos bastante convincentes que demonstram que Camões conhecia a Divina Comédia e a imitou em vários versos d'Os lusíadas.

${ }^{3}$ A divisão tripartite obedece ao modelo da epopeia clássica, mas nesse modelo a Introdução ou Exórdio costumava conter apenas duas partes, Proposição e Invocação. A essas duas partes, Camões acrescentou uma Dedicatória.
} 
I. O "eu poemático". ${ }^{4}$ Embora devamos fazer distinção entre o autor e o narrador da obra, no caso d'Os lusíadas, em razão de várias características biográficas, muitas vezes somos tentados a identificar o narrador em primeira pessoa com o próprio autor da obra, Camões. O "eu poemático" não se manifesta, contudo, apenas pelo recurso à primeira pessoa. Mesmo em trechos narrados na terceira pessoa, ele se evidencia pelo uso de outros recursos estilísticos, como o emprego de qualificativos e demonstrativos, e pelos tempos verbais e formas modais. O ponto de vista do "eu poemático" está presente ao longo de todo o poema, mas se mostra de modo mais nítido na Introdução e nos epifonemas (as considerações feitas pelo narrador principal, sobretudo ao final de alguns Cantos).

II. Narrador onisciente, em terceira pessoa. Esse ponto de vista é o predominante na narração do poema, a partir da estrofe 19, o que dá a essas passagens o tom de impessoalidade característico do contador de histórias.

III. Personagens-narradoras. Para imprimir maior dramaticidade à narrativa, o narrador principal muitas vezes cede a palavra a uma personagem, que se expressa por meio do discurso direto. Isso ocorre diversas vezes n'Os lusíadas. Para citar alguns exemplos: no Canto I, durante o Consílio dos Deuses, manifestam-se Júpiter, Baco, Vênus e Marte; do Canto III até o Canto V, é Vasco da Gama que conta ao rei de Melinde a história de Portugal e de sua própria viagem até aquele momento; no Canto IV, o Velho do Restelo toma a palavra para criticar a expedição marítima portuguesa; no Canto V, Adamastor narra a sua própria história; no Canto VI, Baco exorta os deuses marinhos a punirem os portugueses; no Canto VII, Vasco da Gama discursa perante o samorim; no Canto VIII, Paulo da Gama explica ao catual as figuras das bandeiras; no Canto IX, Veloso exorta os companheiros a descobrirem se as ninfas da Ilha de Vênus são seres fantásticos ou reais; no Canto X, uma ninfa narra as futuras façanhas dos portugueses e Tétis descreve a Gama a Máquina do Mundo. Para D’Onofrio (1981, p. 128), existe também uma necessidade estrutural para essas intervenções de personagens no plano da enunciação: a de expressar ações e sentimentos "que nem o eu poemático nem o narrador onisciente poderiam expressar sem cair na inverossimilhança”. Por exemplo, para poder descrever os acontecimentos futuros, posteriores à época da viagem de Vasco da Gama, Camões precisou recorrer a seres sobrenaturais, como Júpiter, Tétis e a ninfa, todos dotados de saber profético.

Cleonice Berardinelli (1973, pp. 16-17) observa que a presença desses diversos narradores não resulta em uma visão estereoscópica, pois não existem divergências

\footnotetext{
${ }^{4}$ Para outros autores, "locutor", ou ainda (expressão que adotamos também neste trabalho), “o Poeta”.
} 
significativas entre as visões dos narradores. Os narradores secundários não passam de um artifício pelo qual o narrador principal disfarça a sua própria visão. Essa univocidade seria típica da poesia épica, que visa à afirmação de uma verdade - no caso, a glória dos feitos do povo lusitano. No que diz respeito à ideologia, no entanto, Berardinelli admite que tanto no nível do narrado quanto do comentado há certa ambiguidade, pois a narração repousa "sobre um ideológico duplo" (a mescla de feudalismo e humanismo que caracterizava o Quinhentismo português, chamada de "bifrontismo" por alguns camonistas). Esse bifrontismo explicaria a aparente contradição entre a ideologia expressa na maioria das passagens mais narrativas e aquela manifestada nos excursos (ou epifonemas) e no episódio do Velho do Restelo.

A concepção de história que Camões externa nas narrativas de acontecimentos históricos n'Os lusíadas é aristocrática. Os valores senhoriais - virtudes cavaleirescas como a honra, a lealdade, a coragem, a capacidade de liderança - impregnam todo o poema. A história se faz por meio das ações dos grandes homens, dos heróis, e não por intermédio de movimentos sociais. Segundo Silveira, Mongelli e Cunha (1993, p. 33), “O processo, mais ou menos difuso, nos episódios históricos de Os lusíadas, permite concluir [...] que os portugueses são escolhidos por Deus em razão de seus méritos, para edificarem o Quinto Império: o surgimento da monarquia justifica-se pela vontade divina, e D. João I é santificado por seus atos”. Estado e Igreja caminham juntos e justificam-se reciprocamente; os anseios imperiais encontram-se vinculados à vocação missionária e ao espírito cruzadístico.

Ao se analisar o poema como um todo, percebe-se que está embasado na ideologia imperialista dominante, mas, ao mesmo tempo, deixa entrever, especialmente nos epifonemas, algumas notas dissonantes a essa ideologia. Como vimos acima, alguns camonistas atribuem a ambiguidade que percebemos n'Os lusíadas ao bifrontismo do Quinhentismo português, que combinava elementos ainda feudais a outros humanistas. Para outros camonistas, como Jorge de Sena e Vítor Aguiar e Silva, essa ambiguidade seria uma das características a demonstrar a filiação de Camões ao Maneirismo. Não é nossa intenção, no âmbito deste trabalho, elegermos apenas uma interpretação como "correta" ou "definitiva". O que importa é ressaltarmos a presença dessa ambiguidade que perpassa a obra. É ela que, a nosso ver, confere à epopeia camoniana um caráter moderno. Nas palavras de Berardinelli (1973, p. 29), “Os lusíadas são a epopeia de novos tempos, tempos contraditórios”. Os lusíadas são, como veremos a seguir, uma expressão do ideal de translatio studii et imperii - uma apologia do Império Português e a glorificação de suas conquistas; mas lá encontramos, concomitantemente, sobretudo nos epifonemas e no episódio do Velho do Restelo, a crítica a 
vários aspectos do Império Português e até mesmo ao próprio ideal expansionista imperialista. $^{5}$

\subsection{A TRANSLATIO N'OS LUSÍADAS}

A teoria da translatio studii et imperii - que associamos a Portugal mais comumente no contexto seiscentista da doutrina messiânica do Quinto Império, do Padre Antônio Vieira - foi utilizada, junto com outras teorias messiânicas, por D. Manuel I, para fundamentar as suas pretensões imperialistas. ${ }^{6}$ O historiador lusitano Luís Filipe Thomaz (2008, p. 100) interpreta o projeto imperial de D. Manuel como "uma espécie de grande síntese de todos os projetos de cruzada, mitos, aspirações e utopias do outono da Idade Média”, cuja novidade estava na fusão entre os aspectos messiânicos medievais e a estratégia universalista moderna.

\footnotetext{
${ }^{5}$ Essa crítica aparece claramente em outro poema de Camões, a autobiográfica Elegia I (“O poeta Simónides falando"), que contém vários elementos reutilizados pelo poeta n'Os lusíadas. Nessa elegia, Camões comenta, em tom sarcástico, a batalha desigual (da qual participou como soldado logo ao chegar à Índia, em 1553) na ilha de Porcá, no Malabar, que havia sido tomada por Chembe, o "rei da Pimenta":
}

Desta arte me chegou minha ventura

a esta desejada e longa terra,

de todo o pobre honrado sepultura.

Vi quanta vaïdade em nós se encerra, e dos próprios* quão pouca; contra quem foi logo necessário termos guerra. Que ũa ilha que o rei de Porcá tem, que o rei da Pimenta lhe tomara, fomos tomar-lha, e sucedeu-nos bem. Com ũa armada grossa, que ajuntara o vizo-rei de Goa, nos partimos com toda a gente d'armas que se achara, e com pouco trabalho destruímos a gente no curvo arco exercitada; com mortes, com incêndios, os punimos. Era a ilha com águas alagada, de modo que se andava em almadias; enfim, outra Veneza trasladada. Nela nos detivemos sós dous dias, que foram para alguns os derradeiros, que passaram de Estige as águas frias. Que estes são os remédios verdadeiros que para a vida estão aparelhados aos que a querem ter por cavaleiros. (CAMÕES, 1953, pp. 254-255).

\footnotetext{
* “próprios" são os habitantes locais, os nativos da região.

${ }^{6}$ O título assumido por D. Manuel desde a volta de Vasco da Gama da Índia, "Senhor da conquista, navegação e comércio da Etiópia, Arábia, Pérsia e Índia”, anuncia as pretensões imperialistas do rei. É interessante também a observação de Thomaz (2008, p. 45), de que "esta é a primeira e talvez a única vez que um soberano inclui a atividade comercial em seus títulos reais".
} 
Embora o sucessor de D. Manuel, D. João III, não tenha aplicado as mesmas estratégias do pai, as ambições imperialistas e o espírito cruzadístico continuaram bem vivos em Portugal durante seu reinado.

Os lusíadas refletem claramente essas influências, a ponto de podermos considerá-los uma encenação da teoria da translatio studii et imperii. Camões utiliza a Eneida de Virgílio como modelo a orientar a translatio, adotando as virtudes da ética romana e transferindo para Portugal várias marcas distintivas atribuídas a Roma.

Já na proposição, o Poeta enuncia a intenção de, conforme os preceitos clássicos, superar seus modelos no campo literário (o "sábio Grego" indica Homero, e o "Troiano" é Eneias, o protagonista da Eneida de Virgílio) e, no mesmo passo, declara Portugal o sucessor, na história, da Antiguidade Clássica (representada por Alexandre e Trajano):

Cessem do sábio Grego e do Troiano

As navegações grandes que fizeram;

Cale-se de Alexandro e de Trajano

A fama das vitórias que tiveram

Que eu canto o peito ilustre Lusitano [...] $(\mathrm{I}, 3)^{7}$

Logo em seguida, temos o Consílio dos Deuses, que imita a matriz virgiliana. Só que, enquanto na Eneida Júpiter faz uma longa profecia sobre o destino dos romanos, n'Os lusíadas ele discorre sobre a sucessão de impérios (Assírios, Persas, Gregos e Romanos) e anuncia Portugal como o futuro império mundial:

"Se do grande valor da forte gente

De Luso não perdeis o pensamento,

Deveis de ter sabido claramente

Como é dos Fados grandes certo intento

Que por ela se esqueçam os humanos

De Assírios, Persas, Gregos e Romanos.” (I, 24)

No Canto II, estrofes 44 a 46, Júpiter o reafirma:

"Que eu vos prometo, filha, que vejais

Esquecerem-se Gregos e Romanos,

Pelos ilustres feitos que esta gente

Há-de fazer nas partes do Oriente

[...]

\footnotetext{
7 As citações d'Os lusíadas são extraídas da edição organizada pelo Dr. Álvaro Júlio da Costa Pimpão (CAMÕES, 2000). Fizemos, contudo, algumas (raras) correções e alterações ortográficas quando julgamos necessário.
} 
E por eles, de tudo enfim senhores,

Serão dadas na terra leis milhores."

Outro prognóstico da glória futura de Portugal imitado da Eneida é o sonho de D. Manuel. Na Eneida (Livro VIII), o rio Tibre aparece em sonhos a Eneias, anunciando as grandes realizações que levarão à fundação de Roma; n'Os lusíadas (Canto IV), D. Manuel sonha com os rios Indo e Ganges, que, assumindo a forma de dois anciãos, antecipam-lhe que as terras por eles banhadas serão conquistadas pelos portugueses.

\footnotetext{
"Ó tu, a cujos reinos e coroa

Grande parte do mundo está guardada,

Nós outros, cuja fama tanto voa,

Cuja cerviz bem nunca foi domada,

Te avisamos que é tempo que já mandes

A receber de nós tributos grandes." (IV, 73)
}

Até mesmo Baco, o inimigo, sabe que esse é o destino dos portugueses - decidido por um poder superior ao dos deuses pagãos:

\author{
Via estar todo o Céu determinado \\ De fazer de Lisboa nova Roma; \\ Não no pode estorvar, que destinado \\ Está doutro Poder que tudo doma. (VI, 7)
}

Esse destino já se evidencia desde o início da história de Portugal como relatada por Paulo da Gama: o primeiro rei, Afonso Henriques, é tão amado por Deus e tão heroico que por ele "no Estígio lago jura a Fama / De mais não celebrar nenhum de Roma” (VIII, 11).

Um aspecto curioso relacionado à translatio studii et imperii n'Os lusíadas é a antropomorfização de Portugal e da Europa:

\footnotetext{
"Eis aqui se descobre a nobre Espanha, Como cabeça ali de Europa toda, Em cujo senhorio e glória estranha Muitas voltas tem dado a fatal roda [...]" (III, 17)

"Eis aqui, quási cume da cabeça De Europa toda, o Reino Lusitano, Onde a terra se acaba e o mar começa E onde Febo repousa no Oceano." (III, 20)
} 
Essas passagens ecoam a tradição de antropomorfização - tanto na cartografia quanto nas letras - pela qual se atribuía ao reino lusitano o papel de "cabeça" da Europa. O iniciador da tradição cartográfica parece ter sido Johann Putsch ${ }^{8}$ (1516-1542), que publicou em Paris, em 1537, um mapa alegórico intitulado Europa in forma virginis [Europa em forma de donzela], depois conhecido como Europa Regina [Rainha Europa]. O mapa celebrava a hegemonia dos Habsburgos sob Carlos V representando a Europa como uma rainha cuja cabeça coroada é a Ibéria, com Portugal como elo central da coroa. (PEREIRA, 2006, pp. 1719).

\footnotetext{
${ }^{8} \mathrm{Ou}$, na forma latinizada do nome, Johannes Bucius Aenicola.

${ }^{9}$ Fernando Pessoa dá a sua versão dessa antropomorfização em "O dos Castellos", o primeiro poema de Mensagem:
}

A EUROPA jaz, posta nos cotovellos: De Oriente a Occidente jaz, fitando, E toldam-lhe romanticos cabellos Olhos gregos, lembrando.

O cotovello esquerdo é recuado: $\mathrm{O}$ direito é em angulo disposto. Aquelle diz Italia onde é pousado; Este diz Inglaterra onde, afastado, A mão sustenta, em que se appoia o rosto.

Fita, com olhar sphyngico e fatal, O Occidente, futuro do passado.

O rosto com que fita é Portugal. 


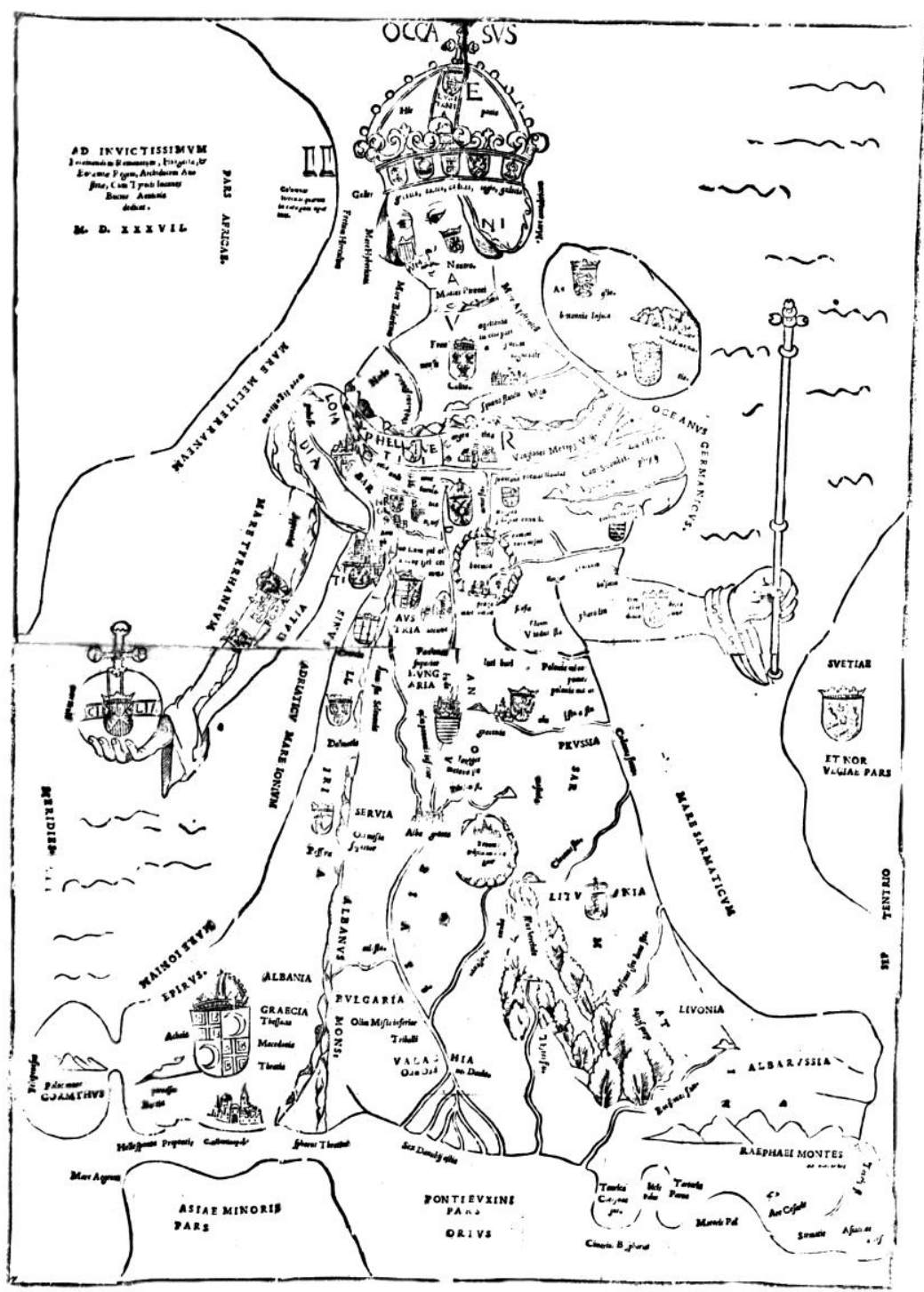

Figura 1. Reprodução do mapa original de Johannes Putsch, publicado em Paris em 1537 (Tiroler Landesmuseum Ferdinandeum, Innsbruck). Disponível em:

<http://belgeo.revues.org/docannexe/image/7711/img-1.jpg>. Acesso em 11 ago. 2013.

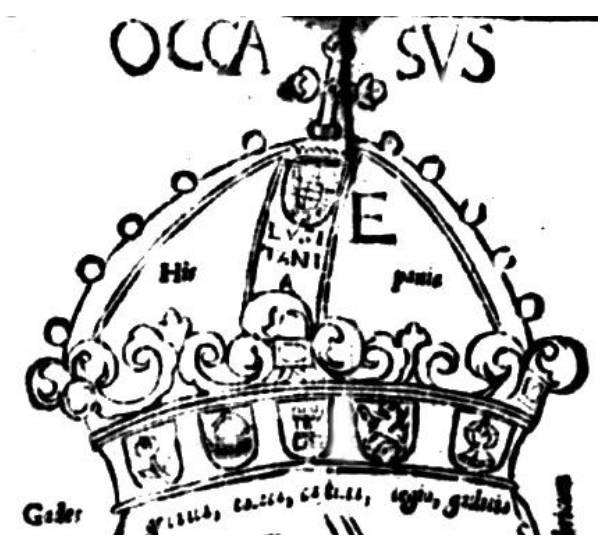

Figura 2. Detalhe do mapa original de Johannes Putsch, publicado em Paris em 1537 (Tiroler Landesmuseum Ferdinandeum, Innsbruck). Disponível em:

<http://belgeo.revues.org/docannexe/image/7711/img-1.jpg>. Acesso em 11 ago. 2013. 
N'Os lusíadas, os portugueses são anunciados não apenas como os herdeiros dos romanos, mas como aqueles que os irão ultrapassar. A questão da língua, enfatizada por Petrarca como um dos elementos fundamentais da translatio studii, também se faz presente na epopeia camoniana, quando Vênus declara que os portugueses se assemelham tanto aos romanos que até mesmo a língua portuguesa lembra o latim:

Sustentava contra ele Vénus bela,

Afeiçoada à gente Lusitana,

Por quantas qualidades via nela

Da antiga, tão amada, sua Romana;

Nos fortes corações, na grande estrela,

Que mostraram na terra Tingitana,

E na língua, na qual quando imagina,

Com pouca corrupção crê que é a Latina. (I, 33)

Nas palavras de Luís de Oliveira e Silva (2011, p. 344):

Em Camões, como em Du Bellay, a imitação, ligada à translatio studii, que muitas vezes complementa a translatio imperii, oferece um caráter abertamente nacionalista relacionado com a "defesa e ilustração" da língua vernácula, capaz de manifestar superiormente uma renovada identidade nacional, social e pessoal.

A própria simbologia cavaleiresca da união das armas e das artes/letras - "Nũa mão sempre a espada e noutra a pena" (Os lusíadas, VII, 79) - que perpassa o épico camoniano evoca a ligação entre a translatio imperii e a translatio studii. Mais do que isso: n'Os lusíadas o Poeta formula a ideia de que sem o canto, não há feitos; sem a epopeia, não há façanhas históricas:

Enfim, não houve forte Capitão

Que não fosse também douto e ciente,

Da Lácia, Grega ou Bárbara nação,

Senão da Portuguesa tão somente.

Sem vergonha o não digo: que a razão

De algum não ser por versos excelente

É não se ver prezado o verso e rima,

Porque quem não sabe arte, não na estima.

Por isso, e não por falta de natura,

Não há também Virgílios nem Homeros;

Nem haverá, se este costume dura,

Pios Eneias nem Aquiles feros. (V, 97-98) 
Camões vale-se do código épico para construir uma identidade imperial para Portugal a partir do modelo clássico de Virgílio. Os lusíadas são, portanto, um instrumento de legitimação histórica e a encenação de uma translatio studii et imperii.

\subsection{RECEPÇÃO}

\subsubsection{Recepção da obra em Portugal entre os séculos XVI e XVIII}

Segundo Sheila Moura Hue (1999), a edição princeps de Os lusíadas atesta o isolamento de Camões, pela ausência de paratextos - os prólogos e sonetos laudatórios que eram comuns naquele tempo. Vários testemunhos da época indicam que, ao longo de sua vida, Camões teria feito fortes inimizades entre os poetas. Fernão Álvares do Oriente, um dos primeiros a reconhecer Camões como mestre, menciona, em seu livro Lusitânia transformada, os ataques a Camões vindos de poetas daquela época. Estêvão Lopes, organizador das duas primeiras edições das Rimas, diz, no prólogo de 1598, que "juízos pobres" perseguem o poeta. E o primeiro comentador de Os lusíadas, Manuel Correia, declara que o poema era uma obra não entendida por todos e caluniada por muitos.

Pêro de Magalhães de Gândavo foi o primeiro autor a fazer um elogio público a Camões, nas suas Regras que ensinam a maneira de escrever, impressas por Antônio Gonçalves, o mesmo editor d'Os lusíadas, em 1574, dois anos depois da publicação do épico camoniano. Outro dos poucos quinhentistas a citar Camões foi André Falcão de Resende, autor de uma sátira dedicada ao poeta na qual critica aqueles que desprezam a alta cultura e denuncia a situação de pobreza a que Camões fora relegado em Lisboa. (HUE, 1999).

O número de edições de suas duas obras publicadas demonstra que Camões foi muito lido no século que se seguiu à sua morte. Os lusíadas tiveram quatro edições ainda no século XVI (a primeira em 1572; duas em 1584; uma em 1597), e mais quinze edições ao longo do século XVII; as Rimas receberam duas edições no século XVI e cerca de doze reedições no século seguinte. Alguns autores da época chegaram a fornecer, não se sabe com que precisão, os números de exemplares impressos: mais de 12 mil volumes de Os lusíadas até 1613, segundo Pedro de Mariz; mais de vinte mil até 1624, de acordo com Severim de Faria; quanto às Rimas, Faria e Sousa estima que, entre 1595 e 1640, se tenham publicado pelo menos 22 mil exemplares (PIRES, 1982, pp. 7-8).

Entre os leitores de Camões, há eclesiásticos ou religiosos como Severim de Faria, Soares de Brito, Franco Barreto e Faria e Sousa; membros da nobreza, como D. Francisco 
Manuel de Melo e Antônio de Sousa Macedo; membros de várias academias - Severim de Faria e Pires de Almeida, da Academia dos Ambientes, de Évora, e André Nunes da Silva, da Academia dos Singulares, de Lisboa, são apenas alguns dos exemplos mais ilustres. Os principais poetas daquele tempo, como Rodrigues Lobo, D. Francisco Manuel de Melo, Veiga Tagarro, Faria e Sousa, Barbosa Bacelar e Leitão Ferreira o citam e imitam. (PIRES, 1982, pp. 8-10).

O tom dominante da crítica a Os lusíadas nesse período é o de exaltação. Camões é chamado de "Príncipe dos poetas heroicos". Alguns, como Faria e Sousa e Severim de Faria, alçam-no à altura de Virgílio e Homero, considerando-o até superior a esses modelos em alguns aspectos. Antônio de Sousa Macedo chega a afirmar a superioridade de Camões em relação aos dois poetas da Antiguidade.

Nos séculos XVI e XVII as análises se baseiam, de modo geral, nas normas de gênero enunciadas por Aristóteles e Horácio, desenvolvidas e comentadas por teóricos italianos, como Castelvetro, Piccolomini, Scaligero, Paolo Beni e Sperone Speroni. A conformidade às normas do gênero serve como critério de valorização da obra, que é considerada tanto mais perfeita quanto melhor se adequar ao modelo do gênero. (PIRES, 1982, pp. 12-13).

Algumas das polêmicas que serão travadas em torno do valor poético de Os lusíadas já se prenunciam no parecer emitido pelo censor da Inquisição, Frei Bartolomeu Ferreira, impresso logo antes do início do poema na primeira edição:

Vi por mandado da santa \& geral inquisição estes dez Cantos dos Lusíadas de Luís de Camões, dos valerosos feitos em armas que os Portugueses fizerão em Asia \& Europa, e não achey nelles cousa algũa escandalosa, nem contraria à fee \& bõs costumes, somente me pareceo que era necessario aduertir os Lectores que o Autor pera encarecer a difficuldade da nauegaçam \& entrada dos Portugueses na India, usa de hũa fição dos Deoses dos Gentios. E ainda que Sancto Augustinho nas suas Retractações se retracte de ter chamado nos liuros que compos de Ordine aas Musas "Deosas". Toda via, como isto he Poesia \& fingimento, \& o Autor como poeta, não pretenda mais que ornar o estillo Poético, não tiuemos por inconueniente yr esta fabula dos Deoses na obra, conhecendoa por tal, \& ficando sempre salua a verdade de nossa sancta fee, que todos os Deoses dos gentios sam Demonios. E por isso me pareceo o Livro digno de se imprimir, \& o Autor mostra nelle muito engenho, \& muita erudição nas sciencias humanas. Em fe do qual assiney aqui.

Frey Bertholameu Ferreira (CAMÕES, 1572).

O censor aponta o tema central do poema (os "valerosos feitos em armas que os Portugueses fizerão em Asia \& Europa"), elogia o "engenho" e a erudição do poeta, e faz 
apenas um reparo quanto ao uso da "fição dos Deoses dos Gentios", considerando-o, no entanto, justificável como recurso poético - já que "he Poesia \& fingimento, \& o Autor como poeta, não pretenda mais que ornar o estillo Poético" - e aceitável, na medida em que permanece "sempre salua a verdade de nossa sancta fee, que todos os Deoses dos gentios sam Demonios".

O desaparecimento de muitos dos textos que apontavam defeitos na epopeia de Camões não nos permite reconstituir totalmente os argumentos desses opositores, mas as objeções levantadas por eles podem ser identificadas examinando-se as próprias refutações apresentadas pelos textos de apologistas como Manuel Correia, Severim de Faria, D. Marcos de São Lourenço, Faria e Sousa, João Soares de Brito e João Franco Barreto. Além disso, graças aos esforços de pesquisadores como Antônio Soares Amora, foi possível, desde meados do século passado, recuperar os manuscritos de Manuel Pires de Almeida (15971655), um crítico e polemista erudito e vigoroso, do qual nos valeremos aqui para ilustrar as discussões travadas em torno da qualidade poética d'Os lusíadas à luz dos cânones clássicos e dos modelos consagrados.

Severim de Faria (1584-1655), no texto "Vida de Luis de Camões com um particular juizo sobre as partes que há-de ter o poema heróico e como o Poeta as guardou todas nos seus Lusíadas" destaca, entre as principais características que o poema épico deveria ter, a necessidade de a ação ser única, heroica, honesta e útil, e expressa em "estilo deleitoso". Louvando as perfeições do poema camoniano, Severim de Faria rebate as críticas formuladas contra o poema e conclui que Camões, na sua epopeia, "guardou excelentemente" todos os preceitos da arte. No texto "Exame sobre o particular juízo que fez Manuel Severim de Faria das partes que há-de ter a epopeia”, Pires de Almeida refuta os argumentos de Severim de Faria, não apenas censurando aspectos que considera incorretos na teorização apresentada por ele como recusando os elogios feitos à obra de Camões como realização perfeita do modelo do gênero. Entre as muitas críticas dirigidas por Pires de Almeida a Severim de Faria está a de não haver interpretado corretamente a Poética de Aristóteles em vários aspectos, dando pouca atenção ao princípio da unidade de ação; considerando a utilidade e o deleite como partes essenciais da epopeia, quando são fins de toda poesia; e ignorando a doutrina sobre os episódios na epopeia. Nesse texto, Pires de Almeida afirma que a ação d'Os lusíadas pode ser considerada una, mas não é realizada apenas por uma pessoa, e sim por várias, o que seria um defeito - o mesmo cometido pelos diversos poetas da Argonáutica: "sua acçam he huma, mas nam de hum: e nam forma idea de Principe, para governo publico, nam tem mudança de fortuna, he huma maes que simples". Não é una, nem o seu argumento possui a dignidade 
apropriada, pois trata de dificuldades comuns, enfrentadas por todos os navegantes, e (citando Paolo Beni) "nenhum descubrimento maritimo (maritimo), por maes admiravel que seja, dara sogeito a Epopeia, por lhe convir acçam que leve por alvo formar idea, e exemplo de principe, e capitam para publico governo, e publica felicidade" (apud AMORA, 1955, p. 120). Logo, a ação também não obedece ao princípio da honestidade e da utilidade, pois, em vez de "contar huma acçam de hum principe legitimo, que trabalhe por libertar, e felicitar a seus vassalos" (p. 122), Camões coloca em seu poema ações indignas de príncipes. A proposição do poema contém defeitos, pois não respeita a regra tríplice de "nam dizer coisa superflua; propor com modo poetico, mas claro, presentar de tal modo toda acção, que esta corresponda à aquella e aquella a esta. Nenhuma dellas ha na de Camões" (pp. 121-122). Além disso, a proposição d'Os lusíadas abarca os episódios, o que não deveria acontecer - a proposição não deveria conter partes acidentais, apenas as essenciais. Quanto ao uso do fabuloso, Pires de Almeida considera injustificável e indefensável, pois atribuir poder aos deuses pagãos "é semear idolatria”, e a interpretação alegórica, proposta pelos apologistas, não justifica tal uso. A respeito do estilo, embora Pires de Almeida reconheça que é, em geral, deleitoso, encontra nele vários defeitos: a presença de prosa versificada; o excesso de erudição; a falta de novidade e de artifício de muitos dos episódios; o emprego do estilo jocoso (que não é próprio ao gênero épico); o abuso de latinismos e o desrespeito ao princípio da boa proporção das partes do poema (os episódios não deveriam afogar a ação principal, como, segundo o crítico, ocorre n'Os lusíadas). Critica também a falta de modéstia do autor, que louva seus próprios versos. (AMORA, 1955, pp. 47-60, p. 75, pp. 109-175; PIRES, 1982, pp. 20-21).

Em 1639, foi publicada em Madrid uma edição d'Os lusíadas que veio a exercer grande influência sobre a interpretação do épico de Camões. Dotado de vasta erudição clássica, o poeta, crítico e historiador Manuel de Faria e Sousa (1590-1649) escreveu, para essa edição, um prólogo, uma biografia ("Vida del Poeta"), um ensaio ("Juizio del Poema") e comentários que procuravam explicar cada detalhe da obra. No "Juizio del Poema", enumerou sete condições a que uma epopeia deveria obedecer: 1) assunto nem muito remoto, nem muito moderno; 2) ação heroica e exemplar; 3) ação una e com um só herói; 4) narração fragmentada e não linear; 5) conter episódios, figuras, imitação e outros adornos; 6) o estilo deve ser sublime e elegante, mas também fácil, suave e doce; 7) locução variada de acordo com as diferentes personagens que falam. A epopeia de Camões, segundo o comentador, cumpre essas sete condições. (SENA, 1972, pp. 47-48). Quanto ao uso da mitologia pagã na obra, Faria e Sousa o interpretou como essencialmente retórico. Os adornos eram utilizados para dar mais brilho à viagem do herói, Vasco da Gama (exatamente como explicara frei 
Bartolomeu Ferreira, o censor da Inquisição, em 1572). Júpiter representaria o poder de Deus; Vênus, o Anjo da Guarda; e Baco, o Demônio. Os deuses pagãos deveriam, portanto, ser encarados como alegorias, como figuras retóricas dentro de um contexto cristão.

Severim de Faria, Faria e Sousa, Leitão Ferreira e outros exaltadores d'Os lusíadas tecem elogios a Camões também quanto à obediência ao princípio fundamental da criação poética segundo Aristóteles: a imitação. Seguir os modelos literários era uma das principais normas da estética vigente desde o Renascimento até o Neoclassicismo. Mas a imitação não devia ser simples cópia; era preciso que houvesse também invenção própria, criação. Esses comentadores enfatizam que Camões imitou os modelos de maior prestígio no gênero, Virgílio e Homero, mas não se limitou a copiá-los: transformou-os conforme seu próprio “engenho". Como a originalidade não era uma qualidade prezada na época, os admiradores d'Os lusíadas se viram diante da necessidade de defender o direito do poeta à expressão original do seu talento - nas palavras de Faria e Sousa, "o direito de abrir e revelar novos caminhos".

O mesmo Manuel Pires de Almeida, que vimos acima como crítico de Camões, escreveu dois textos muito interessantes defendendo Os lusíadas exatamente do ponto de vista da originalidade: o "Discurso apologético em que se mostra serem assunto dos Lusíadas de Luís de Camões as ações que os reis, príncipes, capitães e ilustres varões portugueses obraram em Europa, África e Ásia" e a "Resposta ao juízo do poema dos Lusíadas de Luís de Camões, em que se mostra não ter as perfeições que lhe atribui e ter outras conformes a sua invenção e sua matéria" - este último escrito em Lisboa em 1639, em polêmica com Faria e Sousa. Como a maioria das questões abordadas por esses dois textos são as mesmas, trataremos aqui apenas do primeiro texto, que apresenta um enfoque mais geral do que o segundo.

No "Discurso apologético", Pires de Almeida aponta com muita clareza que o assunto do poema não é apenas a navegação do Gama, mas também "as cavaleirosas ações da ilustre nação portuguesa", o que o leva a atribuir ao poema camoniano um caráter híbrido entre o poema heroico e a novela de cavalaria. Camões, conhecendo tanto a poesia greco-latina como as novelas de cavalaria, "apartou-se de todos por novo caminho":

Apartou-se dos Romançadores necessitado da matéria verdadeira, que empreendia cantar, a qual como constava de ações multiplicadas não lhe era possível observar a Poética de Aristóteles, seguindo as pisadas de Homero e Virgílio, nem menos guiar-se com a luz dos Romanços dos poetas seus antecessores, que narravam suas ações fabulosas quase como historiadores [...]. E assim sujeitou a multiplicidade de ações verdadeiras à verdadeira navegação do famoso Capitão Vasco da Gama, e a ele encaminhou e aplicou 
todas sem atender ao progresso do tempo, e compôs um poema, que nem é Romanço, escrito como os Orlandos ou Amadis, nem é Poema heroico ajustado à Odisseia e Ilíada, ou Eneida, mas participa de ambos e entre ambos está posto na Livraria de Apolo, e Camões sentado no Parnaso, tendo à mão direita Homero e Virgílio, e à esquerda Ariosto e Bernardo Tasso, e com razão, porque o seu Poema dos Lusíadas é belicoso como a Ilíada, moral como a Odisseia, abraçando infinitas guerras e infinitas moralidades; piedoso e prudente como a Eneida, tem mais heróis que os Orlandos Furioso e Namorado, que também se dizem Poemas heroicos pelos muitos capitães e guerreiros valorosos de que constam. (Apud CUNHA; PIVA, 1980, p. 118, itálicos do autor).

Pires de Almeida continua, como em seu debate com Severim de Faria, se opondo a apologistas como o próprio Severim de Faria, Faria e Sousa e João Soares de Brito, que alegavam que Os lusíadas obedeciam às regras da Poética de Aristóteles. Como poema heroico, diz Pires de Almeida, há defeitos n'Os lusíadas: “falta-lhe a unidade da Fábula, é episódico". Esses defeitos são vistos, no entanto, como mérito: por tratar de múltiplas ações, o poema fazia-se "mais deleitoso". Já para ser novela de cavalaria, como as de Boiardo e Ariosto, Pires de Almeida acredita que o épico camoniano "tem mais perfeições do que o necessário, porque suas ações são verdadeiras, seus episódios verossímeis e necessários, seu Costume é de muito decoro, sua Sentença é grande e sua Locução é magnífica”. (Apud CUNHA; PIVA, 1980, p. 119). Sob esse enfoque, vários dos defeitos da epopeia camoniana apontados por Pires de Almeida em textos anteriores deixam de ser defeitos, sendo encarados como desvios em relação às normas aristotélicas, mas ganhando aprovação no contexto de uma obra de gênero híbrido. Outras obras da época, como Aminta, de Torquato Tasso, o Pastor Fido [O pastor fiel], de Giovanni Battista Guarini e a Secchia rapita [O balde roubado] de Alessandro Tassoni, evidenciam um caráter igualmente híbrido, mas Os lusíadas se destacam pela excelência do estilo.

No século XVIII, o prestígio de Camões se consolidou em Portugal. As discussões em torno da adequação d'Os lusíadas às regras da poesia épica continuaram, sem grandes inovações. Apenas no século XIX, com o Romantismo, o épico de Camões passou a ser interpretado sob um novo olhar, convertendo-se em mito nacional, em símbolo da própria nação portuguesa. Mas a visão romântica de Camões e de sua epopeia é um assunto que já escapa aos limites deste trabalho. 


\subsubsection{Recepção da obra em outros países europeus entre os séculos XVI e XVIII}

Para melhor situar a recepção d'Os lusíadas na Europa, é preciso, antes de tudo, reconhecer que Portugal nunca exerceu muita influência sobre os demais países europeus em termos literários - pelo menos não em um nível comparável à Itália, Espanha, França, Inglaterra e Alemanha. A literatura portuguesa sempre teve um papel bastante modesto internacionalmente - o que não significa que não conte com obras de nível equivalente às melhores de outras nações. Da mesma forma, a língua portuguesa nunca teve um prestígio internacional comparável ao do inglês, francês, italiano, espanhol e alemão. Poucos eram os estrangeiros que a aprendiam; quando o faziam, usualmente era em razão de viagens ou negócios. Não é de se estranhar que muitos dos que vieram a traduzir obras de autores portugueses entre os séculos XVI e XVIII fossem portugueses de origem, ou viajantes, comerciantes e diplomatas estrangeiros que se estabeleceram em Portugal durante algum tempo.

Apesar do baixo prestígio da língua e da literatura portuguesa, encontramos, em buscas na Internet, referências a traduções d'Os lusíadas para o alemão, árabe, armênio, boêmio, catalão, chinês, concani (língua dos católicos romanos de Goa, na Índia), dinamarquês, esloveno, espanhol, esperanto, francês, grego, hebraico, húngaro, inglês, italiano, japonês, latim, neerlandês, polonês, russo, siciliano, sueco e tcheco. A influência d'Os lusíadas sobre os demais países europeus está, obviamente, ligada à história de suas diversas traduções. Por essa razão, as traduções ocupam um lugar primordial nesta subseção. Tendo em vista que o nosso principal objetivo ao discutir a recepção d'Os lusíadas é fornecer elementos que contribuam para uma melhor compreensão do contexto em que se inscreve a tradução de Mickle, trataremos apenas das críticas e traduções que vieram à luz até o final do século XVIII, quando foi publicada essa tradução.

\subsubsection{Espanha}

Na Espanha, a importância de Camões foi logo reconhecida. Alguns poetas, como Fernando Herrera e Lope de Vega, já o conheciam e admiravam em vida. Baltasar Gracián elogia Camões várias vezes no seu Agudeza y arte de ingenio [Agudeza e arte de engenho] pela excelência de sua força expressiva. (BECHARA; SPINA, 1999, p. 24). Há uma história, recontada por vários comentadores, inclusive Faria e Sousa, de que D. Filipe II, ao entrar em Portugal, quisera conhecer o grande poeta português, e ficara triste ao saber que este falecera 
recentemente. Esse relato pode não passar de lenda, mas a verdade é que o rei concedeu a Camões o título honorífico de "Príncipe dos poetas de Espanha", em um gesto que simboliza muito bem a "apropriação" do poeta português pela aristocracia espanhola. Não é de surpreender, portanto, que as primeiras traduções d'Os lusíadas tenham sido para o espanhol, produzidas nas mais prestigiadas universidades espanholas de então - Alcalá de Henares e Salamanca. A tradução do português Bento (ou Benito) Caldeira, de 1580, publicada em Alcalá de Henares quando Camões ainda estava vivo, estabelecia pela primeira vez, segundo Chaves (2001, p. 69), um paralelo entre Os lusíadas e a Eneida, e foi muito elogiada pelo círculo de Lope de Vega e Cervantes ${ }^{10}$; a do espanhol Luis Gómez de Tapia, lançada em Salamanca, também em 1580, foi celebrada por intelectuais como Francisco Sanchez de las Brozas e o jovem Luís de Góngora. Essas duas traduções tiveram forte impacto na literatura espanhola, servindo de inspiração a novos textos, que extraíram do poema camoniano elementos de estrutura, episódios míticos e heroicos, detalhes formais e recursos estilísticos. É possível até remontar às primeiras traduções d'Os lusíadas a introdução de numerosos cultismos na linguagem poética castelhana do tempo (ANAST ÁCIO, 2004, p. 7). Na opinião de Vanda Anastácio, ambos os tradutores se mantiveram próximos do original, introduzindo apenas algumas adaptações "indispensáveis à sua divulgação junto do novo público: a atenuação das referências menos lisonjeiras a Castela e aos castelhanos dispersas pelo poema de Camões”. A essas duas traduções iniciais seguiu-se a do português Henrique Garcez, impressa em Madrid em 1591. Uma curiosidade sobre essa tradução é que ela teria sido trazida para o Novo Mundo, pois o autor era radicado no Peru.

Em 1639, foi publicada em Madrid a edição d'Os lusíadas comentada por Manuel de Faria e Sousa, a que já nos referimos na subseção anterior, contendo: uma tradução em prosa para o espanhol; uma biografia de Camões; vários textos em louvor ao poeta, entre os quais o soneto de Torquato Tasso dedicado a Vasco da Gama, em que Camões é citado; e minuciosos

\footnotetext{
${ }^{10}$ Sobre essa tradução, Cervantes (1547-1616) comenta em sua novela La Galatea (2009, p. 336):

Tú que de Luso el sin igual tesoro trujiste en nueva forma a la ribera del fértil río, a quien el lecho de oro tan famoso le hace adonde quiera, con el debido aplauso y el decoro debido a ti, BENITO DE CALDERA, $\mathrm{y}$ a tu ingenio sin par, prometo honrarte y de lauro y de yedra coronarte.
}

Cervantes cita Camões também em O Engenhoso Fidalgo Dom Quixote de la Mancha: “[...] trazemos estudadas duas éclogas, uma do famoso poeta Garcilaso e outra do sublime Camões, na sua própria língua portuguesa" (CERVANTES, 1978, p. 543). 
comentários de Faria e Sousa. Essa edição teve grande influência em Portugal, na Espanha e também sobre as traduções que seriam feitas em outros países europeus nos anos seguintes.

\subsubsection{Latim}

Embora sejam conhecidas três traduções feitas para o latim por escritores portugueses nessa época, apenas uma foi publicada antes do século XIX: a de Frei Tomé de Faria, bispo de Targa (1622). Estranhamente, essa tradução não faz nenhuma referência ao nome de Camões - o tradutor se apresenta, na dedicatória e no prólogo, como o autor do poema e declara ter-se dedicado a essa tarefa como incentivo ao fortalecimento do espírito nacionalista, em atitude que denota a resistência ao domínio espanhol.

\subsubsection{Inglaterra}

A primeira tradução para o inglês de Os lusíadas, publicada em Londres em 1655 e intitulada The Lusiad, or, Portugals Historicall Poem: Written in the Portingall Language by Luis de Camoens; and now newly put into English, é de autoria de Sir Richard Fanshawe, poeta que atuou como embaixador em Portugal e Espanha, vindo a exercer um papel importante nas negociações para o casamento entre D. Catarina de Bragança e o rei Carlos II da Inglaterra (1662). Monarquista, Fanshawe foi preso por alguns meses logo após a Batalha de Worcester, em setembro de 1651, e depois forçado a se exilar em Yorkshire entre 1653 e 1654. Valeu-se desse período de reclusão para traduzir duas obras do autor espanhol Antonio Hurtado de Mendoza - a peça Querer por solo querer e Fiestas de Aranjuez - e Os lusíadas. Tradutor experiente, já havia traduzido obras do latim (poemas de Boécio, Marcial e Horácio, e o Livro IV da Eneida) e italiano - traduzira, em 1647, o Pastor Fido, de Guarini, tradução elogiada por John Denham no poema "To Sir Richard Fanshaw, Upon His Translation Of 'Pastor Fido""11, uma das primeiras teorizações feitas na Inglaterra sobre a arte de traduzir poesia, a ser comentada no Capítulo 3 desta tese. Não há, contudo, nenhum registro de que Fanshawe houvesse estado alguma vez em Portugal até então ou que conhecesse a língua portuguesa. (WALKER, 1994, pp. 44-46). Roger Walker (1994) demonstrou, por meio de reproduções de manuscritos de Fanshawe, que este utilizou a edição de Manuel de Faria e Sousa como base para a sua tradução.

\footnotetext{
${ }^{11}$ Traduzido por Fernando L. Dantas como "A Sir Richard Fanshawe por sua tradução do Pastor Fido". In: MILTON; VILLA (2013), pp. 25-26.
} 
A tradução de Fanshawe conserva a oitava rima e é bastante próxima do original em termos de conteúdo. Apesar do uso excessivo de figuras de linguagem, são raras as passagens em que Fanshawe se afastou de modo significativo do original (um dos casos em que isso ocorreu foi para atenuar uma crítica a Henrique VIII e à Reforma). A falta de notas é um dos grandes problemas dessa tradução, como observou Mickle (ver as críticas de Mickle à tradução de Fanshawe no Capítulo 4, subseções 4.7.5 e 4.7.6) - sem dúvida um texto complexo como esse, e distante do cotidiano dos ingleses no século XVII, exigiria diversas explicações. Fanshawe parece ter-se dado conta dessa dificuldade, pois algumas vezes acrescentou explicações entre parênteses no próprio poema traduzido, como pode ser visto nestes dois exemplos:

Mas já o claro amador da Larisseia

Adúltera inclinava os animais (X, 1, 1-2).

But now the Larissean Lasses Frend (who for a wealthier Lover did foregoe the God of Verse) $[\ldots]^{12}$

(CAMÕES, 1655, p. 193, itálicos do tradutor).

Ali verão as setas estridentes (X, 40, 5).

There shall the hissing Shafts (like living swarms) ${ }^{13}$

(CAMÕES, 1655, p. 201, itálicos do tradutor).

A ausência de notas provavelmente se deve ao fato de que, em razão das complicações políticas enfrentadas por Fanshawe, a tradução foi publicada de forma apressada, sem que ele pudesse sequer revisar as provas. (BULLOUGH, 1963, p. 27).

Outro problema dessa tradução é que, sendo embaixador na Espanha durante o domínio espanhol sobre Portugal, Fanshawe adaptou alguns termos do original às circunstâncias de seu tempo, incorporando a noção de "Hispânia" corrente no século XVII.

O que esta sua nação só merecia.

(IX, 86, v. 8).

which $\mathrm{He}$ alone, and his Brave SPANIARDS merit. ${ }^{14}$

(CAMÕES, 1655, p. 191, itálicos e versalete do tradutor).

\footnotetext{
12 "Mas já o amigo da jovem Larisseia (que por Amante mais rico abandonou o Deus da Poesia) [...]".

13 "Ali [irão] as sibilantes setas (como enxames vivos)".

14 "que apenas Ele, e seus Bravos ESPANHÓIs merecem."
} 
Ademais, Fanshawe não demonstrou muito tato para com os portugueses ao discorrer sobre a inferioridade da língua portuguesa na dedicatória ao conde de Strafford:

\begin{abstract}
Meu bom Senhor,
Não sei como Vossa Senhoria encararia o fato de que, em uma língua tão incivilizada como a de PORTUGAL, possa existir um Poeta capaz de competir com vosso amado TASSO. Como ele próprio encarou esse fato, eu sei: pois se sabe que ele declarou (quando a sua grande JERUSALÉM era ainda um Embrião) que NÃO TEMIA A NENHUM HOMEM EXCETO CAMÕES; não obstante, ele ofertou um Soneto em sua homenagem. ${ }^{15}$

(CAMÕES, 1655, tradução nossa, tentando reproduzir os itálicos e versaletes do autor).
\end{abstract}

Talvez por ter sido escrita sob a influência do estilo renascentista que já estava saindo de moda na época de sua publicação ${ }^{16}$, essa tradução não alcançou repercussão fora do pequeno círculo de intelectuais a que pertencia Fanshawe. Veremos, no Capítulo 4, as críticas de Mickle à tradução de Fanshawe (subseções 4.7.5 e 4.7.6) e a opinião de alguns periódicos (seção 4.9) sobre as traduções de Fanshawe e de Mickle.

\title{
2.6.2.4 Itália
}

Na Itália, Camões era conhecido ainda em vida por autores como Torquato Tasso, que, em um soneto em que fala sobre Vasco da Gama, se referiu a Camões como o "colto e buon Luigi”. (Esse soneto foi republicado na edição de Os lusíadas comentada por Faria e Sousa, de 1639, e depois em várias traduções europeias da obra, inclusive a de Mickle.)

Em 1658, publicou-se em Lisboa aquela que é considerada a primeira tradução completa de Os lusíadas para o italiano, de autoria de Carlo Antonio Paggi. No ano seguinte, imprimiu-se uma segunda edição corrigida da mesma tradução, com emendas feitas por Henrico Valente de Oliveira. O tradutor trabalhou como procônsul da República de Gênova em Lisboa entre 1656 e 1666. Assim como Fanshawe, Paggi se baseou na edição de Faria e Sousa. A tradução de Paggi conserva a oitava rima e reflete o clima de admiração pela obra de Camões que dominava os círculos da alta nobreza e da intelectualidade de Portugal na época.

\footnotetext{
15 “My good Lord

I can not tell how your Lordship may take it, that in so uncourted a language, as that of PORTUGAL, should be found extant a Poet to rival your beloved TASSO. How himself took it, I can: for he was heard to say (his great JERUSALEM being then an Embrio) HE FEARED NO MAN BUT CAMÕES: Notwithstanding which, he bestow'd a Sonet in his praise."

${ }^{16}$ Cardim (1940, p. 40) comenta que Fanshawe seguiu Fairfax na escolha da oitava rima - que já estava fora de moda -, mas que Fanshawe não possuía a mesma "brandura de estilo" de Fairfax, que fora mais facilmente acolhido pelos augustanos.
} 
Uma curiosidade a respeito dessa tradução é que Paggi acrescentou alguns versos enaltecendo Cristóvão Colombo, de origem genovesa, na estrofe 143 no Canto X, no esforço de consertar um "lapso" de Camões, que se "esquecera" de incluir o célebre navegador, e outros versos em louvor a Gênova na estrofe 16 do Canto III. Além disso, o tradutor adicionou seis oitavas ao final do poema, exaltando Camões e a Itália em um tom emotivo, que Chaves chega a considerar pré-romântico. Essas seis oitavas foram, no século XIX, traduzidas por Garrett para o português, e vieram a exercer influência sobre o Romantismo em Portugal (CHAVES, 2001, p. 86).

Mais de um século depois, no ano de 1772 surgiu uma nova tradução completa de $O s$ lusíadas na Itália, feita por Michele Antonio Gazano, em oitava rima e estilo neoclássico.

\subsubsection{França}

Segundo Chaves (2001, p. 67, p. 69, p. 73), as duas primeiras traduções francesas d'Os lusíadas, ambas anônimas, uma ainda do século XVI e outra de 1612, teriam sido perdidas.

$\mathrm{O}$ ano de 1674 assinala a publicação dos primeiros comentários sobre Camões na França. O jesuíta René Rapin, em uma obra intitulada Réflexions sur la Poétique d'Aristote et sur les ouvrages des poètes anciens et modernes, publicada em Paris, faz uma apreciação das obras em literatura vernácula na Europa usando como critério de avaliação as regras aristotélicas. (SOUSA, 1998, p. 3). Lope de Vega e Cervantes estão entre os que são considerados dignos de elogios, mas a maioria das outras obras é avaliada negativamente. Rapin (1970, p. 47) critica Camões por ser obscuro ("Um dos maiores defeitos do discurso é a obscuridade: é disso que Camões, que os portugueses chamam de seu Virgílio, é culpável; pois seus versos são tão obscuros que poderiam passar por enigmas" ${ }^{\text {"17 }}$ ); por não ter senso de proporção (p. 72); pela simbiose entre as divindades greco-latinas e cristãs (p. 87); e por exprimir apenas o orgulho de sua nação (p. 95): “Camões, que é o único poeta heroico de Portugal, não pensou em mais nada além de exprimir o orgulho de sua nação em seu poema da conquista das Índias. Assim, ele é soberbo e magnífico em sua composição, mas tem pouco decoro". ${ }^{18} \mathrm{O}$ fato de Rapin não mencionar a epopeia camoniana pelo nome, designando-a

\footnotetext{
17 “Un des plus grands défauts du discours est l'obscurité : c'est en quoi le Camoens, que les Portugais appellent leur Virgile, est blâmable; car ses vers sont si obscurs, qu'ils pourraient passer pour des mystères [...]”.

18 “Le Camoens, qui est le seul Poète héroique de Portugal, n'a pensé qu'à exprimer l'orgueil de sa nation en son Poème de la conqueste des Indes. Car il est fier \& fastueux dans sa composition, mais il a peu de conduite".
} 
como "poema da conquista das Índias"19, leva Sousa (p. 4) a supor que o crítico francês não houvesse lido Os lusíadas.

No mesmo ano de 1674, foi lançada a primeira edição do Grand Dictionnaire Historique ou le Mélange Curieux de l'Histoire Sacrée et Profane, de Louis Moreri, com um longo artigo sobre a vida de Camões e Os lusíadas, reproduzindo as mesmas críticas de Rapin. Curiosamente, nas sucessivas reedições do dicionário essas críticas foram abrandadas, e alguns erros biográficos foram corrigidos. (SOUSA, 1998, p. 3).

Em 1685, Adrien Baillet elogiou entusiasticamente Camões em Jugements des çavants sur les principaux ouvrages des auteurs, embora, como seus predecessores, tenha censurado a mistura do maravilhoso pagão com a religião cristã. (SOUSA, 1998, p. 5).

Na França do século XVIII, as regras aristotélicas passaram a ser encaradas com extrema rigidez. Os gêneros literários eram ordenados hierarquicamente, com a epopeia a encabeçar a lista, e as normas a serem seguidas incluíam:

[...] primazia da razão; estudo da natureza profunda e permanente do homem; a imitação aos antigos; o respeito pelas conveniências em relação ao tema, ao público, aos costumes - segundo o conceito de decorum da Antiguidade; intenção moralista através da clareza, da acessibilidade, da densidade estilística. (CHAVES, 2001, p. 98, itálicos do autor).

Esse clima de prescrições neoclássicas muito estritas, somado à influência do pensamento jesuítico, se reflete no ensaio de Voltaire dedicado à poesia épica, Essay upon the Epick Poetry of the Europeen Nations from Homer to Milton, publicado em inglês durante seu exílio na Inglaterra, em 1727, e em francês, em versão revisada, em 1733, com o título Essai sur la poésie épique. Nesse ensaio - que, segundo René Wellek (apud CHAVES, 2001, p. 97), teria sido escrito para defender a Henriade, epopeia composta pelo próprio Voltaire, das acusações de apresentar um herói histórico e não mítico, e de não conter imaginário pagão -, Voltaire avalia os grandes autores épicos europeus: Homero, Virgílio, Lucano, Trissino, Torquato Tasso, Alonso de Ercilla, John Milton e Camões. Em sua análise d'Os lusíadas, Voltaire condena, em nome do racionalismo, a mistura do maravilhoso pagão com elementos cristãos, rejeitando a interpretação alegórica proposta por Faria e Sousa. Como poderia Vênus atender à súplica de Vasco da Gama, se o navegador, como verdadeiro cristão, solicitou a ação do Deus cristão, e não a interferência pagã? Voltaire (1792, p. 367) ironiza: "Essa nova alegoria explicará tudo; ninguém ficará mais tão surpreso que Gama, em uma tempestade,

\footnotetext{
19 “poème de la conquête des Indes".
} 
dirija suas preces a Jesus Cristo e que seja Vênus que venha em seu socorro [...]. Falando com mais seriedade, um maravilhoso tão absurdo desfigura toda a obra aos olhos dos leitores sensatos." ${ }^{20}$ Voltaire ridiculariza outros detalhes do poema, como a suposição de Camões de que o rei de Melinde conhecesse Homero e Virgílio, e compara, com um moralismo surpreendente em um racionalista, o episódio da Ilha dos Amores a um cabaré de Amsterdam: "[...] parece-se mais com um cabaré de Amsterdam do que com qualquer coisa de honesto". O filósofo francês critica, também, a falta de ligação entre as várias partes do poema: "[...] de todos os defeitos desse poema, o maior é a pouca ligação existente entre suas partes; ele se parece com a viagem de que trata". ${ }^{21}$ Elogia, entretanto, os episódios de Inês de Castro e do Adamastor, e conclui que Os lusíadas só não naufragaram como poema porque "a poesia do estilo e a imaginação na expressão lhe deram sustentação". ${ }^{22}$ De qualquer modo, o próprio fato de Voltaire ter incluído Camões na lista de autores a serem examinados demonstra que o poeta português e sua epopeia já haviam alcançado certo renome na Europa. E o ensaio de Voltaire - que, por muitos anos, foi a principal fonte de avaliação do épico camoniano na Europa - contribuiu para que Camões e Os lusíadas se tornassem ainda mais conhecidos em todo o continente. Alguns anos mais tarde, William Julius Mickle, na Introdução à sua tradução d'Os lusíadas, criticará violentamente essa análise de Voltaire e atribuirá vários erros de interpretação do filósofo ao fato de este ter lido o poema na "infiel" tradução para o inglês feita por Sir Richard Fanshawe. Veremos as críticas de Mickle em detalhe no Capítulo 4, subseções 4.7.5 e 4.7.6.

Talvez uma decorrência da divulgação do ensaio de Voltaire tenha sido o surgimento, em 1735, da primeira tradução d'Os lusíadas para o francês, realizada por Duperron de Castera, literato e diplomata francês. Trata-se de uma tradução em prosa, em três volumes, incluindo biografia do autor; o soneto de Torquato Tasso dedicado a Vasco da Gama, em que Camões é louvado; um resumo no início de cada canto e notas detalhadas ao final de cada canto. Nas notas, Castera demonstra profundo conhecimento da mitologia clássica. Não poupa elogios ao poema e procura defendê-lo das acusações de Voltaire, afirmando que o uso do maravilhoso era uma das exigências para a composição de uma epopeia e repetindo, com

\footnotetext{
20 "Cette allégorie nouvelle rendra raison de tout; on ne sera plus autant surpris que Gama, dans une tempête, adresse ses prières à Jésus-Christ, et que ce soit Vénus qui vienne à son secours [...] A parler plus sérieusement, un merveilleux si absurde défigure tout l'ouvrage aux yeux des lecteurs sensés."

21 “[...] de tous les défauts de ce poème, le plus grand est le peu de liaison qui règne dans ses parties; il ressemble au voyage dont il est le sujet".

22 "la poesie du style et l'imagination dans l'expression l'ont soutenu".
} 
algumas variações, os argumentos de Faria e Sousa sobre as intenções alegóricas do uso do maravilhoso pagão.

A segunda tradução de Os lusíadas para o francês, publicada em 1776 (mesmo ano da publicação da primeira edição da tradução de Mickle na Inglaterra) foi resultado da colaboração de dois tradutores: Vaquette d'Hermilly (tradutor de autores espanhóis, como Quevedo) fez uma tradução literal do poema e Jean-François de La Harpe, poeta e crítico literário, adaptou a tradução em estilo poético. A nota do editor estampada no começo do livro é típica da época:

Esta nova tradução de Camões, da qual podemos, de modo geral, garantir a fidelidade, é a obra de um escritor muito conhecido: ela se baseia em uma versão literal do texto português: versão composta, com todo o cuidado e toda a exatidão possíveis, por um homem muito versado na língua de Camões. O novo tradutor se propôs a animar com o fogo da poesia essa versão escrupulosamente fiel. Ele não se permitiu nenhuma outra liberdade além daquela de resumir algumas passagens um tanto longas, mas raramente, e essa diminuição do texto é bem pouca. (CAMÕES, 1776b, pp. i-ii). ${ }^{23}$

La Harpe, admirador e discípulo de Voltaire, tomou grandes liberdades com o texto original. E, assim como Voltaire, La Harpe não gostou muito da obra (com a exceção dos episódios do Adamastor e de Inês de Castro):

[...] não há em seu poema nem ação, nem personagens e, em consequência, nenhum interesse. É toda a história de Portugal, contada em episódios que se sucedem tediosamente, e que são, muitas vezes, mal fundamentados. Não há nem grandes perigos, nem situações suficientemente cativantes, nem personagens suficientemente heroicos para formar a fábula de um poema. (CAMÕES, 1776b, p. xix). ${ }^{24}$

\footnotetext{
23 “Cette nouvelle Traduction de Camoëns, dont on peu en général garantir la fidélité, est l'ouvrage d'un Écrivain très-connu : elle a été faite sur une version littérale du texte Portugais : version composée, avec tout le soin \& toute l'exactitude possible, par un homme très-versé dans la langue de Camoëns. Le nouveau traducteur s'est proposé d'animer du feu de la poésie cette version scrupuleusement fidelle. Il ne s'est permis d'autre liberté que celle de resserrer quelques endroits un peu longs, mais rarement; \& cette diminution du texte est très-peu de chose."

24 “'...] il n'y a dans son Poëme ni action, ni caractères, \& par conséquent point d'interêt. C'est toute l'Histoire du Portugal, amenée en episodes qui se succèdent ennuyeusement, \& qui sont souvent mal fondées. Il n'y a ni d'assez grands dangers ni de situations assez attachantes, ni de personnages assez héroiques pour former la fable d'un Poëme.."
} 


\subsubsection{Holanda, Polônia, Rússia}

Durante muitos anos, a tradução de La Harpe foi a principal fonte de Os lusíadas na Europa, tendo sido a base da primeira tradução para o holandês, de autoria de Lambertus Stoppendaal Pieterszoon, de 1777 - uma tradução em prosa que não alcançou grande repercussão; da primeira tradução russa, de Alexander Dmitrieff, em 1788, também em prosa, e da primeira tradução para o polonês, por Jacek Idzi Przybylski, em 1790, em versos de 13 sílabas, que veio a ter um papel de relevância no Romantismo polonês. (CHAVES, 2001, p. 79; JUROMENHA, 1860, pp. 298-301; KALEWSKA, pp. 28-29; DE VRIES, 2007, p. 40). Com essas três traduções indiretas (para o holandês, o russo e o polonês) completamos o quadro de todas as traduções de Os lusíadas feitas até o final do século XVIII.

\subsubsection{Século XIX}

O estudo da recepção do épico camoniano no século XIX foge ao escopo deste trabalho; apenas, como um breve comentário em contraponto às interpretações que discutimos neste capítulo, observamos que, nesse século revolucionário, de grandes mudanças históricas e culturais, os românticos interpretarão Camões e sua obra sob novas luzes, criando toda uma mitologia a partir de fontes biográficas que já circulavam anteriormente. Madame de Staël publica na Biographie Universelle, em 1811, uma biografia de Camões extremamente romantizada; Friedrich Schlegel, em seu Geschichte der alten und neuen literatur [História da literatura antiga e moderna], de 1815, aponta Camões como o paradigma da poesia épica, exaltando-o como guerreiro, viajante, marinheiro e aventureiro, destacando essa rica vivência como fator principal a desencadear a criação literária materializada na epopeia. Schlegel, integrante do grupo conhecido como "os românticos de Jena", elogia "o livre jogo da fantasia no maravilhoso" presente n'Os lusíadas. Os escritores românticos prezam a liberdade de imaginação, rejeitando as normas rígidas dos neoclássicos, e valorizam os temas nacionais, sobretudo os feitos heroicos patrióticos. É natural, portanto, que vejam Camões e Os lusíadas sob um ponto de vista diferente dos clássicos e neoclássicos. Schlegel e os românticos alemães viam em Camões um exemplo da liberdade de imaginação e do patriotismo. (CHAVES, 2001, pp. 119-126). O interesse dos românticos pela obra camoniana levou à publicação de novas traduções: a primeira tradução completa para o alemão, entre 1806 e 1807, de autoria de Carl Christian Heise, em oitava rima; a tradução de Fichte do episódio de Inês de Castro, publicada em 1810; a tradução para o alemão de toda a obra de Camões por 
Wilhelm Storck, que publica também uma monumental biografia, Luis' De Camoens Leben, em 1890, traduzida para o português como Vida e obras de Camões por D. Carolina Michaelis de Vasconcelos em 1897; ao longo do século XIX, são lançadas cinco traduções para o italiano, cinco para o inglês, sete para o alemão, sete para o francês e quatro para o espanhol, além de traduções para o sueco, dinamarquês, húngaro e outras línguas. (BECHARA e SPINA, p. 25; DE VRIES, 2007; JUROMENHA, 1860, pp. 299-301). 


\section{A GRÃ-BRETANHA SETECENTISTA}

Este capítulo examina o ponto de chegada da translatio reencenada por William Julius Mickle: o momento histórico, social, político, econômico e cultural em que foi efetuada a tradução de Mickle de Os lusíadas para o inglês.

A primeira seção aborda o contexto histórico, social, político e econômico: no final do século XVIII, a Grã-Bretanha, um império construído com base no comércio e expandido pelas armas, vivia uma fase de extraordinário crescimento econômico e o início da Revolução Industrial. Conhecer esse cenário - inclusive o papel exercido pela poderosa Companhia Britânica das Índias Orientais - é importante não apenas para entendermos várias discussões levantadas por Mickle nos paratextos do Lusiad como para interpretarmos a conjuntura em que surge essa tradução.

A segunda seção trata dos aspectos culturais da Grã-Bretanha nesse mesmo período, em sete subseções. A primeira subseção (3.2.1) descreve, de modo geral, essa era do comércio, dos autores e da "harmonia universal"; a segunda subseção (3.2.2) discorre sobre as concepções de identidade nacional e a visão de mundo dos britânicos dessa época; a terceira subseção (3.2.3) apresenta as principais ideias e pensadores do Iluminismo; a quarta subseção (3.2.4) examina o Neoclassicismo; a quinta subseção (3.2.5) trata da Graveyard School e do chamado "Pré-Romantismo".

A terceira seção descreve, em linhas gerais, a retórica como era estudada na GrãBretanha do século XVIII, com um destaque especial para a retórica de Hugh Blair, que expõe as regras e conceitos retóricos mais influentes na época de Mickle, até mesmo a respeito da poesia épica.

$\mathrm{Na}$ quarta seção, estudamos as ideias sobre tradução no setecentismo britânico (inclusive a influência das ideias francesas e de épocas anteriores sobre o mesmo tema). A primeira subseção (3.4.1) aborda a tradução nos séculos XVII e XVIII na França (as belles infidèles e seu principal expoente, Nicolas Perrot d'Ablancourt); a segunda subseção (3.4.2) examina as ideias sobre tradução na Grã-Bretanha, percorrendo os escritos sobre tradução de vários autores da época: John Denham, Abraham Cowley, Wentworth Dillon (Conde de Roscommon), John Dryden, Alexander Pope e Alexander Fraser Tytler. Ainda nessa subseção, comentaremos brevemente a tradução, feita na mesma época que o Lusiad de Mickle, de outra epopeia moderna: a tradução de John Hoole da Jerusalém libertada, de Torquato Tasso. 
Na quinta seção, voltamos a acompanhar o percurso da translatio studii et imperii na Grã-Bretanha, comentando vários poemas dos séculos XVII e XVIII em que o conceito de translatio é usado como modelo retórico teleológico para a construção de uma identidade nacional comercial e imperialista para a Grã-Bretanha.

A sexta e última seção apresenta algumas considerações gerais a respeito dos tópicos abordados no capítulo.

\subsection{CONTEXTO SÓCIO-HISTÓRICO-POLÍTICO-ECONÔMICO}

$\mathrm{Na}$ Inglaterra, a chamada "Revolução Comercial", uma expansão das atividades comerciais vinculada à exploração do mundo colonial entre os séculos XV e XVIII, permitiu o acúmulo de capitais, a ampliação dos mercados de consumo e o acesso a novas fontes de matérias-primas. Com a fundação do Banco da Inglaterra, em 1694, instituiu-se um sistema de crédito, criando condições estáveis para a extensão e a ampliação de um mercado de capitais centrado em Londres. (O’BRIEN, 2002, pp. 62-63). As transformações aplicadas na agricultura ao longo do século XVIII, conhecidas como a "Revolução Agrária", resultaram em um aumento acentuado da produtividade agrícola. A esses fatores, somou-se a ampliação da rede de transportes, tanto terrestres quanto fluviais. O século XVIII foi também um momento de importantes inovações tecnológicas nos setores têxtil, energético (com a invenção da máquina a vapor) e metalúrgico (a utilização do carvão mineral em lugar do carvão vegetal promoveu um grande aumento na produção).

No cenário político, as revoluções inglesas do século XVII levaram ao fim do absolutismo em 1688, com o Bill of Rights (considerada, historicamente, a primeira carta de direitos), que instaurou a monarquia parlamentar. Em 1707, foi criada a Grã-Bretanha, a partir da união das coroas e dos parlamentos da Inglaterra e da Escócia, o que demonstrava a obtenção de certo nível de unidade nacional e estabilidade política (a Irlanda continuou sendo um reino separado, embora subordinado à Coroa Britânica, até 1801, quando foi incorporada ao Reino Unido). Essas novas bases econômicas e políticas foram fundamentais para que a Grã-Bretanha se tornasse o primeiro país a realizar a Revolução Industrial.

A Revolução Industrial provocou o deslocamento da produção do âmbito doméstico para o fabril. A urbanização se acelerou, pois os trabalhadores rurais eram atraídos pela perspectiva de trabalharem nas indústrias. Surgiram duas novas classes sociais: o operariado 
industrial, que se organizou fundando sindicatos e cooperativas, e a classe média urbana ${ }^{1}$, que exercia atividades administrativas nas indústrias.

Uma das consequências da Revolução Industrial foi a exacerbação do imperialismo, em razão das disputas por territórios entre as diversas potências industriais, e o estabelecimento de uma maior dependência entre as várias regiões do mundo. Algumas regiões se especializaram na produção de matérias-primas, enquanto outras se dedicavam à produção industrial.

As vitórias da Grã-Bretanha na Guerra da Sucessão Espanhola (1702-1713) causaram impacto, demonstrando o novo poderio militar do país, assinalando o início de uma hegemonia britânica na Europa. O Império Britânico - até então composto pela Irlanda e vários centros de colonização na América do Norte, nas Índias Ocidentais (nome pelo qual era conhecida a região do Caribe), nas Índias Orientais (sudeste e sul da Ásia) e outros pequenos territórios na América do Sul e na África - foi ampliado com a cessão de Acádia, Terra Nova, Baía de Hudson e Ilha de São Cristóvão pela França, e de Gibraltar (que veio a se tornar uma importante base naval, permitindo aos britânicos o controle da passagem entre o Atlântico e o Mediterrâneo) e Minorca, pela Espanha. A Guerra dos Sete Anos, entre 1756 e 1763, foi o primeiro conflito travado em escala global, envolvendo a Europa, a Índia, a América do Norte, o Caribe, as Filipinas e a costa africana. Com a assinatura do Tratado de Paris, em 1763, a França cedeu a Nova França, e a Espanha entregou a Flórida à Grã-Bretanha. Na Índia, as guerras Carnáticas levaram à imposição de restrições sobre as feitorias francesas, subordinando-as ao governo britânico. A vitória britânica sobre a França na Guerra dos Sete Anos transformou a Grã-Bretanha na maior potência mundial. (MARSHALL, 2001b, pp. 1-2; PAGDEN, 2001, p. 90).

Seguindo os princípios mercantilistas então vigentes, pelos quais a riqueza de um país era estimada em função da maior quantidade de moedas ou metais preciosos em seu poder, a Grã-Bretanha utilizava suas colônias para obter uma balança de comércio favorável. A estrutura de produção das colônias deveria complementar a economia da metrópole, pelo sistema do monopólio: as colônias eram autorizadas a produzir apenas matérias-primas e a comerciar unicamente com a Grã-Bretanha. Esse sistema levou ao acirramento das relações entre as colônias norte-americanas e a Grã-Bretanha em meados do século XVIII. A cobrança de impostos decidida sem a aprovação dos habitantes das colônias acabou conduzindo à

\footnotetext{
${ }^{1}$ Nos séculos XVII e XVIII usava-se a expressão "the middling sort" para se referir ao que hoje chamamos de “classe média" [middle class].
} 
Guerra da Independência Norte-Americana em 1775 e, no ano seguinte, à declaração da independência dos Estados Unidos. (MARSHALL, 2001b, pp. 11-12).

A perda das Treze Colônias norte-americanas, com o surgimento dos Estados Unidos, em 1776 (o mesmo ano em que foi publicada a tradução de Mickle de Os lusíadas), assinala a passagem do primeiro Império Britânico ao segundo. O foco dos interesses da Grã-Bretanha se voltou para a Ásia, o Pacífico e, mais tarde, a África. No influente livro The Wealth of Nations $^{2}$, também publicado em 1776, Adam Smith afirmava que as colônias não eram necessárias e que o livre-comércio deveria substituir as antigas políticas mercantilistas que haviam caracterizado o primeiro período de expansão colonial. Segundo Smith, o exclusivismo mercantilista colocava empecilhos ao livre-comércio e só beneficiava a burguesia mercantil. Os circuitos de distribuição implantados pela expansão marítima transmitiam a ilusão de que a criação da riqueza era uma questão de controle cambial e comercial, o que mascarava a verdadeira origem da riqueza: o trabalho e o consumo. $\mathrm{O}$ crescimento do comércio entre os Estados Unidos e a Grã-Bretanha após 1783 confirmou a ideia de Smith de que o controle político territorial não era necessário para o sucesso econômico. (MARSHALL, 2001a, p. 576 e 585; PORTER, 2000, p. 386).

Como vimos no Capítulo 2, o primeiro país europeu a formar um império com base no comércio foi Portugal. Em meados do século XV, Portugal já havia fundado postos comerciais e feitorias em vários pontos da Europa, estendendo-as aos poucos às costas da África e depois à Índia, à China e a outros locais na Ásia. Os britânicos e os holandeses vieram não só a suceder os portugueses, como a transformar o comércio na base ideológica de suas vastas pretensões imperialistas. (PAGDEN, 2001, p. 88).

O domínio exercido pelo Império Britânico sobre Portugal e o Brasil também ilustra as novas relações econômicas que estavam se estabelecendo. Enfraquecido após libertar-se do domínio espanhol, em 1640, Portugal precisava recuperar-se economicamente, proteger-se de ataques e defender as colônias ultramarinas. A solução encontrada foi estabelecer uma aliança com a Inglaterra, uma potência militar e econômica. Pelos tratados comerciais firmados entre Portugal e Inglaterra em 1642, 1654 e 1661, os portos de Portugal foram abertos aos navios ingleses; comerciantes ingleses residentes em Portugal obtinham privilégios fiscais, civis e judiciais; e Portugal era forçado a comprar seus navios da Inglaterra. Além disso, os comerciantes ingleses eram autorizados a participar do comércio metropolitano com as colônias, exportando seus produtos (exceto vinho, bacalhau, azeite e farinha, que eram

\footnotetext{
${ }^{2}$ SMITH, Adam. A riqueza das nações. Tradução de Maria Teresa Lemos de Lima. Curitiba: Juruá, 2006.
} 
monopólio lusitano) e transportando os produtos importados, dividindo com Portugal os lucros de venda na Europa de todos os produtos (com a exceção do pau-brasil, cuja venda era direito exclusivo da Coroa Portuguesa). Isso significava, para Portugal, a perda do monopólio colonial. Portugal e suas colônias eram, já na primeira metade do século XVIII, satélites da Grã-Bretanha. Essa situação se agravou com a assinatura do Tratado de Methuen, em 27 de dezembro de 1703. Por esse tratado, a Inglaterra se comprometia a adquirir os vinhos de Portugal com uma redução de dois terços do valor do imposto cobrado aos vinhos franceses; em contrapartida, os portugueses se comprometiam a adquirir os tecidos ingleses. O Tratado de Methuen reforçou a dominação inglesa sobre Portugal e suas colônias, em especial o Brasil, que se tornou um grande importador de mercadorias inglesas. O deficit elevado e constante criado por esse acordo fez com que, no auge da mineração, entre 1700 e 1760, quase todo o ouro brasileiro passasse a ser escoado de Portugal para a Inglaterra, contribuindo para a industrialização inglesa. (MARSHALL, 2001b, pp. 21-22; SIDERI, 1970, pp. 17-18 e pp. 39-40).

Nas Índias Orientais, o monopólio do comércio havia sido entregue pela rainha Elisabete I à Companhia Inglesa das Índias Orientais (mais tarde chamada Companhia Britânica das Índias Orientais), fundada em 1600 por comerciantes de Londres. A companhia comercializava principalmente algodão, seda, índigo (corante), pimenta, sal, salitre, café, chá e ópio. Durante o primeiro século de funcionamento, a Companhia das Índias Orientais concentrou-se no comércio. No século XVIII, entretanto, quando o Império Mogol entrou em decadência e a Companhia Francesa das Índias Orientais começou a fazer concorrência aos britânicos, a Companhia Britânica das Índias Orientais passou a governar amplas regiões da Índia, tendo até mesmo um exército próprio. Entre 1757 e 1858, a Companhia governou a Índia para a Coroa britânica. (BOWEN, 2001, pp. 530-551; ROBINS, 2006, pp. 41-43, 46, 66-75).

Cada vez mais, principalmente após a independência dos Estados Unidos e com a expansão das atividades britânicas na Índia e a ampliação do tráfico de escravos africanos, as relações de exploração e escravismo estabelecidas pelo Império Britânico se evidenciaram, a ponto de os residentes na Grã-Bretanha passarem a encarar as atividades nas colônias como “degeneradas", envolvendo corrupção, crueldade e a opressão dos nativos. Esse sentimento levou até à formação de movimentos antiescravagistas. Resultou também no questionamento do papel da Companhia das Índias Orientais na Ásia - não apenas em relação ao monopólio, criticado pelos defensores do livre-comércio, como a respeito da capacidade de uma companhia comercial administrar, sem o apoio direto da Coroa, regiões tão distantes da 
metrópole. Entre 1766 e 1768, o Primeiro-Ministro William Pitt, o Velho, decidiu intervir nos assuntos indianos a fim de assegurar à Coroa parte das rendas obtidas pela Companhia. Depois de longas negociações, a Companhia concordou em pagar quatrocentas mil libras ${ }^{3}$ por ano à Coroa, mas continuou sendo a representante dos interesses do governo britânico na Índia. As críticas à atuação da Companhia continuaram, no entanto, principalmente por causa de denúncias de inúmeros casos de crimes, corrupção e despotismo cometidos por seus membros. Em 1813, o monopólio da Companhia foi abolido na Índia, e os comerciantes e fabricantes passaram a ter livre acesso aos mercados indianos. (GREENE, 2001, pp. 222-229; BOWEN, 2001, pp. 530-551; ROBINS, 2006, p. 89).

\subsection{CONTEXTO CULTURAL}

\subsubsection{A era da "harmonia universal", do comércio e dos autores}

Na Grã-Bretanha do século XVIII, as classes aristocráticas e alguns setores da classe média desfrutavam, em comparação com o século anterior, de relativa paz e estabilidade política. Era uma sociedade que valorizava a polidez e a sociabilidade, e na qual o comércio configurava diversas práticas e instituições culturais. ${ }^{4}$ (LANGFORD, 1998, p. 2). Londres se transformara no centro da vida literária e intelectual do país, e os escritores passaram a encarar a sociedade "polida" de Londres como o seu público principal. (DAICHES, 1997, p. 590).

Otto Maria Carpeaux (1961, pp. 1.280-1.281 e pp. 1.315-1.316) descreve o século XVIII como uma época de busca da "harmonia universal". A cosmologia de Newton garantia a harmonia entre os movimentos dos corpos celestes. O universo newtoniano, como a própria sociedade, era composto de incontáveis átomos, mas, em seu conjunto, exibia uma ordem natural harmoniosa, que a humanidade podia explorar e dominar por meio da ciência e da técnica. Esse universo era o paradigma perfeito para uma política moderna, estável, harmônica, cristã, governada pela lei. Alexander Pope é, por excelência, o cantor desse mundo harmônico:

\footnotetext{
${ }^{3}$ Correspondentes a cerca de 50 milhões de libras atualmente.

${ }^{4}$ A palavra "commerce" tinha, no século XVIII, o sentido geral de intercâmbio, não se limitando ao sentido de intercâmbio comercial. (Ver JOHNSON, 1778). Mesmo atualmente a palavra conserva a acepção de "social intercourse" [intercâmbio social]. Quanto ao ideal de "politeness" [polidez], disseminado por toda a sociedade britânica ao longo do século XVIII, abarcava aspectos filosóficos, éticos e sociais, constituindo todo um sistema de conduta, envolvendo o controle das paixões e o bom gosto. (BREWER, 2000, pp. 100-108).
} 
All are but parts of one stupendous whole,

Whose body Nature is, and God the soul;

[...]

All Nature is but Art, unknown to thee;

All Chance, Direction, which thou canst not see;

All Discord, Harmony not understood;

All partial Evil, universal Good.

And, spite of pride, in erring reason's spite,

One truth is clear: WHATEVER IS, IS RIGHT. ${ }^{5}$

O sentido desses versos não é apenas filosófico - apresenta implicações políticas e econômicas. Na epístola IV do mesmo poema, Pope (1825, p. 213) diz: “Order is heaven's first law; and this confest, / Some are, and must be, greater than the rest, / More rich, more wise [...]"6. Para Carpeaux (1961, pp. 1.280-1.282), o verso "Whatever is, is right" é a profissão de fé do classicismo liberal e a base metafísica do "laissez faire, laissez aller", pois em Adam Smith "todos os egoísmos em conjunto dão o resultado da harmonia preestabelecida da sociedade”. Os poetas, no entanto, estão excluídos dessa harmonia, pois a sua atividade não tem sentido econômico. Instaura-se, assim, a separação entre a poesia e o público; os literatos profissionais abandonam os salões, refugiando-se nos cafés boêmios. $\mathrm{O}$ Iluminismo, segundo Carpeaux, é a expressão do otimismo da burguesia que se emancipa do feudalismo. Mas o poeta é "a expressão da Intelligentzia que se emancipa da sociedade" e cultiva "a melancolia pessimista do pré-romantismo, sonhando com belezas medievais, com primitivismos populares, com o idílio exótico das ilhas no Pacífico, com os costumes bárbaros mas poéticos dos escoceses de Ossian e do Norte escandinavo". Essas duas atitudes, o otimismo clássico da classe dirigente e a melancolia pré-romântica dos intelectuais, convivem antiteticamente no século XVIII.

Esse é um momento de transição para os escritores e poetas, que deixam de depender apenas da aristocracia e passam à esfera de influência pública. Na França, essa "opinião pública" ainda é formada pelos aristocratas, reunidos nos célebres salões. Mas na Inglaterra nascem os cafés literários, onde se reúne um novo público, anônimo, que assina periódicos e

\footnotetext{
5 "Tudo é parte de um todo de sem par grandeza, Cuja alma é Deus, e cujo corpo é a Natureza; $[\ldots]$

A Natureza toda é uma arte ignota a ti; Todo acaso, desígnio, que não vês aqui;

Toda discórdia, uma harmonia que ouves mal; E todo mal parcial, o bem universal. Malgrado o orgulho, o pensamento pouco aberto, Uma verdade é clara: TUDO O QUE É, É CERTO.” (POPE, 1994, pp. 96-99, tradução de Paulo Vizioli). 6 "A ordem é a primeira lei do céu, e assim, / Alguns são, e devem ser, maiores que os demais / Mais ricos, mais sábios $[\ldots]$ "
} 
debate as questões da atualidade. Para Carpeaux (1961, pp. 1.297-1.298), “O café literário é sintoma de uma nova situação social do escritor: em vez do 'protégé', surge o profissional das letras. É a mudança social mais importante que a literatura sofreu em toda a sua história, entre Homero e a primeira guerra mundial”. Os literatos, sem função econômica quer na nova sociedade, quer nos salões literários, que eram um local de aliança entre a aristocracia e a literatura, encontram um novo lar no café literário e uma nova função no jornalismo.

Em Paris, é o ambiente pré-revolucionário do Palais Royal, com os seus jornalistas, poetas vagabundos, atores, desocupados, prostitutas. Em Londres, é Grub Street, a rua dos jornais, das casas editoras, dos diaristas literários, tradutores famintos, dos ghost-writers redigindo obras que um diletante abastado compra e assina com seu nome; enfim, dos primeiros repórteres. Neste ambiente, não há lugar para crenças dogmáticas; tudo depende do gosto do público anônimo que lê jornais e compra livros. As modas literárias começam a mudar com rapidez inédita. A estética dogmática do classicismo tem que fazer concessões, as antigas "escolas de poetas" desaparecem, substituídas pelas facções e partidos literários.

A literatura se transformou em mercadoria, distribuída em todos os formatos e tamanhos. Clássicos eram lançados a baixos preços como livros de bolso ou em fascículos. $\mathrm{Na}$ primeira edição do Dictionary de Samuel Johnson (1755), com tiragem de duas mil cópias, cada exemplar era vendido a quatro libras e dez shillings ${ }^{7}$; em seguida foi lançada outra edição, em 165 fascículos semanais, vendidos a seis pence ${ }^{8}$ cada um. A Complete History of England, de Smollett, escrita entre 1757 e 1758, vendeu dez mil cópias em fascículos semanais de seis pence. $\mathrm{O}$ acesso aos livros também se tornou mais fácil, com a proliferação das livrarias, dos clubes de livros e bibliotecas. (PORTER, 2000, p. 87). Os periódicos se multiplicaram. Entre os mais influentes estavam o Spectator (1711-1714), fundado por Joseph Addison e Richard Steele; The Rambler (1750-1752), dirigido por Samuel Johnson, e The Gentleman's Magazine (1731-1914), para o qual Johnson contribuía.

No século XVIII, chamado por Johnson (1823, p. 251) de "A Era dos Autores", , o ofício do escritor passou por uma crescente mercantilização. Alexander Pope - embora ainda inserido no sistema aristocrático de patronagem, pois vivia entre aristocratas e desfrutava de seus presentes, hospitalidade e influência - pode ser considerado um dos primeiros escritores profissionais. As traduções de Pope da Ilíada e da Odisseia de Homero, publicadas com o financiamento de uma lista de assinantes, ajudaram-no a assegurar a sua

\footnotetext{
${ }^{7}$ Soma que equivaleria a cerca de 625 libras em 2014.

${ }^{8}$ O equivalente a $£ 3.47 \mathrm{em} 2014$.

9 "The Age of Authors".
} 
independência financeira. Somando-se o valor arrecadado nas duas traduções, Pope teria ganhado, ao longo de 11 anos, entre nove e dez mil libras ${ }^{10}$ (GRIFFIN, 2006, pp. 123-124; ROBINSON, 2002, p. 192; STEPHEN, 1880, p. 61). Lawrence Venuti (1995, p. 66) assinala o século XVIII como o momento em que o sistema de patronagem dá lugar a esse tipo de publicação por assinatura:

O Homero de Pope manteve o refinamento de um discurso poético transparente no dístico heroico, ainda um elitismo literário entre as classes hegemônicas, menos dependentes da patronagem da corte do que de editores com listas de assinatura que eram agora cada vez mais burguesas além de aristocráticas. Virou moda assinar a tradução de Pope: mais de $40 \%$ dos nomes nas listas de sua Ilíada possuíam títulos de nobreza, e os membros do parlamento incluíam tanto Tories quanto Whigs. ${ }^{11}$

Samuel Johnson (1709-1784), o Dr. Johnson, é outra figura importante nesse momento de transição. No início de sua carreira, Johnson precisou fazer traduções mal pagas e trabalhar como ghost writer para editores da Grub Street. Ainda assim, conseguiu se transformar em um dos intelectuais mais influentes de sua época. Em torno dele, reuniam-se outros escritores e artistas, como Oliver Goldsmith, David Garrick, James Boswell, Edmund Burke, Joshua Reynolds e muitos outros - entre eles, o próprio William Julius Mickle. Com o Dictionary of the English Language, Johnson ditou os padrões de correção para a língua inglesa durante várias décadas. Publicado em 1755, o Dictionary vinha atender a um clamor dos escritores por uma regulamentação da língua inglesa, que estava mudando com extrema rapidez. Johnson elaborou o dicionário praticamente sozinho, em nove anos de árduo trabalho. E a coleção de biografias críticas de poetas, The Lives of the English Poets, organizada por ele entre 1779 e 1781, embora reflita as preferências tradicionalistas de Johnson, inaugura um estilo de crítica literária inovador, bastante semelhante ao que é praticado ainda hoje. (CARPEAUX, 1961, pp. 1.317-1.319; PECK; COYLE, 2002, p. 128).

Carpeaux (1961, p. 1.321) exalta a carta em que Johnson nega a Lord Chesterfield o título de patrono do Dictionary como a "declaração de independência" da literatura. O ato de

\footnotetext{
${ }^{10}$ Correspondendo, atualmente, a valores entre um milhão e duzentas mil libras e um milhão e quatrocentas mil libras.

11 "Pope's Homer continued the refinement of a transparent poetic discourse in the heroic couplet, still a literary elitism among the hegemonic classes, dependent less on court patronage than on publishers with subscription lists that were now increasingly bourgeois as well as aristocratic. It became fashionable to subscribe to Pope's translation: over 40 percent of the names on the lists for his Iliad were titled, and the MPs included both Tories and Whigs."
} 
Johnson significaria "o fim de uma época e o começo de uma nova era". ${ }^{12}$ Essas afirmações de Carpeaux contêm certo exagero. Afinal, a carta de Johnson não era a recusa de uma oferta de patrocínio - era o protesto dirigido a um patrono que não havia cumprido com suas obrigações. Ademais, mesmo depois dessa carta Johnson continuou tentando obter patrocínios da nobreza e, após a ascensão de George III ao trono, passou a receber uma pensão de trezentas libras ao ano ${ }^{13}$ - que, apesar de lhe ter sido concedida "por méritos literários" passados, foi acompanhada por frequentes pedidos, por parte de ministros, de artigos em defesa das políticas do rei (pedidos a que Johnson atendeu diversas vezes). Além de Johnson, muitos outros escritores recebiam pensões, patrocínios ou desfrutavam de cargos em virtude do sistema de patronagem. Assim, em vez de falarmos em independência, parece-nos mais adequado dizermos que, nesse período histórico, a dependência do escritor estava em processo de transferência da aristocracia para a burguesia. Esta é, aliás, a opinião de Dustin Griffin, que estudou a fundo a patronagem literária na Grã-Bretanha do século XVIII e descreve essas relações de patronagem literária como um sistema disseminado organicamente na sociedade, envolvendo vários tipos de reciprocidade entre patrono e autor. Griffin (2006, p. 10) afirma que não houve uma transição rápida nem completa da cultura aristocrática para a comercial, nem da economia patronal para a de mercado, e que nesse período os editores/livreiros [booksellers] ganharam poder econômico e cultural, mas não suplantaram o sistema de patronagem aristocrática - que continuou exercendo forte controle sobre a cultura e a política.

\footnotetext{
${ }^{12}$ Quando Johnson resolveu escrever seu dicionário, enviou a Lord Chesterfield, um dos principais secretários de Estado do rei, o projeto de criação da obra. Lord Chesterfield se expressou de modo muito favorável em relação ao projeto, mas nunca fez nada para dar apoio à sua realização. Quando, depois de nove anos de trabalho, Johnson completou o dicionário, Lord Chesterfield, esperando que Johnson fosse lhe dedicar a obra, escreveu dois artigos elogiosos ao Dictionary no The World, um periódico londrino. Foi então que Johnson redigiu a famosa carta a Lord Chesterfield, queixando-se, em termos incisivos, do descaso que o nobre lhe devotara: "Is not a Patron, My Lord, one who looks with unconcern on a Man struggling for Life in the water and when he has reached ground encumbers him with help? [...] I hope it is no very cynical asperity not to confess obligation where no benefit has been received, or to be unwilling that the Public should consider me as owing that to a Patron, which Providence has enabled me to do for myself." ["Será que um patrono, meu senhor, é alguém que observa com indiferença um homem que se debate dentro da água para não morrer e, quando ele alcança a terra firme, cumula-o de cuidados? [...] Espero que não seja uma grosseria por demais brutal não reconhecer obrigações quando nenhum benefício foi recebido, ou não desejar que o público considere que devo a um patrono algo que a Providência me possibilitou fazer por mim mesmo."] Lord Chesterfield não respondeu à carta nem se manifestou publicamente a seu respeito. (BOSWELL, 1998, p. 185).

${ }^{13} \mathrm{O}$ equivalente a cerca de 40 mil libras em 2014.
} 


\subsubsection{Identidade nacional e visão de mundo}

Os ingleses se vangloriavam, já desde o final do século $\mathrm{XV}$, de ser, ao contrário da maioria dos povos da Europa e de todo o mundo, um "povo livre", cujas leis salvaguardavam a liberdade. Essa liberdade - escrita com inicial maiúscula, Liberty, e glorificada como uma deusa pelos poetas - seria a própria "essência" da identidade nacional. Tal sentimento foi reforçado com a Revolução de 1688 e a abolição da censura em 1695, e prevaleceu ao longo de todo o século XVIII. Descontados os exageros ufanistas, a imprensa gozava, de fato, de uma notável liberdade e havia uma tolerância religiosa maior do que a vigente na maioria dos outros países (LANGFORD, 2000, p. 101).

Outro elemento importante associado à identidade nacional era a exaltação do comércio. No século XVIII, o culto do comércio se tornou ainda mais difundido. Os britânicos acreditavam que a superioridade britânica nas artes comerciais era a principal razão pela qual a Grã-Bretanha havia atingido uma situação tão elevada entre as nações modernas. Os pensadores do Iluminismo Escocês viam o comércio como o estágio mais elevado do desenvolvimento social. Aqueles que celebravam o "Espírito do Comércio" diziam que o comércio havia tornado o povo britânico mais polido e civilizado, além de promover a liberdade - a identificação entre "comércio" e "liberdade" era um dos grandes clichês da época; acreditava-se que o comércio e a acumulação de capital só eram possíveis em sociedades livres. (GREENE, 2001, pp. 216-217; PAGDEN, 2001, p. 89). Daniel Defoe (1728, p. x), pioneiro não apenas no romance, mas também no jornalismo econômico, acreditava que o futuro da Grã-Bretanha estava na expansão do comércio exterior, principalmente com as colônias. O comércio, além de trazer riqueza para os britânicos, cumpriria o trabalho de "civilizar as Nações onde nós e outros europeus já estamos assentados; fazer com que os Selvagens nus se vistam e ensinar aos Povos bárbaros como viver". 14

Quanto à questão da liberdade nas colônias, alguns consideravam as colônias como extensões ultramarinas da Grã-Bretanha e entendiam que aqueles que nelas viviam deveriam ter os mesmos direitos e liberdades que os residentes na metrópole. Sob essa perspectiva, a transferência das liberdades da metrópole para as colônias era exatamente o que distinguia a colonização britânica das demais. "Sem liberdade, não seria o Império Britânico"15, dizia

\footnotetext{
14 "civilizing the Nations where we and other Europeans are already settled; bringing the naked Savages to Clothe, and instructing barbarous Nations how to live".

15 "Without freedom, it would not be the British Empire".
} 
Edmund Burke em 1766 (apud LANGFORD, 1981, p. 50). Outros, no entanto, viam as colônias não como sociedades povoadas por cidadãos britânicos livres, mas como meros postos avançados da economia ou do poder estratégico britânico.

A visão de mundo do final do século XVIII era fortemente hierárquica. O sentimento de superioridade europeu, antes baseado principalmente na suposta excelência das virtudes cristãs, ganhava novos elementos, fundados no progresso material, no conhecimento científico e no governo constitucional. Na visão da maioria dos britânicos dessa época, os povos das Américas, da África e do Pacífico eram considerados selvagens, pois viviam da caça, do pastoreio ou de uma agricultura incipiente. Os estereótipos sobre os povos orientais dominavam desde a Idade Média: os grandes imperadores asiáticos eram "déspotas sanguinários"; a religião era "bárbara", cheia de "superstições"; o Islã era um engodo; a arte asiática era "exótica" e "sensual"; as leis eram "retrógradas"; a economia estava "estagnada".

Os povos das regiões recém-descobertas despertavam muita curiosidade - os livros de viagens a essas regiões faziam sucesso. O relato do explorador escocês Mungo Park sobre sua viagem à África, Travels in the Interior Districts of Africa, publicado em 1799, vendeu 1.500 exemplares em poucos meses. Livros de viagens fictícias em que europeus travavam contato com nativos ou exploravam mundos exóticos também se tornaram muito populares: Oroonoko (1688), de Aphra Behn; Robinson Crusoé (1719) e Captain Singleton (1720), de Daniel Defoe; As viagens de Gulliver (1726), de Jonathan Swift; The Adventures of Roderick Random (1748), de Tobias Smollett; Rasselas (1759), de Samuel Johnson; e Vathek (1786), romance gótico escrito em francês por William Beckford e traduzido pelo Reverendo Samuel Henley para o inglês. (PORTER, 2000, p. 354).

A confiança na superioridade britânica sobre os povos ditos primitivos era profundamente arraigada. Geralmente não se baseava em diferenças raciais, pois nessa época a visão cristã sobre a origem comum de toda a humanidade era amplamente aceita. As diferenças entre as sociedades humanas eram atribuídas a causas ambientais e históricas. Algumas sociedades haviam evoluído de modo constante, enquanto outras haviam estagnado. Em condições adequadas, essas diferenças poderiam ser superadas. Era dever dos britânicos criar tais condições, propagando a fé cristã em substituição à ignorância e à idolatria. (MARSHALL, 2001a, pp. 592-593). Acreditava-se que o crescimento do comércio refinaria os costumes dos povos "bárbaros" (BREWER, 2000, p. xx).

Havia até quem rejeitasse a colonização e escravização de outros povos. Samuel Johnson, extremamente conservador em várias outras questões, ao aconselhar James Boswell (1998, pp. 876-879) sobre como defender um escravo negro que estava reivindicando sua 
libertação na Suprema Corte da Escócia, argumentou, baseando-se em Locke ${ }^{16}$, que todos os indivíduos em seu estado original são iguais e que é muito difícil se imaginar que um indivíduo poderia abrir mão de sua liberdade a não ser quando submetido a algum ato de violência. Johnson (1825, p. 200) tinha uma visão extremamente crítica das conquistas marítimas, a ponto de escrever, a respeito do infante D. Henrique, de Portugal (em um discurso que será rebatido por Mickle na Introdução do Lusiad, como veremos no Capítulo 4):

O que a humanidade perdeu e ganhou com o gênio e os projetos desse príncipe levaria muito tempo para comparar e seria muito difícil de estimar. Muitos conhecimentos foram adquiridos e muitas crueldades cometidas; a crença religiosa tem sido muito pouco propagada, e suas leis têm sido ultrajante e imensamente violadas. Os europeus raramente visitaram qualquer costa senão para satisfazer sua cobiça e disseminar a corrupção; para usurpar o poder sem direitos e praticar crueldades sem provocações. Teria sido bom para os oprimidos se os projetos de Henrique houvessem ficado no papel, e com certeza melhor ainda para os opressores. ${ }^{17}$

Alguns intelectuais idealizavam os povos nativos como "filhos da Natureza" - seres inocentes, isentos de corrupção, virtuosos e nobres. O mito do "bom selvagem" surgiu a partir dos primeiros contatos dos europeus com as populações indígenas da América. ${ }^{18}$ Muitos desses defensores da inocência dos "naturais" proclamavam que o verdadeiro bárbaro era o conquistador branco - principalmente os espanhóis, que, incitados pelos sacerdotes católicos, haviam massacrado os nativos americanos.

\subsubsection{O Iluminismo}

O termo "Iluminismo" ou "Ilustração" se refere a um movimento intelectual, de inspiração liberal e racionalista, que floresceu em meados do século XVIII em toda a Europa.

\footnotetext{
${ }^{16}$ Locke (1994, pp. 95-96) afirmava que um indivíduo não poderia ser escravizado sob nenhuma hipótese, exceto nos casos em que perdia o direito à vida - quando era punido com a pena capital, Locke reconhecia o direito daquele que condenou esse indíviduo de transformá-lo em escravo em vez de executá-lo. Apesar disso, Locke possuía ações da Royal African Company, cujo principal negócio era o tráfico de escravos, e defendia a escravização de africanos como uma forma de salvá-los de um destino pior, que seria a condenação eterna e o estado de barbárie. (PAGDEN, 2001, p. 108).

17 "What mankind has lost and gained by the genius and designs of this prince, it would be long to compare, and very difficult to estimate. Much knowledge has been acquired, and much cruelty been committed; the belief of religion has been very little propagated, and its laws have been outrageously and enormously violated. The Europeans have scarcely visited any coast, but to gratify avarice, and extend corruption; to arrogate dominion without right, and practise cruelty without incentive. Happy had it then been for the oppressed, if the designs of Henry had slept in his bosom, and surely more happy for the oppressors".

${ }^{18}$ Jean-Jacques Rousseau, que muitos identificam com o mito do "bom selvagem", na verdade jamais utilizou essa expressão. Ver também a nota 47 do Capítulo 4.
} 
Na França, o Iluminismo desenvolveu-se em um período marcado por conflitos internos ao Antigo Regime, um sistema político e econômico que gerava insatisfação em diversos setores da sociedade, principalmente a burguesia e os pequenos camponeses. O projeto iluminista francês encontrou a sua expressão mais representativa na Enciclopédia (17511772) editada por Denis Diderot (1713-1784) e Jean le Rond d'Alembert (1717-1783), com contribuições de centenas de intelectuais. A Enciclopédia foi concebida com o objetivo de tornar disponível para o maior número possível de leitores uma síntese do pensamento iluminista em todas as áreas do conhecimento - objetivo que foi, em grande parte, cumprido, com a venda de cerca de 25 mil cópias do conjunto de 35 volumes, metade delas fora da França. A Enciclopédia encontrou forte resistência por parte dos poderes constituídos, tendo sido incluída no Index librorum prohibitorum da Igreja Católica. A Coroa revogou a autorização para a sua publicação em duas ocasiões (restaurando-a depois) e mandou prender vários intelectuais iluministas, forçando outros ao exílio. Em termos filosóficos, a Enciclopédia refletiu a ideia central do Iluminismo, de que a razão deveria governar todas as ações humanas. Entre os grandes filósofos que contribuíram para a Enciclopédia e, de modo geral, para o projeto iluminista na França encontram-se Voltaire e Rousseau - este último, embora nascido em Genebra, morou vários anos na França e se manteve em contato com os principais filósofos franceses. (DEWALD, 2004, pp. 258-260).

$\mathrm{Na}$ Inglaterra, o Iluminismo não chegou a ser um projeto ou uma escola, constituindo-se em um estilo de pensamento de elite que cultivava o debate e a tolerância. Os fundamentos das ideias iluministas remontam aos trabalhos de pensadores do século XVII - tanto aqueles associados à "revolução científica", principalmente o físico Isaac Newton, como aos filósofos pioneiros do pensamento racionalista e empírico, entre os quais se destacam Francis Bacon, Thomas Hobbes e John Locke. A maioria dos iluministas do século XVIII eram discípulos ou continuadores desses pensadores do século XVII.

Ainda na primeira metade do século XVIII, floresceu na Escócia o chamado "Iluminismo escocês", com a produção de um conjunto notável de obras em diversas áreas do conhecimento: economia, história, filosofia moral, geologia, astronomia, química, arquitetura e artes. A criação da Encyclopaedia Britannica em 1768, a partir de um projeto de Colin Macfarquhar e Andrew Bell, em Edimburgo, espelhou o anseio da época pela compilação e difusão do saber. 
O filósofo e historiador David Hume (1711-1776), associado ao Iluminismo Escocês, radicalizou o empirismo de Locke em A Treatise of Human Nature ${ }^{19}$ (1739-1740), na tentativa de criar uma "ciência do homem", descrevendo a mente a partir de observações detalhadas e rigorosas. O ceticismo de Hume apresentava dois aspectos: além de afirmar, como Locke, que o entendimento humano é limitado e que devemos ser modestos em nossas asserções, Hume também lançava dúvidas sobre todas as provas empíricas, alegando que encontramos paradoxos e contradições tanto em nossos raciocínios abstratos quanto nos experimentais. Deveríamos, então, limitar as nossas investigações a assuntos mais adequados à estreita capacidade da mente humana. (BROADIE, 2003, pp. 63-66; KLEMME, 2003, pp. 117-122).

Adam Smith (1723-1790), considerado o "pai da economia moderna" e o mais importante teórico do liberalismo, foi amigo de Hume e professor de Filosofia Moral na Universidade de Glasgow. Para Smith, a natureza manifesta uma ordem harmoniosa e benéfica sempre que fica entregue a si mesma. Dessa forma, a máxima fundamental da política econômica deveria ser a de deixá-la caminhar por sua própria conta: Laisser faire, laisser passer. Os indivíduos tenderiam a agir no sentido de seu verdadeiro interesse e, assim agindo, não só realizariam o seu bem pessoal, mas também o bem coletivo, pois o interesse individual e o coletivo coincidem. Em sua obra mais influente, A riqueza das nações (1776), Smith procurou demonstrar que a riqueza fundava-se na iniciativa privada, que deveria ter plena liberdade para agir, com pouca ou nenhuma intervenção governamental. A competição entre os diversos produtores levaria à queda do preço das mercadorias e promoveria inovações tecnológicas, em razão do esforço constante para baratear o produto e vencer os concorrentes. (ABBAGNANO, 2007, p. 300).

\subsubsection{Neoclassicismo}

Ao final da Guerra da Sucessão Espanhola, com a assinatura do Tratado de Utrecht, em 11 de abril de 1713, inicia-se na Grã-Bretanha um "século de ouro", saudado por Alexander Pope (1720, p. 22) no poema pastoral "Windsor-Forest", uma celebração da ordem política estabelecida no reinado da rainha Ana: "Hail, sacred peace! Hail, long-expected days, / That Thames's glory to the stars shall raise!"20

\footnotetext{
${ }^{19}$ HUME, David. Tratado da natureza humana: uma tentativa de introduzir o método experimental de raciocínio nos assuntos morais. Tradução Déborah Danowski. São Paulo: UNESP, 2001.

20 “Salve, paz sagrada! Salve, dias tão esperados, / Que a glória do Tâmisa se erga até as estrelas!"
} 
Em termos culturais, entretanto, a França, apesar de vencida militarmente, ditava os gostos. O Neoclassicismo francês surgiu, entre 1630 e 1660, de uma compilação das doutrinas dos críticos italianos do século XVI, como Castelvetro, Scaligero, Paolo Beni, Victorius, Robortellus e Minturno, que interpretavam os ensinamentos da Antiguidade, principalmente de Aristóteles. Coube a Nicolas Boileau-Despréaux (1636-1711), a seguir, formular os preceitos do novo sistema no tratado L'Art poétique (1674) ${ }^{21}$. Outros escritores, como Rapin, com a obra Réflexions sur la Poétique, também publicada em 1674, e Le Bossu, autor do Traité du poème épique, de 1675 , contribuíram para a cristalização do sistema. Essas três obras foram traduzidas imediatamente para o inglês e exerceram considerável influência sobre a crítica inglesa. (ATKINS, 1951, pp. 3-7).

Resumindo em poucas palavras a doutrina neoclássica francesa: o princípio geral fundamental era o de que a poesia tinha como objetivo a instrução moral. O deleite horaciano era também levado em conta, mas a prioridade era atribuída à função didática. A regra mais importante era a imitação dos antigos, ou seja, das leis formuladas pelos teóricos a partir dos antigos e, em especial, de Aristóteles - leis que se baseavam, segundo os neoclássicos, na natureza, na razão e no bom senso. As outras regras derivavam dessa primeira: a verossimilhança era necessária para não ferir a razão, o decoro ${ }^{22}$ era exigido pelas convenções e pelo gosto contemporâneo. (ATKINS, 1951, pp. 11-12).

À semelhança de seu modelo francês, o Neoclassicismo britânico adotou os ideais de ordem, razão, harmonia, simetria, unidade, proporção, lógica, precisão, correção, bom senso, elegância e decoro, assim como a imitação dos modelos da Antiguidade greco-latina, como Homero, Virgílio, Cícero e Horácio. A estética neoclássica era racional; as emoções deviam ser controladas. A "natureza" deveria ser o modelo para a arte e a escrita. Mas a "natureza" do neoclássico não era a natureza selvagem e mística que os poetas românticos exaltariam mais tarde, e sim a natureza considerada "clássica": a ordem racional e moral do universo. As obras deveriam cumprir a função de deleitar, instruir, educar e corrigir os costumes morais e sociais.

Embora suas origens remontassem à época elisabetana (Ben Jonson, por exemplo, já se inspirava em Horácio), o Neoclassicismo dominou a literatura inglesa desde a Restauração, em 1660, até o final do século XVIII, quando a publicação de Lyrical Ballads de Wordsworth e Coleridge, em 1798, assinalou a emergência do Romantismo.

\footnotetext{
${ }^{21}$ BOILEAU-DESPRÉAUX, Nicolas. A arte poética. Tradução de Célia Berrettini. São Paulo: Perspectiva, 1979.

${ }^{22}$ Conceito da retórica que exigia a adequação do estilo ao tema em cada gênero literário, assim como a obediência aos costumes e convenções sociais.
} 
Na prosa, os gêneros preferidos eram o ensaio, a epístola, a sátira, a paródia, o burlesco e a fábula moral; na poesia, a forma predileta eram os versos emparelhados e rimados, que atingiram grande sofisticação com o dístico heroico (heroic couplet, uma sequência de dois versos com rimas emparelhadas, de preferência encerrando um pensamento completo) de Pope; no teatro, reinavam o drama heroico, o melodrama, a comédia sentimental e a comédia de costumes. Cada um desses gêneros devia seguir estritamente as regras enunciadas por Aristóteles e Horácio. Apenas o romance, um gênero que estava ainda em criação, escapava, até certo ponto, da rigidez dessas regras.

Para o pensamento neoclássico, a natureza humana permanece constante. Assim, em vez de buscar a originalidade, o neoclássico procurava expressar antigas verdades do modo mais inteligível possível. O bom senso era mais valorizado do que a imaginação; o consenso da sociedade prevalecia sobre a opinião individual. A moral e a religião deviam estar ancoradas na razão. Predominava o conformismo social - se a natureza é ordenada e harmônica, rebelar-se é um gesto inútil, pretensioso e absurdo.

O início do período, entre 1660 e 1700, costuma ser chamado de "Restauração", em referência à Restauração monárquica, com a ascensão ao trono de Carlos II. O literato de maior destaque nesse período foi John Dryden (1631-1700). Além de exímio poeta, Dryden foi também um crítico perspicaz e autor de importantes dramas, sátiras e traduções ${ }^{23}$. (DAICHES, 1997, p. 580). Exerceu grande influência sobre os escritores do século seguinte, até mesmo na adoção dos dísticos heroicos. Os critérios para a criação poética que irão vigorar em todo o século XVIII foram fixados já na época da Restauração: um bom poema precisava ter elegância e $w_{i t}{ }^{24}$, fluindo com naturalidade e suavidade. Por outro lado, a dicção poética augustana abusava de expressões convencionais que, hoje em dia, soam artificiais mencionamos, à guisa de ilustração, as expressões perifrásticas formadas por um adjetivo seguido de um nome coletivo ou abstrato, como - os exemplos são citados por Geoffrey Leech (1973, p. 15) - "watery store" ou "feather'd race", para designar respectivamente o "mar" e os "pássaros".

O período seguinte, geralmente delimitado pelos anos de 1700 e 1745 (com algumas variações, conforme diferentes fontes da história da literatura) é conhecido como a "era augustana", por analogia com o reinado de Augusto (27 a.C.-14 d.C.), a época de ouro da literatura romana - um período de paz, prosperidade e refinamento artístico.

\footnotetext{
${ }^{23}$ Mais adiante neste mesmo capítulo falaremos mais sobre as traduções de Dryden.

${ }^{24}$ Palavra que pode ser traduzida de modo aproximado em português como "engenho" ou "agudeza", mas que, em rigor, é intraduzível, englobando as noções de espírito humorístico, inteligência e habilidade verbal.
} 
$\mathrm{Na}$ era augustana, Alexander Pope (1688-1744) foi o poeta de maior relevo. Pope seguiu a tradição da comédia satírica do período anterior, em que Dryden, Denham e outros autores haviam se destacado. Explorou à perfeição os dísticos heroicos popularizados por Dryden. Em Essay on Man ${ }^{25}$ (1733-1734) e nos quatro Moral Essays (1731-1735), Pope demonstra a sua filiação ao ideal clássico augustano, enfatizando a preocupação social e os ideais de moderação, decoro e urbanidade. Na visão de Pope, as regras formuladas pelos Antigos - principalmente Aristóteles - revelam o verdadeiro padrão e universalidade da Natureza. O poeta deveria, portanto, obedecer a essas regras e imitar Homero, Virgílio e Horácio. $^{26}$ (PECK; COYLE, 2002, pp. 117-119).

Um dos poetas que mais influenciou Mickle, junto com Dryden e Pope, foi o escocês James Thomson, o autor de "Rule, Britannia". Thomson está entre os poetas que saudavam a nova sociedade comercial emergente com entusiasmo, deslumbrados com o crescente poder econômico e militar da nação. Na série de poemas The Seasons (1726-1730), Thomson combinou descrições da natureza com passagens de filosofia e moral, além de exaltações à história, à indústria e ao comércio britânicos. (PECK; COYLE, 2002, pp. 125-126). Usando o verso branco, Thomson se distingue dos vários poetas que imitavam os dísticos heroicos de Pope. Além disso, suas descrições da natureza revelam uma fascinação pelo sobrenatural e o misterioso, temas que serão caros ao Romantismo.

\subsubsection{Graveyard School e Pré-Romantismo}

Após a austeridade da era augustana, havia um desejo de mudança. Na segunda metade do século XVIII, alguns escritores começaram a explorar novos rumos, fugindo à racionalidade e convencionalidade augustanas. A melancolia e o interesse pelo primitivo e o exótico - elementos que já estavam presentes no início do século - se intensificaram, assim como a exaltação da imaginação e a preferência por um tom intimista, meditativo. (DAICHES, 1997, p. 663).

A Graveyard School [Escola do Cemitério] engloba vários poetas pré-românticos da Grã-Bretanha, os chamados Graveyard Poets [Poetas do Cemitério], que se caracterizaram por meditações sombrias sobre a mortalidade, repletas de símbolos lúgubres, e o fascínio pelo sobrenatural, o estranho e o sublime, assim como um interesse pelas formas populares e

\footnotetext{
${ }^{25}$ Alguns trechos desse ensaio foram traduzidos por Paulo Vizioli, sob o título "Ensaio sobre o homem". In: POPE, A. Poemas. São Paulo: Nova Alexandria, 1994.

${ }^{26}$ Sobre as traduções de Pope da Ilíada e da Odisseia comentaremos em uma próxima subseção.
} 
antigas de poesia. Seus poemas, geralmente em tom solene e meditativo, tecem reflexões sobre a morte e o fim do mundo, evocando imagens noturnas, de túmulos e cemitérios. Entre os poetas desse grupo podemos mencionar o irlandês Thomas Parnell (1679-1718), autor daquele que é considerado o primeiro poema da Graveyard School: "A Night-Piece on Death" (1722); o escocês Robert Blair (1699-1746), autor de "The Grave" (1743), escrito em versos brancos; William Collins (1721-1759), que explora, em poemas como "Ode to Evening" e “The Passion”, de 1746, áreas de experiência obscuras e ocultas, aspectos perturbadores e reprimidos da mente, antecipando, em várias particularidades, o Romantismo que se seguiria; Thomas Gray, autor da célebre "Elegy Written in a Country Churchyard" 27 (1751); e Edward Young (1683-1765), autor do também célebre The Complaint; or Night Thoughts on Life. (BURGESS, 2005, p. 180; CARPEAUX, 1961, pp. 1.409-1.410; DAICHES, 1997, p. 160 PECK; COYLE, 2002, pp. 130-132).

$\mathrm{O}$ interesse pelo passado e pela poesia antiga intensificou-se com a publicação, em 1765, pelo bispo Thomas Percy, de uma coletânea de baladas e canções antigas, Reliques of Ancient English Poetry, que encantou os leitores com seu estilo mais simples e menos artificial em comparação com os modelos neoclássicos então em voga. O novo interesse por um passado mítico produziu também duas falsificações bastante criativas: o poeta e colecionador escocês James Macpherson (1736-1796), alegando ter encontrado uma coleção de poemas antigos de um suposto bardo gaélico chamado Ossian, começou a publicar pseudotraduções em prosa desses poemas, reunidas nas coleções intituladas Fingal (1762) e Temora (1763), que alcançaram grande repercussão em toda a Europa; e Thomas Chatterton (1752-1770), um jovem de apenas 17 anos, escreveu poemas em uma língua inventada, dizendo serem de um monge medieval chamado Thomas Rowley. (BURGESS, 2005, p. 180).

Os Graveyard Poets são considerados precursores do romance gótico britânico, um tipo de romance de mistério e suspense que foi muito popular entre as décadas de 1760 e de 1820 . Mergulhando no reino do fantástico e do sobrenatural, muitos escritores pareciam se deleitar com a crueldade e o terror. Romances como The Castle of Otranto ${ }^{28}$ (1764), de Horace Walpole, Emmeline (1788), de Charlotte Smith, The Mysteries of Udolpho ${ }^{29}$ (1794), de Ann

\footnotetext{
${ }^{27}$ Existe uma interessante tradução da Marquesa d'Alorna para o português, intitulada "Cemiterio d'Aldêa". In: Obras poeticas de D. Leonor d'Almeida Portugal Lorena e Lencastre, marqueza d'Alorna, condessa d'Assumar e d'Arynhausen, conhecida pelo nome de Alcipe. Tomo IV. Lisboa: Imprensa Nacional, 1844, pp. 180-189. Disponível em: <http://purl.pt/172/1/l-6609-v/l-6609-v_item1/index.html> Acesso em 25 abr. 2013.

${ }^{28}$ WALPOLE, Horace. O castelo de Otranto. Tradução de Alberto Alexandre Martins. São Paulo: Nova Alexandria, 1994.

${ }_{29}$ RADCLIFFE, Ann. Os mistérios do castelo de Udolfo. Tradução de Leyguarda Ferreira. Lisboa: Romano Torres, 1960.
} 
Radcliffe, e The Monk ${ }^{30}$ (1796), de Matthew Gregory Lewis, exploravam o lado inconsciente da mente. (PECK; COYLE, 2002, pp. 145-146).

\subsection{RETÓRICA, POESIA ÉPICA E TRADUÇÃO}

\subsubsection{Retórica na Grã-Bretanha do Século XVIII}

$\mathrm{Na}$ Grã-Bretanha do início da modernidade, a retórica passava por um período de transição. Após a invenção da imprensa e com o aumento da importância atribuída à comunicação escrita, tanto em termos políticos quanto comerciais, a ênfase da retórica deslocou-se do discurso oral para o escrito. (GOLDEN; CORBETT, 1990, p. 5). Além disso, nos séculos XVII e XVIII, os novos estudos desenvolvidos com base em métodos empíricos e racionalistas, assim como a nova configuração política, de monarquia parlamentar, em que os debates políticos ganhavam maior destaque, levaram a um renovado interesse pelas técnicas e estratégias da retórica.

Nem todos os retóricos reagiram da mesma forma a essas modificações. Alguns procuraram conservar as tradições antigas, de Aristóteles, Cícero e Quintiliano. Autores como John Holmer, John Lawson e John Ward são exemplos dessa postura. Outros retóricos, como Thomas Sheridan, John Walker e Gilbert Austin, preferiram dedicar-se apenas à pronuntiatio (elocução ou declamação do discurso). Uma terceira resposta às transformações em desenvolvimento procurou abordar a retórica juntamente com as várias disciplinas a ela relacionadas (poesia, teatro, história, biografia etc.), sob o nome geral de "retórica e belas letras". O estudioso beletrista não se limitava, assim, aos assuntos abordados na Retórica de Aristóteles, mas dava igual destaque à Poética, assim como à teoria da formação cultural [paideia] de Isócrates, ao Tratado do sublime de Longino e à Arte poética de Horácio. (GOLDEN; CORBETT, 1990, p. 8). Essa última corrente, que efetua o casamento entre a retórica e as artes poéticas, entre o aspecto oral e escrito da retórica, é a que nos interessa estudar mais a fundo, já que, neste trabalho, estamos examinando a tradução de um poema.

Adam Smith foi o primeiro estudioso britânico a adotar o movimento beletrista em suas palestras de retórica e belas letras na Universidade de Edimburgo em 1748. As palestras de Smith, que só foram publicadas em 1963, sob o título Lectures on Rhetoric and Belles Lettres, revelam um grande conhecimento não apenas da retórica clássica como de várias outras

\footnotetext{
${ }^{30}$ LEWIS, Matthew Gregory. O monge. Tradução de Egito Gonçalves. Porto: Inova, 1973.
} 
disciplinas. Seguindo os clássicos, Smith (1985, p. 4) destacava a importância da propriedade (proprietas em latim, propriety em inglês), pureza (puritas em latim, purity em inglês) e clareza (perspicuitas em latim, perspicuity em inglês) de expressão - a palavra escolhida deveria adequar-se perfeitamente ao objeto, pertencer a um vocabulário comum e ser compreensível para o grupo específico da comunidade a que se dirige. ${ }^{31}$ Smith defendia o costume adotado pelos "homens de elevada posição social e maneiras refinadas"32 como principal critério para a propriedade. A ornamentação não deveria ser exagerada, para não prejudicar a clareza.

\subsubsection{Hugh Blair: retórica e concepção de poesia épica}

Entre aqueles que assistiam regularmente às palestras de Adam Smith estava um jovem ministro da Igreja Presbiteriana St. Giles, Hugh Blair, que viria a ser considerado o primeiro grande teórico do discurso escrito, alcançando grande impacto e repercussão no final do século XVIII e ao longo de todo o século XIX, tanto no Reino Unido quanto em outros países europeus, com a coletânea de suas palestras, também chamada Lectures on Rhetoric and Belles Lettres. ${ }^{33}$ As opiniões e conceitos expressos nessas palestras refletem as ideias da época em que Mickle elaborou a sua tradução, e a influência dessas ideias sobre o Lusiad é evidente.

Na Introdução à coletânea, Blair $(2005$, p. 4) rejeita a "retórica artificial e escolástica"34 em nome dos "princípios da razão e do bom senso" ${ }^{, 35}$. Isso, para ele, significa "repelir o falso ornamento, dirigir a atenção mais para a substância do que para a aparência, recomendar o bom senso como base de toda a boa composição, e a simplicidade como essencial a todo verdadeiro ornamento". ${ }^{36}$ Esse racionalismo e defesa do bom senso e da simplicidade são típicos do Neoclassicismo da época e não implicam uma negação dos princípios da retórica clássica. Tanto que, logo a seguir, Blair (p. 5) menciona a clareza [perspicuitas] e a pureza [puritas] como elementos a serem preservados na escrita: "Falar ou escrever de maneira clara

\footnotetext{
${ }^{31}$ Sobre os conceitos de proprietas, puritas e claritas ver Rener, 1989.

32 "men of rank and breeding".

33 É muito difícil quantificar essa influência, pois há muitas reedições modificadas da obra. Stephen L. Carr (2002, p. 78) lista 283 versões publicadas entre 1783 e 1911, incluindo 112 obras completas, 110 condensações e 61 traduções.

34 "artificial and scholastic rhetoric".

35 "principles of reason and good sense".

36 "to explode false ornament, to direct attention more towards substance than show, to recommend good sense as the foundation of all good composition, and simplicity as essential to all true ornament".
} 
e agradável, com pureza, graça e força, são realizações da maior consequência para todos que tencionam, quer pela fala, quer pela escrita, se dirigir ao público"37.

Era contra o "brilho afetado" (que, na opinião de Blair, constituía o gosto da segunda metade do século XVII) e não contra a retórica clássica que Blair (2005, p. 15) se insurgia:

[...] quão diferente é o gosto de poesia que prevalece na Grã-Bretanha agora, em relação ao que prevalecia não muito tempo atrás, no reinado de Carlos II, que os autores daquele tempo também consideravam uma era augustana: quando tudo o que estava em voga era um brilho afetado de agudeza [wit]; quando a grandeza simples de Milton não era percebida, e $O$ Paraíso perdido era quase completamente desconhecido; quando os conceitos forçados e artificiais de Cowley eram admirados como a própria quintessência do gênio; a vivacidade alegre de Waller era erroneamente tomada como o terno espírito da poesia de amor; e escritores como Suckling e Etheridge eram apreciados pela composição dramática? ${ }^{38}$

A concepção de língua de Blair (2005, p. 197) era ainda de base aristotélica: “Observei que, sendo as palavras cópias de nossas ideias, deve sempre haver uma ligação muito íntima entre a maneira pela qual cada escritor emprega as palavras e sua maneira de pensar". ${ }^{39}$ Assim, Blair (2005, p. 99) define "estilo" como "a maneira peculiar pela qual alguém expressa suas concepções por meio da língua" ${ }^{40}$. Em decorrência, não há como separar o estilo do "sentimento" que anima o autor. Fala-se, então, em estilo "forte", "fraco", "seco", "nervoso", "afetado" ou "impetuoso", termos que se referiam tanto ao pensamento de um escritor quanto ao seu modo de se expressar. ${ }^{41}$

\footnotetext{
37 "To speak or to write perspicuously and agreeably with purity, with grace and strength, are attainments of the utmost consequence to all who purpose, either by speech or writing, to address the public".

38 " [...] how very different is the taste of poetry which prevails in Great Britain now, from what prevailed there no longer ago than the reign of king Charles II, which the authors too of that time deemed an Augustan age: when nothing was in vogue but an affected brilliancy of wit; when the simple majesty of Milton was overlooked, and Paradise Lost almost entirely unknown; when Cowley's laboured and unnatural conceits were admired as the very quintessence of genius; Waller's gay sprightliness was mistaken for the tender spirit of Love poetry; and such writers as Suckling and Etheridge were held in esteem for dramatic composition?"

39 "I observed that words being the copies of our ideas, there must always be a very intimate connection between the manner in which every writer employs words, and his manner of thinking [...]"

40 " [...] the peculiar manner in which a man expresses his conceptions, by means of Language."

${ }^{41}$ Rener $(1989$, p. 335) encontra um exemplo em que Blair coloca inadvertidamente em questão a separação entre as palavras e as coisas, um dos pilares da teoria clássica da língua. Discorrendo sobre os ornamentos, Blair (2005, pp. 195-196) diz: "It is a very erroneous idea, which many have of the ornaments of Style, as if they were things detached from the subject, and that could be stuck to it, like lace upon a coat [...] Whereas, the real and proper ornaments of Style are wrought into the substance of it. They flow in the same stream with the current of thought." ["É uma ideia bastante errônea, que muitos têm sobre os ornamentos de estilo, a de que eles sejam coisas desligadas do tema, e que possam ser agregados a ele como rendas sobre um casaco [...] Quando, na verdade, os ornamentos de estilo reais e adequados encontram-se fundidos à própria substância dele. Eles correm no mesmo fluxo com a corrente de pensamento."]
} 
Uma das maiores preocupações de Blair é com a clareza do texto. A dificuldade do tema não deve servir de desculpa para a falta de clareza, pois, segundo Blair (2005, p. 100), se o pensamento for suficientemente claro sempre é possível expressá-lo claramente. Para se alcançar a clareza de expressão é preciso cuidar primeiro das palavras e locuções ou expressões isoladas, e depois da construção das frases. Em relação à escolha das palavras e locuções ou expressões, a clareza exige três qualidades: pureza, propriedade e precisão.

A pureza é o uso de palavras e construções pertencentes à língua que se fala, em oposição a palavras e construções importadas de outras línguas, ou obsoletas, ou criadas recentemente (neologismos), ou "usadas sem a devida autoridade"42 (p. 100). Quanto às palavras obsoletas e neologismos, Blair admite o seu uso, com parcimônia, principalmente na poesia, em certas ocasiões.

A propriedade é a escolha de palavras conforme o uso, da forma mais apropriada às ideias que se deseja expressar. Deve-se, assim, evitar palavras vulgares ou de baixo calão; as palavras devem ser estritamente inglesas, sem escocesismos nem galicismos, e corretas do ponto de vista da gramática. Além disso, as palavras devem-se adequar ao assunto e ao estilo do autor.

A precisão implica a eliminação de tudo o que é supérfluo para que o pensamento seja adequadamente expresso. (BLAIR, 2005, p. 101). É preciso cuidar, no entanto, para não cortar todos os ornamentos, senão o estilo pode se tornar seco e sem vida. O ideal é unir abundância e precisão, fluência e graça, correção e exatidão na escolha de cada palavra. (BLAIR, 2005, p. 108).

Quanto à construção das frases, Blair (pp. 112-143) considera essencial que se atente para quatro requisitos:

I. A clareza e a precisão, evitando ambiguidades decorrentes da má organização das palavras.

II. A unidade: deve haver um princípio que conecte as diversas partes; não deve haver transições bruscas de uma pessoa a outra, nem de um assunto a outro; deve-se evitar a inclusão de parênteses no meio da frase; a frase deve chegar a uma conclusão.

III. A força é a qualidade necessária para expressar o conteúdo de modo a ressaltá-lo ao máximo. Para isso é preciso: a) eliminar as palavras redundantes; b) atentar para o bom uso das conjunções e outros elementos de ligação; c) ordenar as palavras de modo a obter o

\footnotetext{
42 "used without proper authority".
} 
melhor efeito; ${ }^{43}$ d) construir um clímax; e) evitar terminar a frase com um advérbio, preposição ou outra palavra que não tenha muita força; f) em uma comparação ou oposição entre coisas, a linguagem deve espelhar essa mesma comparação ou oposição.

IV. A harmonia, compreendendo:

a) A sonoridade em si, que depende da escolha das palavras (envolvendo o equilíbrio entre vogais e consoantes, assim como entre sílabas longas e curtas) e da disposição das palavras (é preciso distribuir bem as pausas e prestar atenção à cadência da frase).

b) A sonoridade ligada à expressão: os sons das palavras podem ser usados para representar outros sons (como, por exemplo, o murmúrio das águas de um rio ou do vento), movimento (rapidez ou lentidão); e as emoções e paixões da mente (a melancolia, por exemplo, é expressa de melhor forma por palavras longas e um ritmo lento). (BLAIR, 2005, pp. 142-143).

Blair (pp. 133-136) comenta que os retóricos antigos criaram muitas regras de sonoridade, mas que essas regras se aplicavam ao grego e ao latim, línguas muito diferentes do inglês. Blair (p. 138) se opõe à inclusão de palavras apenas por efeito de sonoridade. Sobre a importância devotada pela retórica antiga às figuras de palavras e de pensamento, Blair acredita que o uso indiscriminado dos preceitos da retórica antiga no século XVIII torna o estilo formal, afetado e artificial. Recomenda aos escritores que prestem mais atenção aos sentimentos a serem expressos pela figura, e não apenas à técnica retórica. As figuras devem ser adaptadas ao tema que se está desenvolvendo. As metáforas e comparações não devem ser nem muito óbvias nem muito obscuras; os objetos aproximados não devem ser já muito próximos nem muito distantes. (BLAIR, 2005, p. 162 e p. 188). O escritor e o poeta devem evitar metáforas vulgares:

[...] devemos cuidar para nunca empregar alusões que possam evocar na mente ideias desagradáveis, inferiores, vulgares ou sujas. Mesmo quando se escolhem metáforas a fim de difamar e aviltar qualquer objeto, um autor deve cuidar para nunca ser repugnante em suas alusões [...] Mas, em assuntos solenes, é um erro imperdoável introduzir metáforas baixas e vulgares. ${ }^{44}$ (BLAIR, 2005, p. 160)

\footnotetext{
${ }^{43}$ Ao discorrer sobre esse ponto, Blair (p. 127) critica as traduções de Tácito feitas por Thomas Gordon porque este, para tentar imitar o estilo do original, empregou muitas inversões que Blair considera "violentas" e inaceitáveis na língua inglesa. Como exemplos, Blair cita as frases "Into this hole thrust themselves three Roman senators" e "War at that time there was none".

44 “[...] we must beware of ever using such allusions as raise in the mind disagreeable, mean, vulgar, or dirty ideas. Even when Metaphors are chosen in order to vilify and degrade any object, an author should study never to be nauseous in his allusions [...] But, in subjects of dignity, it is an unpardonable fault to introduce mean and vulgar Metaphors."
} 
É interessante notar que Blair (p. 189), em um gesto que pode ser encarado como uma manifestação inicial do historicismo que só se desenvolverá plenamente no Romantismo, justifica o uso de comparações de mau gosto por parte de Homero com base em fatores históricos:

\begin{abstract}
Algumas das comparações de Homero têm sido injustamente censuradas por esse critério. Pois é preciso lembrar que a baixeza ou nobreza de objetos depende, em alto grau, das ideias e costumes da época em que vivemos. Assim, muitos símiles extraídos dos incidentes da vida rural que nos parecem vulgares eram muito nobres naquelas eras mais simples da antiguidade. $^{45}$
\end{abstract}

A influência do psicologismo filosófico de David Hume se faz notar na preocupação devotada por Blair aos sentimentos e à sua análise. Em vários momentos, Blair rompe os limites neoclássicos de refinamento, correção e decoro em nome da fidelidade aos sentimentos. Ao falar, por exemplo, do sublime, Blair, seguindo Edmund Burke, revela o seu fascínio por aqueles elementos que extrapolam os limites do cotidiano. Essa tendência o aproxima do Romantismo que começava a emergir, e talvez explique a popularidade de sua obra ainda no século XIX. Isso se evidencia, por exemplo, na definição de Blair (p. 425) de poesia como "a linguagem da paixão, de uma imaginação avivada, expressa, mais comumente, em versos regulares" 46 . O principal objetivo da poesia seria agradar e comover, relacionando-se, assim, com a imaginação e as paixões. Algumas vezes a poesia pode ter o objetivo de instruir e reformar, mas esse objetivo seria secundário em relação ao objetivo principal de agradar e comover.

Quanto ao poema épico, Blair (2005, pp. 478-480) o define como o relato de um feito heroico em forma poética. O poema épico deveria promover a virtude e ter uma base moral; apresentar um estilo "elevado" e ser, ao mesmo tempo, interessante, solene e instrutivo. A Ilíada e a Eneida eram os grandes modelos do gênero. Blair desaprova os críticos que fixam critérios muito rígidos para a definição do gênero e, com base na definição enunciada acima, considera épicos poemas como O Paraíso perdido de John Milton, a Farsália de Lucano, a Henriade de Voltaire, Os lusíadas de Camões e até mesmo o Fingal de Ossian.

\footnotetext{
45 "Some of Homer's Comparisons have been taxed without reason, on this account. For it is to be remembered, that the meanness or dignity of objects, depends, in a great degree, on the ideas and manners of the age wherein we live. Many Similies, therefore, drawn from the incidents of rural life, which appear low to us, had abundance of dignity in those simpler ages of antiquity."

46 "the language of passion, or of enlivened imagination, formed, most commonly, into regular numbers."
} 
Para Blair (pp. 481-483), a ação deve ser única, importante e interessante. Blair endossa o princípio aristotélico da unidade da ação, ressaltando, para além da exigência de um único protagonista e de uma única época, a necessidade de o tema ser único. A unidade da Eneida estaria no fato de o poema tratar, do início ao fim, do estabelecimento de Eneias na Itália; na Odisseia, seria o retorno de Ulisses à pátria; na Jerusalém libertada, de Torquato Tasso, o resgate de Jerusalém do domínio muçulmano; em $O$ Paraíso perdido, de John Milton, a expulsão de Adão e Eva do Paraíso. Quanto à unidade de ação na Ilíada, Blair não se mostra muito seguro, pois, se o tema é, como afirmado no poema, a raiva de Aquiles e as consequências produzidas por ela, é preciso admitir que Aquiles se mantém fora da ação por muito tempo, e que a maior parte da ação é composta por cenas de guerra.

A unidade de ação obriga que a trama seja apresentada de modo completo, com início, meio e fim, mas não deve ser tão estrita a ponto de excluir a existência de episódios ou de qualquer ação subordinada. Ao contrário: o uso de episódios engrandece o poema, desde que sejam introduzidos de modo natural, tenham ligação com o tema e funcionem como partes secundárias, e não como meros apêndices da trama principal. Os episódios devem também apresentar novidades, pois é justamente em nome da variedade que a sua inclusão no poema épico se justifica, e ser escritos com especial elegância e refinamento, já que cumprem uma função ornamental.

Quanto à segunda exigência, de que a ação seja importante, justifica-se pelo próprio caráter épico do poema. Devem-se escolher, de preferência, temas ligados ao passado. (A Henriade de Voltaire e a Farsália de Lucano não cumprem essa exigência, o que Blair considera uma falha.)

A terceira exigência, de que a ação seja interessante, é uma extensão da anterior. Não basta que a ação do poema épico seja importante; ela precisa também comover os leitores.

Sobre os protagonistas, Blair (2005, p. 485) afirma que devem ser dignos de amor e admiração. É preciso também manter a coerência na caracterização de todas as personagens. "Tudo o que a pessoa diz, ou faz, deve ser adequado a ela, e deve servir para distingui-la de todas as outras". ${ }^{47}$ Deve haver um herói principal, único.

A respeito da "máquina" sobrenatural, a intervenção dos deuses, Blair (pp. 486-487) comenta que os críticos franceses são os maiores defensores da sua presença em um poema épico. Na opinião de Blair, era natural que Homero e Virgílio utilizassem as lendas e crenças de sua época, mas essas mesmas lendas e crenças soam artificiais em outros tempos e lugares.

\footnotetext{
47 "Every thing which that person says, or does, must be suited to it, and must serve to distinguish him from any other."
} 
Por essa razão, seria absurdo exigir a sua utilização. Por outro lado, Blair rejeita também a opinião daqueles críticos que condenam de modo absoluto o uso do imaginário pagão em nome de uma pretensa necessidade de realismo nesse tipo de poema. Blair não vê necessidade de realismo no poema épico, e acha que o maravilhoso pagão pode contribuir para o elemento sublime que costuma estar presente nas epopeias, auxiliando o clima de elevação que se deve atingir.

O estilo do poema épico deve ser elevado e não conter elementos grosseiros ou deselegantes ${ }^{48}$ :

Descrições de objetos repulsivos ou chocantes devem ser evitadas sempre que possível; assim, teria sido melhor que a fábula das Harpias, no terceiro livro da Eneida, e a alegoria do Pecado e da Morte, no segundo livro de $O$ Paraíso perdido, houvessem sido omitidas nesses renomados poemas. (BLAIR, 2005, p. 488). ${ }^{49}$

Em sua Lecture XLIV, Blair (2005, pp. 506-507) faz uma análise d'Os lusíadas muito semelhante àquela feita por Voltaire no Essay upon the Epick Poetry of the Europeen Nations from Homer to Milton. É possível que Blair tenha se baseado diretamente no texto de Voltaire ou, já que admite ter lido o poema camoniano em uma tradução e seu nome consta na lista de assinantes do Lusiad de Mickle, na Introdução a essa tradução, em que os comentários de Voltaire são reproduzidos extensamente. Depois de um breve resumo do poema, Blair (pp. 506-507) avalia que a obra segue os preceitos do gênero épico. "Tanto o tema quanto os incidentes são magníficos; e, mesclados a certa extravagância e irregularidade, mostra-se na execução muito espírito poético, forte imaginação e ousada descrição" ${ }^{50}$. Para Blair, Vasco da Gama é o herói do poema, e não há nele nenhum outro personagem de relevo.

Quanto à máquina sobrenatural d'Os lusíadas, Blair (2005, p. 507) a julga “extravagante", por ser formada pela mistura de ideias cristãs com a mitologia pagã, e porque os deuses pagãos parecem ser os verdadeiros deuses, enquanto Cristo e a Virgem Maria teriam um papel secundário. ${ }^{51}$ Considerando que um dos grandes objetivos da expedição de

\footnotetext{
${ }^{48} \mathrm{Na}$ perspectiva de Lefevere (1992, pp. 87-98), essas restrições seriam atribuídas às diferenças entre os "universos de discurso" do autor e do tradutor (ou, como neste caso, do crítico/teórico).

49 "Descriptions of disgusting or shocking objects, should as much as possible be avoided; and therefore the fable of the Harpies, in the third book of the Aeneid, and the allegory of Sin and Death, in the second book of Paradise Lost, had been better omitted in these celebrated Poems."

50 "Both the subject and the incidents are magnificent; and, joined with some wildness and irregularity, there appears in the execution much poetic spirit, strong fancy, and bold description."

${ }^{51}$ A referência de Blair à Virgem Maria é bastante suspeita, pois, como bem observou Mickle - o que será comentado em nosso Capítulo 4 -, a Virgem Maria não é sequer mencionada n'Os lusíadas. Mais uma vez, Blair parece estar seguindo o comentário de Voltaire.
} 
Vasco, segundo o próprio poema, seria propagar a fé cristã e extirpar o maometismo, Blair estranha que a grande protetora dos portugueses seja Vênus e que seu maior adversário seja Baco. Cita também o mesmo exemplo usado por Voltaire, de quando Vasco da Gama, ao enfrentar a ameaça de uma terrível tempestade, reza a Deus, implorando a ajuda de Cristo e da Virgem, e, em resposta a suas preces, Vênus aparece. Blair acrescenta ainda que, ao final do poema, Camões fornece uma desculpa mal-ajambrada para o uso da mitologia, fazendo a deusa Tétis explicar a Vasco que ela e o resto das divindades que apareceram no poema são apenas os "nomes para descrever as ações da Providência",52.

Blair destaca, no entanto, o bom uso da máquina sobrenatural em episódios como o da aparição, em sonho, do rio Ganges ao rei D. Manuel e, principalmente, o episódio do Adamastor, que Blair (1005, p. 507) considera "um dos mais solenes e impressionantes exemplos de uso da máquina sobrenatural" 53 , a demonstrar, por si só, que "Camões é um poeta de imaginação ousada e sublime, ainda que irregular" $" 54$.

\subsection{A TRADUÇÃO NA GRÃ-BRETANHA DO SÉCULO XVIII}

Estamos lidando com um período em que a própria definição do termo "tradução" ainda não estava solidamente estabelecida e em que há muitas divergências quanto às distinções entre o que seria "tradução", "paráfrase", "imitação" e vários outros termos referentes à tradução ou a atividades limítrofes. Como demonstra Mary Helen McMurran em The Spread of Novels (2010), livro que estuda o surgimento do romance na França e na Grã-Bretanha no século XVIII, nesse período o emaranhamento é tal que não é fácil distinguir entre original e tradução. McMurran (2010, pp. 4-5) cita vários exemplos de narrativas ficcionais que foram traduzidas a partir de um original francês ou inglês, mas depois acidentalmente retraduzidas para a sua língua original, pois o tradutor não sabia que seu “original” já era uma tradução. É o caso de Agnès de Castro [Inês de Castro], de J. B. Brilhac, traduzido para o inglês por Aphra Behn em 1688 e retraduzido para o francês por Marie Thiroux d'Arconville no livro Romans traduits de l'anglais, em 1761. Uma história ainda mais complicada é a do romance de Eliza Haywood, The Fortunate Foundlings [Os órfãos felizes], escrito em 1744. Em 1754 foi lançada uma edição "imitada a partir do inglês", com o título Les Heureux orphelins, traduzida pelo filho ou pela esposa do romancista francês Crébillon. Parte da narrativa em

\footnotetext{
52 "names to describe the operations of Providence".

53 "is one of the most solemn and striking pieces of machinery that ever was employed".

54 "Camoens is a Poet, though of an irregular, yet of a bold and lofty imagination."
} 
francês foi traduzida diretamente, outras partes foram traduzidas livremente, e em certo trecho a obra em francês se desvia completamente do original. Quatro anos depois, uma edição com o título The Happy Orphans foi lançada em inglês, agora "traduzida e aperfeiçoada a partir do original francês". Mais uma vez, parte da versão francesa foi seguida com maior ou menor fidelidade, mas, no mesmo ponto em que o tradutor francês se desviara do original, o tradutor inglês também se desviou, afastando-se tanto do original quanto da tradução francesa. McMurran (2010, p. 7) explica esse emaranhamento em termos históricos:

[...] como fazia muito tempo que a tradução estava inserida na transmissão como a base da cultura literária europeia, concebida no período pré-moderno por meio dos conceitos gêmeos de translatio imperii (a transferência do poder) e translatio studii (a transferência do saber), a atividade tradutória era ainda, de muitas formas, uma tarefa ubíqua que era parte de todas as atividades literárias. ${ }^{55}$

O grande preceito teórico que se tornou o fundamento da prática tradutória dos séculos XVII e XVIII vinha de Cícero, extraído do prefácio às traduções dos oradores, De optimo genere oratorum:

Traduzi os discursos mais notáveis e contrários entre si dos dois mais eloquentes oradores áticos, Ésquino e Demóstenes. E não os traduzi como intérprete, mas como orador, conservando as mesmas ideias e formas, ou "figuras" de pensamento, em uma linguagem de acordo com o nosso uso. E, ao fazê-lo, não considerei necessário traduzir palavra por palavra, mas conservei o estilo geral e a força expressiva. Achei que não deveria transmiti-las [as palavras] ao leitor contando-as como moedas, por quantidade, e sim por peso. ${ }^{56}$

A distinção entre traduzir "como intérprete" e "como orador" espelhava a divisão entre as competências da gramática e da retórica (COPELAND, 1995, p. 2). Ao intérprete cabia traduzir palavra por palavra; Cícero, como retor e orador, considerava-se além dos limites impostos ao gramático, assumindo para si a tarefa de adequar o discurso à plateia.

\footnotetext{
55 " [...] because translating had long been embedded in transmission as the basis of European literary culture, conceptualized in the premodern period in the twin concepts of translatio imperii (the transfer of power) and translatio studii (the transfer of learning), the activity of rendering was still in many ways a ubiquitous task that belonged to all literary endeavor."

56 "Converti enim ex Atticis duorum eloquentissimorum nobilissimas orationes inter seque contrarias, Aeschines et Demostheni; nec converti ut interpres, sed ut orator, sententiis isdem et earum formis tamquam figuris, verbis ad nostram consuetudinem aptis. In quibus non verbum pro verbo necesse habui reddere, sed genus omne verborum vimque servavi. Non enim ea me adnumerare lectori putavi oportere, sed tamquam appendere." Disponível em: < http://www.poole.it/cassino/ARCHIVE/TRANSLATION/cicero_on_translation.htm> Acesso em: 17 fev. 2013. Tradução nossa, cotejada com as traduções para o italiano e o inglês de Federico e Gabriele Poole publicadas nesse sítio.
} 
Outro preceito semelhante originava-se de uma recomendação de Horácio a um poeta sobre o uso de obras literárias antigas: "Nec verbum verbo curabis reddere, fidus interpres" ["Tampouco se preocupe em traduzir palavra por palavra, como um fiel intérprete"]. Interpretado fora de contexto, esse conselho - que, segundo Rener (1989, p. 309), era dirigido a um imitador, ou seja, a um autor que praticava a imitatio - era exaustivamente aplicado à tradução.

$\mathrm{Na}$ prática, esses preceitos autorizavam o tradutor a fazer acréscimos, supressões e outras modificações no original. Muitas vezes os tradutores justificavam essas modificações pela preocupação com a estética (era preciso preservar a cadência, a melodia, a elegância do original) ou o decoro. A maior preocupação dos tradutores da época, segundo suas próprias declarações em prefácios a traduções, era com a preservação do "espírito" que animava o autor ao compor a obra.

\subsubsection{A tradução na França: as belles infidèles}

Em virtude do constante intercâmbio comercial e cultural existente nesse período entre a Grã-Bretanha e a França, assim como da grande influência exercida em toda a Europa pela cultura francesa, é impossível falarmos da tradução na Grã-Bretanha nos séculos XVII e XVIII sem mencionarmos o que estava ocorrendo no campo da tradução na França nesse mesmo período.

O grande teórico da tradução na França no século XVII foi Nicolas Perrot d'Ablancourt. Profundo conhecedor da retórica e da teoria poética, d'Ablancourt propunha a maior equivalência verbal possível para a obra como um todo. Suas traduções de textos da Antiguidade caracterizam-se pela clareza, elegância, simplicidade e decoro. A abordagem tradutória de d'Ablancourt foi se tornando cada vez mais liberal com o tempo. No prefácio à tradução de Octavius, de Minúcio Félix, ecoando as tradições retóricas e enfatizando a recepção na língua de chegada, d'Ablancourt declarou: "Mostra-se um autor apenas pela metade quando se lhe extirpa a eloquência; tão agradável quanto ele era em sua língua, é preciso que seja também na nossa". 57 (Apud GUILLERM, 1996, pp. 25-27; STEINER, 1975, p. 14-16).

A tradução de obras de Luciano de Samósata (1654) marcou uma radicalização no método de d'Ablancourt. Diferentemente das obras históricas que já havia traduzido (de Júlio

\footnotetext{
57 “[...] ce n'est rendre un auteur qu'à demi que de lui retrancher son éloquence; comme il a été agréable en sa langue, il faut qu'il soit encore en la notre".
} 
César, Tácito e outros), os textos de Luciano eram sátiras de costumes, um gênero difícil de traduzir sem adaptações. No prefácio, d'Ablancourt (1709, pp. 23-24) admitiu ter cortado os trechos mais obscenos, suavizado as expressões mais fortes e efetuado mudanças para tornar a tradução "agradável”. Para justificar-se, invocou a metáfora da troca de roupas, muito usada na tradição retórica ${ }^{58}$ : "Tempos diferentes pedem não apenas palavras, mas pensamentos diferentes, e os embaixadores costumam se vestir conforme a moda do país para onde são enviados, por medo de serem ridículos para aqueles a quem procuram agradar" ${ }^{\text {"59. Não }}$ obstante, alegou ter preservado as opiniões de Luciano, "porque, de outro modo, não seria uma tradução",60, mas acabou admitindo: "[...] isto não é exatamente uma tradução, mas vale mais do que a tradução, e os Antigos não traduziam de outra forma"61. Na verdade, d'Ablancourt estendeu os limites de seus princípios a tal ponto que ele mesmo não sabia mais se o que fazia era ainda tradução. Rejeitava o rótulo de "paráfrase" para esses trabalhos, pois o parafrasta não se preocupava em preservar o "espírito" do original. De qualquer forma, d'Ablancourt (1709, pp. 24-25) se justificava dizendo que estava seguindo os exemplos de Terêncio, Cícero e Virgílio. Foi em referência a essa tradução que Gilles Ménage, em 1740, cunhou a metáfora "belle infidèle", explicando: "Apelidei a tradução de a 'bela infiel'. É a alcunha que eu, na juventude, atribuía a uma das minhas amantes" ${ }^{\circ 2}$. (Apud BALLARD, 2007, p. 147).

Na tradução de Tucídides (1662), d'Ablancourt manteve a mesma tendência de adaptar as obras traduzidas ao gosto de sua época. No prefácio, admitiu ter introduzido esclarecimentos no texto e, às vezes, remanejado trechos em nome da clareza. A metáfora da troca de roupas foi estendida ao próprio corpo, que passaria, na tradução, por uma transmigração: "Pois o que temos aqui não é tanto o retrato de Tucídides, mas o próprio

\footnotetext{
${ }^{58}$ A imagem segundo a qual as palavras seriam as vestes das coisas pode ser encontrada tanto em Cícero (1967, pp. 98-99) quanto em Quintiliano (1970, pp. 188-189), e exerceu grande influência sobre os tradutores desde a Antiguidade até o século XVIII. Traduzir seria como trocar as roupas que o autor original utilizou para vestir o conteúdo. Essa troca de roupas frequentemente envolvia mais do que apenas a substituição de uma língua pela outra. Para alguns tradutores, significava remover ou acrescentar características estilísticas.

59 "Les divers temps veulent non-seulement des paroles mais des pensées differentes, \& les Ambassadeurs ont coustume de s'habiller à la mode du Päis où l'on les envoie, de peur d'estre ridicules à ceux à qui ils taschent de plaire".

60 "parce qu'autrement ce ne seroit pas une Traduction".

61 “[...] cela n'est pas proprement Traduction, mais cela vaut mieux que la Traduction, \& les Anciens ne traduisoient point autrement."

62 "Pour moi je l'appelai la belle infidelle, qui étoit le nom que j'avois donné étant jeune à une de mes maîtresses."
} 
Tucídides, que passou para um outro corpo como que por uma espécie de metempsicose, e de grego se tornou francês [...]"63. (Apud ZUBER, 1968, p. 382).

Certos teóricos que defendem a tradução "estrangeirizadora", como Lawrence Venuti e Antoine Berman, criticam as traduções francesas desse período por não preservarem os valores culturais das outras línguas e culturas - as belles infidèles não seriam éticas em termos culturais. Nesse ponto, concordamos com a análise de Julie Hayes (2009, pp. 31-32): muitos tradutores franceses dessa época tinham, sim, consciência das diferenças culturais e linguísticas, e utilizavam essas diferenças como justificativa para a sua prática, pois o que eles consideravam prioritário ao transferir um texto de uma língua para outra não era a palavra e, muitas vezes, nem mesmo o sentido, mas os elementos retóricos, a "eloquência", os efeitos estéticos e emocionais do texto, que era, assim, reencenado na tradução. ${ }^{64}$

\subsubsection{A tradução na Grã-Bretanha}

\subsubsection{Teorizações sobre traduções}

A visão renascentista da tradução como um meio de ampliar e enriquecer a língua materna continuou em voga nos séculos XVII e XVIII, embora de forma atenuada. Como observa John Milton (1998, p. 25), os poetas augustanos procuravam revitalizar a cultura nacional seguindo os modelos clássicos greco-latinos. A tradução, principalmente a dos clássicos greco-latinos, ainda era encarada como um trabalho de grande importância cultural e, em consequência, recebia muitos incentivos. Já desde o século XVI, segundo Flora Amos (1920, p. 136), os amigos e patronos ofereciam conselho e auxílio aos tradutores - são inúmeros os prefácios que relatam esse tipo de ajuda. Muitos patronos hospedavam o tradutor em sua casa. Dryden, por exemplo, traduziu a primeira Geórgica e o final da Eneida na casa de Sir William Bowyer; o sétimo livro da Eneida foi traduzido em Burleigh, residência do Conde de Exeter. Os literatos mais famosos, como Dryden e Pope, dedicavam-se à atividade tradutória em paralelo a outras atividades literárias e intelectuais. As coletâneas de poesia inglesa incluíam traduções, principalmente contemporâneas, de poesias da Antiguidade greco-

\footnotetext{
63 “Car ce n'est pas tant icy le portrait de Thucydide, que Thucydide luy meme, qui est passé dans un autre corps comme par un espece de Metempsycose, et de Grec est devenu François [...]".

${ }^{64}$ Hayes (2009, pp. 31-32) menciona, em especial, d'Ablancourt, que demonstra conhecer, inclusive, as práticas exegéticas midráshicas. Quando d'Ablancourt (apud GUILLERM, 1996, p. 25) afirma "Ce seroit une superstition Judaïque de s'attacher aux mots et de quitter le dessein pour lequel on les employe" ["Seria uma superstição judaica se prender às palavras e abandonar o propósito pelo qual elas são usadas"], ele cria, segundo Hayes, uma abertura no texto para uma outra visão de língua, deslocando a representação clássica como a única norma.
} 
-latina ou de outros países. Esse respeito pela tradução, aliado ao prestígio da crítica literária na época, levou à produção de um amplo corpus de comentários sobre métodos de tradução, na forma, sobretudo, de longos prefácios a traduções ${ }^{65}$. É verdade que esses prefácios continham muitos lugares-comuns, fórmulas incluídas mais como ornamento ou cortesia do que como aprofundamento teórico, mas, ainda assim, por meio deles é possível discernir as principais ideias da época sobre tradução.

Os autores que escreveram sobre tradução nos séculos XVII e XVIII pertenciam a um grupo bastante restrito de intelectuais; conheciam o trabalho uns dos outros e dialogavam entre si. Talvez isso ajude a explicar a relativa homogeneidade das ideias sobre tradução nesse período. A tradução de clássicos gregos e romanos era a preferência da época, e os tradutores competiam entre si na tradução de Homero e Virgílio, geralmente considerados os dois maiores poetas épicos, e Horácio, o maior poeta lírico latino. De acordo com Richard F. Thomas (1995, p. 27), foram feitas trinta traduções da Eneida (entre traduções parciais e completas) apenas no século XVII. Mas vários outros autores clássicos foram traduzidos: Hesíodo, Píndaro, Juvenal, Ovídio, Cícero, Lucano - para citar apenas alguns entre os mais célebres.

A tradução era vista, sobretudo, como mimese - como uma espécie de pintura feita a partir da natureza. Como analisa Steiner (1975, pp. 39-40), a maioria dos tradutores que concebia a sua atividade como mimética estava imitando o "ideal empírico" do original, ou seja, acreditava, como Aristóteles, que a mimese se assentava em modelos e formas selecionados ou abstraídos a partir dos objetos de nossa percepção sensorial. Os tradutores não deviam, portanto, se limitar à cópia de algo já existente; era preciso abstrair o "sentido" do original. Ao longo do século XVII, a preocupação com o sentido do original foi se transferindo para o autor: o tradutor deveria interpretar corretamente as intenções do autor.

O principal método defendido pelos tradutores desse período era a tradução "sentido por sentido" e, concomitantemente, a rejeição da tradução "palavra por palavra". John Denham (1615-1669) compôs uma das primeiras teorizações elaboradas na Inglaterra sobre a arte de traduzir poesia: o poema "A Sir Richard Fanshawe, por sua tradução do Pastor Fido", escrito em 1648 em homenagem à tradução feita por Fanshawe (que depois viria a ser o primeiro tradutor de Os lusíadas para o inglês) de Il Pastor Fido, de Giovanni Battista Guarini. Nesse poema, Denham (2012d, pp. 27-28) elogia Fanshawe por não ter seguido o "caminho servil" de traduzir palavra por palavra, o que seria "Cheap vulgar arts, whose narrowness affords / No

\footnotetext{
65 Amos (1920, p. 139) cita como exemplos de traduções do século XVIII acompanhadas de volumosos comentários a do Orlando furioso, de Ariosto, traduzido por Hoole, e Os lusíadas de Camões, por Mickle.
} 
flight for thoughts, but poorly sticks at words". ${ }^{66}$ Buscando "caminhos novos e mais nobres", Fanshawe seria fiel ao sentido, o que implicaria também o uso da criatividade do tradutor. No Prefácio à sua tradução de The Destruction of Troy (1656), Denham (2012b, pp. 29-30, tradução de Janet Dewey) repete o alerta contra a tradução palavra por palavra, que recomenda apenas para textos históricos ou religiosos:

Ao traduzir poetas, considero um erro vulgar assumir o papel de fidus interpres; deixemos que esses cuidados caibam àqueles que tratam de assuntos de fato, ou assuntos de fé; mas quem visa a isso em poesia, como quem tenta o que não é preciso, jamais conseguirá desempenhar o que tenta; pois não é sua única responsabilidade traduzir uma língua em outra língua, mas poesia em poesia; e a poesia é de um espírito tão sutil que, ao se derramar de uma língua na outra, tudo se evapora; e se um novo espírito não for adicionado na transfusão, nada restará a não ser um caput mortuum $[\ldots]^{67}$

Além dessa metáfora da transfusão alquímica do "espírito" da poesia (caput mortuum são os resíduos sólidos de uma destilação alquímica), Denham (2012b, p. 30, tradução de Janet Dewey) recorre à metáfora da troca de vestuário: "E assim como a fala é a roupagem dos nossos pensamentos, também há certas vestes e modos de falar, que variam com os tempos; o estilo de nossas roupas não se sujeita mais a alterações do que a nossa fala" ${ }^{68}$. Por meio da tradução, o autor passa a se expressar em outra língua; por isso é preciso empregar uma linguagem adequada à época da tradução: "se Virgílio precisasse falar inglês, seria apropriado que falasse não apenas como homem desta Nação, mas também como homem desta época" $"$ 69.

Na tradução de duas odes de Píndaro, em 1656, Abraham Cowley (1618-1667) assume ainda mais liberdades. No prefácio, Cowley (1710, p. 183) alega que a enorme diferença entre a época do autor e a do tradutor justifica esse procedimento: "Se alguém resolvesse traduzir

\footnotetext{
66 "arte barata e vulgar, cuja miséria não transfere / Asas às ideias, mas sempre às palavras adere" (DENHAM, 2012c, p. 26, tradução de Fernando L. Dantas).

67 "I conceive it a vulgar error in translating Poets, to affect being Fidus Interpres; let the care be with them who deal in matters of Fact or matters of Faith ; but whosoever aims at it in poetry, as he attempts what is not required, so shall he never perform what he attempts ; for it is not his business alone to translate Language into Language, but Poesie into Poesie; \& Poesie is of so subtle a spirit, that in pouring out of one language into another, it will all evaporate; and if a new spirit is not added in the transfusion, there will remain nothing but a Caput Mortuum [...]".(DENHAM, 2012a, p. 33).

68 "And as speech is the apparel of our thoughts, so are there certain Modes and Garbs of speaking, which vary with the times ; the fashion of our clothes being not more subject to alteration, than that of our speech". (DENHAM, 2012a, p. 34).

69 "if Virgil must needs speak English, it were fit he should speak not only as a man of this Nation, but as a man of this Age". (DENHAM, 2012a, p. 34).
} 
Píndaro palavra por palavra, pensar-se-ia que um louco traduzira outro". 70 Com essa justificativa, Cowley (p. 184) admite ter subtraído elementos do original e acrescentado outros a seu bel-prazer, pois não era sua intenção transmitir exatamente o que o autor dissera, mas a sua maneira de dizer (estilo). Assim como d'Ablancourt no prefácio às traduções de Luciano, Cowley (1710, pp. 183-184, itálicos do autor) discute a aplicabilidade do nome "tradução" à sua obra:

Não me incomoda nem um pouco que os gramáticos não tolerem que esse modo libertino de apresentar autores estrangeiros seja chamado de tradução; pois não sou tão enamorado do nome tradutor a ponto de não desejar ser algo melhor, mesmo que ainda falte um nome. ${ }^{71}$

Wentworth Dillon, o Conde de Roscommon (1633?-1685) repete vários lugarescomuns das ideias sobre tradução da época em seu poema Essay on Translated Verse (1684), que, por outro lado, é um exemplo interessante, em termos do foco de nosso trabalho, do uso da noção de translatio. No início da era augustana, muitos autores consideravam o inglês uma língua inferior ao grego e ao latim. Ao longo desse período essa atitude começou a mudar, havendo um nítido aumento da satisfação em relação à língua inglesa. Essa nova confiança se reflete na atitude para com os tradutores de outras línguas. Nesse poema, o Conde de Roscommon, após louvar os tradutores franceses de outrora, afirma:

From hence our gen'rous Emulation came, We undertook, and we perform'd the same: But now $W e$ show the world another way, And in Translated Verse do more than They. ${ }^{72}$ (Apud STEINER, 1975, p. 76.)

A parte final do poema apresenta a alegoria (encerrando-se, na segunda edição do Ensaio, que é a que estamos citando, com uma paráfrase do Canto VI de O Paraíso perdido, de Milton) de uma "guerra poética" em que o "exército" britânico vence Roma por meio do

\footnotetext{
70 "If a man should undertake to translate Pindar word for word, it would be thought that one Mad man had translated another [...]".

71 "It does not at all trouble me that the Grammarians perhaps will not suffer this libertine way of rendring foreign Authors, to be called Translation; for I am not so much enamoured of the Name Translator, as not to wish rather to be Something Better, though it want yet a Name."

72 "Deles veio a nossa generosa emulação,

Nós nos empenhamos e fizemos o mesmo:

Mas agora nós mostramos ao mundo outro caminho,

E na tradução de poesia realizamos mais do que eles."
} 
refinamento da outrora bárbara língua inglesa. ${ }^{73}$ Esse trecho está repleto de metáforas bélicas e imperialistas. Entre as imagens evocadas, temos a do poeta Tirteu, que, com seus cânticos de guerra, incitou os espartanos à vitória na Segunda Guerra Messênica:

When, by Impulse from Heaven, Tyrtaus sung, In drooping soldiers a new Courage sprung, Reviving Sparta now the Fight maintain'd; And what Two Gen'rals Lost, a Poet Gain'd. By secret influence of Indulgent Skyes, Empire and Poesy Together rise.

True Poets are the Guardians of a State $[\ldots]^{74}$ (Apud STEINER, 1975, pp. 83-84).

A principal cruzada de Roscommon é contra a rima, uma restrição que cria obstáculos intransponíveis e produz outros defeitos. ${ }^{75}$ A rima seria uma herança bárbara, que poderia ser justificada em tempos antigos, mas que agora deveria ser banida em prol de uma reaproximação com o grego e o latim da Antiguidade:

But now that Phoebus and the sacred Nine, With all their Beams on our blest island shine, Why should not We their ancient Rites restore, And be, what Rome or Athens were Before? ${ }^{76}$ (Apud STEINER, 1975, p. 84).

O poema se encerra com uma evocação ao triunfo da Musa Britânica, livre dos vícios bárbaros:

Oh may I live to hail the Glorious day, And sing loud Pans through the crowded way. When in Triumphant State the British Muse, True to herself, shall barb'rous aid Refuse,

\footnotetext{
${ }^{73}$ Note-se, a propósito, que Roscommon defendia a criação de uma Academia para o refinamento da língua inglesa.

74 "Quando, por impulso dos céus, Tirteu cantou,

Em soldados sem ânimo uma nova coragem brotou,

Reavivada, Esparta sustentou a luta;

E o que dois generais perderam, um poeta ganhou.

Pela secreta influência de céus clementes,

Império e poesia se erguem juntos.

Os verdadeiros poetas são os guardiões de um Estado [...]"

${ }^{75}$ Apesar da rejeição da rima, o Ensaio de Roscommon é composto em dísticos heroicos. É interessante observar também que a paráfrase dos versos de Milton, na segunda edição ampliada do Ensaio, serve também para ilustrar a possibilidade de se usar versos brancos em vez de dísticos heroicos.

76 "Mas agora que Febo e as nove musas,

Com todos os seus raios sobre nossa abençoada ilha brilham,

Por que não restaurarmos os seus antigos ritos,

E sermos o que Roma ou Atenas foram antigamente?"
} 
And in the Roman Majesty appear,

Which none know better, and none come so near. ${ }^{77}$

(Apud STEINER, 1975, p. 85).

Outro ponto interessante é que Roscommon difere da maioria dos tradutores ao declarar-se contrário aos acréscimos e "aperfeiçoamentos" ao original: "Your author always will the best advise, / Fall when He falls, and when He Rises, Rise" (apud STEINER, 1975, p. $80) .^{78}$

John Dryden, o mais célebre poeta e escritor de seu tempo na Grã-Bretanha, foi também considerado o principal teórico da tradução. No prefácio à tradução das Epístolas de Ovídio (1680), Dryden (2012b, p. 43) descreve os três tipos de tradução existentes:

I. Metáfrase, ou tradução palavra por palavra e verso por verso. Um exemplo de metáfrase seria a tradução feita por Ben Johnson da Arte poética, de Horácio.

II. Paráfrase, ou tradução com mais latitude, na qual o tradutor não se afasta completamente do autor, mas segue menos estritamente as palavras do que o sentido - o qual pode ser amplificado, mas não alterado. O exemplo é a tradução do Livro IV da Eneida, de Virgílio, por Waller.

III. Imitação, em que o tradutor (se é que ainda pode ser assim chamado) assume a liberdade não apenas de modificar as palavras e o sentido, mas de abandoná-los quando considerar oportuno, aproveitando somente algumas ideias gerais do original e utilizando-as a seu bel-prazer. A tradução radicalmente livre feita por Abraham Cowley das duas odes de Píndaro e uma de Horácio, em um estilo chamado pelo próprio autor de "libertino", ilustra bem esse último tipo de tradução.

Nada disso era novo - segundo Robinson (2002, p. 172), essas definições haviam sido elaboradas por Philo, em Alexandria, e Quintiliano em Roma, redescobertas durante a Renascença e utilizadas por autores desde Roger Ascham, em 1570, até Pierre-Daniel Huet, em 1661. Mas, de qualquer forma, Dryden as adaptou ao seu ambiente literário, sem deixar de incorporar a preocupação com a transmissão do pensamento do autor, que já era uma característica dos tradutores franceses do século XVII, como d'Ablancourt.

\footnotetext{
77 "Ah, que eu viva para saudar o glorioso dia,

E cantar peãs bem alto entre as multidões do caminho.

Quando em triunfo a Musa Britânica,

Fiel a si mesma, recusar a ajuda bárbara,

E surgir com a magnificência romana,

Que ninguém conhece melhor, e da qual ninguém se aproximou tanto."

78 "Vosso autor será sempre o melhor conselheiro: / caí quando ele cair; e quando ele se erguer, erguei-vos".
} 
Nesse mesmo prefácio, Dryden (2012b, pp. 47-48, tradução de V. Viotto e R. Machado) enuncia os pré-requisitos de um tradutor de poesia: ser poeta; dominar tanto a língua do original quanto a própria; entender as características individuais do autor; conformar o seu gênio ao do autor; respeitar os pensamentos do autor mantendo seu estilo ou, se a língua de chegada não o permitir, "variar somente a roupagem, para não alterar ou destruir a substância"79; fazer com que o autor pareça tão elegante quanto possível sem deturpar o sentido; não introduzir novos pensamentos. Não considera necessário que a tradução contenha o mesmo número de palavras e versos que o original; o que é preciso é que mantenha o estilo. A tradução literal e a imitação eram dois extremos a serem evitados.

Nas traduções e prefácios seguintes Dryden parece mudar de atitude, admitindo cada vez mais liberdades na tradução - segundo a análise de Steiner (1975, p. 31), com os objetivos de agradar ao público e atingir uma precisão estética maior, que lhe permitisse transmitir o que ele considerava ser a essência do original.

No Prefácio às Fábulas Antigas e Modernas de Chaucer - uma tradução intralingual, de atualização da língua usada por Chaucer -, Dryden (2012d, pp. 95-96, tradução de Marina Camera) confessa:

[...] não me prendi à tradução literal, mas frequentemente omiti o que julguei desnecessário ou indigno de aparecer ao lado de melhores pensamentos. Fui além em alguns lugares e acrescentei algo de meu onde achei que meu autor era deficiente, e que não havia dado às suas ideias o brilho real pela insuficiência de palavras nos primórdios de nossa língua. E senti-me encorajado a isso porque [...] me considerei uma alma gêmea e familiarizada com os mesmos estudos. ${ }^{80}$

Apesar da importância de Alexander Pope como poeta e tradutor, suas ideias sobre tradução repetem o que já havia sido dito por teóricos anteriores, principalmente Dryden.

Como observa Amos (1920, p. 170), os prefácios de Pope (como de vários outros tradutores da época) são, intencionalmente ou não, enganosos. Pope (2012b, pp. 115-116, tradução de Marina Camera) inicia o prefácio à tradução da Ilíada de modo ortodoxo, defendendo, como Dryden, o meio termo entre a paráfrase e a tradução literal: “Claro está que

\footnotetext{
79 “[...] to vary but the dress, not to alter or destroy the substance." (DRYDEN, 2012a, p. 55).

80 " ".... I I have not tied myself to a literal translation; but have often omitted what I judg'd unnecessary, or not of dignity enough to appear in the company of better thoughts. I have presum'd farther, in some places, and added somewhat of my own where I thought my author was deficient, and had not given his thoughts their true luster, for want of words in the beginning of our language. and to this I was the more embolden'd, because [...] I found I had a soul congenial to his, and that I had been conversant in the same studies." (DRYDEN, 2012c, pp. 99100).
} 
não há tradução literal que possa fazer jus a um original excelente numa língua superior; mas é um grande erro imaginar (como muitos fizeram) que uma grosseira paráfrase pode corrigir essa falha comum $[\ldots]^{81}$ ". Pope chega a exigir "uma tradução quase literal" ${ }^{82}$, insistindo em que o tradutor não deve tentar aperfeiçoar o autor:

Um grande segredo quando se escreve é saber quando ser simples e quando ser poético e figurativo; e é o que Homero nos ensinará se apenas seguirmos seus passos com humildade. Onde sua dicção é forte e altiva, vamos elevar a nossa tanto quanto pudermos; mas onde ele for simples e humilde, não deveríamos nos sentir tolhidos em imitá-lo pelo medo de enfrentar a censura de um simples crítico inglês. ${ }^{83}$

Mais adiante, Pope (p. 121, tradução de M. Camera) enumera algumas regras que o tradutor de Homero deveria seguir:

[...] copiá-lo em todas as variações de seu estilo e as diferentes modulações de sua métrica; preservar nos trechos mais vigorosos ou descritivos o calor ou elevação; nos trechos mais calmos ou narrativos, simplicidade ou solenidade; nos discursos, fidelidade e clareza; nas frases, concisão e gravidade. Não negligenciar nem mesmo as pequenas figuras de linguagem e jogos de palavras, nem mesmo as formas da época, nem mesmo omitir ou interpretar erroneamente quaisquer ritos ou costumes da Antiguidade. ${ }^{84}$.

$\mathrm{Na}$ verdade, Pope não seguiu seus próprios conselhos. Entre os comentários de críticos da época sobre os "embelezamentos" feitos por Pope no original, o mais sintético é o de Richard Bentley (apud JOHNSON, 1820, p. 184, nota): "É um belo poema, Sr. Pope, mas não se pode dizer que seja de Homero". ${ }^{85}$ Apesar disso, a maioria desses críticos defendia esses “embelezamentos": era o gosto da época. Samuel Johnson (2012b, pp. 150-151, tradução de M. C. Palma) considerava as traduções que Pope fez de Homero "um tesouro de elegância

\footnotetext{
81 "It is certain no literal translation can be just to an excellent original in a superior language: but it is a great mistake to imagine (as many have done) that a rash paraphrase can make amends for this general defect [...]"(POPE, 2012a, p. 123).

82 "a version almost literal" (POPE, 2012a, p. 123).

83 "It is a great secret in writing to know when to be plain, and when poetical and figurative; and it is what Homer will teach us, if we will but follow modestly in his footsteps. Where his diction is bold and lofty, let us raise ours as high as we can; but where his is plain and humble, we ought not to be deterred from imitating him by the fear of incurring the censure of a mere English critic." (POPE, 2012a, p. 124)

${ }^{84}$ "To copy him in all the variations of his style, and the different modulations of his numbers; to preserve, in the more active or descriptive parts, a warmth and elevation; in the more sedate or narrative, a plainness and solemnity; in the speeches a fullness and perspicuity; in the sentences a shortness and gravity: not to neglect even the little figures and turns on the words, nor sometimes the very cast of the periods; neither to omit nor confound any rites and customs of antiquity." (POPE, 2012a, p. 129).

85 "It is a pretty poem, Mr. Pope, but you must not call it Homer."
} 
poética para a posteridade" ${ }^{\text {}}$. Aos críticos que diziam que essas traduções não eram homéricas, Johnson respondia: “o objetivo de um escritor é ser lido, e a crítica que destrói a capacidade de satisfazer deve ser posta de lado" ${ }^{\prime \prime}$.

Segundo Bassnett (2002, p. 65), a Inglaterra augustana valorizava regras e modelos, mas isso não significava que a arte fosse percebida como uma habilidade meramente imitativa. "A arte era a ordenação da Natureza de maneira harmoniosa e elegante." 88 Em nome dessa elegância, era preciso omitir muitos termos, principalmente aqueles julgados impróprios para as damas. Assim, Dryden (1832, p. 129) declara que não tentou reproduzir o “dialeto dórico" de Teócrito, "pois Teócrito escreveu para sicilianos, que falavam esse dialeto, e eu dirijo essa parte de minhas traduções para nossas damas, que nem entendem, nem irão apreciar expressões tão triviais" ${ }^{\circledR 9}$. E Pope, no Prefácio à Ilíada (2012a), recusa o emprego de termos modernos na tradução de Homero; rejeita a tradução literal dos epítetos compostos, para não agredir a língua inglesa, e recomenda que sejam traduzidos em inglês por palavras compostas (o exemplo citado é cloud-compelling Jove ${ }^{90}$ ) ou circunlocuções; recomenda também a introdução de pequenas variações nos epítetos, em vez de repeti-los como faz Homero; e, por fim, aconselha a omissão de todas as repetições quando essas ocorrem muito próximas no texto, para não entediar o leitor.

De acordo com Rener (1989, pp. 218-238), no vasto período compreendido entre Cícero e Tytler a teoria linguística que embasa a teoria tradutória permaneceu a mesma: as palavras e as coisas continuaram separadas; a tradução lidava fundamentalmente com o conteúdo, a res; as palavras [verba] eram secundárias. Embora se valesse da língua como um meio necessário, a tradução não pertencia ao campo linguístico, e sim ao hermenêutico - tanto que o seu nome oficial era interpretatio. Daí a preocupação com a clareza; era preciso adaptar o texto para a compreensão dos leitores, mesmo aqueles que não possuíam um conhecimento erudito. A preocupação com o leitor não se limitava, contudo, à clareza: o tradutor procurava também agradar ao leitor, evitando entediá-lo com repetições ou ofendê-lo com palavras ou expressões contrárias à fé cristã, aos bons costumes ou ao bom gosto. A ideia clássica da tradução como interpretatio inclui normas sociais e morais. Assim, a omissão de termos ofensivos deve ser encarada como um gesto de respeito exigido pelo código de decoro social. A abrangência das

\footnotetext{
86 “[...] a treasure of poetical elegances to posterity." (JOHNSON, 2012a, p. 154).

87 " [...] the purpose of a writer is to be read, and the criticism which would destroy the power of pleasing must be blown aside." (JOHNSON, 2012a, p. 155).

88 "Art was the ordering in a harmonious and elegant manner of Nature [...]".

89 " [...] for Theocritus writ to Sicilians, who spoke that dialect; and I direct this part of my translations to our ladies, who neither understand, nor will take pleasure in such homely expressions."

90 “Júpiter, o que governa as nuvens".
} 
noções de "bons costumes" e "bom gosto" não é facilmente definida; pelos exemplos de omissões justificadas nos prefácios dos tradutores, percebemos que englobam tanto questões éticas quanto estéticas. Os tradutores desse período, tanto na França quanto na Grã-Bretanha, como mostrou Lefevere (1992, pp. 87-98), recusavam-se a traduzir termos triviais e corriqueiros (ligados à cozinha ou a atividades artesanais) empregados por Homero. Isso se deve, de acordo com Lefevere, às diferenças entre os universos de discurso dominantes nas épocas do original e da tradução.

Os prefácios às traduções refletem, segundo Rener (1989, p. 236), essa preocupação com o leitor, exercendo a função que, na retórica, era cumprida pelo proêmio (que procurava estabelecer, já no início do discurso, uma relação amistosa entre o orador e o juiz) na oratória jurídica. Em uma tradução, o papel de juiz é exercido pelo leitor.

Nos séculos XVII e XVIII, a tradução de poesia em prosa era veementemente rejeitada pela ampla maioria dos tradutores britânicos, e os franceses eram frequentemente ridicularizados por recorrerem a esse tipo de tradução. O costume dos tradutores renascentistas de conservar na tradução o mesmo número de versos do original também passou a ser ridicularizado. Poetas e tradutores como Denham, Dryden e Johnson atribuíam a Fanshawe, na tradução de Il Pastor Fido de Guarini, o mérito de ter sido o primeiro a romper com esse preconceito e a introduzir um novo estilo. O dístico heroico se tornou a forma poética predominante - a que era usada, principalmente, na tradução de poemas épicos (até nas epopeias modernas, em substituição à oitava rima italiana). Em termos de formas poéticas era uma época muito conservadora, contrária à inovação, às experiências formais e até mesmo à variação. Nem todos aceitavam a necessidade da rima; havia quem defendesse a tradução de poemas da Antiguidade em versos brancos - mas eram poucos. Dryden se preocupava bastante com o ritmo e procurou introduzir novas cadências em suas traduções. Seus sucessores, no entanto, limitaram-se a imitá-lo, sem os mesmos recursos criativos. Em questões de versificação também não houve grandes mudanças. Johnson (1819, p. 383) mencionou algumas tentativas fracassadas de utilização do verso branco - a tradução da Eneida pelo Dr. Brady e por Joseph Trapp, que repetiu a experiência com as Éclogas e as Geórgicas. As tentativas de fugir ao dístico heroico também foram poucas e geralmente malsucedidas. Mudou apenas o estilo, a dicção da época. Johnson (1819, p. 383) aprovava os preceitos teóricos e as traduções de Dryden, mas via com muito bons olhos as novas 
traduções, pois "o ouvido inglês se acostumou à melifluidade dos versos de Pope, e a dicção poética se tornou mais esplêndida"91.

\subsubsection{Alexander Fraser Tytler (1747-1813)}

O advogado, escritor e historiador escocês Alexander Fraser Tytler, depois Lord Woodhouselee, escreveu o primeiro livro em língua inglesa dedicado inteiramente à tradução, Essay on the Principles of Translation, publicado anonimamente em 1790. Embora essa obra tenha sido publicada após a tradução de Mickle de Os lusíadas, nós a comentaremos aqui pelo seu caráter de síntese das ideias sobre tradução que predominavam nos séculos XVII e XVIII.

Já nas primeiras páginas, Tytler (1907, p. 9) enuncia três regras a serem seguidas pelo tradutor:

I. Dar uma transcrição completa das ideias do original.

II. Seguir o estilo (tanto aquele referente ao assunto do texto quanto o estilo pessoal) ${ }^{92}$ do original.

III. Dar à tradução a mesma fluência da composição original. ${ }^{93}$

Ao longo do ensaio, Tytler procura fornecer detalhes e exemplos para que o tradutor possa compreender melhor o objetivo e alcance dessas regras.

Tytler (1907, pp. 17-18) explicita que o tradutor deve tentar eliminar as ambiguidades do original sempre que possível, estudando o contexto lógico, o estilo do autor, os usos linguísticos da época etc.

O tradutor é autorizado a acrescentar ou eliminar passagens, desde que siga bons critérios e que as alterações aumentem a força e a elegância do original, sem trair o seu “espírito”. Entre os exemplos citados por Tytler (1907, pp. 24-25, traduções para o português feitas pela autora da tese) há um extraído do primeiro livro da Ilíada de Pope. Aquiles, persuadido por Minerva, decide entregar Briseida, e Pátroclo é encarregado de levá-la a Agamenon:

\footnotetext{
91 “[...] the English ear has been accustomed to the mellifluence of Pope's numbers, and the diction of poetry has become more splendid [...]".

${ }^{92}$ No original, "the style and the manner of speaking", uma expressão muito usada em diversas fontes da época e que Rener (1989, p. 194) esclarece não ser um binômio [doublet] sinonímico: a palavra "style" indica o estilo do assunto (em latim, materia) e a expressão "manner of speaking" se refere ao estilo pessoal do autor. Entretanto, é preciso observar que os estilos de assunto não se limitam mais àqueles três da retórica clássica (humilde, médio e grave): Tytler fala em estilo "grave, elevado, fácil, vivaz, floreado e ornamentado ou simples e natural" ["the grave, the elevated, the easy, the lively, the florid and ornamented, or the simple and unaffected"].

${ }_{93}$ Como observa Rener $(1989$, p. 333), as regras de Tytler seguem a retórica clássica, lidando separadamente primeiro com as ideias [res], depois com as palavras [verba] e, finalmente, com o estilo.
} 


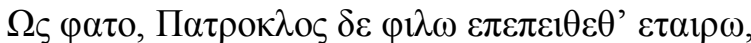

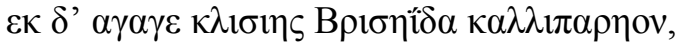

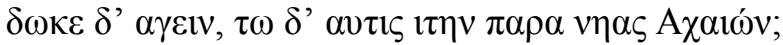

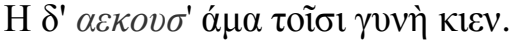

A tradução literal fornecida por Tytler desse trecho é: “Thus he spoke. But Patroclus was obedient to his dear friend. He brought out the beautiful Briseis from the tent, and gave her to be carried away. They returned to the ships of the Greeks; but she unwillingly went, along with her attendants." Traduzindo, de forma igualmente literal, para o português: "Assim ele falou. Mas Pátroclo obedeceu ao amigo querido. Retirou a bela Briseida da tenda e a entregou para que a levassem. Eles retornaram aos navios dos gregos, mas ela foi, contra a vontade, com a comitiva".

A tradução de Pope é:

Patroclus now th' unwilling Beauty brought;

She in soft sorrows, and in pensive thought,

Past silent, as the heralds held her hand,

And oft looked back, slow moving o'er the strand.

[Pátroclo então trouxe a Bela relutante

Ela em suave pranto e pensamentos melancólicos,

Passou silenciosa, os mensageiros segurando-lhe a mão,

E olhava para trás frequentemente, andando devagar pela praia.]

Tytler diz que as ideias contidas nos três últimos versos da tradução de Pope não estão no original, mas estão subentendidas na palavra $\alpha \varepsilon \kappa o v \sigma \alpha$, que indica que Briseida ia contra a vontade e, portanto, andava devagar [slow moving] e olhava para trás frequentemente [oft looked back]. Na opinião de Tytler a amplificação de Pope dá mais efeito ao quadro, e a pausa no terceiro verso, Past silent, é "admiravelmente característica do movimento lento e hesitante que descreve" $" 94$.

Ao elogiar esses recursos usados por Pope, Tytler mostra que a sua visão de tradução ainda está ligada à de Dryden e Pope. Sem dúvida a tradução de Pope é magnífica enquanto poesia: desvela para o leitor os sentimentos de Briseida e descreve seus movimentos de acordo com esses sentimentos. Entretanto, esse tipo de amplificação é característico das traduções dos séculos XVII e XVIII; a partir do século seguinte, passou a ser considerado aceitável apenas em uma "adaptação" ou "imitação", mas não em uma "tradução".

\footnotetext{
94 " [...] admirably characteristic of the slow and hesitating motion which it describes."
} 
Na verdade, Tytler se mostra conservador até mesmo diante de teóricos anteriores, como o Conde de Roscommon, que havia recomendado "descer" quando o autor "desce" e "elevar-se" quando o autor "se eleva", como vimos anteriormente. Tytler (1907, p. 44) responde a esse conselho dizendo:

Longe de adotar a primeira parte dessa máxima, considero que seja dever de um tradutor poético jamais deixar cair o seu original. Deve manter com o autor uma disputa perpétua de gênios; deve acompanhá-lo em seus voos mais altos, e elevar-se, se puder, mais do que ele: e quando perceber, a qualquer momento, uma diminuição de seus poderes, quando vir uma asa pendente, deve erguê-lo em suas próprias asas. ${ }^{95}$

Para Tytler, o tradutor deve corrigir os erros do original, eliminar as "impropriedades". Tytler (1907, p. 46) elogia Pope por ter omitido as "imagens de mau gosto e alusões pueris" 96 de Homero. O tradutor deve também imitar o estilo do autor, mas essa imitação está subordinada "à natureza ou gênio das línguas do original e da tradução"97. O caráter sucinto do latim, as inversões do grego e do latim, e o modo de expressão elíptico do latim não apresentam correspondência exata na língua inglesa, e o tradutor não deve "forçar" a língua para imitá-los. (TYTLER, 1907, pp. 96-105).

A questão é: até onde vai a liberdade do tradutor; até que ponto o tradutor pode embelezar o original e corrigir seus defeitos? Tytler procura fornecer critérios baseados no senso comum, mas esses critérios nos soam, hoje em dia, subjetivos. No fim das contas, o método recomendado por Tytler (1907, p. 114) para que os tradutores cumpram a terceira regra, de conservar a fluência do original, é o mesmo de Dryden e Pope, o de "encarnar" o autor: "Empregando uma expressão ousada, ele deve adotar a própria alma do autor, que deve falar por meio de seus órgãos". 98

\subsubsection{Tradução de outra epopeia moderna}

Na época de Mickle, outra epopeia moderna, a Jerusalém libertada, de Torquato Tasso, recebeu uma tradução, publicada em 1763. O tradutor, John Hoole, pertenceu, como Mickle,

\footnotetext{
95 "Far from adopting the former part of this maxim, I consider it to be the duty of a poetical translator, never to suffer his original to fall. He must maintain with him a perpetual contest of genius; he must attend him in his highest flights, and soar, if he can, beyond him: and when he perceives, at any time a diminution of his powers, when he sees a drooping wing, he must raise him on his own pinions."

96 "low images and puerile allusions"

97 " $[\ldots]$ by the nature or genius of the languages of the original and of the translation."

98 "To use a bold expression, he must adopt the very soul of his author, which must speak through his own organs."
} 
ao círculo do Dr. Johnson, e trabalhou como auditor na Companhia das Índias Orientais. Assim como Os lusíadas já haviam tido uma tradução feita no século anterior, por Fanshawe, também a Jerusalém libertada já havia sido traduzida, por Fairfax. À semelhança de Mickle, Hoole assumiu liberdades tradutórias a fim de, confessadamente, tornar o autor "mais elegante" ou "mais agradável" para o leitor britânico: resumiu bastante vários cantos da epopeia de Tasso; adotou vários elementos estilísticos da poesia britânica da época, como a adjetivação abundante e a musicalidade suave e harmoniosa. Outros pontos em comum entre a tradução de Mickle e a de Hoole são a utilização dos dísticos heroicos ao estilo de Pope e a popularidade alcançada na época da publicação, exatamente em virtude da fluência dos versos e facilidade de leitura.

A declaração de Hoole (1792, p. xvi) no prefácio à tradução repete os chavões da teoria de tradução dos séculos XVII e XVIII: "Meu empenho foi transmitir o sentido de meu autor do modo mais próximo possível, o que jamais poderia ser feito meramente traduzindo suas palavras" $" 99$.

\subsection{A TRANSLATIO NA GRÃ-BRETANHA DOS SÉCULOS XVII E XVIII}

Como teoria, a translatio studii et imperii depende de uma concepção de história providencialista, determinada pela ação de Deus no mundo, e na qual Igreja e Império são concebidos como entidades sagradas, que transcendem o tempo. No setecentismo britânico, dominado por ideias de progresso e valores liberais e racionalistas, a translatio studii et imperii estava perdendo, se já não perdera, seu valor como teoria capaz de explicar adequadamente a história. É interessante observar, no entanto, que os poetas britânicos do século XVIII continuaram utilizando amplamente o conceito da translatio como tropo retórico.

Nos séculos XVII e XVIII, a poesia (tendo como modelo retórico os poetas da Antiguidade greco-latina - em especial Virgílio, traduzido por Dryden) se transformou em um veículo privilegiado para a exaltação dos ideais mercantis do crescente Império Britânico. Vários topoi ligados à translatio studii et imperii foram desenvolvidos pelos poetas. "As armas e as artes”, o comércio e a liberdade eram enaltecidos como virtudes que distinguiam a Grã-Bretanha dos demais países. Profetizava-se que Londres seria a "Nova Roma" e que o Império Britânico em expansão seria o novo Império Romano. Assim como o Império

\footnotetext{
99 "My endeavour has been to render the sense of my author as nearly as possible, which could never be done merely by translating his words."
} 
Romano justificava a sua dominação com base nos benefícios da Pax Romana, também o domínio britânico traria, segundo esses poetas, paz ao mundo, graças às leis britânicas, que promoviam a liberdade - e esta, pelo mito da translatio libertatis, seria transferida às colônias britânicas. (SHIELDS, 1990, p. 16).

Descreveremos brevemente a seguir alguns desses poemas - sem esquecer que cada um deles apresenta especificidades, peculiaridades, ambivalências e muitas vezes até, como bem mostrou Kaul (2000), contradições internas que não serão aqui discutidas.

John Denham retratou a translatio studii no poema "Progress of Learning" (1668): Deus transmitiu o conhecimento para Adão, e esse conhecimento passou sucessivamente pela Caldeia, Egito, Grécia e Itália, de onde se disseminou pelo Império Romano. O Conde de Roscommon, como vimos na seção anterior deste capítulo, desenvolveu o conceito da translatio alegoricamente no poema Essay on Translated Verse (1684).

Dryden, em "Astraea Redux" (1660), foi o primeiro a atribuir o nome de "Augusto" ao rei Carlos II, com alusões virgilianas. Alguns anos depois, em “Annus Mirabilis” (1667), uma notável contribuição poética à construção da identidade britânica, Dryden utilizou o antigo nome "Augusta" para personificar Londres (como Pope fará mais tarde em "WindsorForest"). Recorrendo à retórica e à ideologia para forjar a imagem de uma nação heroica, Dryden encerra o poema com uma visão de Augusta como a "Rainha Donzela", simbolizando o controle britânico sobre os oceanos:

Now, like a maiden queen, she will behold From her high turrets, hourly sutors come: The East with incense, and the West with gold, Will stand, like suppliants, to receive her doom ${ }^{100}$ (DRYDEN, 1810, p. 519).

A última estrofe do poema combina os ideais comerciais e paradisíacos, utilizando até mesmo o tópos do "trade wind" - que não era, como registram atualmente os dicionários de língua inglesa, apenas uma alusão aos ventos alísios, mas um lugar-comum na literatura de viagem e nos poemas épicos ou didáticos desde o século XVII até o início do século XIX na Grã-Bretanha, representando os ventos perfumados que sopravam das ilhas associadas ao comércio de especiarias (MORTON, 1996, p. 1):

\footnotetext{
100 “Agora, como uma rainha donzela, ela irá observar De suas altas torres, de hora em hora, os pretendentes chegando; O Oriente, trazendo incenso, e o Ocidente, ouro Permanecerão em pé, como suplicantes, para receber a sua sentença."
} 
Thus to the eastern wealth through storms we go;

But now, the Cape once doubled, fear no more:

A constant trade-wind will securely blow,

And gently lay us on the Spicy shore. ${ }^{101}$

(DRYDEN, 1810, p. 519).

Ao elogiar o poema de Roscommon em "To the Earl of Roscommon, on his Excellent Essay on Translated Verse" (1684), Dryden recorre à translatio studii. O poema começa com um relato do deslocamento das artes rumo ao oeste, tendo a tradução como eixo. No Egito ou Tiro foram plantadas as sementes que depois floresceram na Grécia; após as invasões dos bárbaros, as artes ressurgiram na Itália da Renascença; Dante, Petrarca e os franceses contribuíram para o aperfeiçoamento artístico, mas o apogeu só foi atingido com os britânicos:

[...] Britain, last,

In manly sweetness all the rest surpass'd.

The wit of Greece, the gravity of Rome,

Appear exalted in the British loom:

The Muses empire is restor' $\mathrm{d}$ again,

In Charles's reign, and by Roscommon's pen. ${ }^{102}$

(DRYDEN, 1810, p. 591)

Alexander Pope aludiu à relação entre o progresso imperial (translatio imperii) e cultural (translatio studii) na parte III de "Essay on Criticism" (1720, p. 65, itálicos do autor):

Learning and Rome alike in empire grew;

And arts still follow'd where her eagles flew;

From the same foes, at last, both felt their doom,

And the same age saw learning fall, and Rome. ${ }^{103}$

101 “Assim, para a riqueza do Oriente, atravessando tempestades, nós vamos;

Mas agora, uma vez dobrado o Cabo, não temos mais medo:

Um constante vento favorável ao comércio seguramente irá soprar,

E gentilmente nos depositar sobre a praia repleta de especiarias."

(Traduzimos "trade wind" literalmente de modo a expressar o que foi explanado no texto sobre esse tópos.)

102 “[...] a Grã-Bretanha, por fim,

Em viril doçura superou todo o resto.

A agudeza da Grécia, a seriedade de Roma,

Parecem exaltadas no tear britânico:

O império das Musas é novamente restaurado,

No reinado de Carlos e pela pena de Roscommon."

103 "O conhecimento e Roma cresceram igualmente no império;

$\mathrm{E}$ as artes ainda seguiram o voo das águias;

Diante dos mesmos inimigos, ao final, ambos experimentaram a ruína,

E o mesmo século viu o conhecimento perecer, junto com Roma." 
Dois anos depois, Pope compôs um hino em louvor à rainha Ana e à Inglaterra, "Windsor-Forest" (1713), saudando a paz e descrevendo uma visão idílica do imperialismo, um tempo futuro em que a paz e a liberdade britânicas se espalhariam por todo o mundo:

The time shall come, when free as seas or wind Unbounded Thames shall flow for all mankind, Whole nations enter with each swelling tyde, And seas but join the regions they divide; Earth's distant ends our glory shall behold, And the new world launch forth to seek the old. ${ }^{104}$ (POPE, 1720, p. 24, itálicos do autor).

"Windsor-Forest" é um dos poemas iniciais de Pope, em que o poeta augustano exibe ainda certa ingenuidade política. Isso iria mudar com o fim da dinastia dos Stuart. A chegada dos hanoverianos deu um novo impulso às alegorias imperialistas, ainda mais que George II se chamava "George Augustus". Kermode (1983, pp. 70-71) observa que há um tom irônico em muito do augustanismo inglês, o que é especialmente evidente na Dunciad ${ }^{105}$ de Pope. Nessa época, a palavra "Augustus" se tornou um insulto, como na "Epistle to Augustus" de Pope. A translatio studii, que Pope havia usado de modo convencional na parte III do "Essay on Criticism", transformou-se em seu inverso, a translatio stultitiae [transferência da burrice], na Dunciad, descrevendo o progresso para o oeste não da sabedoria e do conhecimento, mas da burrice.

Jonathan Swift, que achava absurdas as referências a uma era augustana, lembrava que, depois de chegar ao apogeu, Roma entrara em decadência e ruíra. Swift lamentava o crescimento do luxo e da corrupção, que reproduziam o que ocorrera com o Antigo Império (KERMODE, 1983, pp. 70-71). O tema da ruína, o lado negativo da translatio, era outro tópos da época, como observa Kermode (p. 79): Roma também era "um alerta contra o provável início da decadência e outra idade das trevas"106. Fundada nessa teoria do declínio dos impérios, a rejeição ao luxo - que, derivado do comércio, era também seu grande inimigo

\footnotetext{
104 "Virá o tempo em que, livre como os mares ou o vento

O ilimitado Tâmisa correrá para toda a humanidade,

Povos inteiros entram a cada maré alta,

E mares apenas reúnem as regiões que dividem;

Os fins distantes da terra nossa glória contemplará,

E o novo mundo se lançará em busca do velho."

${ }^{105}$ Alguns trechos da Dunciad foram traduzidos para o português por Paulo Vizioli, com o título Asníada. In: Poemas. São Paulo: Nova Alexandria, 1994.

106 " [...] a warning against the probable onset of decadence and another dark age".
} 
- caracterizava o setecentismo britânico, expressando uma teoria do valor e uma ética tanto individual quanto nacional.

Segundo Kaul (2000, p. 30), os poetas augustanos examinavam não só os impérios do passado, mas as outras nações europeias contemporâneas, a fim de apontar, comparativamente, as virtudes do Império Britânico (a liberdade, a propriedade, a vocação comercial, a polidez, o desenvolvimento da ciência e das artes, a tolerância religiosa, o protestantismo, as habilidades marciais e navais etc.) e, com base nessas virtudes, defender o direito à supremacia britânica, ao mesmo tempo em que alertavam para o risco de degeneração. Exemplos desse tipo de retórica podem ser encontrados em "A Letter from Italy" (1704), de Joseph Addison, e "The Ruins of Rome” (1740), de John Dyer, entre inúmeros outros.

Em "Britannia" (1727), James Thomson incita a Grã-Bretanha a cumprir o seu destino imperial de guardiã da liberdade no mundo, impondo a sua vontade sobre os demais países:

And as you ride sublimely round the World, Make every Vessel stoop, make every State At once their Welfare and their Duty know. This is your Glory; this your Wisdom; this The native Power for which you were design'd By Fate, when Fate design'd the firmest State, That e'er was seated on the subject Sea; A State, alone, where Liberty should live, In these late Times, this Evening of Mankind, When Carthage, Rome, and Athens are no more, The World almost in slavish Sloth dissolv'd. ${ }^{107}$ (THOMSON, 1837b, p. 73)

"Rule, Britannia" (1740), o mais popular poema de Thomson, convertido em hino do nacionalismo britânico, foi composto para o final da mascarada Alfred, escrita em parceria com David Mallet e depois transformada em ópera por Thomas Arne. Nessa canção patriótica

\footnotetext{
107 "E enquanto passeias sublimemente ao redor do Mundo, Faz todo Navio se inclinar, faz todo Estado Conhecer de imediato o Bem-Estar e Dever deles. Esta é a tua Glória; esta é a tua Sabedoria; este O Poder nativo para o qual foste projetada Pelo Destino, quando o Destino projetou o Estado mais firme Que já foi assentado sobre o obediente Mar; Um Estado, o único, em que a Liberdade deve sobreviver, Nestes Tempos recentes, neste Anoitecer da Humanidade, Quando Cartago, Roma e Atenas não mais existem, O Mundo quase em servil Indolência se dissolveu."
} 
as origens divinas da Grã-Bretanha são apresentadas como um contrato que autoriza o domínio sobre as demais nações:

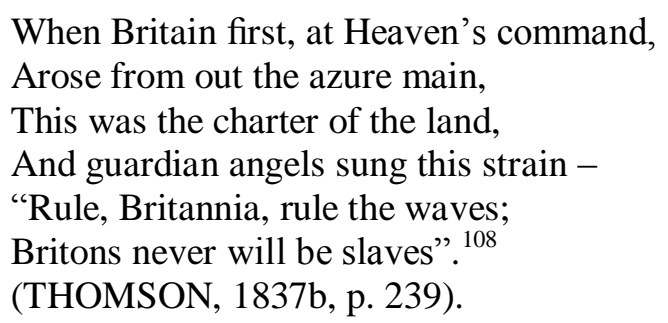

Esse mesmo tema é desenvolvido por Thomson em várias passagens de The Seasons (1726-1730) e "The Castle of Indolence" (1748), e apresentado de forma ainda mais extensa em "Liberty" (1734), um poema que percorre a história dos impérios desde a Antiguidade para estabelecer o destino imperial da Grã-Bretanha: as habilidades militar, naval e comercial são assinaladas como as qualidades necessárias para o florescimento de um império; a tirania, o luxo, a corrupção e a falta de apreço pelas artes caracterizam um império em queda.

Edward Young escreveu duas odes pindáricas, "Ocean: an Ode" (1728) e "Imperium pelagi, or, The Merchant" (1729) enaltecendo a Grã-Bretanha como a sucessora dos gregos e romanos e o novo império marítimo. Em "Imperium pelagi", a mais longa e bem estruturada das duas odes, Young elabora uma verdadeira ética do mercantilismo, elegendo a riqueza como a base da autoridade moral; a natureza atinge a sua realização como comércio e toda a riqueza por ela propiciada está a serviço da Grã-Bretanha:

Others may traffic if they please;

Britain, fair daughter of the seas, Is born for trade, to plough her field, the wave, And reap the growth of every coast:

A speck of land; but let her boast, Gods gave the world, when they the waters gave. ${ }^{109}$ (YOUNG, 1822, p. 158).

\footnotetext{
108 “Quando a Grã-Bretanha, no início, sob o comando dos Céus,

Surgiu no oceano azul,

Isso foi a escritura da terra,

E os anjos da guarda cantaram este refrão -

'Reina, Britânia, reina sobre as ondas;

Os britânicos jamais serão escravos'."

109 "Outros podem traficar, se quiserem;

A Grã-Bretanha, bela filha dos mares,

Nasceu para comerciar, para lavrar o campo, as ondas,

E colher o cultivo de todas as costas:

Um pontinho de terra; mas deixe-a se orgulhar,

Os deuses legaram o mundo quando legaram as águas."
} 
Richard Glover desenvolveu temas similares, de exaltação à liberdade, ao comércio e ao império, no contexto da translatio, em "London; or, The Progress of Commerce" (17371738); William Collins, na "Ode to Liberty" (1746); Thomas Gray em "The Progress of Poesy: a Pindaric Ode" (1754); Oliver Goldsmith em "The Traveller, or a Prospect of Society" (1764). Poderíamos citar ainda muitos outros exemplos - Kaul (2000, p. 32) fornece uma lista de mais de trinta poetas (incluindo William Julius Mickle) que escreveram poemas semelhantes.

Como demonstrou Kaul (2000, p. 27), esses "poetas do comércio" ajudaram a consolidar a ideologia do imperialismo, fornecendo-lhe modelos retóricos e iconográficos e contribuindo para forjar um mito nacional, uma identidade poética e cultural para o Império Britânico.

No final do século XVIII, após a Independência dos Estados Unidos, muitos intelectuais passaram a ver aquele país como "o futuro da humanidade", o que levou ao surgimento de outro tópos relacionado à translatio imperii. George Berkeley, no Essay towards Preventing the Ruin of Great Britain, reclamava da corrupção e degeneração da vida e da arte na Grã-Bretanha. Desiludido com a Grã-Bretanha, Berkeley se mudou para o Novo Mundo. Entre 1728 e 1731, viveu em Rhode Island, tentando fundar um colégio. No poema "America or The Muse's Refuge: A Prophecy”, Berkeley propõe uma translatio da Grã-Bretanha augustana para o Novo Mundo:

Westward the course of empire takes its way;

The first four acts already past,

A fifth shall close the drama with the day;

Time's noblest offspring is the last. ${ }^{110}$

E em outra profecia sobre a América, do poeta visionário William Blake, no poema épico "America: A Prophecy" (1793), o espírito da revolução, Orc, ergue-se do oceano para proclamar o final do império: "The King of England looking westward trembles at the vision." ${ }^{111}$ (Apud PORTER, 2000, p. 402).

Vemos, assim, que o conceito de translatio studii et imperii serviu como tropo retórico para diversos poetas e escritores no século XVIII. Nos capítulos seguintes veremos como

\footnotetext{
110 "Para o oeste o império segue seu caminho;

Os quatro primeiros atos já se passaram,

Um quinto encerrará o drama com o dia;

Os filhos mais nobres do tempo são os últimos."

111 "O Rei da Inglaterra, olhando para o oeste, treme diante da visão".
} 
Mickle aplicou esse conceito em sua tradução de Os lusíadas e no material paratextual que a acompanha.

\subsection{CONSIDERAÇÕES FINAIS}

Para Suvir Kaul (2000, p. 5), os poetas britânicos no século XVIII “conceberam a poesia como uma forma literária única e privilegiada para a enunciação de um vocabulário poderoso (e plástico) referente à nação, especialmente adequado a uma Grã-Bretanha que se mostrasse [...] grande em casa e no exterior" ${ }^{\prime 12}$. Vários poetas escoceses se destacaram nesse esforço retórico, na tentativa de forjar um discurso cultural que lhes conferisse uma plena integração ao Império Britânico. Poetas como James Thomson, por exemplo, buscavam intervir no debate político e moldar os discursos públicos por meio de sua poesia. Esse elo retórico entre poesia e imperialismo levou à exaltação do comércio. Nas palavras de Kaul (2006, p. 27),

\footnotetext{
112 "[...] imagined poetry to be a unique and privileged literary form for the enunciation of puissant (and plastic) vocabulary of nation, particularly one appropriate to Britain proving itself [...] great at home and abroad."

113 " [...] it is important to note that the celebration of British commerce is always part of a larger poetic project: the projection of English 'civilization,' particularly as manifested in its poetry and culture, as more benevolent and humane - more advanced - than that of its European competitors or particularly those of non-European peoples. Poets thus began to develop quasi-anthropological, quasi-historical comparative techniques in their poems, where their surveys of the past and present allowed them to claim Britain and Britons as the latest, and
} 
William Julius Mickle era um desses "poetas do comércio" e, ao escolher traduzir $O s$ lusíadas para o inglês, optou por um gênero - o épico - que constituía um veículo privilegiado para a expressão dos ideais patrióticos e imperialistas.

Naquele período - a segunda metade do século XVIII - a racionalidade, ordem e polidez britânicas começavam a ser abaladas. O empirismo filosófico, ao estudar as sensações, abriu novos caminhos para a mente e a imaginação - caminhos que viriam a ser explorados, até mesmo em seus aspectos mais sombrios e aterradores, pelos românticos. Os pré-românticos do século XVIII - entre os quais, como veremos no Capítulo 4, podemos incluir Mickle - foram precursores nessa exploração e precisaram conviver com as contradições típicas de uma época de transição. Foram eles que, nesse processo, começaram a expandir o papel que era reservado às sensações, ao sentimento e à imaginação, não apenas nas obras poéticas, mas na literatura e na arte, de modo geral.

A tradução na Grã-Bretanha nos séculos XVII e XVIII, assim como as belles infidèles francesas do século XVII, tem recebido, nas últimas décadas, avaliações negativas por parte de muitos teóricos da tradução. Alguns dos rótulos que têm sido aplicados a essas traduções não contribuem, no entanto, para a compreensão do contexto em que elas foram realizadas. Lawrence Venuti (1995), por exemplo, classifica essas traduções como "domesticadoras". A domesticação seria consequência da emergência das nações e línguas modernas durante a Renascença, e essa ideologia teria continuado a operar até o final do século XVIII. Embora concordemos com vários pontos das análises de Venuti, o problema é que uma classificação teórica que aplique a traduções de qualquer época histórica os rótulos de "domesticadora" ou "estrangeirizadora" não dá conta de aspectos importantes da tradução nos séculos XVII e XVIII. Uma questão relevante é que, nesse período, a própria definição de tradução e a sua especificidade em relação a outros tipos de reescritura limítrofes, como a imitação e a paráfrase, ainda não eram claras. Como vários teóricos - entre eles, Maria Tymoczko (2000), Douglas Robinson (1997a, pp. 109-113) e Mary Helen McMurran (2010, pp. 3-4) - já comentaram, os termos "domesticadora" e "estrangeirizadora" foram emprestados do filósofo

most worthy, beneficiaries of the historical rise (and fall) of empires. The medieval model of the movement of culture (translatio studii) was mapped onto the idea that empires followed a westward drift (translatio imperii); thus both the British Muse and the British Empire (however limited, or under threat, this empire might have been in practice) were seen to be the latest and most legitimate inheritors of the achievements of classical and early modern European empires - but with one important difference: the British commitment to Liberty was meant to protect its society and people from the seemingly inevitable decline into the 'Luxury,' degeneracy, and effeminacy that had destroyed otherwise manly and martial empires like those of Sparta and Rome. It was the job of poets both to join in a massed chorus that sang of the virtues of a nation peaceful at home and powerful abroad, and to act as guardians of the social fabric of the nation by intervening in public debates and by warning against political-economic and moral failures." 
alemão Friedrich Schleiermacher e pressupõem um quadro de identidades nacionais, além de noções de autoria e originalidade, que só se estabeleceram após o Romantismo, no século XIX.

Antoine Berman (2007), outro conceituado teórico da tradução, classifica as traduções desse período como "etnocêntricas, hipertextuais e platonizantes". Mais uma vez, mesmo que concordemos, em grande parte, com a atribuição dessas características à tradução dessa época, esse tipo de enfoque não nos parece contemplar várias questões específicas e fundamentais dessas traduções.

De fato, a análise de traduções desse período, assim como das teorias de tradução expressas nos prefácios escritos pelos tradutores, comprova a grande liberdade assumida pela maioria dos tradutores da época, que recorriam a métodos da retórica clássica, como a amplificação e a abreviação, para adequar o original ao gosto e às normas da língua, literatura e cultura "de chegada". Ao fazê-lo, eles estavam seguindo - em geral de modo consciente - as normas de sua época, herdadas da retórica, que privilegiava a eloquência, a transmissão do efeito, a "reencenação" do original em outra língua e cultura. 


\section{WILLIAM JULIUS MICKLE E THE LUSIAD; OR THE DISCOVERY OF INDIA}

O quarto capítulo focaliza o agente da translatio, o tradutor William Julius Mickle, seu modo de inserção no sistema literário, e os modos de circulação, suportes materiais e elementos paratextuais de sua tradução de Os lusíadas, assim como a recepção dessa tradução tanto na época de sua publicação quanto em épocas posteriores.

A primeira seção apresenta a biografia do tradutor; a segunda seção discute as outras traduções efetuadas por ele; a terceira seção comenta a sua obra, destacando os aspectos pré-românticos que irão se refletir na tradução de Os lusíadas. A quarta seção analisa o modo de inserção do tradutor no sistema literário: a sua condição de escocês em Londres na segunda metade do século XVIII e as relações de patronagem estabelecidas por ele, sobretudo aquelas que possibilitaram a confecção dessa tradução. A quinta seção enfoca os modos de circulação da obra - a publicação por meio de uma lista de assinantes e o ambiente editorial em que ocorre. A sexta seção aborda, conforme a definição de Gérard Genette (2009), alguns dos peritextos da tradução: o formato, a encadernação, o título, a epígrafe, a dedicatória e outros elementos da primeira e segunda edições do Lusiad. A sétima seção se dedica à análise realizada à luz dos vários elementos expostos nos capítulos anteriores - dos peritextos prefaciais do livro: a introdução; a história do descobrimento da Índia; a história da ascensão e queda do Império Português no Oriente; a biografia de Camões; a dissertação sobre Os lusíadas e a poesia épica; a dissertação sobre a Ilha dos Amores; e o texto sobre os princípios religiosos e a filosofia dos brâmanes, publicado em nota de rodapé na primeira edição e transformado em ensaio na segunda. Dando prosseguimento à análise dos peritextos, a oitava seção examina, em linhas gerais, as cerca de setecentas notas de rodapé acrescentadas pelo tradutor ao poema. Na nona e última seção, falaremos a respeito da recepção do Lusiad de Mickle, tanto na época de seu lançamento quanto posteriormente.

\subsection{BIOGRAFIA DE MICKLE}

William Julius Mickle nasceu em 29 de setembro de $1734^{1}$, em Langholm, Dumfriesshire, na Escócia. Seu nome de batismo era, na verdade, William Meikle. Era filho de um pastor da Igreja da Escócia, Alexander Meikle, que, entre outras atividades, foi um dos revisores da tradução do renomado Dictionnaire historique et critique de Pierre Bayle, um

\footnotetext{
${ }^{1}$ Essa é a data citada em todas as fontes consultadas, com a exceção de Thomas Bayne (1894, p. 336), para quem a data de nascimento de Mickle seria 28 de setembro de 1735 .
} 
marco do pensamento iluminista. Ao falecer, em 1758, o pai legou a Mickle uma fábrica de cerveja. Mickle não gostava do trabalho de administrador da empresa, e só o assumiu para garantir o sustento da família. ${ }^{2}$

Refugiava-se na poesia. Já aos 13 anos, havia lido The Faerie Queene e se encantado com o estilo de Spenser. Em 1761, publicou anonimamente seus primeiros poemas, "On passing through the Parliament Close at Midnight" e "Knowledge, an Ode", incluídos no segundo volume da Collection of Original Poems by Scottish Gentlemen organizada por Donaldson, um renomado livreiro de Edimburgo.

Uma crise nos negócios obrigou Mickle a abandonar os estudos. Não houve como evitar a falência da cervejaria, em 1762. Esperando obter algum dinheiro, Mickle finalizou um poema, "Providence: or, Arandus and Emilec", que foi publicado em Londres em agosto de 1762. Recebeu elogios no periódico The Critical Review, mas a crítica do Monthly Review não foi tão positiva. Em maio de 1763, perseguido por credores, Mickle evadiu-se para Londres, sem dinheiro nem contatos, levando consigo apenas vagos planos de ganhar a vida como poeta e escritor. Em Londres, mudou a grafia do sobrenome de Meikle para Mickle e, algum tempo depois, acrescentou um segundo nome, Julius, passando a assinar William Julius Mickle.

Entre janeiro de 1763 e dezembro de 1765, no esforço de obter patrocínio, Mickle se correspondeu com Lord George Lyttelton (1709-1773), poeta e historiador do círculo de Alexander Pope, além de membro ilustre do parlamento e patrono de muitos poetas e escritores, entre os quais James Thomson e Henry Fielding. ${ }^{3}$ Apesar da insistência de Mickle, Lyttelton limitou-se ao papel de mentor literário, fornecendo-lhe apenas orientações críticas, sem conceder-lhe nenhum auxílio significativo em termos financeiros ou de promoção de seu trabalho. Mesmo desapontado com a falta de apoio do mentor, Mickle jamais deixou de reconhecer o valor de seus conselhos literários. ${ }^{4}$

Em 1765, Mickle publicou, sem muita repercussão, "Pollio, an Elegiac Ode", que escrevera alguns anos antes, quando da morte de seu irmão George (TAYLOR, 1937, p. 10).

Durante os dois primeiros anos em Londres, Mickle sobreviveu com o pouco dinheiro que seus irmãos, também eles em dificuldades financeiras, conseguiam lhe enviar, além do

\footnotetext{
${ }^{2}$ Várias fontes foram consultadas para redigir essa biografia, mas verificamos que todas se baseiam nas primeiras três biografias publicadas sobre Mickle, as de Isaac Reed (1789), John Ireland (1794) e a do Rev. John Sim (1809), sendo que esta última recorreu, em parte, às duas anteriores. Quando citarmos alguma informação vinda de outras fontes que não essas três, a fonte será devidamente mencionada.

${ }^{3}$ Lyttelton havia sido, entre 1737 e 1744, secretário de Frederico, Príncipe de Gales, e uma das principais figuras da oposição a Robert Walpole.

${ }^{4}$ A correspondência entre Mickle e Lord Lyttelton pode ser lida em Ireland (1794, pp. xiii-xxxiv).
} 
pagamento por artigos que escrevia para periódicos como The St. James's Magazine e The British Magazine. Quando a situação se tornou insustentável e ele estava prestes a partir para a Carolina, na América, como secretário de um comerciante, Mickle foi convidado a assumir o cargo de revisor da Clarendon Press, em Oxford. O salário era modesto, mas garantia-lhe a sobrevivência, e o ambiente de Oxford lhe seria muito auspicioso em termos de contatos e estudos.

Nos anos seguintes, Mickle publicou anonimamente um poema em estilo spenseriano, "The Concubine" (depois rebatizado como "Syr Martyn"), e teve o prazer de vê-lo ser atribuído a vários poetas consagrados. Publicou também panfletos, entre os quais "Voltaire in the Shades; or, Dialogues on the Deistical Controversy”, em que satirizava vários deístas, inclusive o filósofo escocês David Hume.

Em 1772, Mickle foi contratado para revisar a Collection of Poems de Pearch, uma continuação de uma célebre coletânea de Dodsley. Dois poemas originais seus, a balada "Hengist and Mey" e a "Elegy on Mary Queen of Scots" (uma elegia dedicada à rainha Mary Stuart), foram incluídos nessa coleção.

A essa altura, Mickle já era conhecido entre vários intelectuais de Oxford e Londres, até mesmo alguns do círculo do influente Dr. Johnson. James Boswell menciona Mickle algumas vezes em seu Life of Johnson, geralmente em companhia de outros membros do círculo, como John Hoole (tradutor de Ariosto e Tasso), Oliver Goldsmith e o próprio Johnson.

No início da década de 1770, Mickle escreveu uma tragédia sobre o cerco de Marselha, mas a peça foi rejeitada por David Garrick, o famoso ator, diretor e produtor de teatro, que a considerou imprópria para o palco, mesmo depois de Mickle reescrevê-la várias vezes com a colaboração dos irmãos Warton e de John Home. Furioso, Mickle ameaçou escrever uma nova Dunciad tendo Garrick como protagonista...

Uma nova ocupação distraiu Mickle de seu projeto de vingança: a tradução d'Os lusíadas de Camões. Mickle havia lido, aos 17 anos, a tradução francesa de Duperron de Castera, em prosa, e se encantara com o épico camoniano; havia muito tempo pensava em traduzi-lo para o inglês. Dedicou-se, assim, a estudar a língua portuguesa. Quando conseguiu, enfim, iniciar os trabalhos, Mickle preparou um projeto de tradução da obra incluindo a tradução de parte do episódio do Gigante Adamastor (Canto V) e o enviou para The Gentleman's Magazine, um influente periódico da época, que o publicou em março de 1771. Alguns meses depois, Mickle mandou imprimir em Oxford a tradução do Canto I como amostra para angariar assinaturas. Essas primeiras traduções foram tão bem acolhidas que Mickle demitiu-se da Clarendon Press e, na primavera de 1772, foi hospedar-se na mansão 
arrendada por Robert Tomkins em Forest Hill, perto de Oxford, onde cerca de 130 anos antes John Milton escrevera parte de O Paraíso perdido. Lá, Mickle dedicou-se quase exclusivamente à tradução d'Os lusíadas, sem nenhum outro meio de subsistência além do dinheiro arrecadado com as assinaturas. Quatro anos depois, no início de 1776, a tradução completa foi publicada, graças ao financiamento de uma lista de quase seiscentos nomes, contendo pessoas influentes do mundo político e religioso, como Lord Clive, Lord Winchelsea, Sir James Johnstone, os bispos de Oxford, Peterborough e St. Asaph, assim como diversos intelectuais, como o célebre Samuel Johnson, James Boswell, Oliver Goldsmith, John Hoole, Hugh Blair e até mesmo o filósofo David Hume, com quem Mickle antipatizava. (FERREIRA, 1992a, p. 65; TAYLOR, 1937, pp. 17-21).

Mais uma vez, Mickle não teve sorte na escolha do patrono. Por sugestão de amigos, dedicou a obra a um nobre escocês, o Duque de Buccleugh, em cuja casa seu pai servira como capelão. O nobre aceitou a dedicatória, respondendo gentilmente por carta à oferta de Mickle; mas depois de receber um exemplar da tradução, com uma carta de Mickle, não lhe deu mais nenhuma atenção. Segundo alguns biógrafos, Mickle supôs que esse comportamento fosse motivado pelo fato de o Duque ser amigo de David Hume (antigo desafeto de Mickle) e de Adam Smith (cujas doutrinas Mickle criticou, mas apenas dois anos depois, em um dos prefácios à segunda edição da tradução de Os lusíadas). (CAMPBELL, 1819, pp. 110-111; DAVENPORT, 1822, pp. 22-23; IRELAND, 1794, pp. xxxviii-xxxix; SIM, 1806, p. xl-xliii; TAYLOR, 1937, pp. 18-20).

Apesar do desprezo do patrono escolhido, a tradução vendeu muito bem: a primeira edição, de mil exemplares, esgotou-se rapidamente, e uma segunda, com o acréscimo de mais um ensaio e uma gravura especialmente criada pelo pintor John Hamilton Mortimer, seguiu-se dois anos depois, em 1778. Os lucros das duas edições somadas chegaram a quase mil libras ${ }^{5}$ - uma soma considerável, mas insuficiente para que Mickle pudesse pagar todas as dívidas que contraíra com a falência da cervejaria.

Em 1779, em resposta a um livro, mais tarde atribuído a James Macpherson, detalhando os males advindos da Companhia das Índias Orientais, The history and management of the East-India Company, Mickle lançou um panfleto intitulado A candid examination of the reasons for depriving the East-India Company of its charter, contained in "The history and management of the East-India Company, from its commencement to the present time", uma

\footnotetext{
${ }^{5}$ Equivalentes a cerca de 120 mil libras em 2014.
} 
ampliação do ensaio em defesa da Companhia das Índias Orientais que publicara na Introdução a Os lusíadas.

Na primavera de 1779, o ex-governador da Flórida Ocidental, George Johnstone, primo e benfeitor de Mickle, ao ser nomeado comodoro e designado para comandar uma missão em Portugal, indicou Mickle como seu secretário. A bordo do navio de guerra Romney, em novembro daquele ano, Mickle chegou a Lisboa, onde foi recebido por D. João de Bragança, Duque de Lafões, que o aguardava no cais, ansioso para ser o primeiro a lhe dar as boas-vindas. Mickle foi acolhido com honras pela nobreza e intelectualidade lisboetas e, em maio de 1780, nomeado membro da recém-inaugurada Academia Real de Lisboa. Passou cerca de oito meses em Lisboa, onde compôs o poema "Almada Hill, an Epistle from Lisbon", considerado pelo autor como uma espécie de suplemento à sua tradução de Os lusíadas e publicado em $1781 .^{6}$

No final de 1780, voltou à Inglaterra a bordo do Brilliant, agora como tesoureiro do navio. Ao chegar, foi nomeado representante na alienação de bens de navios inimigos apreendidos durante a viagem e recebeu uma soma elevada correspondente à parcela que lhe cabia nesses bens. ${ }^{7}$ Finalmente, Mickle conseguiu saldar todas as suas dívidas.

Em junho de 1781, Mickle se casou com Mary Tomkins, filha do fazendeiro Robert Tomkins, em cuja casa se hospedara durante os anos em que traduzira Os lusíadas. Estabeleceram-se em Wheatley, perto de Oxford. O casal teve apenas um filho, que veio a trabalhar na East India House, o escritório da Companhia das Índias Orientais em Londres.

Mickle contribuiu anonimamente para a coleção de dois volumes do livreiro Thomas Evans, Old Ballads, historical and narrative, with some of Modern Date, publicada em 1777 e republicada em quatro volumes em 1784. Essa coletânea seguia o estilo daquela organizada pelo bispo Thomas Percy (já mencionada no Capítulo 3, em 3.2.5). São de Mickle a balada "Hengist and Mey", publicada no volume 2 da primeira edição (1777) e "The Prophecy of Queen Emma”, incluída no volume 3 da segunda edição (1784). Outras 17 baladas do volume 4 da edição de 1784 são atribuídas a Mickle, entre as quais “Cumnor Hall”, que tanto fascinou

\footnotetext{
${ }^{6}$ Ver análise do poema "Almada Hill” no Apêndice A.

7 O Scots Magazine cita uma carta do Comodoro Johnstone ao almirantado relatando a captura da fragata francesa La Perle, com 18 canhões e 138 tripulantes, e do Artois, uma imponente fragata, nova e bem maior do que o Romney, com 40 canhões e 460 tripulantes. A seguir, citando a Gazette de Londres, a mesma revista lista todos os navios capturados pela esquadra de Johnstone: La Perle, com 18 canhões e 138 homens, o $N$. S. Alephondria de Capaglia e um navio pirata espanhol de 18 canhões, pelo Romney; um paquete francês e um navio pesqueiro norte-americano, pelo Cerberus, e uma corveta francesa, carregada de açúcar, pelo Brilliant. (AFFAIRS..., 1780, pp. 443-444).
} 
Walter Scott - assunto sobre o qual falaremos um pouco mais na subseção 4.3. (TAYLOR, 1937, pp. 115-133).

Nos últimos anos de sua vida, Mickle escreveu uma série de ensaios e resenhas de livros para o periódico The European Magazine, em uma coluna intitulada "Fragments by Leo".

Faleceu aos 54 anos, em Forest Hill, no dia 25 outubro de $1788^{8}$, após uma breve doença quando em visita ao sogro.

\subsection{OUTRAS TRADUÇÕES DE MICKLE}

A única tradução de fôlego empreendida por Mickle foi o Lusiad. Suas outras traduções foram poucas, curtas e sem importância - são raramente comentadas por seus biógrafos ou estudiosos de sua obra. Até a autora do livro mais detalhado sobre a obra de Mickle, Eustace Taylor (1937, p. 169, nota 85), limita-se a listá-las em nota de rodapé e a comentar que "suas outras traduções são insignificantes" ". Essas quatro traduções estão incluídas no volume dedicado a Mickle da coleção The British Poets, including translations (1822, pp. 189-194):

1) Um salmo ("Psalm LXVIII"), em tradução datada de 1775 , não se sabe se traduzido diretamente do hebraico ou parafraseado a partir de outras traduções (FAIRCHILD, 1942, p. 276; LATHAM, 1846, p. 36). Assim como em sua tradução de Os lusíadas, Mickle amplifica alguns trechos e abrevia outros (principalmente as descrições mais violentas). De maneira sintética, poderíamos dizer que é uma paráfrase que cristianiza e atualiza o texto do Antigo Testamento.

2) O Soneto VII do Cancioneiro de Petrarca, em que o poeta expressa o seu desencanto com uma geração que, entregue ao luxo e aos prazeres, despreza a filosofia. Mickle personaliza e sentimentaliza o soneto acrescentando exclamações (“Ah!”); muitos adjetivos ("bloated", "dull”, "blessed", "hallow'd”, “sordid”, "lofty", “fair”); um vocativo inexistente no original para se dirigir a um amigo ("my friend") e, ao final, uma menção a Deus que também não está no original ("and win the smile of God").

3) O soneto de Torquato Tasso incluído no Lusiad (que será comentado na subseção 4.7.5, quando falarmos sobre os peritextos escritos por Mickle para a tradução).

\footnotetext{
${ }^{8}$ Segundo a maioria dos biógrafos: Cary (1822, p. 562); Davenport (1822, p. 511); Reed (1789, p. 320) e Sim (1809, p. liii). Outras datas citadas: Taylor (1937, p. 38) registra 15 de outubro de 1788, embora na p. 43, nota 121, mencione o epitáfio com a data de 25 de outubro de 1788; Chalmers (1815, p. 128) e Bayne (1894, p. 336), 28 de outubro de 1788; Anderson (1795, p. 634) e Ireland (1794, p. 1), 25 de outubro de 1789 (esta última está evidentemente incorreta, pois The Gentleman's Magazine publicou o obituário de Mickle em seu número de novembro/dezembro de 1788).

9 "His other translations are negligible".
} 
4) Um epitalâmio, de autoria de Abram Depas, traduzido do hebraico para uma família de origem portuguesa residente em Londres. Essa tradução provavelmente foi encomendada a Mickle devido ao prestígio que ele obtivera junto à colônia portuguesa por sua tradução de $O s$ lusíadas. Trata-se de uma raridade na época: Hoxie Neale Fairchild (1942, p. 276) observa que não conhece nenhuma outra tradução de poesia hebraica dessa época para o inglês. Como nenhum dos biógrafos comenta que Mickle conhecesse a língua hebraica, é possível que ele tenha apenas versificado alguma tradução literal que lhe tenha sido entregue.

\subsection{ELEMENTOS PRÉ-ROMÂNTICOS NA OBRA POÉTICA DE MICKLE}

Nos séculos XVIII e XIX foram lançadas várias coletâneas de poemas de Mickle. A primeira veio à luz em Londres em 1794, organizada por John Ireland, com o título Poems, and a tragedy. Em 1795 foi publicado em Edimburgo, na coleção The Works of the British Poets, organizada por Robert Anderson, o volume 11, contendo a parte dedicada a Mickle, The poetical works of William Julius Mickle. Em 1807, o reverendo John Sim, amigo de Mickle, lançou em Londres uma edição corrigida de seus poemas, The poetical works of William Julius Mickle. Em 1810, os poemas de Mickle foram novamente publicados em Londres, no volume XVII da coleção de Alexander Chalmers, Works of the English Poets, from Chaucer to Cowper, com o título The poems of William Julius Mickle. Em 1822, foi lançado, na coleção The British Poets, including translations, da Chiswick Press, o volume LXVI, The poems of Mickle, and Smollett.

As primeiras experiências de Mickle em poesia foram com versos no estilo de Thomson e Gray - versos brancos ou estrofes elegíacas. Depois se dedicou à estrofe spenseriana (estrofes de nove versos, oito versos em pentâmetro iâmbico seguidos por um alexandrino em hexâmetro iâmbico, e rimas no padrão $a b a b b c b c c$ ). Em toda a sua obra poética, Mickle utilizou muito pouco a medida da moda, o dístico heroico. Ele o fez apenas na tradução de $O s$ lusíadas e em "Almada Hill”. Mesmo assim, não o utilizou de modo ortodoxo: a métrica e a rima seguiam o padrão tradicional, mas o pensamento nem sempre se completava no dístico. Mickle recorria, com parcimônia, ao enjambement para acrescentar efeitos dramáticos e fugir à monotonia do dístico heroico no estilo de Pope. Nesse aspecto, aliás, Earl Wasserman (1940, p. 243) louva essa tradução como um “oásis no deserto dos dísticos fechados escritos antes da década de $1780 " 10$. A grande variação de formas poéticas utilizada por Mickle mostra

\footnotetext{
10 "oasis in the desert of closed couplets before the " $80 \mathrm{~s}$ ".
} 
a tentativa de adequar a forma ao assunto do poema. Taylor $(1937$, p. 46) vê nessa variação a busca de novas formas, uma característica que faz de Mickle um dos precursores da relativa liberdade métrica que irá marcar o século seguinte.

Não é nossa intenção analisar em detalhe cada poema de Mickle. Apenas gostaríamos de mostrar alguns exemplos que comprovam as suas tendências pré-românticas, tanto pelo estilo das descrições da natureza, quanto pela presença de elementos "góticos".

"Providence" (1762), o primeiro poema publicado por Mickle em Londres, narra a história de Emilec, um pastor à procura de sua amada Caia, que fora raptada. Os últimos versos do poema exibem claros elementos góticos:

[...] the ravens sat

On the old land-mark stones, and drank the blood

Of chiefs and rulers; and when pale the moon

Glimps'd o'er the field, the scene new horrors gain'd:

The winds loud whistling rise, and to the hills

Bear far the hollow groans; - Nature seems mov'd -

And distant echoes groan for groan return.

All the dread night, troops of pale murm'ring ghosts

Glide thro' the moonshine, to their last abode. ${ }^{11}$

(MICKLE, 1762, p. 279).

A elegia "Night-Piece" mostra a influência não apenas de Gray, cuja "Elegy Written in a Country Churchyard" era extremamente popular na época, como de Young, Blair e Parnell todos poetas da chamada Graveyard School, sobre os quais falamos no Capítulo 3 (3.2.5). Taylor (1937, p. 53) aponta várias coincidências entre a "Night-Piece" de Parnell e a de Mickle: as duas elegias mostram o poeta caminhando pelo cemitério à noite, refletindo sobre a fugacidade da fama, e terminam com a menção à recompensa que aguarda aqueles que levam uma vida virtuosa. A maior diferença entre o poema de Mickle e os de Parnell e Gray é que o cemitério de Mickle é urbano, em vez de campestre. Mickle utiliza vários detalhes da elegia de Gray - o dia está chegando ao fim, a calma se instala na cidade, toda a atividade cessa. O poema é um lamento sobre o saber que se extingue com a morte.

\footnotetext{
11 “[...] os corvos pousaram

Sobre os velhos marcos de pedra, e beberam o sangue

De governantes e líderes, e quando a lua pálida

Espiou sobre o campo, o cenário ganhou novos horrores:

Os ventos se erguem soprando ruidosos, e para as colinas

Longínquas carregam os gemidos ocos; - A natureza parece comovida -

E ecos distantes devolvem gemido por gemido.

Toda a noite terrível, bandos de fantasmas pálidos murmurantes

Deslizam pelo luar, até sua última morada."
} 
A elegia "Pollio", composta por ocasião da morte do irmão George, descreve, em tom meditativo, as ruínas de um castelo, os túmulos, a capela e o velho bosque onde Mickle e o irmão costumavam passear na infância. Eric Partridge (2010, p. 137) observa que, nesse poema, a natureza se mescla ao tema pessoal, de triunfo do poeta sobre a dor. Partridge vê semelhanças com a "Ode to Evening" de Collins e a "Elegy" de Gray. A descrição das "torrinhas se esfacelando" [crumbling turrets] cercadas pela sombra dos pinheiros reproduz os clichês do gênero, sem faltar o toque medieval: "Wild round the gates the dusky wallflowers creep, / Where oft the knights the beauteous dames have led" (MICKLE, 1822, p. 41). ${ }^{12}$

Em suas três odes, Mickle segue a tradição neoclássica no tom moral, didático e formal, mas o tema de "May Day", uma celebração druídica do dia da criação, evoca o interesse pelo passado mitológico que será uma das marcas do romantismo e que já se evidencia no final do século XVIII na Grã-Bretanha. A valorização da natureza nas três odes também foge ao estilo neoclássico. O início de "May Day” ilustra bem a forma como Mickle (1822, p. 97) incorpora a natureza à narração:

"Awake, my sons, the milky dawn

Steals softly gleaming o'er the eastern lawn:

Already from their oaken bowers,

Scattering magic herbs and flowers

That scent the morning gale,

With white and purple blossoms crown'd,

From every hill and dell around,

The Druids hasten to the sacred vale."13

Nessa mesma ode (p. 101), os detalhes referentes às flores dão um colorido especial e uma qualidade visual muito vívida à descrição:

\footnotetext{
12 "Os goivos sombrios escalam, indomáveis, os portões / onde muitas vezes os cavaleiros levavam as belas damas".

13 "Acordem, meus filhos, o branco amanhecer

Infiltra-se suavemente brilhando sobre o gramado ao leste:

Já de seus bosques de carvalho,

Espalhando ervas e flores mágicas

Que recendem à ventania matinal,

Coroados com flores brancas e roxas,

De todas as colinas e valeiras ao redor,

Os Druidas lançam-se ao vale sagrado."
} 
For you the blossom'd boughs embower

The craggy glittering steep,

Along whose rifts the cowslips creep,

And dashing fountains pour;

For you the sweetbriar clothes the bank,

For you, along the bordering mead,

The white and yellow flowers, that love the dark,

Their watery carpets spread. ${ }^{14}$

Nas baladas, Mickle segue a moda pré-romântica lançada pelas Reliques (1765) do bispo Percy. Para Eric Partridge (2010, p. 215) "Hengist and Mey", uma balada com todos os ingredientes das novelas de cavalaria, prova que Mickle já havia assimilado os elementos mais superficiais da balada medievalista no estilo de Percy. Em "The Sorceress, or Wolfwold and Ulla" (poema incluído por M. G. Lewis na coletânea de baladas góticas de horror, Tales of Wonder, lançada em 1801) Mickle conta a história de Ulla, filha do rei da Nortúmbria, que vai à gruta de uma feiticeira para saber do destino de seu amado, Lord Wolfwold, que partiu para defender o reino do pai dela do ataque dos dinamarqueses. A descrição da bruxa é um bom exemplo do uso do estranho e do macabro:

A wrinkled hag came forth, array'd

In matted rags obscene.

Around her brows, with hemloc bound, Loose hung her ash-grey hair; As from two dreary caves profound Her blue-flam'd eye-balls glare.

Her skin, of earthy red, appear'd Clung round her shoulder bones; Like wither'd bark, by lightning sear'd When loud the tempest groans.

A robe of squalid green and blue, Her ghostly length array'd, A gaping rent, full to the view Her furrow'd ribs betray'd. ${ }^{15}$ (MICKLE, 1810, p. 530).

\footnotetext{
14 "Por vós os ramos floridos cobrem

O declive escarpado reluzente,

Formando fendas por onde as prímulas se insinuam,

E impetuosas fontes jorram;

Por vós a roseira-brava veste a margem,

Por vós, junto à campina ao redor,

As flores brancas e amarelas, que amam o escuro,

Espalham seus tapetes úmidos."

15 "Uma bruxa enrugada se adiantou, vestida

Em trapos foscos indecentes.
} 
O caráter pré-romântico se evidencia com mais nitidez ainda na série de 17 baladas atribuídas a Mickle que foram publicadas no quarto volume da edição de 1784 das Old Ballads de Evans. Escritas originalmente em uma ortografia que tentava reproduzir o inglês antigo, essas baladas distinguem-se pela beleza das descrições, pelo conhecimento histórico e por uma forma simples e comovente de expressão dos sentimentos. ${ }^{16}$ Entre elas, destaca-se "Cumnor Hall”, cuja melodia cativou Sir Walter Scott. No prefácio a Kenilworth (1821), Scott admitiu ter vindo dessa balada de Mickle a inspiração para esse romance histórico. No mesmo espírito da maioria das baladas de Percy, o clima é de medo e superstição, e o cenário é um local assombrado. Na parte final, na atmosfera lúgubre de Cumnor Hall, há vários elementos góticos: um sino, um corvo, um cachorro que uiva, uma voz etérea, a repetição tripla que é comum na mística medieval:

The death-bell thrice was heard to ring,

An aerial voice was heard to call,

And thrice the raven flapp'd its wing

Around the towers of Cumnor Hall.

The mastiff howled at village door,

The oaks were shattered on the green;

Woe was the hour, for nevermore

That hapless Countess e'er was seen. ${ }^{17}$

(MICKLE, 1822, p. 89).

Ao redor da fronte, amarrados com cicuta,

Pendiam seus cabelos cinzentos;

Enquanto de duas sombrias cavernas profundas

Fulguravam os flamejantes globos oculares azuis.

A pele, de um vermelho terroso, parecia

Grudada à omoplata,

Como cortiça ressecada, queimada pelos raios

Quando a ruidosa tempestade geme.

Um manto de verde e azul imundos,

Seu corpo fantasmagórico trajava,

Um rasgo escancarado, bem à vista

Deixava entrever-lhe as costelas estriadas."

${ }^{16}$ Para mais detalhes sobre as discussões a respeito da autoria dessas baladas, ver Taylor (1937, pp. 115-133) e West (1934a, pp. 274-281).

17 “Ouviu-se tocar três vezes o dobre fúnebre,

Ouviu-se uma voz etérea chamar,

E três vezes o corvo bateu as asas

Ao redor das torres de Cumnor Hall.

O mastim uivou às portas da vila,

Os carvalhos se estilhaçaram sobre a grama;

Triste hora, pois nunca mais

Aquela infeliz Condessa foi vista." 
Nas estrofes finais, que falam do assassinato da protagonista, Amy Robsart, condessa de Leicester, a repetição do nome "Cumnor Hall" funciona como um bordão fúnebre - como Edgar Alan Poe fará, vários anos mais tarde, com o bordão "nevermore" em "The Raven" (1845): "In Cumnor Hall, so lone and drear" (em duas estrofes sucessivas); "Around the towers of Cumnor Hall"; "Have spirits haunted Cumnor Hall"; "Among the groves of Cumnor Hall"; e "The haunted towers of Cumnor Hall"18.

O poema "Sir Martyn", publicado pela primeira vez em 1767 com o título "The Concubine, or The Progress of Dissipation", imita o estilo de Spenser. Mickle não foi o único imitador de Spenser no século XVIII, mas foi o mais prolífico (TAYLOR, 1937, pp. 95). Nesse poema, Mickle combina a alegoria com uma visão pré-romântica da natureza. Citaremos aqui apenas um exemplo retirado do poema:

Soothd by the murmurs of a plaintive streame,

A wyld romantick dell its fragrance shed;

Safe from the thonder showre and scorching beame

Their faerie charmes the summer bowres displaid;

Wyld by the bancks the bashfull cowslips spread,

And from the rock above each ivied seat

The spotted foxgloves hung the purple head,

And lowlie vilets kist the wanderers feet:

Sure never Hyblas bees rovd through a wilde so sweet. ${ }^{19}$

(MICKLE, 1777, p. 40).

O uso do termo "romantick" no segundo verso ("a wyld romantick dell") merece comentário. Eric Partridge (2010, pp. 254-258) faz um breve estudo do uso do adjetivo "romantic" na Grã-Bretanha do século XVIII e registra a progressiva ampliação de sentidos veiculados pela palavra, desde o simples "novelesco" (que tem a qualidade de novela ou encontrado em novelas) ou "romanesco", passando pelos sentidos de "fictício", "imaginário" e "extravagante" até chegar a "belo", "imaginativo", "idealista" e outros sentidos mais

\footnotetext{
18 "Em Cumnor Hall, tão solitário e sombrio"; "Ao redor das torres de Cumnor Hall"; "Espíritos assombraram Cumnor Hall"; "Entre os bosques de Cumnor Hall" e "As torres mal-assombradas de Cumnor Hall".

19 "Acalmado pelos murmúrios de um regato plangente,

Um agreste vale romântico espargia sua fragrância;

A salvo do temporal e do raio abrasador

Encantos fascinantes os caramanchões estivais revelavam;

Livres pelas margens as tímidas prímulas se espalhavam,

E do rochedo sobre cada assento coberto de hera

Pendiam os buquês roxos das dedaleiras,

E humildes violetas beijavam os pés dos caminhantes:

Com certeza jamais as abelhas de Hibla vagaram por uma floresta tão doce.”
} 
próximos daqueles que a palavra irá adquirir no século XIX ${ }^{20}$ Mickle é incluído por Partridge entre os poetas que utilizaram o adjetivo com outros sentidos além daquele que meramente refere às novelas de cavalaria. É o caso do exemplo aqui citado, em que "romantick" parece ter o significado de "belo", "pitoresco".

Hugh Walker (1893, p. 114) inclui Mickle entre os escritores escoceses - como Falconer, Beattie, Macpherson, Logan e Bruce - ligados, de uma forma ou de outra, ao romantismo e a um "tatear às cegas em busca de algo mais espiritualmente substancial do que dísticos à maneira de Pope"21. Sobre Mickle, Walker (pp. 119-120) afirma:

Seu estilo de balada é, com efeito, muito distante daquele dos velhos menestréis, e muitas vezes é levemente retórico; mas sua fluência lírica suave ilustra o surgimento de um gosto diferente daquele da escola clássica. Algumas das elegias também demonstram muita elegância de imaginação e melodia poética. Nelas a influência de Gray é evidente. ${ }^{22}$

Em sua meticulosa análise da obra poética de Mickle, Taylor (1937, p. 104) conclui que ele era um escritor em transição entre o Neoclassicismo e o Romantismo, com uma maior tendência para o Romantismo. Mickle seria pré-romântico, sobretudo em cinco aspectos: 1) Como imitador de Spenser em termos de dicção, alegoria e estilo de descrição; 2) como escritor que expressava o amor pela natureza e um verdadeiro conhecimento de suas manifestações; 3) como baladista que utilizava o estilo gótico e temas medievais; 4) como escritor que usava o sentimento, a imaginação e a fantasia para dar vida aos seus temas morais e patrióticos e 5) como experimentador, pela variedade de métricas e a tendência a formar novas palavras e novas combinações de palavras. ${ }^{23}$

\footnotetext{
${ }^{20}$ O Dictionarium Britannicum de Bailey, em sua segunda edição (1736), registra apenas o significado de "of, or pertaining to, or that favours of a romance" ["de, ou relativo a, ou que favorece uma novela"] para "romantick". Já o Dictionary de Johnson, de 1755, indica três significados para "romantick": "1. resembling the tales of romances; wild. 2. Improbable; false. 3. Fanciful; full of wild scenery." ["1. semelhante às histórias de novelas; extravagante. 2. Improvável; falso. 3. Fantástico; cheio de cenários extravagantes."]

21 "blind groping after something more spiritually nourishing than couplets in the manner of Pope".

22 "His ballad style is indeed far removed from that of the old minstrels, and it is often weakly rhetorical; but its smooth lyric flow illustrates the rise of a taste different from that of the classical school. Some of the elegies also show much grace of fancy and melody of verse. The influence of Gray is conspicuous in them."

${ }^{23}$ Taylor (1937, p. 111) cita um estudo de Thomas Quayle em que este aponta a tendência de Mickle à criação de epítetos a partir de adjetivos compostos, como "thyme-clad mountains" (montanhas cobertas de tomilhos), "daisie-whitened plain" (campina branqueada pelas margaridas), "storm-beaten ocean" (oceano açoitado pela tempestade).
} 


\subsection{MODO DE INSERÇÃO DE MICKLE NO SISTEMA LITERÁRIO}

Uma tradução só se constitui em relação às normas e convenções do ambiente em que surge. Daí a importância de se estudar o modo de inserção do autor no sistema literário, ou seja, a maneira específica como o escritor se relaciona com o sistema literário de sua época. É o que faremos a seguir.

\subsubsection{Um escocês em Londres e Oxford}

O primeiro aspecto para o qual gostaríamos de chamar atenção na biografia de Mickle é o fato de ele ter trocado seu nome ao se mudar para Londres. Richard B. Sher (2006, pp. 7273) menciona uma carta de Mickle a Boswell, que também era escocês, em que Mickle admite ter alterado o sobrenome de Meikle para Mickle "para se adaptar à fonética inglesa"24. A inclusão do segundo nome, "Julius" (ainda que possivelmente em homenagem à mãe, Julia), reproduz as pretensões "augustanas" da Inglaterra da época. Sher (p. 73) também cita uma carta escrita em 1775 por Mickle para William Creech, o famoso livreiro e editor-chefe da Edinburgh Magazine and Review, recomendando-lhe que, quando recebesse a tradução de $O s$ lusíadas, não mencionasse que o autor era escocês. Ou seja, para fugir ao preconceito dos ingleses, Mickle se esforçou ao máximo para ocultar a sua origem escocesa.

Não foi, de forma alguma, o único a fazê-lo. Na segunda metade do século XVIII, Londres estava repleta de escoceses em busca do sucesso no mundo literário, e muitos deles ocultavam suas origens. Malloch alterou o sobrenome para Mallet; o ilustre tipógrafo Strachan, para Strahan. O tenente da marinha John MacMurray, ao abrir uma livraria na Fleet Street, abreviou o sobrenome para Murray, e John Macmillan, editor de Thomson, para Millan. (GRAHAM, 1983, p. 273). David Hume, mesmo não ocultando suas origens, também trocou o sobrenome (era Home) e pedia aos revisores que eliminassem os escocesismos de seus textos (SHER, 2006, p. 52).

Outros escoceses adotaram a atitude oposta: proclamaram altivamente suas origens e declararam-se parte de um grande centro de literatura e aprendizado como era, de fato, a Escócia da segunda metade do século XVIII, com o florescimento do Iluminismo Escocês. Seja como for, assumindo ou não suas origens, os escoceses publicaram, nessa época, centenas de livros nos mais variados assuntos, em uma verdadeira avalanche literária.

\footnotetext{
24 "in order to conform to English phonetics".
} 


\subsubsection{Patronagem}

Outra questão que se destaca ao lermos a biografia de Mickle é a importância da patronagem (ou patronato, ou mecenato). De acordo com André Lefevere (1992, pp. 14-15), há dois fatores de controle sobre o sistema literário. O primeiro é interno, constituído pelos profissionais (críticos, resenhistas, professores, tradutores), que tendem a incentivar apenas as obras que sigam os padrões aceitos no sistema literário, desestimulando as demais, e às vezes reescrevendo as obras para adaptá-las a esses padrões. O segundo fator de controle é externo, formado pelos patronos, ou seja, "os poderes (pessoas, instituições) capazes de promover ou dificultar a leitura, escrita e reescrita da literatura" ${ }^{25}$. Na definição de Lefevere, a patronagem pode ser exercida por pessoas (mecenas como os Médici) ou grupos (religiosos, políticos, editoras, a imprensa etc.). A patronagem tenta regular a relação entre o sistema literário e os outros sistemas que compõem a cultura e a sociedade, e consiste basicamente em três elementos: ideológico (no sentido amplo, de uma rede de convenções e crenças que orienta nossas ações), econômico (o patrono contribui de alguma forma para o sustento do protegido) e de status (a patronagem pode implicar a integração em um grupo e a adoção de seu estilo de vida).

Todos os aspectos desse sistema são claramente visíveis na biografia de Mickle. Na época em que Mickle se mudou para Londres, em 1763, a patronagem era o caminho "natural" para um escritor ser bem-sucedido no sistema literário. Todo o seu esforço em obter auxílio de Lord Lyttelton se inscreve nesse cenário. Na verdade - e aí talvez esteja uma falha do esquema de Lefevere, por não considerar a possibilidade de sobreposições - Lyttelton exercia, de certa forma, controle tanto interno quanto externo sobre o sistema literário, pois não atuava apenas como patrono (controle externo), mas também como mentor literário (controle interno), aconselhando seus patrocinados sobre como aperfeiçoar seus textos ou poemas e até mesmo revisando-os. Apesar de Lyttelton não ter chegado a patrocinar nenhum trabalho de Mickle, a influência exercida pelo mentor em termos poéticos é percebida por alguns estudiosos. Segundo Taylor (1937, p. 14), sob a influência de Lyttelton, a poesia de Mickle se tornou menos didática. Mickle passou a tratar os temas mais polêmicos na forma de prosa (os diversos panfletos sobre assuntos religiosos e políticos lançados por ele) e, apesar de continuar abordando temas históricos e religiosos em seus poemas, deu-lhes uma dicção mais nitidamente poética.

\footnotetext{
25 “the powers (persons, institutions) that can further or hinder the reading, writing, and rewriting of literature".
} 
Quanto à patronagem de Lyttelton, envolvia elementos ideológicos (recusou-se a revisar um poema de Mickle em homenagem a Mary Stuart, porque a considerava uma criminosa ${ }^{26}$ ), econômicos (benefícios dos quais Mickle, para seu pesar, não desfrutou) e de status (mesmo não tendo efetivamente o patrocínio de Lyttelton, Mickle com certeza se aproveitou do status que lhe dava o fato de ter o nobre como mentor literário, e provavelmente se aproximou de outros componentes do círculo de Lyttelton).

A duras penas, Mickle conseguiu publicar alguns poemas por conta própria, mesmo sem apoio financeiro de patronos, e obteve alguma repercussão, embora não o suficiente para lhe garantir a sobrevivência. A tradução de Os lusíadas, uma obra de grande fôlego, exigiria um plano mais complexo. Mickle resolveu recorrer a uma lista de assinaturas, um procedimento que se tornara comum na primeira metade do século, como já comentamos no Capítulo 3 lembremos que Pope ganhou muito dinheiro com as traduções de Homero exatamente por meio desse tipo de lista. Na ampla definição de Lefevere (1992), a publicação por meio de listas de assinantes continua sendo patronagem, pois permanece a influência exercida por pessoas ou instituições sobre o sistema literário (e sobre o tradutor).

É interessante comentarmos os passos seguidos por Mickle para a publicação de sua tradução, já que eles reproduzem alguns dos procedimentos que ainda hoje adotamos para obter patrocínio. A primeira providência de Mickle foi mandar publicar uma nota no periódico The Gentleman's Magazine anunciando a intenção de traduzir a obra e incluindo a tradução de parte do episódio do Gigante Adamastor (Canto V). Diante da boa recepção a essa tradução, Mickle, tendo concluído a tradução do Canto I, mandou imprimi-la em Oxford e, anexando ao pequeno livro um projeto de tradução, vendeu-o por um shilling como amostra da qualidade de seu trabalho, a fim de angariar assinaturas para a tradução completa da obra. Mickle cumpria, assim, funções que ainda hoje precisam ser executadas por aqueles que desejam obter patrocínio para um projeto: descrevia o projeto, justificava a sua importância, declarava seus objetivos e fornecia uma amostra de sua execução. O livrinho ostentava, no frontispício, a citação de Horácio, "Nec verbum verbo curabis reddere fidus Interpres", que será reproduzida na primeira edição da tradução completa. Na breve introdução (duas páginas), Mickle (1771) resumia o tema de Os lusíadas (“a descoberta das Índias Orientais pelos portugueses sob o comando de Vasco da Gama" ${ }^{27}$ ); fazia a defesa da relevância do tema - incluindo uma citação de versos do poema "Summer" [Verão], de James Thomson, em que

\footnotetext{
${ }^{26}$ Em carta reproduzida por Ireland (1794, p. xxi), Lyttelton escreve a Mickle: "Poetry should not consecrate what history must condemn". ["A poesia não deve consagrar aquilo que a história deve condenar."]

27 "[...] the discovery of the East Indies, by the Portuguese under the conduct of Vasco da Gama".
} 
Vasco da Gama e D. Henrique são mencionados; criticava a tradução anterior, de Fanshawe, considerada literal demais; e encerrava com o apelo:

Nos tempos atuais, quando nossa língua foi enriquecida por elegantes traduções de quase todos os escritores célebres, Os lusíadas de Camões, mesmo sendo a única epopeia do continente que merece ser mencionada ao lado da Jerusalém de Tasso, têm sido negligenciados até agora. Apresentálos ao leitor inglês não será, presume-se, inaceitável. ${ }^{28}$

O projeto de tradução prometia a seus assinantes:

I. Um trabalho "elegantemente impresso" 29 em formato in-quarto, em papel de boa qualidade, com notas históricas etc.

II. Biografia de Camões, contendo "mais acontecimentos e reviravoltas do destino, talvez, do que a vida de qualquer outro Herói da literatura" ${ }^{, 30}$.

III. As biografias do infante D. Henrique e de Vasco da Gama.

IV. Preço de 12 shillings $^{31}$, metade a serem pagos na assinatura; metade na entrega do livro, que deveria ficar pronto em 1772. O nome dos assinantes seria publicado no início do livro.

Era fornecida uma lista de locais onde as assinaturas seriam coletadas, junto com os responsáveis pela coleta: nove locais em Londres, três responsáveis pela coleta em Oxford, dois em Cambridge, e um livreiro em Edimburgo.

Depois dessa lista, Mickle, demonstrando a sua vocação de polemista e também já se defendendo de possíveis críticas ao poema que escolhera para traduzir, publicava uma nota [advertisement] de 11 páginas a respeito das críticas de Voltaire a Os lusíadas. Como esse texto é uma versão inicial e menor do ensaio que Mickle publicou na Introdução à tradução do poema completo, que será devidamente analisado em uma próxima subseção, não o comentaremos aqui.

Em seguida vinha o poema de Tasso em homenagem a Camões, em italiano, e a sua tradução por Mickle. (Esse poema e a sua tradução serão também comentados em uma

\footnotetext{
28 "In the present age, when our language is enriched with elegant translations of almost every other celebrated writer, the Lusiad of Camoens, though the only Epic Poem of the continent which deserves to be mentioned with the Jerusalem of Tasso, has been hitherto neglected. To introduce it to the English reader, will not, it is presumed, be unacceptable."

29 "elegantly printed"

30 "more circumstances and diversities of fortune, than the life, perhaps, of any other literary Hero"

${ }^{31}$ Equivalentes a cerca de 75 libras em 2014.
} 
próxima subseção.) E então, finalmente, iniciava-se a tradução do Canto I de Os lusíadas, ocupando 43 páginas. (CAMÕES, 1771). ${ }^{32}$

Quando todo o processo de tradução do poema e redação da longa introdução foi terminado, mais de quatro anos depois (contrariando a previsão exageradamente otimista de Mickle no projeto, de que levaria um ano), a lista de assinantes somava quase seiscentos nomes - incluindo várias pessoas influentes do mundo político, religioso ou cultural, como já comentamos na seção 4.1. Sem o auxílio de alguns desses patronos, como Robert Tomkins, que hospedou Mickle em sua casa em Forest Hill entre 1772 e 1775, e o Comodoro George Johnstone, que era primo de Mickle e sempre procurou ajudá-lo, a tradução d'Os lusíadas teria sido impossível. A influência da patronagem sobre essa tradução vai muito além, no entanto. Como observou George West (1934b, p. 388):

Mas precisamos sempre ter em mente que Mickle foi assistido, e generosamente assistido, por vários membros do círculo Johnsoniano, as faculdades de Oxford, a Companhia das Índias Orientais e a colônia portuguesa em Londres. Hoole, Boswell, Goldsmith e o próprio Johnson contribuíram para o trabalho de um jeito ou de outro. Crowe forneceu muitas das notas; Magalhães, documentos oficiais e informações referentes à história de Portugal. In toto, o Lusiad de Mickle foi a síntese inconsciente de toda uma geração tanto quanto a tese erudita de um indivíduo. ${ }^{33}$

Um ponto importante a se observar é que, em sua longa introdução à tradução, Mickle faz a defesa do trabalho realizado pela Companhia das Índias Orientais. ${ }^{34} \mathrm{O}$ Comodoro Johnstone, benfeitor de Mickle, participava ativamente dos debates sobre as políticas da Companhia das Índias Orientais, da qual chegou a ser diretor. No final da Introdução à tradução, Mickle (1776, p. cliii) agradece aos patrocinadores e assinantes e menciona com especial destaque os "cavalheiros da Companhia das Índias Orientais":

Aos cavalheiros da Companhia das Índias Orientais que são seus assinantes, o tradutor oferece seu especial agradecimento; e com prazer ele lhes

\footnotetext{
${ }^{32}$ Todos esses materiais em preparação à publicação são, pela definição de Gérard Genette, epitextos. Falaremos sobre paratextos, peritextos e epitextos na seção 4.6.

33 "But we must always bear in mind that Mickle was assisted, and liberally assisted, by various members of the Johnsonian circle, the Oxford Colleges, the East India Company, and the Portuguese colony in London. Hoole, Boswell, Goldsmith, and even Johnson himself, contributed to the work in one way or another. Crowe supplied many of the notes, Magellan state-papers and information relating to Portuguese history. In toto, Mickle's Lusiad was as much the unconscious synthesis of a whole generation as the erudite thesis of one individual."

${ }^{34}$ Como já dissemos em 4.1, em 1779 Mickle ampliou essa parte da introdução e publicou-a como uma obra em separado, com o título A candid examination of the reasons for depriving the East-India Company of its charter, contained in "The history and management of the East-India Company, from its commencement to the present time".
} 
assegura que o seu desejo de ver um poema épico, particularmente deles próprios, em inglês, o encorajou muito ao prosseguimento deste laborioso trabalho. ${ }^{35}$

Ao falar em "particularmente deles próprios" [particularly their own] Mickle provavelmente se refere ao assunto do poema, relacionado à conquista das Índias. De qualquer forma, essa expressão denota uma espécie de apropriação do poema de Camões executada por Mickle em nome da Companhia das Índias Orientais.

Mickle prossegue, agradecendo a outro cavalheiro da Companhia das Índias por ajudá-lo a "elucidar o seu autor":

Ao cavalheiro Thomas Pearson, da Companhia das Índias Orientais, ele deve a assistência de alguns historiadores portugueses e outros livros que lhe possibilitaram elucidar o seu autor. A esse cavalheiro ele deve também o agradecimento por uma numerosa lista de assinantes. ${ }^{36}$

Era costume dedicar a obra a algum patrono ou figura ilustre. A conselho de amigos, Mickle resolveu dedicar a tradução d'Os lusíadas ao Duque de Buccleugh. Como já relatamos na primeira seção deste capítulo, esse nobre nem sequer reconheceu a publicação.

A influência das relações de patronagem na obra de Mickle volta a merecer destaque após a tradução d'Os lusíadas, quando, em visita a Lisboa, entre 1779 e 1780, Mickle recebeu o apoio da nobreza de Portugal, em especial de D. João de Bragança, Duque de Lafões. Graças à boa acolhida da nobreza lusitana, Mickle tornou-se membro da Academia Real de Ciências de Lisboa (recém-fundada por D. João de Bragança) e compôs o poema "Almada Hill”, uma homenagem nostálgica à ajuda dos soldados do Duque de Gloucester a D. Afonso Henriques quando da tomada de Lisboa aos mouros. (MICKLE, 1781; TAYLOR, 1937, p. 36, p. 154).

Todos os exemplos mencionados acima mostram que as relações de patronagem estavam profundamente imbricadas na vida e na obra de Mickle. Os conselhos de um mentor literário (Lyttelton) ajudaram a moldar sua poesia; o sistema de publicação por assinatura colocou o Lusiad sob a nítida influência de vários patronos, inclusive a Companhia das Índias

\footnotetext{
35 "To the Gentlemen of the East India Company, who are his Subscribers, the Translator offers his singular thanks; and with pleasure he assures them, that their desire to see an Epic Poem, particularly their own, in English, greatly encouraged him in the prosecution of his laborious work." (Tradução nossa, propositalmente literal.)

36 "To Thomas Pearson, Esq; of the East India Company's Service, he owes the assistance of some Portuguese Historians and other books, which have enabled him to elucidate his author. To this Gentleman he also owes the acknowledgement for a numerous list of Subscribers."
} 
Orientais; a boa acolhida da nobreza lusitana rendeu prestígio a Mickle e talvez o tenha levado a compor "Almada Hill". Até mesmo a ajuda prestada a Mickle pelo Comodoro Johnstone ao nomeá-lo seu secretário na viagem a Lisboa pode ser relacionada indiretamente ao sistema literário, pois o fato de Mickle ter se tornado conhecido como o tradutor d'Os lusíadas pode ter contribuído para justificar sua nomeação para o cargo (pelo suposto conhecimento da língua e da história portuguesas e pelo prestígio de Mickle junto aos portugueses).

\subsection{MODO DE CIRCULAÇÃO DA OBRA}

Considerando que o estudo de uma obra não pode ser separado de seus modos de transmissão e de suas redes de comunicação, resolvemos abordar a questão do modo de circulação do Lusiad de Mickle nesta seção, após a discussão sobre o modo de inserção do tradutor no sistema literário e antes de iniciarmos a análise dos peritextos da obra.

Já foi comentado no Capítulo 3 que o século XVIII é, na Grã-Bretanha, um momento de transição para os literatos, que deixam de depender exclusivamente da aristocracia e passam à esfera da burguesia. O Lusiad de Mickle é publicado nesse novo ambiente, povoado de cafés literários onde se reúne um novo público, anônimo, leitor de periódicos e ávido por discutir as questões da atualidade. Periódicos como o Monthly Review (o primeiro periódico britânico dedicado a resenhas, lançado em 1749) e o Critical Review publicam resenhas, influindo na escolha do público. Como relata Richard B. Sher (2006, pp. 5-7), na segunda metade do século XVIII os editores ou livreiros (a palavra que se usava na época era bookseller, e não publisher) eram muito próximos dos autores, e os livros costumavam ser produzidos conjuntamente pelo livreiro e o autor. Além disso, muitos livreiros promoviam festas concorridas e faziam de suas livrarias verdadeiros pontos de encontro de escritores. (SHER, 2006, pp. 198-199).

A forma como a tradução de Mickle foi publicada, com o patrocínio de uma lista de assinantes, coloca os cafés literários no centro de sua produção e circulação. A importância dos periódicos em todo o processo também é evidente: antes de lançar a lista, em março de 1771, Mickle enviou um primeiro anúncio para o Gentleman's Magazine; quando foi lançado o livro-amostra contendo a tradução do Canto I, em julho de 1771, vários periódicos (Critical Review, Gentleman's Magazine, Monthly Review) anunciaram e comentaram; finalmente, depois que a tradução foi lançada, foram publicadas resenhas em vários periódicos (Critical 
Review, Gentleman's Magazine, London Magazine, Monthly Review, The Town and Country Magazine).

Uma carta de Boswell (1809, pp. 385-386) a Mickle datada de 26 de setembro de 1775 mostra como vários amigos de Mickle se envolveram na coleta de assinaturas para a tradução de Os lusíadas, e também a proximidade entre os escritores e os livreiros. Boswell comenta sobre a coleta de assinaturas em Edimburgo, mencionando que Mr. Creech (William Creech, livreiro e editor da Edinburgh Magazine and Review) perdeu a lista dele, mas, como esta continha poucos nomes, ele prometia conseguir o dobro das assinaturas que já haviam sido obtidas. Boswell diz que é até melhor que eles não houvessem ainda conseguido muitos nomes, pois concorda com o Dr. Johnson ou Hoole (não lembra exatamente qual dos dois) que o preço fixado por Mickle estava muito baixo e deveria ser aumentado. Boswell pergunta se Mickle quer a lista dos literatos escoceses que já assinaram e garante que o nome de David Hume está na lista de Mr. Creech.

$\mathrm{Na}$ folha de rosto da tradução está a indicação da gráfica ("Printed by Jackson and Lister") ${ }^{37}$ de Oxford - a maioria dos livros nessa época era impressa em Londres, mas, como Mickle vivera e trabalhara durante muitos anos em Oxford, deve ter sido mais vantajoso para ele mandar imprimir o livro lá - e dos editores/livreiros ("Sold by CADELL, in the Strand; DILLY, in the Poultry; BEW, Pater-noster-Row; FLEXNEY, Holborn; EVANS, near York-Buildings; RICHARDSON and URQUHART, under the Royal-Exchange; and GOODSMAN, near Charing-Cross, LONDON"). Havia, portanto, uma rede de livreiros distribuindo o livro. Cadell e Dilly estavam entre os livreiros de maior prestígio naquela época em Londres. Thomas Cadell foi o editor de muitos autores famosos, como Edward Gibbon, William Robertson, David Hume, William Blackstone, Adam Smith, Samuel Johnson e Tobias Smollett. Os irmãos Edward e Charles Dilly tinham uma casa na rua Poultry que se tornou ponto de encontro de políticos e intelectuais; eram mais do que editores de Boswell eram verdadeiros patronos, oferecendo-lhe jantares, pagando-lhe viagens, emprestando-lhe dinheiro e hospedando-o em sua casa. (SHER, 2006, p. 200).

\footnotetext{
${ }^{37}$ William Jackson (1724-1795), além de um gráfico muito respeitado em Oxford, foi dono de vários jornais, entre os quais o Oxford Journal. Assim como Mickle, trabalhou na Clarendon Press. Os Lister eram uma tradicional família de gráficos, com ligações familiares e profissionais com os Jackson. (Do sítio Headington history: People. Disponível em <http://www.headington.org.uk/history/famous_people/jackson_holt.pdf> . Acesso em 19 jan. 2013.)
} 


\subsection{PERITEXTOS I}

"Paratexto" é o conjunto de elementos, textuais ou gráficos, que acompanha um texto principal. O conceito foi cunhado por Gérard Genette (2009, p. 9), para quem “o paratexto é aquilo por meio de que um texto se torna livro e se propõe como tal a seus leitores, e de maneira mais geral ao público". O paratexto seria um limiar, um vestíbulo, um elemento de ligação entre o leitor e o texto.

Genette estabelece a distinção entre peritexto - os elementos paratextuais incluídos na própria obra (título, prefácio, notas de rodapé, bibliografia etc.) - e epitexto - os elementos paratextuais exteriores à obra (entrevistas com o autor, anúncios em jornais e revistas, resenhas etc.), mas que se referem a ela. Nesta seção e nas duas que se seguem não trataremos dos epitextos; alguns epitextos relacionados à tradução de Mickle já foram examinados na seção 4.5 (o material veiculado pelo tradutor em periódicos, cafés e entre amigos e conhecidos para anunciar e divulgar a tradução) e outros deverão ser examinados na seção 4.9, que tratará da recepção à tradução de Mickle.

Genette (2009, p. 21) chama alguns dos elementos sobre os quais falaremos nesta seção de "peritextos editoriais", pois se referem à

[...] zona do peritexto que se encontra sob responsabilidade direta e principal (mas não exclusiva) do editor, ou talvez, de maneira mais abstrata porém com maior exatidão, da edição, isto é, do fato de um livro ser editado, e eventualmente reeditado, e proposto ao público sob uma ou várias apresentações mais ou menos diferentes.

A palavra "zona" indica, para Genette, que esse tipo de peritexto é caracterizado principalmente em termos espaciais e materiais, remetendo ao peritexto mais exterior (capa, folha de rosto etc.) e à realização material do texto (formato, papel etc.). No caso desta tradução, acreditamos que o termo "editorial" se refira mais à "edição" do que a "editores" ou "livreiros", já que é muito provável que Mickle tenha preparado pessoalmente os peritextos editoriais ou, pelo menos, influído bastante em sua confecção. Na época em que foi publicada essa tradução, os autores e tradutores tinham mais influência sobre o processo de edição do que vieram a ter em épocas posteriores. Além disso, tratava-se de uma obra financiada por assinaturas, o que implicava um maior controle do autor sobre a edição, e Mickle conhecia muito bem o processo de impressão e edição, pois, além de ter trabalhado durante vários anos na Clarendon Press, seu irmão era tipógrafo, e Mickle planejava fundar uma editora em parceria com ele. 
Exatamente por acreditarmos que Mickle exerceu um papel determinante na elaboração de todos os elementos peritextuais, analisaremos os chamados "peritextos editoriais" junto com outros elementos peritextuais. Com essa ressalva, seguiremos, na descrição dos elementos peritextuais, o modelo apresentado por Genette (2009).

\subsubsection{Formato, Papel, Número de Cópias, Encadernação, Capa}

No projeto elaborado para angariar assinaturas para a tradução d'Os lusíadas, Mickle (1771) promete um trabalho "elegantemente impresso" em formato in-quarto, em papel de boa qualidade, com notas históricas etc., ao preço de 12 shillings ${ }^{38}$ para os assinantes, metade na assinatura, metade na entrega do livro. O livro foi, de fato, lançado em formato in-quarto $(11 "$ x $8.5 "$ - aproximadamente $28 \mathrm{~cm} \mathrm{x} 21 \mathrm{~cm})$, contendo 484 páginas, com cerca de setecentas notas e ainda uma introdução de 167 (clxvii) páginas. O preço da primeira edição para não assinantes foi de um guinéu, ou seja, uma libra e um shilling (ou 21 shillings) ${ }^{39}$.

Richard B. Sher (2006) discute os diversos formatos de livros que eram comuns na época do Iluminismo Escocês, comentando o prestígio e as especificidades de cada formato. O quarto era o formato de maior prestígio. Como explica Sher (2006, pp. 50-51), os termos "fólio", "quarto, “oitavo" e "duodécimo" se referiam, tecnicamente, ao número de vezes em que uma folha de papel era dobrada (respectivamente, uma, duas, três ou quatro vezes, produzindo cadernos de duas, quatro, oito e doze folhas), mas o tamanho das folhas usadas variava. Segundo Sher (p. 28):

[...] os quartos eram usados apenas para certos tipos de gênero e eram mais legíveis do que os formatos menores (uma consideração importante quando se tenta ler à luz de velas ou sem óculos de precisão); e os oitavos, cujo preço era considerado acessível pela maior parte do público que comprava livros, tinham dimensões não maiores do que a maioria dos livros em brochura atuais. ${ }^{40}$

Assim como hoje em dia, nos Estados Unidos e em alguns países europeus, publica-se uma primeira edição mais cara do livro em capa dura [hardcover] e, alguns meses depois, uma edição mais barata em brochura [paperback], na segunda metade do século XVIII se

\footnotetext{
${ }^{38}$ Equivalentes a cerca de 75 libras em 2014.

${ }^{39}$ Correspondentes a 130 libras em 2014.

40 " [...] quartos were used only for certain kinds of genres and were more readable than smaller formats (an important consideration when trying to read by candlelight or without precision eyeglasses); and octavos, which were considered affordable by much of the book-buying public, had dimensions no larger than most paperback trade books today."
} 
costumava lançar primeiro uma edição em quarto e depois, se a venda o justificasse, outra em oitavo. Entretanto, ao contrário do que ocorre hoje em dia com as edições em capa dura e em brochura, como afirma Sher (p. 29), "no século XVIII uma primeira edição em quarto e uma segunda edição em oitavo eram coisas muito diferentes (sempre em termos de papel e tipo, e geralmente em termos de conteúdo), e seus preços respectivos guardavam certa relação com as diferenças em seus custos de produção". ${ }^{41}$ A grande maioria dos livros - ficção, drama, política - era publicada em oitavo ou duodécimo. O quarto habitualmente era reservado para livros de alta cultura ou acadêmicos; livros de história, economia política e poesia ("especialmente poesia épica" ${ }^{2}$, comenta Sher, citando o Fingal e o Temora de James Macpherson além da tradução de Mickle de Os lusíadas). Já o fólio - um tamanho grande demais, difícil de manejar - era reservado apenas para livros de direito, medicina e belas artes. (SHER, 2006, p. 81).

O número de cópias impressas de cada livro dependia da fama do autor, do interesse que o editor esperava despertar, do número de páginas, do formato, do gênero e de vários outros fatores. Variava, em média, entre quinhentas e duas mil. A tiragem de mil exemplares da primeira edição do Lusiad de Mickle estava, portanto, dentro da média esperada.

As encadernações também devem ser consideradas. Às vezes os livros eram vendidos no atacado com as folhas soltas, mas dificilmente chegavam assim ao público. Os quartos geralmente eram encadernados em papelão grosso, os chamados boards, ou em encadernações mais luxuosas, em pele de carneiro ou couro de bezerro. Os oitavos e duodécimos eram apenas costurados em invólucros de papel. (SHER, 2006, pp. 83-84). Como diz Genette (p. 27),
A capa impressa, portanto em papel ou papelão, é um fato bastante recente, que parece remontar ao início do século XIX. Na era clássica, os livros apresentavam-se em encadernação de couro muda, salvo a indicação resumida do título e, às vezes, do nome do autor, que figurava na lombada.

A terceira edição do Lusiad de Mickle foi lançada na Irlanda, em 1791. A proposta de lançamento dessa edição reproduzia mais ou menos os mesmos pontos da proposta da primeira edição, mas o papel a ser usado é especificado como "superfino" [Superfine Writing

\footnotetext{
41 "in the eighteenth century a quarto first edition and an octavo second edition were very different entities (always in their paper and type, and usually in their content), and their respective prices bore some relation to differences in their costs of production".

42 "especially epic poetry".
} 
Paper], com uma fonte "totalmente nova"43. O formato era de dois volumes in-octavo a um preço exclusivo para os assinantes de 11 shillings e 4 pence ${ }^{44}$ com a capa em papelão [boards] ou 14 shillings e um penny ${ }^{45}$ para livros encadernados em couro [elegantly bound]; para os não assinantes, o preço seria 13 shillings $^{46}$ para o livro com capa em papelão e 16 shillings e 3 pence $^{47}$ para os exemplares com capa de couro. (MICKLE, 1791, p. 2). Essa edição irlandesa foi publicada pelo livreiro John Archer, de Dublin, e vendida, de fato, pelo preço anunciado na proposta. Era comum um livro ser publicado na Irlanda alguns anos depois da primeira edição na Inglaterra, geralmente em formato menor e mais barato. Capas em papelão ou couro não eram comuns para livros in octavo, mas talvez a oferta dessas capas se explique pelo fato de Mickle vender os livros por assinatura a pessoas com maior poder aquisitivo.

\subsubsection{Folha de Rosto}

De cima para baixo, o primeiro elemento a aparecer na folha de rosto do Lusiad é o título. No século XVIII (e em épocas anteriores), os títulos costumavam ser mais longos do que aqueles a que estamos acostumados hoje em dia. Só como um exemplo, o título completo do livro que conhecemos como Robinson Crusoé, ao ser publicado em 1719, era uma verdadeira sinopse: The Life and Strange Surprizing Adventures of Robinson Crusoe, of York. Mariner: Who lived Eight and Twenty Years, all alone in an un-inhabited Island on the Coast of America, near the Mouth of the Great River of Oroonoque; Having been cast on Shore by Shipwreck, wherein all the Men perished but himself. With An Account how he was at last as strangely deliver'd by Pyrates. ${ }^{48}$ Em comparação, o título da tradução de Mickle é até simples e curto: The Lusiad; or, the discovery of India. An epic poem. Aplicando a sugestão de Genette (2009, p. 56), podemos dividi-lo em três partes: "título", "subtítulo" e "indicação genérica". O título seria The Lusiad. Ao usar o singular, "Lusiad", em vez de "Lusiads" para traduzir "Lusíadas", Mickle seguia Castera, que intitulara a sua tradução La Lusiade du Camoens, poeme héroique sur la Découverte des Indes Orientales, e Fanshawe, que batizara a sua tradução como The Lusiad, or, Portugals Historicall Poem. Essa opção aproximava o

\footnotetext{
43 "entirely new".

${ }^{44}$ Equivalentes a cerca de 60 libras em 2014.

${ }^{45}$ Correspondendo a cerca de 75 libras em 2014.

${ }^{46}$ Correspondendo a cerca de 70 libras em 2014.

${ }^{47}$ Cerca de 87 libras em 2014.

48 "A vida e as surpreendentes estranhas aventuras de Robinson Crusoé, de York, marinheiro, que viveu 28 anos absolutamente sozinho em uma ilha desabitada na costa da América, perto da foz do rio Orenoco, depois de ter sido lançado à praia por um naufrágio em que todos os homens, exceto ele próprio, pereceram. Com um relato de como ele foi, enfim, estranhamente resgatado por piratas."
} 
título dos seus modelos da Antiguidade greco-latina, a Ilíada e a Eneida. Este é, aliás, um dos casos de títulos com conotações de gênero comentados por Genette (2009, p. 85); são títulos que ligam um elemento temático (que indica o tema da obra) a um remático (que fala sobre a obra; por exemplo, indicando o gênero ou alguma outra característica da obra): “[...] sufixo em -ada, -ade ou -ide nos títulos das epopeias clássicas (Ilíada, Eneida, Franciade, Henriade etc.) que juntam de maneira muito econômica uma indicação temática (pelo nome) e uma remática (pelo sufixo)". Sobre esses títulos, diz ainda Genette (p. 85): "Tantos ecos que, com igual eficácia e mais economia que uma epígrafe (que vem, na verdade, com frequência completá-los [...]), fornecem ao texto a garantia indireta de outro texto, e o prestígio de uma filiação cultural".

No subtítulo, the Discovery of India, Mickle também acompanhou Castera, chamando atenção para a ação histórica do poema e para a Índia, em contraposição ao subtítulo de Fanshawe, Portugals Historicall Poem, que se refere a Portugal. É preciso destacar, ainda, o caráter eurocêntrico desse subtítulo, pois quando os portugueses chegaram à "Índia" já havia povos civilizados naquela região há pelo menos quatro milênios - povos que já haviam até passado por processos de unificação, o primeiro dos quais ocorrido durante o Império Máuria (322 a.C.-185 a.C.).

Em terceiro lugar, a indicação do gênero da obra: An Epic Poem. Como a obra em questão é uma tradução, acrescentou-se ainda a frase "Translated from the Original Portuguese of Luís de Camoëns", que deixa claro que se trata de uma tradução feita a partir do original português e que o autor da obra é Camões.

Segue-se o nome do tradutor: William Julius Mickle. Como já comentamos, William Meikle mudou seu nome para William Mickle para se aproximar da fonética inglesa e acrescentou o segundo nome "Julius", provavelmente para dar um estilo neoclássico, augustano, ao nome. Mesmo que ele tenha alterado oficialmente o seu nome, como parece ter feito, o processo se assemelha ao da adoção de um nome artístico.

Embaixo do nome do autor vem a epígrafe, que é a célebre citação da Arte poética de Horácio: "Nec verbum verbo, curabis reddere, fidus interpres" [Tampouco deverás traduzir palavra por palavra, como fiel intérprete]. Trata-se de um verdadeiro chavão em prefácios de tradutores daquela época. Como epígrafe desse livro, é interessante porque chama atenção para o processo de tradução e não para o conteúdo do texto original ou traduzido. De resto, essa epígrafe acompanha o estilo da época: Genette (2009, p. 132) diz que as epígrafes, surgidas em meados do século XVII, tornaram-se comuns no século XVIII, quando geralmente consistiam em citações em latim, colocadas no início dos livros. 


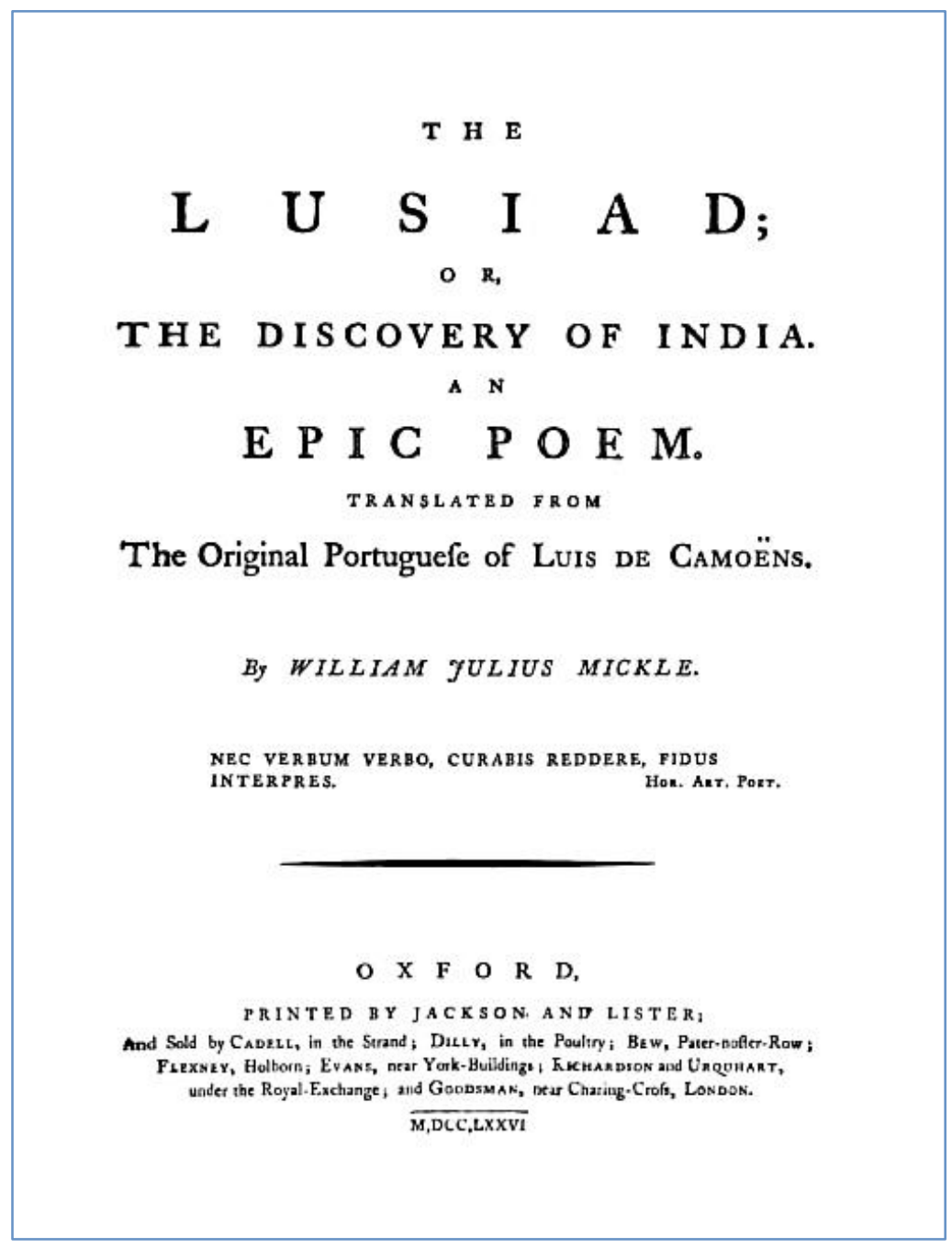

Figura 3. Reprodução da folha de rosto da primeira edição de The Lusiad; or The Discovery of India.An Epic Poem. Fonte: Camões (1776a).

Ao pé da página aparecem, como de praxe, o nome da cidade onde foi impressa a obra (Oxford), o nome da gráfica (Jackson and Lister), os editores-distribuidores (Cadell, Dilly etc.) e, por fim, o ano da publicação em números romanos: M,DCC,LXXVI.

\subsubsection{Dedicatória, Lista de Assinantes, Página de Errata}

A prática de dedicar a obra a um mecenas vinha da Antiguidade latina e prolongou-se até as primeiras décadas do século XIX. No século XVIII esse tipo de dedicatória era bastante convencional, assumindo a forma de uma carta assinada pelo autor. Genette (2009, pp. 110111) observa que, em uma época em que os direitos autorais ainda não estavam assegurados, esse tipo de dedicatória era uma das fontes de renda dos escritores, sendo considerada um tributo a ser recompensado de alguma forma. 
A dedicatória da tradução de Mickle está na segunda página do livro. Como comentamos anteriormente neste mesmo capítulo, o livro foi dedicado ao Duque de Buccleugh, um nobre escocês em cuja casa o pai de Mickle desempenhara as funções de capelão. O objetivo implícito na dedicatória era que esse nobre atuasse como patrono, mas o Duque ignorou Mickle e seu Lusiad completamente. A observação de Genette mencionada acima confirma que desconsiderar uma dedicatória era um gesto que seguramente seria visto como indelicado na época.

Genette (2009, p. 123) vê nesse tipo de dedicatória um ato performativo endereçado não apenas ao dedicatário, mas também ao público, que serve como testemunha. Por meio da dedicatória, o autor diz ao dedicatário que está dedicando o livro a ele, mas diz também ao leitor que está dedicando o livro ao dedicatário; ao mesmo tempo, diz ao dedicatário que está dizendo ao leitor que está dedicando o livro a ele - e assim ad infinitum. A dedicatória é uma fórmula de demonstração, de ostentação, de exibição. Nesse aspecto, é interessante notar que Mickle não retirou a dedicatória na segunda edição, apesar da desconsideração com que foi tratado pelo Duque. Poderíamos supor que Mickle quis demonstrar, ostentar, exibir, realçar ainda mais a indelicadeza do nobre diante do público e do próprio Duque.

Na terceira página inicia-se a longa lista de assinantes (mais de seis páginas de duas colunas). Nela estão muitos amigos de Mickle na Universidade de Oxford, mas também várias pessoas influentes: políticos como William Pitt (o Velho), Henry Bathurst (segundo Conde Bathurst, que foi Presidente da Câmara dos Pares de 1771 a 1778), Lord Clive, Lord Winchelsea, Sir James Johnstone, Charles Lennox (terceiro Duque de Richmond), Augustus FitzRoy (terceiro Duque de Grafton, Primeiro Ministro da Grã-Bretanha entre 1768 e 1770), Michael Angelo Taylor e o cientista, teólogo dissidente e teórico político Joseph Priestley; religiosos, como os bispos de Oxford, Peterborough e St. Asaph; membros da alta nobreza europeia, como o Príncipe de Anhalt-Dessau, os duques de Aremberg e de Chaulnes e os principes Pignatelli e Massalsky; intelectuais britânicos, como o Dr. Samuel Johnson, James Boswell, Oliver Goldsmith, John Hoole (tradutor de Ariosto e Tasso), Hester Thrale, os irmãos Warton, David Garrick, Bennet Langton, William Jones, o rev. Thomas Percy, Thomas Caldecott, William Crowe, William Lisle Bowers, John Home e David Hume; intelectuais de outros países europeus, como o abade Jean-François de Marci, chanceler da Universidade de Louvain; e membros da comunidade portuguesa em Londres, como D. Luís Pinto de Sousa Coutinho, Visconde de Balsemão; o famoso médico Dr. António Ribeiro Sanches, da Academia Imperial de S. Petersburgo; os professores de Coimbra Miguel Ciera e Miguel Franzini; o embaixador de Portugal em Paris, D. Vicente de Sousa Coutinho; Dr. 
Isaac Henriques de Sequeira; Moses Franco; Abraham de Paz e Manuel Francisco Silva. (WEST, 1934b, pp. 388-389; MOSER, 1994, p. 210; LEITE, 1972, p. 23).

A seguir, temos a errata. Segundo Seth Lerer (2003, p. 45), a folha de errata se tornou comum nos livros europeus do século XVI. Não corrigia somente erros tipográficos, mas também grafias de diferentes dialetos ou mesmo erros textuais. É o caso da errata de Mickle: não contém correções apenas de erros tipográficos. Há também a admissão implícita de que modificações históricas ocorridas quando a obra já estava no prelo tornaram o texto defasado: a errata alerta para o fato de que a nota da página 279 já havia sido impressa quando foi concluída a paz entre os turcos e os russos; da mesma forma, a página vii da Introdução já estava pronta quando foi proclamada a Independência dos Estados Unidos. Além disso, Mickle esclarece as declarações que fizera na Introdução a respeito dos méritos de Cristóvão Colombo em comparação com os do infante D. Henrique e ressalta alguns aspectos em que o épico camoniano seria superior à Eneida. Essas correções demonstram a preocupação constante de Mickle em escolher uma argumentação clara e eficaz para defender suas ideias e enaltecer a obra traduzida.

\subsubsection{Ilustração do Frontispício da Segunda Edição}

Na segunda edição, Mickle publicou no frontispício uma gravura feita especialmente para ele pelo pintor John Hamilton Mortimer. A gravura representa Mickle de joelhos entregando a tradução d'Os lusíadas a Britânia (a personificação feminina da ilha da GrãBretanha), que aponta com uma das mãos o Templo da Fama, sobre um rochedo. A Fama, sustentada por uma densa nuvem sobre a cabeça de Britânia, segura um trompete. Atrás dela vê-se uma série de medalhões, entre os quais é possível distinguir a figura de Dante. O tradutor é, portanto, representado como aquele que traz a cultura para a sua nação e, em troca, obtém fama e prestígio. 


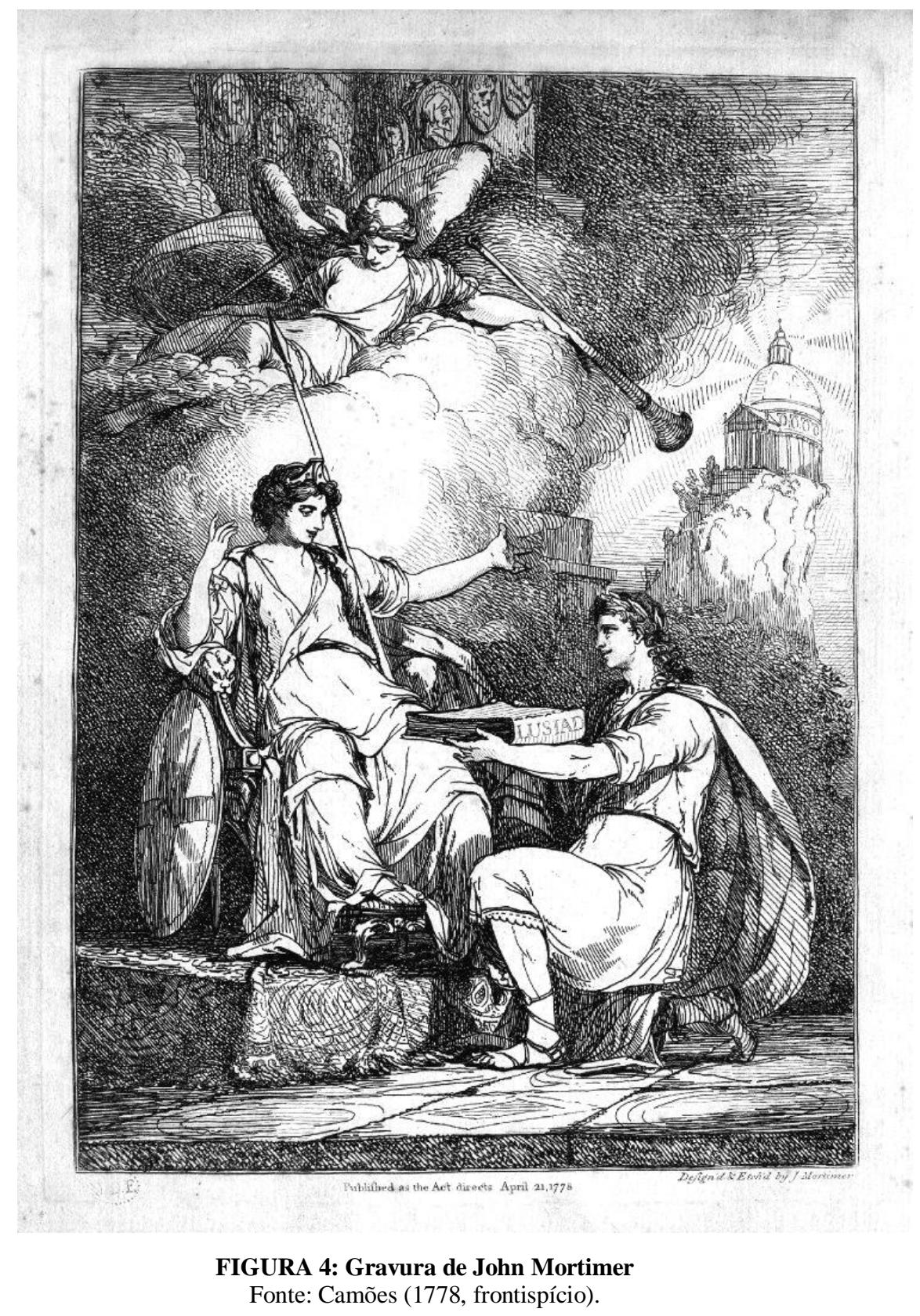

\subsection{PERITEXTOS II: OS ENSAIOS DA INTRODUÇÃO À TRADUÇÃO DE OS} LUSÍADAS

Na classificação de Genette (2009, pp. 175-177, p. 233, itálicos do autor), os vários ensaios introdutórios de Mickle seriam "prefácios alógrafos autênticos”. A função principal de um prefácio alógrafo, assim como a de um prefácio autoral assuntivo original (ou, mais resumidamente, prefácio original) é "garantir ao texto uma boa leitura". A ação aí enunciada é dupla: "1. obter uma leitura e 2. conseguir que essa leitura seja boa". O prefácio alógrafo diz por que e como o livro deve ser lido. 
Para cumprir as funções relacionadas ao "porquê", o autor procura fazer o que, na retórica latina, era conhecido como captatio benevolentice (conquistar a simpatia). Em outras palavras, valorizar o texto sem parecer valorizar demais o autor perante o leitor. Para o tradutor, a tarefa é mais fácil, já que ele pode valorizar tanto o texto quanto o autor; principalmente no caso de um prefácio escrito quando o autor da obra já está morto. Um dos principais métodos para valorizar um texto é enfatizar a importância do tema. Esta é, sem dúvida, uma das funções que os ensaios introdutórios de Mickle procuram cumprir. A importância e utilidade do tema podem ser vinculadas ao seu valor documental, intelectual, moral, religioso, social e político - Mickle apela a todos esses elementos mencionados por Genette (2009, pp. 177-178). Já para indicar ao leitor “como" ler o texto, conforme explica Genette (p. 186), o autor fornece a ele informações. Também essa função é cumprida por Mickle em seus ensaios introdutórios, que fornecem informações sobre o contexto social, histórico, político, econômico e cultural em que Os lusíadas foram escritos, assim como uma biografia ("Life of the Author") de Camões, o que era de praxe no século XVIII.

Na primeira edição do Lusiad (1776), a introdução foi publicada em bloco, sem subdivisões, com as páginas numeradas de i até clvii, seguida por uma seção intitulada “Dissertation On the Machinery of Tasso's Jerusalem, and Voltaire's Henriade" [Dissertação sobre a máquina da Jerusalém de Tasso e da Henriade de Voltaire], que vai até a página clxvii. ${ }^{49} \mathrm{Na}$ segunda edição, de 1778, Mickle subdividiu a introdução em várias partes. Para facilitar o estudo, adotaremos a divisão e os títulos utilizados na segunda edição e comentaremos sempre que houver alguma discrepância relevante entre as duas edições. Analisaremos primeiro os ensaios da primeira edição, e depois o material que foi acrescentado na segunda edição.

\subsubsection{Introdução (1776, pp. i-xix; 1778, pp. i-xxiv)}

O primeiro parágrafo da Introdução expressa muito claramente uma das ideias fundamentais para Mickle (1776, p. i): a de que Os lusíadas é uma obra importante por retratar um acontecimento central para o nascimento do comércio. Mostra, também, qual é o público a que Mickle se dirige: os filósofos (no século XVIII essa palavra costumava ser

\footnotetext{
${ }^{49}$ Na segunda edição, essa dissertação foi resumida e transformada em nota à "Dissertação sobre Os lusíadas e observações sobre a poesia épica". Omitiu-se a análise da Jerusalém libertada, conservando-se apenas os comentários sobre a Henriade. (MICKLE, 1778, p. ccxiv).
} 
usada em um sentido mais amplo, próximo do que hoje poderíamos designar como “intelectuais"), os políticos e os cavalheiros.

Se uma concatenação de eventos centrados em uma grande ação - eventos que deram origem ao atual Sistema Comercial Mundial -; se esses eventos são de primeira importância na história civil da humanidade, então Os lusíadas, entre todos os poemas, invocam a atenção do Filósofo, do Político e do Cavalheiro. ${ }^{50}$

Em decorrência disso, Mickle propõe o rótulo de "Epopeia do Comércio" (Epic Poem of Commerce) para Os lusíadas: "Em contraste com a Ilíada e a Eneida, o Paraíso perdido" costuma ser chamado de Epopeia da Religião. Da mesma forma, Os lusíadas poderiam ser chamados de Epopeia do Comércio" $" 52$.

Em seguida, Mickle elogia uma figura que será transformada em um dos heróis de sua tradução - o infante D. Henrique, a quem o tradutor atribui o mérito pelo nascimento do comércio: "A feliz realização dos importantíssimos projetos de Henrique, Duque de Viseu, príncipe de Portugal, a quem a Europa deve tanto Gama quanto Colombo, tanto o mundo oriental quanto ocidental, constitui o assunto desta célebre epopeia"53.

Ao definir como assunto do poema apenas a descoberta da Índia (e o nascimento do comércio), Mickle efetua um desvio em relação ao que é declarado no original, pois n'Os lusíadas o Poeta enuncia sua intenção de cantar as façanhas dos heróis que se aventuraram por territórios desconhecidos e dos reis que dilataram a Fé e o Império - em suma, o "peito ilustre lusitano". Elegendo como foco central a descoberta da Índia, Mickle relega todos os outros feitos lusitanos narrados no poema a um papel secundário.

Mickle (1776, pp. i-ii) tenta rebater a opinião dos que lamentam a descoberta da Índia e consideram o aumento do comércio como fonte de degeneração e vícios. ${ }^{54}$ Admite a

\footnotetext{
50 "If a concatenation of events centered in one great action, events which gave birth to the present Commercial System of the World, if these be of the first importance in the civil history of mankind, the Lusiad, of all other poems, challenges the attention of the Philosopher, the Politician, and the Gentleman." (Todas as traduções da Introdução de Mickle à tradução de Os lusíadas são da autora desta tese.)

${ }^{51}$ Nos livros da primeira e segunda edições do Lusiad raramente é usado algum destaque (itálico, negrito etc.) para os títulos de obras; mantivemos a grafia encontrada nos livros.

52 "In contradistinction to the Iliad and the ÆEneid, the Paradise Lost has been called the Epic Poem of Religion. In the same manner may the Lusiad be named the Epic Poem of Commerce".

53 "The happy completion of the most important designs of Henry Duke of Viseo, prince of Portugal, to whom Europe owes both Gama and Columbus, both the Eastern and the Western worlds, constitutes the subject of this celebrated Epic Poem".

${ }^{54}$ Entre esses pensadores estava o Dr. Johnson - Mickle (1776, p. v) menciona - de forma levemente modificada e sem citar o autor -, uma frase extraída do texto escrito por Johnson em 1857 que citamos na página 75: "it had been happy for both the old and the new worlds if the East and West Indies had never been discovered" ["teria sido bom tanto para o velho quanto para o novo mundo se as Índias Orientais e Ocidentais nunca houvessem sido
} 
superfluidade de muitas importações, mas acredita que os benefícios trazidos pelo comércio superam os malefícios. Ao afirmar que o ser humano nasceu para a sociedade e só atinge o estado adequado à sua natureza quando cultiva a razão, Mickle alega estar se contrapondo às ideias de Rousseau, de que o estado natural do ser humano seria o selvagem ${ }^{55}$ : "Os devaneios, as fantasias de um Rousseau, podem retratar a vida paradisíaca de um hotentote, mas é apenas em tais sonhos que a felicidade do bárbaro existe"

Mickle acrescenta que o fato de o selvagem relutar em abandonar o seu estilo de vida não é prova de sua felicidade. Essa relutância mostra apenas o poder do hábito, que permite que nos adaptemos às condições mais desagradáveis. Em seguida, a segunda edição difere da primeira. Na primeira edição, Mickle (1776, p. iii) invoca as violentas guerras entre as tribos de nativos americanos e as crueldades que estes praticavam contra os prisioneiros de guerra como prova de sua "mais brutal depravação" "57. Soma-se a isso a "horrível superstição" "58 que os domina. Nesse aspecto, todos os selvagens seriam iguais: todos aterrorizados por maus espíritos e submissos a um Deus tirano, venerado por meio de rituais cruéis. Em uma nota de rodapé, Mickle cita como uma das fontes da ideia de que a vida dos selvagens é melhor do que a dos civilizados o livro Histoire philosophique et politique des établissements et du commerce des Européens dans les deux Indes, mais conhecido como Histoire des deux Indes [História das duas Índias], uma enciclopédia sobre o comércio dos europeus no Extremo Oriente e uma das principais obras de anticolonialismo e antiescravismo publicadas no século XVIII. Na primeira edição da tradução de Mickle, a Histoire des deux Indes é apresentada

descobertas"]. Após a morte de Johnson, em carta a Boswell (1998, p. 1258), Mickle relata a discussão entre ele e Johnson sobre esse tema, e diz que procurou responder, na Introdução à sua tradução, à frase de Johnson. Depois da publicação do Lusiad, quando Johnson encontrou Mickle novamente, comentou: "Well, you have remembered our dispute about Prince Henry, and have cited me too. You have done your part very well indeed: you have made the best of your argument; but I am not convinced yet". ["Muito bem, você se lembrou da nossa controvérsia sobre o infante D. Henrique, e me citou, também. Você fez a sua parte muito bem, com efeito: tirou o máximo proveito de seus argumentos; mas ainda não estou convencido.”]

${ }^{55} \mathrm{Na}$ verdade, Rousseau jamais usou a expressão "bom selvagem"; não achava que os indígenas americanos estivessem em "estado de natureza" e não acreditava que fosse possível ou desejável voltar aos tempos primitivos. O que Rousseau (1865, p. 97) escreveu foi que, no estado de natureza, os homens eram iguais e viviam em uma situação de independência recíproca e ausência de conflitos: "Não havendo, nesse estado, nenhuma espécie de relação moral nem deveres conhecidos entre os homens, estes não podiam ser bons nem maus, e não tinham nem vícios nem virtudes". A origem das diferenças sociais estaria no surgimento da propriedade privada da terra. Rousseau pregava uma reorganização do Estado, de modo que a liberdade de cada cidadão fosse assegurada. Sobre o conceito de "estado de natureza" em Rousseau e o mito do "bom selvagem", ver Arthur O. Lovejoy. The Supposed Primitivism of Rousseau's Discourse on Inequality. Modern Philology. Vol. 21, n. 2, nov. 1923, pp. 165-186. Disponível em: 〈http://www.jstor.org/stable/433742〉. Acesso em 31 ago. 2013; Victor Gourevitch (Ed.). Rousseau: The Discourses and Other Early Political Writings. Col. Cambridge Texts in the History of Political Thought. Cambridge: Cambridge University Press, 1997 e Ter Ellingson. The Myth of the Noble Savage, University of California, 2001.

56 "The reveries, the fairy dreams of a Rousseau, may figure the paradisial life of a Hottentot, but it is only in such dreams that the happiness of the barbarian exists".

57 "most brutal depravity".

58 "horrible superstition". 
como anônima, mas na segunda já é atribuída a Guillaume-Thomas François Raynal, o abade Raynal. (Acredita-se, no entanto, que outros filósofos, principalmente Diderot, tenham colaborado na redação da obra.) Resumindo drasticamente o resumo feito por Mickle: o autor da Histoire des deux Indes acreditava que o selvagem é mais feliz do que o civilizado porque se satisfaz com aquilo que a natureza the oferece. Os bens refinados de que o civilizado usufrui são obtidos à custa do trabalho de uma multidão de despossuídos, e o civilizado precisa se submeter a leis, autoridades, preconceitos e costumes que restringem a sua liberdade. Mickle (p. v, nota) concorda que não podemos desejar o que não conhecemos, mas argumenta que disso não se segue, de modo algum, que o estado selvagem seja mais feliz. Para desmentir essa tese, Mickle lembra os perigos enfrentados pelo selvagem e o estado miserável em que este se vê quando chega à velhice e não pode mais caçar ou lutar.

Na segunda edição Mickle (1778, p. iv) acrescenta algumas linhas ao início do trecho, reconhecendo que as tribos de nativos americanos apresentam certo grau de civilidade. Considera-os "grandes mestres da oratória marcial" populares abertas aos jovens em que estes aprendem a história de sua tribo e absorvem o espírito guerreiro. Admira-lhes os estratagemas e os exercícios atléticos, e admite que, embora eles não inflijam castigos corporais a membros de sua própria tribo, uma reprimenda de um membro mais velho, proferida em assembleia, é encarada por eles como uma degradação e castigo mais severos do que qualquer das punições adotadas pelas nações civilizadas. Essa seria uma vantagem "de existência impossível em um vasto império comercial" dessa vantagem e do bom clima de que usufruem, esses nativos deixam suas abundantes terras não cultivadas e se matam uns aos outros em violentas guerras. (Neste ponto, Mickle retoma o texto da primeira edição, descrito acima.)

Depois de afirmar a sua posição sobre o caráter dos selvagens, Mickle (1776, p. vi) passa a rebater outros argumentos levantados contra a colonização. Reconhece que as atrocidades cometidas pelos espanhóis no Novo Mundo "envergonham a natureza humana"

Os grandes e florescentes impérios do México e do Peru, mergulhados no sangue de quarenta milhões de seus filhos, apresentam uma perspectiva melancólica, que deve despertar a indignação em todos os bons corações. Apesar disso, tal destruição não é a consequência infalível do descobrimento. E mesmo que admitíssemos que a depravação da natureza humana é tão grande que a cobiça do comerciante e a rapacidade do soldado

\footnotetext{
59 "Great masters of martial oratory".

60 "impossible to exist in a large commercial empire".

61 "disgrace human nature".
} 
infestarão com atribulações todas as novas regiões descobertas, ainda há outras visões, mais abrangentes, a serem consideradas antes que decidamos nos opor ao intercâmbio introduzido pela navegação. ${ }^{62}$

Mickle cita como exemplo as conquistas de Alexandre, que foram um mal temporário, mas geraram felicidade e progresso para a civilização. Mesmo alguns locais colonizados pelos espanhóis, como o Paraguai, foram bem-sucedidos, avalia Mickle. E "se o México não é tão

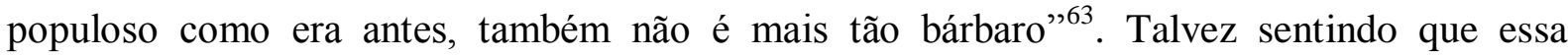
declaração pudesse escandalizar alguns leitores, Mickle (pp. vi-vii) acrescenta uma nota de rodapé para comentar que os nativos americanos não eram exatamente modelos de comportamento. Seus costumes civis e ritos religiosos eram "horríveis" "64. Em algumas tribos, o incesto e a pederastia eram praticados; os prisioneiros de guerra eram tratados com violência e, muitas vezes, devorados em rituais; os rituais religiosos exigiam o sacrifício de crianças, virgens e escravos. Os sacrifícios no México eram tão numerosos que os tlaxcaltecas se aliaram a Cortez contra os astecas. Mickle prossegue relatando sacrifícios horrendos cometidos por astecas e incas. Por mais despóticos que possam ser os governos espanhóis, conclui Mickle (p. vii), pelo menos as suas colônias desfrutam das oportunidades de melhorias por meio do comércio e das letras.

No caso da América britânica, as perspectivas eram muito mais auspiciosas. Mickle escreveu esse ensaio antes da proclamação da Independência dos Estados Unidos (a tradução d'Os lusíadas foi finalizada em 1775 e publicada no início de 1776). Na segunda edição Mickle $(1778$, p. $x)$ reconhece esse fato em uma nota de rodapé e lamenta a guerra civil em andamento, mas mantém o que escrevera antes.

Aqui agora a população se espalha aos milhares, e a sociedade surge em todas as suas bênçãos de ajuda mútua, e as luzes mútuas de aperfeiçoamento intelectual. [...] Ter dado a um continente selvagem uma imagem da Constituição Britânica é, com efeito, a maior glória da coroa britânica, "maior do que qualquer outra nação já obteve" "65; e em consequência do

\footnotetext{
62 "The great and flourishing empires of Mexico and Peru, steeped in the blood of forty millions of their sons, present a melancholy prospect, which must excite the indignation of every good heart. Yet such desolation is not the certain consequence of discovery. And even should we allow that the depravity of human nature is so great, that the avarice of the merchant and rapacity of the soldier will overwhelm with misery every new discovered country, still are other, more comprehensive views, to be taken, ere we decide against the intercourse introduced by navigation."

63 "If Mexico is not so populous as it once was, neither is it so barbarous [...]".

64 "horrid".

${ }^{65}$ Mickle cita aqui um discurso de Jonathan Shipley, então bispo de St Asaph, grande defensor das colônias norte-americanas e amigo de Benjamin Franklin. Shipley teria sido o único bispo da Igreja da Inglaterra a se opor às medidas punitivas votadas no parlamento contra a cidade de Boston pelos incidentes da Festa do Chá. O bispo de St Asaph foi também um dos assinantes do Lusiad de Mickle.
} 
gênio de Henrique, Duque de Viseu, o império britânico americano surgiu, um império que, se não for retardado pelo espírito intolerante e desumano do fanatismo religioso, será, em poucos séculos, talvez a glória do mundo. ${ }^{66}$

Essa citação revela claramente a importância que Mickle atribui ao comércio como um meio de aperfeiçoar a sociedade em termos intelectuais, políticos e religiosos. Mickle procura vincular as conquistas propiciadas pelo comércio à navegação, e esta ao "gênio" de D. Henrique. Esses argumentos são apresentados para comprovar a sua tese de que Os lusíadas são a epopeia do comércio.

Quanto à ação dos portugueses e outras nações europeias na Índia, Mickle (1776, p. viii) alega que, se houve derramamento de sangue, isso não era novidade às margens do Ganges. Os príncipes locais sempre foram ambiciosos e guerrearam entre si, e os "conquistadores asiáticos" promoveram horríveis massacres e pilhagens jamais igualados pelos europeus. $\mathrm{Na}$ opinião de Mickle, com o estabelecimento dos governos europeus haveria maior justiça e melhores leis.

O tom ufanista em relação ao Império Britânico e o paternalismo para com os indianos, características presentes em toda a Introdução, são evidentes na seguinte citação (que, por ter sido modificada na segunda edição, citaremos duplamente), em que Mickle efetua a transferência, para os britânicos, de uma profecia de Camões sobre os portugueses - em uma encenação de um movimento de translatio studii et imperii. Eis a versão da primeira edição:

A superioridade das artes civis e militares dos britânicos, não obstante o caráter odioso de alguns indivíduos, é atualmente contemplada na Índia com todo o assombro de admiração; e admiração é sempre seguida, ainda que muitas vezes em passos atrasados, pelo forte desejo de uma melhoria semelhante. Isso, apesar de atrasos provocados por várias causas, deve, a seu tempo, produzir um efeito da maior importância: deve cumprir a profecia de Camões, e transferir para os britânicos o grande cumprimento que ele presta a seus compatriotas; ${ }^{67}$

\footnotetext{
66 "Here now population spreads her thousands, and society appears in all its blessings of mutual help, and the mutual lights of intellectual improvement. [...] To have given a savage continent an image of the British Constitution is indeed the greatest glory of the British crown, "a greater than any other nation ever acquired;" and from the consequences of the genius of Henry Duke of Viseo, did the British American empire arise, an empire which, unless retarded by the illiberal and inhuman spirit of religious fanaticism, will in a few centuries, perhaps, be the glory of the world."

67 "The superiority of the civil and military arts of the British, notwithstanding the hateful character of some individuals, is at this day beheld in India with all the astonishment of admiration; and admiration is always followed, though often with retarded steps, by the strong desire of similar improvement. This however retarded by various causes, must in time have a most important effect, must fulfil the prophecy of Camoens, and transfer to the British the high compliment he pays to his countrymen [...]".
} 
Beneath their sway majestic, wise and mild,

Proud of her victor's laws thrice happier India smiled. ${ }^{68}$

(MICKLE, 1776, p. vii).

$\mathrm{Na}$ segunda edição, para dar mais força ao seu argumento por meio de uma analogia, Mickle (1778, p. xi) acrescenta uma menção à adoção das leis romanas, após a queda do Império Romano, por nações que os romanos consideravam bárbaras (destacamos os acréscimos em negrito):

A superioridade das artes civis e militares dos britânicos, não obstante o caráter odioso de alguns indivíduos, é atualmente contemplada na Índia com todo o assombro de admiração; e admiração é sempre seguida, ainda que muitas vezes em passos atrasados, pelo forte desejo se uma melhoria semelhante. Muito tempo depois da queda do Império Romano, as leis romanas foram adotadas por povos que Roma Antiga considerava bárbaros. E assim, no decorrer de eras, as leis britânicas, segundo todas as probabilidades, produzirão um efeito da maior importância: cumprirão a profecia de Camões e transferirão para os britânicos o grande cumprimento que ele presta a seus compatriotas $[\ldots]^{69}$

Esse acréscimo reforça o tom de translatio studii et imperii no argumento de Mickle: assim como houve a passagem do domínio do Império Romano para as nações europeias, o domínio dos portugueses na Índia se transfere para os britânicos, e da mesma forma que os indianos se beneficiaram com o domínio português, beneficiar-se-ão com o domínio britânico. Implicitamente, nessa transferência do Império, Camões e Mickle desempenham o papel de agentes da transferência da cultura e do conhecimento (translatio studii). ${ }^{70}$

\footnotetext{
68 "Sob o seu domínio majestoso, sábio e brando, Orgulhosa das leis do seu vencedor, três vezes mais feliz a Índia sorriu."

69 "The superiority of the civil and military arts of the British, notwithstanding the hateful character of some individuals, is at this day beheld in India with all the astonishment of admiration; and admiration is always followed, though often with retarded steps, by the strong desire of similar improvement. Long after the fall of the Roman empire the Roman laws were adopted by nations which ancient Rome esteemed as barbarous. And thus, in the course of ages, the British laws, according to every test of probability, will have a most important effect, will fulfil the prophecy of Camoens, and transfer to the British the high compliment he pays to his countrymen $[\ldots]$ "

${ }^{70}$ Os "poetas do comércio" que discutimos no capítulo anterior (Dryden, Pope, Thomson e outros) referiam-se à translatio como uma transmissão de leste para oeste; muitas vezes esses poetas consideravam que o último império havia sido o Romano ou o Carolíngio, sem levar em conta o Sacro Império Romano Germânico e o Império Português. Mickle, que não podia ignorar o Império Português, não menciona explicitamente uma translatio de leste para oeste, mesmo porque, embora algumas partes da Irlanda (que já fazia parte do Império Britânico) fiquem a oeste de Portugal, as longitudes de Portugal e da Grã-Bretanha são bastante próximas, e um deslocamento de Portugal para a Grã-Bretanha seria descrito de forma mais precisa como indo do sul para o norte. Para os efeitos da presente tese, importa ressaltar que o que Mickle faz não é uma aplicação mecânica da teoria da translatio, mas uma reencenação e atualização dessa teoria.
} 
Sobre os versos d'Os lusíadas citados aqui comentaremos em maior detalhe no Capítulo 5, mas, apenas para que o leitor possa localizá-los, o original está no Canto VII, estrofe 56, quando Camões menciona auspiciosamente a futura dominação da Índia pelos portugueses:

[...] a bélica excelência,

Nas armas e na paz, da gente estranha

Será tal, que será no mundo ouvido

$\mathrm{O}$ vencedor por glória do vencido.

Mickle (1776, p. ix) prossegue relatando as pilhagens e massacres perpetrados pelos príncipes indianos e maometanos, afirmando que "As ideias de patriotismo e de honra raramente eram conhecidas nos gabinetes dos príncipes orientais até a chegada dos europeus" ${ }^{, 71}$, e aproveita para ressaltar o papel da Companhia das Índias Orientais:

[...] alguns dos governadores portugueses, e muitos dos funcionários ingleses, lhes ensinaram que humanidade para com o conquistado é a melhor, a mais correta política. A brutal ferocidade de seus próprios conquistadores é agora o objeto de seu maior temor; e a superioridade dos britânicos na guerra convenceu seus príncipes de que uma aliança com os britânicos é a garantia mais segura da paz e prosperidade gerais. Enquanto a Companhia Inglesa das Índias Orientais conservar a grandeza atual, estará em seu poder difundir pelo Oriente todas as bênçãos que advêm das políticas mais sábias e humanas $[\ldots]^{72}$

É inabalável a confiança que Mickle (1776, pp. ix-x) deposita nas leis britânicas e na superioridade dos britânicos em relação aos "desalentados e passivos" indianos ${ }^{73}$ :

A introdução das leis britânicas na Índia, leis já admiradas como ditadas pelos céus, devem, no decorrer das eras, exercer um efeito amplo e estupendo. $\mathrm{O}$ espírito abjeto da submissão asiática será ensinado a ver e a reivindicar aqueles direitos da natureza dos quais os desalentados e passivos hindus mal podiam, até recentemente, formar uma ideia. A partir disso, tão naturalmente quanto a tarde se segue ao amanhecer, advirão as outras bênçãos da civilização. ${ }^{74}$

\footnotetext{
71 "The ideas of patriotism and of honour were seldom known in the cabinets of the eastern princes till the arrival of the Europeans".

72 " [...] some of the Portuguese governors, and many of the English officers, have taught them that humanity to the conquered is the best, the truest policy. The brutal ferocity of their own conquerors is now the object of their greatest dread; and the superiority of the British in war has convinced their princes, that an alliance with the British is the surest guarantee of their national peace and prosperity. While the English East India Company are possessed of their present greatness, it is in their power to diffuse over the East every blessing which flows from the wisest and most humane policy [...]"

${ }_{74}^{73}$ A palavra usada por Mickle aqui foi Gentoo, que designava o hindu não muçulmano.

74 "The introduction of the British laws into India, of laws already admired as the dictates of heaven, must, in the course of ages, have a wide and stupendous effect. The abject spirit of Asian submission, will be taught to
} 
Concluindo seus argumentos em defesa da colonização dos povos asiáticos, Mickle (1776, pp. x-xi) proclama: "Foi aquele povo de comerciantes, os fenícios, que difundiu o uso das letras entre os antigos, e o Comércio, sem dúvida alguma, difundirá as mesmas bênçãos pelo mundo moderno"75.

Mickle (1776, p. xii) passa, então, a enumerar os benefícios auferidos pela Europa por meio das viagens de Gama e Colombo. Ou, nas palavras de Mickle, "vamos ver o que era a Europa antes que o gênio de D. Henrique gerasse o espírito da descoberta moderna"76. O quadro pintado por Mickle é o de um sistema feudal regido pela mais absoluta tirania, e de reinos em constante guerra uns com os outros. As obras clássicas dormiam nas prateleiras dos monastérios; o analfabetismo era quase geral; e o comércio, incompatível com as regras do sistema feudal, era escasso:

Enquanto todos os ramos da investigação filosófica, racional, eram, assim, inexplorados e desconhecidos, o Comércio, incompatível com o sistema feudal, era igualmente negligenciado e não aperfeiçoado. Sempre que a mente é ampliada e iluminada pelo Conhecimento, planos de comércio irão se desenvolver, e esses, em troca, trarão, de todas as partes do mundo, novas aquisições para a filosofia e a ciência. As origens do Conhecimento e do Comércio podem ser diferentes, mas seu crescimento é mútuo e dependente um do outro. ${ }^{77}$

Em meio ao ambiente obscurantista do feudalismo, surgiu D. Henrique, "para libertar a humanidade do sistema feudal e dar a todo o mundo todas as vantagens, todas as luzes que podem ser difundidas pelo Intercâmbio do comércio ilimitado" ${ }^{78}$ (p. xiii). Nesse ponto, Mickle cita os versos de Thomson sobre D. Henrique no poema "Summer":

For then from ancient gloom emerg'd

The rising world of Trade: the Genius, then,

Of Navigation, that in hopeless sloth

Had slumber'd on the vast Atlantic deep

\footnotetext{
see, and to claim those rights of natures, of which the dispirited and passive Gentoos could, till lately, hardly form an idea. From this, as naturally as the noon succeeds the dawn, must the other blessings of civilization arise."

75 "It was that nation of merchants, the Phoenicians, which diffused the use of letters through the ancient, and Commerce will undoubtedly diffuse the same blessings through the modern world".

76 "let us view what Europe was, ere the genius of Don Henry gave birth to the spirit of modern discovery".

77 "While every branch of philosophical, of rational investigation, was thus unpursued and unknown, Commerce, incompatible in itself with the feudal system, was equally neglected and unimproved. Where the mind is enlarged and enlightened by Learning, plans of Commerce will rise into action, and which, in return, will, from every part of the earth, bring new acquirements to philosophy and science. The birth of Learning and Commerce may be different, but their growth is mutual and dependent upon each other."

78 "to set mankind free from the feodal system, and to give to the whole world every advantage, every light that may possibly be diffused by the Intercourse of unlimited commerce”.
} 
For idle ages, starting heard at last

The Lusitanian Prince, who, Heaven-inspir'd,

To love of useful glory rous'd mankind,

And in unbounded Commerce mix'd the world. ${ }^{79}$

Comparando os tempos modernos com os do feudalismo, Mickle (1776, pp. xiv-xv) diz que as desigualdades diminuíram, a agricultura se desenvolveu muito e alcançou-se um maior controle sobre os fatores geradores da fome. Além disso, a violência e a falta de proteção à propriedade eram muito maiores nos tempos feudais. Foram, portanto, várias as dádivas concedidas pelo comércio. E D. Henrique - filho de uma inglesa, não deixa de acrescentar Mickle - é o responsável por tudo isso:

A abolição do sistema feudal, um sistema de absoluta escravidão, e aquela igualdade da humanidade que permite a proteção da propriedade, e todos os outros incentivos à indústria, são as dádivas gloriosas que o espírito do Comércio, despertado pelo príncipe Henrique de Portugal, concedeu à Europa em geral; e, como que dirigido pela alma de sua mãe, uma filha da Inglaterra, sobre o Império Britânico em particular. ${ }^{80}$

É, então, como se D. Henrique houvesse abolido o sistema feudal em nome do Império Britânico, para que este último pudesse se desenvolver plenamente...

Ecoando a preocupação com os aspectos negativos da translatio - expressa, como vimos no capítulo anterior (seção 3.5), por vários poetas de sua época -, Mickle (1776, pp. xviii-xix) alerta para um perigoso fator que levou à queda tanto do Império Romano quanto do Português: a segurança pode levar à dissipação e à ociosidade.

O luxo predomina; títulos e família são o único mérito, e todo o corpo da nobreza ignora completamente os princípios do comércio e da correta administração. Uma grandeza suntuosa é preservada, mas é apenas externa, tudo está arruinado por dentro, e na primeira tempestade o frágil tecido se

\footnotetext{
79 "Então das trevas antigas emergiu

O mundo nascente do Comércio: o Gênio

Da Navegação, que em desesperançada indolência

Estivera adormecido nas vastas profundezas do Atlântico

Durante eras ociosas, despertando ouviu, enfim,

O Príncipe lusitano, que, inspirado pelos Céus,

Ao amor da glória útil incitou a humanidade,

E em Comércio ilimitado uniu o mundo todo."

80 "The abolition of the feodal system, a system of absolute slavery, and that equality of mankind which affords the protection of property, and every other incitement to industry, are the glorious gifts which the spirit of Commerce, awaked by Prince Henry of Portugal, has bestowed upon Europe in general; and, as if directed by the manes of his mother, a daughter of England, upon the British empire in particular."
} 
desintegra. Assim ascendeu e caiu o império de Roma, e o ainda mais vasto de Portugal. ${ }^{81}$

A situação da Grã-Bretanha, no entender de Mickle, era muito diferente; a ciência e os estudos estavam se desenvolvendo e se disseminando pelo império. A política alcançara um estágio muito mais civilizado do que na época da monarquia de Carlos I ou da república de Cromwell. Embora o aumento da riqueza - admite Mickle (1778, p. xxii) na segunda edição houvesse de fato contribuído para a corrupção dos costumes, a sabedoria da legislação impedira os males que a Espanha e Portugal haviam experimentado com suas conquistas nas duas Índias.

Encerrando essa primeira parte de sua introdução, Mickle, aludindo ao vínculo entre o império e as artes, liga a queda do Império Português ao descaso dispensado a Camões pela nobreza do país - um sinal da ignorância e falta de cultura da nobreza lusitana da época (tal como havia descrito o próprio Camões n'Os lusíadas):

Mas além do total eclipse de sua glória, o que poderia se esperar de uma nobreza, rude e iletrada como é descrita a de Portugal pelo autor d'Os lusíadas, uma corte e nobreza que selaram a verdade de todas as críticas que ele the dirigira sujeitando aquele grande homem, a luz de seu tempo, a morrer em um asilo para pobres! O que senão a queda de seu Estado poderia se esperar de bárbaros como esses! Tampouco podem os anais da humanidade produzir um exemplo de queda de império em que o caráter dos nobres fosse diferente daquele atribuído a seus compatriotas por Camões. ${ }^{82}$

\subsubsection{A história do descobrimento da Índia (1776, pp. xix-lvii; 1778, pp. xxiv-lxix)}

O objetivo de Mickle na parte da introdução intitulada, na segunda edição, "The History of the Discovery of India" é apontar os erros cometidos por Portugal na gestão de seu império, para que os britânicos não cometam os mesmos equívocos. A análise dessa parte e da próxima, em que Mickle relata a história do Império Português no Oriente, são importantes para entendermos a concepção de Mickle de um "bom governo" e para discernirmos como

\footnotetext{
81 "Luxury prevails; titles and family are the only merit, and the whole body of nobility are utterly ignorant of the principles of commerce and true policy. A stately grandeur is preserved, but it is only outward, all is decayed within, and on the first storm the weak fabrick falls to the dust. Thus rose and thus fell the empire of Rome, and the much wider one of Portugal."

82 "But what other than the total eclipse of their glory could be expected from a nobility, rude and unlettered as those of Portugal are described by the author of the Lusiad, a court and nobility, who sealed the truth of all his complaints against them by suffering that great man, the light of their age, to die in an alms-house! What but the fall of their state could be expected from barbarians like these! Nor can the annals of mankind produce one instance of the fall of empire, where the character of the grandees was other than that ascribed to his countrymen by Camoens."
} 
Mickle se apropria do poema de Camões (e da história portuguesa) em nome do Império Britânico.

A intenção de Mickle se evidencia já na máxima com que inicia esse trecho da introdução: "Nenhuma lição pode ter maior importância geral do que a história da ascensão e queda de um império comercial" ${ }^{, 83}$.

Para Mickle (1776, p. xix), a história de Portugal como potência naval e comercial tem início com os planos do infante D. Henrique. Mas, a fim de melhor elucidar o contexto em que despontou esse gênio do comércio e da navegação, Mickle inicia o relato com a invasão dos sarracenos à Península Ibérica (então parte do Império Romano) e a criação de poderosos reinos muçulmanos na Espanha.

Como não é nosso objetivo aqui contar a história de Portugal, limitar-nos-emos a destacar, no relato de Mickle, alguns pontos de interesse para nossa tese.

Em seu relato histórico, Mickle enfatiza aspectos heroicos. Ao se referir ao começo do movimento de Reconquista, Mickle (p. xx) diz: “[...] um espírito militar romanesco reviveu na Europa sob os auspícios de Carlos Magno" ${ }^{\text {} 84}$. Mesmo que o termo romantic aqui se refira especificamente às novelas de cavalaria $^{85}$, ele apresenta uma clara conotação positiva, sinalizando a valorização das Cruzadas e do cavaleirismo medieval - evidenciando a predileção de Mickle, como já analisamos na seção 4.3, por esses temas que serão valorizados no Romantismo. Esse espírito romanesco teria dado origem às Cruzadas, que, embora envoltas em lendas e embelezadas em novelas (o exemplo citado é o Orlando furioso de Ariosto), tiveram bases históricas.

Ao descrever a forma como Afonso Henriques (cujo nome Mickle traduz como “Alonzo") se tornou rei, Mickle (1776, p. xxii) projeta nesse acontecimento a ideologia britânica de sua época, que valorizava a monarquia constitucional:

O governo a que os portugueses haviam sido sujeitados sob os espanhóis e mouros, e as vantagens que viam serem derivadas de seu próprio valor, haviam-lhes ensinado o amor à liberdade [...]. O próprio Afonso entendia o espírito de seus súditos bem demais para que fizesse a menor tentativa de se instalar como um monarca despótico [...]. Depois de seis anos passados em outras vitórias, ampliando e assegurando seus domínios, ele convocou uma

\footnotetext{
83 "No lesson can be of greater national importance than the history of the rise and the fall of a commercial empire".

84 "[...] a romantic military spirit revived in Europe, under the auspices of Charlemagne".

${ }^{85}$ Ver nosso comentário na seção 4.3 a respeito do estudo de Eric Partridge (2010, pp. 254-258) sobre o emprego do adjetivo "romantic" nas poesias do século XVIII na Grã-Bretanha.
} 
assembleia do clero, nobreza e povo a se reunir em Lamego. ${ }^{86}$ Quando a assembleia se iniciou, Afonso apareceu sentado no trono, mas sem qualquer outra marca de dignidade real. E antes que ele fosse coroado, a constituição do Estado foi estabelecida, e dezoito leis foram solenemente confirmadas por juramento como a carta do rei e do povo; leis diametralmente opostas ao direito divino e ao poder arbitrário dos reis, princípios que inculcam e exigem a obediência passiva ilimitada do súdito. ${ }^{87}$

Mais um exemplo do enfoque heroico e cavaleiresco (romantic) dado ao relato histórico por Mickle (1776, p. xxiii) aparece na descrição do espírito guerreiro dos primeiros reis portugueses:

Conscientes do que deviam ao seu próprio valor, os fundadores da monarquia portuguesa transmitiram aos herdeiros aqueles princípios generosos de liberdade que completam e adornam o caráter marcial. O fervor do voluntário, um fervor desconhecido do escravo e do mercenário, acrescido das mais cavaleirescas ideias de glória militar, caracterizavam os portugueses sob o governo de seus primeiros monarcas. ${ }^{88}$

Há momentos em que o ensaio adquire um tom didático e moralista que beira o panfletário (não esqueçamos que o Neoclassicismo valorizava o aspecto didático e moral da obra literária). Por exemplo, quando Mickle ressalta, mais uma vez, o valor da liberdade, dizendo: "E tal era o espírito viril desses tempos que as leis de Lamego receberam artigos adicionais em favor da liberdade, uma prova convincente de que o heroísmo geral de um povo depende dos princípios de liberdade" ${ }^{, 89}$.

\footnotetext{
${ }^{86}$ Desde as pesquisas de Alexandre Herculano, no século XIX, a existência dessa assembleia, conhecida como as Cortes de Lamego, é questionada. As Atas das Cortes de Lamego, que afirmavam que as mulheres só poderiam transmitir direitos sucessórios para nobres portugueses, teriam sido forjadas com intenções nacionalistas, em 1641, a fim de assegurar que D. João IV fosse aclamado rei de Portugal.

87 "The government the Portuguese had experienced under the Spaniards and Moors, and the advantages which they saw were derived from their own valour, had taught them a love of liberty [...]. Alonzo himself understood their spirit too well to make the least attempt to erect himself a despotic Monarch [...]. After six years spent in farther victories, in extending and securing his dominions, he called an assembly of the prelates, nobility, and commons, to meet at Lamego. When the assembly opened, Alonzo appeared seated on the throne, but without any other mark of regal dignity. And ere he was crowned, the constitution of the state was settled, and eighteen statutes were solemnly confirmed by oath as the charter of king and people; statutes diametrically opposite to the jure divino and arbitrary power of kings, to the principles which inculcate and demand the unlimited passive obedience of the subject."

88 "Conscious of what they owed to their own valour, the founders of the Portuguese monarchy transmitted to their heirs those generous principles of liberty which compleat and adorn the martial character. The ardour of the volunteer, an ardour unknown to the slave and the mercenary, added to the most romantic ideas of military glory, characterised the Portuguese under the reigns of their first monarchs."

89 "And such was the manly spirit of these ages, that the statutes of Lamego received additional articles in favour of liberty, a convincing proof that the general heroism of a people depends upon the principles of freedom".
} 
A mesma superioridade que Mickle (1776, p. xxiii) atribui aos civilizados em relação aos "selvagens", ele confere aos portugueses em relação aos mouros ao falar sobre o governo de D. Pedro, o Justo:

As ideias de equidade e literatura foram então difundidas por esse grande príncipe, que era ele próprio um intelectual culto e um cavalheiro consumado. E Portugal começou a perceber as vantagens de talentos refinados, e a sentir a sua superioridade sobre os bárbaros governos dos ignorantes mouros. ${ }^{90}$

Percebe-se, assim, que Mickle projeta nos portugueses as qualidades que valoriza nos britânicos: o amor à liberdade, a coragem na guerra, a sabedoria, a cultura.

O perfil que Mickle (1776, pp. xxvii-xxviiii) traça do infante D. Henrique é não apenas de um grande matemático, geógrafo e astrônomo, mas também de um político de grande visão, que, estudando a história de Tiro e Cartago, percebeu a importância que o comércio havia desempenhado na Antiguidade - algo que os romanos não perceberam, destruindo as cidades, a agricultura e o comércio nas regiões que conquistavam. Nomeado comandante das forças lusitanas na África, D. Henrique mandou reconstruir, no extremo sudoeste do Algarve, a vila fortificada de Sagres, que se tornou o núcleo da expansão marítima portuguesa. A fonte citada por Mickle para esse relato é Manuel Faria e Sousa (ver CAMÕES, 1639, p. 434). D. Henrique teria impulsionado a arte de construção de navios, sugerido o uso da bússola e dos conceitos de latitude e longitude na navegação. Por essas ideias, Mickle compara D. Henrique a Bacon e a Newton.

Mickle (1776, pp. xxxi-xxxii) atribui o início do tráfico de escravos à guerra permanente contra os mouros, que eram levados como prisioneiros para Portugal. ${ }^{91} \mathrm{O}$ tradutor condena os excessos cometidos no aprisionamento dos africanos, mas também ressalta, como fatores atenuantes, a miséria em que os nativos viviam e a vontade dos portugueses de convertê-los à fé cristã.

Ao morrer, em 1463, D. Henrique havia estabelecido a rota para o mundo oriental. Mickle (1776, p. xxxiii) não poupa elogios a ele, considerando-o maior do que Alexandre:

\footnotetext{
90 "The ideas of equity and literature were now diffused by this great prince, who was himself a polite scholar, and most accomplished gentleman. And Portugal began to perceive the advantages of cultivated talents, and to feel its superiority over the barbarous politics of the ignorant Moors."

${ }^{91}$ O tráfico de escravos africanos teve início sob o comando de D. Henrique. No dia 8 de agosto de 1444, 235 africanos foram levados do Senegal para o porto de Lagos, em Portugal, e ali vendidos em um mercado improvisado. (PAGDEN, 2001, p. 102). O cronista-régio Gomes Eanes de Zurara (1410-1474) relata, em "A partilha dos escravos", na Crônica dos feitos de Guiné (Lisboa: Agência Geral das Colônias, 1949, cap. XXV, pp. 124-126), os sofrimentos desses africanos.
} 
E a ele, como seu primeiro criador, devem-se todas as inestimáveis vantagens que já advieram, ou sempre irão advir, da descoberta da maior parte da África, das Índias Orientais e Ocidentais. Toda melhoria no estado e costumes dessas regiões, ou qualquer região que venha ainda a ser descoberta, deve-se estritamente a ele; também a diferença entre o estado atual da Europa e a era monástica em que ele nasceu é resultado de seu gênio e esforço. O que é um Alexandre, coroado com troféus à frente de seu exército, comparado a Henrique contemplando o oceano de sua janela sobre o rochedo de Sagres! Um sugere a ideia do espírito maligno; o outro, a da Divindade. ${ }^{92}$

Nesse elogio a D. Henrique como maior do que Alexandre, Mickle faz uma avaliação evolutiva da translatio ocorrida do Império Grego-Helenístico para o Império Português, julgando que o desenvolvimento do comércio tornou o Império Português superior.

Ao iniciar o relato sobre a expedição enviada por D. Manuel à Índia que é o tema d' $O s$ lusíadas, Mickle (1776, p. xxxvi) dá destaque àquele que considera o herói do poema, Vasco da Gama, descrevendo a sua nomeação pelo rei em tons solenes, evocando as novelas medievais de cavalaria:

Todo o entusiasmo do desejo de cumprir a meta, acrescido do maior dos heroísmos, da mais rápida compreensão e da mais fria prudência, somaram-se para formar o caráter de Gama. [...] O rei expressou grande confiança em sua prudência e honra, e deu-lhe, com sua própria mão, a bandeira que ele deveria carregar. Diante dessa bandeira, que ostentava a cruz da Ordem Militar de Cristo, Gama, com grande regozijo por merecer as honras que the eram conferidas, prestou o juramento de fidelidade. ${ }^{93}$

Mickle (1776, pp. xxxvii-xxxix) destaca também os perigos que Vasco da Gama teria de enfrentar e sua fé cristã, que o levou a passar a noite anterior à partida rezando em uma capela. Salientando o heroísmo de Gama ao enfrentar uma tempestade durante a viagem, Mickle cita novamente os versos de "Summer", de Thomson, agora em referência ao Gama:

\footnotetext{
92 "And to him, as to their primary author, are due all the inestimable advantages which ever have flowed, or ever will flow from the discovery of the greatest part of Africa, of the East and West Indies. Every improvement in the state and manners of these countries, or whatever country may be yet discovered, is strictly due to him; nor is the difference between the present state of Europe and the monkish age in which he was born, less the result of his genius and toils. What is an Alexander crowned with trophies at the head of his army compared with a Henry contemplating the ocean from his window on the rock of Sagrez! The one suggests the idea of the evil dæmon, the other of the Deity."

93 "All the enthusiasm of desire to accomplish his end, joined with the greatest heroism, the quickest penetration, and coolest prudence, united to form the character of Gama. [...] The king expressed great confidence in his prudence and honour, and gave him, with his own hand, the colours which he was to carry. On this banner, which bore the cross of the military order of Christ, Gama, with great enthusiasm to merit the honours bestowed upon him, took the oath of fidelity."
} 
With such mad seas the daring Gama fought For many a day, and many a dreadful night, Incessant labouring round the stormy Cape, By bold ambition led. ${ }^{94}$

Mickle (1776, p. xlviii) não economiza palavras para enaltecer Vasco da Gama quando este, em Calecute, concorda com o pedido do samorim para que aproxime sua nau do porto e, tendo consciência do risco que corre, recomenda a Paulo da Gama e Nicolau Coelho que, caso seja aprisionado, não façam nada para salvá-lo, abandonem Melinde e prossigam a viagem. Mais uma vez, Mickle compara Gama a Alexandre (um símbolo, para Mickle, da coragem guerreira, enquanto Gama representaria a coragem aliada à razão e à dignidade):

Ele entregou a seu irmão Paulo e a Coelho o comando da esquadra em sua ausência; e, nas ordens que lhes deixou, demonstrou um heroísmo superior ao de Alexandre ao cruzar o Grânico. O do macedônio foi violento e frenético, fruto de ambição cruel; o de Gama foi filho da mais forte razão, gerada a partir da mais valorosa dignidade mental: era o alto orgulho da honra, um orgulho do qual pode ser absolutamente incapaz o homem que, na fúria da batalha, consegue correr para a boca de um canhão. ${ }^{95}$

\subsubsection{A história da ascensão e queda do Império Português no Oriente (1776, pp. Ivii- cviii; 1778, pp. lxix-clxxxvii)}

Ao anunciar, na parte anterior, o trecho da introdução que agora comentaremos, Mickle (1776, p. lvii) explica que resolveu escrevê-lo para que os leitores pudessem entender a “canção profética” do Canto X d'Os lusíadas. Além disso, essa história seria "da maior importância para todos os Estados comerciais, principalmente aquela nação que agora controla o comércio do Oriente" ${ }^{, 96}$. Fica claro, assim, que Mickle pretende extrair da história da ascensão e queda do Império Português no Oriente lições a serem aproveitadas pela Grã-Bretanha.

\footnotetext{
94 “Com mares tão bravios o ousado Gama lutou

Durante muitos dias e muitas noites terríveis,

Esforçando-se incessantemente por dobrar o tormentoso Cabo, Levado por destemida ambição."

95 "He gave his brother Paulus and Coello the command of the fleet in his absence; and in the orders he left them, displayed a heroism superior to that of Alexander, when he crossed the Granicus. That of the Macedonian was ferocious and frantic, the offspring of vicious ambition; that of Gama was the child of the strongest reason, begotten upon the most valorous mental dignity: It was the high pride of honour, a pride, of which the man, who in the fury of battle can rush on to the mouth of a cannon, may be utterly incapable."

96 "of the utmost importance to every commercial state, particularly to that nation which now commands the trade of the East".
} 
O ensaio descreve as Armadas da Índia enviadas por Portugal desde a primeira expedição de Vasco da Gama. A primeira delas foi a expedição de Pedro Álvares Cabral, que deveria construir um forte e uma feitoria perto de Calecute (essa é a mesma expedição que, a caminho das Índias, “descobriu” o Brasil). As primeiras negociações em Calecute pareciam auspiciosas, mas o entreposto português foi atacado e destruído. Cabral retaliou incendiando dez navios mouros que estavam ancorados e bombardeando Calecute, provocando a morte de seiscentos moradores locais. Apesar disso, Mickle (1776, p. lix) descreve as ações de Cabral em tom bastante favorável aos portugueses, dizendo que Cabral esperara uma explicação do samorim por um bom tempo até resolver atacar.

Ao relatar a segunda viagem de Gama à Índia, Mickle (1776, p. 1xi) atribui os ataques dos portugueses contra os nativos a vinganças por ataques recebidos anteriormente:

Em vingança das conspirações contra ele próprio, e dos ferimentos sofridos por Cabral, ele [Gama] castigou a cidade de Quíloa com seus canhões, e fez o rei sujeitar-se a pagar tributo a Manuel. Ao encaminhar-se para Calecute, encontrou um grande navio de Meca que havia deixado aquele porto recentemente levando muitas pessoas ilustres em peregrinação ao túmulo de seu profeta. Esse navio, após uma luta obstinada, em que trezentos mouros foram mortos, ele capturou e incendiou. E de alguns navios de Calecute, ao se aproximar daquele porto, ele recolheu cerca de trinta prisioneiros. ${ }^{97}$

Não é sempre que Mickle defende as ações dos portugueses. De modo geral, Mickle exalta os capitães, vice-reis e governadores ${ }^{98}$ que promoveram o comércio e o diálogo, guardando a tolerância em termos religiosos, e critica aqueles que buscaram auferir vantagens próprias, praticando pirataria ou cobrando tributos extorsivos; que se comportaram de modo autoritário ou demonstraram intolerância para com as religiões dos nativos. Veremos alguns exemplos a seguir para entender como Mickle constrói a sua ideia de governo ideal (que deveria ser adotado pelos britânicos) e a sua defesa da Companhia das Índias Orientais.

Um dos capitães das Armadas da Índia que é violentamente censurado por Mickle (1776, p. lxv) é Rui Lourenço Ravasco (“Roderic Ravasco” na tradução):

\footnotetext{
97 "In revenge of the plots against himself, and the injuries received by Cabral, he [Gama] battered the city of Quiloa with his cannon, and made the king submit to pay tribute to Emmanuel. As he proceeded for Calicut, he met a large ship of Mecca, which, with many people of distinction who were going on a pilgrimage to the tomb of their prophet, had lately left that harbour. This vessel, after an obstinate struggle, in which 300 Moors were killed, he took and burnt. And from some vessels of Calicut, as he approached that port, he took about thirty prisoners."

${ }_{98}$ Note-se que o título de "vice-rei" se alterna com o de "governador". Ambos se referem ao mesmo cargo, mas o título de "vice-rei" só era atribuído a membros da alta nobreza.
} 
[...] Ravasco agiu como um pirata fora da lei na costa de Zanzibar. Embora os inocentes moradores tivessem feito um tratado de paz com Gama, ele apreendeu muitos de seus navios, pelos quais extorquiu elevadas somas de resgate, e forçou o príncipe de Zanzibar a pagar um tributo anual e declarar-se vassalo de Manuel. ${ }^{99}$

Quando o capitão Tristão da Cunha chegou à Índia, a animosidade contra os portugueses havia atingido grandes proporções. A atitude desse capitão não contribuiu em nada para melhorar a situação:

No saque à cidade de Lamo, alguns dos soldados sob o comando de Cunha cortaram as mãos e orelhas das mulheres para tomarem seus braceletes e brincos com mais rapidez. Embora esses vilões, sobrecarregando os barcos com a pilhagem, tenham todos afundado, essa nódoa na reputação dos portugueses voltou-se contra o nome e os interesses dos portugueses. ${ }^{100}$ (1776, p. lxix).

Logo ao chegar a Quíloa, Francisco de Almeida, o primeiro vice-rei da Índia, marcou um encontro com o rei local. Este, supersticioso, não compareceu porque um gato preto cruzou seu caminho... Em reação, Almeida arrasou a cidade e nomeou outro rei, subordinado a D. Manuel. Francisco de Almeida retornou à Europa cumulado de glórias militares, porém Mickle (1776, p. lxx) diz que suas ações "foram contrárias ao espírito do comércio"101, e que, apesar de suas conquistas, ele deixou mais inimigos dos portugueses no Oriente do que os encontrou lá.

Caberia a seu substituto, Afonso de Albuquerque, estabelecer bases mais sólidas para o Império Português no Oriente. Mickle (1776, pp. lxxi-lxxiv) elogia bastante Albuquerque por seu comportamento generoso, que lhe valeu a estima dos comandados locais. Ao reduzir as taxas aduaneiras, Albuquerque conseguiu aumentar o comércio, dobrando os rendimentos recebidos pelo rei. Além disso, promoveu o casamento de seus soldados com mulheres nativas, o que levou a um aumento da segurança para todos. Quando necessário, Albuquerque recorria às armas, mas, segundo Mickle (p. lxxii), a sua principal preocupação era estabelecer

\footnotetext{
99 " [...] Ravasco acted as a lawless pirate on the coast of Zanzibar. Though the innocent inhabitants were in a treaty of peace with Gama, he took many of their ships, for which he extorted large ransoms, and compelled the prince of Zanzibar to pay an annual tribute and own himself the vassal of Emmanuel."

100 "At the sack of the city of Lamo, some of the soldiers under Cugna cut off the hands and ears of the women to get their bracelets and earrings with more expedition. But though these villains, by overloading their boat with their plunder, were all drowned, this stain on the Portuguese character made war against the Portuguese name and interest."

101 "were contrary to the spirit of commerce".
} 
boas relações com os príncipes indianos; dessa forma, ele conseguiu firmar tratados de comércio satisfatórios para todas as partes. Nos cinco anos de seu governo,

[...] ele não só abriu todo o mundo oriental ao comércio de Portugal como, por meio de regulamentos de seu governo humano e nobre, por meio do estabelecimento de uma estrita distribuição de justiça, assegurou seu poder em uma base que apenas a suspensão de suas medidas poderia subverter. ${ }^{102}$

Quando Albuquerque morreu, conta-nos Mickle (1776, p. 1xxiii), os príncipes indianos, que o consideravam como um pai, vestiram trajes de luto.

Lopo Soares de Albegaria, enviado por Lisboa para substituir Albuquerque, não tinha a mesma generosidade e capacidade de negociação. Com seu governo, iniciou-se um período em que o domínio português passou a ser exercido sobretudo pelas armas, o comércio sendo substituído pela pilhagem. "Quando a Corte de Lisboa enviou um Soares para substituir um Albuquerque, fez uma profecia da queda do seu império"103, diz Mickle (1776, p. lxxv). Na segunda edição, Mickle (1778, p. xcii) acrescenta, citando Faria e Sousa, que o próprio rei recebia uma parte das rendas advindas de mercadorias obtidas por pilhagens. Mickle (1778, p. xcii, itálicos do autor) aproveita para "alfinetar" os defensores dos fins dos privilégios da Companhia das Índias Orientais:

Era tão deplorável o estado do livre-comércio dos portugueses na Índia, um comércio cujas vantagens superiores, (pois vantagens superiores devem estar implicadas no argumento) têm sido recentemente apregoadas como um exemplo e prova da conveniência de retirar a concessão da Companhia Inglesa das Índias Orientais. ${ }^{104}$

Mickle deixa claro, em nota de rodapé, que está se referindo aqui ao livro A riqueza das nações, de Adam Smith. O que Mickle sugere é que retirar o monopólio da Companhia das Índias Orientais seria como autorizar a livre pirataria na Índia. Esse comentário só aparece na segunda edição porque a obra de Smith foi publicada depois da primeira edição do Lusiad.

Sobre o governo de Diogo Lopes de Sequeira, o quarto governador da Índia, Mickle (1776, p. lxxvi) comenta: “Conflitos contínuos [...] tingiram todas as praias de sangue, sem

\footnotetext{
102 " [...] he not only opened all the eastern world to the commerce of Portugal, but by regulations of his humane and exalted policy, by the strict distribution of justice which he established, secured its power on a basis, which nothing but the discontinuance of his measures could subvert."

103 "When the Court of Lisbon sent a Soarez to supercede an Albuquerk, they gave a prophecy of the fall of their empire". (Esse comentário foi retirado na segunda edição.)

104 "Such was the miserable state of the free trade of the Portuguese in India, a trade whose superior advantages, (for superior advantages must be implied in the argument) have lately been held forth as an example and proof of the expediency of depriving the English East India Company of their charter."
} 
que se pensasse em nenhum método para cultivar a amizade dos nativos hostis" ${ }^{\text {105 }}$. Sequeira impôs pelas armas o pagamento dos tributos cobrados aos nativos e muitas vezes exigiu que o valor dos tributos fosse dobrado. Mickle sentencia:

É realmente espantoso que se espere que um domínio mantido dessa forma possa durar muito tempo; que não se veja que tais vitórias tanto semearam quanto nutriram as sementes de uma guerra futura. Até os historiadores portugueses adotaram as ideias insensatas e anticomerciais de seus governadores. ${ }^{106}$

A morte de D. Manuel propicia a Mickle (1776, p. lxxvii) a oportunidade de fazer um comentário sobre a dificuldade de se governar uma colônia distante - uma observação que serve como argumento em defesa do governo da Índia pela Companhia das Índias Orientais:

Se essa história parece incriminar o governo dele, também provará como é difícil para o rei mais vigilante receber sempre informações corretas. Pois Manuel era um rei tão eminente quanto virtuoso. De grande vigilância em conselho, de grande magnanimidade na execução de todos os empreendimentos. De grande capacidade em distinguir as habilidades dos indivíduos, e naturalmente liberal na recompensa do mérito. Se um governante como Manuel errou, se a sua administração dos negócios da Îndia compromete em qualquer instância o seu governo, infira-se daí qual a precisão, em termos de coleta de informações, que é necessária para o bom governo de uma colônia distante. ${ }^{107}$

As queixas sobre a má administração na Índia chegaram às Cortes de Lisboa, e Vasco da Gama foi nomeado vice-rei, em virtude de seu prestígio e capacidade de comando. Porém Gama veio a falecer com apenas três meses no cargo.

Uma das guerras brutais travadas entre os portugueses e os habitantes nativos envolveu o sultão de Guzarate (Cambaia), Bahadur, que Mickle diz ser "uma daquelas figuras horrendas que são comuns na história oriental"108. Após relatar as crueldades de uma guerra travada entre Bahadur e os mogóis, Mickle (1776, p. lxxxvii, maiúsculas do autor) faz,

\footnotetext{
105 "Continual Skirmishes [...] dyed every shore with blood, while no method of cultivating the friendship of the hostile natives was thought of".

106 "It is truly astonishing how men should expect that dominion thus supported should continue long; that they could not see that such victories both sowed and nourished the seeds of future war. Even the Portuguese historians adopted the impolitical uncommercial ideas of their governors."

107 "If this history seem to arraign his government, it will also prove how difficult it is for the most vigilant king always to receive just intelligence. For Emmanuel was both a great and a good king. Of great vigilance in council, of great magnanimity in the execution of all his enterprizes: Of great capacity in distinguishing the abilities of men, and naturally liberal in the reward of merit. If such a prince as Emmanuel erred, if his administration of Indian affairs in any instance arraign his policy, let it thence be inferred, what exactitude of intelligence is necessary to the happy government of a distant colony."

108 "one of those horrid characters common in oriental history".
} 
novamente, a defesa do domínio europeu para pôr um fim às atrocidades cometidas no Oriente:

\begin{abstract}
Nesta visão resumida das políticas sombrias e bárbaras, a perfídia desavergonhada, e as guerras devastadoras do sultão Bahadur, do sultão de Delhi, e de Hidalcão, temos uma completa epítome da história da Índia. Século após século contendo apenas uma repetição das mesmas mudanças de políticas, as mesmas destruições e as mesmas torrentes de sangue derramado. E quem pode contemplar um quadro tão horrendo sem perceber os benefícios inestimáveis que PODEM SER DIFUNDIDOS no Oriente por um forte povoamento de europeus, benefícios que a política correta, que o próprio interesse deles exige que lhes sejam dados, que têm sido dados em parte, e com certeza serão um dia amplamente difundidos. ${ }^{109}$
\end{abstract}

Mickle (1776, p. lxxxviii) - um defensor das políticas de tolerância religiosa - elogia o comportamento do governador Nuno da Cunha, que obteve um acordo de paz com Bahadur:

Acima da intolerância, ele não recorreu à Bula Papal em busca dos fundamentos de autoridade. O livre exercício das religiões maometanas e brâmanes foi permitido em todos os territórios portugueses, e não apenas as leis e os funcionários nomeados, mas até mesmo as pensões dadas pelo sultão Bahadur foram mantidas. ${ }^{110}$

Sob o governo de Martim Afonso de Sousa, a tolerância religiosa foi eliminada, dando lugar a perseguições. Os templos de Malabar foram incendiados. Mickle (1776, p. xci), naturalmente, condena essas ações: "Isso os historiadores portugueses mencionam como o maior mérito da piedade de seus compatriotas, ignorando o ódio que tal crueldade certamente desperta em relação à religião que a inspira [...]"111 .

Mickle (1776, p. xciii) chama D. João de Castro de "grande homem", relata a sua luta para restaurar a justiça e conta que ele morreu pobre, ao contrário da maioria dos governantes portugueses. Na primeira edição, Mickle menciona ainda Garcia de Sá, que conseguiu fechar

\footnotetext{
109 "In this abridged view of the dark barbarous politics, unblushing perfidy, and desolating wars of king Badur, the king of Delhi, and the Hydal Can, we have a complete epitome of the history of India. Century after century contains only a repetition of the same changes in policy, the same desolations, and the same deluges of spilt blood. And who can behold so horrid a picture without perceiving the inestimable benefits which MAY BE DIFFUSED over the East by a potent settlement of Europeans, benefits which true policy, which their own interest demand from their hands, which have in part been given, and certainly will one day be largely diffused." 110 "Superior to bigotry, he did not look to the Pope's Bull for the foundation of authority. The free exercise of the Mohammedan and Brahmin religions was permitted in every Portuguese territory, and not only the laws, the officers appointed, but even the pensions given by king Badur, were continued."

111 "This the Portuguese historians mention as the greatest honour of the piety of their countrymen, ignorant of the detestation which such cruelty must certainly bring upon the religion which inspires it [...]".
} 
vários acordos de paz, e diz que aí "se encerra a canção profética de Camões"112. Na segunda edição, contudo, Mickle (1778, p. cxix) corrige essa menção transferindo-a para o final do relato sobre D. João de Castro, antes de falar sobre Garcia de Sá: “Com o elogio a Castro, Camões conclui sua canção profética, e aqui também termina o mais glorioso período do Império Português na Ásia" ${ }^{113}$.

A crônica de Mickle prossegue, no entanto. A primeira e a segunda edição divergem a partir desse ponto, sendo a segunda edição ampliada e bem mais detalhada. De qualquer forma, tanto na primeira quanto na segunda edição prosseguem os relatos de escaramuças, pilhagens e guerras. Sobre a atitude dos governantes portugueses, diz Mickle (1778, p. cxxvi) na segunda edição:

A rapina de indivíduos se tornou mais impudente e geral a cada ano. Enquanto uma devoção idólatra a santos e imagens os tornava implacáveis na crueldade para com aqueles de devoções diferentes, eles se abandonavam sem reservas aos prazeres mais obscenos, e todos os funcionários tinham o seu harém de cinco, seis ou oito das mais belas mulheres. As mulheres indianas da nobreza eram publicamente arrancadas do seio de sua família por estupradores portugueses. ${ }^{114}$

A partir da página cxxxiii, a segunda edição passa a coincidir novamente com a primeira (p. xcv) durante algumas páginas. Nesse ponto da narrativa, Mickle (1776, p. xcv) lembra as denúncias de Camões e, atribuindo mais uma vez aos portugueses qualidades que remetem aos mitos e características nacionais britânicas (origem nacional no espírito de cavalaria, ideias de liberdade, monarquia constitucional), sintetiza:

Quando os erros do governo começam, os sábios veem a doença secreta, mas é a geração seguinte que sente os piores efeitos. Camões, cujo entendimento político era, talvez, inigualado em sua época e país, viu a decadência dos costumes e prognosticou, em vão, a queda do império. Portugal devia a sua existência ao espírito de cavalaria e às ideias de liberdade, que foram confirmadas pelas leis de Lamego. ${ }^{115}$

\footnotetext{
112 "Here Camões ends his prophetic song [...]".

113 "With the eulogium of Castro, Camoens concludes his prophetic song, and here also the most glorious period of the Portuguese empire in Asia terminates".

114 "The rapine of individuals became every year more shameless and general. While an idolatrous devotion to saints and images rendered them inexorable in their cruelty to those of a different worship, they abandoned themselves without restraint to the most lascivious luxury, and every officer had his seraglio of five, six or eight of the finest women. Indian women of quality were publickly dragged from their kindred by Portuguese ravishers."

115 "When errors in government begin, the wise see the secret disease, but it is the next generation that feels the worst of its effects. Camoens, whose political penetration was perhaps unequalled in his age and country, saw the declension of manners, and foretold in vain the fall of empire. Portugal owed its existence to the spirit of chivalry and the ideas of liberty, which were confirmed by the statutes of Lamego."
} 
Para sustentar sua opinião, Mickle (1776, p. xcvi) cita a caracterização dos cortesãos portugueses feita por Camões em Os lusíadas:

[...] each, for some base interest of his own,

With Flattery's manna'd lips assail the throne. ${ }^{116}$

Depois desse ponto, a segunda edição (p. cxxxiv) volta a conter mais detalhes do que a primeira. Mickle descreve a decadência do Império Português no Oriente à medida que os governantes se sucedem. Sob o governo de D. Duarte de Meneses, com Portugal já sob o domínio espanhol, é criada a Companhia Portuguesa das Índias Orientais, que recebeu o privilégio exclusivo de comerciar com a Índia (MICKLE, 1778, pp. cxxxvii-cxxviii).

Sobre a Companhia Holandesa das Índias Orientais, fundada em 1602, diz Mickle (1778, p. cxxxix): “[...] uma instituição de profunda sabedoria comercial: uma máquina metódica, interligada em todas as suas operações, e o exato oposto daquele monstro cego, aquele Pólipo dividido, a anarquia despótica portuguesa"117. De acordo com o tradutor, apesar do combate dos portugueses, o comércio holandês prosperou na Índia, sendo bem recebido pelos povos locais, que a essa altura odiavam os portugueses.

Quatro anos após a chegada dos holandeses, os ingleses também apareceram na Índia, onde Sir James Lancaster fundou várias feitorias a partir de 1601.

A Espanha praticamente abandonou o Império Português no Oriente à sua sorte. No vice-reinado de D. Jerônimo de Azevedo a situação chegou a tal ponto que o vice-rei recebeu ordens para distribuir todos os cargos públicos em leilão, a fim de arrecadar dinheiro para o governo. Mickle (1776, p. c) conclui:

Não precisamos acrescentar mais nenhuma informação. A história da queda do Império Português completa-se aqui. Depois tudo foi uma rápida decadência. A sucessão de governadores continuou, e ainda continua; mas de todas as numerosas colônias em todas as costas do mundo oriental, apenas os portos de Goa e Diu na Índia, e a ilha de Macau, na baía de Cantão, permanecem em posse dos portugueses. ${ }^{118}$

\footnotetext{
${ }^{116}$ No original:

"Vê neles que não têm amor a mais

Que a si somente, e a quem Filáucia ensina." (IX, 27)

117 " [...] an institution of deep commercial wisdom: a regular machine, connected in all its operations, and the very reverse of that blind monster, that divided Polypus, the Portuguese despotical anarchy"

118 "We now need add no circumstance more. The history of the fall of the Portuguese empire is here complete. Every thing after was headlong declension. A succession of governors continued, and still continue; but of all their numerous settlements on every coast of the eastern world, the ports of Goa and Diu in India, and the isle of Macao in the bay of Canton, only remain in the possession of the Portuguese."
} 
Na segunda edição, Mickle (1778, pp. clii-cliii) prossegue relatando os acontecimentos durante o vice-reinado de Nuno Álvares Botelho e do Conde de Linhares e, depois, em 1640, a libertação de Portugal do domínio espanhol. A rivalidade dos comerciantes portugueses com os holandeses e, depois da Guerra Civil na Inglaterra, com os ingleses fez com que o governo português passasse a se dedicar mais ao Brasil e negligenciasse os assuntos da Índia.

Na primeira edição, Mickle (1776, p. ci) inicia uma nova parte no ensaio para discutir algumas das ideias expostas pelo autor da Histoire des deux Indes (na segunda edição Mickle cita o autor, abade Raynal, pelo nome, mas esse trecho é interrompido e só continua ao final do ensaio). Raynal afirmara que "enquanto a Corte de Lisboa planejava o descobrimento da Índia e esperava riquezas inesgotáveis, os mais moderados e esclarecidos previram e predisseram os males que se seguiriam ao sucesso"119. Mickle $(1776$, p. ci) considera essa opinião equivocada, já que aqueles que haviam sido contrários à viagem do Gama estavam longe de ser "mentes esclarecidas". As objeções eram que os portugueses só encontrariam desertos; que a viagem era longa demais para ser rentável; que o acesso a novas riquezas traria uma degeneração de costumes fatal ao reino; que o estabelecimento de povoações no exterior levaria ao despovoamento e abandono da agricultura em Portugal; e que, se era necessário estabelecer colônias, a África estava muito mais perto e seria muito mais adequada. Não foram esses males, diz Mickle, que levaram à decadência do Império Português, e sim a pirataria, a pilhagem e o mau governo exercido pelos portugueses na Índia.

O que Mickle quer desmentir é a asserção de que os britânicos sofrerão o mesmo destino dos portugueses na Índia. Para isso, ele se propõe a identificar as causas da queda do Império Português.

Para Mickle (1776, p. cii), o bem mais importante que as colônias podem proporcionar não são as minas de ouro, mas a possibilidade de aumentar a população do país, o que só pode ser obtido pelo crescimento do emprego. Essa era uma visão tipicamente mercantilista, segundo a qual quanto maior fosse a população de um país, mais gente haveria para trabalhar na manufatura e servir ao exército. Ainda segundo Mickle, os artigos mais necessários para um país deveriam ser produzidos "em casa”, com o aperfeiçoamento da agricultura. Na visão de Mickle, a agricultura e o comércio não se opõem, mas se completam. As colônias serviriam fundamentalmente para a exportação de artigos manufaturados e a importação de bens primários. O problema de Portugal e da Espanha, na análise de Mickle, é que essas nações não fizeram isso; não estabeleceram comércio com as colônias.

\footnotetext{
119 "while the court of Lisbon projected the discovery of India, and expected inexhaustible riches, the more moderate and enlightened foresaw and foretold the evils which would follow success".
} 
Além disso, prossegue Mickle (1776, pp. cii-ciii), o território de Portugal era pequeno demais para que o país pudesse sediar um império extenso. Um domínio permanente precisava ser assegurado por tropas sediadas na colônia. As guarnições portuguesas no Brasil, na África e na Ásia exigiam mais equipamentos do que a sede do império podia fornecer sem prejudicar sua própria defesa.

Quanto ao risco da degeneração de costumes em razão do aumento da riqueza, Mickle (1776, p. cliii) sugere que isso pode ser controlado por um governo que estabeleça o mérito como a única forma válida de promoção. Nessa questão, Mickle (1776, p. cv) adverte que todo cuidado é pouco, e que a Companhia Britânica das Índias Orientais deveria atentar para as lições da história portuguesa. As consequências nefastas para o comércio advindas de guerras provocadas por motivos injustos ou mesquinhos e a autodestruição promovida pelo domínio despótico são, de acordo com Mickle, as principais causas da destruição de um império comercial exemplificadas na história de Portugal na Ásia.

Na segunda edição, Mickle (1778, p. clvi) acrescenta:

O comércio da Índia é do mais essencial valor para a nação britânica. Por meio dos bens indianos distribuídos pela Europa, o equilíbrio essencial de comércio se mantém a nosso favor. Mas se o comércio com a Índia deve ser efetuado por uma Companhia Exclusiva, ou deixado aberto a qualquer aventureiro, é a questão do momento, uma questão da maior relevância para o Império Britânico. E para essa questão o exemplo dos portugueses é de primeira importância. ${ }^{120}$

Na primeira edição, o ensaio se encerra com a defesa de Mickle (1776, pp. cvii-cviii, maiúsculas do autor) do sistema legal britânico, indispensável para dar sustentação ao comércio: "Uma predominância essencial decisiva da justiça de leis como as britânicas pode, por si só, assegurar a prosperidade do mais poderoso sistema comercial, ou tornar a sua existência VANTAJOSA ou mesmo SEGURA para a sede do Império" ${ }^{121}$.

Na segunda edição, Mickle faz uma breve recapitulação de todo o ensaio, ressaltando o aspecto aventureiro da exploração da Índia pelos portugueses. A falta de políticas sólidas e contínuas de comércio, amparadas na lei, teria gerado uma anarquia e pirataria generalizadas.

\footnotetext{
120 "The commerce of India is of most essential value to the British nation. By the Indian goods distributed over Europe, the essential balance of trade is preserved in our favour. But whether the Indian commerce should be conducted by an Exclusive Company, or laid open to every Adventurer, is the question of the day, a question of the first importance to the British empire. And to this question the example of the Portuguese is of the first consequence."

121 "An essential decisive predominancy of the justice of laws like the British, can alone secure the prosperity of the most powerful commercial system, or render its existence ADVANTAGEOUS or even SAFE to the seat of Empire".
} 
A seguir, sob o título "The APPLICATION" [A APLICAÇÃO], Mickle (1778, pp. clxiclxxxvi) rebate algumas das ideias expostas em A riqueza das nações por Adam Smith, um dos maiores defensores da abolição do monopólio da Companhia das Índias Orientais.

Segundo Mickle, os argumentos de Smith podem ser reduzidos a quatro pontos:

I. Empresas exclusivas são perniciosas em todos os aspectos.

II. No comércio dos portugueses na Índia, durante mais de um século, não houve uma companhia exclusiva, o que prova que tal monopólio é desnecessário.

III. Com o livre-comércio, os mercadores se estabeleceriam na Índia a seu bel-prazer, e o comércio se ajustaria naturalmente.

IV. Em caso de necessidade, fortalezas e guarnições militares deveriam ser fornecidas pelo soberano.

Respondendo ao primeiro e ao segundo pontos, em uma abordagem histórica, que remonta às hansas medievais, Mickle (1778, p. clxii) lembra que o monopólio foi, em outros tempos, a única forma de dar amparo a um comércio nascente, e que funcionou muito bem e produziu altos rendimentos. De acordo com Mickle (1778, p. clxiv), um soberano que deseje comerciar com regiões distantes, como a Índia, tem apenas duas opções: conceder privilégios exclusivos a uma companhia ou gastar fortunas construindo fortalezas e enviando soldados e esquadras de guerra todos os anos. Caso se escolha a segunda alternativa, outras duas opções se apresentam: reservar o monopólio do comércio à Coroa ou liberar o comércio a todos os súditos. Para lidar com o comércio na Índia, os holandeses e ingleses escolheram companhias exclusivas, enquanto os reis portugueses adotaram o monopólio da coroa. Smith menciona o fato de Portugal não ter utilizado uma companhia exclusiva como um argumento contra a necessidade das companhias exclusivas; Mickle responde que Smith parece desconhecer que as relações comerciais desenvolvidas por Portugal na Índia foram um completo desastre.

Quanto ao terceiro ponto, Mickle (1778, pp. clxv-clxvi) lembra os argumentos de Smith no Capítulo 4 de $A$ riqueza das nações, segundo os quais, quando um país ainda não está maduro para o comércio com uma região distante, é melhor que compre os bens de que necessita em locais mais próximos, mesmo que precise pagar mais caro; por outro lado, quando um país está maduro para tal comércio, este poderá se dar livremente, sem companhias exclusivas. Ora, pergunta Mickle, se os portugueses, holandeses e ingleses houvessem esperado até alcançar tal maturidade, não teriam nem pisado na Índia. A necessidade de fortalezas e tropas militares na Ásia era, ainda, uma realidade - e Smith o reconhecia, tanto que esse era o tema de seu quarto ponto. Na Índia, os comerciantes não poderiam ser deixados desprotegidos. 
Mickle (1778, pp. clxx-clxxii) alerta, então, para o fato de que um território hostil, de vasta extensão, governado por tropas e funcionários de um soberano distante, como no plano proposto por Smith, é algo extremamente similar ao plano português. Por que se deveria esperar que funcionários enviados pelo rei a lugares tão distantes não incorressem nos mesmos desvios imputados por Smith à Companhia das Índias Orientais, cedendo às tentações de extorsão, pilhagem e tirania? Além disso, pergunta Mickle (itálicos do autor), "Será desejo dos residentes fixos exportar uma renda, ou cuidar disso?",122

Mickle (1778, pp. clxxiii-clxxiv) enfatiza as elevadas rendas obtidas pela Companhia das Índias Orientais para o reino britânico e pergunta se valeria a pena destruir tudo isso em troca de uma teoria não comprovada; de um sistema de livre-comércio que proporcionaria menos rendas; um sistema de instalação complexa e demorada, e que tornaria o soberano "o déspota militar de um território rico e imenso" ${ }^{" 123}$. Mickle (1778, p. clxxiii) cita, em nota de rodapé, um trecho do panfleto Thoughts on our acquisitions in the East Indies, de seu parente e benfeitor, o Governador Johnstone (depois Comodoro Johnstone): "Com o progresso da sociedade, muitas vezes escoras e contrapesos adicionais tornar-se-ão necessários. Isso de demolir todo um edifício para erguer um novo prédio geralmente termina com a destruição da comunidade, e sempre leva a convulsões que ninguém pode prever"124.

Para corrigir eventuais erros no sistema, Mickle (1778, p. clxxx) propõe a instituição de inspeções e, quando necessárias, correções. O Parlamento Britânico teria poder constitucional para efetuar tais inspeções e correções.

Mickle encerra a segunda edição retomando o debate com o abade Raynal conforme se encontra na primeira edição, e que já comentamos acima.

\subsubsection{A vida do autor (1776, pp. cviii-cxxi; 1778, pp. clxxxvii-cxcix)}

A biografia de Camões redigida por Mickle foi, durante muitos anos, a principal fonte sobre Camões na Grã-Bretanha. Vários periódicos da época a reproduziram integral ou parcialmente. ${ }^{125} \mathrm{~A}$ influência dessa biografia não se esgota na mera reprodução literal de seu

\footnotetext{
122 "Will it be the desire of fixed Residents to export a revenue, or to be careful of it?"

123 "the military Despot of an immense and rich territory".

124 "In the progress of society, addicional props and balances will often become necessary. That of pulling down a whole edificie, to erect a new building, generally ends in the destruction of the community, and always leads to convulsions which no one could foresee".

${ }^{125}$ As nossas pesquisas resultaram em uma interessante descoberta: em 1778, quando do lançamento do terceiro volume da segunda edição (1777-1784) da Enciclopédia Britânica - filha do Iluminismo Escocês, como comentamos no Capítulo 3 -, a "Life of Camoens" de Mickle foi incluída (sem nenhum crédito ao autor) como o
} 
conteúdo, pois, em virtude de sua ênfase nos aspectos heroicos e sentimentais, ela constituirá a base da imagem de Camões que será cultuada na Grã-Bretanha ao longo do século XIX, especialmente durante o Romantismo.

Mickle (1776, p. cviii) inicia a biografia de Camões em um tom extremamente depreciativo em relação à cultura portuguesa: "Quando a glória das armas de Portugal atingiu o seu esplendor culminante, a Natureza, como que com pena da rudeza literária daquela nação, produziu um grande poeta para registrar as inúmeras ações de espírito elevado executadas por seus compatriotas"

O importante para Mickle no surgimento de Camões é que "É da natureza peculiar da poesia dar um colorido a ações heroicas e expressar indignação contra quebras da honra, em um espírito que simultaneamente cativa o coração do homem de sentimentos e carrega consigo uma condenação instantânea"127. Mickle destaca, em suma, o poder da poesia de ressaltar o valor ético das ações e de despertar a indignação - o papel moral e político da poesia, ligado ao seu poder retórico.

Baseando-se em declarações de Nicolau António e Manuel Correia, que teriam sido amigos de Camões, Mickle (1776, p. cviii) diz que Camões teria nascido em 1517. (Atualmente os historiadores indicam 1524 ou 1525 como ano de nascimento de Camões.)

Mickle (1776, p. cix) afirma que Camões foi educado na Universidade de Coimbra (algo de que não existe nenhuma comprovação) e lhe atribui um grande conhecimento dos clássicos: "O que ele adquiriu lá as suas obras revelam; uma intimidade com os clássicos igual

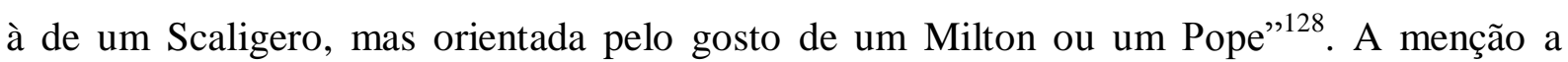
Milton e Pope procura valorizar Camões e alçá-lo ao nível dos dois poetas mais apreciados na época de Mickle.

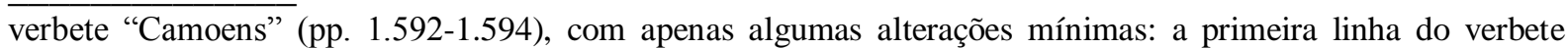
difere do texto de Mickle; o último parágrafo da página cxi e o terceiro da página cxiv foram omitidos; e o verbete se encerra no meio do segundo parágrafo da página cxvi da "Life of Camoens" de Mickle. O verbete foi republicado sem alterações até a sexta edição. Na sétima edição, publicada entre 1830 e 1842, foi acrescentado um parágrafo ao final, mas o restante do texto continuou inalterado. Na oitava edição, de 1854 (Vol. 6), o texto sofreu algumas modificações, mas a base do relato ainda era a de Mickle. Na nona edição (1875) e nas seguintes o verbete foi completamente reescrito, não guardando mais semelhanças significativas com a biografia redigida por Mickle.

126 "When the glory of the arms of Portugal had reached its meridian splendour, Nature, as if in pity of the literary rudeness of that nation, produced a great poet to record the numberless actions of high spirit performed by his countrymen".

127 "It is the peculiar nature of poetry to give a colouring to heroic actions, and to express indignation against breaches of honour, in a spirit which at once seizes the heart of the man of feeling, and carries with it instantaneous conviction".

128 "What he acquired there his works discover; an intimacy with the classics, equal to that of a Scaliger, but directed by the taste of a Milton or a Pope". 
Ao mencionar a primeira missão de Camões ao chegar à Índia, Mickle (1776, p. cxi, itálicos do autor) revela a sua falta de compreensão da ironia camoniana, ou uma falta de conhecimento do poema mencionado:

Quando Camões chegou à Índia, uma expedição já estava preparada para zarpar a fim de vingar o rei de Cochim em sua luta contra o rei da Pimenta. Sem qualquer descanso ao desembarcar depois da longa viagem, ele juntou-se a essa tropa e, na conquista das ilhas Alagadas, exibiu sua bravura costumeira. Mas a modéstia talvez seja o que nele é mais louvável. Em um soneto, ele menciona essa expedição: Fomos punir o rei da Pimenta, diz ele, e succedeones bem [sic]. Quando se considera que o Poeta cumpriu uma parte relevante na vitória, nenhuma ode pode ser concluída com mais elegância e de forma mais adequada do que essa. ${ }^{129}$

Sem nos preocuparmos em corrigir o português de Mickle, gostaríamos de observar que não é em um soneto que Camões menciona essa expedição, mas na elegia "O poeta Simónides falando", na qual o Poeta comenta, em tom moral ("Vi quanta vaidade em nós se encerra, e dos próprios quão pouca”) e sarcástico, o caráter desigual da batalha travada contra os nativos (os "próprios"). Portanto, não é exatamente modéstia que Camões demonstra nessa elegia, mas uma espécie de revolta, de indignação impotente, que ele extravasava pela ironia. ${ }^{130}$ Aliás, logo em seguida Mickle menciona que, alguns anos depois, sob o vice-reinado de Francisco Barreto, Camões teria sido banido para a China por escrever sátiras. (Não há informações seguras a respeito desse banimento, nem se sabe com certeza se Camões sofreu realmente um banimento ou se foi para a China em virtude de uma nomeação.)

Mickle (1776, p. cx) procura ressaltar os aspectos da biografia de Camões que hoje chamaríamos de "românticos": a vida aventureira, as campanhas militares - sempre ao lado da atividade poética:

[...] nem a urgência do serviço efetivo nem a intemperança do acampamento puderam sufocar-lhe o gênio. Ele continuou seus Lusíadas, e vários dos seus mais belos sonetos foram escritos na África, tendo, como ele diz

Numa mão sempre a espada, e noutra a pena. ${ }^{131}$

\footnotetext{
129 "When Camoens arrived in India, an expedition was ready to sail to revenge the king of Cochin on the king of Pimenta. Without any rest on shore after his long voyage, he joined this armament, and in the conquest of the Alagada islands, displayed his usual bravery. But his modesty, perhaps, is his greatest praise. In a sonnet he mentions this expedition: We went to punish the king of Pimenta, says he, e succedeones bem, and we succeeded well. When it is considered that the Poet bore no inconsiderable share in the victory, no ode can conclude more elegantly, more happily than this."

${ }^{130}$ Ver trecho já citado dessa elegia na nota 5 do Capítulo 2.

131 “" [...] neither the hurry of actual service nor the dissipation of the camp could stifle his genius. He continued his Lusiadas, and several of his most beautiful sonnets were written in Africa, while, as he expresses it One hand the pen, and one the sword employ'd".
} 
Nesse espírito "romântico", Mickle (1776, p. cxii) reconta a história lendária do naufrágio no Mecom, em que Camões teria conseguido salvar seus poemas segurando-os em uma mão enquanto nadava com a outra.

Quando, enfim, Camões conseguiu voltar a Lisboa, encontrou a cidade infestada pela peste. Só três anos depois conseguiu publicar Os lusíadas. Dedicou-os, diz Mickle (1776, p. cxiv), "em um cumprimento muito elegante" ${ }^{132}$, ao jovem rei Sebastião, então com 18 anos. A fonte citada aqui é Castera, o tradutor francês da edição pela qual Mickle teve acesso pela primeira vez ao épico camoniano em sua juventude:

O rei, diz o tradutor francês, ficou tão satisfeito com suas virtudes que concedeu ao Autor uma pensão de quatro mil réis, sob a condição de que ele residisse na Corte. Mas a pensão, diz o mesmo escritor, foi cancelada pelo Cardeal Henrique, o sucessor no trono de Portugal, perdido por Sebastião na batalha de Alcácer. ${ }^{133}$

Mickle incorre aqui em alguns enganos. Há muitas informações contraditórias sobre essa pensão, mas o texto do alvará parece deixar claro que essa tença anual (no valor de 15 mil réis por três anos) foi concedida tanto pelo "engenho e habilidade" e "suficiência" demonstrados pelo poeta em Os lusíadas quanto pelos serviços prestados à Coroa na Índia como soldado:

Eu elrei faço saber aos que este aluara virem que avendo respeito ao serviço que luís de camões caualeyro fidalgo de minha casa me tem feyto nas partes de India por muitos annos e aos que espero que ao diante me fara e a Informação que tenho de seu engenho e habellidade, e a sufficiencia que mostrou no liuro que fez das cousas da Indya, ey por bem e me praz de lhe fazer merce de quynze mil reis de tença em cada hum anno, por tempo de tres annos somente que começarão de doze dias do mes de março deste anno presente de mil quinhentos setenta e dous em diante [...] (Apud GARRETT, 1863, pp. 260-261).

A tença foi renovada em 1575, novamente em 1578 e, depois da morte de Camões, ainda uma vez, em 1582, para que a mãe dele pudesse recebê-la. No entanto, depois de transmitir a opinião de Castera, Mickle (1776, p. cxiv) insiste:

\footnotetext{
132 "in a most elegant turn of compliment".

133 "The king, says the French translator, was so pleased with his merit, that he gave the Author a pension of 4000 reals, on condition that he should reside at court. But the salary, says the same writer, was withdrawn by Cardinal Henry, who succeeded to the crown of Portugal, lost by Sebastian at the battle of Alcazar."
} 
Mas essa história da pensão é muito incerta. Correa e outros autores contemporâneos não a mencionam, ainda que alguns escritores recentes tenham dado crédito a ela. Se Camões, todavia, recebia uma pensão, é altamente provável que Henrique o tenha privado dela. Enquanto Sebastião se dedicava à caça, seu tio-avô, o Cardeal, presidia o Conselho, e Camões, no discurso ao rei que encerra Os lusíadas, aconselha-o a excluir o clero dos assuntos de Estado. ${ }^{134}$

Mickle narra a morte de Camões em tons melodramáticos e de forte apelo moral. Conta que Camões morreu na miséria, sem nem mesmo a proteção de um abrigo para pobres, e que seu escravo javanês pedia esmolas nas ruas para ele. Mickle (1776, p. cxv) associa o destino de Camões à decadência de Portugal:

Aos olhos de um observador atento, o destino de Camões lança fortes luzes sobre o de seu país, e parecerá rigorosamente conectado a ele. A mesma ignorância, o mesmo espírito degenerado que sujeitou Camões a depender de esmolas recolhidas nas ruas por seu velho escravo, o mesmo espírito que causou essa situação, afundou o reino de Portugal na mais abjeta sujeição já experimentada por uma nação conquistada. ${ }^{135}$

Mickle (1776, p. cxvi) cita, então, dois trechos de cartas que Camões teria escrito antes de morrer - ambos mencionados por Juromenha (1860, pp. 126-127 e p. 506, nota 71). $\mathrm{O}$ primeiro é "Em fim, accaberey à vida, e verràm todos que fuy afeiçoada a minha patria, \&tc." [sic] ${ }^{136}$. O segundo trecho é citado apenas em inglês, mas transcreveremos aqui o original, na grafia com que foi publicada por Juromenha (p. 127): "Quem ouviu dizer que em tão pequeno theatro, como o de um pobre leito, quizesse a fortuna representar tão grandes desventuras! E eu, como se ellas não bastassem, me ponho ainda da sua parte, porque

\footnotetext{
134 "But this story of the pension is very doubtful. Correa, and other contemporary authors, do not mention it, though some late writers have given credit to it. If Camoens, however, had a pension, it is highly probable that Henry deprived him of it. While Sebastian was devoted to the chace, his grand uncle, the Cardinal, presided at the council board, and Camoens, in his address to the king, which closes the Lusiad, advises him to exclude the clergy from state affairs."

135 "To the eye of a careful observer, the fate of Camoens throws great light on that of his country, and will appear strictly connected with it. The same ignorance, the same degenerate spirit, which suffered Camoens to depend on his share of the alms begged in the streets by his old hoary servant, the same spirit which caused this, sunk the kingdom of Portugal into the most abject vassalage ever experienced by a conquered nation."

${ }_{136}$ Doente, vítima da peste que assolava Lisboa, Camões teria escrito ao amigo, capitão D. Francisco de Almeida, uma carta da qual só teria restado um fragmento - publicado pela primeira vez na edição de 1626 de Os lusíadas, editada por Craesbeeck - aludindo às ameaças à independência nacional: "Enfim, acabarei a vida e verão todos que fui tão afeiçoado à minha Pátria que não só me contentei de morrer nela, mas com ela". Mickle parece ter copiado a citação de Castera (CAMÔES, 1735, Tome 1, p. lxiv), mas acrescentou alguns erros tipográficos e não considerou necessário citar a frase toda em português. Como em seguida ele a traduz para o inglês na íntegra, achamos por bem reproduzir aqui o original, em ortografia atual. Não há, contudo, provas de que essa carta tenha sido escrita.
} 
procurar resistir a tantos males, pareceria especie de desvergonhamento". ${ }^{137}$

Mickle (1776, p. cxvii) desculpa os defeitos que outros escritores (ele não cita nenhum autor específico) criticam em Camões atribuindo-os a infelicidades que o destino teria colocado no caminho do bardo lusitano. Reforça, assim, o estereótipo (que, mais uma vez, diríamos "romântico") do poeta com um destino infeliz, ao mesmo tempo em que acrescenta, em um comentário tipicamente neoclássico, aproximando Camões, como um novo Virgílio, da era augustana:

[...] quando todas as causas forem consideradas, as desventuras de Camões mostrar-se-ão como culpa e desonra de sua época e país, e não do homem. Seus talentos ter-lhe-iam assegurado um quarto no palácio de Augusto, mas tais talentos são uma maldição para seu possuidor em uma nação iletrada. ${ }^{138}$

Mickle (1776, p. cxxi) conclui a biografia de Camões com uma defesa das virtudes da poesia, citando John Milton, segundo o qual "um verdadeiro gosto pela boa poesia dá refinamento e energia a todos os outros estudos, e é de suprema importância para a formação do senador e do cavalheiro"

\subsubsection{Dissertação sobre Os lusíadas e observações sobre a poesia épica (1776, pp. cxxi- cxlviii; 1778, pp. cxcx-ccxxii)}

Nesse ensaio Mickle responde às críticas dirigidas por Voltaire a Os lusíadas em seu ensaio sobre a poesia épica, o Essay upon the Epick Poetry of the Europeen Nations from Homer to Milton, publicado em inglês em 1727 e em francês, em versão revisada, em 1733, com o título Essai sur la poésie épique, que já mencionamos no Capítulo 2, em 2.6.2.5.

Já de início, Mickle (1776, p. cxxi) lança a hipótese de que muitos dos equívocos de Voltaire se devem ao fato de o filósofo francês ter lido Os lusíadas na tradução "impudente, rude, apoética" de Fanshawe. ${ }^{140}$

\footnotetext{
${ }^{137}$ Nessa mesma obra, no volume V (posterior), Juromenha (1866, p. 237) reúne esses dois fragmentos como parte de uma mesma carta: "Quem ouvio dizer nunca que em hum tão pequeno leito, quizesse a fortuna representar tão grandes desaventuras? E eu como se ellas não bastassem me ponho ainda da sua parte; porque procurar resistir a tantos males, pareceria especie de desavergonhamento. E assi acabarei a vida, e verão todos que fui tão affeiçoado à minha patria, que não sòmente me contentei de morrer n'ella, mas de morrer com ella". 138 " $[. .$.$] when all the causes are weighed together, the misfortunes of Camoens will appear the fault and disgrace$ of his age and country, and not of the man. His talents would have secured him an apartment in the palace of Augustus, but such talents are a curse to their possessor in an illiterate nation."

139 "a true taste for the great poetry gives a refinement and energy to all other studies, and it's of the last importance in forming the senator and the gentleman".

140 "'"bold, harsh, unpoetical version of Fanshaw."
} 
Considerando, acertadamente, que o ensaio de Voltaire, embora cheio de equívocos, era encarado na maioria dos países europeus como uma avaliação acurada d'Os lusíadas, Mickle (1776, p. cxxi) se propõe a refutá-lo ponto a ponto. Isso era necessário não apenas para prestigiar e valorizar o trabalho de Camões, demonstrando a filiação clássica e "decoro" do poema a fim de facilitar-lhe a aceitação por parte do público britânico setecentista, como para defender o tema histórico do épico camoniano e enfatizar, mais uma vez, as suas relações com o comércio. Daí a necessidade de examinarmos essa refutação. Acompanhemos, então, ponto a ponto, os comentários de Mickle ao ensaio de Voltaire, acrescentando nossa própria avaliação quando oportuno.

I. Na edição inglesa, Voltaire cita erradamente tanto o nome do poeta - "Camouens" quanto daquele que, na interpretação de Mickle, é o herói do poema - "Velasco da Gama". O nome de Vasco da Gama foi corrigido na edição francesa, mas o poeta continuou sendo chamado de "Camouens" em todas as edições.

II. Voltaire diz que "Emanuel o segundo rei de Portugal"" 141 enviou "Velasco da Gama" em expedição "para encontrar um novo caminho para as Índias Orientais pelo oceano"142. Mickle esclarece que, até então, Portugal não tivera nenhum rei chamado Manuel II; fora D. Manuel I quem nomeara Vasco capitão da expedição às Índias. Além disso, Mickle observa que, se Voltaire houvesse lido Os lusíadas com atenção, saberia que não havia um caminho para as Índias pelo oceano antes da expedição de Vasco. Ou seja, Mickle interpretou a frase de Voltaire sobre "um novo caminho" como uma indicação de que o filósofo francês não soubesse que antes de Vasco ninguém havia ainda chegado às Índias pelo oceano, o que nos parece inverossímil; parece-nos mais provável que Voltaire tenha se expressado de forma ambígua. Seja como for, esses erros foram corrigidos em edições subsequentes.

III. Sobre a descrição dada por Voltaire da infância de Camões, "Sua infância perdida em meio à ociosidade e ignorância da Corte de Lisboa"143, Mickle objeta que isso não pode ser verdade, pois Camões demonstra, em sua obra, um impressionante conhecimento de todos os ramos da literatura antiga. Em nossa opinião, Voltaire foi desnecessariamente rude em sua declaração, mas, nessa questão, tudo são suposições, pois ninguém sabe exatamente o que Camões fez na infância. A amplitude de conhecimentos demonstrada por Camões parece, com efeito, indicar uma boa educação desde a infância, mas não há como garantir que esses

\footnotetext{
141 “Emanuel the second king of Portugal”. [Mantivemos, em nossa tradução, a (falta de) pontuação ambígua do original.]

142 "to find a new way to the East Indies by the ocean".

143 "His infancy lost amidst the idleness and ignorance of the court of Lisbon".
} 
conhecimentos foram adquiridos na infância e não na juventude ou início da idade adulta afinal, Camões teria cerca de 25 anos de idade quando partiu para a Índia.

IV. Voltaire afirma que Camões estava na primeira expedição de Vasco da Gama à Índia. Mickle estranha que o filósofo francês não tenha percebido o absurdo de sua afirmação, já que a expedição de Gama à Índia data de 1497, e Camões teria nascido em 1517 (Mickle se engana quanto a essa data, hoje estabelecida entre 1524 e 1525, mas seu argumento continua válido). Quando essas objeções foram comunicadas a Voltaire, este não quis, a princípio, reconhecer o erro. Na edição de 1738 de seu ensaio, publicada em Amsterdam, Voltaire diz que Camões era espanhol, nascido durante o reinado de Fernando e Isabel, que fora para Lisboa no primeiro ano de reinado de D. Manuel e que era amigo íntimo de Vasco da Gama, a quem acompanhara em sua primeira viagem. Na edição de 1768 de um ensaio chamado Idée de la Henriade, Voltaire finalmente reconheceu que Camões não havia acompanhado $\mathrm{Gama}^{144}$, mas, algumas páginas antes, incorreu no mesmo erro, escrevendo: "Camões, que é o Virgílio dos portugueses, celebrou um acontecimento do qual ele próprio foi testemunha" ${ }^{145}$.

V. Camões não sofreu um naufrágio na costa do Malabar como registra Voltaire, mas no rio Mecom, na China.

VI. Voltaire diz sobre Os lusíadas:

Lá nenhuma guerra sangrenta é travada, nenhum herói é ferido de mil formas diferentes; nenhuma mulher é seduzida e raptada, nem o mundo vira de cabeça para baixo por sua causa; nenhum império é fundado; em suma, nada do que anteriormente se considerava como os únicos temas da poesia. ${ }^{146}$

Mickle (1776, p. cxxvii, itálicos do autor) se mostra indignado diante dessas afirmações: “Nenhuma batalha travada, nenhum império fundado! Que insulto para o mundo literário é esse!". ${ }^{147}$ Afinal, na interpretação de Mickle, o próprio assunto do poema é a fundação do Império Português no Oriente.

VII. Voltaire escreve: "O Poeta conduz a frota portuguesa para a foz do Ganges, contornando a costa da África" ${ }^{\prime 48}$. Se considerarmos que o Ganges fica ao norte da Índia e que Vasco da Gama chegou até Calecute, no sudoeste (na costa do Malabar), é preciso

\footnotetext{
${ }^{144}$ Segundo Florence Donnell White (1915, p. 108) Voltaire já havia corrigido esse erro 25 anos antes.

145 "Le Camoüens, qui est le Virgile des Portugais, a célébré un événement dont il avait été témoin lui-même $[\ldots] "$

146 "There no bloody wars are fought, no heroes wounded in a thousand different ways; no woman enticed away, and the world overturn'd for her cause; no empire founded; in short, nothing of what was deem'd before the only subject of poetry".

147 "No battle fought, no empire founded! What insult to the literary world is this!".

148 "The Poet conducts the Portuguese fleet to the mouth of the Ganges, round the coasts of Africk".
} 
concordar com Mickle (1776, p. cxxvii) que Voltaire não se aprofundou suficientemente na leitura da epopeia para registrar corretamente a sua geografia.

VIII. Ao referir-se à máquina pagã do épico camoniano, Voltaire diz que "Gama, em uma tempestade, dirige suas preces a Cristo, mas é Vênus quem vem socorrê-lo"149. Mickle (1776, p. cxxvii) replica que não há tal passagem n'Os lusíadas. Gama, em meio a uma tempestade, reza para a

Divina Guarda, angélica, celeste,

Que os céus, o mar e terra senhoreias;

$\mathrm{Tu}$, que a todo Israel refúgio deste

Por metade das águas Eritreias;

$\mathrm{Tu}$, que livraste Paulo e o defendeste

Das Sirtes arenosas e ondas feias,

E guardaste, com os filhos, o segundo

Povoador do alagado e vácuo mundo [...]

$(\mathrm{VI}, 81)^{150}$

Mickle alega que Cristo não é mencionado nenhuma vez em toda essa passagem. Voltaire teria sido induzido ao erro pela tradução de Fanshawe desse trecho: "Thou who didst keep and save thy servant Paul"151 (apud Mickle, 1776, p. cxxvii, itálicos de Mickle). Na edição de 1768, Voltaire acrescentou: "Baco e a Virgem Maria se encontrarão, muito naturalmente, juntos"152. Entretanto, argumenta Mickle, a Virgem Maria não é mencionada em nenhuma parte do poema. Embora Voltaire houvesse realmente exagerado em seus comentários a fim de produzir um efeito cômico, nesse ponto nos parece que Mickle invoca detalhes irrelevantes para defender Camões; não importa se Gama se dirige ao "poder divino" ou a Cristo. Em qualquer das hipóteses, a mistura entre a mitologia pagã e a cristã na epopeia camoniana é inegável.

IX. Voltaire sentencia: "Falando seriamente, um maravilhoso tão absurdo desfigura toda a obra aos olhos dos leitores sensatos"153. Em seguida, acrescenta: "Camões incorre quase sempre em semelhantes disparates" $" 154$. Como exemplo de um desses disparates, Voltaire (1915, pp. 110-111, itálicos do autor) relata: "Lembro-me que depois que Velasco da Gama

\footnotetext{
149 "Gama, in a storm, addresses his prayers to Christ, but 'tis Venus who comes to his relief".

${ }^{150}$ Tradução em prosa dada por Mickle (1776, p. cxxvii) para essa estrofe neste ensaio (diferente da tradução em versos do Lusiad): "the holy Power, to whom nothing is impossible, the sovereign of earth, sea, and land, who led Israel through the waves, who delivered Paul, and who protected the children of the second father of the world from the deluge".

151 "Tu que preservaste e salvaste teu servo Paulo."

152 "Bacchus \& la Vierge Marie se trouveront tout naturallement ensemble".

153 “A parler serieusement, un merveilleux si absurde, defigure tout l'ouvrage aux yeux des lecteurs sensés",

154 "Le Camouens tombe presque toujours dans de telles disparates".
} 
relatou suas aventuras ao rei de Melinde, ele diz, Oh, rei, julgue se Ulisses $e$ Eneias viajaram para tão longe e passaram por tantas dificuldades: como se aquele bárbaro africano conhecesse Homero e Virgílio!" 155 Mickle (1776, pp. cxxviii-cxxix) responde que, de acordo com a história, os melindanos eram um povo civilizado e culto. A família real e os nobres eram árabes maometanos. Na descrição desse episódio, Osório registra que o príncipe demonstrou grande educação e inteligência. Esse príncipe teria tido a oportunidade de conhecer Homero, já que as obras do aedo foram traduzidas para o siríaco, em um dialeto usado pelos intérpretes de Gama para conversar com o príncipe de Melinde. Em nota de rodapé, Mickle acrescenta que os árabes costumavam traduzir textos gregos.

X. Na edição inglesa de seu ensaio, Voltaire (1915, p. 111) comenta que Os lusíadas, “estão cheios de incontáveis Erros e Belezas, semeados compactamente uns perto dos outros;

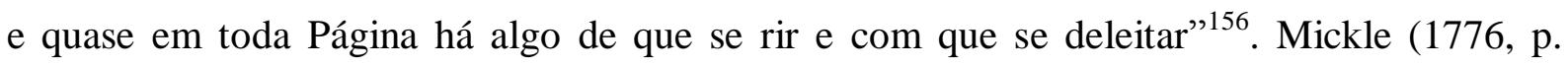
cxxix) refuta esse comentário afirmando que não há, n’Os lusíadas, trocadilhos ou gracejos, exceto em duas ou três passagens (entre as quais a fala de Veloso, no Canto V), e vê nessa opinião de Voltaire outra prova de que o filósofo francês leu Os lusíadas na tradução de Fanshawe, “onde, em toda página, há trocadilhos, metáforas extravagantes e expressões vulgares e estranhas, sem contrapartida no original"157.

XI. Voltaire aponta uma semelhança entre os versos em que Camões apela às ninfas do Tejo n'Os lusíadas e os versos em que John Denham se dirige ao Tâmisa em “Cooper's Hill”. Mickle (1776, p. cxxix) contesta dizendo que no original não há tal semelhança, apenas na tradução de Fanshawe. De fato, a comparação entre os trechos citados mostra que a tradução de Fanshawe é bem mais próxima do poema de Denham do que o original - ainda que a analogia entre a fluência do rio e do discurso já estivesse no original ("um estilo grandíloco e corrente"):

O could I flow like thee, and make thy Stream,

My great Example, as it is my Theme;

\footnotetext{
155 "I remember, that after Velasco da Gama, hath related his Adventures to the king of Melinda, now says he, $\mathrm{O}$ King, judge if Ulysses and Eneas have travelled so far, and undergone so many hardships: as if that barberous African, was acquainted with Homer and Virgil!"

156 "is full of numberless Faults and Beauties, thick sown near one another; and almost in every Page there is what to laugh at, and what to be delighted with".

157 "where, in every page, there are puns, conceits, and low quaint expressions, uncountenanced by the original".
} 
Tho' deep, yet clear, tho' gentle, yet not dull,

Strong without Rage, without o' erflowing full. ${ }^{158}$

(DENHAM, “Cooper's Hill”)

Eis a tradução feita por Fanshawe (I, 4, 3-6, itálicos do autor):

If I in low, yet tuneful Verse, the praise

Of your sweet River always did proclame:

Inspire me now with high and thund'ring lays;

Give me them cleer and flowing like his stream $[\ldots]^{159}$

E aqui está o original:

Se sempre em verso humilde celebrado

Foi de mim vosso rio alegremente,

Dai-me agora um som alto e sublimado,

Um estilo grandíloco e corrente $[\ldots]$

(I, 4, 3-6)

XII. Em edições mais recentes de seu ensaio, Voltaire (1792, p. 367) acrescentara uma crítica: "Mas, de todos os defeitos desse poema, o maior é a pouca ligação que reina entre todas as partes: ele se parece com a viagem de que trata". 160

Para responder a esse comentário, Mickle escreveu uma pequena dissertação sobre a poesia épica, em que demonstra a filiação d'Os lusíadas ao modelo clássico de Homero e Virgílio por meio de comparações de trechos dessas três obras e descreve detalhadamente a máquina sobrenatural utilizada na epopeia camoniana.

Referindo-se à última vez em que a máquina é acionada, no episódio da Ilha dos Amores, Mickle (1776, p. cxxxiv) repudia a aproximação, feita por Voltaire, da Ilha dos Amores a um cabaré de Amsterdam, alegando: "Tudo na Ilha dos Amores lembra a estátua da Vênus de Médici. A descrição é, com efeito, ardente, mas é casta como os primeiros amores

\footnotetext{
158 “Ah, se eu pudesse fluir como tu, e fazer de tua Correnteza, Meu grande Exemplo, assim como é meu Tema; Apesar de profundo, claro; apesar de brando, não tedioso, Forte sem Fúria, cheio sem transbordar."

159 "Se em humilde, ainda que melódica Poesia, o louvor

De vosso doce Rio sempre proclamei: Inspirai-me agora em cantos altos e troantes; Dai-mos claros e fluentes como a correnteza dele [...]".

160 "Mais, de tous les défauts de ce poëme, le plus grand, est le peu de liaison qui règne dans toutes les parties : il ressemble au voyage dont il est le sujet."
} 
de Adão e Eva em Milton" ${ }^{\text {161 }}$. Se, por um lado, Mickle se mostra determinado, nos ensaios introdutórios, nas notas e na própria tradução, a "cristianizar" a Vênus de Camões, amenizando a carga erótica que, a nosso ver, é evidente nos gestos e ações da deusa n'Os lusíadas, por outro lado também não concordamos com o rebaixamento da alegoria camoniana executado por Voltaire ao compará-la a um cabaré, demonstrando um preconceito tacanho, embora talvez explicável por sua educação jesuíta e neoclássica.

Mickle (1776, pp. cxxxv- cxxxvi) aceita a explicação de Camões, de que sua máquina é alegórica, e comenta que assim era também a de Homero, a quem Camões tomou como modelo. Não obstante, Mickle ridiculariza a interpretação que Castera, o tradutor francês d' $O s$ lusíadas, deu às alegorias camonianas, segundo a qual, por exemplo, Marte seria Jesus Cristo. Mickle reafirma, no entanto, que Camões quis representar as "Divinas Guardas" [guardian powers] cristã e maometana nas duas principais personagens de sua máquina: a Vênus celeste simbolizaria o cristianismo e Baco, o maometismo.

Para corroborar a sua interpretação - que nos parece convincente - de que Baco representaria o maometismo, Mickle invoca Camões, citando o Canto I, em que Baco é apresentado como uma divindade celebrada no Oriente, e o Canto VIII, em que Baco assume a forma de Maomé e aparece em um sonho a um sacerdote maometano; além disso, considerando que um dos principais objetivos da expedição de Gama era estabelecer o cristianismo no Oriente e que Baco era o seu principal opositor, a identificação entre ambos seria imediata.

Ainda em defesa da máquina pagã de Camões, Mickle (1776, p. cxxxvi) sustenta que esse recurso foi usado durante três mil anos e que seria muito difícil, se não impossível, criar um novo tipo de máquina adequado à epopeia. Observa que Voltaire se sentia autorizado a utilizar as flechas de Cupido na Henriade sem que isso fosse interpretado como uma intromissão do paganismo no mundo cristão; mas ridicularizava esse mesmo recurso quando usado por Camões. Mickle invoca as regras de Boileau (1979, p. 46) na Arte poética para justificar as alegorias camonianas:

A poesia épica, [...], no amplo relato de uma longa ação, se sustenta pela fábula e vive de ficção. Tudo aí é usado para fascinar-nos. Tudo toma um corpo, uma alma, um espírito, uma face. Cada virtude se torna uma divindade: Minerva é a prudência; e Vênus, a beleza. Não é mais a nuvem que produz o trovão, mas Júpiter armado para assustar a terra. Uma terrível

\footnotetext{
161 "Every thing in the Island of Love resembles the statue of Venus de Medicis. The description is warm indeed, but it is chaste as the first loves of Adam and Eve in Milton".
} 
tempestade, aos olhos dos marinheiros, é Netuno colérico que repreende as ondas $[\ldots]$.

Segundo Mickle, apenas em um ponto Os lusíadas não seguem as regras de Boileau: quando estas exigem que o tema da epopeia seja profano. Apesar disso, Mickle (1776, p. cxxxviii) se esforça para provar que não há mistura entre os personagens pagãos e cristãos na epopeia camoniana. Para ele, embora os heróis sejam cristãos, as partes alegórica e histórica são essencialmente diferentes. Se às vezes a parte histórica é conduzida sob o véu da alegoria, é em obediência aos preceitos de Boileau. Mickle não apenas invoca o uso poético, como também alega que Baco era considerado, na época de Camões, um demônio real. Nas primeiras eras da cristandade, acreditava-se que os deuses pagãos eram anjos caídos; John Milton teria adotado esse sistema em $O$ Paraíso perdido.

Ao crítico que, apesar de todos esses argumentos, insiste em rejeitar a máquina de Camões, Mickle lança um último argumento: entre os autores épicos, Camões é o menos censurável nesse aspecto. Dante, na Divina comédia, mescla personagens pagãos e cristãos; Ariosto e Tasso incorrem no mesmo erro; O Paraíso perdido apresenta a mesma mistura. E se for um erro usar a máquina poética antiga em um poema em que os heróis são cristãos, a Henriade de Voltaire está ainda mais infectada por misturas do que Os lusíadas, pois se baseia na mitologia pagã e, ao mesmo tempo, tem como um de seus personagens o próprio Deus cristão.

Em nota de rodapé, Mickle (1776, p. cxl) responde também às críticas de René Rapin ${ }^{162}$ e Lord Kames ao épíco camoniano. Diante da avaliação de Rapin (1970, p. 47) de que o grande defeito d'Os lusíadas seria a falta de clareza, naturalidade e harmonia, Mickle (1776, p. cxl, nota) deduz que Rapin jamais leu o original, pois "Clareza, elegante simplicidade e a harmonia mais natural e tranquila é a verdadeira característica do estilo de Camões"163. Lord Kames, figura importante do Iluminismo Escocês, concordando com as críticas de Voltaire a Os lusíadas, reproduziu-as em seu Sketches of the history of man (1774), ridicularizando a máquina pagã de Camões. Mickle o acusa de ignorância e responde às criticas com veemência - não reproduzimos aqui essas respostas porque a argumentação repete, em linhas gerais, os mesmos pontos já abordados na discussão com Voltaire.

\footnotetext{
162 Já falamos sobre as críticas de Rapin no Capítulo 2, em 2.6.2.5.

163 "Perspicuity, elegant simplicity, and the most natural unstrained harmony, is the just characteristic of the style of Camoens".
} 
Mickle (1776, p. cxl) atribui essas críticas injustas ao fato d'Os lusíadas terem sido escritos em português, "uma língua desconhecida na literatura refinada"164. Poucos críticos tinham condições de apreciar a beleza do original.

Sobre a crítica de Voltaire de que "Nenhum herói é ferido de mil formas diferentes"165, Mickle (1776, p. cxliv) pondera que a falta de longas descrições de batalha é um ponto a favor d'Os lusíadas, em comparação com as tediosas descrições de Homero, muitas vezes imitadas por Virgílio e, ao longo dos séculos, por dezenas de outros autores de poemas épicos.

Mickle (1776, p. cxlv) não poupa elogios à escolha do tema d' Os lusíadas, ressaltandolhe a modernidade e, como sempre, exaltando o comércio e as conquistas imperialistas:

Uma viagem considerada difícil demais para qualquer homem ousar; as aventuras dessa viagem através de oceanos desconhecidos vistos como intransponíveis; o mundo do Oriente afortunadamente descoberto, e para sempre indissoluvelmente ligado e dado ao Ocidente; o grande Império Português no Oriente fundado; a civilização da humanidade e o comércio universal como consequência! $O$ que são as aventuras da chegada de um velho herói fabuloso na Bretanha, o que são a Grécia e o Lácio guerreando por uma mulher, comparados a isso! Troia está em cinzas, e mesmo o Império Romano não existe mais. Mas os efeitos da viagem, aventuras e bravura do Herói d'Os lusíadas serão sentidos e contemplados, e talvez cresçam em importância, enquanto o mundo existir. ${ }^{166}$

Ao encerrar essa parte da Introdução, Mickle (1776, p. cxlvii) procura justificar o interesse que atribui à epopeia camoniana com base no tema do comércio, que seria aplicável a qualquer nação que obtivesse o controle do comércio na Índia. Dessa forma, ele estabelece uma translatio, uma continuidade entre o Império Português no Oriente e o Império Britânico:

Embora o tema de Camões seja especialmente interessante para seus compatriotas, também possui a peculiar felicidade de ser o Poema de todas as nações comerciais. É a Epopeia do Nascimento do Comércio. E, de um modo especial, a Epopeia de qualquer país que tenha o controle e a posse do comércio da Índia. ${ }^{167}$

\footnotetext{
164 "a language unknown in polite literature".

165 No heroes are wounded a thousand different ways".

166 "A voyage esteemed too great for man to dare; the adventures of this voyage through unknown oceans deemed unnavigable; the Eastern World happily discovered, and for ever indissolubly joined and given to the Western; the grand Portuguese empire in the East founded; the humanization of mankind and universal commerce the consequence! What are the adventures of an old fabulous hero's arrival in Britain, what are Greece and Latium in arms for a woman, compared to this! Troy is in ashes, and even the Roman empire is no more. But the effects of the voyage, adventures, and bravery of the Hero of the Lusiad, will be felt and beheld, and perhaps increase in importance, while the world shall remain."

167 "But though the subject of Camoens be particularly interesting to his countrymen, it has also the peculiar happiness to be the Poem of every trading nation. It is the Epic Poem of the Birth of Commerce. And in a
} 
Ao final do ensaio, Mickle (1776, p. clxxviii) reproduz, como já haviam feito Manuel de Faria e Sousa, Duperron de Castera e Sir Richard Fanshawe, o soneto composto por Torquato Tasso em homenagem a Vasco da Gama e a Camões no original e, em seguida, o traduz.

A tradução de Mickle desse soneto é reveladora. No primeiro quarteto, chama atenção a passagem final, "and brought / The wealth of India to thy native shore"168. A menção à "riqueza da Índia" foi claramente introduzida por Mickle. O original ("e fer colà Ritorno / Dove egli par che di cadere accenne") se refere apenas - por meio de uma alusão poética ao poente como o local onde o sol desaparece - ao retorno de Vasco para o Ocidente. Contrastese a tradução de Mickle com a de Fanshawe (1655): “and back again advanc'd / To where in Seas all Night he steeps his Ray"169.

No segundo quarteto, a tradução do último verso, "Never such pomp of naval honours wore" ${ }^{, 170}$, também se desvia bastante do original, "Ne diè più bel Subietto a colte penne", que poderíamos traduzir literalmente como "Não deram mais belo tema a penas cultas". A tradução dá mais ênfase, assim, às honras navais de Vasco. Fanshawe (1655), sempre mais literal, traduz o verso como "Afforded Learned Pens a fairer Theam"171.

Ao incluir esse poema e essa tradução ao final de sua longa introdução, Mickle ratifica a sua interpretação do poema camoniano, destacando Vasco da Gama como o herói e o nascimento do comércio como tema de Os lusíadas.

\subsubsection{Comentários de Mickle sobre a sua concepção de tradução (1776, pp. cxlix-clii; 1778, pp. cexxii-ccxxv)}

Ao final da Introdução, Mickle finalmente faz alguns comentários sobre a tradução em si. Na primeira edição esses comentários não estão separados dos outros ensaios; na segunda edição estão acoplados à "Dissertação sobre Os lusíadas e observações sobre a poesia épica", igualmente sem separação. Decidimos destacar esses comentários em uma subseção própria, por motivos de clareza e porque o assunto é de grande importância para a nossa tese.

Mickle (1776, p. cxlix) principia esse trecho mencionando outras traduções d'Os lusíadas. Sobre a tradução para o francês de Duperron de Castera, diz que é "uma paráfrase

particular manner the Epic Poem of whatever country has the controul and possession of the commerce of India."

168 “e [os navios] levaram / A riqueza da Índia para a tua terra natal”.

169 "e em retorno avançaram / Para onde nos Mares toda Noite ele mergulha seu Raio."

170 "Nunca ostentaram tal esplendor em honras navais."

171 "[Não] Proporcionaram a penas cultas um tema mais belo." 
livre e apoética d'Os lusíadas" "172. Em nota de rodapé, acrescenta que Castera "não percebeu as belezas de seu autor. Ele suprime ou rebaixa as passagens mais poéticas, e acrescenta lantejoulas francesas e impertinências em seu lugar" ${ }^{\prime 13}$.

A tradução de Sir Richard Fanshawe não recebe melhor avaliação por parte de Mickle (1776, p. cxlix): “Embora estrofe seja traduzida por estrofe, embora à primeira vista pareça ser extremamente literal, essa versão é, não obstante, extremamente infiel" "174. A tradução de Fanshawe não transmite a solenidade necessária a um épico; Fanshawe "teems with many a dead-born jest" ${ }^{175}$, diz Mickle, citando um verso da tradução de Pope da Odisseia. Em nota de rodapé, Mickle sugere que as críticas de Voltaire, Rapin e outros a Os lusíadas se deveriam à tradução de Fanshawe. Em especial a opinião de Rapin, de que Camões seria “obscuro", Mickle atribui à falta de clareza de Fanshawe, comentando, em tom jocoso:

Fanshaw é de fato tão obscuro que, ao mergulhar em sua tradução, o presente Tradutor, mesmo em partes que já havia traduzido, foi muitas vezes obrigado a recorrer ao [original] português a fim de descobrir seu significado. Sancho Pança não era mais afeiçoado a provérbios [do que Fanshaw]. Ele introduziu muitos em sua versão. Ele nunca se cansava de metáforas extravagantes, nem de alusões e expressões vulgares. ${ }^{176}$

Nessa mesma nota, Mickle critica Fanshawe por não ter escrito uma nota sequer em sua tradução (o que, como observamos no Capítulo 2, pode se dever às circunstâncias especiais dessa publicação, que não teria sido revisada pelo tradutor).

Qual seria, então, a tradução ideal de um épico? Mickle (1776, pp. cxlix-cl) responde que não há regras absolutas:

Apenas os sentimentos do tradutor devem orientá-lo, pois o espírito da poesia certamente evapora na tradução literal.

A tradução literal de poesia é, na verdade, um solecismo. Podes interpretar o teu autor, sem dúvida, mas se, como alguns Tradutores, te vanglorias de teres deixado o teu autor falar por si mesmo, de não teres nem acrescentado nem reduzido, na realidade tu o maltrataste rudemente, e enganaste a ti mesmo. [...] A tua tradução literal não pode ter nenhuma

\footnotetext{
172 "a loose unpoetical paraphrase of the Lusiad".

173 "did not perceive his author's beauties. He either suppresses or lowers the most poetical passages, and substitutes French tinsel and impertinence in their place".

174 "Though stanza be rendered for stanza, though at first view it has the appearance of being exceedingly literal, this version is nevertheless exceedingly unfaithful".

175 "Pulula de muitas piadas natimortas".

176 "Fanshaw is indeed so obscure, that in dipping into him, into parts which he had even then translated, the present Translator has often been obliged to have recourse to the Portuguese, to discover his meaning. Sancho Panza was not fonder of proverbs. He has thrust many into his version. He can never have enough of conceits, low allusions, and expressions."
} 
pretensão à graça de expressão do original; à energia, elegância e ardor do poema original. Pode ter, de fato, uma semelhança; mas uma semelhança como a que o cadáver no sepulcro tem para com o homem de outrora, quando ainda no fulgor e vigor da vida.

Nec verbum verbo curabis reddere, fidus

Interpres,

era o gosto da era de Augusto. Ninguém além de um poeta pode traduzir um poeta. A liberdade advinda desse preceito irá, portanto, nas mãos de um poeta, não apenas instilar a energia, elegância e ardor da poesia de seu autor em sua própria versão, mas também lhe dar o espírito de um original. ${ }^{177}$

As recomendações de Mickle repetem vários bordões da época sobre a tradução, já estudados em nosso Capítulo 3: a "evaporação do espírito" da poesia do original na tradução; a condenação das traduções literais; a metáfora da tradução literal como cadáver; a citação do Nec verbum verbo de Horácio; a ideia de que somente um poeta pode traduzir um poeta; e o princípio de que é preciso infundir um novo espírito à poesia traduzida de modo que ela se pareça com uma obra original.

Foi essa a receita que Mickle procurou seguir na tradução d'Os lusíadas. Mickle (p. cl, comentário entre colchetes do tradutor) ainda confessa: "Liberdades ainda maiores, em um ou dois casos, pareceram-lhe [ao Tradutor] vantajosas"178. (Seria o caso de perguntarmos: só "um ou dois”?) Mickle não fornece detalhes sobre esses casos em que admite ter tomado maiores liberdades com o texto, exceto pela menção, em nota de rodapé, a algumas alusões históricas ou mitológicas que o tradutor achou melhor abreviar e um único exemplo de omissão, justificada por ele em nome da sonoridade em inglês. Nessa mesma nota, Mickle (p. cli) declara: "Não era satisfazer os poucos enfadonhos, cujo maior prazer ao ler uma tradução é ver o que o autor diz exatamente; oferecer um poema que pudesse viver na língua inglesa é que era a ambição do Tradutor" ${ }^{, 179}$.

177 "The translator's feelings alone must direct him, for the spirit of poetry is sure to evaporate in literal translation.

Literal translation of poetry is in reality a solecism. You may construe your author, indeed, but if with some Translators you boast that you have left your author to speak for himself, that you have neither added nor diminished, you have in reality grossly abused him, and deceived yourself. Your literal translation can have no claim to the original felicities of expression; the energy, elegance, and fire of the original poetry. It may bear indeed a resemblance; but such a one as a corps in the sepulchre bears to the former man when he moved in the bloom and vigour of life.

\section{Nec verbum verbo curabis reddere, fidus}

Interpres,

was the taste of the Augustan age. None but a poet can translate a poet. The freedom which this precept gives, will, therefore, in a poet's hands, not only infuse the energy, elegance, and fire of his author's poetry into his own version, but will give it also the spirit of an original."

178 "Even farther liberties in one of two instances seemed to him [the Translator] advantageous".

179 "It was not to gratify the dull few, whose greatest pleasure in reading a translation is to see what the author exactly says; it was to give a poem that might live in the English language which was the ambition of the Translator". 
Embora Mickle lhe tenha dado um fraseado original, "oferecer um poema que pudesse viver na língua inglesa" é apenas mais uma variação da fórmula repetida por diversos tradutores dos séculos XVII e XVIII em prefácios, sobre a necessidade de se infundir uma nova vida ao texto traduzido para que este pudesse ser apreciado pelos leitores da língua de chegada.

\subsubsection{Agradecimentos de Mickle aos assinantes (1776, pp. clii-cliviii; 1778, p. ccxxv- clxxix)}

Mickle inicia essa parte de sua Introdução pedindo desculpas aos assinantes por ter excedido o prazo combinado para o término do livro, mas diz que, por outro lado, a ampliação da Introdução e das Notas, que o tradutor considerou necessária, deve compensar pela espera prolongada.

O tradutor agradece, nesta ordem: a certos cavalheiros da Universidade de Oxford; ao Duque de Buccleugh (o nobre a quem Mickle dedicou a obra e que a ignorou completamente); ao Governador Johnstone (depois Comodoro Johnstone), seu parente e benfeitor; aos cavalheiros da Companhia das Índias Orientais (segue-se o comentário que já citamos na subseção 4.4.2, sobre o desejo desses cavalheiros de verem um poema épico, "particularmente deles próprios", publicado em inglês); a Thomas Pearson, Esq., funcionário da Companhia das Índias Orientais, pelo empréstimo de fontes de História Portuguesa e por ter angariado várias assinaturas para a publicação da tradução - comentário também já citado na subseção 4.4.2); a James Boswell, Esq.; a Mr. Hoole, o "elegante Tradutor de Tasso"180; ao Dr. Johnson; ao recentemente falecido Dr. Goldsmith; a vários literatos portugueses que leram a tradução e forneceram muitas informações ao tradutor - entre eles, Mr. Magellan (Magalhães), descendente de Fernão de Magalhães, o navegador que comandou a primeira viagem de circunavegação do globo.

Em seguida, Mickle (1776, p. cliv) confessa o seu temor de que uma obra épica como Os lusíadas possa não ser bem recebida em tempos em que até mesmo $O$ Paraíso perdido de John Milton é desprezado pelo público. E acrescenta: "A era atual, com efeito, é felizmente auspiciosa para a Ciência e as Artes; mas a Poesia não é nem do gosto geral nem a moda favorita destes tempos" ${ }^{\prime 181}$. Em comentário a essa questão, Mickle encerra a Introdução com

\footnotetext{
180 "the elegant Translator of Tasso".

181 "The present age, indeed, is happily auspicious to Science and the Arts; but Poetry is neither the general taste nor the fashionable favorite of these times".
} 
um poema inacabado seu, escrito ao estilo de Spenser, com estrofes de nove versos. O poema, conhecido como "On The Neglect of Poetry", trata do descaso votado à poesia, negligenciada enquanto suas artes irmãs, a pintura e a música, recebem todos os incentivos.

\subsubsection{Dissertação sobre a Jerusalém libertada e a Henriade (1776, pp. clix-clxvii)}

Nessa dissertação Mickle, ainda preocupado em defender seu autor das acusações dos críticos neoclássicos, procura provar que Tasso e Voltaire - dois autores de epopeias modernas aclamados por grande parte da crítica literária do século XVIII - apresentam, em seus épicos, uma mistura de paganismo e cristianismo tão acentuada quanto a encontrada n'Os lusíadas, ou ainda maior.

Ao resumir a máquina da Jerusalém libertada, Mickle (1776, p. clix) já aponta a intricada mescla dos elementos pagãos e cristãos: Deus envia o arcanjo Gabriel a Godofredo para incitá-lo a reiniciar a guerra pela retomada de Jerusalém, ainda em poder dos sarracenos. O mago Ismeno, a serviço dos árabes, mistura ritos cristãos e profanos em seus encantamentos, e aconselha o rei Aladino a apoderar-se de uma estátua da Virgem e colocá-la em uma mesquita para, assim, proteger a cidade. Plutão, o inimigo dos homens, convoca um consílio dos poderes infernais, ao qual comparecem centauros, górgonas, quimeras etc. Diante do consílio, Plutão relata a sua própria queda do Céu, o nascimento de Cristo e a descida de Cristo ao Inferno. Deus envia o arcanjo Miguel para socorrer os cristãos e expulsar os demônios para o Inferno. Ismeno invoca novamente os demônios. Um mago de Ascalon liberta Reinaldo do feitiço que o mantinha preso. Ao final do poema, o arcanjo Miguel aparece a Godofredo e mostra-lhe as hostes celestiais prontas a auxiliar os cristãos na batalha.

A seguir, Mickle (pp. clx-clxvii) analisa a Henriade, poema cujo tema (a ascensão de Henrique IV ao poder) considera muito inferior, em termos épicos, ao d'Os lusíadas. Mickle destaca a mistura de elementos pagãos e cristãos na máquina do poema. Apenas como exemplo, mencionaremos que o espírito de São Luís assume o papel da Vênus na Eneida; o "Deus do Universo" ordena que a tempestade leve Henrique de Navarra à ilha de Jersey; e as forças da Liga, contrárias a Henrique de Navarra, são ajudadas pelas deusas Discórdia e Política. Mickle (pp. clxi-clxiii; p. clxvi) indica os momentos em que a ação da Henriade se afasta do princípio da unidade: a visita de Henrique de Navarra a Elisabete da Inglaterra, que ocupa quase um terço do poema, não serviria a nenhum propósito importante na ação, já que a participação dos ingleses nos conflitos é mencionada apenas uma vez e sem nenhum destaque; e a passagem de Henrique pelo Céu e pelo Inferno desvia a ação em um momento 
fundamental sem nenhuma grande justificativa, parecendo artificial e forçada. Os resultados obtidos não são fruto da ação, e sim da máquina. Mickle (p. clxvii) encerra o ensaio concluindo que "a França ainda não tem uma epopeia, embora Voltaire tenha escrito a Henriade ${ }^{, 182}$.

\subsubsection{Apêndice à segunda edição (1778, pp. ccxxx-ccxxxvi)}

Mickle acrescenta ao livro uma cópia das patentes dos vice-reis e capitães-gerais da Índia, conforme encontradas no Conselho Ultramarino em Lisboa, e um esclarecimento a respeito de seu conteúdo. As cópias desses dois documentos, enviadas ao tradutor diretamente de Portugal, são, em seguida, traduzidas para o inglês. O documento especifica as funções e âmbito de ação de cada um dos órgãos de administração portuguesa na Índia.

Após a tradução, Mickle faz alguns comentários sobre as três principais expedições marítimas que tinham como objetivo encontrar o caminho para as Índias: a de Vasco da Gama, a de Colombo e a de Fernão de Magalhães. Mickle aponta a expedição de Gama como a mais bem equipada de todas. Esse comentário é feito para confirmar a grandiosidade do tema escolhido por Camões para a sua epopeia.

Com esse apêndice, Mickle demonstra a preocupação de fundamentar suas ideias com documentos e, possivelmente, a pretensão de vir a ser conhecido como especialista em assuntos portugueses.

\subsubsection{Dissertação sobre o episódio da Ilha dos Amores (1776, pp. 411-414; 1778, pp. 424-427) $)^{183}$}

Mickle (1776, p. 411) aponta afinidades entre o episódio da Ilha dos Amores e várias descrições famosas de palácios, florestas e jardins na poesia: os jardins de Alcino na Odisseia; os Campos Elíseos da Eneida e, principalmente, a ilha e o palácio de Alcina e a descrição do Paraíso no Canto XXXIV do Orlando furioso. Mas essas descrições, pondera Mickle, são

\footnotetext{
182 "France has yet no Epic poem, though Voltaire has written the Henriade."

${ }^{183}$ Incluímos essa dissertação entre os peritextos prefaciais, embora ela tenha sido colocada após o Canto IX no livro, porque Genette (2009, p. 145) chama de prefácio "toda espécie de texto liminar (preliminar ou pósliminar), autoral ou alógrafo, que consiste num discurso produzido a propósito do texto que segue ou que antecede". Apesar de Genette não mencionar "entrefácios", acreditamos que essa dissertação se enquadra na definição de prefácio fornecida por Genette.
} 
extremamente comuns em poemas, novelas e até mesmo na ficção oriental, e a mera semelhança não implica necessariamente cópia ou imitação.

Apesar dessas semelhanças, a ficção da Ilha dos Amores n'Os lusíadas se destaca, segundo Mickle (p. 413), pelo requinte e completude da gradação e da coleção de elementos magníficos. Tasso teria utilizado esse episódio como modelo para compor a ficção de Armida, e Spenser, por sua vez, ter-se-ia apropriado da ficção de Tasso para descrever o jardim de Acrásia (que seria uma tradução do episódio de Tasso).

Mas a principal virtude do episódio, na opinião de Mickle, está na alegoria da recompensa concedida aos heróis, construída em imitação à Eneida. Mickle ressalta o estilo sublime com que Camões resume o poema: "All these are given to the Western World by You"184. Mickle se refere, provavelmente, aos versos do original "Eis aqui as novas partes do Oriente / Que vós outros agora ao mundo dais" (X, 138, 1-2), traduzidos por Mickle em seu Lusiad como "That world where every boon is shower'd from heaven, / Now to the West, by Thee, Great Chief, is given" ${ }^{185}$. Mickle (p. 413) não poupa elogios a esse resumo:

É impossível qualquer poema ser resumido de forma mais sublime. A Queda de Troia não é nada comparada a isso. E isso não é tudo: a ficção mais magistral, o mais belo elogio e o fim supremo da Eneida não apenas são imitados de forma nobre, como a conduta de Homero, na conclusão da Ilíada [...] é equiparada, sem que nem mesmo um detalhe seja emprestado. ${ }^{186}$

Mickle (p. 414) conclui o ensaio sugerindo que John Milton poderia ter lido Os lusíadas na tradução de Fanshawe, e que os dois últimos livros de $O$ Paraíso perdido se inspirariam na epopeia camoniana. O relato feito por Miguel a Adão espelha as previsões narradas por Tétis a Vasco da Gama. ${ }^{187}$ Entretanto, nos últimos livros de $O$ Paraíso perdido a qualidade poética de Milton teria decaído, não se mostrando à altura do estilo sublime do incansável poeta lusitano.

\footnotetext{
184 "Tudo isso é dado ao Mundo Ocidental por Vós".

185 "Esse mundo onde toda dádiva emana dos Céus, / Agora ao Ocidente, por Vós, Grande Comandante, é dado".

186 "It is impossible any poem can be summed up with greater sublimity. The Fall of Troy is nothing to this. Nor is this all: the most masterly fiction, finest compliment, and ultimate purpose of the Eneid, is not only nobly imitated, but the conduct of Homer, in concluding the Iliad [...] is paralleled, without one circumstance being borrowed."

${ }^{187}$ Embora não cite Mickle, C. M. Bowra (1962, p. 238) dá como certo que Milton se inspirou n'Os lusíadas para escrever essa cena. Uma prova disso seria a citação dos nomes de lugares em "Mombaza, and Quiloa, and Melind / And Sofala" (XI, 399-400), ecoando o verso d'Os lusíadas "De Quíloa, de Mombaça e de Sofala" (I, 54, 4). Autores mais recentes, como James H. Sims ("Echoes of Camoëns' Lusiads in Milton's Paradise Lost", Revista Camoniana 3, São Paulo, 1971) e Louis L. Martz ("Camoens and Milton", Ocidente, n. especial, Lisboa, nov. 1972) confirmaram, em estudos mais abrangentes, a influência de Camões sobre Milton.
} 


\subsubsection{Dissertação sobre os brâmanes (1778, pp. 305-332) $)^{188}$}

Uma discussão aprofundada sobre esse assunto foge, sem dúvida, aos objetivos de nosso trabalho; apesar disso, este texto é valioso para caracterizarmos o enfoque ideológico dado por Mickle aos brâmanes, no contexto colonialista e imperialista. Com essa finalidade, resumiremos aqui as concepções expressas pelo tradutor a respeito das crenças dos brâmanes.

Mickle (1778, p. 305) principia a dissertação defendendo a importância desse tema para a leitura de um livro como Os lusíadas, que celebra a conquista do Oriente. O Canto VII, em especial, exigiria do leitor certos conhecimentos sobre a religião brâmane.

Mickle descreve o sistema de crenças do bramanismo como exposto em duas obras de dois ex-funcionários da Companhia Britânica das Índias Orientais, Josiah Holwell e Alexander Dow. Percebendo diversas contradições entre os dois autores, Mickle (p. 319; p. 327) conclui que há vários relatos diferentes sobre o bramanismo porque os brâmanes se contradizem uns aos outros até mesmo nas questões mais fundamentais, como, por exemplo, a da autoria de suas sagradas escrituras.

Além disso, Mickle qualifica várias concepções dos brâmanes como incoerentes e até absurdas. Como exemplo, podemos citar o princípio, mencionado por Holwell, de que qualquer animal que destrua a forma mortal de outro, seja a de um mosquito, abelha, vaca ou homem, terá seu espírito lançado no Onderah, um local de profunda escuridão, por um longo tempo e depois será forçado a reiniciar o ciclo de 89 transmigrações para alcançar a purificação, independentemente do estágio que já houvesse atingido nesse ciclo. Mickle (p. 307; p. 309) indaga a que propósito serviriam, então, os peixes e outros animais que, por instinto natural, alimentam-se uns dos outros ou de outros animais. Estariam condenados a reiniciar eternamente o ciclo de transmigrações, sem possibilidade de progredir? Mickle argumenta que mesmo o filósofo indiano que deixa os ratos passarem sobre seu corpo e cuida para não pisar em nenhum inseto em seu caminho causa a morte de inúmeras criaturas vivas ao comer uma verdura ou tomar um copo de água. A salvação, de acordo com tal sistema, seria impossível.

Segundo a resenha de Mickle (1778, pp. 312-313), Holwell procura aproximar o bramanismo do cristianismo; Dow, embora não tenha essa mesma preocupação, sustenta que os brâmanes eruditos afirmam a unidade suprema de Deus, negando a existência de divindades inferiores. O politeísmo seria apenas a veneração simbólica dos atributos divinos.

\footnotetext{
${ }^{188}$ Essa dissertação aparece após o Canto VII, na segunda edição do Lusiad de Mickle. Nós a incluímos aqui como peritexto prefacial pelas mesmas razões expostas na nota 175 .
} 
Porém Mickle julga que a opinião popular precisa ser levada em conta, e tanto Holwell quanto Dow reconhecem que os hindus ignorantes acreditam na existência das divindades inferiores.

Mickle (pp. 315-316) recorre aos depoimentos de historiadores antigos, como Plínio, Ctésias, Calanus, Cícero, Lucano e outros a fim de obter mais informações sobre a religião dos brâmanes. Esses historiadores registram a crença na metempsicose e várias práticas que Mickle considera bárbaras. Entre essas práticas, Mickle cita os rituais da queima de viúvas e a aspersão com excrementos de vaca.

A avaliação de Mickle (1778, p. 314) é severa:

Que a religião dos brâmanes é altamente repreensível todo moralista deve concordar, quando considera que as mais indignas ideias de Divindade, ideias destrutivas da moralidade, surgem naturalmente da veneração a ídolos; e o vulgo, todos confessam, não consegue evitar o abuso. ${ }^{189}$

Mickle (1778, p. 316) sentencia: “[...] e a depravação humana, em nenhum outro lugar do globo, já produziu ficções tão detestáveis de impureza como as contidas nas lendárias histórias das Divindades dos brâmanes" ${ }^{\prime 190}$.

Uma questão muito enfatizada por Mickle (1778, p. 320) é que esses rituais não conduziriam a um aperfeiçoamento espiritual:

[...] mudanças de atitude, arrependimento ou aversão à corrupção moral não parecem ser condições para essa purificação. Todavia, alguns poucos indivíduos cujas ideias têm se aperfeiçoado por meio de conversas com europeus podem explicar e detalhar que a total ignorância da filosofia moral, que não tem a menor ideia da corrupção moral, é o verdadeiro caráter da devoção brâmane. E a filosofia de que tanto se gabam também não vem se mostrando capaz de perceber a imoralidade de suas penitências e da prática do suicídio como um passaporte garantido para o Paraíso. O que pode o verdadeiro moralista pensar do indiano que, por princípios religiosos, afogase no Ganges ou joga-se sob as rodas da carruagem de seu pagode, para morrer esmagado pela sagrada carga? Os deveres que temos para com nossos parentes em particular e a sociedade em geral, o Criador da Natureza nos impôs por princípios inescusáveis. Entretanto, esses deveres são rejeitados pelo piedoso suicida com base nos princípios da mais débil superstição. E o moralista não pode encarar as horríveis austeridades às quais os filósofos brâmanes se submetem sob qualquer outra luz. ${ }^{191}$

\footnotetext{
189 "That the religion of the Brahmins is highly reprehensible every moralist must allow, when he considers, that the most unworthy ideas of the Divinity, ideas destructive of morality, naturally arise from idol worship; and the vulgar, it is every where confessed, cannot avoid the abuse."

190 "[...] and human depravity, in no quarter of the globe, ever produced such detestable fictions of impurity, as are contained in the Legendary histories of the Deities of the Brahmins".

191 " [...] alteration of heart, repentance, or abhorrence of moral turpitude, appear to be no conditions of this purification. However a few individuals, whose ideas have been improved by conversation with Europeans, may gloss and refine, that gross ignorance of moral philosophy, which has no idea of moral turpitude, is the just
} 
Sobre a opinião de Camões quanto às crenças brâmanes, Mickle (1778, p. 314) diz: “Camões, cuja profundidade de observação o tornava imune aos ardis do brâmane mais enganador, e que permaneceu muito tempo no Oriente, fornece-nos, no Canto precedente, uma ideia bastante desfavorável da veneração religiosa e dos costumes da Índia" ${ }^{\text {"192 }}$. Algumas páginas depois, Mickle (p. 321, itálicos do autor) busca o apoio de Camões para as suas críticas:

Todos os viajantes que já visitaram o Oriente, inclusive os Srs. Holwell e Dow, descrevem a grande multidão de indianos como o mais supersticioso e mais devasso dos povos. Os detalhes mais impressionantes podem ser assim resumidos: as incontáveis superstições executadas às margens do Ganges fornecem um quadro lamentável das fraquezas da humanidade. Como mencionado por Camões, (Lusíadas VII e X) não apenas cadáveres são transportados de regiões distantes para serem jogados nas águas sagradas, mas os doentes são levados para junto do rio, onde ${ }^{193}$

On beds and litters o'er the margin laid

The dying lift their hollow eyes, and crave

Some pitying hand to hurl them in the wave.

Thus heaven they deem, though vilest guilt they bore

Unwept, unchanged, will view that guilt no more. ${ }^{194}$

Entretanto, a tradução desses versos d'Os lusíadas feita por Mickle introduz muitos elementos que não estão no original, como o melancólico cenário de moribundos abandonados à margem do rio. $\mathrm{O}$ original diz apenas:

\footnotetext{
character of Brahmin piety. Nor has their boasted philosophy been able to perceive the immorality of their penances, and of committing self-murder as the certain passport to heaven. What can the true moralist think of the Indian, who, upon religious principles, drowns himself in the Ganges, or throws himself under the wheels of his pagod's chariot, to be crushed to death by the holy load? The duties we owe to our relatives in particular, and to society in general, the Author of Nature has imposed upon us by an indispensible canon. Yet these duties by the pious suicide are refused on the principles of the weakest superstition. Nor can the moralist view the dreadful austerities to which the Brahmin philosophers submit themselves in any other light."

192 "Camoens, whose depth of observation rendered him greatly superior to the imposition of the most specious Brahmin, and who was long in the East, gives us in the preceding book, a very unfavourable idea of the religious worship and manners of India".

193 "Every traveller who has visited the East, Messrs. Holwell and Dow not excepted, represent the great multitude of the Indians as the most superstitious and most abandoned of people. The most striking particulars may be thus summed up: The innumerable superstitions performed on the Banks of the Ganges, afford a pitiable picture of the weakness of humanity. As mentioned by Camoens, (Lusiad VII. and X.) not only dead corpses are conveyed from distant regions to be thrown into the sacred water, but the sick are brought to the river side, where $[\ldots] "$

194 "Em leitos e macas sobre as margens depositados

Os moribundos erguem seus olhos vazios, e anseiam

Por uma mão piedosa que os atire nas ondas.

Assim o Paraíso, estimam eles, embora carreguem as culpas mais vis

Sem chorar, sem mudar, não verá mais essa culpa."
} 
Ganges, no qual os seus habitadores

Morrem banhados, tendo por certeza

Que, inda que sejam grandes pecadores,

Esta água santa os lava e dá pureza.

Mickle (1778, p. 322) invoca novamente Camões em seu apoio ao defender a ideia de que os indianos são insensíveis ao amor - essa seria a razão pela qual não sentiriam ciúme e a castidade feminina não seria abordada nas leis indianas. ${ }^{195}$ Mickle cita a sua própria tradução d'Os lusíadas:

Lost to the heart-ties, to his neighbour's arms

The willing husband yields his spouse's charms:

In unendear'd embraces free they blend;

Yet but the husband's kindred may ascend

The nuptial couch $[\ldots]^{196}$

No original, porém, o enfoque dado a essa questão parece até positivo:

Gerais são as mulheres, mas somente

Pera os da geração de seus maridos:

(Ditosa condição, ditosa gente,

Que não são de ciúmes ofendidos!)

(VII, 41)

${ }^{195}$ Essa ideia de que os povos recentemente colonizados seriam incapazes de amor encontra-se também em outros poemas britânicos dos séculos XVII e XVIII. Em "Summer", de Thompson (1837a, p. 65), por exemplo: "[...] Love dwells not there,

The soft regards, the tenderness of life,

The heart-shed tear, the ineffable delight

Of sweet humanity: these court the beam

Of milder climes; in selfish fierce desire,

And the wild fury of voluptuous sense,

There lost. The very brute-creation there

This rage partakes, and burns with horrid fire."

(“[...] O amor não mora lá,

Os suaves cuidados, a ternura da vida,

A lágrima sincera, o deleite inefável

Da doce compaixão: tudo isso corteja os raios

De climas mais temperados; em feroz desejo egoísta,

E na fúria selvagem da sensação voluptuosa,

Lá perdidos. A própria criação bruta lá

Compartilha essa raiva e arde com um fogo horrendo.")

196 "Desprovido de laços afetuosos, para os braços dos vizinhos,

O marido, de bom grado, entrega os encantos da esposa:

Em abraços sem afeto, livres eles se fundem;

Mas somente os homens da mesma casta do marido podem subir

Ao leito nupcial $[\ldots] "$ 
Mickle (1778, p. 330) nega as alegações feitas por alguns estudiosos do bramanismo de que a religião brâmane seria a mais antiga do mundo. Para Mickle, essa religião se alterou muito ao longo dos séculos, aperfeiçoando-se sob a influência dos europeus.

A superstição e idolatria dos brâmanes modernos certamente, da mesma forma, receberam grandes aperfeiçoamentos de elementos das conversas com europeus, cujo exemplo, ainda que falho em outros campos, não pôde deixar de convencê-los do absurdo de tais fraquezas mentais. ${ }^{197}$

Portanto, as teorias expostas no tempo de Mickle por estudiosos como Holwell e Dow não corresponderiam aos princípios dos antigos hindus, e difeririam até mesmo daqueles observados na época de Camões.

A conclusão de Mickle (1778, p. 331) é peremptória:

E assim, a partir do testemunho concomitante de todos os antigos viajantes, a maioria deles essencialmente confirmados pelos Srs. H. e D., exibimos o espírito caótico, volúvel e rude da teologia hindu; a interminável confusão de suas lendas; a impiedade e puerilidade de sua metafísica; a ignorância a respeito de filosofia natural; a imoralidade de suas penitências e idolatria; a depravação e ignomínia geral do caráter hindu; a alteração de seus princípios e costumes ao longo dos tempos; a profunda incerteza sobre as diversas datas das escrituras que consideram sagradas; e, acima de tudo, o absurdo daqueles que sustentam que essas escrituras permaneceram inalteradas durante quase quatro mil anos e que seus registros são mais antigos do que os de qualquer outra nação. ${ }^{198}$

O que vemos nesse ensaio de Mickle é a avaliação do bramanismo feita do ponto de vista de um moralista cristão que, na realidade, conhece muito pouco da religião brâmane, baseando suas opiniões no relato de historiadores e viajantes europeus que, em sua maioria, nem sequer conheciam o sânscrito ou outras línguas nativas da Índia. Mickle ridiculariza alguns rituais brâmanes e considera-os inúteis ou prejudiciais em termos morais. Mas como será que um brâmane avaliaria os rituais cristãos e os martírios dos santos? Em que medida seriam estes mais “justificáveis” do que os jejuns e rituais de banhos no Ganges?

\footnotetext{
197 "The superstition and idolatry of the modern Brahmins have certainly, in the same manner, received great improvement of features from the conversation of Europeans, whose example, however otherwise vicious, could not fail to convince them of the absurdity of such mental weakness."

198 "And thus, from the concurrent testimony of all former travellers, most virtually confirmed by Mess. H. and D. we have displayed the wild, capricious, and gross spirit of the Gentoo theology; the endless confusion of their legends; the impiety and puerility of their metaphysics; their ignorance of natural philosophy; the immorality of their penances and idolatry; the general turpitude and baseness of the Hindoo character; the alteration of their principles and manners in various ages; the utter uncertainty of the various dates of their writings held sacred; and, above all, the absurdity of those who have maintained that these writings have remained unaltered almost these 4000 years, and are of superior antiquity to the records of any other nation."
} 
Para efeitos de nosso trabalho, como já adiantamos, o que devemos destacar é a postura de superioridade que Mickle ostenta em relação aos indianos; a atitude arrogante e paternalista que o leva a dizer que a religião brâmane está evoluindo graças ao contato com os europeus; e, ainda mais importante, a forma como Mickle manipula o original de Camões em sua tradução para utilizar Os lusíadas como apoio para essa postura de menosprezo das crenças indianas ${ }^{199}$ - uma postura ideológica, na medida em que justifica a dominação britânica na Índia com base na missão de "civilização" dos nativos e "aperfeiçoamento" de seus costumes.

\subsection{PERITEXTOS III: NOTAS DE RODAPÉ}

De acordo com Genette (2009, p. 282), as notas guardam um parentesco de função com os textos prefaciais, com os quais mantêm uma relação estreita de continuidade e homogeneidade. Essa afirmação se aplica perfeitamente à relação entre os textos prefaciais e as notas de Mickle. É fácil perceber uma complementaridade entre os vários peritextos do Lusiad.

Mickle acrescentou quase setecentas notas de rodapé à sua tradução, além de cerca de cem notas à Introdução à tradução. Não faremos aqui uma análise detalhada dessas notas limitar-nos-emos a sintetizar, dando alguns poucos exemplos, as principais funções cumpridas por elas: explicitar o significado de termos; acrescentar informações históricas, geográficas ou culturais; elogiar ou defender Camões; apontar as influências clássicas de Camões; criticar os tradutores anteriores d'Os lusíadas (o primeiro tradutor para o inglês, Fanshawe, e o primeiro tradutor para o francês, Castera); defender ou exaltar a Inglaterra (ou Grã-Bretanha); defender um ponto de vista moral; e defender um ponto de vista ideológico.

\subsubsection{Explicitar o significado de termos}

O exemplo é a primeira nota da tradução, que explica o significado do título "The Lusiad": "The Lusiad; no original, Os Lusíadas, The Lusiads, do nome de Portugal em latim

\footnotetext{
${ }^{199}$ Veremos no Capítulo 5, subseção 5.2.4, que Os lusíadas também refletem uma perspectiva etnocêntrica, mas nos exemplos citados nesta subseção isso não chega a se evidenciar claramente.
} 
derivado de Lusus ou Lysas, o companheiro de Baco em suas viagens e que estabeleceu uma colônia na Lusitânia. Ver Plin. I.iii.c.i." ${ }^{200}$.

\subsubsection{Acrescentar informações históricas, geográficas ou culturais}

A nota $n$ da página 13 conta a história do pastor Viriato, acentuando seu caráter heroico e pacifista; a nota $d$ da página 19 conta a lenda de Fáeton, além de citar os versos da Eneida que serviram de modelo para Camões.

Na nota $t$ da página 63, para explicar os versos "Ali vereis o Mouro furioso / De suas mesmas setas traspassado", Mickle cita os relatos das crônicas de Barros e Castanheda de que, durante a guerra de Ormuz, um forte vento súbito fez com que as flechas desferidas pelos persas e mouros voltassem em direção aos próprios atiradores, ferindo muitos deles.

$\mathrm{Na}$ primeira nota da página 65, Mickle conta quem foi o navegador Fernão de Magalhães, citado n'Os lusíadas (II, 55) como “o agravado Lusitano".

Na nota $o$ da página 468, que se estende até a página 472, Mickle fornece um resumo sobre a situação histórica e cultural da China. Essa nota está repleta de afirmações preconceituosas em relação à China. Para citar alguns exemplos:

Os chineses não têm a menor noção das belezas de uma escrita refinada; provavelmente a maior culpa disso reside em sua língua; mas a falta completa de estrutura em suas pinturas e de simetria em sua arquitetura, duas áreas em que eles têm longa experiência, permite uma forte acusação contra o seu gênio. ${ }^{201}$

Incrivelmente não inventivos, pois, embora as possuam, as artes não fizeram progresso entre os chineses ao longo desses vários séculos $[\ldots]^{202}$

Qualquer que tenha sido a sua sabedoria política, atualmente ela é estreita e bárbara. ${ }^{203}$

Nenhuma indústria além da chinesa e da holandesa poderia manter o comércio e a população de um país sob o controle de rufiões armados. Mas

\footnotetext{
200 "The Lusiad; in the original, Os Lusiadas, The Lusiads, from the Latin name of Portugal derived from Lusus or Lysas, the companion of Bacchus in his travels, and who settled a colony in Lusitania. See Plin. I.iii.c.i.”.

201 "The Chinese have no idea of the graces of fine writing; here most probably the fault exists in their language; but the total want of nature in their painting and of symetry in their architecture, in both of which they have so long been experienced, afford a heavy accusation against their genius."

202 "Amazingly uninventive, for, though possessed of them, the arts have made no progress among the Chinese these many centuries [...]".

203 "Whatever their political wisdom has been, at present it is narrow and barbarous."
} 
dessa forma o imperador tem tempo de lazer para cultivar os jardins e escrever odes abomináveis para as suas concubinas. ${ }^{204}$

\subsubsection{Elogiar ou defender Camões}

Na nota $h$ da página 53, Mickle invoca Homero, Virgílio, Dante e até a Bíblia para justificar o uso, por parte de Camões, de metáforas envolvendo sapos e formigas - seres que não costumam ser citados em epopeias por não terem a devida "elevação" ou solenidade.

Na nota $c$ da página 74, Mickle elogia o estilo do discurso de Gama ao rei de Melinde (Canto II, estrofe 84).

Na nota $l$ na página 96, o tradutor, em comentário à referência de Camões (Canto III, estrofe 27) à participação de Henrique de Borgonha na reconquista de Jerusalém, diz que historicamente essa participação teria sido extremamente improvável, mas que Camões fez bem em mencioná-la, pois acrescentava solenidade ao poema.

Ao traduzir a estrofe 35 do Canto $\mathrm{V}$, reproduzindo o diálogo zombeteiro entre o marinheiro Fernão Veloso e seus companheiros, Mickle acrescenta uma nota (p. 202). Para defender Camões das críticas (vindas, principalmente, dos neoclássicos franceses) que repudiavam a mistura do cômico ao épico, Mickle cita passagens cômicas nos poemas épicos de Homero, Virgílio e John Milton.

Há momentos, no entanto, em que Mickle critica Camões. Um exemplo é a nota $c$ da página 436, sobre Garcia de Noronha: “Aquele bravo e generoso espírito que levou Camões a condenar o grande Albuquerque por injustiça contra um soldado comum o desertou aqui. Em lugar de elogio poético, Noronha, pelo terror evocado por seu nome, merecia a infâmia"205. Mickle não deixa, portanto, de criticar um personagem que considera injusto e intolerante e, assim, nefasto para o bom governo do Império, mesmo que isso o leve a censurar Camões.

\subsubsection{Apontar as influências clássicas de Camões}

Na nota $r$ da página 23, Mickle diz que, na passagem "Da Lũa os claros raios rutilavam / Pelas argênteas ondas Neptuninas [...]”, Camões imitou Homero ao estilo de Virgílio; identifica a passagem aludida no Livro VIII da Eneida e cita doze versos da tradução de Pope.

\footnotetext{
204 "Nothing but Chinese or Dutch industry could preserve the traffic and population of a country under the controul of armed ruffians. But hence the emperor has leisure to cultivate his gardens, and to write despicable odes to his concubines."

205 "That brave generous spirit, which prompted Camoens to condemn the great Albuquerque for injustice to a common soldier, has here deserted him. In place of poetical compliment, on the terrors of his name, Noronha deserved infamy."
} 
Na nota $o$ da página 59, Mickle cita os versos do Livro I da Eneida que forneceram o modelo para os versos 5 e 6 da estrofe 42 do Canto II de Os lusíadas.

\subsubsection{Criticar os tradutores anteriores de Os lusíadas (Fanshawe e Castera)}

Na nota $h$ da página 95, referente à tradução dos versos "Destes Anrique (dizem que segundo / Filho de um Rei de Hungria exprimentado)” (III, 25), Mickle esclarece que Camões seguiu o cronista Duarte Galvão, mas que há muitas divergências entre os historiadores portugueses e espanhóis a respeito da origem desse estrangeiro. Mickle acredita que o relato mais confiável seja o de um fragmento escrito por um monge beneditino no início do século XII, segundo o qual esse Conde Henrique seria o filho único de Roberto, o primeiro duque da Borgonha, irmão mais novo de Henrique I da França. Apesar disso, Mickle se mantém fiel à versão de Camões, traduzindo essa passagem como "The first and bravest of the foreign bands / Hungaria's younger son, brave Henry stands"206 e critica Fanshawe por haver tomado liberdades indevidas em sua tradução - "Amongst These Henry (saith the History) / A younger son of France, and a brave Prince ${ }^{, 207}$-, alterando dados mencionados pelo autor.

Na nota $r$ da página 104, Mickle critica a tradução de Castera da estrofe 52 do Canto III, dizendo que o tradutor francês faz uma paráfrase não poética das mais belas passagens de Camões.

Na página 164, ao traduzir a estrofe 38 do Canto IV, que descreve o momento em que D. João incita os guerreiros portugueses ao combate contra os castelhanos, Mickle introduz uma nota $(p)$ elogiando os versos "E, sopesando a lança quatro vezes, / Com força tira; e deste único tiro / Muitos lançaram o último suspiro", considerando-os poéticos e moldados ao estilo de Homero, e critica a sua omissão por parte de Castera. Critica também a introdução, por parte do primeiro tradutor francês, de vários personagens que não constam do original.

Comentando, na nota c da página 390, a tradução da expressão "sombrio vale" (Canto IX, estrofe 60), Mickle diz que sua tradução, "shadowy vale", é literal, e que Fanshawe, ao traduzir a expressão como "the gloomy valley" transformou uma paisagem que era para ser festiva em funérea.

\footnotetext{
206 “O primeiro e mais corajoso de todos os grupos estrangeiros / O filho mais novo [do rei] da Hungria, o bravo Henrique, apresenta-se."

207 "Entre eles Henrique (conta a História) / Um filho mais novo [do rei] da França, e bravo Príncipe".
} 


\subsubsection{Defender ou exaltar a Inglaterra (ou Grã-Bretanha)}

Quando Camões menciona o cerco a Silves (III, 86) com ajuda da "Germânica armada", a tradução de Mickle (CAMÕES, 1776a, p. 118) omite a menção aos alemães, dizendo apenas 'In Tagus' breast a gallant navy sought / The shelt'ring port, and willing glad assistance brought" 208 . O tradutor introduz uma nota $(f)$ explicando que os portugueses, na guerra contra os mouros, eram ocasionalmente ajudados por ingleses e alemães e que "no caso em questão, a frota era principalmente inglesa"209 . Cita como fonte as Crónicas dos Reis de Portugal, de Nunes de Leão. Entretanto outras fontes, como Rui de Pina (1727, p. 18), dizem que essa ajuda era de alemães, flamengos e franceses; outras ampliam a lista, citando alemães, flamengos, bretões e ingleses. De qualquer forma, todas as fontes que consultamos incluem os alemães na lista. Mais adiante, na estrofe 88, Camões repete a menção aos germânicos ("Do Germano ajudado"), porém Mickle traduz como "sent by Heaven, a foreign naval band"210, eliminando novamente a referência aos alemães.

Na nota $w$ das páginas 168-169 - referente à tradução da estrofe 50 do Canto IV -, Mickle discorre sobre D. João I, elogiando-lhe a boa educação, justiça, prudência, heroísmo, afabilidade e dignidade. Aproveita para comentar que esse magnífico rei era pai de D. Henrique, "aquele grande príncipe cuja paixão ardente pelos assuntos marítimos gerou todos os aperfeiçoamentos modernos na navegação" ${ }^{211}$ e finaliza mencionando a rainha de origem inglesa, D. Filipa de Lencastre: "Sua afeição pela rainha Filipa o levou a estimar os ingleses, cuja amizade cultivou e por quem foi muitas vezes auxiliado" ${ }^{\text {212 }}$

Os versos "Vede-lo duro Inglês, que se nomeia / Rei da velha e santíssima cidade" (VII, 5, 1-2), referentes a Henrique VIII, são traduzidos por Mickle como "High sound the titles of the English crown, / King of Jerusalem, his own renown!"213. O tradutor, contudo, acrescenta uma nota (CAMÕES, 1776a, p. 272, nota $b$ ) dizendo que se trata de um erro de Camões, pois o título de "Rei de Jerusalém" nunca foi assumido pelos reis da Inglaterra. Robert, Duque da Normandia, filho de Guilherme, o Conquistador, teria sido eleito Rei de Jerusalém por seu exército na Síria, mas teria recusado esse trono na esperança de assumir o da Inglaterra, o que

\footnotetext{
208 "No seio do Tejo uma corajosa armada buscou / O porto de abrigo, e resoluto auxílio levou".

209 "In the present instance the fleet was mostly English".

210 "enviada pelos Céus, uma esquadra estrangeira".

211 "that great prince whose ardent passion for maritime affairs gave birth to all the modern improvements in navigation"

212 "His affection to his queen Philippa made him fond of the English, whose friendship he cultivated, and by whom he was frequently assisted."

213 "Altos soam os títulos da Coroa Inglesa, / Rei de Jerusalém, sua própria consagração!"
} 
não veio a se concretizar. Mickle reconhece, no entanto, que Henrique VIII merecia as censuras de Camões em razão de sua vida de devassidão e brutalidade.

\subsubsection{Defender um ponto de vista moral}

No Canto X, na descrição da Máquina do Mundo, a nota $m$ da página 446 comenta o verso "Bem como quis o Padre omnipotente", que Mickle traduz como "Such are their laws imprest / By God's dread Will" ${ }^{, 14}$. O tradutor advoga a necessidade da presença de uma divindade particular em um poema épico, a fim de emprestar mais solenidade e nobreza aos personagens e à narrativa, e fornece vários argumentos de tom moral, como, por exemplo: "Se admitirmos, e quem pode negá-lo, que o ser humano tem uma noção do certo e do errado, e um poder de agir de uma forma ou de outra, então ele é um agente moral, ou, em outras palavras, um agente racional $[\ldots], 215$.

\subsubsection{Defender um ponto de vista ideológico}

Na longa nota $d$ da página 3, da qual citaremos apenas as primeiras linhas, Mickle elogia os colonizadores portugueses em contraposição aos espanhóis:

Em nenhum período da História a Natureza Humana se mostrou em traços mais brutais, mais diabólicos do que nas guerras de Cortez, e os conquistadores espanhóis da América do Sul. Para a honra imortal dos descobridores portugueses, a sua conduta foi, em todos os aspectos, a oposta. Estabelecer um comércio igualmente vantajoso para os nativos assim como para eles próprios era a motivação que os impulsionava; a honra mais estrita, e aquela humanidade que é sempre inseparável da verdadeira bravura, presidiam todas as suas transações; e só recorriam a hostilidades quando eram provocados, quer pela violência direta, quer pela perfídia dos Nativos. $^{216}$

\footnotetext{
214 “A tal ponto são suas leis marcadas / Pela Vontade terrível de Deus".

215 "If we admit, and who can possibly deny it, that man has an idea of right and wrong, and a power of agency in both, he is then a moral, or in other words, a reasonable agent [...]".

216 "In no period of History does Human Nature appear with more shocking, more diabolical features than in the wars of Cortez, and the Spanish Conquerors of South America. To the immortal honour of the Portuguese Discoverers, their conduct was in every respect the reverse. To establish a traffic equally advantageous to the natives as to themselves, was the motive on which they acted; the strictest honour, and that humanity which is ever inseparable from true bravery, presided over their transactions; nor did they ever proceed to hostilities till provoked, either by the open violence or by the perfidy of the Natives."
} 
Na nota $g$ da página 6 , ao comentar a antiga pujança e atual decadência do Império Português, e a forma como os holandeses se apoderaram de territórios que haviam pertencido a Portugal, Mickle envia um recado à Companhia das Índias Orientais (!):

Que a Companhia Inglesa das Índias Orientais, em meio a seus sucessos, lembre-se do destino de seus predecessores, e esteja sempre prevenida contra aquele povo astucioso, que, seguindo os princípios sob os quais sempre agiu, poderia tirar proveito das fraquezas da Inglaterra, assim como fez até agora das dificuldades de Portugal! ${ }^{217}$

Na longa nota $(m)$ que se estende da página 277 à 279, Mickle justifica a exortação de Camões a uma Cruzada lusitana fazendo, na verdade, uma defesa geral das Cruzadas, que se encerra com uma evocação à ligação entre as Cruzadas e o ressurgimento do comércio após a Idade Média, baseada no historiador escocês William Robertson (1721-1793):

As esquadras que acompanhavam as Cruzadas introduziram o comércio e a liberdade de cidades comerciais em seus países natais. Isso, como observa Robertson, se mostrou destrutivo para o sistema feudal, que havia então degenerado na opressão mais sombria, e gerou planos de um governo regular [...] O espírito de invenção reviveu, o comércio se tornou objeto de atenção e começou a florescer. A população aumentou. A independência se estabeleceu, e a riqueza afluiu para as cidades que haviam sido por muito tempo centros de pobreza e opressão. ${ }^{218}$

\subsection{RECEPÇÃO DO LUSIAD DE MICKLE}

Desde a publicação do Lusiad até hoje, Mickle é designado pelos historiadores e críticos literários como "o tradutor de Os lusíadas". Outra obra de Mickle mencionada com destaque é a balada "Cumnor Hall”, por ter influenciado Walter Scott e contribuído para o ressurgimento do gênero, mas, sem sombra de dúvida, é principalmente pela tradução de Os lusíadas que Mickle é lembrado.

\footnotetext{
217 "May the English East India Company, in the midst of their successes, remember the fate of their predecessors, and ever be guarded against that politic people, who, according to the principles on which they have always acted, would take the same advantages of the weakness of England, which heretofore they took of the distresses of Portugal!"

218 "The fleets which attended the crosses introduced commerce, and the freedom of commercial cities into their mother countries. This, as Robertson observes, proved destructive to the feudal system, which had now degenerated into the most gloomy oppression, and introduced the plans of regular government. [...] The spirit of industry revived, commerce became an object of attention, and began to flourish. Population increased. Independence was established, and wealth flowed into cities which had long been the seat of poverty and oppression."
} 
Na Grã-Bretanha, o Lusiad de Mickle teve nove edições em pouco mais de um século, entre os séculos XVIII e XIX: Oxford, 1776 e 1778; Dublin, 1791; Londres, 1798, 1807, 1809 (duas edições), 1810 e 1877. Nos Estados Unidos, o Lusiad foi publicado em 1822, na Filadélfia, e reeditado em 1825. No início do século XX, mais duas edições em Londres, em 1900 e 1907 (ESTORNINHO, 1960, p. 153). Nenhuma outra tradução de Os lusíadas desfrutou de tal popularidade.

\subsubsection{Recepção na época da publicação}

Na época de sua publicação, o Lusiad de Mickle foi muito bem acolhido pelos periódicos. Ao lançar o livro-amostra, com a tradução do Canto I, em julho de 1771, Mickle recebeu resenhas favoráveis do Critical Review e do Gentleman's Magazine, e uma negativa, do Monthly Review. O que é interessante observarmos é que tanto as críticas quanto os elogios recebidos espelham claramente as preferências da época em termos de tradução.

A resenha do Gentleman's Magazine (THE FIRST..., 1771b, pp. 323-325) equivoca-se na grafia do título de livro, chamando-o de Luciad. Depois de uma breve apresentação da obra original, do autor, do tradutor e sua proposta de tradução, o resenhista acrescenta que a obra ainda não havia sido traduzida para o inglês, excetuando-se a tradução de Fanshawe, sobre a qual comenta: "Fanshaw é impossível de ler, e assim o seria mesmo que o original fosse muito mais excelente do que é, e sua tradução fosse tão fiel ao sentido quanto o mostrador do relógio é ao sol"219 (p. 324). Como que para provar essa declaração, o Gentleman's Magazine publica, a seguir, as traduções das estrofes 45 e 46 do Canto I d'Os lusíadas feitas por Fanshawe e Mickle, como se a superioridade da tradução de Mickle fosse evidente a qualquer leitor. Para o leitor contemporâneo, o que fica evidente ao cotejar as duas traduções com o original é que a tradução de Fanshawe é bem mais literal, mais próxima do original do que a de Mickle. Mas o leitor inglês daquela época buscava a fluência de linguagem e a cadência ao estilo de Pope, e nesses quesitos a tradução de Mickle agradava muito mais do que a de Fanshawe.

O resenhista do Critical Review (THE FIRST..., 1771a, p. 106) elogia Os lusíadas; lamenta a falta de uma boa tradução para o inglês até o momento; reconhece as boas qualificações de Mickle para a tarefa e expressa o desejo de que a nova tradução seja melhor do que a anterior (“'O autor da presente versão parece qualificado para fazer justiça a Camões;

\footnotetext{
219 "Fanshaw it is impossible to read, and so it would be if the original was ever so much more excellent than it is, and his translation as faithful to the sense, as the dial to the sun".
} 
e parabenizamos os amantes da poesia diante da perspectiva de haver uma tradução tão elegante d'Os lusíadas em nossa língua"220). Essas linhas iniciais comprovam o que observamos algumas linhas acima a respeito da resenha do Gentleman's Magazine: o gosto da época rejeitava as traduções literais, favorecendo as traduções fluentes, "elegantes".

A seguir, o Critical Review publica o início da tradução de Mickle do Canto I e comenta: "Seria uma injustiça para com o tradutor não reconhecer que ele cumpriu a tarefa com elegância e vigor, e, até o ponto em que podemos julgar a partir de uma comparação com outras versões, com toda a fidelidade exigida de uma tradução livre"221. Não obstante, o resenhista propõe quatro pequenas correções. Em uma delas, sugere que a repetição da palavra flight soa deselegante na passagem 'Yet flight they purpos'd, tho' they dar'd the fight, / To lead brave GAMA by their sudden flight" ${ }^{222}$. Essa foi a única correção aparentemente aceita por Mickle, que alterou esses versos na edição final para:

Yet seeming artless, though they dared the fight,

Their eager hope they placed in artful flight,

To lead brave GAMA where, unseen by day, In dark-brow'd shades their silent ambush lay. ${ }^{223}$

(CAMÕES, 1776a, p. 32).

O crítico do Monthly Review enfoca a tradução de Mickle sob o ponto de vista daquilo que considera uma falha no original: o uso da máquina pagã em um poema cristão. O resenhista julga essa mistura disparatada [preposterous]. Diante disso, ele acredita que nem valia a pena traduzir essa obra para o inglês:

É tão poderosa a objeção contra Os lusíadas; uma objeção que nem a força do gênio, nem a riqueza de imaginação que [o poema] exibe poderá jamais tornar inconsequente; e admitimos que, diante desse embaraço, independentemente das habilidades que o Tradutor possua, não desejaríamos vê-lo na língua inglesa. Ignorar as belezas d'Os lusíadas é de menor importância para nós como povo do que ver nosso sistema religioso

\footnotetext{
220 "The author of the present version seems qualified for doing justice to Camoens; and we congratulate the lovers of poetry, on the prospect of having so elegant a translation of the Lusiad in our language".

221 "It would be injustice to the translator not to acknowledge that he has performed his task with elegance and spirit, and as far as we are able to judge from a comparison with other versions, with all the fidelity required in a free translation".

222 "Entretanto fugir eles planejavam, embora tenham ousado lutar, / Para conduzir o bravo GAMA com a sua súbita fuga."

223 "Apesar de aparentemente ingênuos, embora ousassem lutar,

Sua ávida esperança eles colocavam em uma fuga astuciosa,

Para conduzir o bravo GAMA aonde, oculto ao dia,

Em sombras taciturnas eles armaram uma emboscada silenciosa."
} 
desacreditado por um uso fabuloso de seu autor. ${ }^{224}$ (THE FIRST..., 1771c, pp. 181-182).

O resenhista acrescenta ainda que o tradutor francês, Duperron de Castera, omitiu as partes cristãs da máquina, e que Mickle deveria ter-lhe seguido o exemplo. A seguir, o crítico cita, na íntegra, o comentário de Voltaire sobre Os lusíadas em seu Essay on the Epic Poetry, embora inclua, em notas de rodapé, as correções de Mickle aos erros mais flagrantes do filósofo francês. Ao final, o resenhista publica um trecho da tradução de Mickle e conclui dizendo:

O Sr. Mickle anteriormente deu provas de seus talentos poéticos em Pollio, an elegy; e em Concubine, a poem. É nossa opinião, todavia, que na amostra agora publicada há muitos versos a que falta força e alguns que exigiriam polimento. $^{225}$ (THE FIRST..., 1771c, p. 188).

Essa resenha negativa do Monthly Review mostra bem o clima da época neoclássica, contrário às traduções literais e propenso a exigir a censura de tudo o que fosse considerado ofensivo à fé e aos "bons costumes". Para esse resenhista, Mickle deveria ter omitido ou atenuado ainda mais passagens d'Os lusíadas do que o fez...

Em agosto de 1771, um mês depois do lançamento da tradução do Canto I, uma carta-ensaio muito interessante, reconhecidamente inspirada por essa tradução, foi publicada no Gentleman's Magazine com o título "An Essay on Translation” e assinada apenas com as iniciais “D. Z.” (1771, pp. 349-352). O ensaísta principia lamentando o descaso votado por sua época aos tradutores em comparação com o aplauso recebido pelos autores de obras originais. Indaga-se se esse descaso se deveria à má qualidade das traduções ou à noção equivocada - no caso da tradução poética - de que um tradutor não pode ser um poeta. Contra essa opinião, D. Z. (p. 349) argumenta:

Quão comumente o mundo exclama, quando alguma tradução é feita por alguém que demonstrou criatividade suficiente para compor uma obra original, que pena é que tal gênio se submeta ao árduo trabalho da tradução; esquecendo-se de que o gênio de Pope não considerava uma humilhação

\footnotetext{
224 "Such is the powerful objection which rests against the Lusiad; an objection which neither the force of genius, nor the wealth of fancy it exhibits can ever render unconsequential; and we own that, under this predicament, whatever abilities the Translator might possess, we should not wish to see it in the English language. To be ignorant of the beauties of the Lusiad is of much less consequence to us as a people, than to see our religious system discredited by a fabulous use of its founder."

225 "Mr. Mickle has, before this, given proofs of his poetical talents in Pollio, an elegy; and in the Concubine, a poem. We are of opinion, however, that in the specimen now published there are many lines that want the strengthening, and some that require the polishing hand."
} 
traduzir Homero, nem o gênio muito maior ainda de Dryden, traduzir Virgílio. ${ }^{226}$

O ensaísta acredita que o tradutor deve ser tão qualificado quanto o autor de um original e enumera as qualificações que seriam necessárias ao tradutor:

[...] um bom julgamento para discernir e preservar todas as belezas do original; uma capacidade de fornecer ao estilo as suas marcas fortes e dinâmicas; às falas, o seu verdadeiro caráter e espírito; aos sentimentos, a sua plena força e sublimidade; às descrições, as suas cores naturais e animadas, além da dicção e harmonia poética, que são inteiramente dele próprio $[\ldots]^{227}$

Atendidos esses requisitos, a distância entre a tradução e o original desapareceria. D. Z. (p. 350) declara-se contra as traduções literais, mas levanta uma importante questão: "É algo digno da atenção de um tradutor fazer com que seu poema soe como um original. Ora, isso jamais será obtido por uma tradução literal; mas a questão é, que liberdades lhe devem ser permitidas?"228

O próprio ensaísta responde que isso depende do autor a ser traduzido; um grande autor como Homero ou Virgílio deve ser traduzido mais literalmente, mas, mesmo nesses casos, é preciso suavizar tudo o que parecer rude ou vulgar:

Ao traduzir autores de muito discernimento como Homero e Virgílio, ele deve segui-los tão de perto quanto possível, se quer preservar sua chama e espírito. O exemplo [dos autores] será o melhor guia sobre quando ser simples e quando figurativo e poético; quando se alçar ao ousado e sublime; quando ser humilde e sem enfeites, e quando prestar uma atenção especial àquela harmonia imitativa, em que eles próprios tanto se destacam. Porém mesmo nesse caso ele deve, muitas vezes, corrigir as expressões idiomáticas que se tornaram obsoletas e grosseiras; deve suavizar as falas e os costumes, que para esta era eolítica pareceriam rudes e vulgares; e nisso ele pode ser guiado apenas por seu próprio discernimento. ${ }^{229}$

\footnotetext{
226 "How commonly does the world exclaim, when any translation is made by one who has had invention enough to compose an original piece, what pity it is that such a genius should submit to the drudgery of translation; forgetting that the genius of Pope thought it no submission to translate Homer, nor the much greater genius of Dryden to translate Virgil."

227 " [...] a nice judgment to distinguish and preserve all the beauties of their original; a capacity of giving to the manners their strong and lively marks; to the speeches their true character and spirit; to the sentiments, their full force and sublimity; to the descriptions, their natural and animated colours, besides the diction and harmony of verse, which are entirely their own $[\ldots]$ "

228 "It is worthy of the attention of a translator to make his poem read like an original. Now this can never be attained by a literal translation; but the question is, what latitude shall be allowed to him?"

229 "In translating authors of so much judgment as Homer and Virgil, he cannot follow them too closely, if he preserves their fire and spirit. Their example will best teach him when to be plain, and when figurative and poetical; when to rise into the bold and sublime; when to be humble and unadorned, and when to pay a particular regard to that imitative harmony, in which they themselves so much excel. Yet even here, he must often correct
} 
Para D. Z., na tradução de autores menos ilustres, o tradutor pode e deve tomar mais liberdades:

Mas com poetas de menos eminência ele pode tomar maiores liberdades. Deve exercitar seu gosto para descobrir-lhes os defeitos, e sua arte para ocultá-los. Deve emprestar-lhes vigor quando eles são tediosos, e corrigir o que for ardente demais. Deve se esforçar por realçar-lhes as belezas, e, quando essas faltarem, pode-se arriscar a fornecê-las. ${ }^{230}$

Sobre Os lusíadas e a tradução anunciada por Mickle, o tema que motivou o ensaio, D. Z. (p. 350) afirma:

Este célebre poema, ainda que não se iguale às epopeias de primeira linha, como as de Homero, Virgílio e Milton, pode muito bem ocupar uma posição eminente entre as de segunda linha; e é com grande prazer que contemplo a decisão de traduzi-lo para o inglês tomada por um escritor tão hábil quanto o autor de Concubine. ${ }^{231}$

Comparando a tradução de Mickle com a de Fanshawe, D. Z. conclui que a tradução de Fanshawe "é, com efeito, fiel ao sentido de Camões; mas não se pode compará-la à do Sr. Mickle tanto quanto não se pode comparar uma tradução em prosa com a tradução da Eneida feita por Dryden" 232 .

D. Z expressa e justifica seu entusiasmo com a tradução de Mickle:

Se me permitem dar uma opinião, a tradução do Sr. Mickle promete estar à altura de qualquer outra feita em língua inglesa. Seus personagens são bem preservados e fortemente marcados; os discursos possuem grande força e vigor, as descrições são magistrais e sublimes; os versos são escritos com uma dicção tensa e grandiosa, e com uma bela harmonia poética. ${ }^{233}$

\footnotetext{
the idioms which are become obsolete and uncouth; he must soften the speeches and the manners, which to this Eolite age would appear rude and coarse; and in this he can be guided only by his own judgment."

230 "But in poets of less eminence he may use greater liberties. He must exercise his taste to discover their defects, and his art to conceal them. He must lend them spirit where they are dull, and correct that which is too ardent. He must labour to heighten their beauties, and, where they are wanting, he may venture to supply them." 231 "This celebrated poem, though not equal to the first-rate Epics of Homer, Virgil, and Milton, may well hold a distinguished rank among the second; and it is with great pleasure that I behold a resolution taken of rendering it into English, by so able a writer as the author of the Concubine."

232 "is indeed true to the sense of Camoens; but no more to be compared to Mr. Mickle's than a prose translation of the Æneid to Dryden's".

233 "If you will permit me to give an opinion, Mr. Mickle's translation promises well to stand in competition with any made in the English language. His characters are well preserved and strongly marked; his speeches have great force and spirit, his descriptions are masterly and sublime; his verse is written in a nervous and lofty diction, and in a fine harmony of numbers."
} 
A seguir, o ensaísta dá exemplos dessas características percebidas na tradução de Mickle, citando passagens em que destaca as qualidades poéticas, a beleza das figuras empregadas e das descrições.

D. Z. (p. 351) enfatiza também as qualidades de Mickle em termos de "harmonia sentimental" e "harmonia imitativa". ${ }^{234}$ Por "harmonia sentimental" D. Z. entende a adaptação dos sons, da duração e cadência das frases aos sentimentos. Um bom escritor - e especialmente um poeta - deveria ter um bom ouvido para ser capaz de expressar as emoções por meio dos sons. D. Z fornece vários exemplos do uso da harmonia sentimental na tradução de Mickle do Canto I de Os lusíadas, dos quais reproduziremos apenas um:

The bursting whirlwinds tear their rapid course,

The shatter'd oaks crash; and with echoes hoarse The mountains groan $[\ldots]^{235}$

Quanto à "harmonia imitativa", seria produzida "por uma escolha adequada de palavras que expressem o tema por meio do som" ${ }^{236}$. D. Z. (p. 352) cita como exemplo do uso desse tipo de harmonia por Mickle a seguinte descrição de uma batalha:

Strait as he spoke the Magazines display'd

Their glorious shew, where, tire on tire inlaid, Appear'd of glittering steel the carabines, There the plum'd helms, and pond'rous brigandines; O'er the broad bucklers' sculptor'd orbs embost, The crooked faulchions dreadful blades were crost; There clasping greaves, and plated mail-quilts strong, The long-bows here, and rattling quivers hung, And like a grove the burnish'd spears were seen, With darts, and halberts double edg'd, between; Here dread grenadoes and tremendous bombs, With deaths ten thousand lurking in their wombs; And far around of brown and dusky red, The pointed piles of iron balls were spread. ${ }^{237}$

\footnotetext{
${ }^{234}$ O próprio Mickle (1776, p. 405, nota l) mencionou esses dois conceitos, referindo-se às traduções de Homero por Pope e dizendo que a tradução da fala de Leonardo, nas estrofes 76-81 do Canto IX d'Os lusíadas, poderia, ao leitor apressado, parecer descuidada e às vezes inflada e formal, mas que se trata de uma tentativa de harmonia sentimental e imitativa.

235 "Os redemoinhos que irrompem rasgam seu rápido curso,

Os carvalhos estilhaçados tombam; e com ecos roucos

As montanhas gemem [...]". (Note-se que, neste exemplo e no que se segue, as observações do resenhista se referem à sonoridade do original, que nem sempre foi reproduzida em nossa tradução.)

236 "by a proper choice of words expressive of the subject by their sound".

237 "Assim que ele falou o paiol exibiu

Seu espetáculo glorioso em que, fileira após fileira,

Surgiram de ferro reluzente as carabinas,

Os elmos emplumados e pesadas brigandinas;
} 
Sobre essa passagem, D. Z. comenta:

Armas e armaduras são mais plenamente representadas à imaginação por termos de um tom brusco e sonoro: assim o poeta, na seguinte descrição, escolheu palavras compostas de vogais abertas e amplas, somadas às mais ásperas consonantes. A descrição em si é pictórica e magistral. ${ }^{238}$

Após o lançamento da tradução completa, em 1776, novas resenhas foram publicadas no Critical Review, Gentleman's Magazine, London Magazine, Monthly Review, The Town and Country Magazine e, na Escócia, em The Edinburgh Magazine and Review.

A resenha do Critical Review (THE LUSIAD..., 1776a, pp. 15-26) foi escrita pelo mesmo resenhista de 1771 e repete os elogios e felicitações então endereçados ao tradutor. Comenta detalhadamente a Introdução do tradutor, citando a longa passagem que se refere ao infante D. Henrique como o criador do sistema comercial mundial; resume a biografia de Camões redigida por Mickle; e aplaude os argumentos utilizados por Mickle para defender $O s$ lusíadas das críticas de Voltaire. Depois de reproduzir quase quatro páginas do início do Canto III do Lusiad, o resenhista (p. 23) afirma que as intervenções de Camões em seu poema são, realmente, estranhas à narrativa épica, mas concorda com o tradutor ao reconhecer a beleza dessas digressões.

O crítico não economiza elogios ao se referir ao episódio da Ilha dos Amores (do qual cita também vários versos):

A ficção da Ilha de Vênus, que encerra a ação n'Os lusíadas, fornece não apenas um exemplo impressionante da riqueza da imaginação do autor como, ao mesmo tempo, o mais belo episódio que pode ser citado na conclusão de um poema épico, antigo ou moderno. ${ }^{239}$ (THE LUSIAD..., 1776a, p. 25).

\footnotetext{
Sobre as esferas esculpidas entalhadas no amplo escudo, As cimitarras curvas, temíveis espadas, se cruzavam;

Ali grevas afiveladas e sólidas cotas de malha chapeadas acolchoadas,

A longa proa aqui, e aljavas chocalhantes penduradas,

E viu-se um bosque de lanças polidas,

Com dardos, e alabardas de duplo fio, no meio;

Aqui horrendas granadas e terríveis bombas,

Com dez mil mortes espreitando em seus úteros;

E ao longe, em torno, em castanho e vermelho-escuro,

As pilhas pontiagudas de balas de ferro se espalhavam."

238 "Arms and armour are more fully represented to the imagination by terms of a bold and sonorous tone: accordingly the poet in the following description has selected such words as are composed of open and broad vowels, joined with the roughest consonants. The description in itself is picturesque and masterly."

239 "The fiction of the Island of Venus, with which the action of the Lusiad terminates, affords not only a striking instance of the richness of the author's imagination, but is at the same time the most beautiful episode that can be cited in the conclusion of an epic poem, either ancient or modern."
} 
O resenhista lembra as correções que sugerira anteriormente ao tradutor. Curiosamente, embora Mickle tenha adotado apenas uma de suas quatro sugestões, o resenhista declara:

Em nossa resenha do primeiro livro desse poema, nós sugerimos umas poucas correções, a respeito das quais temos o prazer de verificar que o Sr. Mickle não foi desatento. Nossa satisfação é ampliada ao observarmos que agora, quando o trabalho está completo, apresenta-se com um grau de elegância e correção que dificilmente poderá receber aperfeiçoamentos em uma edição subsequente. ${ }^{240}$ (THE LUSIAD..., 1776a, p. 26).

A avaliação final é absolutamente positiva:

Quanto à fidelidade da versão, confiamos inteiramente na criatividade do tradutor; e a respeito do espírito épico e decoro com que é executada, o exame que nós mesmos efetuamos nos deixou satisfeitos. Os lusíadas podem, de agora em diante, ser lidos em inglês, talvez com tanto prazer quanto na composição original de Camões. ${ }^{241}$ (THE LUSIAD..., 1776a, p. 26).

O resenhista do Gentleman's Magazine (THE LUSIAD..., 1776b, 367-369) parabeniza o tradutor por haver completado a tradução, elogiando-o pelo meticuloso trabalho de pesquisa da introdução histórica e literária. Ressalva, no entanto, que em certas passagens Mickle se exaltou em demasia, o que não seria necessário, já que seus argumentos eram sólidos. Discute em detalhe algumas questões históricas, comparando as diferentes opiniões de Mickle e do abade Raynal e destacando a originalidade do trabalho de pesquisa de Mickle. Lembra o artigo publicado pela revista em 1771, ressaltando a qualidade da tradução nos aspectos de harmonia sentimental e imitativa, e indica ao leitor algumas passagens de especial beleza.

O London Magazine assemelha Os lusíadas a um planeta distante e luminoso, mas cuja grandeza e beleza eram inacessíveis aos britânicos. A partir dessa metáfora, compara a tradução de Fanshawe à de Mickle: "Fanshaw com sua tradução forneceu a nossos compatriotas um telescópio por meio do qual esse ilustre planeta podia ser visto de forma

\footnotetext{
240 "In our Review of the first book of this poem, we suggested a few emendations, respecting which we have the pleasure to find that Mr. Mickle has not been inattentive. Our satisfaction is increased by observing, that now, when the work is completed, it appears with a degree of elegance and correctness, which can hardly receive improvement in a subsequent edition."

${ }^{241}$ "For the fidelity of the version, we rely with entire confidence on the ingenuity of the translator; and in respect to the epic spirit and dignity with which it is executed, we are satisfied from our own examination. The Lusiad may henceforth be read in English, perhaps with as much delight as in the original composition of Camoëns.”
} 
mais nítida; mas estava reservado ao Sr. Mickle produzir um trabalho mais puro e perfeito"242. O crítico elogia a excelência poética da tradução de Mickle e seu trabalho de pesquisa histórica e literária. (THE LUSIAD..., 1776c, pp. 210-211).

A resenha do Monthly Review foi publicada em três partes, em abril, maio e julho de 1776. Na primeira parte, o resenhista avalia:

O Sr. Mickle prefaciou de modo bastante criterioso a sua tradução com uma copiosa e satisfatória introdução à história do poema. Esta consiste principalmente em uma narrativa das operações e descobertas dos portugueses na Índia (que constitui o tema d'Os lusíadas) e de uma história da vida do autor. A narrativa é generosa e elegante, entremeada de várias observações sensatas e reflexões políticas justas. ${ }^{243}$ (THE LUSIAD..., 1776d, p. 250).

Na segunda parte, o articulista analisa o poema em detalhe, comparando-o à Eneida, Odisseia e Ilíada, citando longos trechos da tradução de Mickle e elogiando-lhes a elegância. Em duas passagens o crítico sugere pequenas modificações - algumas delas foram adotadas por Mickle na segunda edição do Lusiad.

A terceira parte contém mais citações comentadas da tradução. O resenhista louva a excelência das descrições de Camões e a elegância do tradutor. O último parágrafo da resenha deve ter deixado Mickle muito contente, ainda mais se considerarmos que o elogio vinha de um periódico que fizera críticas negativas ao seu primeiro poema publicado (ver seção 4.1 do Capítulo 4) e à sua tradução do Canto I de Os lusíadas (ver acima nesta mesma seção): “O Sr. Mickle ultrapassou até a si próprio na tradução desse livro - tal é a suave harmonia, espírito e riqueza de sua poesia. Em suma, não hesitamos em concluir dizendo que essa tradução não encontra rival à sua altura, com a exceção da tradução da Ilíada"244 . (THE LUSIAD..., 1776e, p. 16).

The Town and Country Magazine publicou uma resenha curta, de apenas meia coluna, louvando a tradução ("Devemos nos juntar aos amantes de poesia em geral dando a nossa

\footnotetext{
242 "Fanshaw by his translation furnished our countrymen with a telescope, through which this illustrious planet might be viewed to some advantage; but it was reserved to Mr. Mickle, to produce a more pure and perfect work".

243 "Mr. Mickle has very judiciously prefaced his translation with a copious and satisfactory introduction to the history of the poem. This consists principally of a narrative of the operations and discoveries of the Portuguese in India (which make the subject of the Lusiad) and of some memoirs of its Author. The narrative is liberal and elegant, interspersed with many sensible observations and just political reflections."

244 "Mr. Mickle has excelled even himself in his translation of this book - such is the mellow harmony, spirit, and richness of his verse. - In short, we do not hesitate to conclude that this translation stands unrivalled by any but that of the Iliad".
} 
forte aprovação a essas produção" ${ }^{245}$ ) e citando os versos iniciais do Canto III. (THE LUSIAD..., 1776f, p. 156).

O periódico escocês The Edinburgh Magazine and Review, em seu número de maio de 1776, louva a iniciativa de Mickle de traduzir a epopeia portuguesa, mas critica alguns supostos defeitos do original, sobretudo o uso da mitologia pagã. O que o resenhista não percebeu, por não ter lido o original, é que alguns desses "defeitos" se devem a distorções introduzidas pelo tradutor. Ao destacar como único assunto do poema a "descoberta" da Índia, o tradutor faz com que muitos dos episódios do poema pareçam irrelevantes. O resenhista comenta:

Depois de sua máquina incongruente, o principal defeito de nosso autor parece ser a introdução de episódios longos e frequentes demais, e em locais impróprios; alguns desses episódios não apresentam nenhuma relação com o assunto do poema. Todo o Canto III e o Canto IV são tomados por um episódio em que a história de Portugal é descrita. Parte dos Cantos VII e VIII é tomada pelo mesmo tema $[\ldots]^{246}$ (SHER; ZACHS, 1998, p. 204).

Se o único assunto de Os lusíadas é a expedição de Gama, as longas passagens narrando a história portuguesa parecem realmente extravagantes. A interpretação do resenhista provavelmente teria sido diferente se o tradutor houvesse enfatizado a intenção do Poeta de cantar as façanhas realizadas pelos heróis lusitanos ao longo de toda a história de Portugal.

Apesar de não ser usual, na época, a publicação de resenhas sobre segundas edições de traduções, em 1778, quando a segunda edição do Lusiad foi lançada, o Gentleman's Magazine e o Monthly Review anunciaram a publicação, salientando as modificações introduzidas. $\mathrm{O}$ Gentleman's Magazine discute em detalhe a dissertação sobre a Companhia das Índias Orientais e as divergências entre Mickle e Adam Smith, e faz breves comentários sobre os outros acréscimos:

[...] a queda do Império Português na Ásia é agora descrita em detalhes; os enormes abusos dos funcionários de um rei, quando colônias distantes são submetidas a seu poder, são apresentados nas cores mais fortes; e o Dr. Smith é citado, quando este afirma que um monopólio régio é o mais desastroso dos métodos de comércio. $O$ absurdo de supor que os funcionários de um rei, a mais de 15 mil quilômetros de distância, como o Dr. propõe, seriam mais isentos de interesse do que os funcionários de uma

\footnotetext{
245 "We must unite with the general lovers of poetry, in highly approving this production".

246 "Next to his incongruous machine, the principal defect in our author appears to be his introducing too long and frequent episodes, and at improper places; episodes, some of which have no relation to the subject of his poem. The whole third and fourth books are taken up in an episode, in which the history of Portugal is described. Part of the seventh and eighth is taken with the same $[\ldots]$ "
} 
Companhia, é posto sob as luzes mais claras; e tenta-se indicar o perigo à constituição, caso a coroa venha a controlar as fortalezas e as receitas territoriais da Índia. ${ }^{247}$ (THE LUSIAD..., 1778, pp. 427-428, itálicos do autor).

O tom da resenha em relação à argumentação de Mickle é sempre de aprovação. Ao final, o resenhista elogia o ensaio sobre os brâmanes incluído na segunda edição dizendo que lá "a pretensa antiguidade maior das escrituras hindus é refutada do modo mais claro, sob os princípios mais indiscutíveis" ${ }^{, 248}$. (THE LUSIAD..., 1778, p. 428).

O Monthly Review publicou apenas uma nota curta, mas muito positiva:

Já fizemos, desde a primeira edição, um amplo exame dessa obra extremamente criativa, e estamos felizes em ver o gosto e a generosidade do público dando apoio ao notável mérito. Os lusíadas, com efeito, devem encontrar um lugar na biblioteca de todo cavalheiro que estima o seu próprio valor quer pelo amor, quer pelo estímulo às letras. Nesta edição há alguns acréscimos, mas, que se diga, em mérito da obra, poucas correções, pois poucas eram necessárias. As poucas alterações que recomendamos ao autor, foram, cortesmente, levadas em consideração por ele. - Os acréscimos às notas etc. são bastante consideráveis. ${ }^{249}$ (MICKLE'S..., 1778, p. 311).

Em 1782, William Hayley publicou An Essay on Epic Poetry, em que elogia muito a obra de Camões. Sobre a tradução de Mickle, Hayley (1782, p. 273) diz: “Os poderes épicos de Camões receberam a honra merecida em nossa língua com a elegante e vigorosa tradução do Sr. Mickle"250. Segundo George Monteiro (1996, pp. 23-24), Hayley, fã da tradução de Mickle, recomendou-a ao poeta norte-americano Joel Barlow, que a teria utilizado como modelo para o poema épico que estava compondo, The Columbiad.

A primeira biografia e breve resenha da obra de Mickle de que temos notícia é anônima e foi publicada em The European Magazine, and London Review quando Mickle ainda estava

\footnotetext{
247 “ " [...] the fall of the Portuguese empire in Asia is now minutely traced; the enormous abuses of the servants of a King, when distant colonies are submitted to their power, are held up in the strongest colours; and Dr. Smith is cited, where he confesses that a regal monopoly is the most ruinous method of commerce. The absurdity to suppose that the servants of a King, at ten thousand miles distance, as the Dr. calls it, would be more disinterested than the servants of a Company, is placed in the clearest light; and the danger to the constitution, were the crown possessed of the forts and territorial revenues of India, is endeavoured to be established."

248 "this pretended superior antiquity of the Gentoo Scriptures, is there refuted in the clearest manner, upon the most indisputable principles".

249 "We have already given, from the first edition, an ample account of this most ingenious work, and are happy to see the public taste and liberality supporting distinguished merit. The Lusiad, indeed, ought to find a place in the library of every gentleman, who values himself either on his love, or his encouragement, of letters. In this edition there are some additions, but, to the credit of the work be it spoken, few emendations, for few were wanting. The little alterations we recommended to the Author, he has politely attended to. - The additions to the notes, \&c. are very considerable."

250 "The Epic powers of Camoens have received their due honour in our language, by the elegant and spirited translation of Mr. Mickle".
} 
vivo, em junho de 1782. Sobre a tradução de Os lusíadas, o resenhista não poupa elogios: "ele a realizou de tal forma que obteve um lugar nas fileiras mais altas dos poetas vivos. Enquanto a língua inglesa existir, o Lusiad do Sr. Mickle será considerado uma de suas maiores e melhores produções"251 (ANECDOTES..., 1782, p. 451).

\subsubsection{Recepção em Portugal no século XVIII}

Em sua viagem a Portugal, entre 1779 e 1780, Mickle foi recebido com muitas celebrações e entusiasmo como tradutor d'Os lusíadas para o inglês.

O biógrafo anônimo do European Magazine, and London Review (ANECDOTES..., 1782, p. 452) mencionado na subseção anterior relatou também as repercussões do Lusiad de Mickle em Portugal:

Recebemos a garantia, da parte de autoridade indiscutível, que essa história da Ásia Portuguesa foi traduzida para o português por um dos autores mais capazes daquele país e agora está no prelo em Lisboa. E que honra singular, o Sr. Mickle ter apresentado o poeta de Portugal para os seus próprios compatriotas. Portugal não é uma nação literária, e Camões era conhecido e lido apenas por uns poucos. Mas quando se soube em Lisboa que as obras de um poeta português foram recebidas com aplausos em Londres, todos tiveram o desejo de lê-las; e Os lusíadas, que eram vendidos a seis shillings e nove pence, subiram imediatamente para $36^{252}$, e logo se esgotaram. Duas novas edições foram lançadas desde então, com um prefácio que menciona a tradução do Sr. Mickle com altos elogios; e quando nosso correspondente, cerca de meio ano atrás, deixou Lisboa, estava sendo discutido entre os literatos o lançamento de uma edição elegante em quarto de seu poeta, adornada com entalhes no estilo requintado com que a nação francesa honra seus clássicos, e à qual deverá ser acrescentada a introdução histórica e as notas do Sr. Mickle, traduzidas para o português; e vários membros da mais alta nobreza estão encabeçando essa proposta. ${ }^{253}$

\footnotetext{
251 "he accomplished it in a manner that has procured him a place in the highest rank of living poets. While the English language remains, Mr. Mickle's Lusiad will he considered as one of its greatest and best productions."

${ }^{252}$ Em moeda atual, o preço teria subido de cerca de 35 libras para cerca de 200 libras - um aumento realmente espantoso, a se confiar nas informações do periódico.

253 "We are assured from undoubted authority, that this history of Portuguese Asia has been translated into Portuguese by one of the ablest pens of that country, and is now in the press at Lisbon. And what is a singular honour, Mr. Mickle has introduced the poet of Portugal to the acquaintance of his own countrymen. Portugal is not a literary nation, and Camoens was known and read by only a few. But when it was heard in Lisbon that the works of a Portugese poet were received with applause in London, every one was desirous to read them; and the Lusiadas, which were sold for a six-and-ninepence, immediately rose to a six-and-thirty, and were soon not to be had. Two new editions have since appeared, the preface to which mentions Mr. Mickle's translation with high encomium; and when our correspondent, about half a year ago, left Lisbon, it was in agitation among the literati to give an elegant quarto edition of their poet, adorned with sculptures in the superb manner with which the French nation honours its classics, and to which was to be added the historical introduction and notes of Mr. Mickle, translated into the Portuguese; and several of the first of the nobility are at the head of the proposal."
} 
Apesar dessas repercussões positivas da tradução de Mickle em Portugal, o padre Thomas José de Aquino, organizador da edição das obras completas de Camões - cuja primeira edição (1779-1780) teria sido, de acordo com o artigo do European Magazine citado acima, um reflexo do novo entusiasmo por Camões despertado por essa tradução - escreveu a primeira crítica realmente negativa ao Lusiad de Mickle ainda em 1782, na segunda edição das Obras de Camões. Aquino (1782, p. 31) mantém o texto da primeira edição em que reconhece méritos na tradução de Mickle:

Guilherme Julio Mickle traduzio o Poema da Lusíada em verso Inglez Rhythmado ; e esta traducçaõ já passou por duas edições em Londres, huma no anno de 1776, e a segunda no anno de 1778, signal evidente de que foi bem aceita entre os Inglezes. Como este Traductor applicou huma grande diligencia, e cuidado, naõ sómente em conservar na sua traducçaõ toda a harmonia, energia, clareza, e espirito Poetico de Camões (o que pôs em execuçaõ maravilhosamente) $[\ldots]$

Aquino reproduz nessa segunda edição grande parte da descrição de Mickle (1776, p. cxxxii) da máquina mitológica d'Os lusíadas, traduzida pelo Rev. Michael Daly, do Colégio Irlandês de Lisboa, ${ }^{254}$ e ainda comenta:

Depois desses Tratados Preliminares vem a traducçaõ do Poema, que se póde pronunciar a mais poetica, das que apparecêraõ até agora. Acompanha a traducçaõ com notas historicas, e críticas, em que mostra grande conhecimento da Historia de Portugal, e hum juizo crítico solido. (AQUINO, 1782, p. 52).

Em outros trechos, acrescentados na segunda edição, Aquino (1782, p. 29) reconhece que, ao fazer os comentários anteriores, na primeira edição, desconhecia os detalhes da tradução de Mickle, tendo-se contentado em reproduzir os elogios feitos por outros. Agora, na segunda edição, com a ajuda do Rev. Daly, Aquino (1782, p. 52) julga-se em condições de fornecer uma verdadeira análise, e passa a criticar as liberdades tomadas por Mickle na tradução, questionando "se hum traductor deve affastar-se tanto do seu original". Aquino (pp. 53-55) descreve em detalhe as duas maiores alterações introduzidas no poema: no episódio do Adamastor, em que a narrativa feita pelo gigante é transferida para o rei de Melinde, e no início do Canto IX, em que o tradutor modifica a história do conflito entre o samorim e o

\footnotetext{
${ }^{254}$ Nessa edição Aquino dá os devidos créditos a Mickle, mas as reedições seguintes (ao menos as de 1818 e 1865) continuam estampando o texto de Mickle sem que a sua autoria seja adequadamente atribuída.
} 
Gama, introduzindo mais de trezentos versos sem correspondência com o original. ${ }^{255}$ Mencionando o trecho da Introdução em que Mickle explicita a sua teoria de tradução, com a citação do "Nec verbum verbo" de Horácio, Aquino (pp. 56-57) objeta:

Mas naõ obstante tudo isto, huma traducçaõ deve ser huma fiel representaçaõ do seu Original; o que bem póde ser, ainda que naõ esteja feita palavra por palavra, como mostraõ varias traducções poeticas de Homero, e Virgilio nas linguas polidas da Europa, e principalmente na lingua Ingleza. Ellas conservaõ o espirito dos seus Originais inteiro, sem que supprimaõ, ou accrescentem passagens compridas. Nem val ao Traductor a authoridade de Horacio; por que evidentemente parece do contexto, que o preceito he sómente para Imitadores, e naõ para Traductores, e sem duvida a imitaçaõ he mui differente da traducçaõ.

A seguir, Aquino (pp. 57-58) faz uma observação muito interessante:

Huma traducçaõ a onde se tomaõ taõ grandes liberdades, póde facilmente enganar o leitor: supponhamos que hum Voltaire futuro, que naõ souber a lingua Portugueza, queira formar huma idéa do Poema de Camões, por meio da Traducçaõ do senhor Mickle; se lhe vier á cabeça imaginar, que na descripçaõ da tempestade, e da batalha do Livro nono ha muito do estilo inchado, e do falso sublime, naturalmente todos estes defeitos attribuirá ao Original, ainda que nelle naõ ha vestigio de taes descripções; e assim enganar-se-ha, como se enganou o outro Voltaire, attribuindo a Camões os defeitos da ridicula versaõ de Fanshaw.

Aquino (pp. 58-59) reconhece que nos ensaios introdutórios o tradutor demonstrou muito empenho, erudição e "juízo exato", mas se queixa de "erros crassos" e injustiças cometidas contra a "Nação Portuguesa" e a religião católica, pela qual o tradutor revela "ódio e aversão".

\subsubsection{Análises do Lusiad publicadas logo após a morte de Mickle}

Com o falecimento de Mickle, em 1788, vários periódicos publicaram obituários e biografias do poeta escocês. O obituário do Gentleman's Magazine diz:

25 de novembro. Em Wheatley, perto de Oxford; William Julius Mickle, bem conhecido no mundo literário como tradutor d'Os lusíadas de Camões, cujo primeiro Canto foi publicado como amostra em 1771 (veja nosso vol. XLI. p. 323), e a tradução completa em 1776, 4to, com valiosas notas (XLVI. 367), e uma segunda edição, bastante aperfeiçoada, em 1778

\footnotetext{
${ }^{255}$ Essas alterações serão analisadas em detalhe em nosso Capítulo 5.
} 
(XLVIII. 427). O Sr. M. foi também o autor de "Concubine, a Poem", ao estilo de Spenser, 1767; republicado sob o título de "Sir Martyn", 1777, 4to; e "Almada Hill, a Poem", $1781 .{ }^{256}$ (OBITUARY, 1788, p. 1.029).

No número seguinte, o Gentleman's Magazine publicou, em acréscimo ao obituário, uma pequena biografia em que o resenhista anônimo elogiou a tradução d'Os lusíadas, dizendo que foi executada "em um estilo que não seria considerado indigno de seus grandes predecessores nessa linha de poesia, Dryden e Pope"257 (ADDITIONS..., 1788, p. 1.121).

Sobre os ensaios introdutórios do Lusiad, o resenhista os qualifica como uma refutação completa das visões de Rousseau e outros filósofos e "uma introdução peculiarmente adequada à única epopeia do comércio que já foi escrita". ${ }^{258}$ (ADDITIONS..., 1788, p. $1.121)$.

Em setembro e novembro de 1789 foi publicada no European Magazine, em duas partes, a biografia de Mickle escrita por Isaac Reed (1789, pp. 155-157 e pp. 317-321), que teria sido amigo de Mickle. Sobre o Lusiad, Reed (p. 156) declara:

Uma obra que um dos melhores escritores ingleses avaliou como igual ao Homero de Pope, e inferior apenas ao Virgílio de Dryden; e que podemos nos arriscar a profetizar que permanecerá um monumento a transmitir o nome do autor para a mais distante posteridade. ${ }^{259}$

Em 1795 é lançado The poetical works of William Julius Mickle, o volume 11 da coleção The Works of the British Poets, contendo uma biografia de Mickle escrita por Robert Anderson, o organizador da coleção. Após a biografia, Anderson faz uma breve análise da obra poética de Mickle. Sobre a tradução d'Os lusíadas, Anderson (p. 635) repete o que outros já haviam dito: “[A versificação de Mickle] une a liberdade de Dryden à força e

\footnotetext{
256 " 25 November. At Wheatley, near Oxford; William Julius Mickle, esq. well known in the literary world as translator of The Lusiad of Camoens, of which the first book was published as a specimen in 1771 (see our vol. XLI. p. 323), and the whole in 1776, 4to, with valuable notes (XLVI. 367), and a second edition, much improved, in 1778 (XLVIII. 427). Mr. M. was also author of "The Concubine, a Poem," in the manner of Spenser, 1767; republished under the title of "Sir Martyn," 1777, 4to; and "Almada Hill, a Poem," 1781."

257 "in a manner that would not be deemed unworthy of its great predecessors in this line of poetry, Dryden and Pope".

258 "a peculiarly proper introduction to the only commercial epic poem that ever was written."

259 "a work which one of the finest English writers declared he esteemed equal to Pope's Homer, and inferior only to Dryden's Virgil; and which we may venture to prophesy will remain a monument to transmit the author's name with honour to the latest posterity."
} 
harmonia de Pope. O Lusiad inglês é uma realização clássica, e não encontra rival em nenhuma outra produção desse tipo em nossa língua, exceto a Ilíada inglesa"260.

\subsubsection{Repercussão entre os românticos}

O poeta romântico Robert Southey (1774-1843) - um dos "Poetas do Lago", ao lado de Coleridge e Wordsworth - viveu algum tempo em Portugal e veio a se tornar lusitanista e hispanista. Southey não gostava de Camões, mas admirava muito o Lusiad de Mickle e contribuiu para o ressurgimento do interesse por essa tradução entre os românticos. Assinando com as iniciais T. Y., Southey (1796, pp. 787-789) publicou no volume 2 de The Monthly Magazine a tradução para o inglês de todas as críticas feitas por Thomas José de Aquino à tradução de Mickle e, no volume 4 do mesmo periódico, comentou-as em detalhe em um artigo que principia assim:

Qualquer um que tenha lido Os lusíadas apenas no poema do SR. MICKLE deve imaginar que o esplendor e riqueza descritivos são uma virtude característica de Camões. ${ }^{261}$

Now from the Moorish town the sheets of fire, Wide blaze succeeding blaze, to heaven aspire. Black rise the clouds of smoke, and by the gales Borne down, in streams hang hov'ring o'er the vales; And slowly floating round the mountain's head Their pitchy mantle o'er the landscape spread. Unnumber'd sea-fowl rising from the shore, Beat round in whirls at every cannon's roar; Where o'er the smoke the masts' tall heads appear, Hov'ring they scream, then dart with sudden fear; On trembling wings far round and round they fly, And fill, with dismal clang, their native sky. ${ }^{262}$

\footnotetext{
260 “It [Mickle's versification] unites the freedom of Dryden with the force and harmony of Pope. The English Lusiad is a classical performance, and stands unrivalled by any production of the kind in our language, but the English Iliad".

261 "Whoever has read the Lusiad only in Mr. MICKLE's poem, must conceive a pomp and luxuriance of description to be the characteristic excellence of Camoens."

262 "Agora da cidade moura as cortinas de fogo,

Imensas labaredas atrás de labaredas, ao céu se lançam.

Negras se erguem as nuvens de fumaça, e pelas ventanias

Trazidas para baixo, pairam em torrentes sobre os vales;

E devagar contornam, flutuando, o cume da montanha

Seu manto tenebroso se espalha sobre a paisagem.

Inúmeras aves marinhas decolam da praia,

Agitam-se em redemoinhos a cada estrondo de canhão;

Onde sobre a fumaça as altas cabeças dos mastros aparecem,

Pairando elas [as aves] gritam, depois se lançam em súbito medo;

Com asas trêmulas, voam em círculos cada vez maiores,
} 
Esses versos são muito bonitos, mas nem uma única imagem neles contida é encontrada no português; são raras as passagens na tradução em que casos semelhantes não ocorram. ${ }^{263}$ (SOUTHEY, 1797, p. 98, versaletes do autor).

A seguir, Southey (p. 99) cita a teoria tradutória exposta por Mickle em sua Introdução (ver subseção 4.7.6 deste mesmo capítulo) e pondera:

E o Sr. Mickle certamente produziu um poema que viverá na língua inglesa, e que bem merece viver. O Orlando Enamorado é mais conhecido como o poema do reescritor do que do autor, mas o Sr. Mickle fez mais por Camões do que Berni fez por Boiardo. [...] Uma única estrofe de Camões é dilatada na tradução para vinte versos; e é a essa dilatação que se deve todo o seu mérito. ${ }^{264}$

Southey entendia que, mais do que um tradutor, Mickle era um verdadeiro poeta e havia transformado Os lusíadas em um poema inglês, em vez de fazer estritamente uma tradução do original português. Além disso, Mickle teria aperfeiçoado Camões, eliminando vários defeitos do poema, esforçando-se por justificar os "deslizes" de Camões e embelezando várias passagens. Southey (1797, p. 99) sintetiza assim a sua opinião sobre a tradução de Mickle:

Por mais que eu possa depreciar os méritos do Sr. Mickle como tradutor fiel, eu lhe faria todos os merecidos elogios como poeta; e um balanço completo sobre o que pertence a ele e o que pertence a Camões aumentaria a sua reputação em vez de prejudicá-la. Jamais li um poema rimado de extensão considerável que me tenha enfadado tão pouco quanto o Lusiad; a versificação tem a naturalidade de Dryden sem os seus descuidos, e a harmonia de Pope sem a sua doçura enjoativa. ${ }^{265}$

Vários anos depois, em um artigo publicado em The Quarterly Review, Southey (1822, pp. 1-39) explicita suas críticas a Os lusíadas. O tema da epopeia, apesar de extremamente importante em termos históricos, era desprovido de eventos de interesse épico. Por isso Camões entremeou a viagem de Vasco da Gama a outros acontecimentos da história portuguesa e introduziu a mitologia pagã. Mas, na opinião de Southey, a forma escolhida pelo

E enchem, com um clangor lúgubre, seu céu nativo."

263 "These lines are very beautiful, but not a single image contained in them is to be found in the Portuguese; there is scarcely a passage in the translation from which similar instances might not be produced."

264 "And Mr. Mickle certainly has produced a poem that will live in the English language, and that well deserves to live. The Orlando Innamorato is better known as the poem of the reversifier than of the author, but Mr. Mickle has done more for Camoens than Berni did for Boardo. [...] A single stanza of Camoens is dilated in the translation into twenty lines; and to this dilation it is indebted for all its merit."

265 "However I may detract from Mr. Mickle's merits as a faithful translator, I would give him all due praise as a poet; and a complete statement of what belongs to him, what to Camoens, would increase his reputation instead of impairing it. I never read a rhyme poem of any considerable length, that wearied me so little as the English Lusiad; the versification has the ease of Dryden without his negligence, and the harmony of Pope without his cloying sweetness." 
bardo português para lidar com a mitologia foi grosseira e pueril. Southey (1822, p. 21) cita na íntegra a descrição de Tritão ${ }^{266}$ - aprovando a forma atenuada com que Mickle a traduzira, mas rejeitando a justificativa acrescentada por Mickle em nota de rodapé, de que o original fora escrito "no estilo dos clássicos" - como exemplo de "absurdo flagrante e revoltante"267 pelas imagens utilizadas.

Nesse artigo, Southey (1822, pp. 29-30) atribui, com muita perspicácia, a escolha por Mickle de Os lusíadas como poema a traduzir à necessidade do poeta escocês de obter destaque no mundo literário:

Os lusíadas eram uma obra que havia adquirido grande fama; o tradutor, assim, tinha o direito de apresentar o seu autor com altas pretensões. [O poema] celebrava o estabelecimento de um império europeu na Índia aquele império passara às nossas mãos; um interesse poderia, portanto, ser despertado pela tradução entre os britânicos. Nós éramos um povo comercial - ele apresentou o Lusiad como a epopeia do comércio; e recomendou sua obra para a Companhia das Índias Orientais, com um discurso preliminar, contendo uma breve história do domínio português na Ásia, e uma defesa bastante hábil e satisfatória de uma companhia majestática que possuísse o monopólio do comércio. ${ }^{268}$

A partir dessa constatação, no entanto, Southey conclui que a escolha se baseou nas vantagens que o tema proporcionava ao tradutor, e não em uma verdadeira admiração pelo poema - uma conclusão subjetiva, de difícil comprovação. Além disso, para Southey (1822, p. 30) todos os méritos do Lusiad são atribuídos ao tradutor, que teria elevado Os lusíadas a uma excelência que não está no original:

[...] Ele [Mickle] tomou [o poema] como um advogado que aceita uma causa difícil, e decidiu fazer o melhor possível. Nenhum trabalho árduo foi poupado se pudesse acrescentar importância à obra; copiosas notas, e prolegômenos, e dissertações foram anexados, demonstrando grande habilidade e aplicação; e as belezas do original foram destacadas, sempre que se pudesse encontrar ou imaginar belezas, com uma licença de admiração que se concede a tradutores e editores. A dificuldade era como fazer o poema sustentar as pretensões desmedidas com que foi apresentado;

\footnotetext{
${ }^{266}$ Ver nossa análise da tradução de Mickle desta passagem no Capítulo 5, em 5.3.4.

267 "the gross and revolting absurdity".

268 "The Lusiad was a work which had acquired a great name; the translator therefore was entitled to come forward with high pretensions on the part of his author. It celebrated the establishment of an European empire in India; - that empire had passed into our hands; a British interest therefore might be excited by the translation. We were a commercial people, - he presented the Lusiad as the epic poem of commerce; and he recommended his work to the East India Company, by a preliminary discourse, containing a brief history of the Portugueze dominion in Asia, and a very able and satisfactory defence of a chartered company, possessing an exclusive trade."
} 
e para isso Mickle confiou em sua própria habilidade de alterá-lo e enriquecê-lo $[\ldots]^{269}$

Nesse processo, Mickle tomou liberdades em demasia, o que procurou manter em segredo, apesar da defesa das traduções não literais na Introdução. Southey (1822, pp. 30-31) lança uma hipótese interessante, relacionando essa estratégia de alterações sigilosas com a escolha do dístico heroico para traduzir Os lusíadas:

Assim Mickle guardou, prudentemente, seu segredo, e não correu o risco de
ser prematuramente descoberto: naquela época provavelmente não havia
nem meia dúzia de pessoas na Grã-Bretanha que entendesse português, com
a exceção dos comerciantes envolvidos nos negócios com Lisboa, e ele sabia
muito bem que ninguém que fosse comentar a sua tradução acharia
necessário ter algum conhecimento do original. Não é improvável, no
entanto, que tenha sido com o propósito de encobrir suas numerosas
alterações e acréscimos que ele tenha escolhido o dístico em vez da estrofe
spenseriana para a sua tradução. Mickle, cujo gosto e sentimentos estavam
muito adiante do tempo em que viveu, certamente preferia a estrofe
spenseriana para a narração, e a usou em seu poema Sir Martyn. Com efeito,
sabe-se que ele é um daqueles poetas cuja chama poética foi atiçada pela
perene lamparina de Spenser. ${ }^{270}$

Encerrando a avaliação da tradução de Mickle, Southey (1822, pp. 31-32) elogia as correções feitas pelo tradutor ao poema, como a transferência da narrativa da história do Adamastor para o rei de Melinde e as modificações introduzidas na disputa entre Vasco da Gama e o samorim, pois, no relato de Camões, Vasco da Gama havia "com pouca honra e ainda menos humanidade" ${ }^{271}$ se retirado com alguns dos comerciantes que havia aprisionado, deixando de cumprir o acordo feito com o samorim, pelo qual deveria ter havido uma troca de prisioneiros $^{272}$ (o samorim cumprira sua promessa, libertando os portugueses que havia

\footnotetext{
269 " $[. .$.$] he took that, as an advocate takes a sorry cause, and determined to make the best of it. No labour was$ spared that could give importance to the work; copious notes, and prolegomena, and dissertations were annexed, in which great ability and industry were displayed; and the beauties of the original were pointed out, wherever beauties could be found or fancied, with a licence of admiration in which translators and editors are permitted to indulge. The difficulty was how to make the poem support the inordinate pretensions with which it was brought forward; and for this Mickle trusted to his own skill in altering and enriching it [...]"

270 "Mickle therefore prudently kept his own secret, and it was in no danger of being prematurely discovered: at that time there were probably not half-a-dozen persons in Great Britain who understood Portugueze, except those merchants who were engaged in the Lisbon trade, and he very well knew that no one who reviewed his translation would think it necessary to have any knowledge of the original. It may however, not improbably, have been for the purpose of covering his numerous alterations and additions that he chose the couplet instead of the stanza for his version. Mickle, whose taste and feeling were much beyond the age in which he lived, certainly preferred the stanza for narration, and used it in his poem of Sir Martyn. Indeed it is known that he is one of those poets whose light has been kindled at the everlasting lamp of Spenser."

271 "with little honour and less humanity".

${ }^{272}$ Contaremos essa história em detalhe no Capítulo 5, subseção 5.4.2.
} 
aprisionado). Southey (p. 32) sentencia: "Não há nada de heroico nem poético nisso"273. Sobre os mais de trezentos versos acrescentados por Mickle nessa passagem, Southey comenta, com ironia:

Segue-se um combate à vista do samorim e seus prisioneiros, e os vitoriosos portugueses, após destruírem a flotilha do inimigo, aproximam-se e bombardeiam a cidade, se não antes de as bombas serem inventadas, com certeza um século inteiro antes de qualquer lugar ser bombardeado ${ }^{274}-$ um anacronismo no qual Camões não poderia ter incorrido. ${ }^{275}$

Sobre a influência de Southey na divulgação do Lusiad de Mickle, George West (1934b, p. 394) comenta:

Com Southey, o Lusiad de Mickle alcançou o zênite de sua influência [...]. Suas numerosas e entusiásticas resenhas da tradução resultaram em uma recrudescência de popularidade, e entre 1798 e 1822, período durante o qual foi republicado seis vezes, o Lusiad foi lido como nunca havia sido durante a vida de Mickle. ${ }^{276}$

Outro crítico literário do século XX, Félix Walter (1927, pp. 45-46), comenta a respeito da influência exercida pelo Lusiad de Mickle tanto na época de sua publicação quanto sobre os românticos:

Hoje em dia talvez não apreciemos muito sua tradução d'Os lusíadas, mas é certo que, no século XVIII, ela foi considerada um clássico. Os projetos de Mickle haviam causado certa agitação e, mesmo antes de sua publicação, sua obra desfrutava de um bom sucesso de crítica. [...] Todos os primeiros poetas românticos parecem ter lido Os lusíadas de Mickle em determinado momento. Foi nesse livro que o jovem Southey e o jovem Byron recolheram uma primeira ideia de Portugal. Na juventude, Walter Scott, que tinha uma grande admiração pelos poemas de Mickle, e principalmente por Cumnor Hall, que ele utilizou mais tarde em Kenilworth, ficou a tal ponto impressionado com a leitura da tradução de Camões que, segundo seu biógrafo Lockhart, tentou imitá-la em 1798 em um poema sobre o cerco de Granada. Os contemporâneos de Mickle comparavam com naturalidade sua

\footnotetext{
273 "There is nothing either heroic or poetical in this".

${ }^{274}$ Nesse ponto Southey exagera, pois já em 1453 os turcos haviam bombardeado Constantinopla, na célebre conquista do Império Romano do Oriente. E em 1500, apenas dois anos depois da expedição do Gama, Pedro Álvares Cabral bombardeou Calecute, naquele que é considerado o primeiro bombardeio naval de uma cidade.

275 "An action ensues in sight of the Zamorim and his prisoners, and the victorious Portugueze, after destroying the enemy's flotilla, approach, and bombard the city, - if not before bombs were invented, certainly a full century before any place was bombarded, - an anachronism into which Camoens could not possibly have fallen."

276 "In Southey, Mickle's Lusiad reached the zenith of its influence [...]. His numerous and enthusiastic reviews of the translation resulted in a recrudescence of popularity, and between 1798 and 1822, during which period it was six times republished, the Lusiad was read as it had never been read during Mickle's life."
} 
tradução à que Pope havia feito da Ilíada e, ao final do século, ela ocupava certamente uma posição bastante elevada. [...] Com Mickle, a consagração de Camões se tornou quase definitiva $[\ldots]^{277}$

Walter (1927, p. 51) também relata que, no final do século XVIII e início do século XIX, os britânicos viajavam a Lisboa carregando consigo o Lusiad de Mickle, que servia como guia de viagem e era considerado a Bíblia dos lusófilos.

\subsubsection{Recepção no período vitoriano}

Após o lançamento de sua tradução d'Os lusíadas, o explorador, orientalista, soldado, tradutor e escritor Sir Richard Francis Burton (1821-1890) publicou dois volumes contendo uma biografia de Camões e comentários à sua própria tradução. Há uma parte dedicada à avaliação das traduções da obra para o inglês feitas por Fanshawe, Mickle, Musgrave, Quillinan, Mitchell, Aubertin, Hewitt, Duff e o próprio Burton (1881, pp. 135-180).

A avaliação de Burton (1881, p. 149-150, itálicos do autor, colchetes nossos) sobre a tradução de Mickle é extremamente negativa:

Mickle é a encarnação do Traduttori, traditori (tradutores = traidores). Sua traição, contudo, é cometida com ousadia; na verdade, ele se regozija com seu crime. [...] Nestes dias mais escrupulosos, Mickle teria intitulado o seu poema "Os lusíadas de Camões adaptados", e assim teria sido elogiado como um artista semioriginal. Em seu próprio tempo, ele era considerado "fluente, solene e harmonioso". Só posso dizer que o estilo dele ataca meus nervos, me dá "crispações".

Como tradutor, Mickle merece a mais severa crítica. Suas liberdades são licenciosas: na melhor das hipóteses ele é splendidè mendax [nobremente falso]. Ele não se satisfaz com paráfrase e omissões: exulta com intrusões e interpretações impertinentes, e evidentemente acredita, com autossuficiência consumada, que está aperfeiçoando Camões. As 17 estrofes que iniciam o Canto IX foram aumentadas a mais do que o dobro - de 136

\footnotetext{
277 “Aujourd'hui, peut-être, nous n'apprécions pas beaucoup sa traduction des Lusiades, mais il est certain qu'au $\mathrm{XVIII}^{\mathrm{e}}$ siècle, elle fut considérée comme un classique. Les projets de Mickle avaient fait un certain bruit, et, même avant sa publication, son œuvre jouit d'un beau succès d'estime. [...] Tous les premiers poètes romantiques semblent avoir lu les Lusiades de Mickle à un moment donné. C'est dans ce livre que le jeune Southey et le jeune Byron ont puisé une première idée du Portugal. Dans sa jeunesse, Walter Scott, qui avait une grande admiration pour les poésies de Mickle, et surtout pour son Cumnor Hall, qu'il utilisa plus tard pour Kenilworth, fut impressionné à tel point par la lecture de sa traduction de Camoëns que, selon son biographe Lockhart, il en tenta une imitation en 1798 dans un poème sur le siège de Grenade. Les contemporains de Mickle comparaient volontiers sa traduction à cette que Pope avait fait jadis de l'Iliade et à la fin du siècle, elle occupe certainement une très haute place. [...] Avec Mickle, la consécration de Camoëns est devenue presque définitive $[\ldots] "$
} 
versos para 300. Ele falsifica a história, a topografia, a onomatologia, tudo. ${ }^{278}$

Burton (1881, p. 153) lamenta que, apesar de todos esses defeitos, a tradução de Mickle ainda seja popular na Grã-Bretanha, mesmo em sua época:

Mas esse excesso de liberdades, essas infidelidades, não são nada para o leitor inglês. Em consequência o Poema, com todos os seus defeitos de suavidade artificial, túrgida, de "melodia pobre e pomposa", tem mantido até o presente a influência que exerceu sobre o último século e se tornou um pseudoclássico na literatura inglesa. ${ }^{279}$

Nessa mesma época, a influência do Lusiad de Mickle já se estendia a autores norte-americanos. O poeta Henry Wadsworth Longfellow (1807-1882) era admirador de Camões e incluiu trechos d'Os lusíadas, na tradução de Mickle, em um grande livro organizado por ele, The Poets and Poetry of Europe. Das trinta páginas desse livro reservadas a poetas portugueses, Camões ocupava nove, com dois excertos d'Os lusíadas (o episódio de Inês de Castro e o do Gigante Adamastor), onze sonetos e nove poemas líricos. Essa antologia foi publicada em meados do século XIX, em pleno romantismo norte-americano (um pouco posterior em relação ao romantismo inglês). Entre 1876 e 1879, Longfellow publicou outra antologia, Poems of Places, incluindo novamente a tradução de Mickle do episódio de Inês de Castro e outras traduções de poemas de Camões. Nessa mesma época, no entanto, Longfellow conheceu a tradução do primeiro e do segundo cantos d'Os lusíadas por James Edwin Hewitt (que traduziu apenas esses dois cantos), e passou a criticar a tradução de Mickle. Em carta a Hewitt, Longfellow elogiou-o por manter a oitava rima do original, sem tentar encaixar o poema em uma nova forma. E em 1877, em carta ao imperador do Brasil, D. Pedro II, de quem foi amigo e correspondente, Longfellow diz que a tradução de Mickle "é fácil e

\footnotetext{
278 "Mickle is the incarnation of the Traduttori, - traditori (translators = traitors). His treason, however, is boldy committed, indeed, he glories in his crime. [...] In these more exact days, Mickle would have called his poem "The Lusiads adapted from Camoens," and thus he would have won praise as a quasi-original artist. In his own time he was considered "fluent, lofty, and harmonious". I can only say that his style attacks my nerves, gives me 'crispations'.

As a translator, Mickle deserves the severest blame. His liberty is licentious: at his best he is splendide mendax. He is not satisfied with paraphrase and omissions: he rejoices in impertinent intrusions and interpretations, and he evidently holds, with consummate self-sufficiency, that he is improving upon Camoens. The seventeen stanzas which begin Canto IX are eked out to more than double - 300 for 136 lines. He falsifies history, topography, onomatology, everything."

279 "But this over-freedom, these infidelities, are nothings to the home reader. Consequently the Poem with all its faults of stilted, turgid smoothness, of "flimsy pompous chime," has maintained up to the present the hold which it took upon the last century; and has become a pseudo-classic in English literature." ("Flimsy pompous chime" é uma citação do poema "English Bards and Scottish Reviewers", de Lord Byron, referindo-se ao poeta Erasmus Darwin, avô de Charles.)
} 
graciosamente versificada, mas não é, estritamente falando, uma tradução, e sim uma paráfrase bastante livre, ou rifacimento do original” ${ }^{280}$. Mesmo assim, Longfellow manteve as traduções de Mickle no livro Poems of Places, que foi publicado depois desses comentários críticos. (MONTEIRO, 1996, pp. 86-89).

Herman Melville (1819-1891) leu Os lusíadas na tradução de Mickle. Pelo que mostra George Monteiro (1996, pp. 51-81), a influência d'Os lusíadas sobre Moby-Dick é profunda e incontestável. No romance White-Jacket (1850), Camões e Mickle são mencionados:

Camões! Jaqueta Branca, Camões! Já o leste? Os lusíadas, quero dizer? É a epopeia-belonave do mundo, meu rapaz. Dá-me Gama como Comodoro, eu digo - Nobre Gama! E Mickle, Jaqueta Branca, já ouviste falar dele? William Julius Mickle? O tradutor de Camões? Um homem desapontado, apesar de tudo, Jaqueta Branca. Além de sua tradução d'Os lusíadas, ele escreveu muitas coisas esquecidas. Já leste a balada de Cumnor Hall? Não? Ora, ela deu a Sir Walter Scott a inspiração para Kenilworth. Meu pai conheceu Mickle quando foi para o mar a bordo do velho navio de guerra Romney. Quantos grandes homens foram marinheiros, Jaqueta Branca! ${ }^{281}$ (MELVILLE, 1990, p. 274).

\subsubsection{Recepção no século XX e nos tempos atuais}

No século XX, a tradução de Mickle perdeu popularidade, sendo comentada apenas por acadêmicos especialistas em poesia épica ou na obra de Camões. Citaremos a seguir alguns desses comentários.

No livro La Littérature Portugaise en Angleterre à l'Époque Romantique, o pesquisador canadense Félix Walter (1927, pp. 41-42) descreve assim a tradução de Mickle:

Quanto à própria tradução, é realmente muito bela. Mickle era um sentimental, um sentimental quase romântico, e frequentemente deu livre curso à emoção; se não foi sempre no mesmo momento que Camões, pouco importa. Como Pope, ele amava os crepúsculos, as tempestades, todas as descrições de fenômenos da natureza, e [...] chegou a criar algumas para seu próprio prazer. Sua tradução é muito suave, muito elegante, muito mais, na verdade, do que seus próprios poemas, o que faz supor que os amigos lhe tenham dado mais do que uma pequena ajuda. Naturalmente, a tradução não é sempre muito fiel, mas o que se poderia esperar de alguém que havia

\footnotetext{
280 "It is easily and gracefully versified, but properly speaking is not a translation, but a very free paraphrase, or rifacimento of the original."

281 "Camoens! White-Jacket, Camoens! Did you ever read him? The Lusiad, I mean? It's the man-of-war epic of the world, my lad. Give me Gama for a Commodore, say I--Noble Gama! And Mickle, White-Jacket, did you ever read of him? William Julius Mickle? Camoens's Translator? A disappointed man though, White-Jacket. Besides his version of The Lusiad, he wrote many forgotten things. Did you ever see his ballad of Cumnor Hall?-No?--Why, it gave Sir Walter Scott the hint of Kenilworth. My father knew Mickle when he went to sea on board the old Romney man-of-war. How many great men have been sailors, White-Jacket!"
} 
escolhido como epígrafe de sua obra o "Nec verbum verbo curabis reddere, fidus Interpres" $[\ldots]^{282}$

O lusófilo norte-americano George West, autor de ensaios sobre Mickle, além de reconhecer as qualidades poéticas do Lusiad, considera Mickle o primeiro estudioso [scholar] anglo-lusitano, por haver despertado o interesse pela cultura e literatura portuguesas na Grã-Bretanha. West (1934, p. 389) faz um comentário relevante sobre o interesse despertado pela teoria tradutória de Mickle:

A teoria de tradução de Mickle renovou o interesse em um tema sempre popular e polêmico, e o Lusiad se tornou o exemplo favorito dos periódicos até que o Essay on the Principles of Translation (1791) de Tytler lhes fornecesse uma nova base para discussão. ${ }^{283}$

Em Projecção de Camões nas letras inglesas, o português Luís Cardim (1940, p. 40) sugere uma explicação para o sucesso do Lusiad de Mickle:

Se Fanshaw escreveu a sua tradução nos moldes dum período que se extinguia, e não podiam por isso ser já bem acolhidos, Mickle, pertencendo também a uma época de transição, mas encontrando-se, ao invés daquele, logo ao começo dela, soube aliar ao uso do dístico augustano um sentimentalismo já decididamente romântico. Daí, em grande parte, o largo êxito da sua versão, a-pesar-de muito mais infiel que a de Fanshaw, o que de momento, aliás, não foi conhecido; mas, dentro dos moldes da época, as suas qualidades poéticas são também incontestáveis, sendo tanto mais curioso o seu êxito quanto o movera a esse trabalho um motivo mercenário: o de obter um lugar na Companhia das Índias, onde Hoole, o novo tradutor de Ariosto e de Tasso, já encontrara a sua sinecura.

Ao final, Cardim (1940, p. 45) conclui que nenhuma das outras traduções d'Os lusíadas possui "um valor poético intrínseco como a de Mickle, e nenhuma também registou o seu êxito".

\footnotetext{
282 "Quant à la traduction elle-même, elle est vraiment très belle. Mickle était un sentimental, un sentimental presque romantique, et il a souvent donné libre cours à son émotion; si ce n'est pas toujours au même moment que Camoëns, peu importe. Comme Pope, il aimait les couchers de soleil, les orages, toutes les descriptions des phénomènes de la nature, et $[\ldots]$ il en a même fabriqué pour son propre plaisir. Sa traduction est très souple, très élégante, beaucoup plus, à vrai dire, que ne le sont ses propres poésies, ce qui laisse supposer que ses amis lui avaient donné plus d'un coup de main utile. Naturellement, la traduction n'est pas toujour très fidèle, mais que pouvait-on attendre de quelqu'un qui avait choisi comme devise pour son œuvre le 'Nec verbum verbo curabis reddere, fidus Interpres' [...]"

283 "Mickle's theory of translation renewed interest in a subject always popular and controversial, and the Lusiad became the favourite illustration of the periodicals until Tytler's Essay on the Principles of Translation (1791) provided them with a new basis for discussion."
} 
Na segunda metade do século XX, os méritos da tradução de Mickle continuaram sendo reconhecidos. E. M. W. Tillyard, especialista britânico em literatura clássica, considera Fanshawe e Mickle os melhores tradutores d'Os lusíadas para a língua inglesa. No influente livro The English Epic and Its Background, Tillyard (1954, p. 240) comenta que Fanshawe, embora melhor poeta do que Mickle, era preguiçoso e irregular; nas passagens de relato histórico, Fanshawe não conseguia reproduzir a limpidez do original, tornando-se obscuro. Segundo Tillyard, é aí que Mickle sobressai:

Ele viu essa limpidez de Camões e resolveu ser legível a todo custo. [...] Mickle consegue dar um colorido poético à sua tradução por inteiro. Pode-se lê-la em um só fôlego com prazer, de uma forma como não se consegue ler Fanshawe; e nessa legibilidade prolongada é, entre todas as traduções para o inglês, a mais fiel ao original. ${ }^{284}$

O estudioso português Carlos Estorninho (1960, pp. 152-153) também considera a tradução de Mickle "fiel ao espírito do original":

[...] a obra de Mickle representa o primeiro esforço sério e sistemático de divulgação, em Inglaterra, do poema máximo de Camões e de sua atribulada biografia.

Precedida de extensos prolegómenos, em que o autor disserta, com razoáveis conhecimentos, sobre a vida de Camões, o significado dos Lusíadas e a história do estabelecimento e decadência do império português do Oriente, e enriquecida com copiosas e pertinentes notas explicativas, a famosa versão de Mickle, muito embora bastante livre e aumentada - mas fiel ao espírito do original - constitui um bom poema em si, tendo disfrutado [sic] de espantosa popularidade, como o atestam as suas numerosas edições - doze, pelo menos - feitas tanto em Inglaterra como na América.

Mesmo nos dias de hoje, importantes obras britânicas de referência continuam repetindo certos chavões extraídos dos prefácios de tradutores do século XVIII. The Oxford Guide to Literature in English Translation, por exemplo, apesar de descrever a tradução de Mickle como uma paráfrase bastante livre, acrescenta o comentário: "que certamente captura o espírito do poema"285 (FRANCE, 2000, p. 440).

Em Portugal, o Dicionário de Luís de Camões, publicado recentemente, situa a tradução de Mickle, no verbete "Receção de Camões na Literatura Inglesa", redigido por João de Almeida Flor (2011, p. 807), no “contexto macroeconómico da expansão e consolidação do

\footnotetext{
284 "He saw this limpidity of Camoens and resolved at any cost to be readable. [...] Mickle succeeds in giving a poetic colouring to the whole of his translation. One can read it at a stretch with pleasure as one cannot read Fanshawe; and in this sustained legibility it is the most faithful to its original of all the English translations." 285 "which certainly catches the spirit of the poem".
} 
império mercantil britânico" e, em termos periodológicos, "no processo de evolução do paradigma cultural racionalista, próprio do neoclassicismo augustano, para o quadro da sensibilidade proto-romântica, anunciadora das poéticas oitocentistas emergentes".

Com muita propriedade, Flor (2011, pp. 807-808) vê, por parte de Mickle, a adoção de soluções de compromisso:

[...] enquanto a nível prosódico opta pela contenção e rigidez do dístico heroico fechado, ao gosto do neoclassicismo, o tradutor explora igualmente categorias estéticas já protorromânticas. A título exemplificativo, citaremos o pitoresco paisagístico do exotismo tropical e a intensidade estética do sublime, presente na descrição do oceano tempestuoso, das forças cósmicas em fúria e no retrato grandioso e patético do gigante Adamastor. Além disso, transpondo Camões para os horizontes mercantis do século XVIII, Mickle interpreta globalmente a obra como a moderna epopeia do contacto e do comércio internacionais, no duplo sentido de celebrar o diálogo com o Oriente e de inaugurar auspiciosas rotas que viabilizam as comunicações e as trocas de mercadorias no espaço euro-afro-asiático. Desta forma, relegando para posição subalterna o sentido coletivo e teleológico da História portuguesa que se depreende d'Os Lusíadas, as atenções de Mickle concentram-se na heroicidade individual do Gama e na especificidade espaciotemporal dos Descobrimentos. Com efeito, estes parecem-lhe constituir um legado e um precedente históricos suscetíveis de legitimar a translação do império marítimo, construído pelo Portugal quinhentista, para a supremacia empresarial do colonialismo britânico do século XVIII.

Apesar de apontar as inexatidões da tradução de Mickle, Flor (2011, p. 808) não deixa de reconhecer-lhe a qualidade poética e o mérito de haver granjeado lugar de realce na camonologia inglesa. 


\section{ANÁLISE COMPARATIVA ENTRE ORIGINAL E TRADUÇÃO}

Este capítulo apresenta uma análise comparativa entre o original em português d'Os lusíadas e sua tradução para o inglês feita por William Julius Mickle. A análise é orientada pelos conceitos de André Lefevere, e seu objetivo é indicar e comentar as modificações que foram introduzidas pelo tradutor a fim de adaptar o poema camoniano à Grã-Bretanha de sua época. Essas modificações, que incluem aspectos tanto ideológicos quanto poéticos, confluem para moldar a reencenação de uma translatio studii et imperii do antigo Império Português para o Império Britânico em expansão.

Após uma breve parte introdutória, de observações gerais sobre a tradução, a análise se divide entre os aspectos ideológicos e poéticos, os dois fatores que, conforme Lefevere (1992, p. 41), "determinam a imagem de uma obra de literatura como projetada por uma tradução"1. Após as subseções dedicadas separadamente à ideologia e à poética, inserimos uma subseção para abordar aqueles tópicos que apresentam simultaneamente aspectos ideológicos e poéticos. Levando em conta o exemplo do próprio Lefevere (1985, p. 225), que atribui tanto a fatores ideológicos quanto poéticos a eliminação dos termos considerados mais "fortes" ou vulgares das obras de Homero nas traduções neoclássicas francesas, entendemos justificável e pertinente o acréscimo dessa subseção.

\subsection{OBSERVAÇÕES GERAIS}

Quanto à estrutura geral do poema, percebe-se que a oitava rima do original ( $a b a b a b c c)$ foi substituída na tradução por dísticos heroicos [heroic couplets], a forma preferida pelos mais renomados tradutores britânicos da época, como Dryden e Pope, para a tradução de poemas épicos. Os decassílabos heroicos do original foram transformados em pentâmetros iâmbicos, também seguindo a tradição da época entre os britânicos.

Muitas passagens foram alongadas na tradução, com a introdução de conteúdos, representações e valores inexistentes no original; por outro lado, muitas estrofes do original foram suprimidas na tradução.

Como não há divisão em estrofes na tradução, nem, muitas vezes, correlação perceptível em termos de conteúdo ou na ordem da exposição do conteúdo, não é fácil estabelecer alguma correspondência entre trechos da tradução e do original. As divisões que propomos não são,

\footnotetext{
1 “ $[\ldots]$ determine the image of a work of literature as projected by a translation."
} 
de maneira alguma, absolutas ou incontestáveis - são apenas as que consideramos mais adequadas para comentar cada passagem ou cada aspecto da tradução.

Quanto aos nomes próprios, Mickle (1776, p. cli, nota) afirma ter tentado usá-los, como John Milton, para dar solenidade [dignity] ao poema, procurando a melhor sonoridade na língua inglesa. Por essa razão, o tradutor reconhece que "não se limitou à pronúncia dos nomes próprios em português ou espanhol"2. A verdade é que, pelo menos para o leitor contemporâneo, essa opção de Mickle parece terrivelmente caótica. Alguns (poucos) nomes próprios foram mantidos em português - "Vasco da Gama" é o exemplo mais ilustre, mas também o nome de "Fernando Coutinho" permaneceu inalterado na Introdução à tradução. Outros nomes foram traduzidos, integral ou parcialmente, para o latim (Paulo da Gama se tornou "Paulus de Gama"); para o inglês (o nome de Estêvão da Gama foi traduzido como "Stephen de Gama", e o de Rui Lourenço Ravasco se transformou em "Roderic Ravasco"); ou para o espanhol (o nome de Lopes Soares foi grafado como "Lopez Soares" e o nome "Afonso" foi traduzido como "Alonzo", "Alphonso" ou ainda "Alphonsos"). A tradução de outros nomes próprios virou uma curiosa mistura de línguas: Nicolau Coelho foi chamado de "Nicholas Coello"; Francisco de Albuquerque, de "Francis Albuquerk" (embora em algumas passagens Mickle tenha mantido "Albuquerque"); Tristão da Cunha, de "Tristan de Cugna"; "Mascarenhas" às vezes é "Mascarenhas" mesmo, outras vezes é "Mascarene". Na primeira edição, Mickle cometeu um erro de ortografia e chamou Gil Eanes, o navegador que primeiro ultrapassou o Cabo do Bojador, de "Galianez". Em outras ocorrências nessa edição o tradutor escreveu o nome corretamente como "Gilianez" (a grafia castelhana do nome). Mas, na segunda edição, em vez de corrigir a única ocorrência em que palavra havia sido grafada de modo errado, todas as ocorrências foram incorretamente alteradas para "Galianez".

Mickle adota uma dicção poética de base neoclássica, empregando adjetivação abundante: adjetivos criados a partir de substantivos com o acréscimo de um " $y$ " ao final ("beamy”, “moony”, "silvery", "pearly”); compostos com adjetivação dupla (“mild pale red”, "glimmering ghastly blue", "fiery pestilential star") ou, conforme comentamos na nota 23 do Capítulo 4, epítetos formados por adjetivos compostos ("snow-clad mountains", "blue-tinged Mecon”, “dark-brow'd shades"); epítetos apoiados no particípio presente ("rising gale", "darkling grove", "sounding ground"); e expressões perifrásticas como aquelas a que nos referimos no Capítulo 3, subseção 3.2.4, formadas por um adjetivo seguido de um nome coletivo ou abstrato - como exemplos, podemos citar "watery waste" (CAMÕES, 1776a,

\footnotetext{
2 "he has not confined himself to the Portuguese or Spanish pronunciation of proper names".
} 
p. 1), para designar o mar, e "feathered race" (p. 450), indicando os pássaros. Esses artifícios eram compartilhados pela maioria dos poetas de seu tempo. A essa base augustana neoclássica, no entanto, Mickle acrescenta elementos românticos, como as descrições da natureza enfatizando aspectos sinestésicos e valorizando ao máximo o sublime características que veremos em detalhe na seção 5.3.

Outra observação geral que se pode fazer sobre a tradução do poema é que Mickle não se preocupou em reproduzir as aliterações, assonâncias e figuras de linguagem de Camões, embora tenha acrescentado as suas próprias aliterações, assonâncias e figuras de linguagem em várias ocasiões. Ou seja, Mickle tinha muito cuidado com a dicção poética e os recursos estilísticos, mas nem sempre se preocupou em reproduzir a dicção poética e os recursos estilísticos do original.

\subsection{FATORES IDEOLÓGICOS: A EPOPEIA DO COMÉRCIO}

Para Lefevere (1992, p. 41), a ideologia é o fator de maior importância na determinação da imagem projetada por uma tradução: “A ideologia dita a estratégia básica que o tradutor vai usar". ${ }^{3}$ As passagens que selecionamos para exemplificar o efeito exercido pela ideologia na tradução de Mickle se referem a cinco tópicos principais: a glorificação do comércio (o alicerce principal sobre o qual se assenta a ideologia do Lusiad de Mickle); a "bélica excelência" (o elogio ao poder bélico português e, indiretamente, britânico); a apropriação dos heróis portugueses (para defender valores britânicos prezados pelo tradutor); a forma imperialista e colonialista de descrever os povos nativos, considerando-os "primitivos", "selvagens" ou "atrasados" (cabendo aos europeus a missão de educá-los e convertê-los à fé cristã); e a translatio da translatio studii et imperii (pela qual Mickle se apropria, em nome dos britânicos, de vários elementos que, no original, se referiam ao Império Português).

\subsubsection{A glorificação do comércio}

\subsubsection{O comércio n'Os lusíadas}

Jorge de Sena (1980, p. 271) questiona se Os lusíadas seriam uma celebração aristocrática que diminuiria "a importância e as virtudes do mercantilismo burguês". Sena

\footnotetext{
${ }^{3}$ The ideology dictates the basic strategy the translator is going to use $[\ldots]$ ".
} 
ressalta que os protagonistas da epopeia camoniana são provenientes da aristocracia menor, classe à qual o próprio Camões pertencia e sobre a qual se assentava a própria estrutura ativa da sociedade portuguesa. Por outro lado, a concepção de aristocracia de Camões, exposta claramente n'Os lusíadas, "não é de modo algum passiva e garantida: ninguém é nobre só porque os avós o foram, mas porque o confirma e merece pelos seus actos e qualidades" (p. 272). Quanto ao mercantilismo, obviamente Camões não poderia condená-lo em bloco, sabendo muito bem qual era o propósito da viagem de Vasco da Gama. O que ele condenava, segundo Sena, eram os interesses exclusivamente materiais.

Nossas análises nos levam, contudo, a concordar com Richard Helgerson (1995, pp. 155-163) quando este afirma que Camões se esforçou ao máximo por ocultar os objetivos mercantilistas da expedição de Gama. Helgerson reconhece a existência de traços desses objetivos mercantilistas no poema e cita descrições em que se chega a sugerir que o comércio "enobrece" as cidades. De Calecute, por exemplo, se diz "Cidade já por trato nobre e rica" (VII, 35); de Malaca, "por empório enobrecido" (X, 123). Além disso, os outros povos distinguem com clareza os motivos comerciais da expedição de Gama. Os nativos de Mombaça supõem que Gama esteja em busca de mercadorias (II, 4$)^{4}$ e os mercadores de Jedá reconhecem nos portugueses concorrentes ao comércio indiano (IX, 4). Mas essas percepções não são, ressalta Helgerson, compartilhadas pelos portugueses, que insistem em declarar como seus motivos os ideais de "dilatar a Fé e o Império" - ideais mais compatíveis com os de um nobre medieval do que com os de um renascentista. O quadro que Helgerson descreve de Portugal na época de Camões é o de uma nação dividida entre a ideologia medieval (cavaleirismo cristão, Cruzadas) e a mercantilista. Essas duas vozes são discerníveis n'Os lusíadas, mas o autor privilegia a primeira. ${ }^{5}$

\subsubsection{O comércio no Lusiad de Mickle}

Diferentemente de Camões, Mickle se mostra, em sua tradução d'Os lusíadas, empenhado em ressaltar os aspectos mercantilistas da expedição de Vasco da Gama. Vejamos alguns exemplos:

$\mathrm{Na}$ tradução da primeira estrofe do Canto I, o acréscimo de "lifts her spicy breast" (ressaltado em negrito no quadro a seguir) é atribuído por alguns autores (RAMOS;

\footnotetext{
${ }^{4}$ Essa estrofe é analisada a seguir, em 5.2.1.2.

${ }^{5}$ Helgerson (1995, p. 162) destaca também o fato d'Os lusíadas terem sido escritos sob as pressões do patronato da realeza. Nesse sentido, não é de se estranhar que o rei D. Sebastião tivesse feito exatamente o que Camões o aconselhara a fazer (conduzindo, assim, a nação a um desastre irreparável). Afinal, o poema teria sido escrito justamente para agradar às preferências do rei.
} 
LOUSADA, 1992, p. 48; FERREIRA, 1992b, p. 74) à tendência de Mickle a enfatizar o objetivo comercial associado à viagem de Vasco da Gama e à descoberta do caminho marítimo para a Índia (as “especiarias”).

\begin{tabular}{|l|l|}
\hline \multicolumn{1}{|c|}{ ORIGINAL (CANTO I, ESTROFE 1) } & \multicolumn{1}{c|}{ TRADUÇ̃̃O (PP. 1-2) } \\
\hline AS armas e os Barões assinalados & ARMS and the Heroes, who from Lisbon's shore, \\
Que da Ocidental praia Lusitana & Thro' Seas where sail was never spread before, \\
Por mares nunca de antes navegados & Beyond where Ceylon lifts her spicy breast, \\
Passaram ainda além da Taprobana, & And waves her woods above the watery waste, \\
Em perigos e guerras esforçados & With prowess more than human forc'd their way \\
Mais do que prometia a força humana, & To the fair kingdoms of the rising day: \\
E entre gente remota edificaram & What wars they wag'd, what seas, what dangers past, \\
Novo Reino, que tanto sublimaram; & What glorious Empire crown'd their toils at last,, 6 \\
\hline
\end{tabular}

É verdade que há outros fatores que podem explicar a inclusão dessa expressão. Embora Camões empregue a palavra "especiaria” apenas cinco vezes n'Os lusíadas - enquanto Mickle usa os termos "spicy" / "spice(s)" / "spicery" o dobro de vezes (dez) -, a associação entre a Índia e as especiarias é algo natural; não é preciso ter como objetivo exaltar o comércio para estabelecer tal associação. Além disso, o verso de Mickle lembra o primeiro verso da estrofe 59 da tradução de Fanshawe do Canto I, "And when Aurora left her Spicy Bed"” (CAMÕES, 1655, p. 15), o que pode indicar uma influência, consciente ou não, da tradução anterior. ${ }^{8}$ Entretanto, a inclusão dessa expressão não é um fato isolado. Os exemplos que se seguem reforçam a interpretação de que Mickle procura, sempre que possível, mencionar os objetivos comerciais da expedição de Vasco da Gama.

Ao traduzir a estrofe 96 do mesmo Canto I, Mickle emprega outra vez o termo "spicy" associado à Índia (destacado em negrito no quadro):

\footnotetext{
6 “As Armas e os Heróis, que da praia de Lisboa,

Por Mares onde as velas nunca haviam sido desfraldadas,

Além de onde o Ceilão ergue seu peito de especiarias,

E balança suas matas sobre a imensidão aquática,

Com proezas sobre-humanas forçou seu caminho

Rumo aos belos reinos do sol nascente:

As guerras que travaram, os mares, os perigos que passaram,

O glorioso Império que coroou seus esforços enfim,"

(A retradução de todos os versos de Mickle é de nossa autoria).

7 "E quando a Aurora deixou o seu leito de especiarias."

${ }^{8}$ Essa expressão, junto com o verso seguinte ("And waves her woods above the watery waste"), é um exemplo do uso da natureza para emoldurar cenas ou personificar sensações e sentimentos. Falaremos mais a respeito do uso da natureza por Mickle em uma de nossas próximas subseções.
} 


\begin{tabular}{|l|l|}
\hline \multicolumn{1}{|c|}{ ORIGINAL (CANTO I, ESTROFE 96) } & \multicolumn{1}{c|}{ TRADUÇ̃̃O (P. 37) } \\
\hline Destarte despedida, a forte armada & The lovely forms of sea-born nymphs arose. \\
As ondas de Anfitrite dividia, & The while brave VASCo's unsuspecting mind \\
Das filhas de Nereu acompanhada, & Yet fear'd not ought the crafty Moor design'd: \\
Fiel, alegre e doce companhia. & Much of the coast he asks, and much demands \\
O Capitão, que não caía em nada & Of Afric's shores and India's spicy lands. ${ }^{9}$ \\
Do enganoso ardil que o Mouro urdia, & \\
Dele mui largamente se informava & \\
Da Î́ndia toda e costas que passava. & \\
\hline
\end{tabular}

Como dissemos, essa associação é óbvia; afinal, um dos principais objetivos da expedição portuguesa era chegar à Índia para restabelecer o comércio de especiarias. Em consequência, seria mais do que natural que Vasco da Gama perguntasse pelas especiarias. Camões, no entanto, não o menciona. Este é um dos exemplos, aliás, a justificar as alegações de Helgerson (1995, pp. 155-163) de que Camões se esforçou ao máximo por ocultar os objetivos mercantilistas da expedição de Gama. Mickle, ao contrário, procura enfatizá-los ao máximo. $^{10}$

Outro exemplo de inclusão de referências comerciais é, ainda no Canto I (CAMÕES, 1776a, p. 41), após o que é descrito na estrofe 104, a introdução de alguns versos na tradução, sem correspondência no original, aludindo ao fato de os mouros levarem produtos da terra ao Gama:

And now, swift crowding through the horned bay, The Moorish barges wing'd their foamy way, To GAMA's fleet with friendly smiles they bore The choicest products of their cultured shore. ${ }^{11}$

Quando, na estrofe 4 do Canto 2, Camões finalmente menciona mercadorias - mas pela boca do "pérfido" mouro -, Mickle se alonga em detalhes sobre cada uma das especiarias, drogas e gemas preciosas:

\footnotetext{
9 “As adoráveis formas de ninfas do mar se ergueram. Enquanto o bravo VASCO, que de nada suspeitava, Não temia nada que o ardiloso mouro planejava: Muito sobre a costa ele pergunta, e muito indaga Sobre as costas da África e as terras de especiarias da Índia."

${ }^{10}$ Mickle segue uma longa tradição do uso retórico e poético do termo "spice" na Grã-Bretanha como símbolo de luxo e objeto de desejo, associado ao fortalecimento do capitalismo. Sobre esse assunto, ver Timothy Morton. The Poetics of Spice: Romantic Consumerism and the Exotic. Cambridge: Cambridge University Press, 2000.

11 "E agora, rapidamente amontoando-se pela baía em forma de chifre,

As barcas mouras atravessavam céleres o caminho espumoso,

Para a frota de GAMA com sorrisos amistosos carregavam

Os melhores produtos de sua costa cultivada."
} 


\begin{tabular}{|l|l|}
\hline \multicolumn{1}{|c|}{ ORIGINAL (CANTO II, ESTROFE 4) } & \multicolumn{1}{|c|}{ TRADUÇãO (PP. 44-45) } \\
\hline "E se buscando vás mercadoria & Or if your toils and ardent hopes demand \\
Que produze o aurífero Levante, & The various treasures of the Indian strand, \\
Canela, cravo, ardente especiaria & The fragrant cinnamon, the glowing clove, \\
Ou droga salutífera e prestante; & And all the riches of the spicy grove; \\
Ou se queres luzente pedraria, & Or drugs of power the fever's rage to bound, \\
O rubi fino, o rígido diamante, & And give soft languor to the smarting wound; \\
Daqui levarás tudo tão sobejo & Or if the splendour of the diamond's rays, \\
Com que faças o fim a teu desejo." & The sapphire's azure, or the ruby's blaze, \\
& Invite your sails to search the Eastern world, \\
& Here may these sails in happy hour be furl'd: \\
& For here the splendid treasures of the mine, \\
& And richest offspring of the field combine \\
& To give each boon that human want requires, \\
& And every gem that lofty pride desires; \\
& Then here, a potent King your generous friend, \\
& Here let your per'lous toils and wandering searches end.12 \\
\hline
\end{tabular}

A menção ao ouro da Índia também é frequente em Mickle, mesmo quando não há correspondência no original. Isso ocorre na tradução da estrofe 51 do Canto I, com a introdução dos versos "From farthest west, the Lusian race reply, / To reach the golden Eastern shores we try"13 (CAMÕES, 1776a, p. 21); no Canto II, estrofe 63, quando Mickle traduz "Índia" como "India's golden strand"14 (p. 68); no Canto VII, estrofe 47, quando Mickle acrescenta o ouro aos materiais usados nas esculturas do templo (no original, "Esculpidas em pau e em pedra fria"; na tradução, "The gods of wood, cold stone, and shining gold"15 (p. 301); no Canto X, estrofe 51, quando a "cortiça cálida, cheirosa" da Taprobana é

\footnotetext{
12 "Ou se os teus árduos trabalhos e ardentes esperanças procuram

Os vários tesouros da costa indiana,

A fragrante canela, o ardente cravo,

E todas as riquezas do jardim de especiarias;

Ou drogas com poder para a fúria da febre conter,

E dar suave languidez ao ferimento de dor lancinante;

Ou se o esplendor dos raios do diamante,

O azul-celeste da safira, ou o fulgor do rubi,

Convidam tuas velas a procurar o mundo oriental,

Aqui essas velas podem ser enroladas em boa hora:

Pois aqui os esplêndidos tesouros da mina,

$\mathrm{E}$ os mais ricos frutos do campo se combinam

Para fornecer todo conforto que as necessidades humanas requerem,

E toda joia que o imponente orgulho deseja;

Então aqui, com um poderoso rei como teu amigo generoso,

Que aqui teus árduos e arriscados trabalhos e buscas errantes se encerrem."

13 "Do Ocidente mais distante, os lusitanos respondem, / Chegar às praias douradas do Oriente nós buscamos".

14 "Costa dourada da Índia."

15 "Os deuses de madeira, pedra fria e ouro reluzente".
} 
traduzida como "Its incense, precious as the burnish'd gold"16 (p. 433) - o que talvez seja uma incorreção de Mickle, já que, segundo várias fontes, a "cortiça" seria a canela ${ }^{17}$.

Outras vezes é a menção geral a "riquezas", como no verso "And all the riches of his cultured fields" (em negrito abaixo), incluído na tradução da estrofe 75 do Canto II, sem correspondência direta com o original:

\begin{tabular}{|l|l|}
\hline \multicolumn{1}{|c|}{ ORIGINAL (CANTO II, ESTROFE 75) } & \multicolumn{1}{c|}{ TRADUÇÃO (P. 71) } \\
\hline O Rei, que já sabia da nobreza & The Lusian fame the king already knew, \\
Que tanto os Portugueses engrandece, & What gulfs unknown the fleet had labour'd through, \\
Tomarem o seu porto tanto preza, & What shelves, what tempests dared. His liberal mind \\
Quanto a gente fortíssima merece; & Exults the Captain's manly trust to find; \\
E com verdadeiro ânimo e pureza, & With that ennobling worth, whose fond employ \\
Que os peitos generosos enobrece, & Befriends the brave, the Monarch owns his joy, \\
Lhe manda rogar muito que saíssem & Entreats the leader and his weary band \\
Pera que de seus reinos se servissem. & To taste the dews of sweet repose on land, \\
& And all the riches of his cultured fields \\
& Obedient to the nod of GAMA yields.18 \\
\hline
\end{tabular}

Quando Camões, na estrofe 96 do Canto III, se refere a um momento áureo do reino português, sob D. Dinis, detalhando-o como um tempo de paz e prosperidade que floresceu "em constituições, leis e costumes", Mickle aproveita para inserir três versos contendo louvores à agricultura e ao comércio (em negrito no quadro seguinte):

\footnotetext{
16 "Seu incenso, precioso como o ouro brunido".

18 “A fama lusitana o rei já conhecia,

Que golfos desconhecidos a frota havia vencido,

Que bancos de areia, que tempestades enfrentara. Sua mente generosa

Exulta ao encontrar a confiança viril do Capitão;

Com aquele valor enobrecedor, cujo prestimoso emprego

Protege os bravos, o monarca confessa a sua alegria,

Insta o líder e seu grupo cansado

A experimentarem os bálsamos de doce repouso em terra,

E todas as riquezas de seus campos cultivados

Obediente ao assentimento de GAMA oferece."
}

17 A Flora dos Lusíadas, do Conde de Ficalho (1880, p. 56), é a principal fonte das notas das edições de $O s$ lusíadas sobre esse termo: "A canella é a casca do Cinnamomum zeylanicum Breyne, arvore da familia das Lauraceas, indigena da ilha de Ceylão; uma qualidade mais ordinaria, é produzida por diversas especies do mesmo genero, que habitam na India, China e outras partes do Oriente". A expressão utilizada por Fanshawe (1655, p. 203), o primeiro tradutor de Os lusíadas para o inglês, foi "fragrant Barke" - menos comprometedora. 


\begin{tabular}{|l|l|}
\hline \multicolumn{1}{|c|}{ ORIGINAL (CANTO III, ESTROFE 96) } & \multicolumn{1}{c|}{ TRADUÇÃO (P. 122) } \\
\hline Eis despois vem Dinis, que bem parece & And now brave Diniz reigns, whose noble fire \\
Do bravo Afonso estirpe nobre e dina, & Bespoke the genuine lineage of his Sire. \\
Com quem a fama grande se escurece & Now heavenly peace wide waved her olive bough, \\
Da liberalidade Alexandrina. & Each vale display'd the labours of the plough, \\
Co este o Reino próspero floresce & And smiled with joy: the rocks on every shore \\
(Alcançada já a paz áurea divina) & Resound the dashing of the merchant-oar. \\
Em constituições, leis e costumes, & Wise laws are form'd, and constitutions weigh'd, \\
Na terra já tranquila claros lumes. & And the deep-rooted base of Empire laid. \\
& Not Ammon's son with larger heart bestow'd, \\
& Nor such the grace to him the Muses owed.19 \\
\hline
\end{tabular}

Na tradução da estrofe 77 do Canto V, Mickle dedica um verso para falar dos tesouros da Índia (em negrito abaixo):

\begin{tabular}{|c|c|}
\hline ORIGINAL (CANTO V, ESTROFE 77) & TRADUÇÃO (P. 223) \\
\hline $\begin{array}{l}\text { Pela Arábica língua que mal falam } \\
\text { E que Fernão Martins mui bem entende, } \\
\text { Dizem que, por naus que em grandeza igualam } \\
\text { As nossas, o seu mar se corta e fende; } \\
\text { Mas que, lá donde sai o Sol, se abalam } \\
\text { Pera onde a costa ao Sul se alarga e estende, } \\
\text { E do Sul pera o Sol, terra onde havia } \\
\text { Gente, assi como nós, da cor do dia. }\end{array}$ & $\begin{array}{l}\text { Their speech, though rude and dissonant of sound, } \\
\text { Their speech a mixture of Arabian own'd. } \\
\text { Fernando, skill'd in all the copious store } \\
\text { Of fair Arabia's speech and flowery lore, } \\
\text { In joyful converse heard the pleasing tale, } \\
\text { That o'er these seas full oft the frequent sail, } \\
\text { And lordly vessels, tall as ours, appear'd, } \\
\text { Which to the regions of the morning steer'd, } \\
\text { And back returning to the southmost land, } \\
\text { Convey'd the treasures of the Indian strand; } \\
\text { Whose chearful crews, resembling ours, display } \\
\text { The kindred face and colour of the day. }\end{array}$ \\
\hline
\end{tabular}

\footnotetext{
19 "E agora reina o bravo Dinis, cujo nobre ardor

Evidenciava a descendência autêntica de seu ancestral.

Agora a ampla paz celestial acenou com seu ramo de oliveira,

Todos os vales exibiam os labores do arado,

E sorriam de alegria: os rochedos de todas as costas

Ressoavam com as batidas do remo do comerciante.

Leis sábias são elaboradas, e constituições ponderadas,

$\mathrm{E}$ as bases profundamente arraigadas do Império assentadas.

O filho de Amon não presenteava com coração mais generoso,

Nem tal generosidade a ele as Musas deviam."

20 "Sua fala, embora rude e de som dissonante,

Sua fala é uma mistura de origem arábica.

Fernão, habilidoso em todas as copiosas variedades

De falas e tradições floreadas da bela Arábia,

Em alegre conversa escutou a agradável história,

Que por aqueles mares frequentemente barcos a vela,

E navios nobres, altivos como os nossos, apareciam,

Que para as regiões do levante rumavam,

E ao retornarem para as terras mais ao sul,

Transportavam os tesouros da costa indiana;

As alegres tripulações, semelhantes às nossas, ostentavam

O rosto e a cor semelhantes ao dia."
} 
Em nota de rodapé a esse trecho, Mickle comenta que, quando Gama chegou ao Oriente, já havia um intenso comércio desenvolvido entre as Índias Orientais e o Mar Vermelho pelos comerciantes mouros. (CAMÕES, 1776a, p. 223, nota).

Vemos também nesse trecho um procedimento utilizado por Mickle ao longo de todo o poema: a ênfase na Índia como objetivo da viagem de Vasco da Gama. Quando Camões não menciona isso especificamente, ou deixa vaga a referência, Mickle se encarrega de especificar ou esclarecer. Apenas para citar mais um exemplo, vejamos a tradução da estrofe 84 do Canto $\mathrm{V}$, em que a vaga referência de Camões ("E pela costa abaixo o mar abrimos / Buscando algum sinal de mais firmeza") é explicitada por Mickle ("With joyful hope of India's shore elate"):

\begin{tabular}{|l|l|}
\hline \multicolumn{1}{|c|}{ ORIGINAL (CANTO V, ESTROFE 84) } & \multicolumn{1}{c|}{ TRADUÇ̃̃O (P. 225) } \\
\hline "Assi que deste porto nos partirmos & Now deeply yearning o'er our deathful fate, \\
Com maior esperança e mor tristeza, & With joyful hope of India's shore elate, \\
E pela costa abaixo o mar abrimos & We loose the haulsers and the sail expand, \\
Buscando algum sinal de mais firmeza. & And upward coast the Ethiopian strand. \\
Na dura Moçambique, enfim, surgimos, & What danger threaten'd at Quiloa's isle, \\
De cuja falsidade e má vileza & Mozambic's treason, and Mombassa's guile; \\
Já serás sabedor, e dos enganos & What miracles kind heaven our guardian wrought, \\
Dos povos de Mombaça, pouco humanos." & Loud Fame already to thine ears has brought: ${ }^{21}$ \\
\hline
\end{tabular}

Entre a tradução das estrofes 36 e 37 do Canto VII, durante a descrição que o mouro Monçaide faz do samorim e dos habitantes da região, Mickle enxerta uma série de versos em louvor ao comércio em Calecute sem nenhuma contrapartida no original:

\footnotetext{
21 "Profundamente ansiosos quanto ao nosso destino letal, Com alegre esperança inflada pela costa da Índia, Soltamos os cabos e as velas desfraldamos, E fomos subindo a costa da Etiópia.

Os perigos que nos ameaçaram na ilha de Quíloa,

A traição de Moçambique e a fraude de Mombaça;

Os milagres que o céu bondoso, nosso guardião, obrou,

A sonorosa Fama já aos teus ouvidos trouxe",
} 
And soon to Calicut's commodious port

The fleets, deep-edging with the wave, resort:

Wide o'er the shore extend the warlike piles,

And all the landscape round luxurious smiles.

And now her flag to every gale unfurl'd,

She towers the Empress of the eastern world:

Such are the blessings sapient kings bestow,

And from thy stream such gifts, O Commerce, flow. ${ }^{22}$

(CAMÕES, 1776a, p. 290).

Ainda no Canto VII, na estrofe 62, em que Vasco da Gama propõe ao samorim um pacto de paz, amizade e, sim, intercâmbio comercial, Mickle amplifica a referência ao comércio com três versos encomiásticos (salientados abaixo em negrito):

\begin{tabular}{|l|l|}
\hline \multicolumn{1}{|c|}{ ORIGINAL (CANTO VII, ESTROFE 62) } & \multicolumn{1}{c|}{ TRADUÇÃO (P. 308) } \\
\hline E se queres, com pactos e lianças & Pleased thy high grandeur and renown to hear, \\
De paz e de amizade, sacra e nua & My Sovereign offers friendship's bands sincere: \\
Comércio consentir das abondanças & Mutual he asks them, naked of disguise, \\
Das fazendas da terra sua e tua, & Then every bounty of the smiling skies \\
Por que cresçam as rendas e abastanças & Shower'd on his shore and thine, in mutual flow, \\
(Por quem a gente mais trabalha e sua) & Shall joyful Commerce on each shore bestow.23 \\
De vossos Reinos, será certamente & \\
De ti proveito, e dele glória ingente. & \\
\hline
\end{tabular}

O tradutor glorifica o comércio, fonte de dádivas ("every bounty”, "shower'd”, “on each shore bestow") e alegrias ("smiling skies", “joyful Commerce”). É verdade que o original menciona "abondanças", "fazendas", "rendas", "abastanças" e "proveito", porém o enfoque dado pelo tradutor é mais positivo. Note-se que, nessa estrofe, Camões suprime o interesse econômico como motivo da ação do rei de Portugal - o proveito seria apenas do samorim, enquanto ao monarca lusitano caberia a "glória ingente". Mickle só traduz o verso "De ti proveito, e dele glória ingente" várias linhas depois ${ }^{24}$, após o conteúdo da estrofe seguinte,

\footnotetext{
22 "E logo ao confortável porto de Calecute

As esquadras, em contato profundo com as ondas, recorrem:

Amplamente sobre a praia se estendem as lanças de guerra,

E toda a paisagem ao redor sorri, exuberante.

E agora sua bandeira é desfraldada para todos os ventos,

Ela se eleva sobre a Imperatriz do mundo oriental:

Tais são as dádivas que os reis sábios concedem,

E de teu rio tais presentes, oh Comércio, fluem.”

23 "Satisfeito de saber de tua alta nobreza e renome,

Meu Soberano oferece laços de amizade sincera:

Mútuos ele os requisita, sem disfarces,

Então todas as dádivas dos céus risonhos

Derramadas sobre as terras dele e tuas, em fluxo mútuo,

O alegre Comércio em ambas as terras fornecerá."

${ }^{24} \mathrm{~A}$ tradução de Mickle: "The glory his, the gainful harvest thine" ["A glória será dele; a proveitosa ceifa, tua"].
} 
que se refere à oferta de apoio bélico. Esse deslocamento faz com que a distinção estabelecida no original entre os "ganhos" a serem auferidos pelo governante de Calecute e pelo rei de Portugal (“de ti proveito" / "dele glória ingente") perca a força e o comércio seja apresentado como algo de benefício mútuo. Assim todos são reunidos indistintamente em uma celebração ao comércio ("mutual he asks them" e "in mutual flow").

Um dos aspectos relacionados à glorificação do comércio na tradução de Mickle é a exaltação do rio Tejo. Ferreira (1992b, p. 76) enumera exemplos em que Mickle traduz "Portugal" por “Tejo" ou alguma expressão relativa ao Tejo:

[Original:] "Portugal [...]" (III, 25, v. 3)

[Tradução:] "[...] the fields where Tagus flows,",25 (CAMÕES, 1776a, p. 95)

[Original:] "[...] - Quem te trouxe a estoutro mundo, / Tão longe da tua pátria Lusitana? - “(VII, 25, v. 3-4)

[Tradução:] "What friendly angel from thy Tago's shore / Has led thee hither? [...]"26 (CAMÕES, 1776a, p. 280)

[Original:] "Português de nação [...]" (VIII, 25, v. 2)

[Tradução:] "[...] his birth shall Tagus ever boast." ${ }^{, 27}$ (CAMÔES, 1776a, p. 330)

Para Ferreira, essa preferência se justifica pelas imagens associadas ao Tejo:

Grande via fluvial de acesso entre Portugal e o mundo, ele evoca, em sentido lato, a ideia da expansão, sobrepondo-se, assim, à noção de continentalidade veiculada pelo vocábulo "Portugal". Nesta medida, o seu apego ao Tejo liga-se ao comércio, elo igualmente fundamental, segundo Mickle, no contacto entre os povos e as várias nações.

Em “Almada Hill” - como pode ser visto em nossa análise, no Apêndice A desta tese -, encontramos essa mesma valorização do Tejo, lá descrito como o berço do comércio, sendo, por isso mesmo, dotado de um esplendor superior ao do Tâmisa.

Em outros momentos, Mickle introduz menções ao Tejo ausentes no original. É o caso da tradução da estrofe 61 do Canto I, em que o bravo e generoso Vasco oferece ao mouro um vinho tinto espumante do Tejo, quando no original era apenas um "ardente / Não usado licor, que dá alegria":

\footnotetext{
25 “os campos onde o Tejo corre".

26 "Que anjo amigo de tua margem do Tejo / Conduziu-te para cá?"

27 "[...] de seu nascimento o Tejo sempre irá se gabar."
} 


\begin{tabular}{|l|l|}
\hline \multicolumn{1}{|c|}{ ORIGINAL (CANTO I, ESTROFE 61) } & \multicolumn{1}{c|}{ TRADUÇ̃̃O (P. 25) } \\
\hline Recebe o Capitão alegremente & Brave VASCO hails the chief with honest smiles, \\
O Mouro e toda a sua companhia; & And gift for gift with liberal hand he piles. \\
Dá-lhe de ricas peças um presente, & His gifts, the boast of Europe's arts disclose, \\
Que só pera este efeito já trazia; & And sparkling red the wine of Tagus flows. ${ }^{28}$ \\
Dá-lhe conserva doce e dá-lhe o ardente, & \\
Não usado licor, que dá alegria. & \\
Tudo o Mouro contente bem recebe, & \\
E muito mais contente come e bebe. & \\
\hline
\end{tabular}

Com muita precisão, Ferreira (1992b, p. 76) conclui: "Enquanto Camões canta a gente de Luso, Mickle canta a raça do Tejo, fazendo, assim, recair a nota épica sobre tudo o que com o comércio de uma forma mais ou menos directa se relaciona".

\subsubsection{A "bélica excelência"}

O Império Britânico se estabeleceu com base no comércio, é verdade, mas o apoio de um forte exército foi um fator fundamental para a sua expansão e consolidação. A necessidade do apoio armado é algo inerente às concepções imperialistas de Mickle, e isso se evidencia no Lusiad.

Encontramos um exemplo disso na tradução da estrofe 63 do Canto VII. No original, Vasco da Gama, depois de oferecer ao samorim um pacto de paz, amizade e comércio, completa o "pacote" com a oferta de apoio militar. A tradução de Mickle desse trecho é amplificada por detalhes desse poderio bélico oferecido: "trembling Afric"; "Dread as it roars, our battle thunder hear"; "That dreadful thunder on thy foes shall roar"; “Our banners o'er the crimson field shall sweep"; "Till not a foe against thy land shall rear".

\begin{tabular}{|l|l|}
\hline \multicolumn{1}{|c|}{ ORIGINAL (CANTO VII, ESTROFE 63) } & \multicolumn{1}{c|}{ TRADUÇ̃̃O (P. 308) } \\
\hline "E sendo assi que o nó desta amizade & Our might in war, what vanquish'd nations fell, \\
Entre vós firmemente permaneça, & Beneath our spear, let trembling Afric tell; \\
Estará pronto a toda adversidade & Survey my floating towers, and let thine ear, \\
Que por guerra a teu Reino se ofereça, & Dread as it roars, our battle thunder hear. \\
Com gente, armas e naus, de qualidade & If friendship then thy honest wish explore, \\
Que por irmão te tenha e te conheça; & That dreadful thunder on thy foes shall roar. \\
E da vontade em ti sobr'isto posta & Our banners o'er the crimson field shall sweep, \\
Me dês a mi certíssima resposta." & And our tall navies ride the foamy deep, \\
& Till not a foe against thy land shall rear \\
& Th' invading bowsprit, or the hostile spear; \\
& My King, thy brother, thus thy wars shall join,,29 \\
\hline
\end{tabular}

\footnotetext{
28 “O bravo VASCO saúda o governante com sorrisos sinceros, E presente por presente com mãos generosas ele amontoa. Seus presentes, a excelência das artes europeias revelam, E o vinho tinto e espumante do Tejo flui."

29 "Nossa força na guerra, os povos vencidos que caíram,
} 
A seguir, na tradução da segunda metade da estrofe 72 , Mickle se vale do mesmo recurso, detalhando o poderio bélico dos portugueses, descrevendo o seu efeito sobre os inimigos ("The shore with trembling hears the dreadful sound, / And rampired walls lie smoaking on the ground"):

\begin{tabular}{|l|l|}
\hline \multicolumn{1}{|c|}{ ORIGINAL (CANTO VII, ESTROFE 72) } & \multicolumn{1}{c|}{ TRADUÇ̃̃O (P. 311) } \\
\hline "Vai ver-lhe a frota, as armas e a maneira & Then let thine eyes their lordly might admire, \\
Do fundido metal que tudo rende & And mark the thunder of their arms of fire: \\
E folgarás de veres a polícia & The shore with trembling hears the dreadful sound, \\
Portuguesa, na paz e na milícia." & And rampired walls lie smoaking on the ground. \\
& Speed to the fleet; their arts, their prudence weigh, \\
& How wise in peace, in war how dread, survey.30 \\
\hline
\end{tabular}

\subsubsection{A apropriação dos heróis portugueses}

Além de Vasco da Gama - cuja glorificação por parte de Mickle estudaremos na subseção 5.4.2, por apresentar a influência de fatores tanto ideológicos quanto poéticos -, Mickle reverencia entusiasticamente outros heróis portugueses em sua tradução. Ao fazê-lo, enfatiza nesses heróis supostas virtudes que interessam ao projeto imperialista e colonizador britânico, em um processo que pode ser caracterizado como o de uma apropriação dos heróis portugueses em nome do Império Britânico.

Entre esses heróis, destaca-se D. Henrique, o homem que, diz Mickle (1776, p. xiii) na Introdução ao Lusiad, "nasceu para libertar a humanidade do sistema feudal e dar a todo o mundo todas as vantagens, todas as luzes que podem ser difundidas pelo intercâmbio do comércio ilimitado" "31; o "gênio" que teria dado origem aos descobrimentos. Para exaltar ainda mais a figura de D. Henrique, Mickle inverteu as estrofes 37 e 38 do Canto VIII do

\footnotetext{
Sob nossa lança, que a África narre tremendo;

Examina as minhas torres flutuantes, e deixa o teu ouvido,

Medonho quando ruge, nosso trovão de guerra escutar.

Se amizade então teu desejo sincero cogita,

Aquele medonho trovão sobre teus inimigos rugirá.

Nossas bandeiras varrerão o campo escarlate,

E nossos grandes navios cruzarão as profundezas espumosas,

Até que nenhum inimigo levante contra tua terra

O gurupés invasor, ou a lança hostil;

Meu rei, teu irmão, se juntará a ti em tuas guerras [...]”,

30 "Então deixa teus olhos admirarem seu altivo poder,

E perceberem o trovão de suas armas de fogo:

A praia com tremores escuta o medonho som,

E muralhas com baluartes jazem fumegantes ao solo.

Corre até a frota; suas artes, sua prudência avalia,

Quão sábia na paz, na guerra quão terrível, examina.”

31 " [...] born to set mankind free from the feudal system, and to give to the whole world every advantage, every light that may possibly be diffused by the intercourse of unlimited commerce".
} 
original, para que a galeria de personagens descritos por Paulo da Gama ao catual se encerrasse com D. Henrique e não, como no original, com D. Pedro e D. Duarte de Menezes. Além disso, inseriu 16 versos na tradução da estrofe 37. Ao glorificar D. Henrique, Mickle adapta o poema à conjuntura histórica e cultural da Grã-Bretanha de seu tempo, herdeira das descobertas portuguesas do século XVI, e atende a seus próprios interesses, de enaltecer o comércio e a política expansionista a fim de agradar à Companhia das Índias Orientais, uma das patrocinadoras da tradução.

\begin{tabular}{|l|l|}
\hline \multicolumn{1}{|c|}{ ORIGINAL (CANTO VIII, ESTROFE 37) } & \multicolumn{1}{|c|}{ TRADUÇÃO (PP. 335-338) } \\
\hline "Olha cá dous Infantes, Pedro e Henrique, & Illustrious, lo, two brother-heroes shine, \\
Progénie generosa de Joane; & Their birth, their deeds, adorn the royal line; \\
Aquele faz que fama ilustre fique & To every king of princely Europe known, \\
Dele em Germânia, com que a morte engane; & In every court the gallant Pedro shone. \\
Este, que ela nos mares o publique & The glorious Henry - kindling at his name \\
Por seu descobridor, e desengane & Behold my sailors' eyes all sparkle flame! \\
De Ceita a Maura túmida vaidade, & Henry the chief, who first, by heaven inspired, \\
Primeiro entrando as portas da cidade." & To deeds unknown before, the sailor fired, \\
& The conscious sailor left the sight of shore, \\
& And dared new oceans, never ploughed before. \\
& The various wealth of every distant land \\
& He bade his fleets explore, his fleets command. \\
& The ocean's great Discoverer he shines; \\
& Nor less his honours in the martial lines: \\
& The painted flag the cloud-wrapt siege displays, \\
& There Ceuta's rocking wall its trust betrays. \\
& Black yawns the breach; the point of many a spear \\
& Gleams through the smoke; loud shouts astound the ear. \\
& Whose step first trod the dreadful pass? whose sword \\
& Hew'd its dark way, first with the foe begored? \\
& 'Twas thine, O glorious Henry, first to dare \\
& The dreadful pass, and thine to close the war. \\
& Taught by his might, and humbled in her gore \\
& The boastful pride of Afric tower'd no more. ${ }^{32}$ \\
\hline
\end{tabular}

32 "Ilustres, olha, dois heróis-irmãos brilham,

Seu nascimento, suas façanhas, adornam a linhagem real;

Por todos os reis da Europa nobre conhecido,

Em todas as cortes o garboso Pedro brilhou.

O glorioso Henrique - inflamando-se diante do nome dele

Vê como os olhos de todos os meus marinheiros reluzem, faiscantes!

Henrique, o líder que, pela primeira vez, pelos Céus inspirado,

Incitou os marinheiros a façanhas antes desconhecidas,

O marinheiro consciente perdeu a costa de vista,

E aventurou-se por novos oceanos, nunca antes singrados.

As várias riquezas de todas as terras distantes

Ele ordenou que suas frotas explorassem, que suas frotas dominassem.

Como o grande Descobridor do oceano ele se distingue;

Não são menores os seus méritos nas fileiras marciais:

A bandeira pintada o cerco envolto em nuvens exibe,

Lá a muralha de pedra trai a confiança de Ceuta.

A brecha negra se escancara; as pontas de muitas lanças

Refulgem em meio à fumaça; altos gritos surpreendem o ouvido.

De quem foi o primeiro passo a pisar na temível passagem? De quem era a espada 
As qualidades elogiadas por Mickle em D. Henrique nesse trecho são o que ele chama de "espírito de descoberta" [spirit of discovery], e que poderíamos interpretar como o impulso à política expansionista ("the chief, who first, by heaven inspired, / To deeds unknown before, the sailor fired"; "And dared new oceans, never ploughed before"); a promoção do comércio ("The various wealth of every distant land / He bade his fleets explore, his fleets command"); a coragem guerreira ("Nor less his honours in the martial lines"; "first to dare the dreadful pass") e também a fama e o reconhecimento público ("kindling at his name / Behold my sailors' eyes all sparkle flame!”). Os dois últimos versos da tradução chamam atenção pelo tom imperialista: "Taught by his might, and humbled in her gore / The boastful pride of Afric tower'd no more". É verdade que o tom imperialista já estava, de certa forma, no verso original, "e desengane / De Ceita a Maura túmida vaidade". O imperialismo camoniano, no entanto, remete às guerras religiosas da Reconquista, enquanto Mickle - até mesmo ao usar o termo mais geral, "Afric", em lugar de "Ceita" - evoca implicitamente o imperialismo britânico em expansão.

No mesmo Canto VIII, Mickle enfatiza novamente as virtudes de D. Henrique na tradução da estrofe 71, nos trechos ressaltados em negrito:

\begin{tabular}{|l|l|}
\hline \multicolumn{1}{|c|}{ ORIGINAL (CANTO VIII, ESTROFE 71) } & \multicolumn{1}{c|}{ TRADUÇ̃̃O (P. 350) } \\
\hline "Conceito dino foi do ramo claro & Sprung from the Prince, before whose matchless power \\
Do venturoso Rei que arou primeiro & The strength of Afric wither'd as a flower \\
O mar, por ir deitar do ninho caro & Never to bloom again, great Henry shone, \\
O morador de Abila derradeiro; & Each gift of nature and of art his own; \\
Este, por sua indústria e engenho raro, & Bold as his sire, by toils on toils untired, \\
Num madeiro ajuntando outro madeiro, & To find the Indian shore his pride aspired. \\
Descobrir pôde a parte que faz clara & Beneath the stars that round the Hydra shine, \\
De Argos, da Hidra a luz, da Lebre e da Ara." & And where fam'd Argo hangs the heavenly sign, \\
& Where thirst and fever burn on every gale \\
& The dauntless Henry rear'd the Lusian sail.33 \\
\hline
\end{tabular}

Que abriu seu escuro caminho, a primeira manchada com o sangue do inimigo?

Era a tua, oh, glorioso Henrique, o primeiro a ousar

A temível passagem, e coube a ti encerrar a guerra.

Vencido pela força dele, e humilhado em seu próprio sangue

O orgulho prepotente da África não se manteve mais ereto."

33 "Nascido do Príncipe [D. João I], diante de cujo poder inigualável

A força da África murchou como uma flor

Para nunca mais florir, o grande Henrique brilhou,

Todo dom de natureza e arte ele possuía;

Ousado como o pai, com árduo trabalho e mais trabalho, sem cansar,

Encontrar as terras da Índia o seu orgulho ambicionava.

Sob as estrelas que cercam o brilho da Hidra,

E onde o famoso Argo pendura o sinal celestial,

Onde a sede e a febre queimam em cada ventania

O destemido Henrique ergueu as velas lusitanas." 
No original, o nome de D. Henrique não é mencionado, mas Mickle torna a alusão explícita ao escrever "great Henry shone" e "The dauntless Henry rear'd the Lusian sail". Mais uma vez, chama-nos atenção a imagem forte, cruel, utilizada em tom triunfante por Mickle em referência à conquista de Ceuta: "The strength of Afric wither'd as a flower / Never to bloom again". A expressão usada por Camões ("por ir deitar do ninho caro / O morador de Abila derradeiro"), além de não nos parecer tão brutal, refere-se mais claramente apenas a Ceuta (representada pelo monte Ábila), sem generalizar para toda a África como faz Mickle.

Outro herói enaltecido por Mickle é Afonso de Albuquerque. Na Introdução ao Lusiad (ver Capítulo 4, subseção 4.7.3) Mickle já o havia elogiado por sua generosidade e espírito comercial. No original, a estrofe 14 do Canto I contém apenas uma rápida menção a Albuquerque: “Albuquerque terribil”. Na tradução, Mickle transfere Albuquerque para o final da lista de heróis e alonga-se nos elogios a ele no trecho salientado por nós em negrito:

\begin{tabular}{|l|l|}
\hline \multicolumn{1}{|c|}{ ORIGINAL (CANTO I, ESTROFE 14) } & \multicolumn{1}{c|}{ TRADUÇÃO (PP. 8-9) } \\
\hline Nem deixarão meus versos esquecidos & Those heroes, too, who thy bold flag unfurl'd, \\
$\begin{array}{l}\text { Aqueles que nos Reinos lá da Aurora } \\
\text { Se fizeram por armas tão subidos, }\end{array}$ & And spread thy banners o'er the Eastern world, \\
Vossa bandeira sempre vencedora: & Whose spears subdued the kingdoms of the morn, \\
Um Pacheco fortíssimo e os temidos & Their names and glorious wars the song adorn: \\
Almeidas, por quem sempre o Tejo chora, & The daring GAMA, whose unequal'd name \\
Albuquerque terríbil, Castro forte, & Proud monarch shines o'er all of naval fame: \\
E outros em quem poder não teve a morte. & Castro the bold, in arms a peerless knight, \\
& And stern Pacheco, dreadful in the fight: \\
& The two Almeydas, names for ever dear, \\
& By Tago's nymphs embalm'd with many a tear; \\
& Ah, still their early fate the nymphs shall mourn, \\
& And bathe with many a tear their hapless urn: \\
& Nor shall the godlike Albuquerque restrain \\
& The Muse's fury; o'er the purpled plain \\
& The Muse shall lead him in his thund'ring car \\
& Amidst his glorious brothers of the war, \\
& Whose fame in arms resounds from sky to sky, \\
& And bids their deeds the power of death defy. ${ }^{34}$ \\
\hline
\end{tabular}

\footnotetext{
34 “Aqueles heróis, também, que vossa ousada bandeira desfraldaram,

E espalharam vossos estandartes pelo mundo oriental,

Cujas lanças subjugaram os reinos do levante,

Seus nomes e guerras gloriosas adornam o canto:

$\mathrm{O}$ audacioso GAMA, cujo nome inigualado

Monarca orgulhoso brilha sobre todos os de fama naval:

Castro o ousado, em armas um cavaleiro incomparável,

E o severo Pacheco, terrível na luta:

Os dois Almeidas, nomes para sempre queridos,

Pelas ninfas do Tejo embalsamados com muitas lágrimas;

$\mathrm{Ah}$, sua fatalidade prematura as ninfas ainda lamentarão,

E banharão com muitas lágrimas sua urna desafortunada:

O divino Albuquerque também não conterá

A fúria da Musa; sobre a planície cor de púrpura
} 
Além de Vasco da Gama, D. Henrique e Afonso de Albuquerque, Mickle reverencia no Lusiad outros de seus heróis portugueses prediletos. Como os recursos encomiásticos utilizados são os mesmos já analisados nesta subseção, faremos aqui apenas um breve comentário sobre algumas dessas homenagens. No Canto X, na tradução das estrofes de 56 a 60, Mickle efetua um completo remanejamento da narrativa e inclui vários versos em homenagem a Pedro de Mascarenhas, a quem Mickle (1776, pp. lxxx-lxxxiv) admira pelos grandes feitos militares e por ter promovido o comércio quando era governador de Malaca. No original, Mascarenhas é mencionado primeiro, seguido por Sampaio e Heitor. Mickle emoldura todo o trecho com a história de Mascarenhas: fala primeiro de Mascarenhas, depois brevemente de Sampaio e Heitor e, finalmente, volta a Mascarenhas para fazer-lhe um longo elogio e lamentar as injustiças cometidas contra ele ${ }^{35}$; em seguida, na estrofe 61 , o tradutor acrescenta vários versos em louvor a Nuno da Cunha - a quem, na Introdução, Mickle (p. lxxxiv-xc) aplaudira pela habilidade política e tolerância religiosa. Finalmente, na estrofe 62, o tradutor enaltece as ações do filho de Vasco, Estêvão da Gama, a quem chamara de "bravo e generoso"36 na Introdução (p. xc). (CAMÕES, 1776a, pp. 435-437).

\subsubsection{Os Povos Nativos: Visões Imperialistas e Colonialistas}

Os lusíadas de Camões expressam a visão cristã e aristocrática que era hegemônica em sua época - uma visão que hoje em dia qualificaríamos como etnocêntrica, pois interpreta o mundo da perspectiva de seu próprio grupo, mostrando-se incapaz de entender outros grupos e culturas que adotem valores diferentes dos seus. Assim, enquanto os portugueses são glorificados por seus valores cristãos e civilizados, os povos nativos são descritos como “Cafres, ásperos e avaros" (V, 47); "Cafres selvagens" (X, 38), "selvática gente, negra e nua" (X, 93). Já aos "mouros"37 é concedida uma identidade cultural, mas apenas como os tradicionais inimigos da fé cristã. Recebem, em consequência, uma adjetivação que denota, quase sempre, falsidade e maldade: "falso Mouro" (I, 72; I, 99); "bruta gente" capaz de "vil malícia, pérfida, inimiga” (I, 92); “malina gente” (I, 99; VIII, 58); “infidas gentes” (II, 1);

\footnotetext{
A Musa o conduzirá em seu carro trovejante Em meio aos seus gloriosos irmãos na guerra,

Cuja fama em armas ressoa de céu a céu,

E desafia com suas façanhas o poder da morte."

${ }^{35}$ Comentaremos mais sobre esses versos na subseção 5.3.3, neste mesmo capítulo.

36 "brave and generous".

${ }^{37}$ A palavra vem de "mauro", habitante da Mauritânia, e era inicialmente aplicada aos árabes-bérberes do Norte da África e na Península Ibérica, mas foi depois estendida a todos aqueles que professavam a fé islâmica (hoje chamados de islamitas, muçulmanos ou maometanos).
} 
“infiel e falsa gente" (II, 6); "pérfida, inimiga e falsa gente" (II, 30); “os Perros" (III, 48), “o povo imundo" (VII, 2); seguidores do "falso Mahamede" (II, 50); o "Profeta falso e noto" (VIII, 47).

Por seu turno, a visão de Mickle dos habitantes da África e da Ásia é, geralmente, a de povos primitivos que podem evoluir e civilizar-se pelo contato com os europeus. Essa visão, que é, como já vimos, claramente expressa nos peritextos do Lusiad, se reflete na própria tradução.

Quanto à forma de se referir aos "mouros", precisamos lembrar que a tolerância religiosa é um valor prezado por Mickle, ainda mais quando favorece o comércio. Assim como pode ser visto no quadro abaixo, em que retomamos as expressões negativas em referência aos mouros encontradas no original pareando-as à tradução dada por Mickle - o tradutor atenua a adjetivação pejorativa do original ou, em alguns casos, procura torná-la mais específica e menos geral ("treacherous" em vez de "falso", caracterizando mais estritamente o ato de traição; "fear'd that fraud its viper-sting might veil" e "fraudful Malice", em referência aos atos negativos praticados, em vez de "infiel e falsa gente" ou "pérfida, inimiga e falsa gente", que definem depreciativamente o povo em si):

\begin{tabular}{|l|l|}
\hline \multicolumn{1}{|c|}{ ORIGINAL } & \multicolumn{1}{|c|}{ TRADUÇ̃̃O (1776) } \\
\hline "falso Mouro" (I, 72; I, 99) & "The Moor" (p. 27); "the treacherous Moor"38 (p. 38) \\
\hline $\begin{array}{l}\text { "bruta gente" / "vil malícia, pérfida, } \\
\text { inimiga" (I, 92) }\end{array}$ & "their perfidy"39 (p. 36) \\
\hline "malina gente" (I, 99; VIII, 58) & "swarthy race"40 (p. 38) \\
\hline "infidas gentes" (II, 1) & "the eager natives"41 (p. 45) \\
\hline "Se fia da infiel e falsa gente" (II, 6) & "fear'd that fraud its viper-sting might veil"42 (p. 46) \\
\hline "pérfida, inimiga e falsa gente" (II, 30) & $\begin{array}{l}\text { "fraudful Malice" / "the poison of thy gilded snare"43 (p. } \\
\text { 55) }\end{array}$ \\
\hline "os Perros" (III, 48) & "Th' astonish'd Moors"44 (p. 103) \\
\hline "o povo imundo" (VII, 2) & [Trecho não traduzido.] \\
\hline seguidores do "falso Mahamede" (II, 50) & "their prophet"45 (p. 63) \\
\hline "Profeta falso e noto" (VIII, 47) & [Trecho não traduzido.] \\
\hline
\end{tabular}

Há casos, no entanto, em que Mickle também atribuiu qualificações negativas aos mouros - se não de modo generalizado como Camões, pelo menos aos mouros que faziam o papel de "vilões" da narrativa camoniana. Na tradução da estrofe 66 do Canto II, por

\footnotetext{
38 "o mouro traiçoeiro".

39 "a perfídia deles".

40 "raça morena".

41 "os ansiosos nativos".

42 "temia que a fraude pudesse esconder sua picada de víbora".

43 "Malícia fraudulenta" / "o veneno da tua armadilha dourada".

44 "Os mouros estupefatos".

45 "o profeta deles".
} 
exemplo, Mickle chama os mouros fugitivos de "vermin" ("animais daninhos", "praga", "peste", "parasitas"; referindo-se a pessoas, "canalha", "gentalha" - em nossa retradução, "ratos") - palavra que grafamos em negrito no quadro abaixo:

\begin{tabular}{|l|l|}
\hline \multicolumn{1}{|c|}{ ORIGINAL (CANTO II, ESTROFE 66) } & \multicolumn{1}{c|}{ TRADUÇ̃̃O (PP. 68-69) } \\
\hline Neste tempo que as âncoras levavam, & When Heaven again its guardian care display'd; \\
Na sombra escura os Mouros escondidos & Above the wave rose many a Moorish head, \\
Mansamente as amarras lhe cortavam, & Conceal'd by night they gently swam along, \\
Por serem, dando à costa, destruídos; & And with their weapons sawed the cables strong, \\
Mas com vista de linces vigiavam & That by the swelling currents whirl'd and tost, \\
Os Portugueses, sempre apercebidos; & The navy's wrecks might strew the rocky coast. \\
Eles, como acordados os sentiram, & But now discover'd, every nerve they ply, \\
Voando, e não remando, lhe fugiram. & And dive, and swift as frighten'd vermin fly. ${ }^{46}$ \\
\hline
\end{tabular}

Se ao falar dos "mouros" Mickle tende a ser menos depreciativo do que Camões, ao se referir a outros povos africanos e asiáticos frequentemente o tradutor acaba acentuando o etnocentrismo do original por meio de amplificações que detalham o estado primitivo e "bárbaro" desses povos. A seguir, analisaremos alguns exemplos em que isso se evidencia.

Já ao traduzir a segunda estrofe do Canto I, Mickle inclui quatro versos (destacados abaixo em negrito) que não apresentam uma correspondência exata no original, explicitando e detalhando a menção, no original, a "terras viciosas" e à dilatação da Fé:

\begin{tabular}{|l|l|}
\hline \multicolumn{1}{|c|}{ ORIGINAL (CANTO I, ESTROFE 2) } & \multicolumn{1}{c|}{ TRADUÇÃO (PP. 2-3) } \\
\hline E também as memórias gloriosas & Vent'rous I sing, on soaring pinions borne, \\
Daqueles Reis que foram dilatando & And all my Country's wars the song adorn; \\
A Fé, o Império, e as terras viciosas & What Kings, what Heroes of my native land \\
De Âfrica e de Âsia andaram devastando, & Thunder'd on Asia's and on Afric's strand: \\
E aqueles que por obras valerosas & Illustrious shades, who levell'd in the dust \\
Se vão da lei da Morte libertando, & The idol-temples and the shrines of lust: \\
Cantando espalharei por toda parte, & And where, erewhile, foul demons were rever'd, \\
Se a tanto me ajudar o engenho e arte. & To Holy Faith unnumber'd altars rear'd: \\
& Illustrious names, with deathless laurels crown'd, \\
& While time rolls on in every clime renown'd!47 \\
\hline
\end{tabular}

46 "Quando o Céu outra vez mostrou o seu cuidado guardião;

Sobre as ondas se ergueram muitas cabeças mouras,

Ocultas pela noite eles nadaram suavemente,

E, com suas armas, serraram os fortes cabos,

Que pelas correntes da maré alta rodopiaram e se debateram,

Os destroços da esquadra poderiam se dispersar pela costa rochosa.

Mas agora descobertos, eles reúnem toda a coragem,

E mergulham, e céleres como ratos assustados, fogem."

47 "Destemido eu canto, sustentado em asas ascendentes,

E todas as guerras do meu país o canto adornam;

Os Reis, os Heróis de minha terra natal

Proclamados na costa da Ásia e da Àfrica:

Ilustres espíritos, que reduziram a pó

Os templos idólatras e os santuários da luxúria:

E onde, pouco tempo atrás, demônios repugnantes eram reverenciados, 
Mickle menciona especificamente a destruição dos templos dedicados a ídolos e santuários "da luxúria" ("The idol-temples and the shrines of lust"), onde eram cultuados “demônios repugnantes" (“foul demons”), e a construção de altares cristãos. Dessa forma, o tradutor amplifica a exaltação aos valores cristãos e o menosprezo às religiões africanas e asiáticas já presentes no original.

Ao traduzir a estrofe 49, ainda no Canto I, Mickle introduz a expressão "barb' rous race", sem correspondência no original, para se referir aos nativos (grafado em negrito abaixo):

\begin{tabular}{|l|l|}
\hline \multicolumn{1}{|c|}{ ORIGINAL (CANTO I, ESTROFE 49) } & \multicolumn{1}{c|}{ TRADUÇãO (P. 20) } \\
\hline Cos panos e cos braços acenavam & And now with hands and kerchiefs wav'd in air \\
Às gentes Lusitanas, que esperassem; & The barb'rous race their friendly mind declare. \\
Mas já as proas ligeiras se inclinavam, & Glad were the crew, and ween'd that happy day \\
Pera que junto às Ilhas amainassem. & Should end their dangers and their toils repay. \\
A gente e marinheiros trabalhavam & The lofty masts the nimble youths ascend, \\
Como se aqui os trabalhos s' acabassem: & The ropes they haule, and o'er the yard-arms bend; \\
Tomam velas, amaina-se a verga alta, & And now their bowsprits pointing to the shore, \\
Da âncora o mar ferido em cima salta. & A safe moon'd bay, with slacken'd sails they bore: \\
& With cheerful shouts they furl the gather'd sail \\
& That less and less flaps quivering on the gale; \\
& The prows, their speed stopt, o'er the surges nod, \\
& The falling anchors dash the foaming flood; ${ }^{48}$ \\
\hline
\end{tabular}

O adjetivo, "barbarous" significava na época, segundo o dicionário de Johnson (1755, p. 201): 1. Estranho à civilização; selvagem; não civilizado; 2. ignorante; que não conhece as Artes; 3. cruel; desumano. ${ }^{49}$ Seja qual for a acepção pretendida, a palavra denota menosprezo pelos povos nativos. Um atenuante para o uso do termo na tradução é o fato de que o próprio Camões chamava de "bárbaros" os povos que não fossem gregos nem latinos, como pode ser visto no Canto III, estrofe 7, verso 8 (“Co sangue Mauro, bárbaro e nefando") e no Canto V,

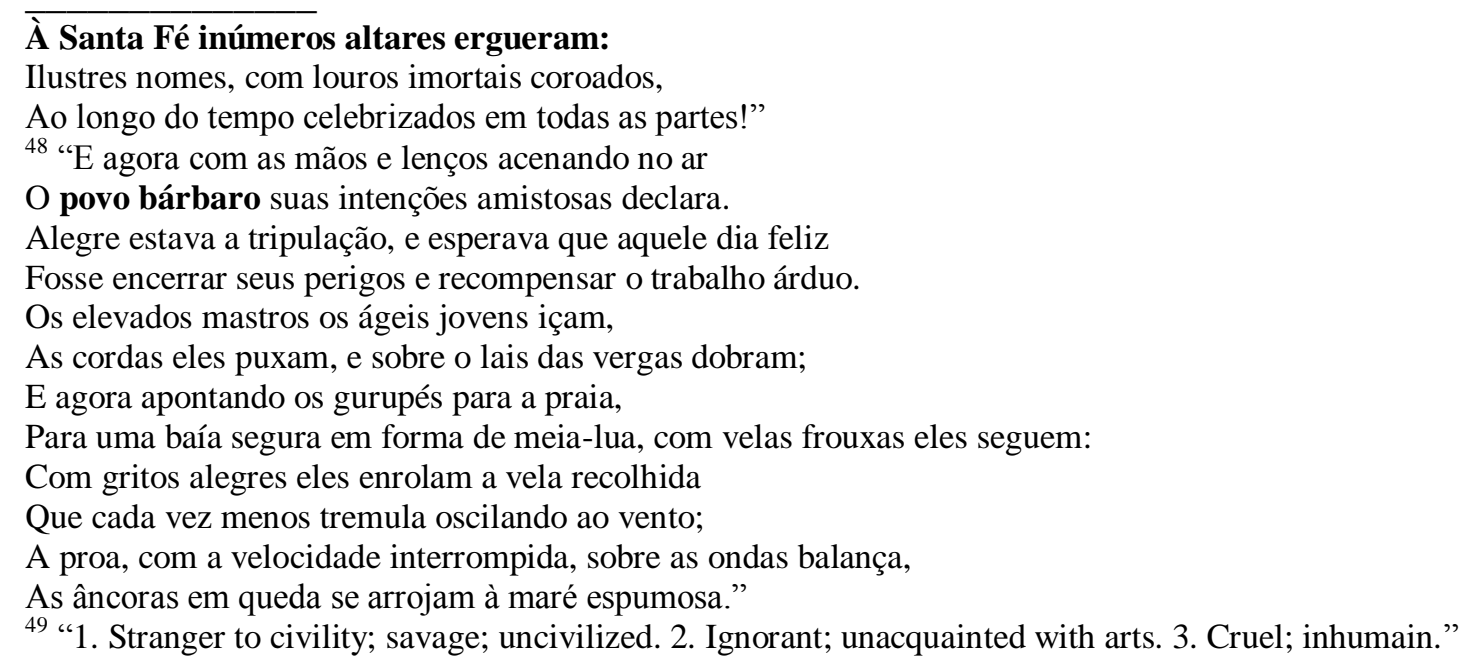


estrofe 97, verso 3 ("Da Lácia, Grega ou Bárbara nação”), para citarmos apenas dois exemplos entre várias ocorrências.

Os mesmos preconceitos contra a religião brâmane evidenciados na "Dissertação sobre os Brâmanes" que comentamos no Capítulo 4 (4.7.11) são expressos na tradução da estrofe 40 do Canto VII:

\begin{tabular}{|l|l|}
\hline \multicolumn{1}{|c|}{ ORIGINAL (CANTO VII, ESTROFES 40) } & \multicolumn{1}{c|}{ TRADUÇ̃̃O (PP. 291-292) } \\
\hline "Brâmenes são os seus religiosos, & Whate'er in India holds the sacred name \\
Nome antigo e de grande preminência; & Of piety or lore, the Brahmins claim: \\
Observam os preceitos tão famosos & In wildest rituals, vain and painful, lost, \\
Dum que primeiro pôs nome à ciência; & Brahma their founder as a God they boast. \\
Não matam cousa viva e, temerosos, & To crown their meal no meanest life expires, \\
Das carnes têm grandíssima abstinência. & Pulse, fruit, and herbs alone their board requires: \\
Somente no Venéreo ajuntamento & Alone in lewdness riotous and free, \\
Têm mais licença e menos regimento." & No spousal ties with-hold, and no degree:50 \\
\hline
\end{tabular}

Enquanto no original o relato de Monçaide, um mouro que acaba se convertendo ao cristianismo, demonstra certo respeito pela religião brâmane ("Nome antigo e de grande preminência"), na tradução o discurso de Monçaide é bastante crítico em relação ao bramanismo. Já nos primeiros versos aparece a sugestão de que os brâmanes se arrogam direitos sobre tudo o que é sagrado na Índia: "Whate'er in India holds the sacred name / Of piety or lore, the Brahmins claim”. Essa impressão negativa sobre os brâmanes é confirmada pelos adjetivos empregados na tradução ("wildest rituals"; "vain and painful, lost", "riotous"), que denotam desprezo pelo bramanismo. E a expressão até certo ponto neutra do original, "Venéreo ajuntamento", é traduzida por um termo de conotações claramente negativas: "lewdness" ("lascívia", "obscenidade").

Ao traduzir a estrofe 92 do Canto X, Mickle introduz a sua própria visão da situação da África. O original diz "dos bens do mundo avara", "Inculta e toda cheia de bruteza" e "gente sem Lei, quási infinita". O tradutor se estende, descrevendo a falta de cultivo das terras ("Her lands uncultured"; "neglected fields"), a falsidade ("her sons untrue"), brutalidade ("Savage and fierce they roam in brutal strife") e falta de refinamento cultural dos africanos ("Ungraced with all that sweetens human life"; "naked").

\footnotetext{
50 “Tudo o que na Índia ostenta o nome sagrado De religiosidade ou tradições, os brâmanes reivindicam: Nos mais selvagens rituais, vãos e dolorosos, perdidos, Brahma seu criador como um Deus eles glorificam. Para coroar sua refeição nenhuma vida inferior perece, Apenas sementes, frutas e ervas a refeição exige: Sozinhos em lascívia desregrada e livre, Não formam vínculos conjugais, nem de hierarquia”.
} 


\begin{tabular}{|l|l|}
\hline \multicolumn{1}{|c|}{ ORIGINAL (CANTO X, ESTROFE 92) } & \multicolumn{1}{c|}{ TRADUÇÃO (PP. 449-450) } \\
\hline "Vês Europa Cristã, mais alta e clara & Here Christian Europe lifts the regal head. \\
Que as outras em polícia e fortaleza. & Afric behold, alas, what alter'd view! \\
Vês África, dos bens do mundo avara, & Her lands uncultured, and her sons untrue; \\
Inculta e toda cheia de bruteza; & Ungraced with all that sweetens human life, \\
Co Cabo que até 'qui se vos negara, & Savage and fierce they roam in brutal strife; \\
Que assentou pera o Austro a Natureza. & Eager they grasp the gifts which culture yields, \\
Olha essa terra toda, que se habita & Yet naked roam their own neglected fields. ${ }^{51}$ \\
Dessa gente sem Lei, quási infinita." & \\
\hline
\end{tabular}

No Canto X, estrofe 126, versos 7 e 8, encontramos a afirmação, expressa no estilo sucinto de Camões: "Humana carne comem, mas a sua / Pintam com ferro ardente, usança crua". A tradução de Mickle dessa passagem (destacada abaixo em negrito) inclui juízos de valor cristãos a respeito da prática da antropofagia, além de acrescentar detalhes mais sórdidos ("they suck the human blood / And gnaw the reeking limbs, their sweetest food"), chocantes para o leitor britânico, ressaltando a animalidade do comportamento desses povos ("brutalized"; "fiend-like"; "brutal mein"; "frothing jaws"; "wolf-like"; "ruthless lust”):

\begin{tabular}{|l|l|}
\hline \multicolumn{1}{|c|}{ ORIGINAL (CANTO X, ESTROFE 126) } & \multicolumn{1}{c|}{ TRADUÇÃO (PP. 465-467) } \\
\hline "Vês neste grão terreno os diferentes & And thousands more, of laws, of names unknown, \\
Nomes de mil nações, nunca sabidas: & That vast of land inhabit. Proud and bold, \\
Os Laos, em terra e número potentes; & Proud of their numbers here the Laos hold \\
Avás, Bramás, por serras tão compridas; & The far spread lawns; the skirting hills obey \\
Vê nos remotos montes outras gentes, & The barbarous Avas and the Bramas' sway. \\
Que Gueos se chamam, de selvages vidas; & Lo, distant far another mountain chain \\
Humana carne comem, mas a sua & Rears its rude cliffs, the Guios' dread domain; \\
Pintam com ferro ardente, usança crua." & $\begin{array}{l}\text { Here brutalized the human form is seen, } \\
\text { The manners fiend-like as the brutal mein: }\end{array}$ \\
& $\begin{array}{l}\text { With frothing jaws they suck the human blood } \\
\text { And gnaw the reeking limbs, their sweetest food; } \\
\end{array}$ \\
& $\begin{array}{l}\text { Horrid with figured seams of burning steel } \\
\text { Their wolf-like frowns their ruthless lust reveal.52 }\end{array}$ \\
\hline
\end{tabular}

51 “Aqui a Europa Cristã ergue a sua cabeça régia.

Vede a África, ai, que visão diferente!

Suas terras incultivadas e seus filhos desleais;

Desprovidos de tudo o que adoça a vida humana,

Selvagens e ferozes eles perambulam em conflitos brutais;

Ávidos agarram as dádivas que o cultivo produz,

Mas andam nus por seus campos abandonados.”

52 "E mais milhares, de leis, de nomes desconhecidos,

Aquela vasta terra habitam. Orgulhosos e audaciosos,

Orgulhosos de sua numerosidade aqui o Laos possui

Os prados mais extensos; as colinas ao redor obedecem

Ao poder dos bárbaros Avás e Bramás.

Vede, lá longe outra cadeia de montanhas

Eleva seus brutos penhascos, o domínio dos terríveis Gueos;

Aqui brutalizada é vista a forma humana,

Os costumes demoníacos e a aparência brutal:

Com mandíbulas espumando eles sugam o sangue humano

E roem os membros fétidos, sua comida mais doce;

Horrendos com cicatrizes estampadas com ferro ardente 
Na tradução da estrofe 130 do Canto X, em vez de comentar, como o original, o fato de os reis chineses não serem sagrados por descendência, e sim eleitos por mérito ${ }^{53}$, Mickle menciona os "horrores" que se espalham pela região, referindo-se, com isso, conforme explicado na nota $p$ da página 472 do Lusiad, às "superstições do Oriente",54 - os tártaros do Tibete adorariam um Deus vivo (o Dalai Lama), um rapaz sentado de pernas cruzadas no trono do grande templo, adornado com ouro e diamantes. Esse "Deus" seria reles marionete dos sacerdotes, fazendo tudo o que lhe ordenavam.

\begin{tabular}{|l|l|}
\hline \multicolumn{1}{|c|}{ ORIGINAL (CANTO X, ESTROFE 130) } & \multicolumn{1}{c|}{ TRADUÇÃO (PP. 471-472) } \\
\hline "Olha o muro e edifício nunca crido, & A prouder boast of regal power displays \\
Que entre um império e o outro se edifica, & Than all the world beheld in ancient days. \\
Certíssimo sinal, e conhecido, & Not built, created seems the frowning mound; \\
Da potência real, soberba e rica. & O'er loftiest mountain tops and vales profound \\
Estes, o Rei que têm, não foi nascido & Extends the wondrous length, with warlike castles crown'd. \\
Príncipe, nem dos pais aos filhos fica, & Immense the northern wastes their horrors spread; \\
Mas elegem aquele que é famoso & In frost and snow the seas and shores are clad. 55 \\
Por cavaleiro, sábio e virtuoso." & \\
\hline
\end{tabular}

Todos esses exemplos evidenciam que a tradução muitas vezes acentua o etnocentrismo já existente no original, transmitindo uma caracterização negativa das práticas sociais, religiosas, culturais e econômicas dos povos nativos da África e da Ásia, o que serve, por contraste, para ressaltar a superioridade dos portugueses e - direta ou indiretamente britânicos.

\subsubsection{A translatio da translatio studii et imperii}

A tese que defendemos é a de que o Lusiad de Mickle, como um todo, reencena uma translatio studii et imperii para a Grã-Bretanha de seu tempo. Nesta subseção, examinaremos trechos em que Camões expressou a sua visão da teoria da translatio e, comparando-os com a tradução, procuraremos demonstrar que Mickle efetuou uma translatio da translatio camoniana.

\footnotetext{
A expressão lupina revela-lhes o apetite cruel."

${ }^{53}$ Segundo Leonard Bacon, o tradutor norte-americano de Os lusíadas, essa descrição de sistema sucessório seria aplicável aos imperadores mongóis, mas não aos chineses. (CAMÕES, 1950, p. 404).

54 "superstitions of the East".

55 "Uma exibição mais orgulhosa do poder régio

Do que todo o mundo contemplou nos dias de outrora.

Não parece construída, mas criada a partir dos montes carrancudos;

Nos topos das montanhas mais altas e nos vales mais profundos

Estende-se a prodigiosa extensão, coroada por castelos bélicos.

Imensa espalha seus horrores pelos desertos do norte;

Em gelo e neve os mares e praias são cobertos."
} 
Na estrofe 24 do Canto I temos, no original, a declaração de Júpiter sobre o destino dos portugueses, inspirada no ideal da translatio studii et imperii. Mickle introduz uma explicitação ("A potent empire in the East shall rear") que reduz o âmbito do Império Português ao Oriente, distorcendo a representação feita por Camões e tornando-a aplicável à própria Grã-Bretanha:

\begin{tabular}{|l|l|}
\hline \multicolumn{1}{|c|}{ ORIGINAL (CANTO I, ESTROFE 24) } & \multicolumn{1}{c|}{ TRADUÇÃO (P. 12) } \\
\hline "Eternos moradores do luzente, & Immortal heirs of light, my purpose hear, \\
Estelífero Pólo, e claro Assento: & My counsels ponder, and the Fates revere: \\
Se do grande valor da forte gente & Unless Oblivion o'er your minds has thrown \\
De Luso não perdeis o pensamento, & Her dark blank shades, to you, ye gods, are known \\
Deveis de ter sabido claramente & The Fate's decree, and ancient warlike Fame \\
Como é dos Fados grandes certo intento & Of that bold race which boasts of Lusus' name; \\
Que por ela se esqueçam os humanos & That bold advent'rous race, the Fates declare, \\
De Assírios, Persas, Gregos e Romanos." & $\begin{array}{l}\text { A potent empire in the East shall rear, } \\
\text { Surpassing Babel's or the Persian fame, }\end{array}$ \\
& \begin{tabular}{l} 
Proud Grecia's boast, or Rome's illustrious name.56 \\
\hline
\end{tabular}
\end{tabular}

Um dos recursos utilizados por Mickle no processo de reencenação da translatio é tomar emprestadas para o Império Britânico no Oriente aquelas qualidades do Império Português no Oriente que ele considera positivas. O tradutor faz isso de diversas maneiras; veremos, a seguir, um exemplo.

No Canto VII, as estrofes de 50 a 54 descrevem painéis desenhados e esculpidos nas paredes do palácio do samorim, representando cenas da Antiguidade. A estrofe 54 alude à Terceira Monarquia, de Alexandre, o Grande, que sucedeu ao Império dos Assírios e dos Persas. Na sequência dessa evocação à teoria da sucessão dos impérios, nas estrofes 55 e 56, o catual lembra as profecias dos sábios magos sobre a futura dominação da Índia por "gentes estrangeiras". A interpretação é clara: temos aqui uma referência auspiciosa ao Quinto Império dos portugueses. As qualidades desse império são resumidas assim no original:

\footnotetext{
56 "Herdeiros imortais da luz, ouvi meu plano, Ponderai meus conselhos, e os Fados honrai: A não ser que o Esquecimento sobre vossas mentes tenha lançado Suas sombras escuras e vazias, por vós, deuses, são conhecidos $\mathrm{O}$ decreto do Fado e a antiga Fama guerreira Daquele povo ousado que assume o nome de Luso; Aquele povo ousado, aventureiro, os Fados declaram, Um poderoso império no Oriente erguerá, Ultrapassando a fama da Babilônia ou dos persas, Os méritos da orgulhosa Grécia, ou o nome ilustre de Roma."
} 
Mas também diz que a bélica excelência,

Nas armas e na paz, da gente estranha

Será tal, que será no mundo ouvido

$\mathrm{O}$ vencedor por glória do vencido.

(VII, 56)

A tradução de Mickle especifica os atributos do domínio português de maneira um tanto diferente:

But swift behind these wintery days of woe

A spring of joy arose in liveliest glow,

Such gentle manners leagued with wisdom reign'd

In the dread victors, and their rage restrain'd.

Beneath their sway majestic, wise, and mild,

Proud of her victors' laws thrice happier India smiled. ${ }^{57}$

(CAMÕES, 1776a, p. 306).

Vemos, nesses versos, que Mickle atribui aos futuros vencedores não apenas o poder e a capacidade de inspirar medo e respeito ("dread victors"; "sway majestic"), mas também a gentileza ("gentle manners"); a sabedoria ("wisdom"; "wise"); o controle da ira ("their rage restrain'd"); e a temperança ("mild"). Todas essas virtudes fariam os dominados se alegrarem com a sua condição de dominados ("A spring of joy arose in liveliest glow"; "Proud of her victors' laws thrice happier India smiled"). Essa seria uma boa síntese do imperialismo "paternalista" defendido por Mickle - e também a síntese da própria ideologia do imperialismo britânico.

Outro tipo de manipulação efetuada por Mickle sobre a visão de Camões de um futuro Império Português acontece na tradução do episódio da Ilha dos Amores. Como mostra Vítor Manuel de Aguiar e Silva (1994, pp. 131-143), esse episódio não é apenas uma cena idílica, de locus amœnus. Nele, Camões denuncia os desmandos, a corrupção e as injustiças disseminadas na Corte. Tal corrupção tem origem no desprezo pelo Amor - entendido como princípio unificador do universo, segundo as concepções neoplatônicas.

\footnotetext{
57 "Mas logo depois desses dias hibernais de angústia Uma fonte de alegria surgiu com o brilho mais vívido, Tais maneiras gentis associadas à sabedoria reinavam Nos temíveis vencedores, e sua raiva contida. Sob o seu domínio majestoso, sábio e brando, Orgulhosa das leis de seu vencedor, três vezes mais feliz, a Índia sorriu."
} 
E vê do mundo todo os principais,

Que nenhum no bem público imagina;

Vê neles que não têm amor a mais

Que a si somente, e a quem Filáucia ensina.

Vê que esses que frequentam os reais

Paços, por verdadeira e sã doutrina

Vendem adulação, que mal consente

Mondar-se o novo trigo florescente.

Vê que aqueles que devem à pobreza

Amor divino, e ao povo caridade,

Amam somente mandos e riqueza,

Simulando justiça e integridade;

Da feia tirania e da aspereza

Fazem direito e vã severidade;

Leis em favor do Rei se estabelecem,

As em favor do povo só perecem.

Vê, enfim, que ninguém ama o que deve,

Senão o que somente mal deseja.

Não quer que tanto tempo se releve

$\mathrm{O}$ castigo que duro e justo seja.

Seus ministros ajunta, por que leve

Exércitos conformes à peleja

Que espera ter co a mal regida gente

Que lhe não for agora obediente.

(IX, 27-29)

A utopia de Camões implica o estabelecimento, pelos portugueses, de uma nova ordem, aquela já profetizada por Júpiter no Canto II, estrofe 46: "E por eles, de tudo enfim senhores, / serão dadas na Terra leis milhores". A Ilha dos Amores - alegoria, como diz o próprio poema, das "deleitosas honras", "Aquelas preminências gloriosas, / Os triunfos, a fronte coroada / De palma e louro, a glória e maravilha" (IX, 89) - é o prêmio concedido por Vênus, a deusa do Amor, àqueles que realizaram "obras valerosas" e o "trabalho imenso que se chama / Caminho da virtude" (IX, 90). É o coroamento daqueles que cumpriram um ideal de virtude cavaleiresco, viril, de espírito cruzadístico, e que não cederam às tentações do ócio, do luxo, da riqueza ou das honrarias. Para outro renomado camonista, Jorge de Sena (1970, p. 67), “a Ilha é uma catarse total, não apenas de todos os recalcamentos, mas das misérias da própria História, e das misérias da vida no tempo de Camões e fora dele. É a reconciliação, a transcendência".

Seguindo essa interpretação de Aguiar e Silva e Jorge de Sena, acreditamos que, no Canto IX, estrofe 42, Camões anuncia a instauração de uma nova ordem universal, que irá reparar "os desconcertos do mundo": 


\begin{tabular}{|l|l|}
\hline \multicolumn{1}{|c|}{ ORIGINAL (CANTO IX, ESTROFE 42) } & \multicolumn{1}{c|}{ TRADUÇÃO (P. 381) } \\
\hline "Quero que haja no reino Neptunino, & Thus from my native waves a hero line \\
Onde eu nasci, progénie forte e bela; & Shall rise, and o'er the East illustrious shine; \\
E tome exemplo o mundo vil, malino, & Thus shall the rebel world thy prowess know, \\
Que contra tua potência se rebela, & And what the boundless joys our friendly powers bestow. ${ }^{58}$ \\
Por que entendam que muro Adamantino & \\
Nem triste hipocrisia val contra ela; & \\
Mal haverá na terra quem se guarde & \\
Se teu fogo imortal nas águas arde." & \\
\hline
\end{tabular}

O Poeta está se referindo a algo amplo, universal, que seria o reinado do amor sobre o mundo. O "mundo vil, malino, / Que contra tua potência se rebela" se refere a um combate universal, não restrito a Portugal ou ao Oriente. E em "Mal haverá na terra quem se guarde, / Se teu fogo imortal nas águas arde", "na terra" também se refere a uma universalidade.

A interpretação de Mickle desse episódio não transmite a mesma ideia de universalidade. Mickle atribui a Vênus (como diz na nota $s$ da página 381, citando Castera) a intenção de produzir uma geração de heróis na Índia a partir dos portugueses. Até aí, não há discordâncias. Mas a tradução de Mickle, "Thus from my native waves a hero line / Shall rise, and o'er the East illustrious shine", indica que esse reinado será o que foi estabelecido pelos portugueses na Índia, o que nos parece uma interpretação redutora demais. Mais uma vez, Mickle se mostra preocupado apenas com o Império Português do Oriente, aquele herdado pela Grã-Bretanha. A visão de uma nova ordem mundial governada pelo Amor não parece tão fascinante para Mickle quanto a de um império comercial...

\subsection{FATORES POÉTICOS: PRÉ-ROMANTISMO}

Lefevere (1992, p. 26) define poética como uma combinação de dois componentes: "um inventário de recursos literários, gêneros, motivos, personagens e situações prototípicas e símbolos" $" 59$ e o conceito de qual deve ser o papel da literatura em determinado sistema social. A poética dominante governa o sistema literário de uma determinada época. As instituições reforçam a poética dominante usando-a como padrão para avaliar todas as obras produzidas. Conforme esse padrão, algumas obras são promovidas a "clássicos" enquanto outras são rejeitadas. Entretanto, como a transformação do sistema literário envolve um jogo entre a

\footnotetext{
58 "Assim, de minhas ondas natais uma linhagem de heróis

Surgirá, e sobre o Oriente brilhará, ilustre;

Assim o mundo rebelde conhecerá tuas proezas,

E as alegrias ilimitadas que nossos poderes amigáveis concedem.”

59 “[...] an inventory of literary devices, genres, motifs, prototypical characters and situations, and symbols $[\ldots] "$.
} 
tendência à mudança e a força conservadora das instituições, obras e autores canonizados por uma poética podem perder esse status com a emergência de uma nova poética. Não obstante, obras literárias canonizadas há mais de cinco séculos tendem a manter essa posição independentemente das mudanças nas poéticas dominantes. Isso seria, segundo Lefevere (1992, p. 19), um indício da tendência conservadora do sistema, assim como uma evidência do poder da reescritura, já que, embora a obra permaneça canonizada, a sua interpretação muda, na medida em que "a obra é reescrita para se conformar à 'nova' poética dominante"60. Dessa forma, muitas vezes as obras literárias são retiradas de seu contexto histórico e reinseridas em um novo contexto. É o que acontece com Os lusíadas na tradução de Mickle: a obra é adaptada à poética dominante na Grã-Bretanha do século XVIII, adquirindo uma dicção entre neoclássica e pré-romântica, conformando-se à visão do épico aceita no sistema literário ao qual Mickle pertencia.

As passagens que selecionamos para exemplificar as alterações operadas no original pela tradução de Mickle por influência da poética abrangem quatro tópicos principais: a natureza (que adquire, no Lusiad, tonalidades românticas); o sublime (como experiência estética e psicológica); outros elementos românticos (como, por exemplo, a valorização do passado, do heroico e das novelas de cavalaria); e a adequação ao gênero épico (conforme a visão que predominava na época em que a tradução foi realizada).

\subsubsection{A Natureza}

A natureza clássica, ainda que nem sempre se apresente aos humanos em forma harmônica, é harmônica em sua essência, e a sua representação deveria ser equilibrada, objetiva, racional e realista. N'Os lusíadas encontramos vários exemplos de descrições clássicas da natureza - a descrição da Ilha dos Amores seria o típico exemplo de locus amønus -, muitas vezes como pano de fundo em consonância com o estado de alma dos protagonistas, outras vezes voltando-se contra eles, como no caso da tempestade marítima (VI, 70-84), que é descrita de forma bastante realista, com detalhes que revelam o conhecimento prático de Camões em assuntos marítimos.

Quanto ao uso da natureza por Mickle, já verificamos, no Capítulo 4, seção 4.3, ao tratarmos de sua obra poética, a presença de características que hoje chamaríamos de românticas - a natureza é expressiva, refletindo o estado de espírito e os sentimentos do poeta

\footnotetext{
60 “[...] the work is rewritten to bring it in line with the "new' dominant poetics."
} 
ou de personagens, às vezes evocando climas nostálgicos e meditativos, outras vezes enveredando por atmosferas sombrias e góticas.

Já na tradução da primeira estrofe do poema podemos notar uma característica que se repete ao longo de toda a tradução: a tendência de Mickle a adicionar à narrativa camoniana detalhes descritivos sobre a natureza. O acréscimo do trecho "lifts her spicy breast / And waves her woods above the watery waste" é um dos inúmeros exemplos do uso da natureza nessa tradução para emoldurar cenas ou personificar sensações e sentimentos:

\begin{tabular}{|l|l|}
\hline \multicolumn{1}{|c|}{ ORIGINAL (CANTO I, ESTROFE 1) } & \multicolumn{1}{c|}{ TRADUÇÃO (PP. 1-2) } \\
\hline AS armas e os Barões assinalados & ARMS and the Heroes, who from Lisbon's shore, \\
Que da Ocidental praia Lusitana & Thro' Seas where sail was never spread before, \\
Por mares nunca de antes navegados & Beyond where Ceylon lifts her spicy breast, \\
Passaram ainda além da Taprobana, & And waves her woods above the watery waste, \\
Em perigos e guerras esforçados & With prowess more than human forc'd their way \\
Mais do que prometia a força humana, & To the fair kingdoms of the rising day: \\
E entre gente remota edificaram & What wars they wag'd, what seas, what dangers past, \\
Novo Reino, que tanto sublimaram; & What glorious Empire crown'd their toils at last, ${ }^{1}$
\end{tabular}

O exemplo que se segue é do Canto I, estrofe 55, quando, na narrativa, os portugueses estão na ilha de Moçambique, onde foram acolhidos por muçulmanos que lhes prometeram mantimentos e um piloto que os levasse à Índia. Gostaríamos de chamar atenção apenas para o acréscimo de três versos na tradução (grafados em negrito abaixo):

\begin{tabular}{|c|c|}
\hline ORIGINAL (CANTO I, ESTROFE 55 ) & TRADUÇÃO (PP. 22-23) \\
\hline "E já que de tão longe navegais, & If then your sails for India's shore expand, \\
\hline Buscando o Indo Idaspe e terra ardente, & For sultry Ganges or Hydaspes' strand, \\
\hline Piloto aqui tereis, por quem sejais & Here shall you find a Pilot skill'd to guide \\
\hline Guiados pelas ondas sàbiamente. & Through all the dangers of the per'lous tide, \\
\hline Também será bem feito que tenhais & Though wide-spread shelves, and cruel rocks unseen, \\
\hline Da terra algum refresco, e que o Regente & Lurk in the way, and whirlpools rage between. \\
\hline Que esta terra governa, que vos veja & Accept, mean while, what fruits these islands hold, \\
\hline E do mais necessário vos proveja." & And to the Regent let your wish be told. \\
\hline & $\begin{array}{l}\text { Then may your mates the needful stores provide, } \\
\text { And all your various wants be here supplied. } 62\end{array}$ \\
\hline
\end{tabular}

\footnotetext{
61 “As Armas e os Heróis, que da praia de Lisboa, Por Mares onde as velas nunca haviam sido desfraldadas, Além de onde o Ceilão ergue seu peito de especiarias, E balança suas matas sobre a imensidão aquática, Com proezas sobre-humanas forçou seu caminho Rumo aos belos reinos do sol nascente:

As guerras que travaram, os mares, os perigos que passaram, O glorioso Império que coroou seus esforços enfim."

62 "Se então vossas navegações para a costa da Índia se estenderem, Para o tórrido Ganges ou as margens do Idaspe, Aqui encontrareis um Piloto hábil para vos guiar Por todos os perigos da maré naufragosa, Embora vastos bancos de areia e cruéis rochedos invisíveis,
} 
Aqui a natureza ("tide", "shelves", "rocks", "whirlpools") é utilizada para enfatizar os perigos enfrentados pelos portugueses: "dangers", "perilous", “cruel", "unseen", "lurk", "rage". Não estamos mais diante da natureza clássica, harmônica e ordenada, que pode ser alcançada e dominada por meio da razão ("Piloto aqui tereis, por quem sejais / Guiados pelas ondas sabiamente.”) A natureza de Mickle está ligada aos sentidos, sensações e sentimentos.

Outro exemplo, ainda no Canto I, estrofes 58-59 do original:

\begin{tabular}{|l|l|}
\hline \multicolumn{1}{|c|}{ ORIGINAL (CANTO I, ESTROFES 58-59) } & \multicolumn{1}{|c|}{ TRADUÇÃO (PP. 23-24) } \\
\hline Da Lũa os claros raios rutilavam & Calm Twilight now his drowsy mantle spreads, \\
Polas argênteas ondas Neptuninas; & And shade on shade, the gloom still deepening, sheds. \\
As Estrelas os Céus acompanhavam, & The Moon, full orb'd, forsakes her watery cave, \\
Qual campo revestido de boninas; & And lifts her lovely head above the wave. \\
Os furiosos ventos repousavam & The snowy splendours of her modest ray \\
Polas covas escuras peregrinas; & Stream o'er the glist'ning waves, and quivering play: \\
Porém da armada a gente vigiava, & Around her, glittering on the heav'ns arch'd brow, \\
Como por longo tempo costumava. & Unnumber'd stars, enclos'd in azure, glow, \\
& Thick as the dew-drops of the rosy dawn, \\
& Or May-flowers crowding o'er the daisy-lawn: \\
& The canvas whitens in the silvery beam, \\
& And with a paler red the pendants gleam: \\
& The masts' tall shadows tremble o'er the deep; \\
& The peaceful winds an holy silence keep; \\
& The watchman's carol, echo'd from the prows, \\
& Alone, at times, awakes the still repose.63 \\
\hline
\end{tabular}

Espreitem e redemoinhos se agitem no caminho.

Aceitai, enquanto isso, todos os frutos que essas ilhas contêm,

E ao Regente contai vossos desejos.

Então os vossos marinheiros poderão preparar os estoques necessários,

E todos os vossos vários desejos serão aqui supridos."

63 "O calmo crepúsculo agora estende o seu manto sonolento,

E sombra sobre sombra, a penumbra ainda se aprofundando, irradia.

A lua cheia abandona sua caverna aquosa,

E ergue a adorável cabeça sobre as ondas.

Os esplendores níveos de seus modestos raios

Correm sobre as ondas reluzentes, e vibrantes brincam:

Ao redor dela, cintilando na fronte arqueada do céu,

Inúmeras estrelas, encerradas no azul-celeste, brilham,

Densas como as gotas de orvalho da aurora rósea,

Ou pilriteiros acumulando-se no campo de margaridas:

As velas alvejam sob os raios prateados,

E com um vermelho mais pálido as bandeiras resplandecem:

As altas sombras dos mastros tremem sobre as profundezas;

Os ventos pacíficos guardam um silêncio sagrado;

O canto do vigia, ecoando na proa,

Sozinho, de vez em quando, rompe o repouso imóvel.” 
Mas, assi como a Aurora marchetada

Os fermosos cabelos espalhou

No Céu sereno, abrindo a roxa entrada

Ao claro Hiperiónio, que acordou,

Começa a embandeirar-se toda a armada

E de toldos alegres se adornou,

Por receber com festas e alegria

O Regedor das Ilhas, que partia.
Aurora now, with dewy lustre bright,

Appears, ascending on the rear of night.

With gentle hand, as seeming oft to pause,

The purple curtains of the morn she draws;

The sun comes forth, and soon the joyful crew,

Each aiding each, their joyful tasks pursue.

Wide o'er the decks the spreading sails they throw;

From each tall mast the waving streamers flow;

All seems a festive holiday on board

To welcome to the fleet the island's lord. 64

No início desse trecho, Mickle acrescenta uma nota observando que Camões, nessa passagem, imitou Homero ao estilo de Virgílio. Comenta ainda que a passagem se refere ao Canto VIII da Ilíada e cita a tradução correspondente de Pope, que qualifica de "elegante"

As when the moon, refulgent lamp of night,

O'er heaven's clear azure spreads her sacred light,

When not a breath disturbs the deep serene,

And not a cloud o'ercasts the solemn scene;

Around her throne the vivid planets roll,

And stars unnumber'd gild the glowing pole,

O'er the dark trees a yellower verdure shed,

And tip with silver every mountain's head;

Then shine the vales, the rocks in prospect rise,

A flood of glory bursts from all the skies:

The conscious swains, rejoicing in the sight,

Eye the blue vault, and bless the useful light. ${ }^{66}$

64 "Já a Aurora, com um brilho orvalhado esplendoroso,

Surge, ascendendo no final da noite.

Com mão gentil, muitas vezes parecendo pausar,

As cortinas púrpuras da manhã ela puxa;

O sol avança, e logo a alegre tripulação,

Um ajudando o outro, as prazerosas tarefas desempenham.

Bem amplas sobre os conveses as velas eles desfraldam;

De cada alto mastro as bandeiras tremulam;

Tudo parece um feriado festivo a bordo

Para receber na esquadra o governante da ilha."

65 "elegantly translated by Pope".

${ }^{66}$ Para que o leitor possa comparar com uma tradução mais literal do que a de Pope, acrescentamos aqui a tradução de Odorico Mendes (1956, pp. 161-162) do mesmo trecho:

Ante os fogos pernoitam, quando no éter

Sereno, em cerco da fulgente Lua,

As formosas estrelas aparecem,

Grutas, serros e brenhas aclarando:

Abre-se imensa a região sidérea,

E o pastor em si folga: de Ílio em face

Iam-se tantos lumes acendendo

Entre o Xanto e os baixéis. De mil fogueiras

Homens cinqüenta a cada uma assistem. 
Mickle elimina algumas referências à mitologia clássica presentes no original (as "argênteas ondas Neptuninas"; o "claro Hiperiónio") e estende bastante a tradução dessa passagem, amplificando a descrição dos elementos da natureza. Ressalte-se o vocabulário poético entre neoclássico e romântico empregado por Mickle; alguns termos, como "azure" e “unnumber'd stars", ecoam Pope, mas é notável também a presença de um conjunto de referências que evocam um clima contemplativo, meditativo, procurando transmitir sensações, principalmente visuais, contrastando o claro e o escuro: "twilight", "drowsy mantle", "shade", "gloom", "silvery beam", "shadows", "mild pale red", "holy silence", "dewy lustre bright", "purple curtains".

Na tradução do Canto III, estrofe 16, Mickle acrescenta descrições de elementos da natureza, estendendo e romantizando a narrativa sucinta de Camões. Mickle adiciona uma menção às oliveiras e vinhedos, assim como adjetivos e frases descritivas para cada um dos rios:

\begin{tabular}{|l|l|}
\hline \multicolumn{1}{|c|}{ ORIGINAL (CANTO III, ESTROFE 16) } & \multicolumn{1}{c|}{ TRADUÇÃO (P. 91) } \\
\hline "Gália ali se verá, que nomeada & Onward fair Gallia opens to the view \\
Cos Cesáreos triunfos foi no mundo; & Her groves of olive, and her vineyards blue: \\
Que do Séquana e Ródano é regada & Wide spread her harvests o'er the scenes renown'd, \\
E do Garuna frio e Reno fundo. & Where Julius proudly strode with laurel crown'd. \\
Logo os montes da Ninfa sepultada, & Here Seyn, how fair when glistening to the moon! \\
Pirene, se alevantam, que, segundo & Rolls his white wave, and here the cold Garoon; \\
Antiguidades contam, quando arderam, & Here the deep Rhine the flowery margin laves, \\
Rios de ouro e de prata antão correram." & And here the rapid Rhone impervious raves. \\
& Here the gruff mountains, faithless to the vows \\
& Of lost Pyrene rear their cloudy brows; \\
& Whence, when of old the flames their woods devour'd, \\
& Streams of red gold and melted silver pour'd. ${ }^{67}$ \\
\hline
\end{tabular}

No Canto VII, estrofe 42, Mickle acrescenta vários versos (em negrito no quadro a seguir) sem nenhuma correspondência no original. Talvez o tradutor tenha sentido falta de indicações circunstanciais (em que momento do dia e em que local se encontrava a frota). A descrição de Mickle emprega palavras, expressões e fraseados de estilo romântico, evocando,

\footnotetext{
67 "Mais adiante a bela Gália descortina à vista

Seus olivais, e os vinhedos azuis:

Espalha amplamente suas colheitas sobre as famosas paisagens,

Onde Júlio orgulhosamente marchou coroado de louros.

Aqui o Sena - quão belo quando cintila para a lua! -

Rola as suas ondas brancas, e aqui o frio Garona;

Aqui o profundo Reno banha a margem florida,

E aqui o rápido Ródano brame, impenetrável.

Aqui as rudes montanhas, infiéis aos votos

Da perdida Pirene elevam seus picos enevoados;

De onde, quando outrora as chamas lhe devoraram as florestas,

Rios de ouro vermelho e prata derretida jorravam."
} 
por meio da natureza, sensações e sentimentos: "vapour"; "float"; "smoke"; "rolling darkness"; "hazy clouds"; "black wings"; "The tear-dropt bough hangs weeping in the vale"; "distant navies"; "mist".

\begin{tabular}{|l|l|}
\hline \multicolumn{1}{|c|}{ ORIGINAL (CANTO VII, ESTROFE 42 ) } & \multicolumn{1}{c|}{ TRADUÇÃO (PP. 296-300) } \\
\hline Assi contava o Mouro; mas vagando & While thus the Moor his faithful tale reveal'd, \\
Andava a fama já pela cidade & Wide o'er the coast the voice of Rumour swell'd; \\
Da vinda desta gente estranha, quando & As first some upland vapour seems to float \\
O Rei saber mandava da verdade. & Small as the smoke of lonely shepherd cot, \\
Já vinham pelas ruas caminhando, & Soon o'er the dales the rolling darkness spreads, \\
Rodeados de todo sexo e idade, & And wraps in hazy clouds the mountain heads, \\
Os principais que o Rei buscar mandara & The leafless forest and the utmost lea; \\
O Capitão da armada que chegara. & And wide its black wings hover o'er the sea: \\
& The tear-dropt bough hangs weeping in the vale, \\
& And distant navies rear the mist-wet sail. \\
& So Fame increasing, loud and louder grew, \\
& And to the sylvan camp resounding flew; \\
& A lordly band, she cries, of warlike mien, \\
& Of face and garb in India never seen, \\
& Of tongue unknown, through gulphs undared before, \\
& Unknown their aim, have reach'd the Indian shore.68 \\
\hline
\end{tabular}

Ao traduzir a estrofe 52 do Canto IX, quando se inicia o episódio da Ilha dos Amores, Mickle insere vários elementos descritivos ressaltando cores e brilhos ("green bosom of the dewy lawn"; "Soft blazing"; "silver of the dawn"; "glowing lustre") e um verso que alude aos perfumes da Arábia (“Arabia’s balm was sprinkled o’er the air”) - um elemento exótico, para os padrões europeus - a fim de ampliar os efeitos sinestésicos do poema:

\footnotetext{
68 "Enquanto assim o Mouro sua fiel história revelava,

Ampla sobre a costa a voz do Rumor cresceu;

No início um vapor parece flutuar sobre a terra

Pequeno como a fumaça da cabana de um pastor solitário, Logo sobre os vales a escuridão rolante se espalha,

E envolve em nuvens brumosas o topo da montanha,

A floresta sem folhas e a várzea mais longínqua;

E as amplas asas negras pairam sobre o mar:

$O$ galho pendente lacrimeja sobre o vale,

E esquadras distantes erguem a vela molhada pela névoa.

Assim a crescente Fama ficou mais e mais ruidosa,

E para o acampamento florestal voou, ressoando;

Um grupo altivo, ela grita, de aparência guerreira,

De rosto e trajes na Índia nunca vistos,

De língua desconhecida, por golfos nunca antes enfrentados

Com objetivo desconhecido, chegou à costa indiana."
} 


\begin{tabular}{|l|l|}
\hline \multicolumn{1}{|c|}{ ORIGINAL (CANTO IX, ESTROFE 52 ) } & \multicolumn{1}{c|}{ TRADUÇÃO (PP. 385) } \\
\hline De longe a Ilha viram, fresca e bela, & O'er the green bosom of the dewy lawn \\
Que Vénus pelas ondas lha levava & Soft blazing flow'd the silver of the dawn, \\
(Bem como o vento leva branca vela) & The gentle waves the glowing lustre share, \\
Pera onde a forte armada se enxergava; & Arabia's balm was sprinkled o'er the air. \\
Que, por que não passassem, sem que nela & Before the fleet, to catch the heroes' view, \\
Tomassem porto, como desejava, & The floating isle fair Acidalia drew: \\
Pera onde as naus navegam a movia & Soon as the floating verdure caught their sight, \\
A Acidália, que tudo, enfim, podia. & She fixt, unmov'd, the island of delight. ${ }^{69}$ \\
\hline
\end{tabular}

O Conde de Ficalho (1880, p. 43, itálicos do autor) observa que, entre as 24 plantas que compõem a flora da Ilha dos Amores (Os lusíadas, IX, 52-62), "não há uma que não seja espontânea em Portugal e regiões vizinhas, ou aí introduzida e cultivada já antes do seu tempo". Por outro lado, Ficalho (p. 44) acrescenta: "A flora da ilha é ainda mais clássica que lusitanica. Procede mais da leitura dos poetas que da observação da natureza". Exemplos disso na descrição da Ilha dos Amores são os álemos de Alcides, o loureiro de Apolo, os mirtos de Vênus e os pinheiros de Cibele.

Na tradução desse episódio, Mickle preserva as referências clássicas de Camões, mas, como bem observa Monica Letzring (1965, pp. 40-41), acrescenta carvalhos e cedros às árvores que crescem na Ilha dos Amores, e evoca as regiões campestres britânicas incluindo também duas variedades de prímulas ["primrose" e "cowslip"], assim como morangos ["scarlet strawberries"] e "cordeiros brancos como leite" ["milk-white lambs"]. ${ }^{70} \mathrm{O}$ carvalho e o cedros são acrescentados na tradução das estrofes 57 e 58, em que Mickle adiciona diversos elementos sinestésicos ao original:

\footnotetext{
69 "'Sobre o seio verde do campo orvalhado Resplandecendo suave afluiu a prata da aurora, As ondas gentis compartilham o brilho incandescente,

O bálsamo da Arábia estava pulverizado no ar.

Adiante da esquadra, a fim de atrair a atenção dos heróis,

A ilha flutuante a bela Acidália arrastou:

Assim que avistaram o verde flutuante,

Ela fixou, imóvel, a ilha do prazer."

${ }^{70}$ Além disso, segundo Letzing (1965, p. 41), a cena descrita por Mickle (1776, p. 397) das ninfas nas águas se baseia no episódio da "Morada da Felicidade" ["Bower of Bliss"] da Faerie Queene de Spenser.
} 


\begin{tabular}{|l|l|}
\hline \multicolumn{1}{|c|}{ ORIGINAL (CANTO IX, ESTROFE 57) } & \multicolumn{1}{c|}{ TRADUÇÃO (PP. 388-389) } \\
\hline $\begin{array}{l}\text { As árvores agrestes, que os outeiros } \\
\text { Têm com frondente coma enobrecidos, }\end{array}$ & Wild forest-trees the mountain sides array'd \\
Álemos são de Alcides, e os loureiros & With curling foliage and romantic shade: \\
Do louro Deus amados e queridos; & Here spreads the poplar, to Alcides dear; \\
Mirtos de Citereia, cos pinheiros & And dear to Phœbus, ever verdant here, \\
$\begin{array}{l}\text { De Cibele, por outro amor vencidos; } \\
\text { Está apontando o agudo cipariso } \\
\text { Pera onde é posto o etéreo Paraíso. }\end{array}$ & The laurel joins the bowers for ever green, \\
& The myrtle bowers belov'd of beauty's queen. \\
& To Jove the oak his wide-spread branches rears; \\
& And high to heaven the fragrant cedar bears; \\
& Where through the glades appear the cavern'd rocks, \\
& The lofty pine-tree waves her sable locks; \\
& Sacred to Cybelle the whispering pine \\
& Loves the wild grottoes where the white cliffs shine; \\
& Here towers the cypress, preacher to the wise, \\
& Less'ning from earth her spiral honours rise, \\
& Till, as a spear-point rear'd, at the topmost spray; \\
& Points to the Eden of eternal day. ${ }^{11}$ \\
\hline
\end{tabular}

Além de agregar uma adjetivação que acentua impressões sensoriais e emocionais associadas à natureza (wild forest trees; romantic shade; verdant; fragrant cedar; whispering pine; wild grottoes), o tradutor efetua uma amplificação, acrescentando vários versos.

Os outros elementos da paisagem britânica que mencionamos acima (as prímulas, os morangos e o cordeiro) são acrescentados em uma passagem sem correspondência no original, após a tradução da estrofe 62 do Canto IX:

Where by the stream the lilly of the vale,

Primrose, and cowslip meek, perfume the gale,

Beneath the lilly and the cowslip's bell

The scarlet strawberries luxurious swell.

$[\ldots]$

The milk-white lambs come bleating down the hill. ${ }^{72}$

(CAMÕES, 1776, p. 393).

\footnotetext{
71 “Árvores da floresta agreste se enfileiravam nas encostas da montanha

Com folhas enroladas e uma sombra romanesca:

Aqui se espalha o álamo, caro a Alcides;

E caro a Febo, sempre verdejante aqui,

O loureiro se junta aos caramanchões sempre verdes,

Os caramanchões de mirto amados pela rainha da beleza.

Para Júpiter o carvalho ergue seus ramos bem abertos;

E alto ao céu o cedro perfumado se dirige;

Onde nas clareiras aparecem rochedos cavernosos,

O imponente pinheiro agita seus cachos negros;

Sagrado para Cibele o pinheiro sussurrante

Ama as grutas selvagens onde os penhascos brancos brilham;

Aqui se eleva o cipreste, pregando aos sábios,

Diminuindo a partir da terra, seus ornamentos espirais ergue,

Até que, como a ponta de uma lança hasteada, no ramo mais alto;

Aponta para o Éden do dia eterno."

72 "Onde junto ao regato o lírio-do-vale,

$\mathrm{E}$ as tímidas prímulas perfumam a brisa,

Sob o lírio e a campânula da prímula
} 
A interpolação de descrições da natureza prossegue na tradução do Canto X, onde, entre a primeira e a segunda estrofe, Mickle introduz vários versos sobre o nascer da lua:

Fair o'er the wave that gleam'd like distant snow, Graceful arose the moon, serenely slow;

Not yet full orb'd, in clouded splendor drest, Her married arms embrace her pregnant breast. Sweet to his mate, recumbent o'er his young, The nightingale his spousal anthem sung; From every bower the holy chorus rose, From every bower the rival anthem flows. Translucent twinkling through the upland grove In all her lustre shines the star of love $[\ldots]^{73}$ (CAMÕES, 1776a, p. 416).

O tom romântico desses versos é evidente. A lua, bela e serena; o casal de rouxinóis; o canto dos pássaros; o brilho translúcido da "estrela do amor".

Mais adiante, na tradução da primeira metade da estrofe 106 do Canto X, a natureza aparece em um contexto já não idílico, mas que, ao reproduzir a violência das águas, expressa, em estilo romântico, sentimentos de medo e assombro (ligados, como veremos na próxima subseção, ao sublime):

\begin{tabular}{|l|l|}
\hline \multicolumn{1}{|c|}{ ORIGINAL (CANTO X, ESTROFE 106) } & \multicolumn{1}{c|}{ TRADUÇ̃̃O (P. 455) } \\
\hline OIha a terra de Ulcinde, fertilíssima, & Luxurious here Ulcinda's harvests smile, \\
E de Jáquete a íntima enseada; & And here, disdainful of the seaman's toil, \\
Do mar a enchente súbita, grandíssima, & The whirling tides of Jaquet furious roar; \\
E a vazante, que foge apressurada. & Alike their rage when swelling to the shore, \\
& Or tumbling backward to the deep, they force \\
& The boiling fury of their gulphy course: \\
& Against their headlong rage nor oars nor sails, \\
& The stemming prow alone, hard toiled, prevails. ${ }^{74}$ \\
\hline
\end{tabular}

\footnotetext{
Os morangos escarlates crescem exuberantes.

[...]

Os cordeiros brancos como leite descem a colina balindo."

73 "Bela sobre as ondas que cintilavam como neve distante,

Graciosa ergueu-se a lua, serenamente lenta;

Não cheia ainda, vestida em esplendor enevoado,

Seus braços unidos enlaçam o seio fértil.

Carinhoso com a parceira, reclinado sobre os filhotes,

O rouxinol cantou seu hino conjugal;

De todos os caramanchões o coro sagrado se ergueu,

De todos os caramanchões o hino rival emana.

Cintilando translúcida através do bosque no planalto

Em todo o seu esplendor brilha a estrela do amor".

74 "Exuberantes aqui as colheitas de Ulcinda* sorriem,

E aqui, desdenhosas da labuta do marinheiro,

As marés torvelinhantes de Jáquete rugem furiosas;

Com a mesma fúria quando crescem sobre a praia,

Ou rolam de volta às profundezas, elas forçam
} 
No original a descrição da natureza é bastante sucinta e objetiva; há apenas uma breve menção à "enchente súbita"; Mickle amplifica, descrevendo a fúria da natureza: "whirling tides"; "furious roar"; "tumbling backward to the deep"; "boiling fury"; "headlong rage".

A tendência de Mickle de procurar harmonizar a natureza com os sentimentos é uma das razões pelas quais Taylor $(1937$, p. 104; 169) considera Mickle um escritor mais romântico do que neoclássico - embora Mickle conserve certas características neoclássicas, como a adoção do dístico heroico para a tradução de um poema épico.

\subsubsection{O Sublime}

\subsubsection{O conceito de "sublime"}

O termo "sublime", na retórica, relacionava-se a um dos gêneros - o "elevado", contrastando com o "humilde" e o "médio". No entanto, com o tratado Peri Hypsos [Do Sublime], de Pseudo Longino (século I d.C.), o termo adquire um novo sentido, indicando uma faculdade de expressar sentimentos ou atitudes elevadas ou nobres. Sob a influência das ideias platônicas, Pseudo Longino considera essa faculdade inata, de inspiração divina. $\mathrm{Na}$ literatura, o sublime indicaria o uso de elementos do maravilhoso ou extraordinário para transportar o leitor ao êxtase. Apelando às emoções e à imaginação e aproximando o sublime a uma força da natureza, esse tratado diferia muito das ideias aristotélicas e ciceronianas, e permaneceu esquecido ao longo de vários séculos (ORAVEC, 2000, pp. 784-785). No século XVII, o conceito foi revivido com a tradução do tratado de Pseudo Longino pelo célebre crítico e poeta francês Nicolas Boileau-Despréaux. Embora estudiosos como Curtius (1996, p. 486) avaliem que Boileau interpretou o conceito de forma equivocada e muito restrita, o sublime, paradoxalmente, veio a exercer um papel importante na teoria neoclássica, introduzindo uma tensão em um sistema governado pela razão e pela clareza.

Na Grã-Bretanha, no século XVIII, quando as bases do empirismo já estavam assentadas, o conceito de sublime será reconstruído, tornando-se tema de estudo psicológico. Em 1757, Edmund Burke escreveu o mais importante tratado da época sobre o conceito, Investigação filosófica sobre a origem de nossas ideias do sublime e do belo, que sintetiza as

\footnotetext{
A fúria agitada de seu curso voraginoso: Contra a sua raiva impetuosa nem remos nem velas, Apenas a resistência da proa, com muito trabalho, supera."

* Segundo Pimpão (p. 517), a "terra de Ulcinde" seria o "reino de Cinde", e "Cinde" seria apenas o nome do Indo (Sindh). Não há sentido, portanto, em transcrever o nome como "Ulcinda”, como faz Mickle.
} 
opiniões de vários outros estudiosos britânicos sobre o assunto. Apoiando-se nos estudos psicológicos e filosóficos de Locke e Hume, Burke relaciona o sublime às ideias de dor e perigo:

Tudo que seja de algum modo capaz de incitar as idéias de dor e de perigo, isto é, tudo que seja de alguma maneira terrível ou relacionado a objetos terríveis ou atua de um modo análogo ao terror constitui uma fonte do sublime, isto é, produz a mais forte emoção de que o espírito é capaz. (BURKE, 1993, p. 48).

Entretanto, quando as ideias de dor ou perigo são atenuadas ou não podem se concretizar, elas nos causam deleite. Burke (p. 54) acrescenta:

[...] não há espetáculo que busquemos com tanta avidez quanto o de alguma desgraça incomum e atroz; portanto, quer a desdita ocorra diante de nossos olhos, quer ela se passe na história, sempre nos provoca deleite. Ele não é puro, mas mesclado com um razoável mal-estar. O deleite que auferimos dessas cenas de grande sofrimento impede-nos de evitá-las, e a dor sentida induz-nos a consolar-nos a nós próprios ao fazê-lo àqueles que sofrem; esses impulsos ocorrem anteriormente a qualquer raciocínio, por um instinto que age sobre nós, segundo seus próprios desígnios, sem o concurso de nossa vontade.

É a esse deleite que Burke chama "sublime", uma experiência que se distingue do prazer pelo fato de nascer da dor. Nessa definição, o sublime é uma experiência estética que não se limita ao campo da literatura. A paixão gerada pelo sublime é o assombro, um "estado de alma no qual todos os seus movimentos são sustados por um certo grau de horror" (BURKE, 1993, p. 65).

O sublime também se distingue do belo - a beleza seria "aquela qualidade, ou aquelas qualidades dos corpos em virtude das quais eles despertam amor ou alguma paixão semelhante" (p. 99). Em relação às sensações, a diferença entre o belo e o sublime é que o belo gera um prazer simples, enquanto o sublime gera o deleite (um prazer composto, gerado pela dor e pelo terror).

Burke (1993, p. 77) estuda com especial atenção as fontes do sublime, os fatores que podem sugerir a ideia de perigo e causar terror. A grandiosidade de dimensões é uma das fontes mais poderosas do sublime. A extensão pode ser em comprimento, altura ou profundidade. A altura é um dos elementos que causam impressão mais forte - por exemplo, uma torre ou montanha muito altas. Outra fonte do sublime é a dificuldade. Burke cita como exemplo a arquitetura de Stonehenge, que causaria impressão pela força prodigiosa necessária 
para a sua construção (p. 84). A magnificência também suscita a ideia de grandiosidade. Um céu estrelado impressiona pela quantidade infinita. Uma luz de grande intensidade, como a do sol incidindo diretamente nos olhos, ou um relâmpago, pela grande velocidade, ou qualquer transição brusca da luz para as trevas ou destas para a luz causam forte efeito (p. 86). A escuridão e qualquer tipo de obscuridade (ligada ao desconhecimento das coisas) é, igualmente, fonte de terror e do sublime: “[...] imagens obscuras, confusas, indistintas têm um poder maior sobre a fantasia para incitar as paixões supremas do que aquelas que são mais claras e definidas" (p. 70). Ruídos muito altos, como o de "grandes cataratas, tempestades ululantes, trovão ou artilharia" exercem no espírito um efeito "grandioso e aterrador" (p. 88). Um ruído súbito tem poder idêntico: "Tudo que é súbito e inesperado sobressalta-nos, isto é, percebemos o perigo e nossa natureza estimula-nos a nos pôr em guarda contra ele" (p. 89). Os sons repetidos são especialmente aterrorizantes, pois "a reiteração provoca a expectativa de um novo golpe. E note-se que a própria expectativa gera uma tensão” (p. 146).

Pode-se observar que um único som de uma certa intensidade, embora de curta duração, se repetido intermitentemente, produz um grande efeito. Poucas coisas são mais aterradoras do que o bater de um relógio grande, quando o silêncio da noite impede que a atenção se disperse. $\mathrm{O}$ mesmo ocorre no caso de uma única batida de um tambor, repetida a intervalos, e dos disparos sucessivos de um canhão ouvidos à distância: todos os efeitos mencionados nesta seção derivam de causas muito semelhantes. (BURKE, 1993, p. 89).

A intermitência, como a de uma luz que ora surge, ora desaparece, pode ser mais terrível do que a escuridão total, e "certo tipo de sons indecifráveis, quando as disposições de espírito favoráveis contribuem para isso, é mais assustador do que um silêncio completo". (BURKE, 1993, p. 90). Outros fatores enumerados por Burke como geradores do sublime são a ideia de dor, física ou espiritual, e a ideia de privação (vazio, trevas, solidão, silêncio etc.).

Quanto às palavras, embora não nos afetem da mesma forma que os objetos naturais ou a pintura e a arquitetura, "são tão capazes de incitar as idéias de beleza e do sublime quanto aqueles objetos", tendo às vezes "um poder muito maior do que qualquer um deles" (BURKE, 1993, p. 169).

O tratado de Burke revela distanciamento em relação às ideias clássicas e racionalistas do início do século XVIII ao alegar que o sublime não é apenas um efeito artificial, mas sim fisiológico (e, portanto, um processo natural e psicológico), e ao apontar a influência da 
emoção e da imaginação ${ }^{75}$ sobre a criação literária e artística. Essas questões e outras levantadas no tratado de Burke viriam a ser exploradas em maior profundidade ao longo do Romantismo.

\subsubsection{O sublime no Lusiad}

Obviamente, em um poema épico como Os lusíadas o sublime é um elemento muito importante, e Camões valeu-se dele com maestria. Mas a forma clássica de expressar o sublime já não parecia adequada aos pré-românticos. A tradução de Mickle expressa essas novas ideias sobre o sublime - é o que procuraremos demonstrar por meio de exemplos.

$\mathrm{Na}$ tradução da estrofe 22 do Canto I, Mickle amplifica a descrição de Júpiter, procurando infundir a esse personagem a capacidade de inspirar terror e admiração:

\begin{tabular}{|l|l|}
\hline \multicolumn{1}{|c|}{ ORIGINAL (CANTO I, ESTROFE 22) } & \multicolumn{1}{c|}{ TRADUÇ̃̃O (PP. 11-12) } \\
\hline Estava o Padre ali, sublime e dino, & Sublime and dreadful on his regal throne, \\
Que vibra os feros raios de Vulcano, & That glow'd with stars, and bright as lightning shone, \\
Num assento de estrelas cristalino, & Th' immortal Sire, who darts the thunder, fate, \\
Com gesto alto, severo e soberano; & The crown and sceptre added solemn state; \\
Do rosto respirava um ar divino, & The crown, of heaven's own pearls, whose ardent rays, \\
Que divino tornara um corpo humano; & Flam'd round his brows, outshone the diamond's blaze: \\
Com ũa coroa e ceptro rutilante, & His breath such gales of vital fragrance shed, \\
De outra pedra mais clara que diamante. & As might, with sudden life, inspire the dead: \\
& Supreme Controul throned in his awful eyes \\
& Appear'd, and mark'd the Monarch of the skies.76 \\
\hline
\end{tabular}

Os elementos visuais presentes no original já evocam o sublime, pelo seu brilho e magnificência. Esses elementos são ainda mais ressaltados por Mickle: os versos "Com uma coroa e ceptro rutilante / De outra pedra mais clara que diamante" são traduzidos como "The

75 É preciso ressaltar, no entanto, que para Burke a imaginação é incapaz de criar algo totalmente novo. Revelando, mais uma vez, a influência de Locke, Burke (1993, p. 26) define assim essa faculdade: "[...] o espírito humano possui uma espécie de faculdade criativa própria, quer reproduzindo a seu talante as imagens das coisas na ordem e da maneira em que foram recebidas pelos sentidos, quer combinando-as de um modo novo e segundo uma ordem diferente. Essa faculdade chama-se imaginação e a ela se relaciona tudo que denominamos engenho, fantasia, invenção e outros termos semelhantes. Mas deve-se observar que essa capacidade da imaginação é incapaz de produzir algo inteiramente novo: ela pode apenas variar a disposição das idéias que recebeu dos sentidos".

76 "Sublime e temível em seu trono régio,

Que reluzia com estrelas e, brilhante como o relâmpago, fulgurava,

O Senhor imortal, que lança o trovão, fado,

A coroa e o cetro acrescentavam solenidade;

A coroa, de pérolas celestiais, cujos raios ardentes

Incendiavam-se ao redor de sua fronte, brilhava mais do que o diamante:

O hálito exalava tais ventos de fragrância vital,

Que poderiam infundir súbita vida aos mortos:

O Supremo Controle reinante em seus olhos formidáveis

Apareceu e assinalou o Monarca dos céus." 
crown and sceptre added solemn state; / The crown, of heaven's own pearls, whose ardent rays, / Flam'd round his brows, outshone the diamond's blaze:"; o verso "Do rosto respirava um ar divino" é traduzido como "His breath such gales of vital fragrance shed". O que é mais notável aqui é que Mickle insere elementos na descrição de Júpiter para enfatizar a ideia de poder sublime, capaz de inspirar terror: traduz "dino" por "dreadful”; sugere que Júpiter possa ressuscitar os mortos ("His breath such gales of vital fragrance shed / As might, with sudden life, inspire the dead"); acrescenta as expressões "Supreme Controul" e "awful eyes".

Ainda no Canto I, entre as estrofes 91 e 92 do original, Mickle insere 29 versos descrevendo em detalhes o bombardeio dos portugueses em resposta às provocações dos mouros de Moçambique:

Nor sleeps the vengeance of the Victor here;

To teach the nations what tremendous fate From his right arm on perjur'd vows should wait, He seized the time to awe the eastern world, And on the breach of faith his thunders hurl'd. From his black ships the sudden lightnings blaze, And o'er old Ocean flash their dreadful rays: White clouds on clouds inroll'd the smoke ascends, The bursting tumult heaven's wide concave rends: The bays and caverns of the winding shore Repeat the cannon's and the mortar's roar: The bombs, far-flaming, hiss along the sky, And, whirring through the air, the bullets fly; The wounded air, with hollow deafen'd sound, Groans to the direful strife, and trembles round. ${ }^{77}$

Now from the Moorish town the sheets of fire, Wide blaze succeeding blaze, to heaven aspire. Black rise the clouds of smoke, and by the gales Borne down, in streams hang hovering o'er the vales; And slowly floating round the mountain's head Their pitchy mantle o'er the landscape spread.

\footnotetext{
77 “Tampouco dorme a vingança do Vencedor aqui;

Para ensinar aos povos que tremenda destruição

De seu braço direito sobre os votos perjuros deveriam esperar

Ele aproveitou o tempo para intimidar o mundo oriental,

E sobre a quebra de confiança seus trovões arremessou.

De seus navios negros os súbitos relâmpagos se inflamam,

E sobre o velho Oceano lançam seus terríveis raios:

Em rolos de nuvens e mais nuvens brancas a fumaça ascende,

O tumulto que irrompe rasga a ampla concavidade do céu:

As baías e cavernas da praia tortuosa

Ecoam o estrondo do canhão e do morteiro:

As bombas, flamejando ao longe, sibilam pelo céu,

$\mathrm{E}$, zunindo pelo ar, as balas voam;

$\mathrm{O}$ ar ferido, com um som oco ensurdecido,

Geme para o medonho conflito, e estremece."
} 
Unnumber'd sea-fowl rising from the shore,

Beat round in whirls at every cannon's roar;

Where o'er the smoke the masts' tall heads appear,

Hovering they scream, then dart with sudden fear;

On trembling wings far round and round they fly,

And fill with dismal clang their native sky.

Thus fled in rout confus'd the treacherous Moors

From field to field $[\ldots]^{78}$

(CAMÕES, 1776a, pp. 34-35).

O acréscimo desses versos permite a Mickle detalhar as cenas de batalha: a fumaça subindo aos céus; o estrondo dos canhões; o despontar dos fogos da artilharia; o desespero das aves marinhas. Há vários elementos arrolados por Burke entre aqueles capazes de gerar o sublime: ruídos muito altos ("thunders"; "the cannon's and the mortar's roar"; "The bombs [...] hiss along the sky"; "hollow deafen'd sound"; "groans"; "scream"; "dismal clang"); luz súbita e de grande intensidade ("the sudden lightnings blaze"; "flash their dreadful rays"; "farflaming"; "sheets of fire"; "blaze succeeding blaze"); a reiteração ("White clouds on clouds inroll'd the smoke ascends"; "The bays and caverns of the winding shore / Repeat the cannon's and the mortar's roar"; "blaze succeeding blaze"; "Beat round in whirls at every cannon's roar"); a grandiosidade de dimensões ou quantidade ("White clouds on clouds"; "Black rise the clouds of smoke"; "Unnumber'd sea-fowl rising from the shore"; "the masts' tall heads"); a escuridão ("black ships"; "caverns"; "Black rise the clouds of smoke"; "pitchy mantle"). Ecoando o próprio objetivo dos portugueses ao efetuar esse bombardeio, expresso aqui como "to awe the Eastern world", os versos acrescentados na tradução procuram causar assombro no leitor.

Ao traduzir o início da estrofe 60 do Canto II, Mickle se vale de diversos elementos góticos ("solemn hour", "when midnight reigns", "dimly twinkling”, "ethereal plains", "starry

\footnotetext{
78 "Agora da cidade moura as cortinas de fogo, Imensas labaredas atrás de labaredas, ao céu se lançam. Negras se erguem as nuvens de fumaça, e pelas ventanias Trazidas para baixo, pairam em torrentes sobre os vales; E flutuando devagar ao redor do cume da montanha Seu manto tenebroso sobre a paisagem espalham. Inúmeras aves marinhas erguendo-se da praia, Agitam-se em redemoinhos a cada estrondo de canhão; Onde sobre a fumaça as altas cabeças dos mastros aparecem, Pairando elas [as aves] gritam, depois se lançam em súbito medo; Com asas trêmulas, voam em círculos cada vez maiores, E enchem, com um clangor lúgubre, seu céu nativo. Assim fugiram em atropelo os mouros traiçoeiros De campo a campo [...]"
} 
host", "gloomy silence", "glimmering paleness"), evocando impressões sensoriais de cores, brilhos e silêncio para criar uma paisagem de perigo e mistério:

\begin{tabular}{|l|l|}
\hline \multicolumn{1}{|c|}{ ORIGINAL (CANTO II, ESTROFE 60 ) } & \multicolumn{1}{c|}{ TRADUÇãO (P. 66) } \\
\hline Meio caminho a noite tinha andado, & 'Twas now the solemn hour when midnight reigns, \\
E as Estrelas no Céu co a luz alheia, & And dimly twinkling o'er the ethereal plains, \\
Tinham o largo Mundo alumiado, & The starry host, by gloomy silence led, \\
E só co sono a gente se recreia. & O'er earth and sea a glimmering paleness shed; \\
& When to the fleet, which hemm'd with dangers lay, \\
& The silver-wing'd Cyllenius darts away. \\
& Each care was now in soft oblivion steep'd, \\
& The Watch alone accustom'd vigils kept [.... ${ }^{79}$ \\
\hline
\end{tabular}

Logo em seguida, na tradução da estrofe 62 do mesmo Canto II, Mickle se alonga na descrição das torturas de Diomedes e Busíris:

\begin{tabular}{|l|l|}
\hline \multicolumn{1}{|c|}{ ORIGINAL (CANTO II, ESTROFE 62 ) } & \multicolumn{1}{c|}{ TRADUÇÃO (P. 67) } \\
\hline "Não tens aqui senão aparelhado & Here such dire welcome is for thee prepared \\
O hospício que o cru Diomedes dava, & As Diomed's unhappy strangers shared; \\
Fazendo ser manjar acostumado & His hapless guests at silent midnight bled, \\
De cavalos a gente que hospedava; & On their torn limbs his snorting coursers fed. \\
As aras de Busíris infamado, & Oh fly, or here with strangers' blood imbrew'd \\
Onde os hóspedes tristes imolava, & Busiris' altars thou shalt find renew'd: \\
Terás certas aqui, se muito esperas: & Amidst his slaughter'd guests his altars stood \\
Fuge das gentes pérfidas e feras!" & Obscene with gore, and bark'd with human blood:80 \\
\hline
\end{tabular}

O original não descreve nenhuma das torturas, apenas as menciona de modo sugestivo, mas Mickle, procurando suscitar o horror - lembremos que a dor física é uma das fontes do sublime para Burke -, fala em "torn limbs", "slaughter'd guests", "obscene with gore" e "bark'd with human blood".

\footnotetext{
79 "Era a hora solene em que reina a meia-noite, E cintilando vagamente sobre as planícies etéreas, O exército de estrelas, guiado por um silêncio sombrio, Sobre a terra e o mar derrama uma palidez mortiça; Quando para a esquadra, que estava cercada de perigos, O Cilênio de asas prateadas se lança celeremente.

Toda atenção foi agora em suave esquecimento mergulhada, A Sentinela apenas mantinha as vigílias rotineiras". 80 "Aqui uma horrenda recepção é preparada para ti Como a que os infelizes forasteiros de Diomedes experimentaram; Os desafortunados hóspedes sangraram na silenciosa meia-noite, Seus membros arrancados alimentaram corcéis resfolegantes. $\mathrm{Ah}$, foge, ou aqui impregnados com o sangue de forasteiros Os altares de Busiris acharás revividos:

Em meio aos hóspedes massacrados erguem-se os altares

Repugnantes com sangue coagulado, e cobertos de sangue humano".
} 
De forma semelhante, no Canto III, estrofe 47, quando Camões descreve a luta de um mastim contra um touro, Mickle faz a sua própria versão sublime da cena. Citamos aqui a versão da segunda edição (1778), um pouco mais extensa que a da primeira edição:

\begin{tabular}{|l|l|}
\hline \multicolumn{1}{|c|}{ ORIGINAL (CANTO III, ESTROFE 47 ) } & \multicolumn{1}{c|}{ TRADUÇãO (1778, P. 99) } \\
\hline Qual cos gritos e vozes incitado, & So when the chase excites the rustic throng, \\
Pela montanha, o rábido moloso, & Roused to fierce madness by their mingled cries, \\
Contra o touro remete, que fiado & On the wild bull the red-eyed mastiff flies: \\
Na força está do corno temeroso: & The stern-brow'd tyrant roars and tears the ground, \\
Ora pega na orelha, ora no lado, & His watchful horns portend the deathful wound; \\
Latindo mais ligeiro que forçoso, & The nimble mastiff, springing on the foe, \\
Até que enfim, rompendo-lhe a garganta, \\
Do bravo a força horrenda se quebranta: & Avoids the furious sharpness of the blow: \\
& Now by the neck, now by the gory sides \\
& Hangs fierce, and all his bellowing rage derides: \\
& In vain his eye-balls burn with living fire, \\
& In vain his nostrils clouds of smoke respire; \\
& His gorge torn down, down falls the furious prize \\
& With hollow thundering sound, and raging dies. ${ }^{81}$ \\
\hline
\end{tabular}

A descrição de Mickle - ao contrário da de Camões, que é bastante concisa e objetiva apresenta tonalidades românticas. A abundante adjetivação expressa os sentimentos e sensações dos animais: "fierce madness"; "wild bull”; "red-eyed mastiff"; "stern-brow'd tyrant"; "watchful horns"; "deathful wound"; "furious sharpness"; "gory sides"; "bellowing rage"; "living fire"; "furious prize"; "hollow thundering sound". Os verbos também retratam a violência da cena: "roused"; "flies"; "roars"; "tears"; "springing on"; "burn"; "torn down"; “dies". Mais uma vez, os elementos sublimes são enfatizados: ruídos muito altos ("roars"; "bellowing rage"; "hollow thundering sound"); brilhos intensos ("his eye-balls burn with living fire"); dor física ("deathful wound"; "furious sharpness of the blow"; "gory sides"; "his gorge torn down"; "raging dies").

Na tradução do episódio do Adamastor, no Canto V, Mickle faz várias modificações em relação ao original, na tentativa de acentuar os traços do sublime conforme a concepção de

\footnotetext{
81 “Assim como quando a caça excita a multidão de camponeses, Inflamado a uma feroz loucura por seus gritos reunidos,

Sobre o touro selvagem o mastim de olhos vermelhos se lança;

O tirano carrancudo urra e escava o chão,

Seus chifres em guarda prenunciam o ferimento mortal;

O ágil mastim, saltando sobre o inimigo,

Evita a agudeza furiosa do golpe;

Ora no pescoço, ora nos flancos ensanguentados

Agarra-se com força, e zomba de toda aquela raiva urrante:

Em vão os globos oculares incendeiam-se em fogo vivo,

Em vão as narinas expelem nuvens de vapor,

Com a garganta rasgada, cai a furiosa presa

Com um som oco trovejante, e morre esbravejando."
} 
sua época. Nas duas estrofes em preparação à aparição do gigante, Mickle intensifica o clima de medo e as reações temerosas da tripulação:

\begin{tabular}{|l|l|}
\hline \multicolumn{1}{|c|}{ ORIGINAL (CANTO V, ESTROFES 37-38) } & \multicolumn{1}{|c|}{ TRADUÇãO (PP. 204-205) } \\
\hline "Porém já cinco Sóis eram passados & Now, prosp'rous gales the bending canvas swell'd; \\
Que dali nos partíramos, cortando & From these rude shores our fearless course we held: \\
Os mares nunca d'outrem navegados, & Beneath the glistening wave the God of day \\
Prósperamente os ventos assoprando, & Had now five times withdrawn the parting ray, \\
Quando ũa noute, estando descuidados & When o'er the prow a sudden darkness spread, \\
Na cortadora proa vigiando, & And, slowly floating o'er the mast's tall head \\
Ũa nuvem que os ares escurece & A black cloud hover'd: nor appear'd from far \\
Sobre nossas cabeças aparece. & The moon's pale glimpse, nor faintly twinkling star; \\
\hline Tão temerosa vinha e carregada, & So deep a gloom the louring vapour cast, \\
Que pôs nos corações um grande medo; & Transfixt with awe the bravest stood aghast. \\
Bramindo, o negro mar de longe brada, & Meanwhile a hollow bursting roar resounds, \\
Como se desse em vão nalgum rochedo. & As when hoarse surges lash their rocky mounds; \\
- 'Ó Potestade (disse) sublimada: & Nor had the blackening wave, nor frowning heaven \\
Que ameaço divino ou que segredo & The wonted signs of gathering tempest given. \\
Este clima e este mar nos apresenta, & Amazed we stood - O thou, our fortune's guide, \\
Que mor cousa parece que tormenta?' " & Avert this Omen, mighty God, - I cried; \\
& Or through forbidden climes adventurous stray'd, \\
& Have we the secrets of the deep survey'd, \\
& Which these wide solitudes of seas and sky \\
& Were doom'd to hide from man's unhallow'd eye? \\
& Whate'er this prodigy, it threatens more \\
& Than midnight tempests and the mingled roar, \\
& When sea and sky combine to rock the marble shore. ${ }^{82}$ \\
\hline
\end{tabular}

Na tradução da estrofe 37, para ressaltar o clima de escuridão, Mickle alude à ausência da lua e das estrelas: "nor appear'd from far / The moon's pale glimpse, nor faintly twinkling

82 "Agora ventos propícios inflam as lonas curvas;

Saindo dessas praias agrestes nosso curso destemido seguimos:

Sob as ondas reluzentes o Deus do dia

Recolhera já cinco vezes os raios de despedida,

Quando sobre a proa uma súbita escuridão se espalhou,

E flutuando devagar sobre a cabeça alta do mastro

Uma nuvem negra pairou: não se via ao longe

Nem um pálido luar, nem estrela que cintilasse mesmo fracamente;

Uma escuridão tão profunda o vapor que descia lançou,

Petrificados de terror os mais corajosos ficaram perplexos.

Enquanto isso um estrondo oco e explosivo ressoou,

Como quando roucos vagalhões fustigam os montes rochosos;

Nem a onda negrejante, nem o céu carrancudo

Os sinais habituais de tempestade em formação haviam dado.

Surpresos, permanecemos ali em pé - Ó tu, guia de nossa fortuna,

Desvia este Agouro, poderoso Deus - eu gritei;

Ou errando por regiões proibidas como aventureiros,

Teremos desvelado os segredos das profundezas,

Que estes vastos ermos de mares e céu

Foram condenados a esconder dos olhos profanos da humanidade?

Seja o que for este prodígio, ele é mais ameaçador

Do que as tempestades noturnas e o estrondo unificado

Quando o mar e o céu se combinam para sacudir a praia de mármore.” 
star". Ao traduzir a estrofe 38, enfatiza os elementos geradores do sublime: as expressões de terror ("transfixt with awe"; "aghast"; "Omen"; "midnight tempests"; "doom'd to hide"); os ruídos intensos ("a hollow bursting roar resounds"; "mingled roar"); a escuridão ("blackening wave"); a amplidão ("wide solitudes of seas and sky"). À maneira romântica, há uma correspondência entre a natureza e os sentimentos da tripulação.

A seguir, na descrição do Adamastor, Mickle insere pormenores inexistentes no original, acentuando os aspectos amedrontadores da figura do gigante:

\begin{tabular}{|l|l|}
\hline \multicolumn{1}{|c|}{ ORIGINAL (CANTO V, ESTROFES 39-40 ) } & \multicolumn{1}{c|}{ TRADUÇãO (PP. 205-206 ) } \\
\hline Não acabava, quando ũa figura & I spoke, when rising through the darken'd air, \\
Se nos mostra no ar, robusta e válida, & Appall'd, we saw an hideous Phantom glare; \\
De disforme e grandíssima estatura; & High and enormous o'er the flood he tower'd, \\
O rosto carregado, a barba esquálida, & And thwart our way with sullen aspect lour'd: \\
Os olhos encovados, e a postura & An earthy paleness o'er his cheeks was spread, \\
Medonha e má e a cor terrena e pálida; & Erect uprose his hairs of wither'd red; \\
Cheios de terra e crespos os cabelos, & Writhing to speak his sable lips disclose, \\
A boca negra, os dentes amarelos. & Sharp and disjoin'd, his gnashing teeth's blue rows; \\
\hline Tão grande era de membros, que bem posso & His haggard beard flow'd quivering on the wind, \\
Certificar-te que este era o segundo & Revenge and horror in his mien combined; \\
De Rodes estranhíssimo Colosso, & His clouded front, by withering lightnings scared, \\
Que um dos sete milagres foi do mundo. & The inward anguish of his soul declared. \\
Cum tom de voz nos fala, horrendo e grosso, & His red eyes glowing from their dusky caves, \\
Que pareceu sair do mar profundo. & Shot livid fires: Far ecchoing o'er the waves \\
Arrepiam-se as carnes e o cabelo, & His voice resounded, as the cavern'd shore \\
A mi e a todos, só de ouvi-lo e vê-lo! & With hollow groan repeats the tempest's roar. \\
& Cold gliding horrors thrill'd each hero's breast, \\
& Our bristling hair and tottering knees confest \\
& Wild dread, the while with visage ghastly wan, \\
& His black lips trembling, thus the fiend began:83 \\
\hline
\end{tabular}

83 "Eu disse, quando se erguendo no ar escurecido, Estarrecidos, vimos um horrendo Espectro fulgurar; Alto e enorme sobre a correnteza ele se elevava, E para bloquear nosso caminho com aspecto taciturno desceu: Uma palidez terrena em sua face se espalhava,

Eretos ficaram seus cabelos de um vermelho desbotado; Contorcendo-se para falar seus lábios negros desvelam,

Afiados e desconjuntados, as fileiras azuis de seus dentes rangentes;

A barba esquálida escorria tremulando ao vento,

Vingança e horror em sua expressão se combinavam;

O rosto sombrio, alarmado por relâmpagos fulminantes,

Revelava a angústia íntima da alma.

Os olhos vermelhos brilhando em suas covas escuras,

Lançavam chamas pálidas: ao longe, ecoando sobre as ondas

Sua voz ressoou, como a costa cavernosa

Com um gemido oco repete o fragor da tempestade.

Horreres gelados deslizantes arrepiavam o peito de todos os heróis,

Nossos cabelos eriçados e joelhos bambos confessavam

Medo frenético, no momento em que, com o rosto horripilante lívido,

Os lábios negros tremendo, assim começou o monstro". 
O Adamastor descrito por Mickle é um monstro gótico, com várias características românticas: "hideous Phantom glare"; "sullen aspect"; "earthy paleness"; "clouded front"; "inward anguish of his soul"; "red eyes glowing from [...] dusky caves".

Os versos destacados em negrito no quadro anterior não apresentam nenhuma correspondência com o original, a não ser pela descrição dos olhos, que, para Camões, são “encovados" (“dusky caves”); em nenhum momento Camões diz que os olhos do Adamastor são vermelhos ("red eyes"). A descrição feita por Camões dos dentes do Adamastor, "A boca negra, os dentes amarelos", é traduzida por Mickle como "Sharp and disjoin'd, his gnashing teeth's blue rows" - em vez de amarelos, os dentes da tradução são azuis (talvez porque a imagem de "dentes amarelos" não parecesse, para o tradutor, à altura do sublime); são também mais ameaçadores, por serem afiados.

Na segunda edição de sua tradução, Mickle efetuou uma profunda alteração na estrutura do episódio do Adamastor que talvez se relacione à sua concepção de sublime. No original e na primeira edição do Lusiad, a história passada do Adamastor é contada pelo próprio gigante, assim que ele termina de fazer as profecias referentes aos navegadores portugueses. Na segunda edição, Mickle (1778, p. 206) transfere esse relato para o rei de Melinde, que situa a história do Adamastor em um tempo recuado, "Deep in the days of yore", como se fosse um relato de lendas: "Oh wondrous faith of ancient days, he cries, / Conceal'd in mystic lore and dark disguise! / Taught by their sires, our hoary fathers tell [...]" $]^{\prime 84}$.

Assim, na segunda edição há um pulo do final da estrofe 50 para a 60; o monstro desaparece e inicia-se a narrativa do rei de Melinde, retornando para a estrofe 51.

O tradutor não explica suas razões para essa alteração estrutural; talvez o objetivo fosse enquadrar esse trecho nas regras neoclássicas referentes ao gênero épico, transferindo alguns elementos da mitologia pagã para o campo da lenda, do passado. Uma possível pista é que, no início da tradução do episódio do Adamastor, Mickle (CAMÕES, 1776a, p. 207; 1778, p. 200) elogia muito, em nota de rodapé, a primeira parte do episódio em Camões e silencia a respeito da segunda. Talvez, como supõe Ferreira (1992b, p. 88), Mickle achasse que a segunda parte não se coadunava com "o espírito do verdadeiro sublime"; talvez considerasse que, ao contar sua própria história, o Adamastor, que se revelara cruel e impiedoso na primeira parte, se mostraria melancólico e vulnerável, quebrando-se, assim, a coerência da personagem. De qualquer forma, observa ainda Ferreira, ao reduzir a extensão discursiva da fala do Adamastor, Mickle criou um efeito de amplo alcance:

\footnotetext{
84 “'Oh, maravilhosa fé dos dias antigos, ele grita, / Oculta em tradições místicas e disfarces secretos! / Ensinada por seus ancestrais, nossos velhos pais contam $[\ldots]$ ".
} 
[...] a dicotomização entre as suas dimensões fantasmagórica e humana. A figura monstruosa e soturna do gigante, que retrai de pavor a alma dos que o observam, sobrepõe-se à figura do amante infeliz que, no fundo, ele é, e, assim, a sua faceta sublime sai revitalizada.

A ênfase na infelicidade do amante é reforçada também pelo tom emotivo da tradução de Mickle. Como exemplo, citamos a tradução do início da estrofe 53, em que o gesto de Adamastor, de resolver tomar a ninfa pela força, é dramatizado ao máximo, pelo retrato da dor e desespero do amante infeliz ("madning with love"), que se sente rejeitado por sua feiura ("From my grim form with horror mute she fled") - um tema muito explorado pelos góticos e românticos:

\begin{tabular}{|l|l|}
\hline \multicolumn{1}{|c|}{ ORIGINAL (CANTO V, ESTROFE 53 ) } & \multicolumn{1}{c|}{ TRADUÇÃO (1776, P. 223) } \\
\hline $\begin{array}{l}\text { “Como fosse impossíbil alcançá-la, } \\
\text { Pola grandeza feia de meu gesto, } \\
\text { Determinei por armas de tomá-la [...]" }\end{array}$ & $\begin{array}{l}\text { In vain I woo'd her to the lover's bed, } \\
\text { From my grim form with horror mute she fled. } \\
\text { Madning with love, by force I ween to gain } \\
\text { The silver goddess of the blue domain [... }{ }^{85}\end{array}$ \\
\hline
\end{tabular}

A descrição da tempestade no Canto VI também é magnificamente ampliada por Mickle:

\begin{tabular}{|c|c|}
\hline ORIGINAL (CANTO VI, ESTROFE 53 ) & TRADUÇÃO (PP. 245-246) \\
\hline Já lá o soberbo Hipótades soltava & And now the God of Tempests swift unbinds \\
\hline Do cárcere fechado os furiosos & From their dark caves the various rushing winds: \\
\hline Ventos, que com palavras animava & High o'er the storm the Power impetuous rides, \\
\hline Contra os varões audaces e animosos. & His howling voice the roaring tempest guides; \\
\hline Súbito, o céu sereno se obumbrava, & Right to the dauntless fleet their rage he pours, \\
\hline Que os ventos, mais que nunca impetuosos, & And first their headlong outrage tears the shores: \\
\hline Começam novas forças a ir tomando, & A deeper night involves the darken'd air, \\
\hline Torres, montes e casas derribando. & And livid flashes through the mountains glare: \\
\hline & Up-rooted oaks, with all their leafy pride, \\
\hline & Rowl thundering down the groaning mountains' side; \\
\hline & And men and herds in clamorous uproar run, \\
\hline & The rocking towers and crashing woods to shun. ${ }^{86}$ \\
\hline
\end{tabular}

\footnotetext{
85 "Em vão eu a seduzi ao leito amoroso,

De meu corpo repulsivo com horror mudo ela fugiu.

Enlouquecido de amor, pela força tentei conquistar

A deusa prateada do domínio azul [...]".

86 "E agora o Deus das Tempestades célere liberta

De suas cavernas escuras os vários ventos apressados:

Bem acima da tempestade o Poder impetuoso viaja,

Sua voz uivante guia a tempestade fragorosa;

Diretamente para a destemida frota a sua raiva ele dirige,

E antes de tudo a sua impetuosa revolta rasga as praias:

Uma noite mais profunda envolve o ar escurecido,

E relâmpagos pálidos reluzem pelas montanhas:

Carvalhos arrancados pela raiz, com todas as imponentes folhas,

Rolam ribombantes a encosta plangente das montanhas;
} 
Mickle enfatiza, mais uma vez, os elementos capazes de evocar o perigo e, em consequência, o sublime: a escuridão (“dark caves"; "deeper night”; “darken'd air”); as emoções intensas ("rage"; "headlong outrage"); os ruídos clamorosos ("howling voice"; "roaring tempest"; "rowl thundering down", "groaning mountains", "clamorous uproar", "crashing"); o brilho ("And livid flashes through the mountains glare"); as grandes alturas (“mountains"; “towers"); o poder, em seus vários aspectos - até o poder de destruição ("Power impetuous"; "tears the shores"; "Up-rooted oaks, with all their leafy pride"). Mickle se revela, em trechos como este, um mestre da harmonia imitativa - o uso de recursos estilísticos para reproduzir fenômenos naturais. Neste exemplo, como bem observou Ferreira (1992b, p. 89), Mickle utiliza aliterações em -ing ("rushing"; "groaning"; "rocking"; “crashing”) para "transmitir o estrondo e a vibração de tudo o que é arrastado ou destruído por uma grande tempestade". Com esse mesmo propósito, o tradutor insiste nas consoantes duras, sobretudo as oclusivas "d", “t” e "k" (“dark", "tempest”; “dauntless"; "tears"; “deeper”; "darken'd"; "mountains"; "Up-rooted"; "pride"; "thundering down"; "clamorous"; "rocking towers"; "crashing") junto com a repetição contínua da consoante vibrante "r" ("rushing", "rides"; "roaring"; "Right to the dauntless fleet their rage he pours, / And first their headlong outrage tears the shores"; "darken'd"; "through the mountains glare"; "Up-rooted"; "pride"; "Rowl thundering down the groaning"; "herds in clamorous uproar run, / The rocking towers and crashing").

No Canto VIII, na tradução da estrofe 44, Mickle cria uma atmosfera gótica para preparar a aparição de Baco, disfarçado como Maomé, no sonho de um sacerdote maometano. Ao final do trecho, Mickle acrescenta vários versos (que grafamos em negrito):

E pessoas e rebanhos correm em ruidoso tumulto, Para se desviar das torres de rocha e árvores que desabavam." 


\begin{tabular}{|c|c|}
\hline ORIGINAL (CANTO VIII, ESTROFE 44 ) & TRADUÇÃO (PP. 338-339) \\
\hline $\begin{array}{l}\text { Mas já a luz se mostrava duvidosa, } \\
\text { Porque a alâmpada grande se escondia } \\
\text { Debaxo do Horizonte e, luminosa, } \\
\text { Levava aos Antípodas o dia, } \\
\text { Quando o Gentio e a gente generosa } \\
\text { Dos Naires da nau forte se partia, } \\
\text { A buscar o repouso que descansa } \\
\text { Os lassos animais, na noite mansa. }\end{array}$ & $\begin{array}{l}\text { The falling darkness dimm'd the eastern shore, } \\
\text { And twilight hover'd o'er the billows hoar } \\
\text { Far to the west, when with his noble band } \\
\text { The thoughtful Regent sought his native strand. } \\
\text { O'er the tall mountain-forest's waving boughs } \\
\text { Aslant the new moon's slender horns arose; } \\
\text { Near her pale chariot shone a twinkling star, } \\
\text { And, save the murmuring of the wave afar, } \\
\text { Deep-brooding silence reign'd; each labour closed, } \\
\text { In sleep's soft arms the sons of toil reposed. } \\
\text { And now no more the moon her glimpses shed, } \\
\text { A sudden black-wing'd cloud the sky o'erspread, } \\
\text { A sullen murmur through the woodland groan'd, } \\
\text { In woe-swoln sighs the hollow winds bemoan'd; } \\
\text { Borne on the plaintive gale a pattering shower, } \\
\text { Increased the horrors of the evil hour. } \\
\text { Thus when the great Earthshaker rocks the ground, } \\
\text { He gives the prelude in a dreary sound; } \\
\text { O'er Nature's face a horrid gloom he throws, } \\
\text { With dismal note the cock unusual crows, } \\
\text { A shrill-voiced howling trembles thro' the air } \\
\text { As passing ghosts were weeping in despair; } \\
\text { In dismal yells the dogs confess their fear, } \\
\text { And shivering own some dreadful presence near.87 }\end{array}$ \\
\hline
\end{tabular}

Mickle enfatiza os efeitos sonoros e visuais para dar um clima de mistério à paisagem retratada. Há vários elementos góticos e românticos presentes: "falling darkness"; "twilight"; "the new moon's slender horns"; "pale chariot"; "twinkling star"; "deep-brooding silence reigned"; "A sudden black-wing'd cloud the sky o'erspread"; "sullen murmur"; "hollow winds

\footnotetext{
87 "A escuridão crescente turvou a costa oriental,

E o crepúsculo pairou sobre o gris das ondas

Longe ao oeste, quando com seu nobre grupo

O pensativo Catual buscou sua praia natal.

Sobre as altas florestas montanhosas que agitavam os galhos

Oblíquos ergueram-se os cornos esguios da lua nova;

Junto à sua pálida carruagem brilhou uma estrela faiscante,

E, a não ser pelo murmúrio das ondas ao longe,

Reinou um profundo silêncio taciturno; toda a labuta encerrada,

Nos suaves braços do sono os filhos do árduo trabalho repousaram.

E então a lua não lançou mais seus lampejos,

Uma súbita nuvem de asas negras cobriu o céu,

Um murmúrio soturno gemeu pela floresta,

Em suspiros cheios de angústia os ventos cavernosos se lamuriaram;

Nascida da ventania plangente uma chuva tamborilante,

Ampliou os horrores da hora maléfica.

Assim quando o grande Deus dos Terremotos agita o solo,

Toca o prelúdio em um som melancólico;

Sobre o rosto da Natureza uma horrível tristeza ele lança,

Em tom lúgubre o galo canta estranhamente,

Um uivo estridente vibra pelo ar

Como se fantasmas passassem chorando em desespero;

Em berros funestos os cães confessam seu medo,

E estremecendo reconhecem uma terrível presença próxima."
} 
bemoan'd"; "plaintive gale"; "the horrors of the evil hour"; "dreary sound"; "horrid gloom".

Ferreira (1992b, pp. 90-91) comenta que, nos cinco últimos versos,

Mickle refere ainda o cantar lúgubre do galo e o latir medonho dos cães, dando, assim, relevo à exteriorização de dor dos animais, pois que, como Edmund Burke refere, não só os gritos de aflição das pessoas como também os dos animais são importantes para o despertar de paixões fortes.

A menção a fantasmas que passam chorando em desespero ("passing ghosts [...] weeping in despair”) completa a atmosfera gótica dos versos acrescentados por Mickle.

\subsubsection{Outros Elementos Românticos}

Além do sentimento romântico da natureza e do sublime, há muitos outros elementos românticos na tradução de Mickle. Comentaremos alguns desses elementos a seguir.

Ao longo de toda a tradução Mickle procura detalhar cada sentimento expresso, quer pelos personagens, quer pelo narrador. Um exemplo disso é a tradução da estrofe 84 do Canto III, em que o luto pela morte de Afonso é amplificado pelo acréscimo de detalhes emotivos:

\begin{tabular}{|l|l|}
\hline \multicolumn{1}{|c|}{ ORIGINAL (CANTO III, ESTROFE 84 ) } & \multicolumn{1}{c|}{ TRADUÇÃO (PP. 117-118) } \\
\hline $\begin{array}{l}\text { Os altos promontórios o choraram, } \\
\text { E dos rios as águas saüdosas }\end{array}$ & $\begin{array}{l}\text { Each winding shore for thee, Alonzo, mourns, } \\
\text { Os semeados campos alagaram, }\end{array}$ \\
$\begin{array}{l}\text { Com lágrimas correndo piadosas; } \\
\text { Mas tanto pelo mundo se alargaram }\end{array}$ & $\begin{array}{l}\text { For thee the rivers sigh their groves among, } \\
\text { Com faina suas obras valerosas, }\end{array}$ \\
$\begin{array}{l}\text { Que sempre no seu reino chamarão } \\
\text { "Afonso, Afonso!" os ecos; mas em vão. }\end{array}$ & Their swelling tears o'erflow the wide campaign; \\
& For thee the willow bowers and copses weep, \\
& As their tall boughs lie trembling on the deep; \\
& Adown the streams the tangled vine-leaves flow, \\
& And all the landscape wears the look of woe. \\
& Thus, o'er the wondering world thy glories spread, \\
& And thus thy mournful people bow the head; \\
& While still, at eve, each dale Alonzo sighs, \\
& And, oh, Alonzo! every hill replies; \\
& And still the mountain ecchoes trill the lay, \\
& Till blushing morn brings on the noiseful day.88 \\
\hline
\end{tabular}

\footnotetext{
88 "Toda costa sinuosa está de luto por ti, Afonso,

O nome de Afonso toda triste baía ecoa;

Por ti os rios suspiram junto aos bosques,

E, pranteando em murmúrios funéreos, seguem seu curso;

Suas lágrimas crescentes inundam a vasta campina;

Com espigas flutuantes, por ti, o grão amarelo,

Por ti os caramanchões de salgueiros e arbustos choram,

Enquanto seus ramos altos tremulam sobre as profundezas;

Os rios levam para baixo as emaranhadas folhas de videiras,

E toda a paisagem se veste de tristeza.
} 
O tradutor explica, em nota, que nesse trecho Camões imitou três passagens de Virgílio: “Ipsæ te, Tityre, pinus, / Ipsi te fontes, ipsa hæc arbusta vocabant" (Écloga I) ${ }^{89}$; "Eurydicen vox ipsa et frigida lingua, / Ah miseram Eurydicen, anima fugiente, vocabat: Eurydicen toto referebant flumine ripæ" (Geórgica IV) ${ }^{90}$ e "littus, Hyla, Hyla, omne sonaret" (Écloga VI) ${ }^{91}$. (CAMÕES, 1776a, p. 117). Mickle utiliza a intertextualidade, aproveitando essas fontes para ampliar a emotividade da cena. O vocativo no primeiro verso e a transposição da terceira pessoa ("o choraram"; "suas obras"; "seu reino") para a segunda pessoa (a expressão "for thee", repetida quatro vezes) conferem intimidade a essa passagem; a adjetivação é pródiga e dramática ("woful bay"; "swelling tears"; "blushing morn"; "mournful people"); e outras palavras ressaltam a carga emotiva ("mourns"; "sigh"; "murmurs"; "wailing", "willow"; "trembling"; "woe"; "weep"). Para coroar o conjunto de efeitos de harmonia imitativa, as aliterações em "w" acentuam o tom de lamento.

Outro exemplo a ser comentado encontra-se no Canto X, na tradução das estrofes de 56 a 60. Como já vimos na subseção 5.2.3 deste mesmo capítulo, Mickle reorganiza a narrativa para dar mais destaque a Pedro de Mascarenhas e inclui vários versos em homenagem a ele:

Thy deeds, great Peer, the wonder of thy foes, Thy glorious chains unjust, and generous woes, Shall dim the fierce Sampayo's fairest fame, And o'er his honours thine aloud proclaim. Thy generous woes! Ah gallant injured Chief, Not thy own sorrows give the sharpest grief. Thou seest the Lusian name her honours stain, And lust of gold her heroes' breasts profane; Thou seest ambition lift the impious head, Nor God's red arm, nor lingering justice dread; O'er India's bounds thou seest these vultures prowl, Full gorged with blood, and dreadless of controul;

\footnotetext{
Assim, sobre o mundo admirado tuas glórias se espalham,

E assim o teu povo enlutado inclina a cabeça;

Enquanto ainda à noite todos os vales suspiram por Afonso,

E, oh, Afonso! todas as colinas respondem;

E os ecos da montanha ainda trilam a canção,

Até a aurora rósea trazer o ruidoso dia."

89 "Até os pinheiros, ó Títiro, as fontes e os arbustos clamavam pela tua volta". (Tradução nossa, a partir de várias traduções para o inglês, francês e espanhol.)

90 "Eurídice! ah! triste Eurídice! As margens ecoavam Eurídice, ao longo de todo o rio". (Tradução de Elaine C. Prado dos Santos, in SANTOS, Elaine C. P. O IV canto das Geórgicas. São Paulo: Scortecci, 2007, p. 107.)

91 "Toda a praia ressoava, "Hilas, Hilas"”. (Tradução nossa, a partir de várias traduções para o inglês, francês e espanhol.)
} 
Thou seest and weepst thy country's blotted name, The generous sorrow thine, but not the shame. ${ }^{92}$ (CAMÕES, 1776a, p. 435)

Nesse trecho, como em toda a sua tradução, Mickle insiste no tom de exaltação heroica. O léxico é intensamente solene e dramático: "Thy glorious chains unjust"; "gallant injured Chief"; "sharpest grief"; "her honours stain"; "lust of gold"; "heroes' breasts"; "impious head"; "lingering justice"; "vultures"; "Full gorged with blood, and dreadless of controul / Thou seest and weepst thy country's blotted name"; "generous sorrow".

Essa exaltação do heroísmo encontra-se, em outros exemplos, profundamente ligada ao espírito de cavalaria, outra característica pré-romântica valorizada por Mickle em sua tradução. Veremos, a seguir, alguns exemplos.

Na tradução da estrofe 34 do Canto III, Mickle descreve em maior detalhe a batalha que Camões resume em apenas quatro versos:

\begin{tabular}{|l|l|}
\hline \multicolumn{1}{|c|}{ ORIGINAL (CANTO III, ESTROFE 34 ) } & \multicolumn{1}{c|}{ TRADUÇÃO (P. 98) } \\
\hline Eis se ajunta o soberbo Castelhano, & And sheath'd in brass the proud Castilian rose, \\
Pera vingar a injúria de Teresa, & Resolved the rigour to his daughter shewn \\
Contra o, tão raro em gente, Lusitano, & The battle should avenge, and blood atone. \\
A quem nenhum trabalho agrava ou pesa. & A numerous host against the prince he sped, \\
Em batalha cruel, o peito humano, & The valiant prince his little army led: \\
Ajudado da Angélica defesa, & Dire was the shock; the whizzing javelins sung \\
Não só contra tal fúria se sustenta, & The Hauberks rattled, and the bucklers rung. \\
Mas o inimigo aspérrimo afugenta. & Yet, though around the Stripling's sacred head \\
& By angel hands etherial shields were spread; \\
& Though glorious triumph on his valour smiled, \\
& Soon on his van the baffled foe recoil'd: \\
& With bands more numerous to the field he came, \\
& His proud heart burning with the rage of shame. ${ }^{93}$ \\
\hline
\end{tabular}

\footnotetext{
92 "Tuas façanhas, grande Pedro, o assombro de teus inimigos,

Tuas gloriosas correntes injustas, e generosos infortúnios,

Turvarão até a mais justa fama do cruel Sampaio,

E acima das honras dele as tuas proclamarão em voz alta.

Teus generosos infortúnios! Ah, valente Governante ferido,

Não são as tuas próprias aflições que produzem a dor mais aguda.

Tu vês macularem a honra do nome lusitano,

E a cobiça do ouro profanar o peito de seus heróis;

Tu vês a ambição erguer a ímpia cabeça,

Sem temer nem o braço vermelho de Deus, nem a justiça tardia;

Sobre as fronteiras da Índia tu vês aqueles abutres rondarem,

Com a boca cheia de sangue, e sem medo de controle;

Tu vês o nome manchado de teu país e choras por ele,

Tua é a generosa tristeza, mas não a vergonha."

93 "E em armadura de bronze o orgulhoso castelhano se levantou,

Decidido que o rigor mostrado para com a filha

A batalha deveria vingar e o sangue expiar.

Um numeroso bando contra o príncipe ele despachou,

$\mathrm{O}$ valente príncipe liderou seu pequeno exército:
} 
Mickle relata a batalha em toda a pompa medieval: "proud Castillian"; "sheath'd in brass"; "valiant prince"; "whizzing javelins sung"; "The Hauberks rattled, and the bucklers rung"; "glorious triumph"; "proud heart". O heroico príncipe Afonso Henriques vence comandando um exército pequeno ("his little army led"), ajudado por anjos que lhe fornecem "etherial shields" (aspectos que já estão no original, embora em menor detalhe: "tão rara em gente" e "ajudado de angélica defesa").

A predileção de Mickle por temas medievais é evidente em sua tradução do episódio dos Doze da Inglaterra. O destaque que será dado pelo tradutor ao episódio já se prefigura na tradução de dois versos referentes aos Doze da Inglaterra no Canto I do original:

\begin{tabular}{|l|l|}
\hline \multicolumn{1}{|c|}{ ORIGINAL (CANTO I, ESTROFE 12) } & \multicolumn{1}{c|}{ TRADUÇãO (P. 8) } \\
\hline $\begin{array}{l}\text { Pois polos Doze Pares dar-vos quero } \\
\text { Os Doze de Inglaterra e o seu Magriço; }\end{array}$ & $\begin{array}{l}\text { To match the Twelve so long by Bards renown'd } \\
\text { Here brave Magrizo and his Peers are crown'd } \\
\text { (A glorious Twelve!) with deathless laurels, won } \\
\text { In gallant arms before the English throne. }{ }^{94}\end{array}$ \\
\hline
\end{tabular}

O entusiasmo do tradutor pelo tema se manifesta na interpolação "A glorious Twelve!", na adjetivação (“deathless"; "gallant”) e no tom solene dos dois versos destacados acima em negrito.

No início do episódio dos Doze da Inglaterra, na tradução da estrofe 44, Mickle descreve as damas com muito mais detalhe do que Camões o fizera, não poupando elogios: "With every charm adorn'd, and every grace / That spreads its magic o'er the female face"; "shined"; "The first, the fairest". Não faltam também alguns chavões de novela de cavalaria, como a referência às damas como virgens ("their virgin fame") e a menção à honra ("injured name"; "stain'd the honour"; "defame"; "sacred honour of a lady's name"):

\footnotetext{
Medonho foi o embate; os dardos sibilantes cantaram As armaduras de escamas chocalharam, e os escudos soaram

Porém, embora ao redor da sagrada cabeça do Jovem Por mãos angélicas escudos etéreos fossem espalhados; Embora o glorioso triunfo sorrisse diante de sua bravura,

[E] diante de sua vanguarda o desnorteado inimigo logo recuasse:

Com grupos mais numerosos ao campo de batalha ele [o inimigo] veio,

Seu coração orgulhoso ardendo com a ira da desonra."

94 "Para enfrentar os Doze [Pares] tão celebrados pelos Bardos

Aqui o bravo Magriço e seus Pares são coroados

(Gloriosos Doze!) com louros imortais, obtidos

Em valentes combates diante do trono inglês."
} 


\begin{tabular}{|l|l|}
\hline \multicolumn{1}{|c|}{ ORIGINAL (CANTO VI, ESTROFE 44) } & \multicolumn{1}{c|}{ TRADUÇãO (P. 248) } \\
\hline Entre as damas gentis da corte Inglesa & With every charm adorn'd, and every grace, \\
E nobres cortesãos, acaso um dia & That spreads its magic o'er the female face, \\
Se levantou discórdia, em ira acesa, & Twelve ladies shined the courtly train among, \\
(Ou foi opinião, ou foi porfia). & The first, the fairest of the courtly throng, \\
Os cortesãos, a quem tão pouco pesa & But Envy's breath reviled their injured name, \\
Soltar palavras graves de ousadia, & And stain'd the honour of their virgin fame. \\
Dizem que provarão que honras e famas & Twelve youthful barons own'd the foul report, \\
Em tais damas não há pera ser damas; & The charge at first, perhaps, a tale of sport. \\
& Ah, base the sport that lightly dares defame \\
& The sacred honour of a lady's name!95 \\
\hline
\end{tabular}

Ao final da estrofe 46, Mickle amplifica ainda mais todos esses elementos acrescentando vários versos que não apresentam contrapartida no original:

Adown their cheeks, now paler than the hue

Of snowdrops trembling to the chilly gale,

The slow-paced chrystal tears their wrongs bewail.

When down the beauteous face the dew-drop flows,

What manly bosom can its force oppose!

His hoary curls th' indignant hero shakes,

And all his youthful rage restored awakes $[\ldots]^{96}$

(CAMÕES, 1776a, pp. 249-250).

Vemos aqui o perfeito retrato das damas românticas, pálidas ("paler than the hue / Of snowdrops trembling to the chilly gale"), com lágrimas cristalinas nos olhos ("chrystal tears"), às quais nenhum cavalheiro pode resistir ("What manly bosom can its force oppose!’). Está presente também o herói romântico, embora aqui ele seja um cavalheiro mais velho, cuja indignação the devolve o ímpeto juvenil (“And all his youthful rage restored awakes").

\footnotetext{
95 "Com todos os encantos adornadas, e todas as graças, Que espalham sua magia sobre o rosto feminino, Doze damas brilhavam no séquito da corte, As primeiras, as mais belas da multidão cortesã, Mas o sopro da Inveja vilipendiou seus nomes insultados, E maculou a honra de sua fama de virgens.

Doze jovens barões foram os autores do vil relato, A acusação, a princípio, talvez [fosse] uma brincadeira. Ah, vil a brincadeira que levianamente ousa difamar A honra sagrada do nome de uma dama!"

96 "Descendo-lhes as faces, agora mais pálidas do que o matiz

De campânulas brancas estremecendo ao vento frio,

As lentas lágrimas cristalinas suas ofensas lamentam.

Quando pelos belos rostos as gotas de orvalho descem,

Que peito viril pode se opor à sua força!

Seus cachos grisalhos o herói indignado sacode,

E toda a sua fúria juvenil desperta, restaurada [...]"
} 
Ainda no mesmo episódio, na tradução da estrofe 66, Mickle omite os quatro versos do original (em negrito no quadro) que manifestam a rejeição aos episódios de novelas de cavalaria que apelam para descrições fantasiosas de combates e, ao contrário do narrador do original, estende-se em descrições do combate na tradução da estrofe 65, concentrando-se, principalmente, na figura heroica de Magriço:

\begin{tabular}{|l|l|}
\hline \multicolumn{1}{|c|}{ ORIGINAL (CANTO VI, ESTROFES 65-66) } & \multicolumn{1}{|c|}{ TRADUÇ̃̃O (PP. 256-257) } \\
\hline "Algum dali tomou perpétuo sono & So tired and stagger'd toil'd the doubtful fight, \\
E fez da vida ao fim breve intervalo; & When great Magricio kindling all his might \\
Correndo, algum cavalo vai sem dono, & Gave all his rage to burn: with headlong force, \\
E noutra parte o dono sem cavalo. & Conscious of victory, his bounding horse \\
Cai a soberba Inglesa de seu trono, & Wheels round and round the foe; the hero's spear \\
Que dous ou três já fora vão do valo. & Now on the front, now flaming on the rear, \\
Os que de espada vêm fazer batalha, & Mows down their firmest battle; groans the ground, \\
Mais acham já que arnês, escudo e malha." & The splinter'd shields and cloven helms resound \\
& Beneath his courser; torn the harness gay \\
& Here from the master springs the steed away; \\
& Obscene with dust and gore, slow from the ground \\
& Rising, the master rowls his eyes around, \\
& Pale as a spectre on the Stygian coast, \\
& In all the rage of shame confused and lost: \\
& Here low on earth, and o'er the riders thrown, \\
& The wallowing coursers and the riders groan: \\
& Before their glimmering vision dies the light, \\
& And deep descends the gloom of death's eternal night.97 \\
\hline
\end{tabular}

97 "Cansada e titubeante se arrastava a luta incerta,

Quando o grande Magriço, atiçando toda a sua bravura, Lançou toda a sua ira às chamas: com impetuosa força, Certo da vitória, seu cavalo encilhado Gira o inimigo em círculos; a lança do herói Ora à frente, ora flamejando na retaguarda, Ceifa-lhes o combate mais firme; geme o solo, Os escudos estilhaçados e elmos fendidos ressoam Sob seu corcel; rasgados os arreios vistosos Aqui de debaixo do dono o corcel se evade de um salto; Imundo de poeira e sangue, devagar do chão Se erguendo, o cavaleiro gira os olhos, Pálido como um espectro sobre a praia do Estige, Em toda a ira da vergonha confuso e perdido: Aqui, embaixo, na terra, e sobre os cavaleiros derrubados Os corcéis chafurdando e os cavaleiros gemem:

Diante de sua visão oscilante a luz se apaga,

E descem profundas as trevas da noite eterna da morte." 


\begin{tabular}{|l|l|}
\hline “Gastar palavras em contar extremos & They now who boasted, "Let the sword decide," \\
De golpes feros, cruas estocadas, & Alone in flight's ignoble aid confide: \\
É desses gastadores, que sabemos, & Loud to the skies the shout of joy proclaims \\
Maus do tempo com fábulas sonhadas. & The spotless honour of the ladies' names.98 \\
Basta, por fim do caso, que entendemos & \\
Que com finezas altas e afamadas, & \\
Cos nossos fica a palma da vitória & \\
E as damas vencedoras e com glória." & \\
\hline
\end{tabular}

Ainda sobre a tradução da passagem acima, note-se o tom romântico, com acentos góticos, dos versos "Pale as a spectre on the Stygian coast" e "Before their glimmering vision dies the light, / And deep descends the gloom of death's eternal night".

A seguir, ao final da estrofe 67, Mickle acrescenta uma série de versos para descrever as celebrações na Inglaterra:

\begin{tabular}{|l|l|}
\hline \multicolumn{1}{|c|}{ ORIGINAL (CANTO VI, ESTROFE 67) } & \multicolumn{1}{c|}{ TRADUÇ̃̃O (PP. 256-257) } \\
\hline "Recolhe o Duque os doze vencedores & In painted halls of state and rosy bowers, \\
Nos seus paços, com festas e alegria; & The twelve brave Lusians crown the festive hours. \\
Cozinheiros ocupa e caçadores & Bold Lancaster the princely feast bestows, \\
Das damas a fermosa companhia, & The goblet circles, and the music flows; \\
Que querem dar aos seus libertadores & And every care, the transport of their joy, \\
Banquetes mil, cada hora e cada dia, & To tend the knights the lovely dames employ; \\
Enquanto se detêm em Inglaterra, & The green-boughed forests by the lawns of Thames \\
Até tornar à doce e cara terra." & Behold the victor-champions and the dames \\
& Rouse the tall roe-buck o'er the dews of morn, \\
& While through the dales of Kent resounds the bugle-horn. \\
& The sultry noon the princely banquet owns, \\
& The minstrel's song of war the banquet crowns; \\
& And when the shades of gentle evening fall, \\
& Loud with the dance resounds the lordly hall: \\
& The golden roofs, while Vesper shines, prolong \\
& The measured cadence, and accomp'nied song. \\
& Thus past the days on England's happy strand, \\
& Till the dear memory of their natal land \\
& Sigh'd for the banks of Tagus. [...]99 \\
\hline
\end{tabular}

\footnotetext{
98 “Agora aqueles que se jactaram 'Que a espada decida' Sozinhos na ajuda da desprezível fuga confiam:

Alto para os céus o grito de júbilo proclama

A honra imaculada dos nomes das damas."

99 "Em salões pintados majestosos e caramanchões róseos,

Os doze bravos lusitanos coroam as horas festivas.

O ousado Lancaster promove o festim principesco,

O cálice circula, e a música flui;

E todo cuidado, em um arrebatamento de alegria,

Para atender às adoráveis damas os cavaleiros empregam;

As florestas de ramos verdes junto aos gramados do Tâmisa

Contemplam os campeões vencedores e as damas

Agita-se o alto cabrito montês sobre os orvalhos da manhã,

Enquanto pelos vales de Kent ressoa a corneta de caça.

A tarde quente domina o banquete principesco,

A canção de guerra do menestrel coroa o banquete;

E quando as sombras do suave entardecer caem,
} 
Esses versos compostos por Mickle dão um tom pitoresco a esse episódio, pelo acréscimo de elementos típicos do medievalismo inglês (em estilo spenseriano): "rosy bowers"; "goblet"; "green-boughed forests by the lawns of Thames"; "roe-buck"; "dews of the morn"; "dales of Kent"; "bugle-horn"; "minstrel”.

\subsubsection{Adequação ao Gênero Épico}

Algumas das alterações efetuadas por Mickle se relacionam àquilo que Lefevere (1992) denomina universo de discurso: o conjunto de objetos, conceitos, conhecimentos, crenças e costumes compartilhados por uma determinada cultura em uma determinada época.

Podemos encontrar um exemplo disso na tradução das estrofes 23 e 27 do Canto 2. Na estrofe 23, Camões alude a formigas; na 27, a sapos. Ora, esses seres não eram considerados, no século XVIII, dignos de figurar em um poema épico. Em nota de rodapé, Mickle (CAMÕES, 1776a, pp. 53-54) reconta algumas versões da fábula da transformação de camponeses da Lícia em rãs e pergunta se é permitido, em poesia épica, o uso de comparações baseadas em uma imagem vulgar [low image]. Em defesa de Camões, Mickle alega que esse uso é amparado por Homero e Virgílio, encontrado nas Sagradas Escrituras e em poetas de todas as nações, sendo admissível se usado com elegância, como faz Camões. Além disso, acrescenta o tradutor, o símile dos sapos cumpre aqui a função de representar "não apenas a fuga, mas a baixeza dos mouros" $" 100$. Outra informação muito interessante fornecida por Mickle, que já comentamos no Capítulo 2, nota 2, ao apontarmos a influência de Dante sobre Camões, é a de que esse símile é uma imitação da Divina Comédia (Inferno, IX, 76-78, XXII, 25-27).

Come le rane innanzi a la nemica

Biscia per l'acqua si dileguan' tutte

Fin che a la terra ciascuna s'abbica. ${ }^{101}$

\footnotetext{
Alto com a dança ressoa o salão nobre:

Os telhados dourados, enquanto a Vésper reluz, prolongam

A cadência ritmada e a canção acompanhada.

Assim se passaram os dias na feliz costa da Inglaterra,

Até a cara lembrança de sua terra natal

Suspirar pelas margens do Tejo. [...]”.

100 "not only the flight, but the baseness of the Moors".

101 "E como as rãs que, ante a cobra inimiga, pela água somem rápidas e astutas, até que o bando todo a terra abriga $[\ldots]$ "

(ALIGHIERI, 1998, p. 75, tradução de Italo Eugenio Mauro).
} 
E come a l'orlo de l'acqua d'un fosso

Stan' li ranocchi pur col muso fuori

Si' che celano i piedi, e l'altro grosso. ${ }^{102}$

Apesar de todo esse empenho em defender os símiles, Mickle procura, na tradução, contornar o embaraço de ter de lidar com formigas e rãs - traduz as formigas da estrofe 23 por "Emmet" (uma palavra atualmente considerada arcaica, mas que no século XVIII era usada tão correntemente quanto "ant") com inicial maiúscula, talvez para destacar o caráter proverbial da menção, e reduz os oito versos a apenas quatro: ${ }^{103}$

\begin{tabular}{|l|l|}
\hline \multicolumn{1}{|c|}{ ORIGINAL (CANTO II, ESTROFE 23) } & \multicolumn{1}{c|}{ TRADUÇÃO (P. 52) } \\
\hline Quais pera a cova as próvidas formigas, & The care-earn'd store for Winter's dreary reign, \\
Levando o peso grande acomodado & So toil, so tug, so pant, the labouring Emmet train. \\
As forças exercitam, de inimigas & So toil'd the Nymphs, and strain'd their panting force \\
Do inimigo Inverno congelado; & To turn the Navy from its fatal course: ${ }^{104}$ \\
Ali são seus trabalhos e fadigas, & \\
Ali mostram vigor nunca esperado: & \\
Tais andavam as Ninfas estorvando & \\
À gente Portuguesa o fim nefando. & \\
\hline
\end{tabular}

E na tradução da estrofe 27, Mickle omite a palavra "rãs", valendo-se de uma perífrase: "the hoarse tenants of the sylvan lake":

\footnotetext{
102 "E qual, no charco, à beira d'água postas, ficam as rãs co'o bico só pra fora, patas e dorso a disfarçar propostas [...]"

(ALIGHIERI, 1998, p. 152, tradução de Italo Eugenio Mauro).

${ }^{103}$ A tradução de Fanshawe (1655, p. 27), bem mais literal:
}

As to their Store-House when the Houswife Ants, Carrying th'unequal Burthens plac't with slight To their small shoulders (lest cold Winter's wants Surprize them helpless) exercise their might; This tugs, that shoves, one runs, another pants; Strength far above their size, they All unite:

So toyl the Nymphs, to snatch and to defend The men of Lusus from a dismal end.

104 “A provisão, obtida com cuidado, para o terrível reinado do Inverno Tanto trabalha, tanto se esforça, tanto ofega, a caravana de formigas trabalhadoras. Da mesma forma trabalharam as Ninfas, e esforçaram-se, ofegantes Para desviar o Navio de seu curso fatal". 


\begin{tabular}{|l|l|}
\hline \multicolumn{1}{|c|}{ ORIGINAL (CANTO II, ESTROFE 27) } & \multicolumn{1}{c|}{ TRADUÇÃO (PP. 53-54) } \\
\hline Assi como em selvática alagoa & Thus the hoarse tenants of the sylvan lake, \\
As rãs, no tempo antigo Lícia gente, & A Lycian race of old, to flight betake, \\
Se sentem porventura vir pessoa, & At every sound they dread Latona's hate, \\
Estando fora da água incautamente, & And doubled vengeance of their former fate; \\
$\begin{array}{l}\text { Daqui e dali saltando (o charco soa), } \\
\text { Por fugir do perigo que se sente, }\end{array}$ & All sudden plunging leave the margin green, \\
E acolhendo-se ao couto que conhecem, & And but their heads above the pool are seen. ${ }^{105}$ \\
Sós as cabeças na água lhe aparecem: & \\
\hline
\end{tabular}

Mickle se vê de novo em dificuldades ao traduzir a descrição de Tritão, no Canto VI, estrofe 18. O tradutor acrescenta uma nota $(f)$ para esclarecer, acertadamente, que a descrição foi feita "no estilo dos clássicos"106; cita as descrições de Tritão feitas por Hesíodo e Pausânias. (CAMÕES, 1776a, pp. 239-240). O verso “O corpo nu, e os membros genitais” é recatadamente traduzido como "Around his loins no tangling garb he wore", e os demais detalhes burlescos ("camarões e cangrejos"; "Ostras e camarões do musgo sujos" e “caramujos") são resumidos em outros dois versos, "But all was cover'd with the slimy brood, / The snaily offspring of the unctuous flood", que transmitem um pouco do aspecto asqueroso do monstro, mas não reproduzem plenamente a enargeia (termo retórico que designava uma descrição viva, capaz de evocar um objeto na mente do leitor) clássica e eliminam o caráter pitoresco e até engraçado que a passagem apresenta para o leitor atual, pelo seu caráter de exagero e estranhamento. ${ }^{107}$

\footnotetext{
105 “Assim como as roucas moradoras da lagoa selvática, Antigamente gente de Lícia, para fugir,

A cada som temiam o ódio de Latona,

E a vingança redobrada de seu antigo destino;

Subitamente mergulhando deixam a verde margem,

E apenas as suas cabeças ficam visíveis sobre a lagoa."

106 "in the style of the classics".

${ }^{107}$ Fanshawe, que escreveu e traduziu em um tempo em que a agudeza era mais valorizada, teve, mais uma vez, a ousadia de ser literal:
}

His Body naked, and his genitals,

That he might swim with greater speed, and ease:

But with Maritine little Animals

By Hundreds, cover'd, and all hid, were these;

As Crayfish, Shrimps, and other Fish that crawles,

(Receiving theirs from the pale Moon's increase)

Oysters, and Periwinckles with their slyme;

Snayles, with their Houses on their backs that climbe.

(CAMÕES, 1655, p. 119). 


\begin{tabular}{|l|l|}
\hline \multicolumn{1}{|c|}{ ORIGINAL (CANTO VI, ESTROFE 18) } & \multicolumn{1}{c|}{ TRADUÇÃO (PP. 239-240) } \\
\hline O corpo nu, e os membros genitais, & Around his loins no tangling garb he wore, \\
Por não ter ao nadar impedimento, & But all was cover'd with the slimy brood, \\
Mas porém de pequenos animais & The snaily offspring of the unctuous flood;108 \\
Do mar todos cobertos, cento e cento: & \\
Camarões e cangrejos e outros mais, & \\
Que recebem de Febe crescimento; & \\
Ostras e birbigões, do musco sujos, & \\
Âs costas co a casca os caramujos. & \\
\hline
\end{tabular}

\subsection{FATORES IDEOLÓGICO-POÉTICOS}

Nesta seção estão três tópicos que envolvem aspectos tanto ideológicos quanto poéticos: a cristianização da mitologia camoniana atende tanto ao propósito de acomodá-la à concepção de épico dos britânicos do século XVIII quanto ao de não ofender os princípios cristãos e morais daquela sociedade; a forma como o tradutor apresenta Vasco da Gama como o herói do poema reforça os elementos comerciais da epopeia camoniana e o ajuda a enquadrar o poema no modelo épico neoclássico; e a atenuação ou supressão da voz do "Eu Poemático" camoniano serve tanto para abrandar ou suprimir as críticas sociais expressas por Camões n'Os lusíadas quanto para, mais uma vez, adequar o poema àquilo que o século XVIII britânico esperava de uma epopeia.

\subsubsection{Cristianização da Mitologia Camoniana}

\subsubsection{A cristianização da Vênus e da Ilha dos Amores}

Uma tese sustentada por Mickle ao longo de toda a sua tradução é a de que a Vênus de Camões é a "Vênus celeste", em contraposição à "Vênus terrestre". Segue, nesse ponto, o primeiro tradutor para o francês, Duperron de Castera, que, por sua vez, baseou-se na interpretação de Faria e Sousa. A caracterização da Vênus camoniana como "Vênus celeste" é o principal elemento em torno do qual Mickle constrói a sua cristianização do erotismo presente n'Os lusíadas. Não compartilhamos da visão de Mickle a esse respeito; em nossa interpretação, a Vênus camoniana expressa um conceito de amor que incorpora o erotismo. Vejamos, no entanto, como Mickle fundamenta essa interpretação.

\footnotetext{
108 “Ao redor dos quadris ele não usava nenhuma roupa que the tolhesse os movimentos, Mas tudo estava coberto de prole viscosa, A prole pegajosa da maré oleosa".
} 
Em nota de rodapé à "Dissertação sobre Os lusíadas e observações sobre a poesia épica", na Introdução ao seu Lusiad, Mickle (1776, p. cxxxv, nota) explica que existiam duas Vênus na mitologia pagã: a celeste e a terrestre. A Vênus celeste, segundo Platão, era filha de Urano, sendo por isso também chamada de Urânia. Era retratada usando armadura; suas sacerdotisas eram virgens e nenhum homem era autorizado a entrar em seus templos. De acordo com Mickle, Xenofonte teria dito que Urânia governava o amor à sabedoria e à virtude, que são prazeres da alma, enquanto a Vênus terrestre reinava sobre os prazeres corporais. $^{109}$

Ao traduzir o nome de Vênus na primeira vez que esta é mencionada no poema, Mickle utiliza o nome "Urania-Venus", seguido do aposto "Queen of sacred Love" ["Rainha do Amor sagrado"], em tradução ao adjetivo "bela" empregado no original:

\begin{tabular}{|l|l|}
\hline \multicolumn{1}{|c|}{ ORIGINAL (CANTO I, ESTROFE 33) } & \multicolumn{1}{c|}{ TRADUÇÃO (PP. 15-16) } \\
\hline Sustentava contra ele Vénus bela, & Urania-Venus, Queen of sacred Love, \\
Afeiçoada à gente Lusitana & Arose a pleader on the part of Jove; \\
Por quantas qualidades via nela & Her eyes, well pleas'd, in Lusus' sons could trace \\
Da antiga, tão amada, sua Romana; & A kindred likeness to the Roman race, \\
Nos fortes corações, na grande estrela & For whom of old such kind regard she bore; \\
Que mostraram na terra Tingitana, & The same their triumphs on Barbaria's shore, \\
E na língua, na qual quando imagina, & The same the ardour of their warlike flame, \\
Com pouca corrupção crê que é a Latina. & The manly music of their tongue the same [...]110 \\
\hline
\end{tabular}

Estabelece, assim, desde o início, a opção pela Vênus celeste, que governa o "amor sagrado" e não o profano.

Logo em seguida, na tradução da estrofe 36, Mickle omite a referência ao amor de Marte por Vênus - provavelmente porque esse tipo de paixão não se coaduna com a Vênus celeste.

\footnotetext{
${ }^{109}$ Em O Banquete de Xenofonte (VIII, 9-10), Sócrates realmente descreve as duas Afrodites (Urânia e Pandêmia), mas se mostra em dúvida sobre se a deusa seria realmente duas ou uma só.

110 "Urania-Vênus, Rainha do Amor sagrado,

Ergueu-se como defensora diante de Júpiter;

Seus olhos, satisfeitos, nos filhos de Luso podiam perceber

Uma semelhança de parentesco com a gente Romana,

Por quem há tempos ela guardava afeição;

Os mesmos triunfos na costa de Barbaria,

$\mathrm{O}$ mesmo ardor da chama guerreira,

A música viril de sua língua a mesma [...]".
} 


\begin{tabular}{|l|l|}
\hline \multicolumn{1}{|c|}{ ORIGINAL (CANTO I, ESTROFE 36) } & \multicolumn{1}{c|}{ TRADUÇÃO (PP. 16) } \\
\hline Mas Marte, que da Deusa sustentava & When Mars, high towering o'er the rival gods, \\
Entre todos as partes em porfia, & Stept forth: stern sparkles from his eye-balls glanc'd, \\
Ou porque o amor antigo o obrigava, & And now, before the throne of Jove advanc'd, \\
Ou porque a gente forte o merecia, & O'er his left shoulder his broad shield he throws [...] $]^{111}$ \\
$\begin{array}{l}\text { De antre os Deuses em pé se levantava: } \\
\text { Merencório no gesto parecia; }\end{array}$ & \\
O forte escudo, ao colo pendurado, & \\
Deitando pera trás, medonho e irado; & \\
\hline
\end{tabular}

Mickle insere uma nota de rodapé ao traduzir a estrofe 19 do Canto II (CAMÕES, 1776a, p. 50), citando o comentário de Castera (CAMÕES, 1735, p. 140), de que muitos leitores poderiam pensar que a expressão "no mar salgado nasceu" se refere ao nascimento da Vênus terrestre. Castera nega essa interpretação, dizendo que Camões não estava pensando nas fábulas que situam o nascimento de Vênus nas espumas das ondas, misturadas ao sangue que escorria do ferimento de Urano. A fábula citada por Camões seria "mais nobre": o relato de Nigídio de que, certo dia, dois peixes levaram um ovo até a praia. Esse ovo foi chocado por dois pombos mais brancos do que a neve e deu origem à Vênus Assíria, que, na teologia pagã, é a Vênus celeste. Esta ensinou a religião à humanidade, dando-lhe lições de virtude e justiça. Em recompensa por seus trabalhos, Júpiter prometeu-lhe a realização de um desejo. Ela desejou a imortalidade dos dois peixes, que foram inseridos no zodíaco, formando o signo de Peixes. Toda essa explicação de Castera citada por Mickle contribui para a interpretação de que a Vênus de Camões é a "Vênus celeste", podendo, assim, harmonizar-se mais facilmente com as ideias cristãs, a ponto de ser considerada por Mickle como um símbolo do cristianismo.

\begin{tabular}{|l|l|}
\hline \multicolumn{1}{|c|}{ ORIGINAL (CANTO II, ESTROFE 19) } & \multicolumn{1}{c|}{ TRADUÇÃO (PP. 50-51) } \\
\hline Convoca as alvas filhas de Nereu, & And call'd the sea-born nymphs, a lovely train, \\
Com toda a mais cerúlea companhia, & From Nereus sprung; the ready nymphs obey, \\
Que, porque no salgado mar nasceu, & Proud of her kindred birth, and own her sway. \\
Das águas o poder lhe obedecia; & She tells what ruin threats her fav'rite race $[. . .]^{112}$ \\
E, propondo-lhe a causa a que desceu, & \\
Com todos juntamente se partia & \\
Pera estorvar que a armada não chegasse & \\
Aonde pera sempre se acabasse. & \\
\hline
\end{tabular}

\footnotetext{
111 "Quando Marte, assomando diante dos deuses rivais,

Deu um passo em frente: ásperas faíscas de seus globos oculares lançou,

E agora, avançando para diante do trono de Júpiter,

Sobre o ombro esquerdo joga o amplo escudo [...]"

112 "E chamou as ninfas marítimas, um grupo adorável,

Filhas de Nereu; as ninfas obedecem prontamente,

Orgulhosas de serem parentes dela, e sob seu domínio.

Ela descreve a desgraça que ameaça a sua gente favorita $[\ldots]$ "
} 
$\mathrm{Na}$ cena em que Vênus conversa com Júpiter usando de todos os seus encantos sedutores, Mickle elimina a referência a amores incestuosos ou adúlteros e, em nota de rodapé, mais uma vez cita Castera, que tenta acomodar essa passagem à sua interpretação da Vênus de Camões como "celeste" dizendo que o poeta, aqui, permitiu-se misturar várias mitologias para obter um efeito alegórico.

Vejamos, nessa cena, os trechos que foram mais modificados na tradução:

\begin{tabular}{|l|l|}
\hline \multicolumn{1}{|c|}{ ORIGINAL (CANTO II, ESTROFE 35-37) } & \multicolumn{1}{|c|}{ TRADUÇ̃̃O (PP. 57-59) } \\
\hline E, por mais namorar o soberano & And now confest before the throne of Jove, \\
Padre, de quem foi sempre amada e cara, & In all her charms appears the queen of Love: \\
Se lh' apresenta assi como ao Troiano, & Flush'd by the ardour of her rapid flight \\
Na selva Ideia, já se apresentara. & Through fields of æther and the realms of light, \\
Se a vira o caçador que o vulto humano & Bright as the blushes of the roseate morn, \\
Perdeu, vendo Diana na água clara, & New blooming tints her glowing cheeks adorn; \\
Nunca os famintos galgos o mataram, & And all that pride of beauteous grace she wore, \\
Que primeiro desejos o acabaram. & As when in Ida's bower she stood of yore, \\
& When every charm and every hope of joy \\
& Enraptured and allured the Trojan boy. \\
& Ah! had that hunter, whose unhappy fate \\
& The human visage lost by Dian's hate, \\
& Had he beheld this fairer goddess move \\
& Not hounds had slain him, but the fires of love.113 \\
\hline Pelo colo que a neve escurecia; & Adown her neck, more white than virgin snow, \\
Andando, as lácteas tetas lhe tremiam, & Of softest hue the golden tresses flow; \\
Com quem Amor brincava e não se via; & Her heaving breasts of purer, softer white \\
Da alva petrina flamas lhe saíam, & Than snow hills glistening in the moon's pale light, \\
Onde o Minino as almas acendia. & Except where covered by the sash, were bare, \\
Polas lisas colunas lhe trepavam & And Love, unseen, smil'd soft, and panted there: \\
Desejos, que como hera se enrolavam. & Nor less the zone the god's fond zeal employs, \\
& The zone awakes the flames of secret joys. \\
& As ivy-tendrils round her limbs divine \\
& Their spreading arms the young desires entwine:114 \\
\hline
\end{tabular}

113 "E agora admitida diante do trono de Júpiter,

Em todos os seus encantos aparece a rainha do Amor:

Corada pelo ardor do célere voo

Por campos de éter e reinos de luz,

Brilhantes como o rubor da aurora rósea,

Novos tons florescentes suas faces ardentes adornam;

E todo aquele orgulho de belo encanto ela ostenta,

Como outrora no bosque de Ida,

Quando todos os encantos e todas as esperanças de alegria

Extasiaram e seduziram o rapaz troiano.

$\mathrm{Ah}$ ! Se aquele caçador que, por destino infeliz,

Perdeu o rosto humano por causa do ódio de Diana,

Houvesse contemplado o movimento da deusa mais bela

Não teriam sido os cães de caça a dominá-lo, e sim as chamas do amor."

114 "Do pescoço, mais brancas do que a neve virginal,

Do matiz mais suave as tranças douradas pendem;

Os seios arfantes de um branco mais puro, mais suave

Do que montanhas nevadas reluzentes sob o pálido luar,

A não ser onde cobertos pela faixa, estavam nus,

E o Amor, invisível, sorria suavemente, e ofegava ali: 


\begin{tabular}{|c|c|}
\hline $\begin{array}{l}\text { Cum delgado cendal as partes cobre } \\
\text { De quem vergonha é natural reparo; } \\
\text { Porém nem tudo esconde nem descobre } \\
\text { O véu, dos roxos lírios pouco avaro; } \\
\text { Mas, pera que o desejo acenda e dobre, } \\
\text { Lhe põe diante aquele objecto raro. } \\
\text { Já se sentem no Céu, por toda a parte, } \\
\text { Ciúmes em Vulcano, amor em Marte. }\end{array}$ & $\begin{array}{l}\text { Below her waist, and quivering on the gale, } \\
\text { Of thinnest texture flows the silken veil: } \\
\text { (Ah! where the lucid curtain dimly shows, } \\
\text { With doubled fires the roving fancy glows!) } \\
\text { The hand of modesty the foldings threw, } \\
\text { Nor all conceal'd, nor all was given to view; }{ }^{115}\end{array}$ \\
\hline
\end{tabular}

O tradutor descreve Vênus como deslumbrante e sedutora, mas não lhe atribui a intenção explícita de "namorar o soberano Padre", como diz o original. Acrescenta termos para ressaltar o recato e a pureza celestial da Vênus ("blushes", "glowing cheeks", "more white than virgin snow", "breasts of purer, softer white") e o mite a ousada menção aos "roxos lírios", assim como os comentários sobre o ciúme de Vulcano e o amor de Marte, que aludiam à relação adúltera entre Vênus e Marte. Procura, assim, eliminar as referências que acentuam o aspecto "terrestre" e enfatizar o aspecto "celeste".

A seguir, na estrofe 42, quando Júpiter se mostra tão seduzido pela filha (e amante) que, nas palavras do Poeta, "se só se achara / Outro novo Cupido se gerara”, Mickle omite essa passagem - sobretudo por questões morais, já que aqui se faz referência a uma relação incestuosa:

\begin{tabular}{|l|l|}
\hline \multicolumn{1}{|c|}{ ORIGINAL (CANTO II, ESTROFE 42) } & \multicolumn{1}{c|}{ TRADUÇãO (P. 60) } \\
\hline E destas brandas mostras comovido, & When kindled by those charms, whose woes might move \\
Que moveram de um tigre o peito duro, & And melt the prowling Tyger's rage to love. \\
Co vulto alegre, qual, do Céu subido, & The thundering God her weeping sorrows ey'd, \\
Torna sereno e claro o ar escuro, & And sudden threw his awful state aside: \\
As lágrimas lhe alimpa e, acendido, & With that mild look which stills the driving storm, \\
Na face a beija e abraça o colo puro; & When black roll'd clouds the face of heaven deform; \\
De modo que dali, se só se achara, & With that mild visage and benignant mien \\
Outro novo Cupido se gerara. & Which to the sky restores the blue serene [...] $]^{116}$ \\
\hline
\end{tabular}

Também a cinta ocupa o ardor apaixonado do deus, A cinta desperta os desejos de prazeres secretos. Como gavinhas de hera ao redor dos divinos membros Com os braços abertos os jovens desejos se enroscam". 115 "Abaixo da cintura, e estremecendo ao vento,

Da mais fina textura cai o véu de seda:

(Ah! onde a cortina transparente mostra vagamente,

Com chamas dobradas a imaginação peregrina se anima!)

A mão do recato lançou as pregas,

Nem tudo oculto, nem tudo aberto à visão".

116 "Quando incitado por aqueles encantos, cujas angústias poderiam comover

E transformar em amor a ira do Tigre que espreita.

O Deus trovejante viu-lhe as aflições chorosas

E, de repente, deixou de lado sua postura aterrorizante:

Com aquele olhar brando que detém a enérgica tempestade,

Quando nuvens negras o rosto do céu deformam;

Com aquela expressão suave e aspecto benigno

Que ao céu devolve o azul sereno". 
Como era de se esperar, esse tratamento dado a Vênus pelo tradutor se reflete no episódio da Ilha dos Amores, também conhecida como a Ilha de Vênus. Desse episódio são eliminadas várias alusões eróticas, principalmente aquelas que poderiam escandalizar o conservadorismo cristão do século XVIII britânico, por se referirem a amores que fogem ao padrão do amor cortês, idealizado. Citaremos apenas alguns exemplos.

O trecho abrangendo parte da estrofe 34 e a estrofe 35 do Canto IX, que fala de amores nefandos e indignos, é resumido em dois versos ("In wildest dreams the rustic hind aspires, / And haughtiest lords confess the humblest fires"), sem que haja qualquer menção aos tais amores "nefandos e indignos" nem a exemplificação desses tipos de amores, como há no original:

\begin{tabular}{|l|l|}
\hline \multicolumn{1}{|c|}{ ORIGINAL (CANTO IX, ESTROFES 34-35) } & \multicolumn{1}{|c|}{ TRADUÇÃO (P. 379) } \\
\hline Destes tiros assim desordenados, & Fired by the darts, by novice archers sped, \\
Que estes moços mal destros vão tirando, & Ten thousand wild fantastic loves are bred: \\
Nascem amores mil desconcertados & In wildest dreams the rustic hind aspires, \\
Entre o povo ferido miserando; & And haughtiest lords confess the humblest fires. ${ }^{117}$ \\
E tamboril nos heróis de altos estados & \\
Exemplos mil se vêem de amor nefando, & \\
Qual o das moças Bíbli e Cinireia, & \\
Um mancebo de Assíria, um de Judeia. & \\
\hline E oós, ó poderosos, por pastoras & \\
Muitas vezes ferido o peito vedes; & \\
E por baixos e rudos, vós, senhoras, & \\
Também vos tomam nas Vulcâneas redes. & \\
Uns esperando andais nocturnas horas, & \\
Outros subis telhados e paredes; & \\
Mas eu creio que deste amor indino & \\
É mais culpa a da mãe que a do minino. & \\
\hline
\end{tabular}

Ainda no episódio da Ilha dos Amores, na tradução da estrofe 74, Canto IX, Mickle acrescenta uma referência à ideia (que, embora se afine com o que é relatado no original, não está nele explicitada de modo tão enfático) de que cada ninfa estava destinada a um marinheiro específico - conforme os princípios platônicos e cristãos: "each eager boy / Springs to the nymph whose eyes from all the rest / By singling him her secret wish confest" (em negrito no quadro).

\footnotetext{
117 "Excitados pelas flechas, lançadas por arqueiros novatos, Dez mil amores loucos e fantásticos são gerados:

Em sonhos loucos o rústico camponês se eleva,

E os senhores mais altivos confessam as mais humildes paixões."
} 


\begin{tabular}{|l|l|}
\hline \multicolumn{1}{|c|}{ ORIGINAL (CANTO IX, ESTROFE 74) } & \multicolumn{1}{c|}{ TRADUÇÃO (PP. 401-402) } \\
\hline Qual cão de caçador, sagaz e ardido, & So when the fowler to his cheek uprears \\
Usado a tomar na água a ave ferida, & The hollow steel, and on the mallard bears, \\
Vendo [ò] rosto o férreo cano erguido & His eager dog, ere bursts the flashing roar, \\
Pera a garcenha ou pata conhecida, & Fierce for the prey springs headlong from the shore, \\
Antes que soe o estouro, mal sofrido & And barking cuts the wave with furious joy: \\
Salta n' água e da presa não duvida, & So mid the billow springs each eager boy, \\
Nadando vai e latindo: assi o mancebo & Springs to the nymph whose eyes from all the rest \\
Remete à que não era irmã de Febo. & By singling him her secret wish confest.118 \\
\hline
\end{tabular}

Essa ideia de "correspondência biunívoca" entre cada ninfa e seu marinheiro é novamente enfatizada por Mickle na tradução da estrofe 2 do Canto X, com o acréscimo do adjetivo "wedded" ("wedded lovers") e dos versos "Each with the youth above the rest approved, / Each with the nymph above the rest beloved" (em negrito abaixo):

\begin{tabular}{|l|l|}
\hline \multicolumn{1}{|c|}{ ORIGINAL (CANTO X, ESTROFE 2) } & \multicolumn{1}{c|}{ TRADUÇÃO (PP. 416-417) } \\
\hline $\begin{array}{l}\text { Quando as fermosas Ninfas, cos amantes } \\
\text { Pela mão, já conformes e contentes, }\end{array}$ & $\begin{array}{l}\text { Led by the sacred ray from every bower, } \\
\text { A joyful train, the wedded lovers pour: } \\
\text { E de metais ornados reluzentes, }\end{array}$ \\
$\begin{array}{l}\text { Mandados da Rainha, que abundantes } \\
\text { Eesas d' altos manjares excelentes }\end{array}$ & Each with the youth above the rest approved, \\
Lhe tinha aparelhados, que a fraqueza & They seek the palace of the sovereign dame; \\
Restaurem da cansada natureza. & Of gold the towers, of gold the pillars shone, \\
& The walls were chrystal starr'd with precious stone. \\
& Amid the hall arose the festive board \\
& With nature's choicest gifts promiscuous stor'd: \\
& So will'd the Goddess to renew the smile \\
& Of vital strength, long worn by days of toil. ${ }^{119}$ \\
\hline
\end{tabular}

Entre as estrofes 88 e 89 do Canto IX, Mickle insere alguns versos reproduzindo a fala da Sibila na Eneida (VI, 258): Procul, o procul este profani ["Longe daqui, longe daqui,

\footnotetext{
118 “Como quando o caçador ergue junto ao rosto O cano de ferro, e para o pato selvagem o aponta, Seu cão ansioso, antes que irrompa o relampejante estrondo, Feroz sobre a presa arroja-se, impetuoso, na praia, E latindo atravessa as ondas com uma alegria selvagem:

Assim em meio aos vagalhões salta cada um dos ansiosos rapazes,

Salta para a ninfa cujos olhos, entre todos os outros, Escolhendo a ele o desejo secreto [da ninfa] confessaram."

119 "Guiada pelo raio sagrado vindo de cada caramanchão,

Uma caravana alegre, os amantes casados afluem:

Cada uma com o jovem acima de todos aprovado, Cada um com a ninfa acima de todas amada,

Eles buscam o palácio da dama soberana;

No alto de uma montanha reluzia a maravilhosa construção:

De ouro as torres, de ouro os pilares brilhavam,

As paredes reluziam, cristalinas, com pedras preciosas.

No meio do salão se erguia o banquete festivo

Com as mais refinadas dádivas da natureza misturadas:

Assim quis a Deusa renovar o sorriso

De força vital, muito desgastado por dias de árduo trabalho."
} 
profanos"] para que não haja dúvida de que as cenas que o leitor acaba de ler não são profanas, e que os prazeres ali descritos são "castos e divinos". Com esses versos, que não apresentam nenhuma correspondência no original, o tradutor reforça a sua interpretação da Ilha dos Amores como uma alegoria espiritual:

Hence, ye profane - the song melodious rose, By mildest zephyrs wafted through the boughs, Unseen the warblers of the holy strain Far from these sacred bowers, ye leud profane! Hence each unhallowed eye, each vulgar ear; Chaste and divine are all the raptures here. ${ }^{120}$ (CAMÕES, 1776a, p. 408).

Da mesma forma, na descrição do banquete oferecido por Tétis aos navegantes portugueses (X, 3-4), Mickle acrescenta versos para ressaltar os aspectos de virtude espiritual: "Sacred to noblest worth and Virtue's ear, / Divine as genial was the banquet here"121. Até o vinho ali servido inspira apenas prazeres espirituais: "Divinest transport this alone inspires". (CAMÕES, 1776a, p. 417).

Embora a tendência principal da tradução de Mickle seja a atenuação dos elementos eróticos, há alguns raros momentos em que a nota sensual é preservada e outros em que há uma amplificação do erotismo presente no original. Todas as ocorrências que encontramos dessa amplificação do erotismo na tradução se referem a descrições do corpo feminino, e não envolvem qualquer menção a amores "nefandos" ou "indignos". Entendemos que Mickle, como pré-romântico, demonstra a sua sensibilidade diante da beleza lírica e sensual do poema camoniano, e procura preservá-la, ou mesmo acentuá-la, quando essa beleza não implica, em sua interpretação, uma ofensa aos princípios neoclássicos ou à moralidade britânica setecentista. Um exemplo é a tradução da estrofe 26 do Canto IX, em que Mickle reforça o lirismo e sensualidade ao descrever a nudez de Diana e a reação que esta desperta no jovem Actéon (trecho em negrito), quando o original, sem mencionar que Diana estivesse nua, diz apenas "Mostrar-lhe a formosura de Diana":

\footnotetext{
120 "Longe daqui, vós, profanos - a canção melodiosa se elevou, Carregada pelas mais suaves brisas entre os ramos, Invisíveis as aves canoras da melodia sagrada Longe destes bosques sagrados, vós, lascivos profanos! Longe daqui todos os olhos não santificados, todos os olhos vulgares; Castos e divinos são todos os êxtases aqui."

121 "Sagrado para o valor mais nobre e o ouvido da Virtude, / Tão divino quanto afável era o banquete ali".
} 


\begin{tabular}{|l|l|}
\hline \multicolumn{1}{|c|}{ ORIGINAL (CANTO IX, ESTROFE 26) } & \multicolumn{1}{c|}{ TRADUÇÃO (PP. 376-377) } \\
\hline Via Actéon na caça tão austero, & A young Actæon, scornful of his lore, \\
$\begin{array}{l}\text { De cego na alegria bruta, insana, } \\
\text { Que, por seguir um feio animal fero, }\end{array}$ & Morn after morn pursues the foamy boar, \\
Foge da gente e bela forma humana; & In desart wilds devoted to the chace; \\
E por castigo quer, doce e severo, & Each dear enchantment of the female face \\
Mostrar-lhe a formosura de Diana. & Spurn'd and neglected: Him enraged he sees, \\
E guarde-se não seja inda comido & And sweet, and dread his punishment decrees. \\
Desses cães que agora ama, e consumido). & Before his ravish'd sight, in sweet surprise, \\
& Naked in all her charms shall Dian rise; \\
& With love's fierce flames his frozen heart shall burn, \\
& Coldly his suit, the nymph, unmoved, shall spurn. \\
& Of these loved dogs that now his passions sway, \\
& Ah, may he never fall the hapless prey!122 \\
\hline
\end{tabular}

Outro exemplo em que a tradução reforça a sensualidade do original: ao traduzir a estrofe 65 do Canto IX, Mickle acrescenta - segundo Monica Letzring (1965, p. 41), imitando o estilo de Spenser no episódio da "Morada da Felicidade" ["Bower of Bliss"] da Faerie Queene - vários versos (ressaltados em negrito) que amplificam a sensualidade da cena, descrevendo as ninfas se banhando nuas no lago:

122 "Um jovem Actéon, desdenhoso de suas tradições, Manhã após manhã persegue o javali espumoso, Em desertos selvagens devotado à caça; Todo caro encanto do rosto feminino Desdenhado e desprezado: ele o vê enraivecido, E doce, e terrivel sua punição decreta.

Diante de sua vista deslumbrada, em doce surpresa,

Nua com todos os seus encantos Diana se erguerá; Com as ardentes chamas do amor seu coração gelado queimará, Friamente a corte dele a ninfa, sem se comover, desdenhará.

Desses cães amados que agora suas paixões dominam,

$\mathrm{Ah}$, que ele nunca se transforme em desafortunada presa!" 


\begin{tabular}{|c|c|}
\hline ORIGINAL (CANTO IX, ESTROFE 65) & TRADUÇÃO (P. 397) \\
\hline $\begin{array}{l}\text { Assi lho aconselhara a mestra experta: } \\
\text { Que andassem pelos campos espalhadas; } \\
\text { Que, vista dos barões a presa incerta, } \\
\text { Se fizessem primeiro desejadas. } \\
\text { Algũas, que na forma descoberta } \\
\text { Do belo corpo estavam confiadas, } \\
\text { Posta a artificiosa formosura, } \\
\text { Nuas lavar se deixam na água pura. }\end{array}$ & $\begin{array}{l}\text { Now seeming careless, fearful now and coy, } \\
\text { So taught the goddess of unutter'd joy, } \\
\text { And gliding through the distant glades display } \\
\text { Each limb, each movement, naked as the day. } \\
\text { Some light with glee in careless freedom take } \\
\text { Their playful revels in the chrystal lake; } \\
\text { One trembling stands no deeper than the knee } \\
\text { To plunge reluctant, while in sportful glee } \\
\text { Another o'er her sudden laves the tide; } \\
\text { In pearly drops the wishful waters glide, } \\
\text { Reluctant dropping from her breasts of snow; } \\
\text { Beneath the wave another seems to glow; } \\
\text { The amorous waves her bosom fondly kiss'd, } \\
\text { And rose and fell, as panting, on her breast. } \\
\text { Another swims along with graceful pride, } \\
\text { Her silver arms the glistening waves divide, } \\
\text { Her shining sides the fondling waters lave, } \\
\text { Her glowing cheeks are brighten'd by the wave, } \\
\text { Her hair, of mildest yellow, flows from side } \\
\text { To side, as o'er it plays the wanton tide, } \\
\text { And careless as she turns, her thighs of snow } \\
\text { Their tapering rounds in deeper lustre shew.123 }\end{array}$ \\
\hline
\end{tabular}

\subsubsection{Omissão de Referências Mitológicas}

Muitas referências pagãs presentes n'Os lusíadas são eliminadas na tradução de Mickle. Alguns exemplos: "Qual aparece o arco rutilante / Da bela ninfa filha de Taumante" (II, 99) é traduzido como "with the splendor of the rainbow vie"124 (CAMÕES, 1776a, p. 79); "Apolo" (II, 105) é traduzido como “Sun” (p. 81); logo a seguir, na estrofe 106, a menção a Vulcano é

\footnotetext{
123 "Ora com um ar descuidado, ora temerosa e recatada, Como ensinou a deusa da alegria inexprimida, E deslizando pelas clareiras distantes exibiam Cada membro, cada movimento, nuas como o dia.
}

Algumas irradiando alegria em liberdade despreocupada fazem Deleitosos folguedos no lago de cristal;

Uma, tiritando, não avança mais fundo do que até o joelho Relutante em mergulhar, embora com uma alegria folgazã A súbita maré passa sobre outra;

Em gotas peroladas as águas desejosas escorrem,

Relutantemente caindo-lhe dos seios níveos;

Sob as ondas outra parece ruborizar-se;

As ondas amorosas beijaram-lhe carinhosamente o peito,

E subiram e desceram, como que ofegantes, sobre o seio.

Outra nada com um orgulho gracioso,

Os braços prateados dividem as ondas reluzentes,

Os flancos cintilantes as águas carinhosas lavam,

As faces ardentes são iluminadas pelas ondas,

Os cabelos, do amarelo mais suave, fluem de um lado

A outro, enquanto sobre eles brinca a maré voluptuosa,

E despreocupada ao se virar, as coxas níveas

Mostram em esplendor mais profundo as redondezas afuniladas."

124 "com o esplendor do arco-íris compete". 
omitida na tradução; "o duro Marte" (III, 30) é traduzido como "Civil Discord" (p. 97). No relato do sonho de D. Manuel, Mickle cristianiza o verso "Morfeu em várias formas lhe aparece" (IV, 68) traduzindo-o como "When sent by heaven a sacred dream inspired / His labouring mind"125 (p. 175); continuando a cristianização do sonho, Mickle deixa de mencionar Febo na estrofe 75 ("Estendeu nisto Febo o claro manto / Pelo escuro Hemisfério sonolento") e acrescenta uma menção a um "sacred sign": "The wondering monarch thrill'd with awe divine, / Weighs in his lofty thoughts the sacred sign"126 (p. 177).

Em muitas passagens, Mickle procura separar a mistura de mitologia pagã e cristianismo feita por Camões. Assim, ao traduzir a estrofe 38 do Canto I, Mickle omite a expressão "que criaste" - que é abusiva, já que Júpiter não é considerado, na mitologia grega, o criador do universo (BIRCHAL, 2005, p. 99) -, trocando-a por atributos tradicionais de Júpiter na mitologia grega (“Thine is the sceptre, thine the thunder's fire, / Supreme dominion thine"):

\begin{tabular}{|l|l|}
\hline \multicolumn{1}{|c|}{ ORIGINAL (CANTO I, ESTROFE 38) } & \multicolumn{1}{c|}{ TRADUÇÃO (P. 17) } \\
\hline E disse assim: "Ó Padre, a cujo império & When thus the warrior: "O Eternal Sire, \\
Tudo aquilo obedece, que criaste, & Thine is the sceptre, thine the thunder's fire, \\
Se esta gente, que busca outro hemisfério, & Supreme dominion thine; then, Father, hear, \\
Cuja valia, e obras tanto amaste, & Shall that bold race which once to thee was dear, \\
Não queres que padeçam vitupério, & Who now fulfilling thy decrees of old, \\
Como há já tanto tempo que ordenaste, & Through these wild waves their fearless journey hold, \\
Não ouças mais, pois és juiz direito, & Shall that bold race no more thy care engage, \\
Razões de quem parece que é suspeito." & But sink the victims of unhallow'd rage!"127 \\
\hline
\end{tabular}

\subsubsection{Vasco da Gama, o herói}

O herói da epopeia de Camões é o povo português. Isso já se evidencia no título ("Os lusíadas" designa os portugueses ${ }^{128}$ ) e na proposição (estrofes 1 a 3), em que é declarado o

\footnotetext{
125 "Quando, enviado pelos Céus, um sonho sagrado inspirou / Sua mente ativa".

126 "O estupefato monarca, tomado de assombro divino, / Pondera em seus elevados pensamentos o sinal sagrado".

127 "Quando assim [disse] o guerreiro: "Ó Senhor Eterno,

Teu é o cetro, teu é o fogo do trovão,

Supremo domínio o teu; então, Pai, escuta,

Deve aquela gente ousada que já te foi cara,

Que agora cumprindo teus decretos de outrora,

Por essas ondas inexploradas sua jornada destemida empreende,

Deve essa gente ousada não mais teu cuidado receber,

Mas afundar vítima de uma ira não santificada!"

128 A palavra "lusíadas" foi um neologismo criado pelo humanista André de Resende no poema Carmen eruditum et elegans Angeli Andreae Resendii Lusitani, aduersus stolidos politioris litteraturae oblatratores, mais tarde intitulado Erasmi Encomium, publicado em 1531. É uma forma derivada da palavra Lusus [Luso]
} 
assunto do poema. O Poeta se propõe a cantar "as armas e os barões assinalados" que se aventuraram por territórios desconhecidos e edificaram novos reinos (estrofe 1); assim como "as memórias gloriosas" dos reis e dos heróis que dilataram o império e a fé (estrofe 2). O verso 21 sintetiza a exposição do assunto do poema nas três estrofes iniciais: "[Que] eu canto o peito ilustre Lusitano".

Na tradução de Mickle, diferentemente do que acontece no original, Vasco da Gama é o herói. Isso fica bem claro já na terceira estrofe do Canto I, quando Mickle traduz "Que eu canto o peito ilustre Lusitano" como "A nobler hero's deeds demand my lays / Than e'er adorn'd the song of ancient days, / Illustrious GAMA, whom the waves obey'd, / And whose dread sword the fate of empire sway'd.". A grafia do nome "Gama" com as letras em versalete se mantém ao longo de toda a tradução, destacando o nome do herói.

\begin{tabular}{|l|l|}
\hline \multicolumn{1}{|c|}{ ORIGINAL (CANTO I, ESTROFE 3) } & \multicolumn{1}{c|}{ TRADUÇÃO (PP. 3-4) } \\
\hline $\begin{array}{l}\text { Cessem do sábio Grego e do Troiano } \\
\text { As navegações grandes que fizeram; } \\
\text { Cale-se de Alexandro e de Trajano }\end{array}$ & Let Fame with wonder name the Greek no more, \\
$\begin{array}{l}\text { A fama das vitórias que tiveram; } \\
\text { Que eu canto o peito ilustre Lusitano, } \\
\text { A quem Neptuno e Marte obedeceram. } \\
\text { Cesse tudo o que a Musa antiga canta, } \\
\text { Que outro valor mais alto se alevanta. }\end{array}$ & Nor more the Trojan's wandering voyage boast, \\
& No more let Rome exult in Trajan's name, \\
& A nor Eastern conquests Ammon's pride proclaim; \\
& Than e'er adorn'd the song of ancient days, \\
& Illustrious GAMA, whom the waves obey'd, \\
And whose dread sword the fate of empire sway'd. ${ }^{129}$ \\
\hline
\end{tabular}

A decisão de Mickle de se concentrar em Vasco da Gama se explica tanto por fatores ideológicos quanto poéticos. Ideologicamente, Vasco da Gama simbolizava muito bem os ideais de expansão marítima e comercial. Quanto à poética, a questão é que, segundo a maioria dos teóricos neoclássicos, os padrões do gênero exigiam que um poema épico apresentasse apenas um herói. Assim, do início ao fim de sua tradução, Mickle se empenhou em distinguir e enaltecer a figura de Vasco da Gama.

mediante o sufixo -iades [descendente], conforme o modelo de Virgílio: Aenead, ae, -um [descendentes de Eneias, Eneiadas]. Camões foi o primeiro a empregar a palavra em português. (PEREIRA, 2011, pp. 489-490).

129 "Que a Fama não mencione mais o grego com admiração,

As terras que viu, as dificuldades por que passou no mar;

Nem exalte a viagem errante do troiano,

As tempestades que enfrentou, as muitas costas que percorreu:

Que Roma não mais exalte o nome de Trajano,

Nem os conquistadores do Oriente proclamem o orgulho de Amon;

Exigem meus cantos as façanhas de um herói mais nobre

Do que os outros que adornaram o canto dos dias de outrora

O Ilustre GAMA, a quem as ondas obedeciam

E cuja espada temida influenciou o destino do império.” 
$\mathrm{Na}$ apresentação do Gama (acima) já se evidenciam algumas das características do herói de Mickle: fama ("illustrious"), capacidade de liderança e de impor sua vontade ("whom the waves obey'd / And whose dread sword the fate of empire sway'd").

Na estrofe seguinte, Mickle continua seu trabalho de substituir, no papel de herói, o povo lusitano por Vasco da Gama, adicionando o verso "With all the boldness of your hero's fire" (em negrito no quadro abaixo) para se referir a Vasco.

\begin{tabular}{|l|l|}
\hline \multicolumn{1}{|c|}{ ORIGINAL (CANTO I, ESTROFE 4) } & \multicolumn{1}{c|}{ TRADUÇÃO (P. 4) } \\
\hline E vós, Tágides minhas, pois criado & And you, fair nymphs of Tagus, parent stream, \\
Tendes em mi um novo engenho ardente, & If e'er your meadows were my pastoral theme, \\
Se sempre em verso humilde celebrado & While you have listen'd, and by moonshine seen \\
Foi de mi vosso rio alegremente, & My footsteps wander o'er your banks of green, \\
Dai-me agora um som alto e sublimado, & O come auspicious, and the song inspire \\
Um estilo grandíloco e corrente, & With all the boldness of your Hero's fire [...] \\
$\begin{array}{l}\text { Por que de vossas águas Febo ordene } \\
\text { Que não tenham enveja às de Hipocrene. }\end{array}$ & \\
\hline
\end{tabular}

Na tradução da estrofe 14 do Canto I (que já citamos em 5.2.3, ao falarmos sobre Afonso de Albuquerque), Mickle introduz outra menção a Gama (em negrito no quadro a seguir) no topo da lista de heróis:

\begin{tabular}{|c|c|}
\hline ORIGINAL (CANTO I, ESTROFE 14) & TRADUÇÃO (PP. 8-9) \\
\hline $\begin{array}{l}\text { Nem deixarão meus versos esquecidos } \\
\text { Aqueles que nos Reinos lá da Aurora } \\
\text { Se fizeram por armas tão subidos, } \\
\text { Vossa bandeira sempre vencedora: } \\
\text { Um Pacheco fortíssimo e os temidos } \\
\text { Almeidas, por quem sempre o Tejo chora, } \\
\text { Albuquerque terríbil, Castro forte, } \\
\text { E outros em quem poder não teve a morte. }\end{array}$ & $\begin{array}{l}\text { Those heroes, too, who thy bold flag unfurl'd, } \\
\text { And spread thy banners o'er the Eastern world, } \\
\text { Whose spears subdued the kingdoms of the morn, } \\
\text { Their names and glorious wars the song adorn: } \\
\text { The daring GAMA, whose unequal'd name } \\
\text { Proud monarch shines o'er all of naval fame: } \\
\text { Castro the bold, in arms a peerless knight, } \\
\text { And stern Pacheco, dreadful in the fight: } \\
\text { The two Almeydas, names for ever dear, } \\
\text { By Tago's nymphs embalm'd with many a tear; } \\
\text { Ah, still their early fate the nymphs shall mourn, } \\
\text { And bathe with many a tear their hapless urn: } \\
\text { Nor shall the godlike Albuquerque restrain } \\
\text { The Muse's fury; o'er the purpled plain } \\
\text { The Muse shall lead him in his thund'ring car } \\
\text { Amidst his glorious brothers of the war, } \\
\text { Whose fame in arms resounds from sky to sky, } \\
\text { And bids their deeds the power of death defy. }{ }^{131}\end{array}$ \\
\hline
\end{tabular}

\footnotetext{
130 "E vós, belas ninfas do Tejo, rio matriz,
}

Se as vossas campinas já foram o meu tema pastoral,

Enquanto vós escutastes e vistes ao luar

Minhas pegadas errarem pelas vossas verdes margens,

$\mathrm{Oh}$, vinde auspiciosas, e inspirai o canto

Com toda a ousadia do ardor do vosso Herói [...]"

131 "Aqueles heróis, também, que vossa ousada bandeira desfraldaram,

E espalharam vossos estandartes pelo mundo oriental, 
Em vários pontos da tradução, Mickle atribui ao Gama características positivas que não estão explicitadas no original. O termo "Capitão", por exemplo, normalmente é traduzido por Mickle como "Illustrious GAMA" e, de vez em quando, como "Brave GAMA" ou ainda "Brave VASCO".

As ações de Vasco da Gama, que no original muitas vezes aparecem de modo discreto, são ressaltadas por Mickle sempre que possível. Entre os inúmeros exemplos presentes no Lusiad, citaremos apenas alguns, como este, na tradução da estrofe 84 do Canto I:

\begin{tabular}{|l|l|}
\hline \multicolumn{1}{|c|}{ ORIGINAL (CANTO I, ESTROFE 84) } & \multicolumn{1}{c|}{ TRADUÇÃO (PP. 31-32) } \\
\hline Já o raio Apolíneo visitava & Apollo now had left his watery bed, \\
Os Montes Nabateios acendido, & And o'er the mountains of Arabia spread \\
Quando Gama cos seus determinava & His rays that glow'd with gold; when GAMA rose, \\
De vir por água a terra apercebido. & And from his bands a trusty squadron chose: \\
A gente nos batéis se concertava, & Three speedy barges brought their casks to fill \\
Como se fosse o engano já sabido; & From gurgling fountain, or the chrystal rill: \\
Mas pôde suspeitar-se facilmente, & Full-arm'd they came, for brave defence prepared, \\
Que o coração pres[s]ago nunca mente. & For martial care is ever on the guard: \\
& And secret warnings ever are imprest \\
& On wisdom such as waked in GAMA's breast. ${ }^{132}$ \\
\hline
\end{tabular}

Enquanto Camões diz "Quando o Gama, cos seus determinava [...]”, Mickle transfere todas as ações para o Gama pessoalmente: "when GAMA rose, / And from his bands a trusty squadron chose". Nos versos finais, quando Camões alude ao espírito precavido dos

Cujas lanças subjugaram os reinos do levante,

Seus nomes e guerras gloriosas adornam o canto:

O audacioso GAMA, cujo nome inigualado

Monarca orgulhoso brilha sobre todos os de fama naval:

Castro o ousado, em armas um cavaleiro incomparável,

E o severo Pacheco, terrível na luta:

Os dois Almeidas, nomes para sempre queridos,

Pelas ninfas do Tejo embalsamados com muitas lágrimas;

Ah, sua fatalidade prematura as ninfas ainda lamentarão,

E banharão com muitas lágrimas sua urna desafortunada:

O divino Albuquerque também não conterá

A fúria da Musa; sobre a planície cor de púrpura

A Musa o conduzirá em seu carro trovejante

Em meio aos seus gloriosos irmãos na guerra,

Cuja fama em armas ressoa de céu a céu,

E desafia com suas façanhas o poder da morte."

132 "Apolo agora abandonara seu leito aquoso,

E sobre as montanhas da Arábia espalhava

Os raios com brilho de ouro; quando GAMA se levantou,

E entre seu grupo um esquadrão confiável selecionou:

Três céleres barcaças levaram barris para encher

Na fonte gorgolejante, ou no riacho cristalino:

Completamente armados eles foram, preparados para a corajosa defesa,

Pois o zelo marcial está sempre vigilante:

E advertências secretas são sempre registradas

Em uma sabedoria como a que vigiava no peito de GAMA." 
portugueses (“coração pressago"), Mickle atribui todos os cuidados à sabedoria e experiência marcial do Gama: "On wisdom such as waked in GAMA's breast".

No início do Canto II, Mickle promove Gama novamente a protagonista da cena, acrescentando os versos "When GAMA heard the creaking of the oar, / And markt the white waves lengthening from the shore" (em negrito no quadro):

\begin{tabular}{|l|l|}
\hline \multicolumn{1}{|c|}{ ORIGINAL (CANTO II, ESTROFE 1) } & \multicolumn{1}{c|}{ TRADUÇ̃̃O (P. 43) } \\
\hline JÁ neste tempo o lúcido Planeta, & THE fervent lustre of the evening ray \\
Que as horas vai do dia distinguindo, & Behind the western hills now died away, \\
Chegava à desejada e lenta meta, & And night, ascending from the dim-brow'd east, \\
A luz celeste às gentes encobrindo; & The twilight gloom with deeper shades increast; \\
E da casa marítima secreta & When GAMA heard the creaking of the oar, \\
Lhe estava o Deus Nocturno a porta abrindo, & And markt the white waves lengthening from the shore. \\
Quando as infidas gentes se chegaram & In many a skiff the eager natives came, \\
Âs naus, que pouco havia que ancoraram. & Their semblance friendship, but deceit their aim. 133 \\
\hline
\end{tabular}

Na tradução da estrofe 7 do Canto II, tudo o que acontece ou aconteceu é atribuído por Mickle a Gama - foi ele quem salvou os condenados da morte, pessoalmente: "sav'd by GAMA from the shameful death".

\begin{tabular}{|l|l|}
\hline \multicolumn{1}{|c|}{ ORIGINAL (CANTO II, ESTROFE 7) } & \multicolumn{1}{c|}{ TRADUÇÃO (PP. 46-47) } \\
\hline E de alguns que trazia, condenados & With GAMA sail'd a bold advent'rous band, \\
Por culpas e por feitos vergonhosos, & Whose headlong rage had urg'd the guilty hand: \\
Por que pudessem ser aventurados & Stern Justice for their crimes had ask'd their blood, \\
Em casos desta sorte duvidosos, & And pale in chains condemn'd to death they stood; \\
Manda dous mais sagazes, ensaiados, & But, sav'd by GAMA from the shameful death, \\
Por que notem dos Mouros enganosos & The bread of peace had seal'd their plighted faith, \\
A cidade e poder, e por que vejam & The desolate coast, when ordered, to explore, \\
Os Cristãos, que só tanto ver desejam. & And dare each danger of the hostile shore: \\
& From this bold band he chose the subtlest two, \\
& The port, the city, and its strength to view, \\
& To mark if fraud its secret head betrayed, \\
& Or if the rites of heaven were there displayed. ${ }^{134}$ \\
\hline
\end{tabular}

133 " $O$ brilho intenso dos raios do fim de tarde

Atrás das montanhas do oeste agora se extinguiu,

E a noite, ascendendo do leste de contornos indistintos,

A melancolia do crepúsculo com sombras mais profundas intensificou;

Quando GaMA escutou o rangido do remo,

$\mathbf{E}$ percebeu as ondas brancas se ampliando a partir da praia.

Em muitos esquifes os ávidos nativos se aproximavam,

Com aparência amistosa, mas objetivos traiçoeiros."

134 "Com GAMA navegou um grupo ousado e aventureiro,

Cuja raiva impetuosa havia incitado à mão culpada:

A severa Justiça por seus crimes pedira-lhes o sangue,

E pálidos, acorrentados, postavam-se os condenados à morte;

Mas, salvos por GAMA da morte vergonhosa,

O pão da paz selara o seu compromisso,

A costa despovoada, quando lhe ordenassem, explorar,

E enfrentar todos os perigos da terra hostil: 
A tradução da estrofe 74 do Canto II é outro exemplo em que Mickle dá destaque às ações de Vasco da Gama, enquanto no original as ações são coletivas. Percebe-se, neste exemplo, o trabalho do tradutor no sentido de compor uma caracterização física e psicológica do herói, interpretando-lhe os pensamentos e sentimentos: "Unawed by fear / With warlike pomp adorn'd, himself sincere". Gama recebe também atributos elogiosos: "generous" e "valiant".

\begin{tabular}{|l|l|}
\hline \multicolumn{1}{|c|}{ ORIGINAL (CANTO II, ESTROFE 74) } & \multicolumn{1}{c|}{ TRADUÇÃO (P. 71) } \\
\hline Enche-se toda a praia Melindana & Melinda's sons the shore in thousands crowd, \\
Da gente que vem ver a leda armada, & And offering joyful welcome shout aloud: \\
Gente mais verdadeira e mais humana, & And truth the voice inspired. Unawed by fear, \\
Que toda a doutra terra atrás deixada. & With warlike pomp adorn'd, himself sincere, \\
Surge diante a frota Lusitana, & Into the port the generous GAMA rides; \\
Pega no fundo a âncora pesada; & His stately vessels range their pitchy sides \\
Mandam fora um dos Mouros que tomaram, & Around their chief; the bowsprits nod the head, \\
Por quem sua vinda ao Rei manifestaram. & And the barb'd anchors gripe the harbour's bed. \\
& Strait to the king, as friends to generous friends, \\
& A captive Moor the valiant GAMA sends. ${ }^{135}$ \\
\hline
\end{tabular}

Mickle inicia a tradução do Canto VII com uma saudação a Vasco da Gama ("Hail glorious Chief! where never chief before / Forced his bold way, all hail on India's shore!") que precede a saudação aos heróis lusitanos ("And hail, ye Lusian heroes, fair and wide / What groves of palm, to haughty Rome deny'd, / For you by Ganges' lengthening banks unfold!"). No original, além de não haver menção a Gama, a saudação é menos solene do que a de Mickle, parecendo mais uma exclamação de júbilo: “Ora sus, gente forte, que na guerra / Quereis levar a palma vencedora: / Já sois chegados, já tendes diante / A terra de riquezas abundante".

\footnotetext{
Desse grupo audacioso ele escolheu os dois mais astutos, Para observar o porto, a cidade e suas forças, Para notar se a cabeça secreta da fraude se revelava, Ou se os ritos do Paraíso eram ali executados."

135 "Os filhos de Melinde acumulam-se aos milhares na praia,

$\mathrm{E}$ oferecendo alegres boas-vindas gritam alto:

E verdade a voz inspirava. Sem medo,

Adornado em pompa guerreira, ele próprio sincero,

O porto o generoso GAMA adentra;

Seus navios majestosos alinham as laterais cobertas de breu

Ao redor de seu comandante; os gurupés balançam a cabeça,

$\mathrm{E}$ as âncoras denteadas se agarram ao leito do porto.

Direto ao rei, como amigos a generosos amigos,

O valente GAMA envia um mouro cativo."
} 


\begin{tabular}{|l|l|}
\hline \multicolumn{1}{|c|}{ ORIGINAL (CANTO VII, ESTROFE 1) } & \multicolumn{1}{c|}{ TRADUÇÃO (P. 271) } \\
\hline JÁ se viam chegados junto à terra, & HAIL glorious Chief! where never chief before \\
Que desejada já de tantos fora, & Forced his bold way, all hail on India's shore! \\
Que entre as correntes Índicas se encerra, & And hail, ye Lusian heroes, fair and wide \\
E o Ganges, que no Céu terreno mora. & What groves of palm, to haughty Rome deny'd, \\
Ora sus, gente forte, que na guerra & For you by Ganges' lengthening banks unfold! \\
Quereis levar a palma vencedora: & What laurel forests on the shores of gold \\
Já sois chegados, já tendes diante & For you their honours ever verdant rear, \\
A terra de riquezas abundante. & Proud with their leaves to twine the Lusian spear!136 \\
\hline
\end{tabular}

Para finalizar os exemplos relacionados à exaltação de Vasco da Gama, citaremos aquele que talvez seja o maior "escândalo" da tradução de Mickle de Os lusíadas - um exemplo que contém omissões, acréscimos, amplificações e outros tipos de modificação. No final do Canto VIII, Mickle suprimiu totalmente 19 das últimas 24 estrofes do original, conservando o conteúdo das outras cinco apenas em parte, reaproveitando-o de modo resumido e em contexto alterado, e acrescentou 53 versos inteiramente de sua criação; na sequência, no início do Canto IX, Mickle eliminou 11 das primeiras 15 estrofes, traduziu quatro parcialmente em outro contexto e adicionou 308 versos de sua lavra. Todas essas alterações foram feitas para reescrever a narrativa do original sobre o episódio da disputa entre Vasco da Gama e os governantes de Calecute (o samorim e o catual). Vejamos, então, quais são as diferentes histórias contadas pelo original e pela tradução. (FERREIRA, 1992b, p. 78; SOUTHEY, 1822, p. 32; TAYLOR, 1937, p. 162).

No original, Camões procura, até certo ponto, seguir as fontes históricas: o catual impediu os portugueses de voltarem para suas naus com as mercadorias que haviam obtido por meio de trocas com os comerciantes locais. Em represália, Vasco da Gama mandou aprisionar alguns comerciantes de Calecute que chegaram às naus portuguesas para vender pedras preciosas. Com isso, obteve um acordo, pelo qual os portugueses seriam autorizados pelo samorim a voltar às naus e Vasco da Gama libertaria os prisioneiros. Os portugueses voltaram, de fato, às naus, mas Gama não libertou todos os comerciantes: levou alguns consigo a Lisboa como prisioneiros, descumprindo o acordo. ${ }^{137}$

\footnotetext{
136 "SALVE glorioso Comandante! onde nenhum comandante jamais

Forçou seu ousado caminho, todos saúdam na costa da Índia!

E salve, vós, heróis lusitanos, belos e vastos

Os bosques de palmeiras, à arrogante Roma negados,

Para vós pelas extensas margens do Ganges se abrem!

As florestas de loureiros nas praias de ouro

Para vós suas homenagens sempre verdejantes erguem,

Orgulhosas por entrelaçar suas folhas à lança lusitana!"

${ }^{137}$ O poema original diz que Gama libertou apenas alguns dos reféns, mas afirma também que os malabares levados por Gama a Lisboa teriam sido aprisionados quando, por ordem do samorim, chegaram às naus portuguesas acompanhando os feitores que estavam sendo devolvidos. Esse último relato, segundo Pimpão
} 
Na Introdução ao Lusiad, Mickle relata essa história de forma semelhante, com apenas alguns "atenuantes" para justificar o comportamento de Vasco da Gama. Antes mesmo de o conflito se estabelecer, Mickle (1776, p. xlix) descreve o samorim como movido pelo interesse financeiro:

O caráter desse monarca é fortemente marcado na história da Ásia Portuguesa. A cobiça era a sua paixão dominante; ele era soberbo ou humilde, ousado ou medroso, conforme seus interesses subiam ou desciam na balança de seu julgamento; oscilante e irresoluto sempre que os pratos pareciam indecisos sobre para que lado pender. Ele estava satisfeito com a perspectiva de trazer o comércio da Europa para seus portos, mas sofria também a influência das ameaças dos mouros. ${ }^{138}$

Mickle acentua também o papel dos árabes no conflito, dizendo que estes, não querendo competidores no comércio de Calecute, haviam subornado o catual, que, por sua vez, havia pressionado o samorim a aprisionar os portugueses. Além disso, Mickle explica que Vasco não cumpriu o acordo com o samorim porque Monçaide o avisou de que os árabes preparavam um ataque e tentariam protelar a partida dos portugueses a fim de ganhar tempo para reunir forças suficientes para derrotá-los. Quando os portugueses se preparavam para zarpar, uma calmaria os reteve. Cerca de sessenta navios enviados pelo samorim estavam prestes a atacar Gama quando uma tempestade os dispersou, permitindo que os portugueses se afastassem. Mickle ainda acrescenta que, em seguida, valendo-se de Monçaide como tradutor, Vasco da Gama escreveu uma carta ao samorim relatando os atos desleais do catual e dos mouros, reafirmando o interesse em um acordo comercial e explicando que estava levando os prisioneiros ao rei de Portugal como embaixadores, e que depois eles seriam enviados de volta à Índia.

Em sua tradução, contudo, a história contada por Mickle diverge ainda mais do original e das fontes históricas: Vasco da Gama foi feito prisioneiro pelo samorim, que exigia que as naus dos portugueses aportassem e se entregassem. Vasco da Gama rejeitou terminantemente. Em reação, o samorim mandou atacar as naus portuguesas. Na batalha que se seguiu, houve uma violenta tempestade, e toda a frota do samorim foi destruída. Os portugueses bombardearam Calecute, e o samorim pediu rendição.

(CAMÕES, 2000, p. 414, notas), contradiz o depoimento do cronista Castanheda, para quem os malabares levados a Portugal fariam parte do grupo de comerciantes aprisionados.

138 "The character of this monarch is strongly marked in the history of Portuguese Asia. Avarice was his ruling passion; he was haughty or mean, bold or timorous, as his interest rose or fell in the ballance of his judgment; wavering and irresolute whenever the scales seemed doubtful which to preponderate. He was pleased with the prospect of bringing the commerce of Europe to his harbours, but he was also influenced by the threats of the Moors." 
Para explicar essas alterações introduzidas por Mickle é preciso lembrar o que dissemos acima: Vasco da Gama é o herói da tradução de Mickle. E os padrões neoclássicos exigiam que o herói épico fosse magnífico, de virtude impecável. No episódio da disputa entre Gama e o samorim, Mickle precisou alterar radicalmente o original para que a imagem de seu herói não ficasse conspurcada. Afinal, fazer uma barganha com o inimigo e depois não manter a palavra não são gestos heroicos ou dignificantes... Era necessário, portanto, elevar a figura de seu herói para que se adequasse aos padrões atribuídos ao gênero épico no século XVIII. ${ }^{139} \mathrm{E}$ interessante observar ainda que o gesto de bombardear toda uma cidade em represália a um ataque às naus portuguesas é, para o tradutor britânico, compatível com o de um herói épico.

\subsubsection{Atenuação ou supressão da voz crítica do original}

Ao atenuar ou suprimir na tradução as críticas sociais e políticas veiculadas pelo Poeta no original, o tradutor reflete tanto fatores ideológicos (o interesse em exaltar o aspecto comercial da expedição de Vasco da Gama) quanto poéticos (a adequação aos padrões do gênero épico ditados pelos teóricos da época).

Os exemplos que se seguem abordam em mais detalhe os fatores ideológicos, tendo em vista que os fatores poéticos envolvidos permanecem, grosso modo, invariáveis: o tradutor procura reduzir as digressões camonianas para não ferir o gosto da época, que rejeitava a presença de digressões em epopeias, ou para suprimir as contradições criadas por essas digressões, que enfraqueceriam o "espírito épico", pois a epopeia devia celebrar façanhas incontestavelmente heroicas, calcando-se em uma visão monológica. Não deixamos, contudo, de ressaltar os pontos em que o fator poético se destaca de modo especial.

Os lusíadas celebram a ideologia imperialista dominante, mas, em alguns momentos, abrem espaço para vozes de contestação a essa ideologia. O episódio do Velho do Restelo, o final do discurso de Paulo da Gama e os excursos ou epifonemas contêm claras manifestações de crítica social que são atenuadas ou suprimidas na tradução de Mickle.

\subsubsection{O Velho do Restelo}

No final do Canto IV, o Velho do Restelo, com seu aspecto venerando e o peso de "um saber só d'experiências feito", critica a euforia expansionista e aponta os perigos dos

\footnotetext{
${ }^{139}$ Veja-se também em 5.4.3.3, a seguir, o comentário sobre a tradução do epifonema do Canto VII, que se transforma em discurso encomiástico a Vasco da Gama.
} 
caminhos a que ela está levando o país. Caracteriza-se, assim, uma ambivalência entre a glorificação aos ideais imperialistas que serve de inspiração à epopeia camoniana e a crítica a esses mesmos ideais.

Diversos estudiosos entendem essa ambivalência como necessária para a própria confecção da obra. Segundo Afrânio Peixoto (1932, p. 201), o episódio do Velho do Restelo, ao dar voz aos temores da população quanto aos perigos das navegações, cumpre o papel do coro na tragédia grega, "que fala à razão, com o bom senso popular, com a experiência da idade, e também para não ser ouvido, ou atendido". ${ }^{140}$ Para Hernâni Cidade (1979, pp. 13-14), “a verdade do poema seria mutilada, se nele não tivessem projecção as tragédias por que se pagam os êxitos de tais atrevimentos e não repercutisse o conflito, no coração humano, entre o temor das previsões funestas e o heroísmo que as afronta”. Só ao contar a face trágica, tenebrosa, da história o poeta poderia transmitir a verdadeira dimensão das conquistas heroicas e alcançar o pleno êxito.

Parece-nos, no entanto, que o Velho do Restelo questiona as próprias virtudes heroicas que embasam a epopeia, abalando-lhe os fundamentos. Desconstruindo os conceitos-chave da epopeia, o Velho do Restelo diz que a Fama é "vã cobiça" e "vaidade"; a honra é "fraudulento gosto"; a Fama e a Glória são "nomes com quem se o povo néscio engana”; esforço e valentia não passam de "bruta crueza e feridade". A seguir, ao compararmos esse episódio no original e na tradução de Mickle, veremos em que medida esse questionamento foi preservado.

Para Mickle, o Velho do Restelo personifica a população de Portugal. O tradutor explica, em nota de rodapé, que a expedição de Vasco da Gama era impopular, e o próprio Conselho de D. Manuel se opunha a ela "quase unanimemente" aumento da riqueza levasse ao luxo e à efeminação; outros afirmavam que uma expedição tão perigosa e distante não resultaria em nenhuma vantagem. Havia quem se preocupasse com as reações tanto no Oriente quanto no mundo cristão a um empreendimento tão ousado. $\mathrm{O}$ argumento mais forte era: se a questão era glória, lucros e a propagação do evangelho, o Norte

\footnotetext{
140 Segundo Francisco Achcar (1999, p. 9), o discurso do Velho do Restelo é um propemptikón (canto de despedida), um gênero antigo, cultivado desde os primórdios da poesia grega, composto de certos elementos básicos - o viajante (no caso, Vasco da Gama e os seus marinheiros); aquele que se despede (o Velho); uma relação que una a ambos (a nacionalidade portuguesa) e um cenário apropriado para a despedida (a praia do Restelo, com os navios prestes a partir). O propemptikón deve apresentar certos lugares-comuns: "os perigos e as inconveniências da viagem, os perigos do lugar de destino, considerações sobre os motivos da viagem, a quebra de fé implicada na viagem etc.". Em uma das modalidades desse gênero, o schetliasmos propemptikón, o poeta recorre a lamentos e protestos para convencer o viajante a desistir da viagem. Todos esses elementos se encontram no discurso do Velho do Restelo.

141 "Emmanuel's council were almost unanimous against the attempt".
} 
da África estava muito mais perto e sua exploração seria muito mais vantajosa. (CAMÕES, 1776a, p. 184, nota).

Em uma observação acrescentada ao final do Canto IV, Mickle comenta que a forma como Camões retratou a dor dos amigos e parentes e o discurso severo do respeitável velho na partida de Vasco da Gama dão dignidade e pathos à cena.

Apesar dessas observações, Mickle resume muito a fala do Velho do Restelo e retira, em grande parte, a sua contundência. A não ser pela tradução das estrofes iniciais e finais (9495 e 100-104), que conserva em boa medida o conteúdo do original, o restante do episódio é bastante alterado por Mickle. Analisemos as estrofes alteradas na tradução:

\begin{tabular}{|l|l|}
\hline \multicolumn{1}{|c|}{ ORIGINAL (CANTO IV, ESTROFES 96-97) } & \multicolumn{1}{|c|}{ TRADUÇÃO (P. 185) } \\
\hline "Dura inquietação d'alma e da vida, & \\
Fonte de desamparos e adultérios, & \\
Sagaz consumidora conhecida & \\
De fazendas, de reinos e de impérios! & \\
Chamam-te ilustre, chamam-te subida, & \\
Sendo dina de infames vitupérios; & \\
Chamam-te Fama e Glória soberana, & \\
Nomes com quem se o povo néscio engana!" & \\
\hline "A que novos desastres determinas & What dreadful woes are pour'd on human kind: \\
De levar estes Reinos e esta gente? & Kingdoms and empires in confusion hurl'd, \\
Que perigos, que mortes lhe destinas & What streams of gore have drench'd the hapless world! \\
Debaixo dalgum nome preminente? & Thou dazzling meteor, vain as fleeting air, \\
Que promessas de reinos e de minas & What new-dread horror dost thou now prepare! \\
D'ouro, que lhe farás tão facilmente? & High sounds thy voice of India's pearly shore, \\
Que famas lhe prometerás? Que histórias? & Of endless triumphs and of countless store:142 \\
Que triunfos? Que palmas? Que vitórias?" & \\
\hline
\end{tabular}

O conteúdo da estrofe 96 não é traduzido por Mickle. Nela, o Velho do Restelo aponta a fama e a glória como causas de desgraças, mencionando explicitamente desamparos e adultérios, e lamenta que o povo se deixe enganar por discursos que prometem fama e glória. Na tradução da estrofe 97, Mickle continua omitindo as referências às promessas e discursos vãos e ilusórios. Com essa omissão, perde-se uma crítica social importante e a manifestação de uma voz que destoa das outras vozes que se evidenciam no poema, na medida em que o Velho do Restelo denuncia a própria tarefa cumprida pelo autor, Camões, que escreve uma odisseia nacional exaltando as conquistas marítimas.

\footnotetext{
142 "Que terríveis desgraças são jogadas sobre o ser humano:

Reinos e impérios em confusão lançados,

Que rios de sangue inundaram o mundo desafortunado!

Tu, deslumbrante meteoro, vão como o ar passageiro,

Que novo medonho horror agora preparas!

Alta soa a tua voz falando sobre a costa perolada da Índia,

Sobre intermináveis triunfos e incontável fartura".
} 
Da estrofe 98, Mickle conserva apenas a menção à Queda do Paraíso, eliminando toda a contundência das críticas do Velho do Restelo, que acaba soando mais nostálgico do que crítico:

\begin{tabular}{|l|l|}
\hline \multicolumn{1}{|c|}{ ORIGINAL (CANTO IV, ESTROFE 98) } & \multicolumn{1}{c|}{ TRADUÇ̃̃o (P. 185) } \\
\hline "Mas, ó tu, geração daquele insano & Of other worlds so tower'd thy swelling boast, \\
Cujo pecado e desobediência & Thy golden dreams when Paradise was lost, \\
Não somente do Reino soberano & When thy big promise steep'd the world in gore, \\
Te pôs neste desterro e triste ausência, & And simple innocence was known no more. ${ }^{143}$ \\
Mas inda doutro estado mais que humano & \\
Da quieta e da simples inocência, & \\
Idade d'ouro, tanto te privou, & \\
Que na de ferro e d'armas te deitou [...]" & \\
\hline
\end{tabular}

Na estrofe 99, o Velho do Restelo continua denunciando a fraude ("à bruta crueza e feridade / Puseste nome esforço e valentia"), associando-a agora ao desprezo pela vida. Na tradução, o resumo feito por Mickle continua omitindo a menção à fraude e ao engano, embora reproduza, de modo sucinto, o questionamento quanto ao desprezo pela vida e suas alegrias:

\begin{tabular}{|l|l|}
\hline \multicolumn{1}{|c|}{ ORIGINAL (CANTO IV, ESTROFE 99) } & \multicolumn{1}{c|}{ TRADUÇÃO (P. 185) } \\
\hline "Já que nesta gostosa vaidade & And say, has fame so dear, so dazzling charms? \\
Tanto enlevas a leve fantasia, & Must brutal fierceness, and the trade of arms, \\
Já que à bruta crueza e feridade & Conquest, and laurels dipt in blood, be prized, \\
Puseste nome esforço e valentia, & While life is scorn'd, and all its joys despised?144 \\
Já que prezas em tanta quantidade & \\
O desprezo da vida, que devia & \\
De ser sempre estimada, pois que já & \\
Temeu tanto perdê-la Quem a dá [...]" & \\
\hline
\end{tabular}

$\mathrm{Na}$ estrofe 102, o Velho amaldiçoa o primeiro navegador da história e passa, em seguida, à segunda pessoa do singular ("Nunca juízo algum [...] / Te dê [...]/ Mas contigo se acabe o nome e glória"). Ao traduzir, Mickle (p. 186) mantém a terceira pessoa ("Nor may his name to future times resound; / Oblivion be his meed [...]"), o que atenua o efeito de (auto)crítica a Os lusíadas que essa passagem evoca no original. Além disso, a expressão "cítara sonora ou vivo engenho" remete claramente à poesia épica, mas essa referência não

\footnotetext{
143 "Falando de outros mundos tanto se elevou tua crescente bazófia, Teus sonhos dourados quando o Paraíso foi perdido,

Quando tua grande promessa mergulhou o mundo em sangue,

E a simples inocência deixou de existir."

144 "E dize, tem a fama encantos tão preciosos, tão deslumbrantes?

Devem a ferocidade brutal e o comércio de armas,

A conquista, e louros mergulhados em sangue ser valorizados,

Enquanto a vida é desprezada e todas as suas alegrias desdenhadas?"
} 
está contida na tradução, que alude de modo mais vago às musas e à fama, sem especificar qual seria o veículo por meio do qual os feitos heroicos poderiam vir (ou não) a ser divulgados:

\begin{tabular}{|l|l|}
\hline \multicolumn{1}{|c|}{ ORIGINAL (CANTO IV, ESTROFE 102) } & \multicolumn{1}{c|}{ TRADUÇ̃̃O (P. 186) } \\
\hline "Oh, maldito o primeiro que, no mundo, & Curst be the man who first on floating wood, \\
Nas ondas vela pôs em seco lenho! & Forsook the beach, and braved the treacherous flood! \\
Dino da eterna pena do Profundo, & Oh! never, never may the sacred Nine, \\
Se é justa a justa Lei que sigo e tenho! & To crown his brows, the hallow'd wreath entwine; \\
Nunca juízo algum, alto e profundo, & Nor may his name to future times resound; \\
Nem cítara sonora ou vivo engenho & Oblivion be his meed, and hell profound!145 \\
Te dê por isso fama nem memória, & \\
Mas contigo se acabe o nome e glória!" & \\
\hline
\end{tabular}

Em suma, Mickle não acentua o aspecto de "engano", de "fraude" da empreitada; o tom do discurso do seu Velho do Restelo é menos crítico e mais lamentoso; e as marcas de uma (auto)crítica à epopeia camoniana são eliminadas. O que não é de se estranhar, já que, pelo aspecto ideológico, Mickle defende as ambições comerciais e a política expansionista de D. Manuel, encarnadas na expedição de Vasco da Gama, e pelo aspecto poético, o tradutor procura apagar as contradições que possam empanar o brilho heroico da epopeia, pois, segundo as concepções neoclássicas, a matéria épica deve ser objeto somente de celebração, não devendo ser contestada de forma alguma no interior da própria epopeia.

\subsubsection{O final do discurso de Paulo da Gama}

No final de seu discurso ao catual, em que narra os feitos dos heróis portugueses estampados nas bandeiras que adornam os barcos da esquadra, Paulo da Gama faz uma reflexão sobre a honra e quem a merece, e censura os descendentes dos antigos heróis:

\footnotetext{
145 "Maldito seja o homem que primeiro sobre madeira flutuante, Abandonou a praia e enfrentou a maré traiçoeira! Oh! Que nunca, nunca as Nove sagradas [Musas], Coroem sua fronte, entrelacem a sagrada guirlanda; Nem seu nome em tempos futuros ressoe; O esquecimento seja o seu prêmio, e o inferno profundo!"
} 


\begin{tabular}{|l|l|}
\hline \multicolumn{1}{|c|}{ ORIGINAL (CANTO VIII, ESTROFES 39-41) } & \multicolumn{1}{|c|}{ TRADUÇ̃̃O (P. 338) } \\
\hline "Outros muitos verias, que os pintores & Numerous though these, more numerous warriors shine \\
Aqui também por certo pintariam; & Th' illustrious glory of the Lusian line. \\
Mas falta-lhe pincel, faltam-lhe cores: & But ah, forlorn, what shame to barbarous pride! \\
Honra, prémio, favor, que as artes criam. & Friendless the master of the pencil died; \\
Culpa dos viciosos sucessores, & Immortal fame his deathless labours gave; \\
Que degeneram, certo, e se desviam & Poor man, He sunk neglected to the grave!146 \\
Do lustre e do valor dos seus passados, & \\
Em gostos e vaidades atolados. & \\
\hline Aqueles pais ilustres que já deram & \\
Princípio à geração que deles pende, & \\
Pela virtude muito antão fizeram & \\
E por deixar a casa que descende. & \\
Cegos, que, dos trabalhos que tiveram, & \\
Se alta fama e rumor deles se estende, & \\
Escuros deixam sempre seus menores, & \\
Com lhe deixar descansos corrutores! & \\
\hline Outros também há grandes e abastados, & \\
Sem nenhum tronco ilustre donde venham: & \\
Culpa de Reis, que às vezes a privados & \\
Dão mais que a mil que esforço e saber tenham. & \\
Estes os seus não querem ver pintados, & \\
Crendo que cores vãs lhe não convenham, & \\
E, como a seu contrairo natural, & \\
À pintura que fala querem mal. & \\
\hline Não nego que há, contudo, descendentes & \\
Do generoso tronco e casa rica, & \\
Que, com costumes altos e excelentes, & \\
Sustentam a nobreza que lhe fica; & \\
E se a luz dos antigos seus parentes & \\
Neles mais o valor não clarifica, & \\
Não falta, ao menos, nem se faz escura; & \\
Mas destes acha poucos a pintura." & \\
\hline
\end{tabular}

Há, nessas estrofes do original, uma crítica à falta de valorização das Artes em Portugal (Paulo da Gama reclama da falta de pintores capazes de retratar o heroísmo de outros ilustres guerreiros). A culpa é atribuída aos sucessores dos antigos heróis, os novos reis, que, presos ao luxo e à vaidade pessoal, desviam-se dos feitos dos seus antepassados. Paulo da Gama se queixa também das injustiças cometidas por esses reis, que exaltam os ricos e os nobres, e não aqueles que o mereceriam.

Em nota de rodapé, Mickle critica Camões por ter incluído esses versos na fala de Paulo da Gama, pois eles teriam o efeito oposto ao pretendido, que seria transmitir ao catual uma imagem gloriosa dos portugueses. O tradutor atribui esse erro de Camões ao ressentimento por não ter o seu mérito como poeta reconhecido em Portugal. Mickle fornece, na nota, a

\footnotetext{
146 "Por mais numerosos que sejam estes, ainda mais guerreiros irradiam A glória ilustre do ramo lusitano.

Mas, ah, abandonado, que vergonha para o orgulho bárbaro!

Sem amigos o mestre do lápis morreu;

Fama imortal seus árduos trabalhos eternos produziram;

Pobre homem, Ele foi jogado no túmulo, desprezado!"
} 
tradução literal para o inglês dos versos "Mas falta-lhe pincel, faltam-lhe cores: / Honra, prémio, favor, que as artes criam" ${ }^{147}$. (CAMÕES, 1776a, p. 338). Porém a tradução incluída no Lusiad é outra, ressaltando apenas a injustiça pessoal sofrida por Camões (ver os versos em negrito no quadro acima).

O tradutor afirma que "preservou o espírito do original", mas, na verdade, resumiu quatro estrofes em apenas seis versos, omitindo, em nome da adequação ao "espírito" da epopeia, a severa crítica feita por Camões aos governantes de seu tempo. Os versos incluídos por Mickle constituem, por sua vez, uma crítica dirigida por Mickle à sociedade portuguesa da época de Camões. Assim, Mickle protesta contra o descaso de que Camões foi vítima, mas, por outro lado, silencia a crítica do próprio Camões à mediocridade dos governantes portugueses que lhe eram contemporâneos.

\subsubsection{Os epifonemas}

Como bem analisou Salvatore d'Onofrio (1981, p. 124, itálicos do autor), n'Os lusíadas

[...] a voz do eu poemático faz-se presente de uma forma marcante nos epifonemas, figuras retóricas pelas quais, em tom exclamativo, Camões tece suas reflexões sobre os acontecimentos que acaba de narrar. Encontramo-los, quase sempre, no fim de cada canto, exprimindo o sentido de uma seqüência narrativa, postos como conclusões da matéria tratada.

Mickle efetua uma redução sistemática na extensão das digressões camonianas. Além disso, é visível a atenuação ou supressão do efeito retórico dos epifonemas em muitos casos; em outros casos, o sentido geral das digressões é modificado. Examinemos alguns exemplos.

O epifonema do final do Canto V (estrofes 92-100) apresenta as ponderações do Poeta sobre a importância da poesia épica. O que torna esse epifonema especialmente interessante é que ele surge logo após a longa narração, feita por Vasco da Gama aos melindanos, da história de Portugal desde a fundação do Reino até a chegada da esquadra a Melinde. Ao encerrar-se essa narração, o Poeta toma a palavra e descreve a admiração dos melindanos diante do discurso de Gama:

Da boca do facundo Capitão

Pendendo estavam todos, embebidos,

Quando deu fim à longa narração

Dos altos feitos, grandes e subidos. $(\mathrm{V}, 90)$

147 "But the pencil was wanting, colours were wanting, honour, reward, favour, the nourishers of the arts". 
Logo em seguida, contudo, o Poeta critica os heróis portugueses por não prezarem a poesia e atribui às Musas (na verdade ao próprio Poeta) o nome e a fama de Gama. Estabelece, assim, nas palavras de Cleonice Berardinelli (1973, p. 23), "a dependência do fato histórico em relação à arte, pois só essa lhe dá a dimensão de eternidade”. Ou, como bem analisou Alcir Pécora (2001, p. 150), “o canto [...] não é apenas o elogio posterior de um feito acabado: é a descoberta efetiva do que ele tem de mais sublime; é a sua continuação, por assim dizer, até o imortal. Poder-se-ia dizer que, sem a epopéia, o Bem da proeza não se pode cumprir integralmente".

Analisemos agora a tradução de Mickle desse epifonema.

Em nota de rodapé, Mickle defende os excursos camonianos, que o tradutor chama de digressive declamation [discurso digressivo], dizendo que Aristóteles escolheu Homero como o modelo perfeito do épico, e que, se é verdade que Homero nunca utilizou diretamente o discurso digressivo, também o é que utilizou episódios secundários à trama principal para adornar o poema. A unidade de ação é necessária à poesia épica, mas um discurso do autor, no início ou no fim de um canto, não quebra necessariamente a unidade da ação. Contra os argumentos de Bossu e Rapin, teóricos do neoclassicismo francês, Mickle invoca o "gosto" e os sentimentos do leitor:

Se o discurso de Camões em louvor à Poesia deve ser condenado, que defesa pode ser oferecida para a longa história do vinho de Marão no Canto IX da Odisseia, à qual nem mesmo a poesia de um Pope conseguiu dar nobreza! Entretanto, mesmo que um Bossu ou um Rapin possam condenar as exclamações digressivas de Camões, o leitor de gosto, que julga com base no que sente, com certeza não irá querer que elas sejam apagadas. ${ }^{148}$

(CAMÕES, 1776a, p. 230).

Ainda na mesma nota, Mickle se refere a esse epifonema em particular; defende-o, mas, aparentemente, com algumas reservas, dizendo apenas que, como nesse Canto a expedição de Gama obteve algumas conquistas, esse discurso final apresenta "um contraste apropriado" 149 com o final do Canto IV (o episódio do Velho do Restelo) e que é uma boa conclusão para um episódio que enaltece os feitos militares. (CAMÕES, 1776a, p. 231).

Essa análise de Mickle, além de equivocada, é extremamente redutora. Esse epifonema não nos parece "contrastar" com o episódio do Velho do Restelo - ao contrário, algumas das

\footnotetext{
148 "If the declamation of Camoens in praise of Poetry must be condemned, what defence can be offered for the long story of Maron's wine in the ninth Odyssey, to which even the numbers of a Pope could give no dignity! Yet however a Bossu or a Rapin may condemn the digressive exclamations of Camoens, the reader of taste, who judges from what he feels, would certainly be unwilling to have them expunged."

149 "a proper contrast".
} 
críticas expressas lá parecem ecoar aqui, compondo um perfil crítico dos governantes e da nobreza lusitana. Apesar de ter defendido o epifonema, Mickle o resumiu bastante na tradução: os 72 versos do original passaram a 44 na tradução. $O$ tradutor eliminou alguns exemplos e alterou a ordem de alguns versos para deixar o texto mais fluente. (CAMÕES, 1776a, pp. 228-231). Nesse processo, a crítica de Camões perdeu a sua contundência na tradução. O final da estrofe 97 e a estrofe 98 do Canto V sintetizam a crítica de Camões à sociedade portuguesa por não valorizar a poesia. Nas palavras de Maria Vitalina Leal de Matos (2011, p. 494, itálicos da autora), "Trata-se de um discurso de grande vigor oratório, que pretende justamente envergonhar os destinatários [...]":

\begin{tabular}{|c|c|}
\hline ORIGINAL (CANTO V, ESTROFES 97-98) & TRADUÇÃO (P. 229) \\
\hline $\begin{array}{l}\text { Sem vergonha o não digo: que a razão } \\
\text { De algum não ser por versos excelente, } \\
\text { É não se ver prezado o verso e rima, } \\
\text { Porque quem não sabe arte, não na estima. }\end{array}$ & \multirow{2}{*}{$\begin{array}{l}\text { Alas, on Tago's hapless shores alone } \\
\text { The Muse is slighted, and her charms unknown; } \\
\text { For this, no Virgil here attunes the lyre, } \\
\text { No Homer here awakes the hero's fire. } \\
\text { On Tago's shores are Scipios, Cæsars born, } \\
\text { And Alexanders Lisbon's clime adorn; } \\
\text { But heaven has stampt them in a rougher mould, } \\
\text { Nor gave the polish to their genuine gold. }{ }^{150}\end{array}$} \\
\hline $\begin{array}{l}\text { Por isso, e não por falta de natura, } \\
\text { Não há também Virgílios nem Homeros; } \\
\text { Nem haverá, se este costume dura, } \\
\text { Pios Eneias nem Aquiles feros. } \\
\text { Mas o pior de tudo é que a ventura } \\
\text { Tão ásperos os fez e tão austeros, } \\
\text { Tão rudos e de engenho tão remisso, } \\
\text { Que a muitos lhe dá pouco ou nada disso. }\end{array}$ & \\
\hline
\end{tabular}

O discurso de Mickle não tem o mesmo vigor e sua crítica não é tão clara, pois acentua o caráter de fatalidade, atribuindo a rudeza e a falta de sensibilidade dos portugueses à má sorte ("Tago's hapless shores") ou aos céus ("heaven has stampt them in a rougher mould"). Esse caráter de fatalidade também se evidencia no original, é verdade, mas de forma um tanto contraditória, já que o Poeta diz que não é "por falta de natura" (qualidades naturais) que os governantes portugueses são assim, mas diz também que "a ventura / Tão ásperos os fez e tão austeros". A tradução eliminou os pontos mais fortes da crítica, como os versos "quem não sabe arte, não na estima" e "Tão ásperos os fez e tão austeros, / Tão rudos e de engenho tão remisso / Que a muitos lhe dá pouco ou nada disso", que ressaltam não apenas a falta de refinamento artístico dos capitães portugueses, mas também a sua má vontade em reconhecer

\footnotetext{
150 “Ai, somente nas praias desditosas do Tejo

A Musa é desprezada, e seus encantos desconhecidos;

Por isso, nenhum Virgílio aqui afina a lira,

Nenhum Homero aqui acende a chama do herói.

Nas praias do Tejo nasceram Cipiões, Césares,

E o clima de Lisboa embeleza Alexandres;

Mas o Céu os formou em um molde mais duro,

E não deu polimento ao seu ouro genuíno.”
} 
essa deficiência. Além disso, ao falar em um "genuine gold", um ouro genuíno ao qual apenas faltaria polimento, Mickle atribui aos heróis portugueses um valor real, que não dependeria do reconhecimento poético, o que implica um rebaixamento na tese, defendida pelo Poeta no epifonema original, de subordinação dos feitos heroicos à epopeia.

A seguir, na estrofe 99, quando Camões estende a crítica a Vasco da Gama, Mickle a dirige apenas aos parentes do Gama, em uma clara manipulação para preservar a imagem daquele que é o herói de sua tradução:

\begin{tabular}{|l|l|}
\hline \multicolumn{1}{|c|}{ ORIGINAL (CANTO V, ESTROFE 99) } & \multicolumn{1}{c|}{ TRADUÇÃO (P. 230) } \\
\hline Às Musas agardeça o nosso Gama & Even he whose veins the blood of GAMA warms, \\
O muito amor da pátria, que as obriga & Walks by, unconscious of the Muse's charms: \\
A dar aos seus, na lira, nome e fama & For him no Muse shall leave her golden loom, \\
De toda a ilustre e bélica fadiga; & No palm shall blossom, and no wreath shall bloom; ${ }^{151}$ \\
Que ele, nem quem na estirpe seu se chama, & \\
Calíope não tem por tão amiga & \\
Nem as filhas do Tejo, que deixassem & \\
As telas d'ouro fino e que o cantassem. & \\
\hline
\end{tabular}

Nas estrofes finais (95-99) do Canto VI, o Poeta discorre, em uma crítica aos costumes degenerados de parte da nobreza, sobre as virtudes (que lembram o estoicismo de Sêneca) daqueles que seriam os merecedores da verdadeira glória. Mickle defende de novo as digressões camonianas em nota de rodapé e comenta que essa digressão, em específico, adapta-se perfeitamente ao tema do canto que se encerra. E acrescenta:

Assim, a exclamação no principal eixo de articulação do poema se mostra adequada e revela o ardor do gênio de seu autor. Deve também agradar, pois é fortemente característica do temperamento de nosso poeta-militar. O desprezo viril com que ele fala do cortesão inativo e amante do luxo, e a empolgação e respeito com que fala dos árduos trabalhos do soldado, apresentam a sua própria vida ativa para o leitor de sensibilidade. ${ }^{152}$ (CAMÕES, 1776a, p. 270).

O tradutor resume um pouco as estrofes de 95 a 99 (de 40 para 32 versos), não detalhando tanto os sofrimentos daqueles que merecem a glória e enfatizando o tom heroico, mais emocional, em detrimento do tom moral, "filosófico", de Camões. O que mais chama

\footnotetext{
151 "Mesmo aquele cujas veias o sangue de GAMA aquece,

Passa sem perceber os encantos da Musa:

Por ele nenhuma Musa abandonará o tear de ouro,

Nenhuma palmeira brotará, e nenhuma guirlanda florirá".

152 "The exclamation therefore on the grand hinge of the poem, has its propriety, and discovers the warmth of its author's genius. It must also please, as it is strongly characteristical of the temper of our military poet. The manly contempt with which he speaks of the luxurious inactive courtier, and the delight and honour with which he talks of the toils of the soldier, present his own active life to the reader of sensibility."
} 
atenção na tradução de Mickle desse epifonema é que - seguindo a opinião expressa em sua própria nota, de que os epifonemas deveriam se referir ao que foi narrado -, o tradutor procura relacionar concretamente o discurso de Camões ao poema, tornando-o menos digressivo. Além disso, Mickle concentra todo o epifonema em torno da figura de Vasco da Gama, dirigindo-o, em modo apostrófico, ao Gama, e não ao leitor. Veja-se, como exemplo, a tradução das duas primeiras estrofes do epifonema:

\begin{tabular}{|l|l|}
\hline \multicolumn{1}{|c|}{ ORIGINAL (CANTO VI, ESTROFE 95-96) } & \multicolumn{1}{c|}{ TRADUÇÃO (P. 269) } \\
\hline Por meio destes hórridos perigos, & O glorious chief, while storms and oceans raved, \\
Destes trabalhos graves e temores, & What hopeless toils thy dauntless valour braved! \\
Alcançam os que são de fama amigos & By toils like thine the brave ascend to heaven, \\
As honras imortais e graus maiores; & By toils like thine immortal fame is given. \\
Não encostados sempre nos antigos & Not he, who daily moves in ermine gown, \\
Troncos nobres de seus antecessores; & Who nightly slumbers on the couch of down; \\
Não nos leitos dourados, entre os finos & Who proudly boasts through heroes old to trace \\
Animais de Moscóvia zibelinos; & The lordly lineage of his titled race; \\
Não cos manjares novos e esquisitos, & Proud of the smiles of every courtier lord, \\
Não cos passeios moles e ouciosos, & A welcome guest at every courtier's board; \\
Não cos vários deleites e infinitos, & Not he, the feeble son of ease, may claim \\
Que afeminam os peitos generosos, & Thy wreathe, O GAMA, or may hope thy fame. ${ }^{153}$ \\
Não cos nunca vencidos apetitos & \\
Que a Fortuna tem sempre tão mimosos, & \\
Que não sofre a nenhum que o passo mude & \\
Pera algũa obra heróica de virtude; & \\
\hline
\end{tabular}

A menção a "storms and oceans" no primeiro verso, ausente no original, relaciona o epifonema com o tema naval do poema. E o endereçamento de todo o epifonema ao Gama altera a forma como o leitor o percebe - a vigorosa crítica camoniana aos dirigentes, que inclui o próprio Vasco da Gama, é transformada em um discurso encomiástico ao Gama. Dessa forma, Mickle endossa os valores defendidos por Camões, a crítica camoniana ao luxo e à efeminação da nobreza de seu tempo e, ao mesmo tempo, aproveita para enaltecer ainda mais Vasco da Gama e sua expedição.

\footnotetext{
153 “Oh, glorioso comandante, enquanto tempestades e oceanos se enfureciam, Que árduos trabalhos sem esperança tua coragem destemida enfrentou! Por trabalhos como os teus o bravo ascende ao paraíso, Por trabalhos como os teus a fama imortal é dada. Não aquele que anda diariamente em trajes de arminho, Que dorme à noite em uma cama de plumas; Que orgulhosamente se jacta de velhos heróis para traçar A linhagem senhoril de sua raça nobre; Orgulhosos dos sorrisos de todo senhor cortesão, Um hóspede bem-vindo à mesa de todo cortesão; Não ele, o fraco filho do descanso, pode reivindicar Tua coroa de flores, Ó GAMA, ou esperar a tua fama."
} 
Ao final do Canto VII (77-87), o Poeta se queixa de seus infortúnios e da ingratidão de seus conterrâneos. Apesar da defesa veemente desse epifonema na nota da página 270 e do paralelo traçado na nota $p$ das páginas 317 e 318 entre a situação de Camões e Spenser, ambos abandonados pelos poderosos a quem celebraram, Mickle novamente resume bastante o epifonema, talvez procurando se preservar das críticas dos que consideravam que esse tipo de digressão não cabia em uma epopeia. As estrofes 84, 85 e 87 são resumidas, mas o conteúdo é, em grande parte, preservado na tradução. Já o conteúdo das estrofes 81, 82, 83 e 86 é suprimido ou bastante alterado. Na estrofe 81 do original, o Poeta é bastante vago a respeito das tribulações que lhe foram impostas ("Trabalhos nunca usados me inventaram"). Na tradução, Mickle é bem mais específico, acrescentando dados biográficos do autor ao poema: “Foul Calumny proclaim'd the fraudful tale, / And left me mourning in a dreary jail".

\begin{tabular}{|l|l|}
\hline \multicolumn{1}{|c|}{ ORIGINAL (CANTO VII, ESTROFE 81) } & \multicolumn{1}{c|}{ TRADUÇ̃̃O (PP. 315-316) } \\
\hline E ainda, Ninfas minhas, não bastava & To end my sorrows: woes succeeding woes \\
Que tamanhas misérias me cercassem, & Belied my earnest hopes of sweet repose: \\
Senão que aqueles que eu cantando andava & In place of bays around my brows to shed \\
Tal prémio de meus versos me tornassem: & Their sacred honours, o'er my destined head \\
A troco dos descansos que esperava, & Foul Calumny proclaim'd the fraudful tale, \\
Das capelas de louro que me honrassem, & And left me mourning in a dreary jail. \\
Trabalhos nunca usados me inventaram, & Such was the meed, alas! on me bestow'd, \\
Com que em tão duro estado me deitaram. & Bestow'd by those for whom my numbers glow'd, \\
& By those who to my toils their laurel honours owed.154 \\
\hline
\end{tabular}

No final do Canto VII, o Poeta diz às musas ("Camenas") que não cantará aqueles que roubam o povo, que não pagam devidamente por trabalhos prestados e cobram impostos abusivos:

\footnotetext{
154 "Para encerrar minhas aflições: desgraças sucedendo desgraças

Contrariaram minhas ardentes esperanças de doce repouso:

Em lugar de louros ao redor de minha fronte para irradiar

Suas honras sagradas, sobre minha cabeça predestinada

A imunda Calúnia proclamou a história mentirosa,

E deixou-me a lamentar em uma prisão sombria.

Tal foi a recompensa, ai! a mim entregue,

Entregue por aqueles a quem meus versos exaltavam,

Por aqueles que à minha lida deviam os louros de sua glória."
} 


\begin{tabular}{|l|l|}
\hline \multicolumn{1}{|c|}{ ORIGINAL (CANTO VII, ESTROFES 85-86) } & \multicolumn{1}{c|}{ TRADUÇÃO (PP. 316-317) } \\
\hline Nem, Camenas, também cuideis que cante & Nor he whose honest mien secures applause, \\
Quem, com hábito honesto e grave, veio, & Grave though he seem, and father of the laws, \\
Por contentar o Rei, no ofício novo, & Who, but half-patriot, niggardly denies \\
A despir e roubar o pobre povo! & Each other's merit, and witholds the prize: \\
\hline $\begin{array}{l}\text { Nem quem acha que é justo e que é direito } \\
\text { Guardar-se a lei do Rei severamente, }\end{array}$ & Who spurns the Muse, nor feels the raptured strain, \\
E não acha que é justo e bom respeito & Useless by him esteem'd, and idly vain:155 \\
Que se pague o suor da servil gente; & \\
Nem quem sempre, com pouco experto peito, & \\
Razões aprende, e cuida que é prudente, & \\
Pera taxar, com mão rapace e escassa, & \\
Os trabalhos alheios que não passa. & \\
\hline
\end{tabular}

A tradução de Mickle remove os elementos mais contundentes de crítica social, limitando-se a afirmar que o Poeta não cantará aqueles que negam o mérito ou prêmios, ou que rejeitam a Musa. O que nos parece mais lamentável na tradução desse epifonema é que em nenhum momento são reproduzidos os protestos do Poeta contra a espoliação e exploração do povo e contra os impostos abusivos.

O Canto VIII se encerra com uma reflexão do Poeta sobre a onipotência do dinheiro (da estrofe 96 até o final). Entretanto, como já comentamos na subseção 5.4.2, Mickle suprimiu as últimas estrofes desse canto para preservar a imagem de Vasco da Gama. Assim, com a exceção de um breve comentário sobre a traição do catual, que se rendeu ao poder do ouro, esse epifonema não é traduzido por Mickle, e perdem-se as críticas ao poder corruptor do dinheiro sobre a sociedade - até sobre a ciência, a lei e os governantes, como está dito nas estrofes 98 e 99:

Este rende munidas fortalezas; Faz trédoros e falsos os amigos; Este a mais nobres faz fazer vilezas, E entrega Capitães aos inimigos; Este corrompe virginais purezas, Sem temer de honra ou fama alguns perigos;

Este deprava às vezes as ciências, Os juízos cegando e as consciências.

Este interpreta mais que sutilmente Os textos; este faz e desfaz leis; Este causa os perjúrios entre a gente E mil vezes tiranos torna os Reis.

\footnotetext{
155 "Nem aquele cuja aparência sincera garante o aplauso, Ainda que pareça sério, e pai das leis, Quem, embora semipatriota, nega avaramente O mérito dos outros, e nega o prêmio: Que desdenha a Musa, e não sente a tensão do êxtase, Julgada por ele inútil e ociosamente vã".
} 
Até os que só a Deus omnipotente

Se dedicam, mil vezes ouvireis

Que corrompe este encantador, e ilude;

Mas não sem cor, contudo, de virtude!

Nas últimas doze estrofes do poema, no Canto $\mathrm{X}$, o Poeta sintetiza várias reflexões já feitas nos cantos anteriores. Mickle resume esse epifonema de modo extremo: dos 96 versos do original sobram apenas 26 na tradução. Aqui as modificações são mais de estilo do que de conteúdo - Mickle condensa as digressões, eliminando exemplos, exortações e reflexões. Mas há, ainda assim, perdas e acréscimos de conteúdo. Como exemplo, gostaríamos de citar o início do epifonema, estrofe 145, em que o Poeta se queixa de estar cantando para "gente surda e endurecida" e repreende a pátria por estar "metida no gosto da cobiça":

\begin{tabular}{|l|l|}
\hline \multicolumn{1}{|c|}{ ORIGINAL (CANTO X, ESTROFE 145) } & \multicolumn{1}{c|}{ TRADUÇ̃̃O (P. 483) } \\
\hline Nô mais, Musa, nô mais, que a Lira tenho & Enough, my Muse, thy wearied wing no more \\
Destemperada e a voz enrouquecida, & Must to the seat of Jove triumphant soar. \\
E não do canto, mas de ver que venho & Chill'd by my nation's cold neglect, thy fires \\
Cantar a gente surda e endurecida. & Glow bold no more, and all thy rage expires. ${ }^{156}$ \\
O favor com que mais se acende o engenho & \\
Não no dá a pátria, não, que está metida & \\
No gosto da cobiça e na rudeza & \\
Dũa austera, apagada e vil tristeza & \\
\hline
\end{tabular}

Mickle não menciona a cobiça; fala apenas do "frio desprezo" da nação - como se Camões estivesse apenas expressando lamentações pessoais, sem relação com a situação social, política e econômica do país.

Quanto às digressões mais curtas, espalhadas ao longo do poema, Mickle raramente as traduz. Como exemplo, podemos citar os versos da estrofe 59 do Canto II:

Porque mui pouco val esforço e arte, Contra infernais vontades enganosas; Pouco val coração, astúcia e siso, Se lá dos Céus não vem celeste aviso.

Os versos da estrofe 51 do Canto IV:

\footnotetext{
156 “Basta, minha Musa, tuas asas cansadas não mais Devem ascender triunfantes ao assento de Júpiter. Arrefecida pelo frio desprezo de minha nação, tua inspiração Não mais inflama, e toda a tua ira se extingue."
} 
O bem co mal, o gosto co a tristeza.

Quem viu sempre um estado deleitoso?

Ou quem viu em Fortuna haver firmeza?

Pois inda neste Reino e neste Rei

Não usou ela tanto desta lei?

E os da estrofe 80 do Canto V:

Assi no Céu sereno se dispensa;

Co esta condição pesada e dura

Nascemos: o pesar terá firmeza,

Mas o bem logo muda a natureza.

Todos esses excursos foram omitidos por Mickle. Essas supressões causam profundas alterações estilísticas naquilo que D’Onofrio (1981, pp. 121-125) denomina “voz do eu poemático". De um modo geral, poderíamos dizer que Mickle se apropria dessa voz, retirando dela o tom crítico e digressivo e acrescentando emotividade.

Assim, podemos concluir que, na tradução dos excursos ou epifonemas camonianos, Mickle - quer por fatores poéticos, a fim de adequar o poema aos padrões da época, quer por fatores ideológicos, visando à defesa do comércio e da expansão imperialista - modifica o tom e o conteúdo dos discursos, privilegiando os aspectos comerciais e expansionistas e atenuando a crítica social de Camões, sobretudo nos momentos em que essa crítica poderia levar ao questionamento da própria expansão marítima e comercial. 


\section{CONCLUSÃO}

O conceito de translatio studii et imperii foi, ao longo da história, usado amiúde para justificar as pretensões imperialistas de um país, povo, soberano ou agrupamento político. No Capítulo 1 vimos que os clássicos (e, especialmente, as epopeias) retornaram muitas vezes, sob novas roupagens, para dar sustentação a um novo império, e muitos artistas e intelectuais cumpriram a função de propagadores (hoje diríamos "propagandistas") dessa nova ordem - a translatio studii acompanha sempre a translatio imperii.

Como procuramos mostrar no Capítulo 2, Os lusíadas são uma representação da translatio studii et imperii como Camões a concebia: uma obra que - tendo como modelo a Eneida de Virgílio e apropriando-se, em nome dos portugueses, de várias virtudes éticas atribuídas aos romanos - exalta as façanhas do Império Português, que estaria destinado a ultrapassar os feitos dos impérios anteriores, e declara a si própria a expressão máxima dos conhecimentos alcançados por esse Império.

No Capítulo 3, verificamos que o conceito de translatio foi utilizado pelos poetas setecentistas britânicos como modelo retórico para a elaboração de uma identidade imperial para a Grã-Bretanha - um modelo extremamente adequado porque, ao projetar uma sucessão de leste para oeste e da Antiguidade para o presente, amparava as próprias pretensões imperialistas da Grã-Bretanha e conferia às novas simbologias imperiais uma autoridade que se originava da Antiguidade, que os neoclássicos tanto prezavam.

William Julius Mickle - um poeta que escolheu acrescentar "Julius" como segundo nome, talvez para melhor se adequar às preferências neoclássicas ainda vigentes, e que alterou a grafia escocesa do sobrenome, Meikle, para parecer inglês - apropriou-se da grande epopeia lusitana e, traduzindo-a, transformou-a na "Epopeia do Comércio", um poema em louvor à expansão marítima e comercial, e em defesa da Companhia das Índias Orientais (que, aliás, foi uma das patrocinadoras da tradução). Ao fazê-lo, Mickle reencenou a translatio camoniana, atualizando-a para o Império Britânico da segunda metade do século XVIII.

Para realizar essa tarefa, Mickle recorreu a vários artifícios. No Capítulo 4, analisamos como o tradutor desenvolveu a defesa de sua ideologia no material peritextual: o título, a epígrafe e, sobretudo, os diversos ensaios introdutórios e as notas à tradução. Nos peritextos prefaciais à tradução, Mickle demonstra clara consciência do que está fazendo. Já a partir do subtítulo escolhido, The Discovery of India, percebe-se que o tradutor procura dirigir a atenção do leitor para a viagem de Vasco da Gama, em detrimento de outros temas 
desenvolvidos no épico camoniano, em virtude da importância que esse tema apresenta para a história do comércio e do Império Britânico.

Para o tradutor, Os lusíadas serão "a Epopeia do Comércio", assim como O Paraíso perdido era "a Epopeia da Religião". Se, por um lado, Mickle acerta (a expedição de Vasco da Gama perseguia objetivos eminentemente comerciais), por outro lado a grande ironia é que Camões esforçou-se por ocultar, n'Os lusíadas, as motivações comerciais da expedição. É esse paradoxo que leva Helgerson (1995, p. 189) a se perguntar como Mickle pôde cometer semelhante equívoco, ou, em uma tradução mais literal, como pôde atirar tão longe do alvo ${ }^{1}$ Afinal, Camões exaltava os valores feudais e humanistas: a lealdade, a fidelidade, a coragem, a luta cristã contra os "infiéis", a propagação da fé cristã. O comércio não só não desempenhava nenhum papel nesse quadro como estorvava a matéria épica - Camões não conseguiria conceber uma epopeia comercial. O próprio Helgerson responde, no entanto, que em 1776, quando a Inglaterra controlava o comércio com a Índia, inaugurado por Vasco da Gama, o alvo era o comércio. A leitura de Mickle era tão sobredeterminada que poderia ser considerada quase inevitável.

Não é de se estranhar, portanto, que na Introdução e nas notas do Lusiad o tradutor faça a história do comércio e do Império Britânico remontar às iniciativas do infante D. Henrique, de Portugal, vinculando ao "gênio" de D. Henrique até mesmo a conquista da América. Sobre esses alicerces, Mickle erige a sua translatio, que se evidencia ainda mais claramente quando, como vimos na subseção 4.7.1, o tradutor se apropria, em nome dos britânicos, de uma profecia de Camões sobre a "excelência" do domínio dos portugueses no Oriente. O objetivo é indicar que o domínio britânico é bem-vindo na Índia: assim como, depois da queda do Império Romano, as leis romanas foram adotadas pelas nações consideradas bárbaras, as leis britânicas serão acolhidas pelos indianos com entusiasmo. Dessa forma, Mickle estabelece a continuidade entre o Império Português e o Império Britânico no Oriente. Assim como o domínio do Império Romano foi transferido para as nações europeias, agora o domínio dos portugueses na Índia se transfere para os britânicos. E assim como os indianos se beneficiaram com o domínio português, beneficiar-se-ão com o domínio britânico.

A profecia de Camões sobre um próspero Império Português no Oriente será realizada pelos britânicos, na profecia de Mickle, apropriada de Camões. Mickle assume, destarte, o papel de profeta e agente da translatio studii.

\footnotetext{
1 "How, one wonders, could any reader of Camões, much less a translator, so miss the point?"
} 
A transferência abrange também as denúncias de decadência do Império feitas por Camões. Mickle toma para si a tarefa de alertar para os sinais de corrupção ou desvios do caminho que considera correto, que seria o da promoção do comércio (nas Índias, centralizado nas mãos da Companhia das Índias Orientais), amparado por um governo moralmente honesto, tolerante em termos religiosos e forte militarmente.

No Capítulo 5, examinamos como Mickle manipulou o poema original, traduzindo-o de modo a adequá-lo à ideologia que desejava veicular. A reencenação do processo de translatio studii et imperii foi realizada por meio da transferência para o Império Britânico de várias características dos heróis e da nação portugueses retratados por Camões, ou da apropriação desses heróis e de suas façanhas para a defesa do comércio e da expansão marítima. $\mathrm{O}$ tradutor introduziu inúmeras referências elogiosas ao comércio; defendeu o militarismo e o expansionismo; acentuou, frequentemente, o enfoque etnocêntrico que já se encontrava no original, descrevendo os povos nativos da África e da Ásia como primitivos ou selvagens e enfatizando a "missão" europeia de civilizá-los. Assim como Camões havia tomado a Eneida de Virgílio como modelo a fim de criar uma identidade imperial para Portugal e encenar um processo de translatio, Mickle, ao traduzir Os lusíadas, reforçou a identidade imperial britânica e reencenou uma nova translatio, agora em favor da Grã-Bretanha.

Concomitantemente, Mickle adaptou o poema camoniano ao gosto poético predominante na Grã-Bretanha - com um sucesso atestado pelas oito edições britânicas em apenas 34 anos (desde o lançamento em 1776 até 1810). Os principais recursos empregados pelo tradutor nessa remodelagem foram: retratar a natureza em estilo pré-romântico; enfatizar os elementos sublimes; intensificar a emotividade; eliminar várias alusões mitológicas a fim de tornar o poema mais fluente; atenuar ou eliminar as digressões camonianas, que enfraqueciam - segundo a visão neoclássica - o efeito épico do poema; e remover ou cristianizar as passagens eróticas que pudessem ofender a sensibilidade dos cavalheiros e damas britânicos do século XVIII.

Ao final desse processo, ou seja, na tradução de Mickle, The Lusiad; or, The Discovery of India. An Epic Poem, temos uma verdadeira transmigração, como propugnava a teoria de tradução da época, baseada nos preceitos da retórica latina: Camões, agora falando inglês e expressando-se em versos de dicção entre neoclássica e romântica, faz a defesa do imperialismo britânico nas Índias. 


\section{REFERÊNCIAS BIBLIOGRÁFICAS}

ABBAGNANO, Nicola. Dicionário de Filosofia. Tradução de Alfredo Bosi e Ivone Benedetti. São Paulo: Martins Fontes, 2007.

ACHCAR, Francisco. Velho do Restelo: opinião reacionária ou humanista? Folha de $S$. Paulo, Caderno FOVEST, 22/10/1999, p. 9.

ADDITIONS to, and Corrections in, our last Month's Obituary. The Gentleman's Magazine and Historical Review. London, Vol. 58, pp. 1.121-1.122, Dec. 1778. Disponível em: <http://books.google.com.br/books/download/The_Gentleman_s_Magazine_and_Histor ical.pdf?id=Y3xIAAAAYAAJ\&output=pdf\&sig=ACfU3U1EmuOGt3ZX1 vCbyL6XFnCR5mprw>. Acesso em: 3 jun. 2013.

AFFAIRS in England. Scots Magazine. Edinburgh, Vol. XLII, pp. 442-444, August 1780. Disponível em: <http://books.google.com.br/books/download/The_Scots_ Magazine.pdf?id=SIRAAAAYAAJ\&output=pdf\&sig=ACfU3U1 niOkFFplCUm3RF svSrisrZ9m9MA>. Acesso em 2 nov. 2012.

ALBUQUERQUE, Pedro. Camões e Tartessos: leituras em torno de dois excertos d' $O s$ lusíadas. SPAL, n. 17, 2008, pp. 137-168.

ALIGHIERI, Dante. A Divina Comédia. Tradução de Italo Eugenio Mauro. São Paulo: Ed. 34, 1998.

ALVES, José Edil de Lima. História da literatura portuguesa: fundamentos de geografia e história. Universidade Luterana do Brasil, 2001.

AMORA, Antônio Soares. Manuel Pires de Almeida: um crítico inédito de Camões. São Paulo: USP-FFCL, 1955.

AMOS, Flora Ross. Early theories of translation. New York: Columbia University Press, 1920.

ANASTÁCIO, Vanda. Leituras potencialmente perigosas: reflexões sobre as traduções castelhanas de Os Lusíadas no tempo da União Ibérica. Revista Camoniana, $3^{\mathrm{a}}$ série, $\mathrm{n}^{\mathrm{o}}$ 15, Bauru, São Paulo: EDUSC, 2004, pp. 159-178.

Poetas e príncipes: algumas considerações acerca de dois epitalâmios dedicados ao casamento de D. Maria de Bragança com Alessandro Farnese. Revista Camoniana. 3a série. Bauru, vol. 17, 2005a, pp. 233-252.

El Rei Seleuco, 1645: Reflexões sobre o 'corpus' da obra de Camões. Península. Revista de Estudos Ibéricos, $\mathrm{n}^{\mathrm{o}} 2$ 2, 2005b, pp. 327-342.

ANDERSON, Robert. The Life of Mickle. In The Works of the British Poets. Vol. 11. Edinburgh: Mundell \& Co., 1795, pp. 627-638. 
ANECDOTES of WiLliam JULIUS MiCKLE. The European Magazine and London Review. London, Vol. 1, pp. 451-452, June 1782. Disponível em: <http://books.google.com.br/ books/download/ The_European_Magazine_And_London_Review.pdf?id=o84PAAAA QAAJ\&output=pdf\&sig=ACfU3U3cMsuzV1pq0NDZJZg40qooYhS9Og>. Acesso em: 3 jun. 2013.

AQUINO, Tomás José de (Ed.). Obras de Luís de Camões, príncipe dos poetas de Espanha. Tomo 1. 2 ed. Lisboa: Offic. de Simão Thaddeo Ferreira, 1782.

ATKINS, J. W. H. English literary criticism : 17th and 18th centuries. London: Methuen \& Co., 1951.

BAILEY, Nathan (Org.). Dictionarium britannicum: or a more complete universal etymological English dictionary than any extant [...] 2 ed. London: T. Cox, 1736.

BALLARD, Michel. De Cicéron à Benjamin: Traducteurs, traductions, réflexions. Villeneuve d'Ascq: Presses Universitaires du Septentrion, 2007.

BASSNETT, Susan. Translation Studies. 3rd ed. London \& New York: Routledge, 2002.

BASSNETT, Susan; LEFEVERE, André. General Editor's Preface. In: LEFEVERE, André. Translation, Rewriting and the Manipulation of the Literary Fame. London: Routledge, 1992, pp. vii-viii.

BAYNE, Thomas. Mickle, William Julius. In: LEE, Sidney (Org.). Dictionary of National Biography. Vol. XXXVII. New York: Macmillan and Co.; London: Smith, Elder, \& Co., 1894, pp. 336-337.

BECHARA, Evanildo; SPINA, Segismundo. Os Lusíadas - Antologia. Rio de Janeiro: Grifo/MEC, 1973.

BERARDINELLI, Cleonice. Estudos Camonianos. Rio de Janeiro: MEC / Programa Especial UFF-FCRB, 1973.

BERMAN, Antoine. A tradução e a letra ou o albergue do longínquo. Tradução de MarieHélène Catherine Torres, Mauri Furlan e Andreia Guerini. Rio de Janeiro: 7Letras/PGET, 2007.

.De la translation à la traduction. TTR: traduction, terminologie, rédaction, vol. $1, \mathrm{n}^{\circ}$ 1, 1988, p. 23-40.

BETHENCOURT, Francisco; CURTO, Diogo Ramada (Eds.). Portuguese Oceanic Expansion, 1400-1800. Cambridge: Cambridge University Press, 2007.

BIRCHAL, Hennio Morgan. Os lusíadas: Luís Vaz de Camões - Edição antológica, comentada e comparada com Ilíada, Odisseia e Eneida. São Paulo: Landy, 2005.

BLAIR, Hugh. Lectures on rhetoric and belles lettres. Carbondale : Southern Illinois University Press, 2005. 
BOILEAU-DESPRÉAUX, Nicolas. A arte poética. Tradução de Célia Berrettini. São Paulo: Perspectiva, 1979.

BOSWELL, James. Letter to William Julius Mickle. The Universal Magazine, n. LXVI, Vol. XI, May 1809, pp. 385-386.

. Life of Johnson. Oxford/New York: Oxford University Press, 1998.

BOWEN, H. V. British India, 1765-1813: The Metropolitan Context. In MARSHALL, P. J. (ed). The Oxford History of the British Empire. Vol. 2. The eighteenth-century. New York: Oxford University Press, 2001, pp. 530-551.

BOWRA, C. M. From Virgil to Milton. London: Macmillan \& Co., 1962.

BOXER, Charles Ralph. O império marítimo português 1415-1825. São Paulo: Companhia das Letras, 2006.

BREWER, John. The pleasures of the imagination: English culture in the eighteenth century. Chicago: University of Chicago, 2000.

BROADIE, Alexander. Art and aesthetic theory. In: (Ed.) The Cambridge Companion to the Scottish Enlightenment. Cambridge: Cambridge University Press, 2003, pp. 280-297.

BUESCU, Maria Leonor Carvalhão. História da Literatura Portuguesa. Coleção Sínteses da Cultura Portuguesa. Lisboa: Imprensa Nacional-Casa da Moeda, 1994.

BULLOUGH, Geoffrey. Introduction. In: CAMÕES, L. The Lusiads in Sir Richard Fanshawe's Translation. London: Centaur, 1963, pp. 9-28.

BURGESS, Anthony. A Literatura Inglesa. Tradução de Duda Machado. São Paulo: Ática, 2005.

BURKE, Edmund. Uma investigação filosófica sobre a origem de nossas idéias do sublime e do belo. Tradução de Enid Abreu Dobránszky. Campinas: Editora da UNICAMP, 1993.

BURTON, Sir Richard. Camoens, his life and his Lusiads. Vol. 1. London: Bernard Quaritch, 1881.

CAMÕES, Luís Vaz de. The first book of the Lusiad, published as a specimen of a translation of that celebrated epic poem. Translated by William Julius Mickle. Oxford: W. Jackson et al, 1771. Disponível em: <http://find.galegroup.com/ecco/infomark.do?\&contentSet= ECCOArticles\&type $=$ multipage $\&$ tabID $=$ T001 \&prodId $=$ ECCO\&docId $=$ CW 110194652 $\&$ source $=$ gale $\&$ userGroupName $=$ usp $\&$ version $=1.0 \&$ docLevel=FASCIMILE $>$. Acesso em: 30 jul. 2010.

The Lusiad, or, Portugals Historicall Poem. Translated by Sir Richard Fanshawe. London: Humphrey Mosely et al, 1655. Disponível em: 〈http://purl.pt/14655>. Acesso em: 16 ago. 2012. 
The Lusiad; or, the discovery of India. Translated by William Julius Mickle. London, Oxford: Jackson and Lister, 1776a. Disponível em:

<http://www.archive.org/details/lusiadordiscover00camo>. Acesso em: 30 jul. 2010.

. The Lusiad; or, the discovery of India. Translated by William Julius Mickle. London, Oxford: Jackson and Lister, 1778, 2nd edition. Disponível em: <http://books.google.com.br/books?id=xLcNAAAAYAAJ\&printsec=frontcover \&dq=The_Lusiad_or_The_discovery_of_India>. Acesso em: 30 jul. 2010.

The Lusiads of Luis de Camões. Translated with an Introduction and Notes by Leonard Bacon. New York: Hispanic Society of America, 1950.

. Os lusíadas. Lisboa: em casa de Antonio Gõçaluez, 1572. Disponível em: <http://purl.pt/1>. Acesso em: 30 jul. 2010.

Lusiadas de Luís de Camoens comentadas por Manuel de Faria y Sousa--contienen lo más de lo principal de la Historia y Geografía del mundo, principalmente de España. Madrid: Sanchez, 1639. Vol 1. Disponível em: $<$ http://books.google.com.br/books/download/Lusiadas.pdf?id=4okO6gbXghsC\&hl=ptBR\&output=pdf\&sig=ACfU3U21WqNIuOt0VAyuNYriSK4ySweANg> Vol. 2 Disponível em: $<$ http://books.google.com.br/books/download/Lusiadas.pdf?id=AKfg0oXe_PIC\&hl=ptBR\&output=pdf\&sig=ACfU3U0_n8211ALi_7U_GD6197OcrNV5OQ> Acesso em: 30 jul. 2012.

Lusíadas. Comentadas por Manuel de Faria e Sousa. Introdução de Jorge de Sena. Lisboa: Imprensa Nacional-Casa da Moeda, 1972.

Os lusíadas. Prefácio e Notas de Álvaro Júlio da Costa Pimpão. Lisboa: Ministério dos Negócios Estrangeiros. Instituto Camões, 2000.

. La Lusiade de Louis Camoëns ; poëme herö̈que en dix chants. Traduction de Jean François de La Harpe. Paris : Nyon ainé, 1776b.

Tome I. Disponível em: <http://books.google.com.br/books/download/ La_Lusiade_de_Louis_Camo\%C3\%ABns_po\%C3\%A8me_h\%C3\%A9r.pdf?id= GuQtWHfkz0kC\&output=pdf\&sig=ACfU3U1oCh9lq9y-VO3LYrcoPUumP5-z_Q> Tome II. Disponível em: <http://books.google.com.br/books/download/ La_Lusiade_de_Louis_Camo\%C3\%ABns.pdf?id=3hcBAAAAMAAJ\&output= pdf\&sig=ACfU3U3vxJkoPHveWNpqjZnplQYJcomYXA>Acesso em: 14 fev. 2013.

La Lusiade du Camoens: poeme heroique, sur la decouverte des Indes orientales. Traduction de Duperron de Castera. Paris: Huart, David, Briasson et Clousier, 1735, tomes I, II, III. Disponível em: <http://arquivohistoricomadeira.blogspot.com/ 2010/01/la-lusiade-du-camoens-poeme- heroique.html>. Acesso em: 30 jul. 2010.

. Rimas. Texto estabelecido e prefaciado por Álvaro Júlio da Costa Pimpão. Coimbra: Acta Universitatis Conimbrigensis, 1953.

CAMPBELL, Thomas. William Julius Mickle. In: Specimens of the British Poets. Vol. VII. London: John Murray, 1819, pp. 108-115. 
CARDIM, Luiz. Projecção de Camões nas línguas inglêsas. Lisboa: Inquérito, 1940.

CARPEAUX, Otto Maria. História da literatura ocidental. Vol. 3. Rio de Janeiro: O Cruzeiro, 1961.

CARR, Stephen L. The circulation of Blair's Lectures. In Rhetoric Society Quarterly, Vol. 32, n. 4, Fall 2002.

CARY, Rev. Henry Francis. Lives of the Poets: William Julius Mickle. London Magazine 5, London: Taylor \& Hessey, June 1822, pp. 559-564.

CERVANTES SAAVEDRA, Miguel de. O Engenhoso Fidalgo Dom Quixote de la Mancha. Tradução de Viscondes de Castilho e Azevedo. São Paulo: Abril Cultural, 1978.

La Galatea. Barcelona: Linkgua, 2009, p. 336. Disponível em:

<http://books.google.com.br/books?id=WX9hsII4rtAC\&lpg=PA336\&ots=H2VvJerK1z \&dq> Acesso em: 16 ago. 2012.

CHALMERS, Alexander. Mickle (William Julius). In The general biographical dictionary. Vol. XXII. London: J. Nichols and Son et al, 1815, pp. 118-130.

CHAVES, Henrique de Almeida. O mito de Camões em Itália. Lisboa: Colibri, 2001.

CHEYFITZ, Eric. The poetics of imperialism: translation and colonization from The Tempest to Tarzan. Philadelphia: University of Pennsylvania Press, 1991.

CICERO. De Oratore. Vol. I e II. English translation by E. W. Sutton. London/Cambridge, Massachusetts: William Heinemann Ltd/Harvard University Press, 1967.

CIDADE, Hernâni. Prefácio. In: CAMÕES. Os lusíadas. São Paulo: Abril Cultural, 1979, pp. 7-17.

CIOFFARI, Vincenzo. Camões and Dante: A Source Study. Italica, Vol. 25, No. 4, Dec., 1948, pp. 282-295. Disponível em: <http://www.jstor.org/stable/476000>. Acesso em: 13 ago. 2012.

COPELAND, Rita. Rhetoric, hermeneutics, and translation in the Middle Ages: academic traditions and vernacular texts. Cambridge: Cambridge University Press, 1995.

COSTA, Antonio Carvalho da. Corografia Portugueza, e Descripçam Topografica do Famoso Reyno de Portugal [...]. Lisboa: Deslandes, 1712. Disponível em: $<$ https://play.google.com/store/books/details?id=9mZJAAAAcAAJ\&rdid=book9mZJAAAAcAAJ\&rdot=1>. Acesso em: 30 mai. 2013.

COWLEY, Abraham. The works of Mr. Abraham Cowley: in two volumes. Consisting of those which were formerly printed; and those which he design'd for the press; publish'd out of the author's original copies. Vol. 1.11 ed. London: J. Tonson, 1710. Disponível em: <http:// books.google.com.br/books?id=DiZEAAAAcAAJ>. Acesso em: 20 nov. 2012. 
CUNHA, Maria Helena Ribeiro da; PIVA, Luiz. Lirismo e epopéia em Luís de Camões. São Paulo: Cultrix/EDUSP, 1980.

CURTIUS, Ernst R. Literatura européia e idade média latina. São Paulo: HUCITEC/ EDUSP, 1996.

D. Z. An Essay on Translation. The Gentleman's Magazine and Historical Review. London. Vol. XLI, pp. 349-352, August 1771. Disponível em: <http://books.google.com.br/ books/download/The_Gentleman_s_Magazine_and_Historical.pdf?id=S31IAAAAYAA J\&output=pdf\&sig=ACfU3U2KNDOGbMBN4P0bpZm0OJdew7EsSA> Acesso em: 2 jun. 2013.

DAICHES, David. A Critical History of British Literature. Vol. II. The Restoration to the present day. London: Mandarin, 1997.

DAVENPORT, Richard A. William Julius Mickle. In: The British Poets. Vol. LXVI. London: Chiswick, 1822, pp. 7-26.

DE VRIES, Eti. Os lusíadas na Holanda: a história da recepção entre 1572-1900. Tese de licenciatura em Estudos de Língua e Cultura Portuguesas. Universidade de Utreque, Países Baixos, Junho de 2007.

DEFOE, Daniel. A Plan of the English Commerce. London: Charles Rivington, 1728, p. x.

DENHAM, John. From “The Preface” to The Destruction of Troy. In: MILTON; VILLA, (Orgs.). Os escritos clássicos ingleses sobre a tradução - 1615- 1791. São Paulo: Humanitas, 2012a, pp. 33-34.

. Do "Prefácio" à Destruição de Tróia. Tradução de Janet Dewey. In: MILTON;

VILLA, (Orgs.). Os escritos clássicos ingleses sobre a tradução - 1615-1791. São Paulo: Humanitas, 2012b, pp. 29-31.

. "A Sir Richard Fanshawe, por sua tradução do Pastor Fido". Tradução de Fernando L. Dantas. In: MILTON; VILLA, (Orgs.). Os escritos clássicos ingleses sobre a tradução - 1615-1791. São Paulo: Humanitas, 2012c, pp. 25-26.

. "To Richard Fanshawe, upon his Translation of Pastor Fido". In: MILTON; VILLA, (Orgs.). Os escritos clássicos ingleses sobre a tradução - 1615-1791. São Paulo: Humanitas, 2012d, pp. 27-28.

DEWALD, Jonathan (Ed.). Europe 1450 to 1789: Encyclopedia of Early Modern World. Vol. 2. New York: Thomson Gale, 2004.

D’ONOFRIO, Salvatore. Da Odisséia ao Ulisses (Evolução do Gênero Narrativo). São Paulo: Duas Cidades, 1981.

DRYDEN, John. The Works of the English Poets from Chaucer to Cowper, vol. VIII. London: J. Johnson et al, 1810. 
From the "Preface" to the Epistles of Ovid. In: MILTON; VILLA, (Orgs.). Os escritos clássicos ingleses sobre a tradução - 1615- 1791. São Paulo: Humanitas, 2012a, pp. 51-56.

. Do "Prefácio" às Epístolas de Ovídio. Tradução de Vânia Viotto e Renée Machado. In: MILTON; VILLA, (Orgs.). Os escritos clássicos ingleses sobre a tradução - 16151791. São Paulo: Humanitas, 2012b, pp. 43-49.

. From the "Preface" to Fables Ancient and Modern. In: MILTON; VILLA, (Orgs.). Os escritos clássicos ingleses sobre a tradução - 1615-1791. São Paulo: Humanitas, 2012c, pp. 99-101.

. Do "Prefácio" às Fábulas Antigas e Modernas. Tradução de Marina Camera. In: MILTON; VILLA, (Orgs.). Os escritos clássicos ingleses sobre a tradução - 16151791. São Paulo: Humanitas, 2012d, pp. 95-97.

. Preface to the Second Miscellany. In: The Poetical Works of John Dryden. Vol. III. London: William Pickering, 1832, pp. 119-132.

ESTORNINHO, Carlos. A contribuição inglesa para os estudos camonianos. Panorama: Revista Portuguesa de Arte e Turismo. N. 44, IV Série, Dezembro de 1972, pp. 89-95.

O culto de Camões em Inglaterra. Arquivo de Bibliografia Portuguesa, Coimbra, 6, 1960, pp. 152-169.

EVANS, Thomas; EVANS, R. H. (Eds.) Old Ballads, historical and narrative, with some of Modern Date. London: R. H. Evans, 1810. Disponível em:

<http://books.google.com.br/books/download/Old_ballads.pdf?id=_U15P4SRJAC\&output=pdf\&sig=ACfU3U1CxSX4iO0racYsHKUzSkJJUTIMbQ> Acesso em: 29 dez. 2012.

FAIRCHILD, Hoxie Neale. Religious Trends in English Poetry. Volume 2. New York: Columbia University Press, 1942.

FERREIRA, Isabel Simões. Apontamento biográfico relativo aos tradutores de Os lusíadas. In: SOUZA, Maria Leonor Machado de (coord.). Camões em Inglaterra. Lisboa: Ministério da Educação. Instituto de Cultura e Língua Portuguesa, 1992a, pp. 64-69.

Uma leitura de Os lusíadas: William Julius Mickle. In: SOUZA, Maria Leonor Machado de (coord.). Camões em Inglaterra. Lisboa: Ministério da Educação. Instituto de Cultura e Língua Portuguesa, 1992b, pp. 70-95.

FICALHO, Conde de. Flora dos Lusíadas. Lisboa: Academia Real das Sciencias, 1880. Disponível em: <http://archive.org/details/floradoslusiada00ficagoog>. Acesso em: 2 fev. 2013. 
THE FIRST Book of the Lusiad, published as a Specimen of a Translation of that celebrated Epic Poem. The Critical Review. Vol. 32, pp. 106-109, July 1771a. Disponível em: <http://books.google.com.br/books/download/The_critical_review_or_annals_of_ literat.pdf?id=XY1KAAAAcAAJ\&output=pdf\&sig=ACfU3U06sm52nBDQiXDha9y1s A1hSuSU2g >. Acesso em 3 jun. 2013.

THE FIRST book of the Luciad [sic] of Camoens, translated from the original Portuguese, by Wm. Julius Mickle. The Gentleman's Magazine and Historical Review. London. Vol. XLI , pp. 323-325, July 1771b. Disponível em: <The_Gentleman_s_Magazine_and_ Historical.pdf?id=S3IIAAAAYAAJ\&output=pdf\&sig=ACfU3U2KNDOGbMBN4P0bp Zm0OJdew7EsSA>Acesso em: 2 jun. 2013.

THE FIRST Book of the Lusiad, published as a Specimen of a Translation of that celebrated Epic Poem. By William Julius Mickle. The Monthly Review. London, Vol. XLV, pp. 182-188, Sept. 1771c. Disponível em: <http://books.google.com.br/books/download/ The_Monthly_Review.pdf?id=FoICAAAAYAAJ\&output=pdf\&sig=ACfU3U1bcr2ZT YAcaiarnP5IyYghncodHQ > Acesso em: 2 jun. 2013.

FLOR, João de Almeida. Receção de Camões na literatura inglesa. In : Dicionário de Luís de Camões. São Paulo: LeYa, 2011, pp. 806-814.

FOUCAULT, Michel. L'Ordre du discours. Paris: Gallimard, 1971.

. A arqueologia do saber. Tradução de Luiz Felipe Baeta Neves. Rio de Janeiro: Forense, 1986.

Politics and the Study of Discourse. In: BURCHELL, G., GORDON, C., \& MILLER,P. (eds.). The Foucault Effect. Chicago: The University of Chicago Press, 1991, pp. 53-86.

FRANCE, Peter (Ed.). The Oxford Guide to Literature in English Translation. Oxford : Oxford University Press, 2000.

GARRETT, V. de Almeida. Camões. Tomo I. 6 ed. Lisboa: Viúva Bertrand e filhos, 1863. Disponível em: <http://books.google.com.br/books/download/Obras_litterarias.pdf?id= j3wNAAAAQAAJ\&output=pdf\&sig=ACfU3U128_SKNulA0Y7rFiWc9law58Bfyg > Acesso em: 10 jan. 2013.

GENETTE, Gérard. Paratextos editoriais. Tradução de Álvaro Faleiros. Cotia, SP: Ateliê Editorial, 2009.

GOLDEN, James L.; CORBETT, Edward P. J. The Rhetoric of Blair, Campbell, and Whately. Carbondale and Edwardsville: Southern Illinois University Press, 1990.

GRAHAM, Henry Gray. Scottish Men of Letters in the Eighteenth Century. New York: Garland Press, 1983.

GREENE, Jack P. Empire and Identity from the Glorious Revolution to the American Revolution. In MARSHALL, P. J. (ed). The Oxford History of the British Empire. Vol 2. The eighteenth-century. New York: Oxford University Press, 2001, pp. 208-232. 
GRIFFIN, Dustin H. Literary Patronage in England, 1650-1800. Cambridge: Cambridge University Press, 2006.

GUILLERM, Luce. Les Belles Infidèles, ou l'Auteur respecté (de Claude de Seyssel à Perrot d'Ablancourt). In BALLARD, M. \& D'HULST, L (Orgs.). La traduction en France à l'âge classique. Villeneuve d'Ascq: Presses Universitaires du Septentrion, 1996, pp. 23 42.

HAMILTON, Albert Charles (Org.). The Spenser Encyclopedia. Toronto / Buffalo: Toronto University Press, 1990.

HAYES, Julie. From the Academy to Port-Royal. Translation, subjectivity and culture in France and England, 1600-1800. Stanford, CA: Stanford University Press, 2009.

HAYLEY, William. An Essay on Epic Poetry; in Five Epistles. London: J. Dodsley, 1782. Disponível em: <http://archive.org/details/essayonepicpoetr00hayl>. Acesso em: 13 jun. 2013.

HAYWOOD, L; MONTGOMERY, J. E. Al-Andalus and España: Translatio and Tolerance. Mellon Teaching Seminar Series. CRAASH Lent Term. 2009. Disponível em: $<$ http://www.crassh.cam.ac.uk/uploads/documents/session2.pdf > Acesso em: 25 dez. 2013.

HELGERSON, Richard. Forms of nationhood: the Elizabethan writing of England. Chicago: University of Chicago Press, 1995.

HOMER. The Iliad. Translated by Alexander Pope. Disponível em: <http://www.gutenberg.org/etext/6130> Acesso em: 30 jul. 2010. . Ilíada. Tradução de Odorico Mendes. São Paulo: Atena, 1956.

HOOLE, John. Preface. In: TASSO, Torquato. Jerusalem delivered; an heroic poem: translated from the Italian of Torquato Tasso by John Hoole in two volumes. Vol. 1.7 ed. London: Dodsley, 1792. Disponível em: <http://books.google.com.br/books/ download/Jerusalem_Delivered.pdf?id=JIcHAAAAQAAJ\&hl=pt-BR\&output= pdf\&sig=ACfU3U2Mf2nHnkMXfNnidavKnOQ2nLlmIg>. Acesso em: 31 ago. 2013.

HUE, Sheila Moura. Alguns apontamentos sobre a recepção da obra camoniana no século XVI. In: VI Congresso da Associação Internacional de Lusitanistas. Rio de Janeiro, 1999. Disponível em: <http://www.geocities.ws/ail_br/ algunsapontamentossobrearecepcao.html> Acesso em: 30 jul. 2012.

IRELAND, John. Life of the Author. In: MICKLE, W. J. Poems, and a Tragedy. London: Printed by A. Paris for J. Egerton et al, 1794, pp. xi-lii.

JOHNSON, Samuel. The Adventurer. In: The Works of Samuel Johnson, L.L.D. A new edition in twelve volumes. Vol. III. London: F. C. and J. Rivington et al., 1823, pp. 109-300. 
A Dictionary of the English Language. 6 ed. London: W. Strahan et al, 1778.

A Dictionary of the English Language: A Digital Edition of the 1755 Classic by Samuel Johnson, edited by Brandi Besalke. Last modified: February 3, 2013. Disponível em <http://johnsonsdictionaryonline.com/> Acesso em fev. 2013.

Introduction to The World Displayed. In: The Works of Samuel Johnson, L.L.D, with Murphy's Essay. Vol. V. London: George Cowie and Co., 1825, pp. 191211. Disponível em: <http://books.google.com.br/books/download/The_works_of_ SamuelJohnson_LL_D.pdf?id=bKJCAQAAIAAJ\&output=pdf\&sig= ACfU3U0Mk24yyFKtrSqdbUWZOLWPAcEZFg> Acesso em 23 out. 2013.

From Life of Pope. In: MILTON; VILLA, (Orgs.). Os escritos clássicos ingleses sobre a tradução - 1615-1791. São Paulo: Humanitas, 2012a, pp. 153-156.

Lives of the Most Eminent English Poets, with Critical Observations on their Works. Vol. 1. Philadelphia: Benjamin Warner \& Benjamin C. Buzby, 1819.

Pope. In: The Works of Samuel Johnson, L.L.D. A new edition in twelve volumes. Vol. XI. Lives of the Poets, Vol. III. London: F. C. and J. Rivington et al., 1820, pp. 54-216.

De A Vida de Pope. Tradução de Maria Cecília Palma. In: MILTON; VILLA, (Orgs.). Os escritos clássicos ingleses sobre a tradução - 1615- 1791. São Paulo: Humanitas, 2012b, pp. 149-152.

JUROMENHA, Visconde de. Ensaio biographico. In: CAMÕES, L. Obras de Luiz de Camões. Vol. I. Lisboa: Imprensa Nacional, 1860. Disponível em: <http://books.google.com.br/ books?id=dOkZAQAAMAAJ\&hl>. Acesso em: 11 ago. 2012.

Vol. V. Lisboa: Imprensa Nacional, 1866. Disponível em: <http://books.google.com.br/ books/download/Obras_de_Luiz_de_Cam\%C3\%B5es_Triumphos_de_Fr.pdf?id=gts QAQAAMAAJ\&output=pdf\&sig=ACfU3U12Bk0ujqCGEzzFVlsFZyBHHEk8qg>. Acesso em 24 out. 2013.

KALEWSKA, Anna. Camoes as a Romantic Hero: Biography as "the model of heroism" in the literature of Romanticism in Poland. In: CIESZYŃSKA, Beata (ed). Iberian and Slavonic Cultures: Contact and Comparison. Lisbon: CompaRes, 2007, pp. 27-45.

KAUL, Suvir. Poems of Nation, Anthems of Empire: English Verse in the Long Eighteenth Century. Virginia: The University Press of Virginia, 2000.

. Poetry, Politics, and Empire. In: GERRARD, Christine (Ed.). A Companion to Eighteenth-Century Poetry. Oxford: Blackwell, 2006, pp. 23-37.

KERMODE, Frank. The Classic: literary images of permanence and change. Cambridge, Mass: Harvard University Press, 1983.

KERRIGAN, William e BRADEN, Gordon. The Idea of the Renaissance. Baltimore: Johns Hopkins University Press, 1989. 
KLEMME, Heiner F. Scepticism and common sense. In: BROADIE, A. (Ed.) The Cambridge Companion to the Scottish Enlightenment. Cambridge: Cambridge University Press, 2003, pp. 117-135.

LANGFORD, Paul. Eighteenth-Century Britain: a very short introduction. Oxford: Oxford University Press, 2000.

A Polite and Commercial People: England 1727-1783. New Oxford History of England. Oxford: Oxford University Press, 1998.

The writings and speeches of Edmund Burke. Vol. II. Party, Parliamentary and the American crisis - 1766-1774. Oxford: Clarendon Press; New York: Oxford University Press, 1981.

LATHAM, Henry. Anthologia Davidica, or, A metrical translation of the whole book of Psalms: selected from our published versions with alterations; being an essay towards the compilation of a national Psalm book. London: Francis \& John Rivington, 1846.

LEECH, Geoffrey. A Linguistic Guide to English Poetry. London: Longman, 1973.

LEFEVERE, André. Beyond the Process: Literary Translation in Literature and Literary Theory. In: ROSE, Marilyn Gaddis (Org.). Translation Spectrum: Essays in Theory and Practice. Albany: State University of New York, 1981, pp. 52-59.

. Why Waste Our Time On Rewrites?: The Trouble With Interpretation and the Role Of Rewriting in an Alternative Paradigm. In: HERMANS, Theo. (Ed.) The Manipulation of Literature. London: Croom Helm., 1985, pp. 215-242.

Translation, Rewriting, and the Manipulation of Literary Fame. London and New York. Routledge, 1992.

Tradução, reescrita e manipulação da fama literária. Tradução de Cláudia Matos Seligmann. Bauru: EDUSC, 2007.

LE GOFF, Jacques. História e memória. Tradução de Bernardo Leitão et al. Campinas: Editora da UNICAMP, 1990.

La civilisation de l'occident médiéval. Col. Champs histoire. Paris: Flammarion, 2008.

LEITE, António Pedro de Sousa. "Os lusíadas" da camoniana d'el-rei D. Manuel II no paço ducal de Vila Viçosa. As traduções inglesas do poema. Panorama: Revista Portuguesa de Arte e Turismo. N. 44, IV Série, Dezembro de 1972, pp. 9-23.

LERER, Seth. Errata: print, politics and poetry in early modern England. In: SHARPE, K; ZWICKER, S. (Eds.). Reading, Society and Politics in Early Modern England. New York: Cambridge University Press, 2003, pp. 41-71.

LETZRING, Monica [Madonna]. The Influence of Camoens in English Literature. Revista Camoniana, vols. I-III, São Paulo, 1964, 1965 e 1971, pp. 158-180, 27-54, 57- 134. 
LIPKING, Lawrence. The View from Almada Hill: Myths of Nationhood in Camões and William Julius Mickle. In: FIGUEIREDO, João Ricardo (Org.). Post-Imperial Camões. Portuguese Literary \& Cultural Studies, IX, 2003, pp. 165-176.

LOCKE, John. Segundo Tratado sobre o Governo Civil e outros escritos. Col. Clássicos do Pensamento Político. Petrópolis, RJ: Vozes, 1994.

THE LUSIAD, an Epic Poem, translated from the Portuguese of Camoëns by W. J. Mickle. The Critical Review. London: A. Hamilton, Vol. 41, pp. 15-26, January 1776a. Disponível em: < http://archive.org/details/criticalreviewo17unkngoog>. Acesso em 2 jun. 2013.

THE LUSIAD, or Discovery of India, an Epic Poem; translated from the original Portuguese of Lewis de Camoens, by William Julius Mickle. The Gentleman's Magazine and Historical Review. London. Vol. 46, pp. 367-369, August 1776b. Disponível em: <http://books.google.com.br/books/download/The_Gentleman_s_Magazine_and_ Historical.pdf?id=gntIAAAAYAAJ\&output=pdf\&sig=ACfU3U0yDEky3t0VVTKhY9vrdyuob1P8Q>. Acesso em: 2 jun. 2013.

THE LUSIAD, or Discovery of India, an Epic Poem, translated from the original Portuguese of De Camoens, with Notes, Etc. by William Julius Mickle. London Magazine. London. Vol. 45, pp. 210-211, April 1776c. Disponível em: <https://books.google.com.br/books/ download/The_London_Magazine_Or_Gentleman_s_Month.pdf?id=DfgRAAAAYAAJ $\& \mathrm{hl}=\mathrm{pt}-\mathrm{BR} \&$ output=pdf\&sig=ACfU3U35sc6oZw92N6bxzGmR40ZVZaJ3cw >. Acesso em: 2 jun. 2013.

THE LUSIAD; or the Discovery of India: An Epic Poem. Translated from the original Portuguese of Luis de Camoëns. By William Julius Mickle. The Monthly Review. London, Vol. LIV, pp. 249-260, pp. 369-378. April-May 1776d. Disponível em: <http://books.google.com.br/books/download/The_Monthly_Review_Or_Literary_ Journal.pdf?id=p6vSqXWzNT4C\&output=pdf\&sig=ACfU3U1cLOPsLhVQFpmc HUiY9RIrXljfzw>. Acesso em: 2 jun. 2013.

THE LUSIAD, concluded. The Monthly Review. London. Vol. LV, pp. 5-16, July 1776e. Disponível em: <http://books.google.com.br/books/download/The_Monthly_ Review.pdf?id=nIMCAAAAYAAJ\&output=pdf\&sig=ACfU3U22M1pgt4BOdeWaV3 diputdrIdUlQ>. Acesso em: 2 jun. 2013.

THE LUSIAD; or the Discovery of India, an Epic Poem. Translated from the original Portuguese of Luis de Camoens. By William Julius Mickle. The Town and Country Magazine, or Universal Repository of Knowledge, Instruction and Entertainment. London: A. Hamilton, Vol. VIII, p. 156, March 1776f. Disponível em: <http://books.google.com.br/books/download/The_Town_and_Country_Magazine.pdf ?id=i7sPAAAAQAAJ\&output=pdf\&sig=ACfU3U0Y5Cuh9ITqR1_zIzb-KqEr3LVtA>. Acesso em: 2 jun. 2013. 
THE LUSIAD; or Discovery of India. An Epic Poem. Translated from the Portuguese. By W. J. Mickle. The 2d Edition. The Gentleman's Magazine and Historical Review. London. Vol. 48, pp. 427-428, Sept. 1778. Disponível em: <http://books.google.com.br/books/ download/The_Gentleman_s_Magazine_and_Historical.pdf?id=Y3xIAAAAYAAJ\&out put=pdf\&sig=ACfU3U1EmuOGt3ZX1vCby- L6XFnCR5mprw>. Acesso em: 3 jun. 2013.

MCMURRAN, Mary Helen. National or Transnational? The eighteenth century novel. In: COHEN, Margaret; DEVER, Carolyn (Eds.). The Literary Channel: The Inter-National Invention of the Novel. 2002, pp. 50-72.

The Spread of Novels: translation and prose fiction in the eighteenth century. Princeton, N.J.: Princeton University Press, 2010.

MARSHALL, P. J. Britain Without America - A Second Empire? In: (Ed.) The Oxford History of the British Empire. Vol. 2. The eighteenth-century. New York: Oxford University Press, 2001a, pp. 576-595.

Introduction. In: (Ed.) The Oxford History of the British Empire. Vol. 2. The eighteenth-century. New York: Oxford University Press, 2001b, pp. 1-27.

MATOS, Maria Vitalina Leal de. Lusíadas (Os). In: Dicionário de Luís de Camões. São Paulo: LeYa, 2011, pp. 489-515.

MATTHIESSEN, Francis Otto. Translation, an Elizabethan Art. Cambridge: Harvard University Press, 1931.

MAXWELL, Kenneth. Marquês de Pombal: Paradoxo do Iluminismo. Tradução de Antônio de Pádua Danesi. 2 ed. São Paulo: Paz e Terra, 1997.

MELVILLE, Herman. White-Jacket, or, the world in a man-of-war. Oxford: Oxford University Press, 1990.

MICKLE, William Julius. Almada hill; an epistle from Lisbon. Oxford: printed by W. Jackson: and sold by J. Bew, Paternoster-Row, London; and by the booksellers of Oxford and Cambridge, 1781. Eighteenth Century Collections Online. Gale. USP Reitoria. Disponível em: <http://find.galegroup.com/ecco/infomark.do?\&contentSet $=$ ECCOArticles \& type $=$ multipage $\&$ tabID $=$ T001 $\&$ prodId $=$ ECCO\&docId $=C W 11299671$ $2 \&$ source $=$ gale $\&$ userGroupName $=$ usp $\&$ version $=1.0 \&$ docLevel $=$ FASCIMILE $>$. Acesso em: 23 ago. 2010.

Introduction and Advertisement. In: CAMÕES, Luís Vaz de. The first book of the Lusiad, published as a specimen of a translation of that celebrated epic poem. Translated by William Julius Mickle. Oxford: W. Jackson et al, 1771. Disponível em:<http://find.galegroup.com/ecco/infomark.do?\&contentSet= ECCOArticles\&type $=$ multipage \&tabID=T001\&prodId=ECCO\&docId=CW110194652 $\&$ source $=$ gale $\&$ userGroupName $=$ usp \&version=1.0\&docLevel=FASCIMILE $>$. Acesso em: 30 jul. 2010. 
Introduction and Dissertation On the Machinery of Tasso's Jerusalem, and Voltaire's Henriade. In: CAMÕES, L. The Lusiad; or, the discovery of India. An epic poem. Translated by William Julius Mickle. London, Oxford: Jackson and Lister, 1776, pp. iclxvii. Disponível em: <http://www.archive.org/details/lusiadordiscover00camo>. Acesso em: 30 jul. 2010.

Introduction, dissertations, and appendix. In: CAMÕES, L. The Lusiad; or, the discovery of India. Translated by William Julius Mickle. London, Oxford: Jackson and Lister, 1778, pp. i-ccxxxvi, 2nd edition. Disponível em: <http://books.google.com.br/ books?id=xLcNAAAAYAAJ\&printsec=frontcover\&dq=The_Lusiad_or_the _ discovery_of_India>. Acesso em: 30 jul. 2010.

The poems of Mickle, and Smollett. Col. The British Poets, including translations, in one hundred volumes. Vol. LXVI. Chiswick: C. Whittingham, 1822. Disponível em: <http://books.google.com.br/books/download/The_poems_of_Mickle_and_Smollett. pdf?id=OSJAAAAAYAAJ\&output=pdf\&sig= ACfU3U3ZultYBdPHxalufH7iEZXeStGkmA>. Acesso em: 2 set. 2010.

The poems of William Julius Mickle. Col. The works of the English poets, from Chaucer to Cowper. Vol. XVII. London: J. Johnson et al, 1810, pp. 503-577.

. Proposals for Printing by Subscription, a Translation of the LUSIAD of CAMOENS, from the Portuguese into English Verse [...].The Gentleman's Magazine. Vol. XLI, March 1771, p. 134.

. Proposals for printing by subscription, the Lusiad: or, the discovery of India. An 'epic poem. With notes critical and historical. Translated from the Portuguese of Camöens. To which is prefixed, the history of India; and the rise and fall of the Portuguese empire in the east. Dublin, 1791. Eighteenth Century Collections Online. Gale. USP - FFLCH. Disponível em: <http://find.galegroup.com/ecco/infomark. do? \&source $=$ gale $\&$ prodId $=E C C O \&$ userGroupName $=$ uspfflch $\&$ tabID $=$ T001\&docId $=\mathrm{C}$ $\mathrm{W} 113639489 \& \mathrm{type}=$ multipage $\&$ contentSet $=\mathrm{ECCOArticles} \&$ version $=1.0 \&$ docLevel $=\mathrm{F}$ ASCIMILE>. Acesso em: 2 set. 2010.

. "Providence: or, Arandus and Emilec. - a Poem". The Critical Review. London:

A. Hamilton, Vol 14, pp. 276-279, October 1762. Disponível em: <http://books.google. com.br/books/download/The_critical_review_or_annals_of_literat.pdf?id=i4dKAAAAc AAJ\&output=pdf\&sig=ACfU3U1woZawIcnwZqaPJNBPEKoZFLF7rQ>. Acesso em: 29 jan. 2013.

Sir Martyn, A Poem, in the manner of Spenser. London: Flexney, Evans \& Bew, 1777. Disponível em: <http://books.google.com.br/books/download/Sir_Martyn_ a_poem_in_the_manner_of_Spens.pdf?id=hrJNAAAAMAAJ\&output=pdf\&sig= ACfU3U264EMjqqkfVuDUcDnfgQX9bGU_3w>. Acesso em: 2 fev. 2013.

MiCKLE's Translation of the LUSIAD of CAMOENS. Second Edition”. The Monthly Review. London. Vol. LIX, p. 311, Oct. 1778. Disponível em: <http://books.google.com.br/ books/download/The_Monthly_Review.pdf?id=YkU3AQAAMAAJ\&output=pdf\&sig= ACfU3U0OeLcBWPH5m91B5tK_cNEtXUPx5A>. Acesso em: 3 jun. 2013. 
MILTON, John. Tradução: teoria e prática. São Paulo: Martins Fontes, 1998.

MILTON, John; VILLA, Dirceu (Orgs.). Os escritos clássicos ingleses sobre a tradução1615-1791. São Paulo: Humanitas, 2012.

MOISÉS, Massaud. A literatura portuguesa. 16 ed., São Paulo: Cultrix, 1980.

MONTEIRO, George. The presence of Camões: influences on the literature of England, America \& Southern Africa. Lexington: University Press of Kentucky, 1996.

MORTON, Timothy. Trade winds. In: FLINT, Kate (Ed.). Poetry and Politics: Essays and Studies 1996. Cambridge: D. S. Brewer, 1996, pp. 19-41.

MOSER, Fernando de Mello. Camões: Luís de Camões em Inglaterra. Discurso inacabado: ensaios de cultura portuguesa. Lisboa: Fundação Calouste Gulbenkian, 1994, pp. 193230.

MOURÃO E VASCONCELOS, José Maria do Carmo de Sousa Botelho, Morgado de Mateus. Prefação. In: Camões, Luís de. Os lusíadas. Paris: Firmin Didot, 1847. Disponível em: <https://books.google.es/books/download/Os_Lusiadas.pdf?id= dqg4AAAAYAAJ\&output=pdf\&sig=ACfU3U0U9lfsFUwQqdSMib0jnPzumjwKug >. Acesso em: 11 ago. 2012.

O'BRIEN, Patrick K. Inseparable Connections: Trade, Economy, Fiscal State, and the Expansion of Empire, 1688-1815. In MARSHALL, P. J. (Ed.). The Oxford History of the British Empire. Vol. 2. The eighteenth-century. New York: Oxford University Press, 2001, pp. 53-77.

OBITUARY. The Gentleman's Magazine and Historical Review. London, Vol. 58, p. 1029, Nov. 1778. Disponível em: <http://books.google.com.br/books/download/ The_Gentleman_s_Magazine_and_Historical.pdf?id=Y3xIAAAAYAAJ\&out put=pdf\&sig=ACfU3U1EmuOGt3ZX1vCby- L6XFnCR5mprw $>$. Acesso em: 3 jun. 2013.

ORAVEC, Christine L. Sublime, The. In SLOANE, Thomas O. (Ed.). Encyclopedia of Rhetoric. Berkeley, California: Oxford University Press, 2006.

PAGDEN, Anthony. Peoples and Empires: A Short History of European Migration, Exploration, and Conquest, from Greece to the Present. New York: Modern Library, 2001.

PANOFSKY, Erwin. Renascimento e renascimentos na arte ocidental. Lisboa: Presença, 1960.

PARTRIDGE, Eric. Eighteenth-Century English Romantic Poetry. Whitefish, MT: Kessinger, 2010.

PECK, John; COYLE, Martin. A Brief History of English Literature. New York: Palgrave Macmillan, 2002. 
PÉCORA, Alcir. Máquina de gêneros: novamente descoberta e aplicada a Castiglione, Della Casa, Nobrega, Camões, Vieira, La Rochefoucauld, Gonzaga, Silva Alvarenga e Bocage. São Paulo: EDUSP, 2001.

PEIXOTO, Afrânio. Ensaios Camonianos. Coimbra: Imprensa da Universidade, 1932.

PEREIRA, Paulo. Lisboa (séculos XVI-XVII). Discurso proferido no simpósio internacional "Novos Mundos - Neue Welten. Portugal e a Época dos Descobrimentos" no Deutsches Historisches Museum, em Berlim, 23 a 25 de Novembro de 2006. Disponível em: <http://www.dhm.de/ausstellungen/neue-welten/pt/docs/Paulo_Pereira.pdf > Acesso em: 11 ago. 2013.

PEREIRA, Virgínia Soares. Lusíadas. In: Dicionário de Luís de Camões. São Paulo: LeYa, 2011, pp. 489-490.

PIMPÃO, Álvaro Júlio da Costa. Prefácio. In: CAMÕES, Luís Vaz de. Os lusíadas. Lisboa: Ministério dos Negócios Estrangeiros. Instituto Camões, 2000, pp. i-xiii.

PINA, Rui de. Chronica do muito alto, e muito esclarecido principe D. Sancho I [...] fielmente copiada do seu original por Miguel Lopes Ferreyra. Lisboa: Officina Ferreyriana, 1727. Disponível em: <http://purl.pt/309>. Acesso em: 11 jun. 2014.

PIRES, Maria Lucília Gonçalves. A crítica camoniana no século XVII. Lisboa: ICALP, 1982.

PLETT, Heinrich F. Amplification. In SLOANE, Thomas O. (Ed.). Encyclopedia of Rhetoric. Berkeley, California: Oxford University Press, 2006.

POPE, Alexander. Miscellaneous poems and translations. 3rd ed. London: Bernard Lintot, 1720.

Poemas. Tradução de Paulo Vizioli. São Paulo: Nova Alexandria, 1994.

. The poetical works of Alex. Pope, Esq. London: Baynes and Son et al., 1825.

. From the "Preface" to The Iliad. In: MILTON; VILLA, (Orgs.). Os escritos clássicos ingleses sobre a tradução - 1615-1791. São Paulo: Humanitas, 2012a, pp. 123-129.

Do "Prefácio" à Ilíada. Tradução de Marina Camera. In: MILTON; VILLA, (Orgs.). Os escritos clássicos ingleses sobre a tradução - 1615-1791. São Paulo: Humanitas, 2012b, pp. 115-122.

PORTER, Roy. Enlightenment: Britain and the creation of the modern world. London: Penguin Books, 2000.

QUINTANILHA, F.E.G. William Julius Mickle e a sua tradução de Os lusíadas. Panorama: Revista Portuguesa de Arte e Turismo. N. 44, IV Série, Dezembro de 1972, pp. 67-75.

QUINTILIAN. The Institutio Oratoria. Translation by H. E. Butler. Vol. III. Cambridge, Massachusetts \& London: Harvard University Press \& William Heinemann Ltd., 1970. 
RAMOS, Iolanda F. \& LOUSADA, Isabel C. Traduções de Os lusíadas em Inglaterra. In: SOUZA, Maria Leonor Machado de (coord.). Camões em Inglaterra. Lisboa: Ministério da Educação/Instituto de Cultura e Língua Portuguesa, 1992, pp. 9-63.

RAPIN, René. Réflexions sur la poétique de ce temps et sur les ouvrages des poètes anciens et modernes. Genève: Droz, 1970.

REED, Isaac. An Account of the Life and Writings of William Julius Mickle. In European Magazine. London, Vol. 16, pp. 155-157, Sept. 1789; pp. 317-321, Nov. 1789. Disponível em: <http://books.google.com.br/books/download/The_European_magazine _and_London_review.pdf?id=r1g3AAAAMAAJ\&output=pdf\&sig=ACfU3U0 IdWKIGGKmCl6DWNETkgk64BUBFA> Acesso em: 15 dez. 2012.

RENER, Frederick M. Interpretatio: language and translation from Cicero to Tytler. Amsterdam: Rodopi, 1989.

ROBINS, Nick. The corporation that changed the world: how the East India Company shaped the modern multinational. London: Pluto Press, 2006.

ROBINSON, Douglas. Translation and empire: postcolonial theories explained. Manchester: St. Jerome, 1997a.

Western translation theory: from Herodotus to Nietzsche. Manchester: St. Jerome, 2002.

RODRIGUES, José Maria. Fontes dos lusíadas. 2. ed. Lisboa: Academia das Ciências de Lisboa, 1979.

ROSCOMMON, Earl of (Thomas Wentworth). An essay on translated verse. In: STEINER, T. R. English translation theory 1650-1800. Assen: Van Gorcum, 1975, pp. 75-85.

ROUSSEAU, Jean-Jacques. Oeuvres Complètes de J. J. Rousseau. Tome I. Paris : Librairie de L. Hachette, 1865.

SENA, Jorge de. Introdução. In: CAMÕES, L. Lusíadas. Lisboa: Imprensa Nacional-Casa da Moeda, 1972, pp. 9-56.

. A estrutura de "Os Lusíadas" e outros estudos camonianos e de poesia peninsular do século XVI. Lisboa: Portugália, 1970.

. Trinta anos de Camões 1948-1978 (Estudos camonianos e correlatos). Vol. 1. Lisboa: Edições 70, 1980.

SHER, Richard B. The Enlightenment \& the Book: Scottish Authors \& Their Publishers in Eighteenth-Century Britain, Ireland, \& America. Chicago: University of Chicago Press, 2006.

SHER, Richard B.; ZACHS, William (Orgs.). The Edinburgh Magazine and Review. Volume V. Bristol: Thoemmes Press, 1998. 
SHIELDS, David. Oracles of Empire: poetry, politics, and commerce in British America, 1690-1750. Chicago: The University of Chicago Press, 1990.

SIDERI, Sandro. Comércio e poder: colonialismo informal nas relações anglo-portuguesas. Lisboa: Cosmos; Santos: Martins Fontes, 1970.

SILVA, Luciano Pereira da. A Astronomia dos Lusíadas. Coimbra: Imprensa da Universidade, 1915.

SILVA, Luís de Oliveira e. Épica e império. In: Dicionário de Luís de Camões. São Paulo: LeYa, 2011, pp. 341-345.

SILVA, Vítor Manuel Pires de Aguiar e. Camões: labirintos e fascínios. Lisboa: Cotovia, 1994.

. (Coord.). Dicionário de Luís de Camões. São Paulo: LeYa, 2011.

Teoria da literatura. Vol. 1. 8. ed. Coimbra: Livraria Almedina, 2006.

SILVEIRA, Francisco Maciel; MONGELLI, Lênia Márcia; CUNHA, Maria Helena Ribeiro da. Literatura portuguesa em perspectiva: classicismo, barroco, arcadismo. São Paulo: Atlas, 1993.

SIM, Rev. John. New Life of the Author. In MICKLE, W. J. The poetical works of William Julius Mickle. London: J. Barfield, 1809, pp. ix-lxiv.

SMITH, Adam. Lectures on Rhetoric and Belles Lettres. Indianapolis: Liberty Fund, 1985.

SOUSA, Sérgio Paulo Guimarães de. Sobre a recepção de Os lusíadas em França até ao século XVIII. In Boletim do Centro de Estudos Portugueses, vol. 18, n. ${ }^{\circ} 23$, Universidade Federal de Minas Gerais, Julho/Dezembro de 1998. Disponível em: <http://www.letras.ufmg.br/cesp/textos/(1998)05-Sobre.pdf>

Acesso em: 16 ago. 2012.

SOUTHEY, Robert. Memoirs of the Life and Writings of Luis de Camoens. By John Adamson F. S. A. The Quarterly Review. London, Vol. XXVII, n. LIII, pp. 1-39, April 1822.

. [T. Y.] Observations on Mr. Mickle's Lusiad, with the Portuguese Criticism on that Translation. The Monthly Magazine, or, British Register. London, Vol. II, pp. 787-789, July to December, 1796.

. [T. Y.] Remarks on Mickle's Translation of The Lusiad (continued). The Monthly Magazine, or, British Register. London, Vol. IV, pp. 98-100, July to December, 1797.

ST. PIERRE, Paul. Translation as a Discourse of History. TTR, vol 6, N. 1, 1993, pp. 61-82.

STEINER, T. R. English translation theory 1650-1800. Assen: Van Gorcum, 1975.

STEPHEN, Leslie. Alexander Pope. London: Macmillan and Co., 1880. 
STIERLE, Karlheinz. Translatio studii and Renaissance: From Vertical to Horizontal Translation. In BUDICK \& ISER (Eds.). Translatability of Cultures: Figurations of the Space Between. Stanford, Ca: Stanford University Press, 1996.

TAYLOR, Sister Eustace. William Julius Mickle (1734-1788): A Critical Study. Washington, D.C.: Catholic University of America, 1937.

THOMAS, Richard F. Browsing in the Western Stacks. Harvard Library Bulletin, n.s. 6.3, 1995, pp. 27-33.

THOMAZ, Luís Filipe. A idéia imperial manuelina. In: DORÉ, A.; LIMA, L. F. S.; SILVA, L. G. (Orgs.). Facetas do império na história: conceitos e métodos. São Paulo: Hucitec, 2008.

THOMSON, James. The poetical works of James Thomson, in two volumes. Vol. I. London: Alan Bell and Co., 1837a. Disponível em: <http://books.google.com.br/books/ download/The_Poetical_Works_of_James_Thomson_in_T.pdf?id=D1YAAAAcAAJ\&output= pdf\&sig=ACfU3U2k70csv5TMb6myv6duaZb0VEtA-A $>$. Acesso em: 30 abr. 2014.

The poetical works of James Thomson, in two volumes. Vol. II. London: Alan Bell and Co., 1837b. Disponível em: <http://books.google.com.br/books/download/ The_Poetical_Works_of_James_Thomson_in_T.pdf?id=PVY-AAAAcAAJ\&hl=ptBR\&output=pdf\&sig=ACfU3U1r87nCCKAvC3yB0sMmQWsBqWecJA>. Acesso em: 30 abr. 2014.

TILLYARD, E. M. W. The English Epic and its Background. London: Chatto and Windus, 1954.

TYMOCZKO, Maria. Translation and Political Engagement. Activism, Social Change and the Role of Translation in Geopolitical Shifts. The Translator. Volume 6, n. 1, pp. 23-47, 2000 .

TYTLER, Alexander Fraser. Essay on the principles of translation. London: J. M. Dent \& Co. and New York: E. P. Dutton \& Co, 1907.

VENUTI, Lawrence. The Translator's Invisibility. London and New York: Routledge, 1995.

VIRGÍLIO. Eneida. Tradução de Tassilo Orpheu Spalding. São Paulo: Abril Cultural, 1983.

VOLTAIRE, Euvres de Voltaire: Eloge historique de Voltaire. La Henriade. Essai sur les guerres civiles de France. Essai sur la poésie épique. Paris: Stoope, 1792. Disponível em: <http://books.google.com.br/books/about/\%C5\%92uvres_de_Voltaire_Eloge_ historique_de.html?id=ExE-AAAAYAAJ\&redir_esc=y> Acesso em: 17 ago. 2012. 
VOLTAIRE; WHITE, Florence Donnell. Voltaire's Essay on Epic Poetry: a study and an edition. Dissertation presented to the Faculty of Bryn Mawr College in partial Fulfilment of the Requirements for the Degree of Doctor of Philosophy. Albany, N. Y.: The Brandow Printing Co. 1915. Disponível em: <https://ia700302.us.archive.org/18/ items/voltairesessayo00voltgoog/voltairesessayo00voltgoog.pdf $>$ Acesso em: 17 ago. 2012.

WALKER, Hugh. Three centuries of Scottish literature. Glasgow: James Maclehose and Sons, 1893. Vol. II. Disponível em: <http://www.archive.org/details/threecenturiesof02walk>. Acesso em: 29 dez. 2012.

WALKER, Roger M. Sir Richard Fanshawe's Lusiad and Manuel de Faria e Sousa's Lusíadas Comentadas: New Documentary Evidence. Portuguese Studies, vol. 10, 1994, pp. 44-64. Disponível em: < http://www.jstor.org/stable/41105001 > Acesso em: 13 fev. 2013.

WALTER, Félix. La Littérature Portugaise en Angleterre à l'Époque Romantique. Paris: Librairie Ancienne Honoré Champion, 1927.

WASSERMAN, Earl R. The Return of the Enjambed Couplet. English Literary History. Vol. 7, No. 3 (Sep., 1940), pp. 239-252. The Johns Hopkins University Press. Disponível em: <http://www.jstor.org/stable/2871494>. Acesso em: 26 jun. 2013.

WEST, George. "Cumnor Hall": The Analogue of Scott's "Kenilworth". The Modern Language Review, Vol. 29, No. 3 (Jul., 1934a), pp. 274-281.

The work of W. J. Mickle, the first Anglo-Portuguese scholar. The Review of English Studies, Vol. 10, N. 40, Oct. 1934b, pp. 385-400.

WHITE, Landeg. Translator's Note. In: CAMÕES, Luís Vaz de. The Lusíads. Oxford: Oxford University Press, 2008, pp. xxi-xxii.

YOUNG, Edward. The Poems of Edward Young. Col. The British Poets including translations. Vol. LI. Young, vol. III. London: Chiswick, 1822.

ZUBER, Roger. Les "Belles Infidèles” et la formation du goût classique: Perrot d'Ablancourt et Guez de Balzac. Paris: Armand Colin, 1968. 


\section{APÊNDICE A - Análise do poema “Almada Hill”, de Mickle (1781)}

Analisaremos brevemente aqui o poema "Almada Hill”, de Mickle, publicado em 1781, porque várias das tendências que percebemos no Lusiad se repetem neste que era considerado por Mickle um suplemento à sua tradução d'Os lusíadas. A análise do poema reforça a interpretação proposta em nossa tese a diversos elementos da tradução.

O poema é escrito em forma de epístola, dirigida de Lisboa pelo poeta a um amigo em Roma. Em uma breve nota inicial, Mickle (1781, pp. v-vi), apresentando o tema de inspiração cruzadística, tão caro aos pré-românticos, comenta que poemas de fundo histórico requerem que o leitor conheça as circunstâncias históricas em que se baseiam. A seguir, resume o acontecimento que inspirou o poema. No século XII, grande parte de Portugal e da Espanha estavam sob o domínio dos mouros. D. Afonso Henriques, o primeiro rei de Portugal, comandava um cerco a Lisboa (1147) quando Robert, duque de Gloucester, em cruzada rumo a Jerusalém, passou pelo local. Como a causa era a mesma (o combate ao "infiel"), Robert e seus comandados juntaram-se à luta dos portugueses. Foi decidido que o grupo de Robert atacaria o castelo de Lisboa, situado em uma alta colina, enquanto Afonso investia contra as muralhas e a cidade. A manobra foi bem-sucedida. Em recompensa pelo serviço prestado, Afonso cedeu o castelo de Almada e terras adjacentes aos ingleses que haviam sido feridos ou que, por alguma outra razão, não pudessem prosseguir a jornada rumo à Palestina. ${ }^{1}$

\footnotetext{
${ }^{1}$ N'Os lusíadas esse episódio é referido no Canto III, estrofes 57-60:

"E tu, nobre Lisboa, que no mundo

Facilmente das outras és princesa,

Que edificada foste do facundo

Por cujo engano foi Dardânia acesa;

$\mathrm{Tu}$, a quem obedece o Mar profundo,

Obedeceste à força Portuguesa,

Ajudada também da forte armada

Que das Boreais partes foi mandada.

Lá do Germânico Álbis e do Reno

E da fria Bretanha conduzidos,

A destruir o povo Sarraceno

Muitos com tenção santa eram partidos.

Entrando a boca já do Tejo ameno,

Co arraial do grande Afonso unidos,

Cuja alta fama antão subia aos céus,

Foi posto cerco aos muros Ulisseus.

Cinco vezes a Lũa se escondera

E outras tantas mostrara cheio o rosto,

Quando a cidade, entrada, se rendera

Ao duro cerco que lhe estava posto.

Foi a batalha tão sanguina e fera
} 
Mickle (1781, pp. vi-vii) conta que escreveu o poema em dezembro de 1779, durante sua viagem de oito meses a Portugal. A ideia, diz ele, "foi natural para o tradutor d'Os lusíadas; e o projeto pode, de certa forma, ser chamado de um suplemento àquela obra" ${ }^{2}$. As descrições foram feitas a partir de suas observações quando em visita a Almada.

Em “Almada Hill”, Mickle retoma o tema da ascensão e queda dos impérios, alertando os britânicos para o risco da ruína. ${ }^{3} \mathrm{O}$ tom é moral e didático, visando a transmitir lições sobre os procedimentos que devem ser seguidos para o êxito comercial do Império.

Já no início, ao dirigir-se ao amigo destinatário da epístola, Mickle se mostra preocupado com a situação da Grã-Bretanha, que, em plena Guerra da Independência dos Estados Unidos, enfrentava, além dos norte-americanos, a França, a Espanha e a Holanda. Contrastando a situação tensa da Grã-Bretanha com a serenidade experimentada em Lisboa, Mickle (1781, pp. 2-3) fala em prever o futuro de seu país ("From other ills my country's fate foresee") e, com uma frase de efeito ("Herself is sick and poisoned at the heart"), culpa a própria Grã-Bretanha por seus males, em vez de acusar os países inimigos:

Your generous fears call forth Britannia's doom, What hostile spears her sacred lawns invade, By friends deserted, by her chiefs betray'd, Low fall'n and vanquish'd! - I, with mind serene As Lisboa's sky, yet pensive as the scene Around, and pensive seems the scene to me, From other ills my country's fate foresee. Not from the hands that wield Iberia's spear, Not from the hands that Gaul's proud thunders bear, Nor those that turn on Albion's breast the sword Beat down of late by Albion when it gored Their own, who impious doom their parent's fall Beneath the world's great foe, th'insidious Gaul; Yes, not from these the immedicable wound Of Albion - Other is the bane profound Destined alone to touch her mortal part; Herself is sick and poisoned at the heart. ${ }^{4}$

Quanto obrigava o firme pros[s]uposto

De vencedores ásperos e ousados,

E de vencidos já desesperados.

Destarte, enfim, tomada se rendeu [...]

2 "was natural to the translator of the Lusiad; and the plan may, in some degree, be called a supplement to that work".

${ }^{3}$ Como já comentamos no Capítulo 1 e em outros momentos deste trabalho, o tópos da queda dos impérios, acompanhado de alertas para que se evitasse incorrer em determinados erros, era bastante comum entre os poetas augustanos. E as epístolas redigidas em países estrangeiros eram um dos principais veículos utilizados para reflexões e comentários sobre questões políticas britânicas. Sobre esse assunto, ver Kaul (2000).

4 “Os seus nobres temores evocam a ruína de Britânia,

As lanças hostis que invadem os seus campos sagrados, 
Os elementos pré-românticos presentes nos demais poemas de Mickle e em sua tradução d'Os lusíadas são perceptíveis aqui. A exaltação dos ideais de cavalaria é uma das características dominantes no poema, anunciada logo no início: “O'er Tago's banks where'er I roll mine eyes, / The gallant deeds of antient days arise" (MICKLE, 1781, p. 3).

Mickle (1781, p. 4) estabelece uma ligação entre os acontecimentos históricos portugueses e a Inglaterra com base no espírito de cavalaria que marcou a história dos dois países:

\author{
Almada hill to English Memory dear, \\ While shades of English heroes wander here. \\ To ancient English valour sacred still \\ Remains, and ever shall, Almada Hill; \\ The hill and lawns to English valour given $[\ldots]^{6}$
}

E, logo em seguida:

[...] Romantic days that yield

Of gallant deeds a wide luxuriant field,

Dear to the Muse that loves the fairy plains,

Where ancient honour wild and ardent reigns. ${ }^{7}$

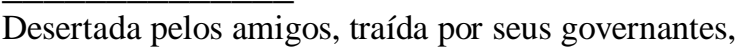

Abatida e derrotada! - Eu, com a mente serena

Como o céu de Lisboa, porém contemplativo como a paisagem

Ao redor, e contemplativa me parece a paisagem,

Por outros males a destruição de meu país antevejo.

Não pelas mãos que empunham a lança da Ibéria,

Não pelas mãos que transportam os orgulhosos trovões da Gália,

Nem aqueles que viram para o peito de Albion a espada

Vencidos recentemente por Albion ao ferir

Os seus próprios, que impiedosos condenam seus pais a cair

Sob o maior inimigo do mundo, a insidiosa Gália;

Sim, não são esses que causam o ferimento incurável

De Albion - Outra é a profunda maldição

A única destinada a tocar-lhe a parte mortal;

Ela própria está doente e envenenada em seu coração."

5 "Sobre as margens do Tejo por todos os lugares em que passo os olhos, / As corajosas façanhas de outrora se erguem".

6 “A colina de Almada, cara à memória dos ingleses,

Enquanto sombras de heróis ingleses vagarem aqui.

Para a antiga coragem inglesa ainda sagrada

Permanece, e sempre permanecerá, a colina de Almada;

A colina e os prados presenteados à coragem inglesa [...]".

7 “[...] Dias romanescos, que produzem

De façanhas corajosas um vasto campo fértil,

Caro à Musa que ama as planícies maravilhosas,

Onde a honra antiga reina indomável e ardente." 
Mickle (1781, pp. 6-12) relata a luta dos chamados povos bárbaros contra os romanos ressaltando a frivolidade e degeneração de costumes dos gregos e romanos, contrastando-as com o "espírito romântico" dos bárbaros.

Apesar do aspecto de fantasia das novelas de cavalaria, Mickle (1781, p. 16) reverencia o espírito de cavalaria. Graças à coragem e paixão da cavalaria, os turcos teriam sido expulsos da Península Ibérica e impedidos de avançar para o norte.

Quanto à ajuda prestada pelos cruzados britânicos aos portugueses durante o cerco de Lisboa, Mickle (1781, p. 5) acredita que os atos heroicos praticados pelos ingleses deixaram marcas na região:

And lawns for English valour still renown'd; Given to Cornwallia's gallant sons of yore, Cornwallia's name the smiling pastures bore; And still their Lord his English lineage boasts From Rolland, famous in the Croisade Hosts. ${ }^{8}$

À maneira romântica, a natureza e a paisagem parecem ter gravado esses momentos históricos do passado, repercutindo as emoções humanas, e agora transmitem essas visões ao poeta:

\footnotetext{
8 "E campos pela coragem inglesa ainda célebres; Dados aos filhos valentes da Cornualha de outrora, O nome da Cornualha os pastos sorridentes receberam; E seu Senhor se gaba de que sua linhagem inglesa descende diretamente De Rolando, famoso nas Hostes dos Cruzados."

${ }^{9}$ Ao traduzir a passagem n'Os lusíadas referente ao cerco de Lisboa, Mickle (1776, p. 108) acrescentou uma nota, citando como fonte A tour through Spain and Portugal (lançado em 1749 com o título An Account of the Most Remarkable Places and Curiosities in Spain and Portugal), de Udal ap Rhys, pseudônimo de Uvedale Tomkyns Price (1685-1764), onde se diz que Afonso Henriques deu aos ingleses Almada, que ficava do outro lado do Tejo em relação a Lisboa, e que Villa-Franca foi povoada pelos ingleses, que a chamaram de Cornualla, quer em homenagem à sua região nativa, quer por analogia com as campinas da região, onde se criava gado como na Cornualha inglesa. Embora o livro de Udal ap Thys contenha muitas incorreções, a ponto de vários comentaristas duvidarem que o autor houvesse realmente estado na Espanha e em Portugal, essas informações são confirmadas por fontes mais antigas, como a Corografia Portugueza, e Descripçam Topografica do Famoso Reyno de Portugal, de Antonio Carvalho da Costa (1712, p. 32).
} 
Iberia's fields with rich and genuine ore

Of ancient manners, wooe the traveller's eye;

And scenes untraced in every landscape lie.

Here every various dale with lessons fraught

Calls to the wanderer's visionary thought

What mighty deeds the lofty hills of Spain

Of old have witness'd $[\ldots]^{10}$

(MICKLE, 1781, p. 7).

Às vezes as impressões recolhidas pelo poeta se tingem de tons góticos, com a evocação de espectros e outros elementos sombrios:

But let the British wanderer thro' the dales

Of Ev'ra stray, while midnight tempest wails:

There, as the hoary villagers relate,

Sertorius, Sylla, Marius, weep their fate,

Their spectres gliding on the lightning blue,

Oft doom'd their ancient stations to renew $[\ldots]^{11}$

(MICKLE, 1781, pp. 9-10).

A ligação do poema com Os lusíadas é estabelecida desde o começo, com versos que aludem à viagem do Gama e seu grupo de audazes marinheiros que enfrentaram o que era considerado uma morte certa:

[...] the strand

Where Gama march'd his death-devoted band,

While Lisboa awed with horror, saw him spread

The daring sails that first to India led $[\ldots]^{12}$

(MICKLE, 1781, pp. 3-4).

\footnotetext{
10 “Os campos da Ibéria impregnados de minérios ricos e genuínos

De costumes antigos, seduzem o olho do viajante;

E cenários não percorridos repousam em todas as paisagens.

Aqui todos os vales repletos de lições

Invocam os pensamentos visionários do caminhante

Que grandes façanhas as altas colinas da Espanha

De outrora testemunharam [...]".

11 "Mas deixe o caminhante britânico pelos vales

De Évora vagar, enquanto a tempestade noturna geme:

Lá, como os aldeãos idosos contam,

Sertório, Sila, Mário, choram seu destino,

Seus espectros deslizando sob o relâmpago azul,

Condenados a retomar seus antigos postos $[\ldots]$ "

12 "[...] a praia

Onde Gama comandou o seu grupo disposto a morrer,

Enquanto Lisboa, tomada de horror, via-o estender

As ousadas velas que levaram à Índia pela primeira vez $[\ldots]$ "
} 
Mickle (1781, pp. 20-21) relembra também o papel do infante D. Henrique como pioneiro da navegação, e a grande habilidade dos portugueses nessa arte e no comércio:

Those arts which rais'd that race of Men, who shone

The heroes of their age on Lisboa's throne.

$[\ldots]$

Till Henry's Naval School its heroes pour'd

From pole to pole wherever Ocean roar'd!

Columbus, Gama, and Magellan's name,

Its deathless boast; and all of later fame

Its offspring - kindling o'er the view the Muse

The naval pride of those bright days reviews;

Sees Gama's sails, that first to India bore,

In awful hope evanish from the shore;

Sees from the silken regions of the morn

What fleets of gay triumphant vanes return!

What heroes, plumed with conquest, proudly bring

The Eastern Sceptres to the Lusian King! $!^{13}$

Ecoando o que já fizera em sua tradução d'Os lusíadas, Mickle (1781, pp. 21-25) elogia Gama, Albuquerque, Sampaio, Nuno da Cunha e Castro por seus atos de justiça, benevolência e bravura na Índia, mas, a seguir, relata a decadência do domínio português no Oriente, a ganância dos dirigentes portugueses e a opressão e exploração dos povos nativos, e afirma que a degeneração dos costumes no Império Português do Oriente se refletiu também em Portugal.

Para Mickle, a decadência do Império Português deve servir de exemplo para que os britânicos não sigam o mesmo caminho. Mais uma vez, Mickle (1781, p. 26) se mostra preocupado com o que está acontecendo na Grã-Bretanha:

Alas, my Friend, how vain the fairest boast Of human pride! how soon is Empire lost! The pile by ages rear'd to awe the world,

\footnotetext{
13 "Aquelas artes que elevaram aquela geração de Homens, que distinguiram Os heróis de sua era no trono de Lisboa.

$[\ldots]$

Até que a Escola Naval de Henrique derramou seus heróis

De polo a polo em todos os lugares onde o Oceano rugia!

Os nomes de Colombo, Gama e Magalhães,

Proclamam a sua imortalidade; e todos os que se celebrizaram depois

São seus descendentes - vibrando diante da visão a Musa

O orgulho naval daqueles dias gloriosos revê;

Vê as caravelas de Gama, que pela primeira vez levaram à Índia,

Em assombrosa esperança desaparecer da praia;

Vê das regiões acetinadas da aurora

As frotas de veletas em alegre triunfo retornarem!

Os heróis, condecorados com a conquista, orgulhosamente trazem

Os Cetros do Oriente para o rei lusitano!"
} 
By one degenerate race to ruin hurl'd!

And shall the Briton view that downward race

With eye unmoved, and no sad likeness trace!

Ah heaven! in every scene, by memory brought,

My fading country rushes on my thought. ${ }^{14}$

O poema se refere a outros acontecimentos da história de Portugal, como a libertação do domínio espanhol, em 1640, e o terremoto de Lisboa, ocorrido em 1755, que Mickle descreve em tons fortes e emotivos, comparando-o à ruína do Império Português no Oriente. Esses relatos se encerram com uma nota de esperança: Mickle (1781, p. 32) prevê dias melhores para Portugal e as colônias ainda sob seu domínio - principalmente o Brasil - em virtude da vocação comercial dos portugueses:

[...] And deep remain

The living roots of Lisboa's ancient reign;

Deep in the castled isles on Asia's strand,

And firm in fair Brazilia's wealthy land. ${ }^{15}$

O Tejo é glorificado - em detrimento até mesmo do Tâmisa ${ }^{16}$ - como o berço do comércio, que é exaltado como uma verdadeira divindade:

Forgive, fair Thames, the song of truth that pays

To Tago's empress-stream superior praise;

O'er every vauntful river be it thine

To boast the guardian shield of laws divine;

But yield to Tagus all the sovereign state

By Nature's gift bestow'd and partial Fate,

The sea-like port and central sway to pour

Her fleets, by happiest course, on every shore.

14 “Ai, meu amigo, quão vã é a mais bela ostentação

De orgulho humano! Quão logo o Império se perde!

A fortuna de eras erguida para maravilhar o mundo,

Por uma geração decadente atirada à ruína!

E devem os britânicos ver essa rápida queda

Com olhos impassivos, e nenhum sinal de tristeza!

Ah, Céus! Em cada paisagem, trazido pelas lembranças,

Meu país moribundo acorre ao meu pensamento."

15 ،[...] E permanecem profundas

As raízes vivas do antigo reino de Lisboa;

Profundamente nas ilhas encasteladas da costa da Ásia,

E firmes na bela terra rica do Brasil."

${ }^{16}$ Lembramos, em contraponto, os versos de Dryden (1810, p. 519) em “Annus Mirabilis" (1667), proclamando que, diante do Tâmisa e seus numerosos navios, "The wealthy Tagus, and the wealthier Rhine, / The glory of their towns no more shall boast" ["O rico Tejo, e o Reno, ainda mais rico, / Da glória de suas cidades não mais se jactarão"]. 
When from the sleep of ages dark and dead, Thy Genius, Commerce, rear'd her infant head, Her cradle bland on Tago's lap she chose, And soon to wandering childhood sprightly rose; And when to green and youthful vigour grown On Tago's breast she fixt her central throne $[\ldots]^{17}$ (MICKLE, 1781, p. 30).

Ferreira (1992b, p. 76) destaca algumas expressões empregadas por Mickle nesse poema, como "Tago's iron race"18 (1781, p. 17) ou "Tago's gallant race"19 (p. 20), que denotam a sobrevalorização do Tejo, executada com o fim de enaltecer tudo o que se relaciona com o comércio.

Em um soneto provavelmente composto também nessa viagem, "On passing the bridge of Alcantara, near Lisbon, where Camoens is reported to have chosen his station when age and necessity compelled him to beg his daily sustenance" [Ao passar pela ponte de Alcântara, perto de Lisboa, o local que se diz ter sido escolhido por Camões quando a idade e a necessidade o impeliram a mendigar seu sustento diário], Mickle (1822, p. 135) descreve uma visão do fantasma de Camões:

Oft as at pensive eve I pass the brook

Where Lisboa's Maro, old and suppliant, stood.

Fancy his injured eld and sorrows rude

Brought to my view. Twas night: with cheerless look

Methought he bow'd the head in languid mood,

As pale with penury in darkling nook

Forlorn he watch'd. Sudden the skies partook

A mantling blaze, and warlike forms intrude.

Here Gama's semblance braves the boiling main.

And Lusitania's warriors hurl the spear;

But whence that flood of light that bids them rear

\footnotetext{
17 "Perdoa, belo Tâmisa, a canção verdadeira que presta

Ao Tejo, corrente-imperatriz, maior louvor;

Sobre todos rios famosos cabe a ti

Proclamar-te o escudo guardião das leis divinas;

Mas cede ao Tejo todo o estado soberano

Por dádiva da Natureza e por Destino parcial entregue,

O porto [tão grande] que parece marítimo e central o direito de lançar

Suas frotas pelo curso mais apropriado em todas as praias.
}

Quando do sono de eras, obscuro e morto,

Teu Gênio, Comércio, ergueu a cabeça infante,

O berço afável no colo do Tejo escolheu,

E logo à infância errante animadamente se elevou;

E quando adquiriu o verde e jovem vigor

Sobre o seio do Tejo fixou seu trono central [...]"

18 "A geração de ferro do Tejo".

19 "A geração valente do Tejo". 
Their lofty brows! From thy neglected strain,

Camoens, unseen by vulgar eye it flows;

That glorious blaze to thee thy thankless country owes. ${ }^{20}$

Em “Almada Hill”, Mickle (1781, pp. 32-34) reporta-se aos sofrimentos de Camões como descritos nesse soneto ao mencionar a fundação da Real Academia de Ciências em Lisboa, à qual o tradutor esteve presente; verifica que agora, graças à cultura dos reis de Bragança e, em especial, do príncipe D. João de Bragança, o Duque de Lafões, a quem Mickle chama de “Ulisses” (aludindo também a D. João I, que seria o Ulisses de outrora), Camões está sendo reabilitado:

Now Heaven-taught Science and her liberal band Of Arts, and dictates by experience plann'd, Beneath the smiles of a benignant Queen Boast the fair opening of a reign serene, Of omen high. - And Camoens' Ghost no more Wails the neglected Muse on Tago's shore; No more his tears the barbarous Age' upbraid: His griefs and wrongs all sooth'd, his happy Shade Beheld th'Ulysses of his age return

To Tago's banks; [...]

The view how grateful to the liberal mind, Whose glow of heart embraces human kind, To see a nation rise! $[\ldots]^{21}$

\footnotetext{
20 "Muitas vezes, ao melancólico anoitecer, eu passo pelo riacho Onde o Marão de Lisboa, velho e suplicante, ficava. Imagino a sua velhice ferida e dores inclementes Trazidas à minha visão. Era noite: com uma aparência triste Pareceu-me que ele inclinava a cabeça sem forças, Enquanto pálido de penúria em um canto escuro Desamparado ele observava. De repente os céus compartilharam Um chama protetora, e formas guerreiras irromperam. Aqui a imagem de Gama enfrenta o mar fervente. E os guerreiros da Lusitânia arremessam a lança; Mas de onde aquela torrente de luz que os incita ergue Sua fronte sublime! Da tua estirpe abandonada, Camões, invisível para os olhos comuns ela flui; Aquela gloriosa chama teu país ingrato deve a ti." 21 "Agora a Ciência ensinada pelos Céus e o seu grupo liberal De Artes, e determinações planejadas a partir da experiência, Sob os sorrisos de uma bondosa Rainha Anunciam a bela abertura de um reinado sereno, De bons presságios. - E o Fantasma de Camões não mais Chora a Musa desprezada nas praias do Tejo; Não mais suas lágrimas a Era bárbara censuram: Seus pesares e injustiças todos acalmados, sua Sombra feliz Contempla o Ulisses de sua era retornar Às margens do Tejo; [...]
} 
Ao final de "Almada Hill", Mickle (1781, p. 35) se dirige novamente aos britânicos, repetindo, em tom dramático, o alerta a seus conterrâneos:

Nor ween, my Friend, that favouring Fate forebodes

That Albion's state, the toil of demi-gods,

From ancient manners pure, through ages long,

And from unnumber'd friendly aspects sprung,

When poison'd at the heart its soul expires,

Shall e'er again resume its generous fires:

No future day may such fair Frame restore:

When Albion falls, she falls to rise no more! $!^{22}$

Como observa Lawrence Lipking (2003, p. 165), "ao converter uma epopeia do Humanismo em uma epopeia do comércio, da liberdade e da civilização, Mickle expressou as tensões de uma era esclarecida. 'Almada Hill' (1781) sobrepõe uma visão da Grã-Bretanha moderna ao passado e presente dos portugueses" 23 .

Mais do que um suplemento, "Almada Hill” é uma espécie de lado negativo da translatio reencenada no Lusiad. Enquanto no Lusiad Mickle representa a transferência do poder e da cultura de Portugal para a Grã-Bretanha, em “Almada Hill” Mickle utiliza a história passada e presente de Portugal para emitir um alerta sobre o risco de queda do Império Britânico.

Que cena aprazível para a mente liberal,

Cujo fulgor do coração abraça a humanidade,

Ver uma nação se erguer! [...]"

22 "Nem imagines, meu amigo, que o Destino favorável preveja

Que a situação de Albion, o labor de semideuses,

De antigos costumes puros, ao longo das eras,

E fruto de inúmeros aspectos favoráveis,

Quando envenenada no coração a sua alma expirar,

Ela vá algum dia recuperar seu rico fulgor:

Nenhum dia futuro poderá restaurar tão belo Quadro:

Quando Albion cai, cai para jamais se erguer!"

${ }^{23}$ "in converting an epic of humanism into an epic of commerce, liberty and civilization, Mickle expressed the tensions of an enlightened age. 'Almada Hill' (1781) superimposes a vision of modern Britain on the Portuguese past and present". 


\section{APÊNDICE B - Lista das traduções completas de Os lusíadas para o inglês}

\begin{tabular}{|c|c|c|c|c|}
\hline & Nome do tradutor & Descrição & $\begin{array}{c}\text { Local de } \\
\text { publicacão }\end{array}$ & Ano \\
\hline 1 & $\begin{array}{l}\text { Sir Richard Fanshawe } \\
(1608-1666)\end{array}$ & $\begin{array}{l}\text { Tradução em oitava rima, bastante } \\
\text { literal, em estilo ainda renascentista. } \\
\text { Não teve grande repercussão na } \\
\text { época, mas foi reabilitada no século } \\
\text { XX e tem admiradores até hoje. }\end{array}$ & Londres & 1655 \\
\hline 2 & $\begin{array}{l}\text { William Julius } \text { Mickle } \\
(1735-1788)\end{array}$ & $\begin{array}{l}\text { Tradução em rimas emparelhadas } \\
\text { (dísticos heroicos). Muito } \\
\text { modificada em relação ao original; } \\
\text { há quem a considere uma paráfrase } \\
\text { e não uma tradução. Estilo entre } \\
\text { neoclássico e romântico. A mais } \\
\text { conhecida e divulgada de todas as } \\
\text { traduções poéticas da obra até hoje. } \\
\text { Objeto de estudo desta tese. }\end{array}$ & Oxford & 1776 \\
\hline 3 & $\begin{array}{l}\text { Thomas Moore Musgrave } \\
(1775-1854)\end{array}$ & $\begin{array}{l}\text { O tradutor era agente de uma } \\
\text { companhia de navegação em Lisboa. } \\
\text { Tradução em versos brancos em } \\
\text { pentâmetro iâmbico, a forma } \\
\text { consagrada por Shakespeare e } \\
\text { Milton. Atenuou a eroticidade do } \\
\text { Canto IX. Estorninho (1972) } \\
\text { considera essa tradução "destituída } \\
\text { de todo o sentido e qualidade } \\
\text { poéticas". }\end{array}$ & Londres & 1826 \\
\hline 4 & $\begin{array}{l}\text { Sir Thomas Livingston } \\
\text { Mitchell (1792-1885) }\end{array}$ & $\begin{array}{l}\text { O tradutor era soldado veterano da } \\
\text { Guerra Peninsular. Foi também } \\
\text { explorador na Austrália. Tradução } \\
\text { em oitava rima. Segundo João de } \\
\text { Almeida Flor (2011, p. 814), "utiliza } \\
\text { uma dicção arcaizante e } \\
\text { excessivamente literalista, com } \\
\text { prejuízo dos valores conotativos e } \\
\text { poéticos do original". }\end{array}$ & Londres & 1854 \\
\hline
\end{tabular}




\begin{tabular}{|c|c|c|c|c|}
\hline & Nome do tradutor & Descrição & $\begin{array}{c}\text { Local de } \\
\text { publicação }\end{array}$ & Ano \\
\hline 5 & $\begin{array}{ll}\text { John James } & \text { Aubertin } \\
(1818-1900) & \end{array}$ & $\begin{array}{l}\text { Edição bilíngue; tradução em oitava } \\
\text { rima. Engenheiro ferroviário, Aubertin } \\
\text { foi o responsável pela construção da } \\
\text { linha entre Santos e São Paulo. Tinha } \\
\text { bom conhecimento da língua e } \\
\text { literatura portuguesas, tendo sido } \\
\text { eleito sócio da Academia Real das } \\
\text { Ciências e Cavaleiro da Ordem de } \\
\text { Santiago. Segue o original de perto, } \\
\text { imitando as inversões sintáticas do } \\
\text { português. Sua tradução foi muito } \\
\text { valorizada em Portugal (para Teófilo } \\
\text { Braga, seria a "tradução definitiva" de } \\
\text { Os lusíadas), mas alguns críticos } \\
\text { ingleses a consideram literal demais. } \\
\text { Landeg White (2008, p. xxi), o tradutor } \\
\text { mais recente, comentou que Aubertin } \\
\text { escreveu em uma língua que não é } \\
\text { inglês, mas uma estranha mistura de } \\
\text { inglês e português. }\end{array}$ & Londres & 1878 \\
\hline 6 & $\begin{array}{l}\text { Robert Ffrench Duff } \\
(1807 ?-1895)\end{array}$ & $\begin{array}{l}\text { O tradutor era descendente de uma } \\
\text { família inglesa estabelecida em } \\
\text { Portugal. A tradução, em versos } \\
\text { spenserianos, ressalta a nota épica e } \\
\text { lírica, intensificando a emotividade do } \\
\text { poema. }\end{array}$ & Londres & 1880 \\
\hline 7 & $\begin{array}{l}\text { Sir Richard Francis } \\
\text { Burton }(1821-1890)\end{array}$ & $\begin{array}{l}\text { O célebre aventureiro, orientalista e } \\
\text { tradutor de As mil e uma noites viajou } \\
\text { pelo mundo todo e conhecia diversas } \\
\text { línguas. A admiração que devotava a } \\
\text { Camões é evidente em sua tradução. } \\
\text { Publicou também dois volumes } \\
\text { contendo a biografia de Camões e um } \\
\text { comentário à sua tradução de Os } \\
\text { lusíadas. Seu estilo, no entanto, é } \\
\text { considerado difícil demais, por } \\
\text { empregar tanto arcaísmos quanto } \\
\text { neologismos e estrangeirismos. } \\
\text { Manteve a oitava rima do original. }\end{array}$ & Londres & 1881 \\
\hline 8 & $\begin{array}{l}\text { Leonard Bacon (1887- } \\
\text { 1954) }\end{array}$ & $\begin{array}{l}\text { A primeira tradução feita nos Estados } \\
\text { Unidos. Publicada pela Hispanic Society } \\
\text { of America. Em oitava rima. Contém } \\
\text { notas explicativas bastante detalhadas. } \\
\text { Na avaliação de Ramos e Lousada } \\
(1992 \text {, p. } 10 \text {, nota 5), algumas } \\
\text { expressões utilizadas por Bacon são } \\
\text { "pouco poéticas", quer por serem muito } \\
\text { simples, quer porque o tradutor recorre } \\
\text { a concretizações, atualizações e } \\
\text { latinismos em demasia. }\end{array}$ & Nova York & 1950 \\
\hline
\end{tabular}




\begin{tabular}{|l|l|l|l|l|}
\hline & Nome do tradutor & \multicolumn{1}{|c|}{ Descrição } & \multicolumn{1}{|c|}{$\begin{array}{c}\text { Local de } \\
\text { publicação }\end{array}$} & Ano \\
\hline 9 & $\begin{array}{l}\text { William Christopher } \\
\text { Atkinson (1902-1992) }\end{array}$ & $\begin{array}{l}\text { Atkinson era professor de estudos } \\
\text { hispânicos em Glasgow. Esta é a } \\
\text { primeira tradução em prosa para o } \\
\text { inglês, publicada na série "The } \\
\text { Penguin Classics". Peca pela } \\
\text { simplificação excessiva, que } \\
\text { descaracteriza e trivializa o poema. }\end{array}$ & 1952 \\
\hline 10 & Hugh Finn (1925-1995) & $\begin{array}{l}\text { Tradução versificada a partir da } \\
\text { tradução em prosa de Atkinson. }\end{array}$ & Rodésia & 1972 \\
\hline 11 & Landeg White (1940-) & $\begin{array}{l}\text { Recebeu o Teixeira-Gomes Prize } \\
\text { atribuído em Londres pela Society } \\
\text { of Authors pela Gulbenkian } \\
\text { Foundation in London e pelo } \\
\text { Portuguese Book Institute. White é } \\
\text { galês, professor da Universidade } \\
\text { Aberta de Lisboa. A tradução } \\
\text { mantém a rima apenas nos dois } \\
\text { últimos versos de cada oitava. Opta } \\
\text { pelo uso do inglês atual, o que a } \\
\text { torna menos solene do que as } \\
\text { traduções anteriores. }\end{array}$ & & \\
\hline
\end{tabular}

Há outra tradução que, apesar de incompleta, costuma ser incluída na lista de traduções importantes de Os lusíadas: a de Edward Quillinan (1791-1851), que traduziu apenas os cinco primeiros cantos. Nascido no Porto, Quillinan se alistou em um regimento britânico durante a Guerra Peninsular e depois se estabeleceu na Inglaterra, tendo se casado com a filha de Wordsworth (contra a vontade deste). Regressou a Portugal com a esposa em 1845. (MOSER, 1994, p. 219). A tradução, em oitava rima, foi publicada com notas de John Adamson, em Londres, em 1853. Em certas passagens é uma tradução bastante livre, acentuando a nota lírica e épica. Empresta várias expressões da tradução de Fanshawe. À diferença das traduções anteriores à sua, entende que o herói do poema não é Vasco da Gama, mas o povo português. (RAMOS; LOUSADA, 1992, pp. 21-22).

Fontes: Estorninho (1972), Flor (2011), Monteiro (1996), Moser (1994), Quintanilha (1972), Ramos e Lousada (1992). 